FÁBIO LUÍS BOSSLER

\title{
OS LIMITES CONSTITUCIONAIS DE ATUAÇÃO DO CONSELHO NACIONAL DE JUSTIÇA
}

\author{
Dissertação de Mestrado
}

Orientador: Professor Associado Dr. Alexandre de Moraes

UNIVERSIDADE DE SÃO PAULO

FACULDADE DE DIREITO

São Paulo-SP

2015 
FÁBIO LUÍS BOSSLER

\title{
OS LIMITES CONSTITUCIONAIS DE ATUAÇÃO DO CONSELHO NACIONAL DE JUSTIÇA
}

\begin{abstract}
Dissertação apresentada à Banca Examinadora do Programa de Pós-Graduação em Direito, da Faculdade de Direito da Universidade de São Paulo, como exigência parcial para a obtenção do título de Mestre em Direito, na área de concentração de Direito do Estado, sob a orientação do Professor Associado Dr. Alexandre de Moraes.
\end{abstract}

\section{UNIVERSIDADE DE SÃO PAULO \\ FACULDADE DE DIREITO}

\section{São Paulo-SP}


Autorizo a reprodução e divulgação parcial deste trabalho, por qualquer meio convencional ou eletrônico, para fins de estudo e pesquisa, desde que citada a fonte.

\section{Serviço de Biblioteca e Documentação}

Faculdade de Direito da Universidade de São Paulo

Bossler, Fábio Luís

Os limites constitucionais de atuação do Conselho Nacional de Justiça / Fábio Luís Bossler : orientador Alexandre de Moraes -- São Paulo, 2015. $394 \mathrm{p}$.

Dissertação (Mestrado - Programa de Pós-Graduação em Direito do Estado) Faculdade de Direito, Universidade de São Paulo, 2015.

1. Poder Judiciário. 2. Conselho Nacional de Justiça. 3. Características. 4. Competências. 5. Limites. I. Moraes, Alexandre de, orientador. II. Título. 
BANCA EXAMINADORA 
A Pequena, por apoiar... por sorrir... por confiar... por sentir... 
Ao Professor Alexandre de Moraes, pela orientação, apoio e paciência. 


\section{AGRADECIMENTOS}

Agradeço a minha querida mãe Francelina e ao meu saudoso pai João por toda a educação que me proporcionaram.

Agradeço aos Eminentes Magistrados Fabiana Calil Canfour de Almeida, Elói Estevão Troly e Rodrigo Capez pelo inestimável apoio material, intelectual e, sobretudo, humano.

Agradeço ao Promotor de Justiça Leonardo Romano Soares pelas considerações que muito enriqueceram o conteúdo desta pesquisa.

E agradeço a todos aqueles que, de algum modo, contribuíram para a consecução deste trabalho. 
"Quando uma criatura humana desperta para um grande sonho e sobre ele lança toda a força de sua alma, todo o universo conspira a seu favor".

(Johann Goethe) 


\section{RESUMO}

BOSSLER, Fábio Luís. Os limites constitucionais de atuação do Conselho Nacional de Justiça. 2015. 394 folhas. Dissertação de Mestrado - Faculdade de Direito, Universidade de São Paulo. São Paulo, 2015.

O Conselho Nacional de Justiça foi instituído no cenário jurídico brasileiro pelo clamor da sociedade por controle, organização e transparência no Poder Judiciário. O órgão, desde sua criação, trouxe muitos avanços na estrutura da Justiça Brasileira, ao centralizar, planejar e coordenar ações administrativas e financeiras, além de previnir e repreender condutas imorais e ilícitas de seus membros. Houve aprimoramento do autogoverno do terceiro poder e resgate da moralidade no seu seio. Críticas, porém, também surgiram, fundadas na violação dos limites constitucionais de atuação do novel Colegiado Administrativo. Importa, pois, investigar qual o seu espaço institucional, não claramente determinado no texto da Carta Política. O presente trabalho, pois, propõe-se, atráves do estudo das próprias características do Conselho Nacional de Justiça e das suas competências especificadas na Constituição, demarcar as fronteiras constitucionais de sua atuação.

Palavras-chave: Poder Judiciário. Conselho Nacional de Justiça. Características. Competências. Limites. 


\section{SINTESI}

BOSSLER, Fabio Luis. I limiti costituzionali di attuazione del Consiglio Nazionale di Giustizia. 2015. 394 pagine. Dissertazione del Master - Facoltà di Giurisprudenza, Università di San Paolo, San Paolo, 2015.

Il Consiglio Nazionale di Giustizia è stato istituito nello scenario giuridico brasiliano per la richiesta crescente della società, di controllo, organizzazione e trasparenza nel Potere Giudiziario. L'organo, dalla sua creazione, ha portato molte innovazioni nella struttura della Giustizia Brasiliana, centralizzando, pianificando e coordinando azioni amministrative e finanziarie, oltre a, prevenire e riprendere condotte immorali e illecite dei suoi membri. C'è stato un miglioramento dell'autogoverno del terzo potere e il riscatto della moralità nel suo interno. Critiche, però, non sono mancate, fondate nella violazione dei limiti costituzionali dell'attuazione del nuovo Collegio Amministrativo. Importante, successivamente, sarà, investigare qual è lo spazio istituzionale, non chiaramente determinato nel testo della Carta Costituzionale. Il seguente lavoro, si propone, attraverso lo studio delle proprie caratteristiche del Consiglio Nazionale di Giustizia e delle sue competenze specificate nella Costituzione, di delimitare le frontiere costituzionali della sua attuazione.

Parole-chiavi: Potere Giudiziario. Consiglio Nazionale di Giustizia. Caratteristiche. Competenze. Limiti. 


\begin{abstract}
BOSSLER, Fábio Luís. The constitutional limits of operation of the National Council of Justice. 2015. 394 pages. Master - Faculty of Law, University of São Paulo. São Paulo, 2015.

The National Council of Justice was established within the Brazilian legal framework due to the clamor from society for control, organization and transparency in the judiciary. The body, since its creation, has brought about many advances in the structure of the Brazilian Courts System, through the centralization, planning and co-ordination of administrative and financial activities, in addition to preventing and rebuking immoral and illicit conduct of its members. There has been improvement in the self-governance of the third power and a recovery of morality from within its midst. Critics, however, have also arisen, based upon the violation of the constitutional limits of operation of the novel Administrative Board. It is therefore important to investigate the nature of its institutional space, as this is not clearly defined in the text of its Charter. This paper therefore proposes, through the study of the characteristics of the National Council of Justice and its powers specified in the Constitution, to demarcate the constitutional boundaries of its operation.
\end{abstract}

KeYwords: Judiciary. National Council of Justice. Characteristics. Competencies. Limits. 


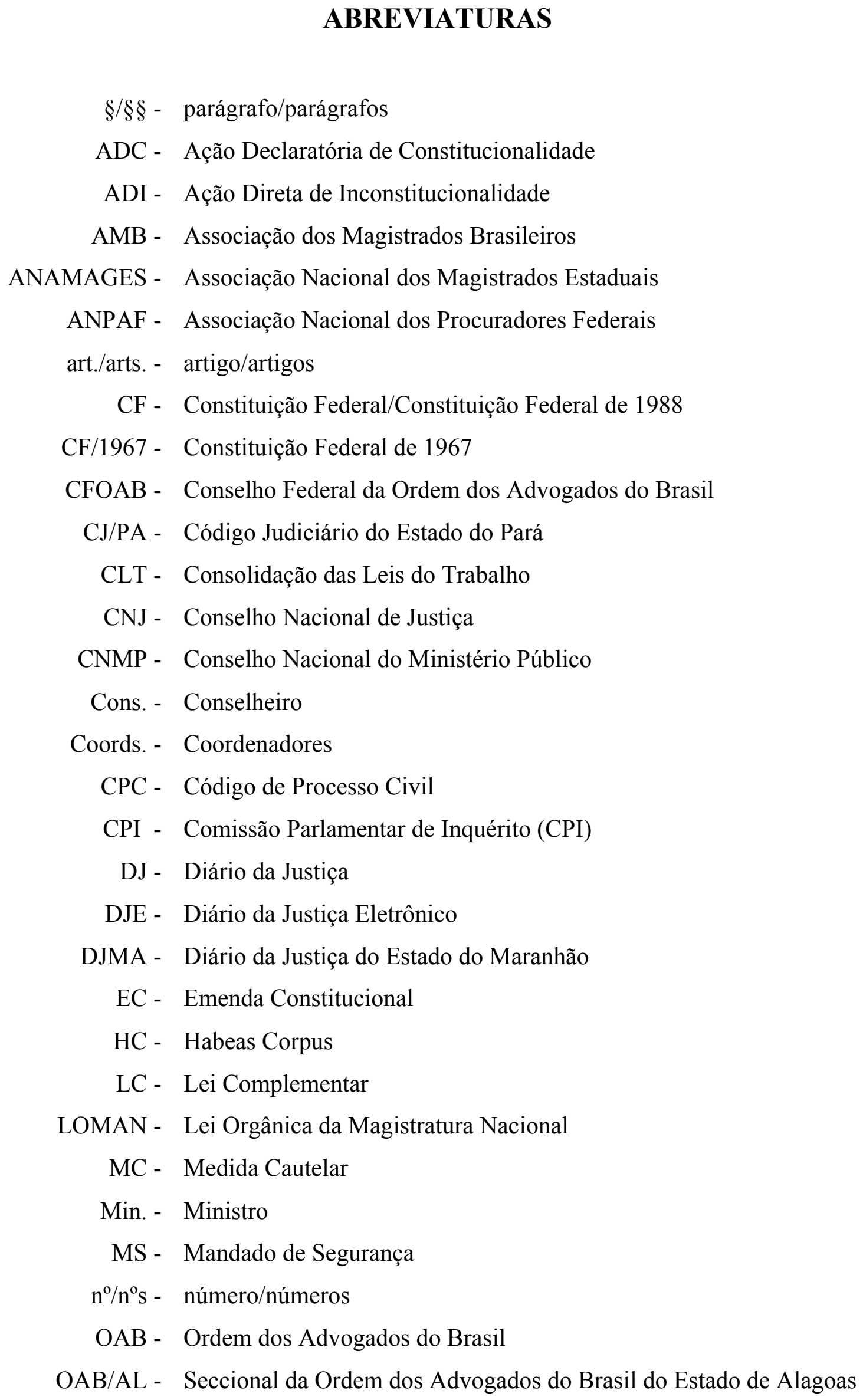


OAB/BA - Seccional da Ordem dos Advogados do Brasil do Estado da Bahia

OBS. - Observação

p./pp. - página/páginas

PCA - Procedimento de Controle Administrativo

PEC - Proposta de Emenda Constitucional

PGR - Procurador-Geral da República

PP - Pedido de Providências

Prov. - Provimento

PSC - Partido Social Cristão

Rcl. - Reclamação

Rel. - Relator

RICNJ - Regimento Interno do Conselho Nacional de Justiça

RISTF - Regimento Interno do Supremo Tribunal Federal

RITRF3 - Regimento Interno do Tribunal Regional Federal da $3^{\text {a }}$ Região

RITSE - Regimento Interno do Tribunal Superior Eleitoral

RJ - Rio de Janeiro

SP - São Paulo

STF - Supremo Tribunal Federal

STJ - Superior Tribunal de Justiça

TCU - Tribunal de Contas da União

TJ - Tribunal de Justiça

TJBA - Tribunal de Justiça do Estado da Bahia

TJMA - Tribunal de Justiça do Estado do Maranhão

TJMG - Tribunal de Justiça do Estado de Minas Gerais

TJMT - Tribunal de Justiça do Estado do Mato Grosso

TJRJ - Tribunal de Justiça do Estado do Rio de Janeiro

TJSE - Tribunal de Justiça do Estado de Sergipe

TJSP - Tribunal de Justiça do Estado de São Paulo

TRE/RS - Tribunal Regional Eleitoral do Rio Grande do Sul

TRE/TREs - Tribunal Regional Eleitoral/Tibunais Regionais Eleitorais

TRT - Tribunal Regional do Trabalho

TRT23 - Tribunal Regional do Trabalho da $23^{\mathrm{a}}$ Região

TSE - Tribunal Superior Eleitoral 


\section{SUMÁRIO}

INTRODUÇÃO .................................................................................................................. 18

OBJETO DA INVESTIGAÇÃO E MÉTODO ADOTADO....................................21

1. Delimitação do objeto da investigação ................................................................ 21

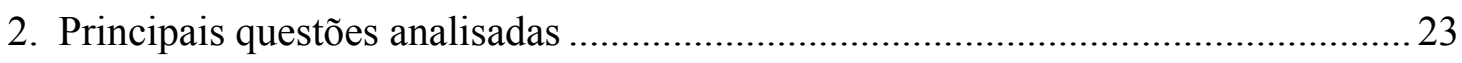

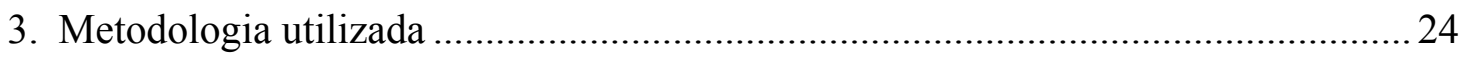

1. CAPÍTULO 1 - ANTECEDENTES HISTÓRICOS ...............................................227

1.1. A origem dos Conselhos Superiores da Magistratura.........................................2 27

1.2. O primeiro Conselho do Brasil: Conselho Nacional da Magistratura ................... 30

1.3. A origem do Conselho Nacional de Justiça ........................................................ 33

\section{CAPÍTULO 2 - LIMITES DECORRENTES DOS ELEMENTOS} CONSTITUCIONAIS CARACTERÍSTICOS DO CNJ .......................................... 41

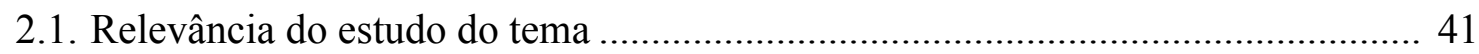

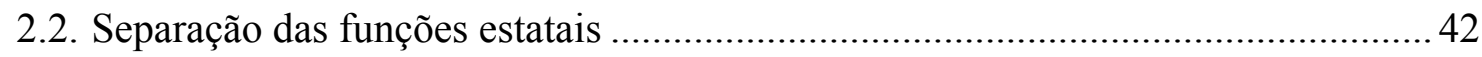

2.3. Os elementos constitucionais característicos do Conselho Nacional de Justiça..... 46

2.3.1. Órgão integrante do Poder Judiciário.......................................................... 52

2.3.1.1.Estudo de norma: Resolução CNJ n ${ }^{\circ}$ 140/2011 - Invasão de competência do Poder Legislativo .......................................................... 56

2.3.1.2. Estudo de norma: RICNJ, art. 11, $\S 4^{\circ}$ - Violação da "quarentena"

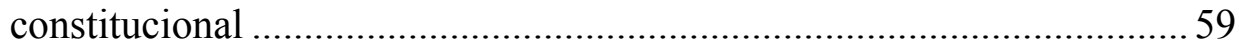

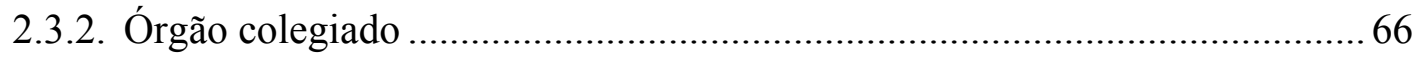

2.3.2.1. A estrutura do Conselho Nacional de Justiça ....................................... 66

2.3.2.1.1. Estudo de norma: RICNJ, art. $9^{\circ}, \S 6^{\circ}-$ Alteração de critérios para composição do $\mathrm{CNJ}$........................................................... 70

2.3.2.2. Princípio da colegialidade e delegação de competências ...................... 72

2.3.2.2.1. Estudo de norma: RICNJ, arts. $6^{\circ}$, XXVI, e 25, XI - Reexame necessário pelo Plenário de decisões monocráticas singulares ...... 82

2.3.2.2.2. Estudo de norma: RICNJ, arts. $115, \S 1^{\circ}-$ Restrições à interposição de recursos administrativos ao Plenário 
2.3.3. Órgão de controle

2.3.3.1.Estudo de norma: Resolução CNJ nº 130/2011 - Fixação de horário uniforme de expediente forense

2.3.4. Órgão que realiza controle interno 116

2.3.4.1. Casuística: impossibilidade de controle de ex-juiz no exercício da advocacia e de ato de governador de Estado 123

2.3.5. Órgão que exerce controle da atuação administrativa e financeira do Poder Judiciário 127

2.3.5.1. Impossibilidade do CNJ exercer controle da jurisdição 128

2.3.5.1.1. Casuística: alteração de acordo judicial e retirada de eficácia de decisões proferidas em writs pelo CNJ.

2.3.5.2. Limitações ao controle sobre funções atípicas desempenhadas no Judiciário 147

2.3.5.2.1. Estudo de norma: Resoluções CNJ nos 48/2007 e 88/2009 Controle sobre iniciativa de lei 166

2.3.6. Órgão que também se ocupa do controle do cumprimento dos deveres funcionais dos juízes 175

2.3.6.1. Casuística: punição de magistrado por comportamento incompatível com o decoro de suas funções

2.3.7. Órgão de sobreposição 195

2.3.7.1. Não sujeição do STF ao controle do CNJ. 196

2.3.7.1.1. Casuística: não conhecimento de pleitos relativos ao STF. 200

2.3.7.1.2. Casuística: representações contra o PGR no CNMP .203

2.3.7.2. Não sujeição do TSE ao controle do CNJ 205

2.3.7.3. Não sujeição parcial da Justiça Eleitoral ao controle do CNJ 212

2.3.7.3.1. Casuística: requisição de servidores pelo TRE/RS.

2.3.7.4. Impossibilidade de controle das sentenças normativas trabalhistas .... 224

2.3.7.5. Sujeição dos membros do $\mathrm{CNJ}$ ao controle do Colegiado 228

2.3.7.5.1. Estudo de norma: Resolução CNJ no 135/2011, art. $1^{\circ}$ Injustificado silêncio eloquente

2.4. Nosso conceito para o $\mathrm{CNJ}$

\section{CAPÍTULO 3 - LIMITES DECORRENTES DAS COMPETÊNCIAS CONSTITUCIONAIS ESPECÍFICAS DO CNJ


3.1. Competências constitucionais específicas do CNJ

3.1.1. Guarda da autonomia do Poder Judiciário

3.1.1.1. Estudo de norma: RICNJ, art. $4^{\circ}$ e $8^{\circ}$ - Provisoriedade da autodisciplina de funcionamento e de atribuições do Ministro-Corregedor.. 244

3.1.1.2. Estudo de norma: Resolução CNJ no 185/2013 - Sistema único de processo judicial eletrônico. 246

3.1.2. Guarda do cumprimento do Estatuto da Magistratura 250

3.1.2.1.Estudo de norma e casuística: LOMAN, art. 102 - Eleição de cargos diretivos nos tribunais 252

3.1.3. Guarda da observância dos princípios e regras da administração pública .. 260

3.1.4. Controle da legalidade dos atos administrativos praticados por membros ou órgãos do Poder Judiciário 277

3.1.4.1.Limite temporal para atuação do CNJ ................................................ 278

3.1.4.2. Controle sobre o ato discricionário.................................................... 281

3.1.4.3. Não sujeição do CNJ ao TCU.............................................................. 283

3.1.4.4. Impossibilidade do CNJ exercer controle de constitucionalidade ....... 286

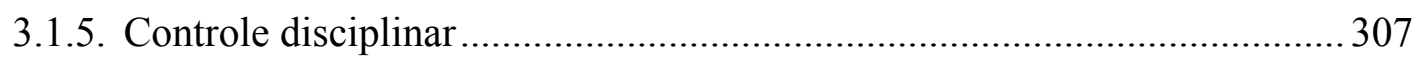

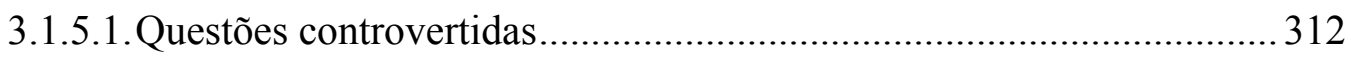

3.1.5.1.1. Ampla defesa e sanções aplicáveis nas revisões de processos

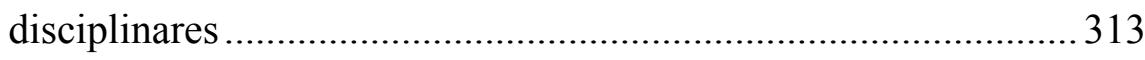

3.1.5.1.2. Motivação e publicidade nos julgamentos disciplinares ........... 315

3.1.5.1.3. Quórum qualificado para imposição de qualquer punição

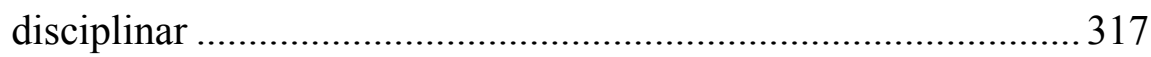

3.1.5.1.4. Tramitação concomitante de processos disciplinares ................ 322

3.1.5.1.5. Impossibilidade de instauração de processo disciplinar ulterior ao julgamento de correlato no tribunal local .................................... 325

3.1.5.1.6. Impossibilidade de revisão dos próprios processos

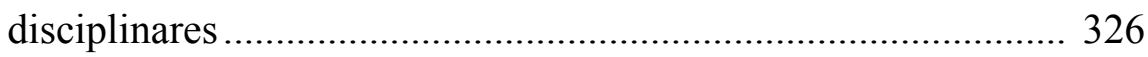

3.1.5.1.7. Termo inicial de contagem do prazo para revisão de processos



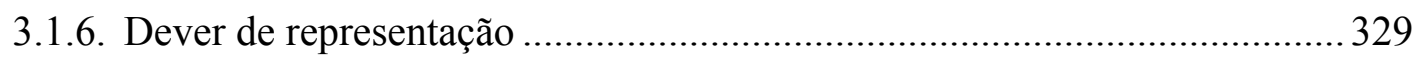

3.1.6.1.Estudo de norma: RICNJ, art. $4^{\text {o }}$, VII - Não discriminação de hipóteses de representação 
3.1.7. Dever de elaboração de relatórios com proposta de providências ao parlamento

3.1.7.1. Estudo de norma: Resolução CNJ no 66/2009 - Requisitos extravagantes na apreciação do auto de prisão em flagrante ................. 336

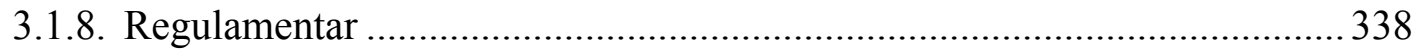

3.2. Competências constitucionais específicas do Corregedor Nacional de Justiça.... 354

3.2.1. Recebimento de reclamações e denúncias 355

3.2.2. Exercício de funções executivas de inspeção e correição 359

3.2.3. Requisição e designação de magistrados e servidores 360

3.2.4. Outras competências previstas no RICNJ 363

3.2.4.1. Estudo de norma: RICNJ, arts. $4^{\circ}, \mathrm{XV}$, e $8^{\circ}, \mathrm{V}$ - Impossibilidade de quebra de sigilo bancário e fiscal pelo $\mathrm{CNJ}$ 365

4. CAPÍtulo 4 - O CONTROLE JURISDiCiONAL DA ATUAÇÃo DO CONSELHO NACIONAL DE JUSTIÇA PELO SUPREMO TRIBUNAL FEDERAL 


\section{INTRODUÇÃO}

O Conselho Nacional de Justiça nasceu a partir da Emenda Constitucional $\mathrm{n}^{\mathrm{o}}$ 45, de 30 de dezembro de 2004, ante os anseios da sociedade por organização, estruturação, transparência, sistematização, moralidade e disciplina nos diversos órgãos do Poder Judiciário.

Práticas ilícitas, nepotismo, falta de gestão eficiente e transparente, gastos exagerados e não planejados, isolamento interno e externo, incapacidade de planejamento coordenado, abuso de poder, morosidade processual foram, entre outros, motivos que levaram a sociedade a clamar pela criação de um órgão central de controle administrativo, financeiro e disciplinar no âmbito do Poder Judiciário.

A resposta veio, após anos de discussão, com a reforma constitucional no final de 2004 e a instituição do Conselho Nacional de Justiça, órgão político-administrativo de alcance nacional, integrante da estrutura do Poder Judiciário Brasileiro, responsável pelo controle de sua atuação administrativa e financeira e pelo cumprimento dos deveres funcionais dos juízes.

A constitucionalidade dos dispositivos da emenda que instituíram o Conselho foi prontamente contestada, através da Ação Direta de Inconstitucionalidade n ${ }^{\circ}$ 3367, ajuizada pela Associação dos Magistrados Brasileiros antes mesmo da publicação oficial da espécie normativa reformadora. O Supremo Tribunal Federal, ao julgar essa ação direta, além de reconhecer a constitucionalidade do Conselho, apresentou diversos elementos para fixar os limites de sua atuação.

Decorridos quase dez anos da sua instalação - o Conselho Nacional de Justiça foi instalado em 14 de junho de 2005 -, muitos avanços são percebidos em todas as esferas da Justiça Brasileira. A centralização de questões administrativas e financeiras em órgão de sobreposição permitiu planejamento adequado e coordenado das ações do Poder Judiciário, antes atomizado em quase uma centena de unidades. A busca pela transparência e pelo aprimoramento das atividades judiciais revelou dificuldades e mazelas na Justiça e norteou a atuação de seus órgãos para melhora na qualidade dos serviços judiciários. A adoção de medidas preventivas e a repressão a condutas imorais e ilícitas foi aplaudida pela sociedade e resgatou a moralidade no seio deste Poder.

Somente através de sua principal atuação normativa, concretizada pela expedição de resoluções de alcance nacional, o Conselho Nacional de Justiça regrou diversas questões essenciais afetas à Justiça como a vedação ao nepotismo, a definição de parâmetros de 
interoperabilidade nos sistemas de informação, a fixação de horário de expediente forense, a regulamentação de direitos e deveres dos magistrados, a uniformização de normas relativas ao procedimento disciplinar aplicável aos juízes e a instituição e norteamento da gestão estratégica dos tribunais.

Inúmeras, também, foram as decisões em procedimentos administrativos (processos disciplinares, procedimentos de controle administrativo, pedidos de providências, reclamações) que impuseram sanções a magistrados e servidores por desvios de conduta.

Mas o atuar do Conselho não ficou imune a críticas, a maior parte delas oriunda do próprio Poder Judiciário: violação da independência funcional dos magistrados, restrição de direitos, invasão de competências de outros órgãos, prática de atos jurisdicionais, abuso no controle disciplinar foram, entre outras, condutas internamente contestadas na atuação do Colegiado Administrativo.

De outra banda, instituições externas também desaprovaram práticas do Conselho, principalmente quando agiu na defesa da autonomia da Magistratura ou para resguardar direitos dos magistrados. Também houve, nesta seara, questionamentos de atos normativos do Colegiado que supostamente ocuparam esfera reservada à lei.

Assim, mesmo após o reconhecimento da constitucionalidade do órgão, centenas de demandas foram propostas no Supremo Tribunal Federal para questionar suas decisões, emanadas do Colegiado ou de seu membros singularmente.

Constata-se que a Emenda Constitucional n 45/2004 não balizou, de forma clara, os limites das competências do Conselho Nacional de Justiça. Essas fronteiras, pois, ora são marcadas, pontualmente, pela doutrina, e ora são estabelecidas nos julgados do Supremo Tribunal Federal.

Não há, porém, uma sistematização do assunto.

Procurou-se, pois, realizar uma investigação aprofundada do tema, com a definição do exato campo de atuação constitucional do Conselho Nacional de Justiça, para, com isso, evitar que suas deliberações confrontem os superiores ditames do Estatuto Fundamental.

O desafio imposto demandou a procura de respostas claras a várias indagações:

Pode o CNJ controlar a constitucionalidade das leis? Pode exercer poder normativo primário? Suas deliberações podem suspender ou modificar decisões judiciais? Os atos do Conselho podem atingir pessoas e entidades estranhas à Justiça? Os membros do Colegiado podem agir e decidir monocraticamente?

Para responder essas e outras questões, este trabalho buscou a fixação dos limites constitucionais de atuação do Conselho Nacional de Justiça. Identificados, ainda se 
examinou como é exercido o controle jurisdicional dos atos do Conselho pelo Supremo Tribunal Federal. 


\section{OBJETO DA INVESTIGAÇÃO E MÉTODO ADOTADO}

\section{Delimitação do objeto da investigação}

A pesquisa investigou, observadas as restrições de uma dissertação de mestrado, os limites constitucionais de atuação do Conselho Nacional de Justiça.

O objetivo do trabalho, pois, foi sistematizar, dentro das largas competências atribuídas ao Conselho Nacional de Justiça, quais são os limites constitucionais de sua atuação e, delineados esses marcos, verificar como é exercido o controle jurisdicional daqueles que os extrapolem.

Apesar de indiscutível relevância, não houve análise casuística de cada um dos atos praticados pelo Conselho Nacional de Justiça, mas, para ilustrar os diversos assuntos abordados, procurou-se buscar exemplos concretos de sua atuação.

Importa, pois, desde logo, estabelecer o que se entende, neste trabalho, por "limites constitucionais de atuação do Conselho Nacional de Justiça".

Para esta investigação, concebeu-se a expressão "limites constitucionais" como a demarcação da esfera de competência constitucional conferida ao Conselho Nacional de Justiça para cumprimento de sua elevada missão. Ultrapassados os "limites constitucionais", o ato praticado pelo Conselho fica maculado de inequívoca inconstitucionalidade $^{1}$, pois invade competência exclusiva atribuída a outro agente ou órgão constitucional.

Como ensina J. J. Gomes Canotilho (2003, p. 543),

Por competência entender-se-á o poder de acção e de actuação atribuído aos vários órgãos e agentes constitucionais com o fim de prosseguirem as tarefas de que são constitucional ou legalmente incumbidos.

A competência envolve, por conseguinte, a atribuição de determinadas tarefas bem como os meios de acção ("poderes") necessários para a sua prossecução. Além disso, a competência delimita o quadro jurídico de actuação de uma unidade organizatória relativamente a outra.

\footnotetext{
${ }^{1}$ O termo "inconstitucionalidade", no contexto, foi utilizado, nas palavras de Elival da Silva Ramos (2010, p. 47), em sentido amplo, "como a relação de desconformidade entre um ato ou omissão, proveniente de pessoa pública ou privada, e a Constituição", apesar do próprio autor, citando Jorge Miranda (1996, p. 311), advertir que essa "fórmula tão ampla se revela de baixa operacionalidade, porquanto abarca regimes jurídicos muito diversos".
} 
Logo, não comportou proceder, neste trabalho, a minucioso cotejo da atuação do Conselho com as inúmeras regras previstas nos mais diversos atos normativos que formam a imensa teia jurídica do ordenamento brasileiro ${ }^{2}$, exceto quando estritamente necessário para a compreensão das ideias expostas. Procurou-se, porém, de forma mais intensa, analisar a atuação do Conselho Nacional de Justiça com as disposições previstas no texto constitucional e nas emendas constitucionais, ainda que, neste último caso, não tenham sido inseridas na Carta Política.

“Atuação", nesta dissertação, compreendeu todos os atos administrativos, normativos ou concretos, praticados pelo Conselho Nacional de Justiça, enquanto Colegiado, ou por algum de seus integrantes, singularmente. Não foi objeto de estudo, pois, qualquer omissão do Conselho Nacional de Justiça no cumprimento de seus deveres constitucionais.

Este trabalho ocupou-se da investigação dos limites constitucionais de atuação do "Conselho Nacional de Justiça". Assim, não se estudou seu órgão coirmão, o Conselho Nacional do Ministério Público (CNMP) ${ }^{3}$, ou qualquer outro conselho ${ }^{4}$ ou órgão regulador previsto na Constituição Federal (CF), exceto quando necessário para confronto com assuntos tratados sobre o Conselho do Poder Judiciário.

Quanto ao controle dos atos do Conselho Nacional de Justiça, cumpre observar que a pesquisa compreendeu-o como espécie de controle jurisdicional exercido pelo manejo de ações contra os atos do Conselho, partindo das disposições constitucionais sobre o tema

\footnotetext{
${ }^{2}$ Conforme notícia publicada no sítio eletrônico do "O Globo" em 18 de junho de 2011, apenas "de 2000 a 2010, o país criou 75.517 leis, somando legislações ordinárias e complementares estaduais e federais, além de decretos federais. Isso dá 6.865 leis por ano - o que significa que foram criadas 18 leis a cada dia, desde 2000. Mas, em vez de contribuir para a aplicação do Direito, boa parte dessa produção só serviu para agravar os problemas da máquina judiciária. A maioria das leis é considerada inconstitucional e acaba ocupando ainda mais os tribunais com a rotina de descartá-las. Outras, mesmo legítimas, viram letra morta, pois o juiz as desconhece ou prefere simplesmente ignorá-las. E outras têm a relevância de, por exemplo, criar o Dia da Joia Folheada ou a Semana do Bebê" (DUARTE, Alessandra; OTAVIO, Chico. Brasil faz 18 leis por dia, e a maioria vai para o lixo. $O$ Globo, Rio de Janeiro, 18.06.2011. Disponível em: $<$ http://oglobo.globo.com/politica/brasil-faz-18-leis-por-dia-a-maioria-vai-para-lixo-2873389>. Acesso em 23.06.2013).

${ }^{3}$ O Conselho Nacional do Ministério Público também foi introduzido no Ordenamento Jurídico Brasileiro pela Emenda Constitucional n ${ }^{\circ}$ 45/2004, que incluiu o art. 130-A no texto da Lei Maior. Suas competências são semelhantes às atribuídas ao Conselho Nacional de Justiça, sendo presidido pelo Procurador-Geral da República.

${ }^{4}$ A Constituição Federal confere e disciplina competências administrativas a outros quatro Conselhos, além do CNJ e do CNMP: a) Conselho da Repúbica (arts. 89 e 90); b) Conselho de Defesa Nacional (art. 91); c) Conselho da Justiça Federal (art. 105, parágrafo único, II); e, d) Conselho Superior da Justiça do Trabalho (art. 111-A, § $2^{\circ}$, II).
} 
(CF, art. 102, I, "a" e "r", e III), ainda que importe também em controle político, no sentido da expressão apresentado por Karl Loewenstein (2000, pp. 39 a 50) .

Procurou-se, nesse ponto, analisar quais os meios de impugnação utilizados para questionamento judicial dos atos praticados pelo Conselho Nacional de Justiça e as orientações emanadas do Supremo Tribunal Federal, sem preocupação, todavia, com aspectos estritamente processuais, salvo quando necessários para esclarecimento de alguma questão constitucional relevante.

Não foram investigadas quaisquer outras espécies de limitações ou controles do Conselho Nacional de Justiça, apesar do Constituinte Reformador, ao instituí-lo, não se descurar de também estabelecer um sistema de contrabalanço político em relação ao órgão: a) a composição do Conselho é rotativa, pois seus membros exercem mandato de dois anos, admitida uma recondução; b) a formação do Colegiado depende da participação dos outros Poderes e Instituições da República, seja quanto à indicação de parte de seus membros $^{6}$, seja pela sabatina a que são submetidos perante o Senado Federal $^{7}$, seja pela nomeação, acometida ao Presidente da República; e, c) os Conselheiros sujeitam-se a processo de impeachment perante o Senado Federal.

\section{Principais questões analisadas}

Para o estudo das fronteiras constitucionais de atuação do Conselho Nacional de Justiça foram, inicialmente, analisados os antecedentes históricos e a origem do Colegiado.

$\mathrm{Na}$ sequência, após discorrer sobre a separação de poderes, passou-se ao exame detalhado dos limites de atuação do órgão decorrentes dos seus elementos constitucionais característicos.

\footnotetext{
${ }^{5}$ Conhecida a proposta de Karl Loewenstein $(2000$, p. 40) de uma nova divisão tripartite das funções do Poder: a) projeto ou determinação política fundamental; b) execução da decisão política; e, c) controle político. No idioma natal do doutrinador (tradução de Rüdiger Boerner): Im folgenden wird eine neue Dreiteilung zur Debatte gestellt: die politische Gestaltungs - oder Grundentscheidung (policy determination), die Aus- oder Durchführung der Grundentscheidung (policy execution) und die politische Kontrolle (policy control).

${ }^{6}$ Dos quinze membros do Conselho Nacional de Justiça seis não integram órgãos do Poder Judiciário: a) dois são indicados pelos Procurador-Geral da República, um proveniente do Ministério Público da União e outro oriundo do Ministério Público Estadual; b) dois são apontados pelo Conselho Federal da Ordem dos Advogados do Brasil, dentre advogados; c) dois são indicados pelas Casas Legislativas Federais, um pela Câmara dos Deputados e outro pelo Senado Federal, dentre cidadãos de notável saber jurídico e reputação ilibada.

${ }^{7}$ Com exceção do Presidente do Supremo Tribunal Federal que, de todo modo, sujeitou-se à arguição no Senado Federal quando indicado para a Corte Suprema, nos termos do art. 101, parágrafo único, da Constituição.
} 
Depois, foram investigados, de forma minudente, os limites de atuação derivados de das competências constitucionais específicas do Conselho e do Corregedor Nacional de Justiça.

Posteriormente, tratou-se do controle jurisdicional dos atos do Conselho Nacional de Justiça pelo Supremo Tribunal Federal.

Por fim, foram expostas as conclusões deste trabalho.

\section{Metodologia utilizada}

A presente pesquisa objetivou, através de exploração, proporcionar maior familiaridade com o tema a ser tratado, permitindo, inclusive, aplicações práticas das conclusões obtidas.

A investigação dos limites de atuação do Conselho Nacional de Justiça importa na compreensão de sua origem, na interpretação dos textos normativos constitucionais que cuidam do órgão e na pesquisa das decisões proferidas pelo Supremo Tribunal Federal no exercício do controle dos seus atos.

Também não se pode precindir do conhecimento doutrinário apresentado em relação ao próprio Colegiado e referente a questões nucleares e gravitacionais vinculadas à definição dos seus limites constitucionais de atuação.

Interessa também observar que, devido à subárea de concentração, o trato do tema foi realizado pelo enfoque do Direito Constitucional. Mas, ante a natureza da instituição em exame, não se pode recusar as contribuições do Direito Administrativo e, por esse motivo, uma abordagem interdisciplinar dos problemas jurídicos foi, muitas vezes, inevitável, para impedir conclusões míopes e parcelares. Como explica André Salgado de Matos (2004, p. 59),

\footnotetext{
A perspectiva metodológica a adoptar perante determinado problema jurídico não deve ser qualquer uma que seja meramente possível. Deve, por força de um constitucionalmente fundado imperativo de racionalidade, ser a mais adequada à compreensão e explicação do objecto da análise.
}

A dissertação partiu da exposição dos antecedentes históricos e da origem do Conselho Nacional de Justiça. Para tanto, valeu-se da pesquisa de textos normativos históricos, notícias publicadas na imprensa e escritos doutrinários. 
Em seguida, passou-se à específica apresentação dos limites constitucionais de atuação do Conselho Nacional de Justiça, o que foi realizado em dois distintos capítulos.

Cumpre observar que, diante das inúmeras possibilidades de abordagem do tema ${ }^{8}$, optou-se por estudar os limites constitucionais de atuação do Conselho Nacional de Justiça em dois círculos concêntricos, de dentro para fora, partindo-se da análise dos limites oriundos da própria essência do órgão para, em seguida, proceder à investigação das limitações decorrentes de suas competências constitucionais. A todo instante esse método foi informado pelo exame da incidência de princípios e regras constitucionais, da palavra da doutrina e da visão da jurisprudência, sobretudo do Pretório Excelso9 .

Assim, primeiro foram extraídos os conteúdos das normas constitucionais e delineados os elementos característicos do CNJ para, a partir de cada um deles, serem apresentados os limites constitucionais de atuação do órgão. Para tanto, fez-se necessário estudo prévio das funções estatais. Fundamental, nesse capítulo, foi também cotejar a palavra da doutrina com o texto da Carta Política e a jurisprudência do Supremo Tribunal Federal. E, para sedimentar as conclusões extraídas, socorreu-se de exemplos decorrentes da investigação de casos concretos, do exame de textos normativos expedidos pelo Conselho, em especial das disposições constantes de seu Regimento Interno e das suas diversas resoluções, e de decisões proferidas pelo Colegiado ou por seus membros singularmente em diversos procedimentos administrativos.

\footnotetext{
${ }^{8} \mathrm{O}$ estudo dos limites constitucionais de atuação do CNJ poderia ser feito, por exemplo, através do cotejo de cada dispositivo da Constituição Federal com atos do órgão ou partindo-se da exposição dos mais relevantes temas de Direito Constitucional para, em seguida, direcionar a pesquisa ao Colegiado. Esses métodos, no entanto, na nossa concepção, não teriam como ponto central de estudo o próprio Conselho e demandariam complexa análise de muitos temas, inviável ante as restrições impostas a uma dissertação de mestrado.

${ }^{9}$ Considerou-se, pois, que os limites decorrentes das características constitucionais do CNJ estão englobados por aqueles oriundos de suas competências e ambos são informados pelos princípios e comandos constitucionais, não sendo o contrário, porém, necessariamente verdadeiro. Dois exemplos podem ilustrar o afirmado: 1) Se, singularmente, conselheiro do CNJ expede ato normativo para zelar pela autonomia do Poder Judiciário, há infringência de limite constitucional à atuação do conselho decorrente da não observância um de seus elementos característicos (no caso, por se tratar de um colegiado, as deliberações normativas do CNJ devem ser feitas pelo seu Plenário) e, por consequência, há transgressão das fronteiras das competências constitucionais específicas atribuídas ao CNJ (se compete ao Conselho expedir atos regulamentares para zelar pela autonomia do Poder Judiciário, não pode um de seus membros fazê-lo monocraticamente) e também violação de comando constitucional expresso (no caso, a norma inserta no art. 103-B, $\S 4^{\circ}$, I, da Constituição Federal). 2) Se o Plenário do CNJ expede ato regulamentar para viabilizar o exercício de sua competência disciplinar sobre os magistrados, atribuindo-se o poder de requisitar de autoridades informações, exames, perícias ou documentos sigilosos para esclarecimento de procedimento de sua competência (RICNJ, art. $\left.4^{\circ}, \mathrm{XV}\right)$, não há infringência de limite decorrente de elemento constitucional característico do Conselho ou da não observância de uma de suas competências constitucionais específicas, mas não se pode deixar de analisar o teor do ato normativo à luz da garantia fundamental consistente na proteção à intimidade e no sigilo de dados se, com base nessa norma, o órgão requisitar informações bancárias ou fiscais do investigado (CF, art. $5^{\circ}, \mathrm{X}$ e XII).
} 
Depois, em outro capítulo, através do mesmo método, foram analisadas as competências constitucionais específicas do Conselho Nacional de Justiça e do seu Ministro-Corregedor. Com base nesse estudo, estabeleceram-se outras fronteiras de atuação do colegiado. Também aqui foram expostos variados exemplos para elucidar as ideias alcançadas.

Sedimentados os limites constitucionais de atuação do Conselho Nacional de Justiça com base no método de pesquisa apresentado, foi dedicado um capítulo para explorar o exercício do controle jurisdicional dos seus atos pelo Pretório Excelso. Em seguida, foram apresentadas as conclusões sobre o tema abordado. 


\section{CAPÍTULO 1 - ANTECEDENTES HISTÓRICOS}

\subsection{A origem dos Conselhos Superiores da Magistratura}

Os primeiros Conselhos Superiores da Magistratura com poderes administrativos e decisórios surgiram na França e na Itália, respectivamente em 1946 e 1947, para garantir a independência do Judiciário, ocupar-se de sua administração e organização, selecionar candidatos para seus postos, cuidar da carreira dos magistrados e exercer poder disciplinar.

A história da França revela que a Revolução do Século XVIII foi, em parte, provocada pela desconfiança que pesava sobre os juízes da época, vistos, como assinala Dalmo de Abreu Dallari (1996, pp. 14 e 15), como defensores do ancien régime pelo povo (para quem vendiam a prestação jurisdicional) e considerados perniciosos pelo governo (pois, para auferirem vantagens pessoais (recebimento de valores para a prestação juridicional) interferiam, com suas decisões, em assuntos do Executivo e do Legislativo), o que levou, no período revolucionário, como pontuado por José Adércio Leite Sampaio (2007, p. 178), a uma radicalização da interpretação do princípio da separação de poderes de Montesquieu, visto sob a lente de Rosseau, e implicou na supervalorização do Poder Legislativo, no reconhecimento do Executivo como poder independente e na mera especialização da função judicial. Os juízes passaram a ser agentes públicos sujeitos a mandato e eleições, encarregados apenas de ser a bouche de la loi, ou seja, de somente aplicar mecanicamente a lei aos casos concretos ${ }^{10}$.

Posteriormente, no período napoleônico, os juízes passaram a ser considerados funcionários públicos, submetidos ao Ministro da Justiça (SAMPAIO, 2007, p. 179) ${ }^{11}$.

A partir de 1814, os magistrados franceses passaram a ser nomeados pelo Poder Executivo. Primeiro pelo Rei (arts. 13 e 57 da Constituição Francesa de 1814) ${ }^{12}$ e depois,

\footnotetext{
${ }^{10}$ A Constituição Francesa de 1791 (Título III, Capítulo V, art. $3^{\circ}$ ) proibia os tribunais de interferirem no exercício do Poder Legislativo, suspender a execução das leis, ou assumir funções administrativas (Les tribunaux ne peuvent, ni s'immiscer dans l'exercice du pouvoir législatif, ou suspendre l'exécution des lois, ni entreprendre sur les fonctions administratives, ou citer devant eux les administrateurs pour raison de leurs fonctions).

${ }^{11}$ Constava nos artigos 78 a 81, do Título IX, da Constituição Francesa do ano X (Constitution de l'an X) de 1802:

Article 78. Il y a un grand-juge ministre de la justice.

Article 79. Il a une place distinguée au Sénat et au Conseil d'État.

Article 80. Il préside le tribunal de cassation et les tribunaux d'appel, quand le Gouvernement le juge convenable.

Article 81. Il a sur les tribunaux, les justices de paix et les membres qui les composent, le droit de les surveiller, et de les reprendre.
} 
com a II ${ }^{\mathrm{a}}$ República $^{13}$, pelo Presidente (arts. 43 e 85 da Constitution du 4 novembre $1848)^{14}$.

Somente em 1946, com a criação do Conseil supérieur de la magistrature na IV República Francesa, iniciou-se o processo político, ainda que parcial, para independência e autonomia do Judiciário (arts. 83 e 84 da Constituição da IV ${ }^{a}$ República) ${ }^{15}$.

Maurice Duverger (1985, p. 434) assinala que a instituição criada na França em $1946^{16}$ passou a promover a independência do Judiciário através do exercício do poder disciplinar sobre os juízes e da indicação de magistrados para nomeação pelo Presidente da

${ }^{12}$ Article 13. La personne du Roi est inviolable et sacrée. Ses Ministres sont responsables. Au Roi seul appartient la puissance exécutive.

Article. 57. Toute justice émane du Roi. Elle s'administre en son nom par des juges qu'il nomme et qu'il institue.

${ }^{13}$ Com apoio em Maurice Duverger (1985, pp. 17 a 186) pode-se sintetizar cronologicamente os diversos sistemas políticos da França após o período revolucionário da seguinte forma: 1) Monarquia limitada (1789 a 1791); 2) I' República (1792 a 1799); 3) Consulado e Primeiro Império (1799 a 1814); 4) Monarquias Semiparlamentares (Restauração e Monarquia de Julho) (1814 a 1848); II ${ }^{a}$ República (1848-1851); Segundo Império (1852-1870); III ${ }^{\mathrm{a}}$ República (1870-1940); Regimes Provisórios (Governo de Vichy e França Livre) (1940-1945); IV República (1944-1958); e, Vª República (1958 até nossos dias).

${ }^{14}$ Article 43. Le peuple français délègue le Pouvoir exécutif à un citoyen qui reçoit le titre de président de la République.

Article 85. Les juges de paix et leurs suppléants, les juges de première instance et d'appel, les membres de la Cour de cassation et de la Cour des comptes, sont nommés par le président de la République, d'après un ordre de candidature ou d'après les conditions qui seront réglées par les lois organiques.

${ }^{15}$ Article 83. Le Conseil supérieur de la magistrature est composé de quatorze membre:

- le président de la République, président;

- le garde des sceaux, ministre de la justice, vice-président;

- six personnalités élues pour six ans par l'Assemblée nationale, à la majorité des deux tiers, en dehors de ses membres, six suppléants étant élus dans les mêmes conditions;

- six personnalités désignées comme suit : quatre magistrats élus pour six ans, représentant chacune des catégories de magistrats, dans les conditions prévues par la loi, quatre suppléants étant élus dans les mêmes conditions ; deux membres désignés pour six ans par le président de la République en dehors du Parlement et de la magistrature, mais au sein des professions judiciaires, deux suppléants étant élus dans les mêmes conditions.

Les décisions du Conseil supérieur de la magistrature sont prises à la majorité des suffrages. En cas de partage des voix, celle du président est prépondérante.

Article 84. Le président de la République nomme, sur présentation du Conseil supérieur de la magistrature, les magistrats, à l'exception de ceux du parquet.

Le Conseil supérieur de la magistrature assure, conformément à la loi, la discipline de ces magistrats, leur indépendance et l'administration des tribunaux judiciaires.

Les magistrats du siège sont inamovibles.

${ }^{16} \mathrm{O}$ Conseil supérieur de la magistrature foi mantido pelo artigo 65 da Constituição Francesa de $1958\left(\mathrm{~V}^{\mathrm{a}}\right.$ República), dispositivo alterado primeiro pela Lei Constitucional n ${ }^{\circ}$ 93-952, de 27 de julho de 1993 e depois pela Lei Constitucional $n^{\circ}$ 2008-724, de 23 de julho de 2008. A independência do Judiciário na França, porém, ainda não é plena. Em 1996, Dalmo de Abreu Dallari (1996, p. 16) já observava que a Constituição da $V^{a}$ República utiliza a expressão "autoridade judiciária" em vez de "Poder Judiciário", a demonstrar "que na França perdura uma herança histórica que não é favorável à equiparação do Judiciário aos demais poderes do Estado nem à independência real dos juízes". Mesmo após as últimas reformas constitucionais, não houve mudança da locução utilizada para designação do Judiciário na Carta Política Francesa. 
República, que poderia recusar os nomes propostos, mas não lhe era facultado nomear outros não indicados pelo Conseil supérieur ${ }^{17}$.

Já na Itália houve, no início do século XX, um Consiglio superiore della magistratura, criado pela Lei $\mathrm{n}^{\circ}$ 511, de 14 de julho de 1907, também denominada de "Lei Orlando" ${ }^{\prime 18}$, porém com funções apenas consultivas ${ }^{19}$.

Mas o Consiglio superiore della magistratura italiano instituído com poderes administrativos, para trazer independência ao Poder Judiciário, surgiu com Constituição Italiana de 22 de dezembro de 1947, que conferiu ao órgão competência para recrutamento, nomeação, transferência, promoção e disciplina dos magistrados ${ }^{20}$.

Posteriormente, conselhos semelhantes foram concebidos em outros Estados da Europa Ocidental ${ }^{21}$, como Grécia (1975), Suécia (1975), Portugal (1976), Espanha (1978), Andorra (1993), Bélgica (1998), Irlanda (1998) e Dinamarca (1999)²2.

\footnotetext{
${ }^{17}$ Nas palavras do Professor de Sorbonne: "Institution nouvelle, le Conseil supérieur de la Magistrature établi en 1946 disposait de deux moyens pour développer l'indépendance des magistrats. D'une part, il exerçait sur eux le pouvoir disciplinaire, lui seul pouvant les suspendre, les déplacer et les révoquer: mais ce pouvoir était auparavant exercé par la Cour de cassation, qui jouissait d'une grande indépendance. D'autre part, le Conseil supérieur proposait au Président de la République les nominations des magistrats du 'siège', c'est-à-dire des magistrats chargés de juger, les nomination des magistrats du "parquet" (juges d'instruction, procureurs, avocats généraux) restant à la discrétion du ministre de la Justice, traditionnellement appelé garde des Sceaux; ce pouvoir est essentiel en matière d'avancement, qui commande l'independánce des magistrats. Le Président de la Repúblique (c'est-à-dire le gouvernement, à l'époque) pouvait refuser de nommer les magistrats proposés, mais il ne pouvant nommer que des magistrats proposés".

${ }^{18}$ Disponível em: <http://augusto.digitpa.gov.it/gazzette/index/download/id/1907174_PM>. Acesso em 30.06.2013.

${ }^{19}$ Costantino Mortati (1958, pp. 813 a 815 ), ao tratar do Consiglio superiore della magistratura italiano e comentar os artigos 104, 105, 106, 107 e 110 da Constituição Italiana de 1947, reporta que o Conselho Superior da Magistratura surgido na Itália em 1907 era encarregado apenas de emitir pareceres nas promoções e remoções de magistrados. Nas suas palavras: "Un consiglio con tale denominazione già esisteva fin dal 1907, ed era stato [...] riformato sia con il far derivare tutti i suoi membri da elezioni di secondo grado dal consigli giudiziari costituiti presso ogni corte di appello, sia con il rendere obbligatorio il suo parere sulla promovibilità dei magistrati, e vincolante quello richiesto per potere rimuovere dalla loro sede quelli fra essi aventi funzioni giudicanti".

${ }^{20}$ Art. 105. Spettano al Consiglio superiore della magistratura, secondo le norme dell'ordinamento giudiziario, le assunzioni, le assegnazioni ed i trasferimenti, le promozioni e i provvedimenti disciplinari nei riguardi dei magistrati.

${ }^{21}$ A expressão "Europa Ocidental" foi utilizada por razões histórico-político-culturais que unem os Estados mencionados. Geograficamente, porém, segundo as Nações Unidas, somente a Bélgica, dentre todos os países citados, situa-se na Europa Ocidental. Grécia, Portugal, Espanha e Andorra situam-se na Europa Meridional. Suécia, Irlanda e Dinamarca localizam-se na Europa Setentrional (UNITED NATIONS. Composition of macro geographical (continental) regions, geographical sub-regions, and selected economic and other groupings. Disponível em: <http://unstats.un.org/unsd/methods/m49/m49regin.htm\#europe>. Acesso em 30.06.2013).

${ }^{22}$ José Adércio Leite Sampaio (2007, pp. 183 a 193) divide esses conselhos em dois grandes modelos. No primeiro, denominado pelo autor de "latino-europeu", que abrange os Conselhos da Magistratura da França, Itália, Espanha, Portugal, Bélgica e Andorra, "dominam os laços do Judiciário com o Executivo, cuidando mais das formas de ingresso da magistratura e das questões disciplinares". O segundo, denominado pelo doutrinador de "nórdico-europeu", que abrange os Conselhos da Suécia, Irlanda e Dinamarca, "caracteriza-se
} 
Esses conselhos, como afirma Alexandre de Moraes (2013b, pp. 531 e 532), surgiram em países "parlamentaristas ou semipresidencialistas [...] para ampliar a autonomia dos magistrados, diminuindo a ingerência política do Parlamento e do Primeiro-Ministro sobre o Judiciário", que perdurava desde a Revolução Francesa e somente se reduziu após os movimentos, pós Segunda Guerra Mundial, de democratização dos Estados europeus.

Diferentemente, no Brasil, cujo Judiciário já desfrutava de independência dos Poderes Executivo e Legislativo, pela inspiração do modelo de sistema político-governamental brasileiro no presidencialismo estadunidense ${ }^{23}$, o surgimento de órgãos semelhantes aos Conselhos Europeus de Magistratura deveu-se a outros motivos, conforme será a seguir analisado.

\subsection{O primeiro Conselho do Brasil: Conselho Nacional da Magistratura.}

O primeiro órgão administrativo colegiado criado no âmbito do Poder Judiciário Brasileiro para controle disciplinar dos atos dos juízes foi o Conselho Nacional da Magistratura, instituído pela Emenda Constitucional (EC) n n $^{\text {7 }}$, de 13 de abril 1977, à Constituição Federal de 1967 (CF/1967), já alterada pela Emenda Constitucional no 1, de 17 de outubro de $1969^{24}$.

Carlos Eduardo Thompson Flores Lenz (2007, p. 473) lembra que, à época, foi atendida sugestão de Comissão Especial do Supremo Tribunal Federal (STF), composta pelos Ministros Thompson Flores, Rodrigues Alckmin e Xavier de Albuquerque, incumbida de realizar estudo intitulado "Diagnóstico do Poder Judiciário", que concluiu ser necessária a criação de órgão superior, estruturado no Supremo Tribunal Federal, para, sem embargo das atividades fiscalizadoras das Corregedorias dos Tribunais, coibir

por ter o Judiciário uma relativa independência do Executivo e por assumir atribuições de autogoverno em sua quase plenitude".

${ }^{23}$ Desde o nacimento dos Estados Unidos da América houve uma preocuparação em erigir o Judiciário como um dos Poderes da República, ante o sistema de freios e contrapesos instituído naquele país, ficando o Poder Judiciário com uma função de controle e de equilíbrio entre o Executivo e o Legislativo. Dalmo de Abreu Dallari (1996, pp. 16 a 20) relata, com apoio em David N. Mayer (1994), as divergências de ideias de Thomas Jefferson e o juiz da Suprema Corte John Marshall sobre o papel dos juízes na recém formada nação norte-americana. Jefferson, apesar de manifestar posições ambíguas sobre o Judiciário, sempre foi favorável à independência dos juízes. E Marshall, por seu turno, em 1803, firmou o papel do Poder Judiciário como guardião da Constituição no famoso caso Marbury v. Madison.

${ }^{24}$ O Supremo Tribunal Federal considera a Emenda no 1/1969 à Constituição Federal de 1967 como uma "nova Constituição pela sua estrutura e pela determinação de quais dispositivos anteriores continuaram em vigor" (Guia de Direito Constitucional. Constituições Brasileiras Anteriores a 1988. Disponível em: $<$ http://www.stf.jus.br/portal/cms/verTexto.asp?servico=bibliotecaConsultaProdutoBibliotecaGuiaDC\&pagin $\mathrm{a}=$ constituicaoanterior1988>. Acesso em 30.06.2013). 
atividades irregulares mais graves dos juízes e dos demais órgãos ou instituições vinculadas ao Poder Judiciário.

A EC no 7/1977 estabeleceu que o Conselho Nacional da Magistratura teria sede na Capital da União, jurisdição em todo o território nacional e seria composto por sete Ministros do Supremo Tribunal Federal, por este escolhidos (CF/1967, art. 120, caput). Definiu, ainda, que ao Conselho caberia "conhecer de reclamações contra membros de Tribunais, sem prejuízo da competência disciplinar destes, podendo avocar processos disciplinares contra juízes de primeira instância e em qualquer caso, determinar a disponibilidade ou a aposentadoria de uns e outros, com vencimentos proporcionais ao tempo de serviço, observado o disposto na Lei Orgânica da Magistratura Nacional" $\left(\mathrm{CF} / 1967\right.$, art. $\left.120, \S 1^{\circ}\right)$. Junto ao Conselho funcionaria o Procurador-Geral da República $\left(\mathrm{CF} / 1967\right.$, art. $\left.120, \S 2^{\circ}\right)$.

A Lei Complementar (LC) $\mathrm{n}^{\mathrm{o}}$ 35, de 14 de março de 1979, conhecida como Lei Orgânica da Magistratura Nacional (LOMAN), repetiu, logo em seu artigo $3^{\circ}$, as disposições introduzidas pela $\mathrm{EC}^{0}$ 7/1977, e acrescentou que: a) os Ministros integrantes do Conselho Nacional da Magistratura seriam escolhidos mediante votação nominal, juntamente com a eleição do Presidente e do Vice-Presidente do Supremo Tribunal Federal, os quais passariam a integrá-lo, automaticamente, e nele exercer as mesmas funções, respectivamente; b) os Ministros permaneceriam no Conselho por um período de dois anos; c) não poderiam recusar o encargo; e, d) o Presidente do STF poderia convocar Ministros não eleitos, observada a ordem decrescente de antiguidade, para substituir os membros do Conselho, nos casos de impedimento ou afastamento temporário.

A LOMAN também definiu, em seus artigos 50 a 60, o trâmite, no Conselho Nacional da Magistratura, da reclamação contra membro de tribunal e da avocação de processo disciplinar contra juiz de instância inferior, bem como as hipóteses em que poderia determinar a aposentadoria ou a disponibilidade de magistrado, sempre em procedimento resguardado pelo sigilo.

O Conselho Nacional da Magistratura foi instalado em 21 de maio de 1979 pelo então Presidente do Supremo Tribunal Federal, Ministro Antonio Nader que, em seu discurso, ressaltou, a necessidade da criação, no Brasil, como ocorrera na França e na Itália, de 
instituição no Poder Judiciário para disciplinar o comportamento dos magistrados, sujeito às fraquezas da espécie humana (LENZ, 2007, p. 473) ${ }^{25}$.

Mas, diferentemente do que sucedera na Europa, onde os Conselhos da Magistratura surgiram para conferir maior independência ao Poder Judiciário, o papel do Conselho Nacional da Magistratura, como afirma José Adércio Leite Sampaio (2007, p. 239), era claramente correicional e censório. Antonio Rulli Neto (2007, p. 192) o definiu como "verdadeiro poder controlador de todo o Poder Judiciário, exercido por um conselho cujos integrantes era designados por um militar em regime ditatorial".

A atuação do Conselho Nacional da Magistratura, porém, foi mais discreta e menos contestada $^{26}$ que a do seu sucessor e, com a abertura política, “o Judiciário seguiu seu rumo sem a interferência do Conselho" (PELEJA JÚNIOR, 2011, p. 102), extinto com o advento da Constituição de $1988^{27}$.

\footnotetext{
${ }^{25}$ Releva destacar que a EC $\mathrm{n}^{\mathrm{o}}$ 7/1977 e, mais especificamente, o art. 51 da LOMAN, estabeleceram competência concorrente entre o Conselho Nacional da Magistratura e os Tribunais para processos disciplinares contra magistrados. Recentemente, essa questão voltou ao debate jurídico pois a AMB, em 16.08.2011, propôs a ADI n 4638 para questionar diversos dispositivos da Resolução CNJ nº 135, de 13 de julho de 2011, em particular seu art. 12, caput, que também estabelece competência concorrente entre o CNJ e os Tribunais para os processos disciplinares e para a aplicação de penalidades a magistrados. Após decisão liminar do Ministro Marco Aurélio Mello conferindo à norma interpretação conforme à Constituição para assentar, em âmbito disciplinar, a competência subsidiária do Conselho Nacional de Justiça, o Pleno do Supremo Tribunal Federal, concluiu, em 8 de fevereiro de 2012, por maioria que o referido Colegiado Administrativo pode iniciar investigação contra magistrados independentemente ou paralelamente à atuação da Corregedoria do Tribunal, sem necessidade de fundamentar a decisão (vide itens 2.3.7.5.1 e 3.1.5).

${ }^{26}$ Pequisa de jurisprudência no sítio eletrônico do Supremo Tribunal Federal com a expressão "Conselho Nacional da Magistratura" (disponível em $<$ http://www.stf.jus.br/portal/jurisprudencia/pesquisarJurisprudencia.asp >. Acesso em 01.11.2014) revela menção ao órgão em apenas quatro julgados do Supremo Tribunal Federal entre 1977 e 1988. Em dois deles $\left(\mathrm{HC} \mathrm{n}^{\mathrm{o}}\right.$ 60350, Relator Ministro Soares Munoz, Primeira Turma, julgado em 18.11.1983, DJ 16.12.1983, e $\left(\operatorname{Rcl}^{\circ}{ }^{1} 195 \mathrm{MC}\right.$, Relator Ministro Néri da Silveira, Tribunal Pleno, julgado em 11.12.1985, DJ 07.03.1986), foi determinada o encaminhamento de peças ao Conselho Nacional da Magistratura para apurações disciplinares envolvendo magistrados. Nos outros dois acórdãos (MS n ${ }^{0}$ 20641, Relator Ministro Celio Borja, Tribunal Pleno, julgado em 02.02.1987, DJ 20.03.1987, e MS n 2 $^{\circ}$ 20577, Relator Ministro Néri da Silveira, Tribunal Pleno, julgado em 20.05.1987, DJ 27.10.1989), o Conselho Nacional de Jutiça figurou como autoridade coatora em mandados de segurança cujas ordem foram negadas pelo STF).

${ }^{27}$ A extinção do Conselho Nacional da Magistratura implicou no não conhecimento liminar de reclamações a ele dirigidas após a promulgação da Carta de 1988. Nesse sentido, podem ser conferidas as decisões monocráticas proferidas pelo Ministro Celso de Mello na Petição n ${ }^{\circ} 1194$, julgada em 08.10.1996, DJ 15.10.1996, na Petição $\mathrm{n}^{\mathrm{o}}$ 1438, julgada em 05.02.1998, DJ 17.02.1998, e na Petição $\mathrm{n}^{\circ}$ 1497, julgada em 07.05.1998, DJ 18.05.1998 (STF, Informativo 120, de 24.08.1998, p. 4). Em todas, Sua Excelência cita lição de José Carlos Moreira Alves (1988, p. 195) e explica que, como o Conselho Nacional da Magistratura "deixou de existir ante a superveniência da nova Constituição Federal, que, ao dispor sobre a estrutura institucional do Poder Judiciário, nela não mais incluiu o órgão administrativo em questão" cessaram "em conseqüência, os poderes de índole disciplinar que lhe haviam sido atribuídos pela ordem constitucional pretérita".
} 


\subsection{A origem do Conselho Nacional de Justiça.}

O Projeto da nova Constituição da Comissão de Sistematização, presidida por Afonso Arinos, com a relatoria de Bernardo Cabral, de julho de 1987, não previa, no âmbito do Poder Judiciário, a instituição de qualquer Conselho de Magistratura ${ }^{28}$.

Durante a Assembleia Nacional Constituinte, porém, vozes se ergueram para a inclusão de um Conselho Nacional de Justiça já na redação original da nova Constituição.

Em setembro de 1987, projeto substitutivo apresentado por Bernardo Cabral procurava estabelecer o sistema parlamentarista de governo e, no Capítulo do Poder Judiciário $^{29}$, com apoio da Ordem dos Advogados do Brasil (OAB), de Nelson Jobim, Nilo Batista e Márcio Thomaz Bastos (SAMPAIO, 2007, p. 241), criava, em seu artigo 144, um Conselho Nacional de Justiça, como "órgão de controle externo da atividade administrativa e do desempenho dos deveres funcionais do Poder Judiciário e do Ministério Público", relegando à lei complementar a definição de sua organização e funcionamento, com obrigatória composição de membros indicados pelo Congresso Nacional, Poder Judiciário, Ministério Público e Conselho Federal da OAB.

Devido a forte pressão de segmentos que consideravam o Conselho um "dedo do autoritarismo sobrevivente" (SAMPAIO, 2007, p. 241) e de membros da Magistratura ${ }^{30}$, o modelo não foi adotado pela texto promulgado em outubro de 1988.

Menos de três anos depois, em $1^{\text {o }}$ de maio de 1992, o deputado Hélio Bicudo apresentou a Proposta de Emenda Constitucional (PEC) n 96/1992 para reforma do Poder Judiciário $^{31}$. A proposta original não dispunha sobre a criação de um órgão de controle administrativo e disciplinar do Poder Judiciário ${ }^{32}$, mas o Deputado Aloysio Nunes Ferreira,

\footnotetext{
${ }^{28}$ Estabelecia o artigo 187 do referido projeto serem órgãos do Poder Judiciário: I - Supremo Tribunal Federal; II - Superior Tribunal de Justiça; III - Tribunais Regionais Federais e Juízes Federais; IV Tribunais e Juízos do Trabalho; V - Tribunais e Juízos Eleitorais; VI - Tribunais e Juízos Militares; VII Tribunais e Juízes dos Estados e do Distrito Federal e Territórios; VIII - Tribunais e Juízos Agrários (Disponível em: <http://www.camara.gov.br/internet/constituicao20anos/DocumentosAvulsos/vol-223.pdf>. Acesso em 10.12.2014).

29 Disponível em: <http://www.camara.gov.br/internet/constituicao20anos/DocumentosAvulsos/vol242.pdf $>$. Acesso em 10.12.2014

${ }^{30}$ A título de exemplo, Rivaldo Chinem publicou, em 6 de novembro de 1987, notícia em que o então Presidente do Tribunal de Justiça de São Paulo, Marcos Nogueira Garcez, afirmou, em repúdio à criação do Conselho Nacional de Justiça, que "nos piores tempos do regime ditatorial militar nunca de pensou em instituir um conselho fiscal de juízes, nunca se quis por essa canga no Judiciário".

31 Disponível em: <http://www.camara.gov.br/proposicoesWeb/fichadetramitacao?idProposicao=14373>. Acesso em 01.11.2014.

${ }^{32}$ Disponível em: <http://imagem.camara.gov.br/Imagem/d/pdf/DCD01MAI1992.pdf\#page=7>. Acesso em 01.11.2014.
} 
em junho de 1995, na Comissão Especial destinada a proferir parecer sobre ela, apresentou o substitutivo número quatro para instituir um órgão denominado Conselho Nacional da Magistratura, composto por dezessete membros, sendo apenas um - advogado, indicado em lista tríplice pelo Conselho Federal da Ordem dos Advogados do Brasil e escolhido em pelo SupremoTribunal Federal - estranho aos quadros da Magistratura ${ }^{33}$.

Poucos dias antes, em 31 de maio de 1995, o Deputado José Genoíno apresentou a Proposta da Emenda à Constituição no 112/1995 para criação de um Sistema de Controle do Poder Judiciário constituído por um Conselho Federal de Justiça e Conselhos Estaduais de Justiça (no Distrito Federal denominado de Conselho Distrital de Justiça), compostos por magistrados, membros do Ministério Público, advogados e cidadãos ${ }^{34}$. Em 30 de setembro de 1995, foi deferido requerimento do mesmo deputado para apensação da PEC $n^{0}$ 112/1995 à PEC no 96/1992.

Ao longo de sua tramitação, a PEC no 96/1992 sofreu sucessivos arquivamentos e desarquivamentos, até que, em 07 de abril de 1999, passou à relatoria do Deputado Aloysio Nunes Ferreira. A ela foram apensadas outras Propostas de Emenda à Constituição relacionadas ao Poder Judiciário ${ }^{35}$ e apresentadas, até 30 de abril de 1999, quarenta e cinco emendas, catorze delas tratando do controle do Poder Judiciário.

José Adércio Leite Sampaio (2007, p. 243) afirma que a PEC n 96/1992, com as emendas ofertadas, destacou seis funções ao Conselho a ser criado:

[...] a) planejamento e avaliação administrativa do Poder Judiciário; b) formulação de planos, projetos e programas destinados a garantir a independência, a autonomia, a eficiência e a eficácia administrativa, orçamentária e financeira do Poder Judiciário; c) elaboração de diretrizes para a organização e a prestação dos serviços judiciários; d)

33

$<\mathrm{http}$ //www.camara.gov.br/proposicoesWeb/prop_mostrarintegra;jsessionid=E18FC917C73C765CD5E4AA 0CF16BC7EA.proposicoesWeb2? codteor $=1243057 \&$ filename $=$ Avulso+-PEC $+96 / 1992>$. $\quad$ Acesso em 01.11.2014.

${ }^{34}$ Disponível em: $<$ http://imagem.camara.gov.br/Imagem/d/pdf/DCD08AGO1995.pdf\#page=94>. Acesso em 01.11.2014.

${ }^{35}$ Em 30.03.1999 foi deferido o requerimento do Deputado Ricardo Barros, solicitando a apensação das PECs n ${ }^{\circ}$ s 127/1995 (elevação para 75 anos a idade limite para aposentadoria compulsória dos magistrados), 215/1995 (aposentadoria facultativa às magistradas, aos 25 anos de serviço, após 5 anos de exercicio efetivo na judicatura), 368/1996 (atribuição de competência à Justiça Federal para julgar os crimes praticados contra os Direitos Humanos) e 500/1997 (criação de efeito vinculante na ADI e na ADC) à PEC no 96/1992 (Disponível em: <http://www.camara.gov.br/proposicoesWeb/fichadetramitacao?idProposicao=14373>. Acesso em 01.11.2014). 
acompanhamento e fiscalização da execução orçamentária; f) zelo pelo cumprimento do Estatuto da Magistratura.

O autor ainda registra que (2007, pp. 243 e 244):

[...] havia emendas que acrescentavam a essas competências outras tantas, como a manifestação sobre a elaboração do orçamento e a criação de cargos (Emendas n. 001 e n. 043); a iniciativa legislativa (Emendas n. 011, n. 013, n. 039 e n. 045); a fiscalização das serventias e serviços notariais e de registro (Emenda n. 013); e a avocação de processos administrativos e disciplinares com perda do cargo e outras penalidades (Emendas n. 013, n. 035 e n. 045).

Em 11 de agosto de 1999, alguns meses após instaurada, no Senado Federal, por requerimento do seu então Presidente, Senador Antônio Carlos Peixoto de Magalhães, uma Comissão Parlamentar de Inquérito (CPI) para apuração de irregularidades nos órgãos do Poder Judiciário, conhecida como CPI do Judiciário ${ }^{36}$, a PEC nº 96/1992 foi redistribuída à relatoria da Deputada Zulaiê Cobra, sendo discutida no Plenário da Câmara dos Deputados em dois turnos, com aprovação de várias emendas aglutinativas. A redação final do projeto na referida Casa Legislativa foi apresentada em 07 de junho de 2000, sendo encaminhada, na mesma data ao Senado Federal ${ }^{37}$.

Na Câmara Alta, o projeto transformou-se na Proposta de Emenda Constitucional $n^{o}$ 29/2000, sendo distribuído ao Senador Bernando Cabral em 02 de agosto de 2000.

Apesar da intenção inicial do relator ${ }^{38}$ em criar um conselho para a Magistratura somente administrativo e consultivo, constituído apenas por membros do Judiciário, tendo

\footnotetext{
${ }^{36}$ A criação da CPI do Judiciário não ficou imune, à época, a críticas no seio da Magistratura e da Acâdemia. Antônio Souza Prudente (CPI sobre o Judiciário: tribunal de exceção. Jus Navigandi, Teresina, ano 4, n. 31, 1 maio 1999. Disponível em: <http://jus.com.br/artigos/230>. Acesso em: 13 nov. 2014) afirmou que ela configurou verdadeiro tribunal de exceção, por violação ao princípio da independência e separação dos Poderes da República. E, assim como o primeiro, Kiyoshi Harada (CPI do Judiciário. Jus Navigandi, Teresina, ano 4, n. 33, 1 jul. 1999. Disponível em: <http://jus.com.br/artigos/1964>. Acesso em: 13 nov. 2014) afirmou que a CPI criada não visou investigar "fato determinado" como manda o texto constitucional $\left(\mathrm{CF}\right.$, art. 58, § $3^{\circ}$ ). Ademais, o Regimento Interno do Senado Federal (RISF), não admite Comissão Parlamentar de Inquérito sobre matérias pertinentes às atribuições do Poder Judiciário (RISF, art. 146, II).

37 Disponível em: < http://www.camara.gov.br/proposicoes Web/fichadetramitacao?idProposicao=14373>. Acesso em 01.11.2014.

${ }^{38}$ Ante a não reeleição do Senador Bernardo Cabral, a PEC n ${ }^{\circ}$ 29/2000 foi redistribuída, em 26 de junho de 2003, à relatoria do Senador José Jorge (Disponível em: $<\mathrm{http} / / /$ www.senado.gov.br/atividade/materia/detalhes.asp?p_cod_mate=44577>. Acesso em 10.12.2014).
} 
em vista posicionamento manifestado pelo Supremo Tribunal Federal, que considerou inconstitucionais conselhos estaduais criados para controle administrativo do Poder integrados por representantes externos (Súmula STF no 649) ${ }^{39}$, (RULLI NETO, 2007, p. 196) e da apresentação de diversas emendas ao texto recebido da Câmara dos Deputados, com discussões que "giraram mais em torno de representação de interesses corporativos do que sobre a oportunidade de criação de órgão de efetivo aperfeiçoamento do Judiciário e de prestação devida e efetiva da jurisdição" (SAMPAIO, 2007, p. 241), o texto final aprovado em Sessão Plenária do Senado Federal em 17 de novembro de 2004 manteve, tal qual havia saído na Câmara dos Deputados, a criação de um conselho com composição híbrida, predominantemente de magistrados, para controle da atuação administrativa e financeira do Poder Judiciário e do cumprimento dos deveres funcionais dos juízes, denominado Conselho Nacional de Justiça.

Em 8 de dezembro de 2004, em sessão Solene do Congresso Nacional, no Plenário da Câmara dos Deputados, foi promulgada a Emenda Constitucional $n^{\circ} 45$, publicada em 30 de dezembro do mesmo ano, conhecida como "Reforma do Judiciário".;

A EC no 45/2004, além de criar o Conselho Nacional de Justiça também, dentre outras mudanças: a) erigiu a direito fundamental a razoável duração do processo $\left(\mathrm{CF}\right.$, art. $5^{\circ}$, LXXVIII); b) estabeleceu que os tratados internacionais sobre direitos humanos aprovados em cada Casa do Congresso Nacional, em dois turnos, por três quintos dos votos dos respectivos membros, serão equivalentes às emendas constitucionais $\left(\mathrm{CF}\right.$, art. $\left.5^{\circ}, \S 3^{\circ}\right)$; c) efetuou modificações nos princípios e regras aplicáveis à Magistratura (CF, art. 93); d) permitiu a aprovação de súmulas com efeito vinculante pelo STF (CF, art. 103-A); e) criou a Escola Nacional de Formação e Aperfeiçoamento de Magistrados (art. 105, parágrafo único, I), a Escola Nacional de Formação e Aperfeiçoamento de Magistrados do Trabalho (CF, art. 111-A, $\left.\S 2^{\circ}, \mathrm{I}\right)$, o Conselho Superior da Justiça do Trabalho (CF, art. 111-A, $\S 2^{\mathrm{a}}$, II) e o Conselho Nacional do Ministério Público (CF, art. 130-A); f) permitiu que, nas hipóteses de grave violação de direitos humanos, o Procurador-Geral da República, com a finalidade de assegurar o cumprimento de obrigações decorrentes de tratados internacionais de direitos humanos dos quais o Brasil seja parte, suscite, perante o Superior Tribunal de Justiça (STJ), incidente de deslocamento de competência para a Justiça Federal $\left(\mathrm{CF}\right.$, art. $\left.109, \S 5^{\circ}\right)$; f) realizou alterações na Justiça do Trabalho e na Justiça Militar (CF, art. 114, 115 e 125); e g) extinguiu os tribunais de alçada (EC 45/2004, art. $4^{\circ}$ ).

\footnotetext{
${ }^{39}$ Súmula STF no 649: "É inconstitucional a criação, por Constituição estadual, de órgão de controle administrativo do Poder Judiciário do qual participem representantes de outros Poderes ou entidades".
} 
No que tange à criação do Conselho Nacional de Justiça, houve inclusão ao texto constitucional dos seguintes dispositivos: a) art. 52, II: definiu competir privativamente ao Senado Federal processar e julgar os membros do referido órgão nos crimes de responsabilidade; b) art. 92, I-A: incluiu o CNJ entre os órgãos do Poder Judiciário; c) art. 92, § 1': fixou que o Conselho Nacional de Justiça tem sede na Capital Federal; d) art. 93, VIII: estabeleceu que o ato de remoção, disponibilidade e aposentadoria do magistrado, por interesse público, fundar-se-á em decisão por voto da maioria absoluta do respectivo tribunal ou do Conselho Nacional de Justiça, assegurada ampla defesa; e) art. 102, I, "r": assentou competir ao STF processar e julgar originalmente as ações contra o CNJ; e, f) art. 103-B: definiu a composição e as competências do Conselho Nacional de Justiça.

No regramento apresentado pela EC no 45/2004, restou estabelecido que o Conselho Nacional de Justiça seria composto por quinze Conselheiros, sendo: a) um Ministro do Supremo Tribunal Federal, indicado pelo respectivo tribunal; b) um Ministro do Superior Tribunal de Justiça, indicado pelo respectivo tribunal; c) um Ministro do Tribunal Superior do Trabalho, indicado pelo respectivo tribunal; d) um desembargador de Tribunal de Justiça, indicado pelo Supremo Tribunal Federal; e) um juiz estadual, indicado pelo Supremo Tribunal Federal; f) um juiz de Tribunal Regional Federal, indicado pelo Superior Tribunal de Justiça; g) um juiz federal, indicado pelo Superior Tribunal de Justiça; h) um juiz de Tribunal Regional do Trabalho, indicado pelo Tribunal Superior do Trabalho; i) um juiz do trabalho, indicado pelo Tribunal Superior do Trabalho; j) um membro do Ministério Público da União, indicado pelo Procurador-Geral da República; k) um membro do Ministério Público estadual, escolhido pelo Procurador-Geral da República dentre os nomes indicados pelo órgão competente de cada instituição estadual; 1) dois advogados, indicados pelo Conselho Federal da Ordem dos Advogados do Brasil; e, m) dois cidadãos, de notável saber jurídico e reputação ilibada, indicados um pela Câmara dos Deputados e outro pelo Senado Federal.

Além disso, ficaram definidos limites mínimo e máximo de idade para ocupar o cargo de Conselheiro (mais de trinta e cinco e menos de sessenta e seis anos de idade), foi fixado que o Órgão seria presidido pelo Ministro do STF, que somente votaria em caso de empate, além de ficar excluído da distribuição de processos na Suprema Corte e ainda restou estabelecido que todos os Conselheiros - inclusive o Ministro do STF - seriam nomeados pelo Presidente da República, depois de aprovada a escolha pela maioria absoluta do Senado Federal (art. 103-B, caput, e $\S \S 1^{\circ}$ e $2^{\circ} \mathrm{CF}$ ). 
Quanto ao espaço de atuação institucional do Conselho Nacional de Justiça, a EC n ${ }^{o}$ 45/2004 definiu (CF, aer. 103-B, $\S 4^{\circ}$ ) competir-lhe o controle da atuação administrativa e financeira do Poder Judiciário e do cumprimento dos deveres funcionais dos juízes, cabendo-lhe, além de outras atribuições que lhe forem conferidas pelo Estatuto da Magistratura: a) zelar pela autonomia do Poder Judiciário e pelo cumprimento do Estatuto da Magistratura, podendo expedir atos regulamentares, no âmbito de sua competência, ou recomendar providências (inc. I); b) zelar pela observância do art. 37 e apreciar, de ofício ou mediante provocação, a legalidade dos atos administrativos praticados por membros ou órgãos do Poder Judiciário, podendo desconstituí-los, revê-los ou fixar prazo para que se adotem as providências necessárias ao exato cumprimento da lei, sem prejuízo da competência do Tribunal de Contas da União (inc. II); c) receber e conhecer das reclamações contra membros ou órgãos do Poder Judiciário, inclusive contra seus serviços auxiliares, serventias e órgãos prestadores de serviços notariais e de registro que atuem por delegação do poder público ou oficializados, sem prejuízo da competência disciplinar e correicional dos tribunais, podendo avocar processos disciplinares em curso e determinar a remoção, a disponibilidade ou a aposentadoria com subsídios ou proventos proporcionais ao tempo de serviço e aplicar outras sanções administrativas, assegurada ampla defesa (inc. III); d) representar ao Ministério Público, no caso de crime contra a administração pública ou de abuso de autoridade (inc. IV); e) rever, de ofício ou mediante provocação, os processos disciplinares de juízes e membros de tribunais julgados há menos de um ano (inc.V); f) elaborar semestralmente relatório estatístico sobre processos e sentenças prolatadas, por unidade da Federação, nos diferentes órgãos do Poder Judiciário; e, g) elaborar relatório anual, propondo as providências que julgar necessárias, sobre a situação do Poder Judiciário no País e as atividades do Conselho, o qual deve integrar mensagem do Presidente do Supremo Tribunal Federal a ser remetida ao Congresso Nacional, por ocasião da abertura da sessão legislativa.

A EC no 45/2004 também estabeleceu (CF, art. 103-B, $\S 5^{\circ}$ ) que o Ministro do Superior Tribunal de Justiça exerceria a função de Ministro-Corregedor do CNJ e ficaria excluído da distribuição de processos no Tribunal, competindo-lhe, além das atribuições que lhe forem conferidas pelo Estatuto da Magistratura, as seguintes: a) receber as reclamações e denúncias, de qualquer interessado, relativas aos magistrados e aos serviços judiciários (inc. I); b) exercer funções executivas do Conselho, de inspeção e de correição geral (inc. II); c) requisitar e designar magistrados, delegando-lhes atribuições, e requisitar 
servidores de juízos ou tribunais, inclusive nos Estados, Distrito Federal e Territórios (inc. III).

Por fim, a EC no 45/2004 estipulou que o Procurador-Geral da República e o Presidente do Conselho Federal da Ordem dos Advogados do Brasil oficiariam junto ao CNJ (art. 103-B, $\S 6^{\circ}$ ) e determinou que a União, inclusive no Distrito Federal e nos Territórios, criasse ouvidorias de justiça, competentes para receber reclamações e denúncias de qualquer interessado contra membros ou órgãos do Poder Judiciário, ou contra seus serviços auxiliares, representando diretamente ao Conselho Nacional de Justiça (art. 103-B, $\S 7^{\circ}$ ).

Para evitar que mais um Ministro do Supremo Tribunal Federal ficasse dispensado da distribuição de processos, a praxe levou à indicação sempre do seu Presidente para integrar e também presidir o Colegiado Administrativo.

Porém, essa prática ficou sob risco quando o Ministro Cezar Peluso estava prestes a assumir a presidência do Pretório Excelso (o que efetivamente ocorreu em 23 de abril de 2010), porque já contava com sessenta e sete anos de idade ${ }^{40}$. Por outro lado, não havia previsão de substituição do Presidente do CNJ por outro Ministro do STF nas suas ausências e impedimentos no órgão.

Assim, em 11 de novembro de 2009, foi publicada e Emenda Constitucional no 61 que: a) acabou com os limites mínimo e máximo de idade para indicação de Conselheiro para integrar o $\mathrm{CNJ}$; b) estabeleceu que o órgão é necessariamente integrado e presidido pelo Presidente do Supremo Tribunal Federal, sempre com direito a voto; c) fixou que, nas ausências e impedimentos do Presidente do STF, o CNJ será presidido pelo VicePresidente da Suprema Corte Brasileira; e, d) eliminou a segunda sabatina pelo Senado Federal a que ficava sujeito o Ministro do STF para integrar o CNJ (todo Ministro do STF, ao ser indicado para a Alta Corte, já é sabatinado pelo Senado Federal - CF, art. 52, III, a, c.c. art. 101, parágrafo único).

As justificativas para a referida reforma constitucional foram apresentadas no Proposta de Emenda Constitucional do Senado Federal no 22, de 10 de maio de 2006, de autoria do Senador Demóstenes Torres, a saber: a) celeridade processual, pois a redação anterior do dispositivo constitucional em comento permitia, em tese, que dois Ministros do Supremo Tribunal Federal ficassem excluídos de distribuição processual (o seu próprio Presidente, se não fosse indicado para o $\mathrm{CNJ}$, e o Ministro indicado pela Alta Corte para o

${ }^{40}$ Conforme informações obtidas no sítio eletrônico do Supremo Tribunal Federal. Disponível em: $<$ http://www.stf.jus.br/portal/ministro/presidente.asp?periodo=stf\&id=37>. Acesso em 10.12.2014. 
Colegiado Administrativo); b) unidade de comando nos dois órgãos do Poder Judiciário; c) possibilidade do Presidente do Supremo Tribunal Federal presidir o Conselho Nacional de Justiça mesmo contando com mais de sessenta e cinco anos de idade; e, d) impossibilidade do Chefe de um dos Poderes da República ser submetido a sabatina de uma das Casas de outro Poder, o que configurava verdadeira capitis diminutio do Poder Judiciário (esta última justificativa foi externada na Emenda de Plenário do Senado Federal no 2, de 2 de julho de 2008) $)^{41}$.

O Conselho Nacional de Justiça foi instalado em 14 de junho de 2005. Desde então, foi presidido, sucessivamente, pelos Ministros do Supremo Tribunal Federal Nelson Jobim, Ellen Gracie, Gilmar Mendes, Cezar Peluso, Carlos Ayres Britto, Jaquim Barbosa e Ricardo Lewandowski (atual Presidente).

${ }^{41}$ Disponível em: <http://www.senado.gov.br/atividade/materia/detalhes.asp?p_cod_mate=77724>. Acesso em 10.12.2014. 


\section{CAPÍTULO 2 - LIMITES DECORRENTES DOS ELEMENTOS CONSTITUCIONAIS CARACTERÍSTICOS DO CNJ}

Apresentados os antecedentes históricos que culminaram na criação, pela Emenda Constitucional $n^{o}$ 45/2004, do Conselho Nacional de Justiça, passa-se à investigação do objeto principal deste trabalho, os limites constitucionais de atuação do órgão.

Ante a proposta da pesquisa, este capítulo será dedicado à identificação dos elementos constitucionais característicos do $\mathrm{CNJ}$ e dos limites que impõem ao órgão. O capítulo seguinte cuidará das competências constitucionais específicas do Conselho e das fronteiras que definem ao Colegiado.

\subsection{Relevância do estudo do tema}

É fundamental, para definição dos limites de atuação do Conselho Nacional de Justiça, analisar os elementos constitucionais característicos dessa Instituição ${ }^{42}$.

Segundo De Plácido e Silva, elemento (2007, pp. 255 e 510) é "tudo que entra na formação de alguma coisa" e característico indica "todo o sinal distintivo de uma coisa". Quanto a este último termo, prossegue o autor:

Os característicos entendem-se, assim, os sinais de individualização da coisa, pela sua descrição, situação e outros elementos particulares que a diferenciam de outras coisas da mesma espécie.

Estudar os elementos constitucionais característicos do Conselho Nacional de Justiça, pois, é investigar tudo o que de constitucionalmente relevante compõe o órgão, o que o individualiza, aproximando-o e afastando-o de outras instituições da República. É o que o torna compreensível no ordenamento, facilita seu conhecimento, possibilita sua conceituação e, para o objetivo deste trabalho, permite delimitar qual o seu campo jurídico constitucional de atuação institucional ${ }^{43}$.

\footnotetext{
${ }^{42}$ O vocábulo "instituição" foi utilizado no sentido de "instituição-órgão", ou seja, organização com estatuto e funcionamento definidos pela lei (ou, no caso do CNJ, pela própria Constituição Federal), conforme Valérie Ladegaillerie (2005, p. 93) e Raymond Guillien e Jean Vincent (1990, p. 278), estes citados por Elival da Silva Ramos (2010, p. 1).

${ }^{43}$ Não se pode perder de vista que a "Ciência Jurídica é uma ciência cultural normativa, visto como o jurista não se limita a explicar o que ocorre, mas envolve, abrange o que acontece, postulando um fim a ser atingido,
} 


\subsection{Separação das funções estatais.}

Antes, porém, de adentrar na análise pormenorizada dos elementos constitucionais característicos do Conselho Nacional de Justiça e das limitações impostas ao órgão deles decorrentes, cumpre discorrer, ainda que brevemente, sobre a separação das funções estatais, pois sua compreensão é predeterminante ao estudo na sequência realizado.

O Estado é detentor de um poder ${ }^{44}$ político uno, indivisível e indelegável, manifestação de sua soberania (SILVA, 2011, p. 355). Esse poder, porém não deve ficar concentrado em apenas um pessoa ou um órgão, pois seu detentor teria domínio ilimitado sobre os demais homens.

Aristóteles (2009, pp. 113 a 117), na "Política", já alertava sobre os efeitos danosos da centralização do poder político, por ficar exposto às vicissitudes do caráter humano.

Montesquieu (2010, pp. 168 a 186), após a sistematização trazida por John Locke ${ }^{45}$,

fim este que é medida de conduta" (REALE, 2002, p. 265).

${ }^{44}$ Para Max Weber (2005, p. 35), poder (em alemão, Macht) é a possibilidade de encontrar obediência a determinado comando. Pode legitimar-se através da norma (poder racional-legal), da tradição (poder tradicional) ou do carisma (poder carismático): a) Poder racional-legal: a sujeição à ordem da autoridade decorre, racionalmente, de uma norma abstrata aceita por um grupo, que legitima a competência de uma pessoa para o comando, como ocorre nas burocracias dos Estados modernos. A autoridade é reconhecida pelo cargo atribuído à pessoa e não por suas próprias características. b) Poder tradicional: a legitimação da autoridade que o detém funda-se em costumes, mitos e práticas culturais, como o patriarca na família ou o senhor feudal da Europa Medieval. "Obedece-se a pessoa por força de sua dignidade própria, santificada pela tradição: por piedade”. A vontade da autoridade é baseada no seu livre arbítrio, no sentimento de equidade, na afeição ou aversão, no favorecimento pessoal. Sustenta-se na dominação e na dependência patrimonial. "Todos os verdadeiros regimes 'despóticos têm este carácter, no qual o domínio é tratado como um vulgar direito de propriedade do senhor”; c) Poder carismático: a obediência às ordens da autoridade investida neste poder decorre de seus dons pessoais, como no caso dos profetas ou dos chefes guerreiros carismáticos. A preservação do poder depende do reconhecimento das características pessoais legitimadoras da posição da autoridade. "O poder carismático é, decerto, um dos grandes poderes revolucionários da história, mas, na sua forma mais pura, é de caráter plenamente autoritário, dominador”. Conforme expõe Jürgen Habermas (1986, p. 75), Hannah Arendt critica Weber, conferindo à sua concepção de poder a justificação para a violência. Para Arendt, o poder pertence a um grupo (e não a um indivíduo), que se forma e age de forma unida e acordada. Uma pessoa não detém o poder, ela é provida de poder pelo grupo para agir em seu nome (ARENDT, 1988, p. 24).

${ }^{45}$ Pela teoria de Locke, os homens consentiram em passar do Estado de Natureza, apesar de viverem em liberdade e igualdade, para o Estado de Sociedade, porque, no primeiro, mesmo sob o império da razão, baseado na Lei da Natureza, todos julgavam e executavam as leis, o que poderia gerar arbitrariedade e ameaçar seus direitos. O consentimento dos homens fez nascer a sociedade e esta criou o governo civil, cujo poder, para sua limitação, é separado em Legislativo (superior aos demais), Executivo e Federativo. Ao Poder Legislativo, composto por muitas pessoas, incumbe elaborar as leis. Cabe ao Poder Executivo, vinculado ao Legislativo, aplicá-las na sociedade. Ao Poder Federativo, também exercido pelo detentor do Poder Executivo, compete o trato com outros Estados, o poder de estabelecer alianças, fazer a guerra, celebrar a paz (1994, pp. 170 a 186). 
apresentou sua clássica teoria da separação das funções estatais, para limitação do poder ${ }^{46}$ e garantia da liberdade política dos cidadão. Segundo o filósofo francês, Senhor de La Brède, as funções de elaborar as leis, executá-las e julgar os conflitos devem ser exercidas por pessoas distintas, sob pena de tirania e opressão. Assim, em cada Estado deve haver três espécies de poderes: o Legislativo, o Executivo e o Judiciário. O primeiro "faz leis para algum tempo ou para sempre, e corrige ou ab-roga as que estão feitas". O segundo "faz a paz ou a guerra, envia ou recebe embaixadas, estabelece a segurança, previne invasões", além de "executar as resoluções públicas". O terceiro "pune os crimes ou julga as demandas dos particulares" (MONTESQUIEU, 2010, pp. 169 e 170).

Pondera José Afonso da Silva (2011, p. 356 e 357):

Temos, por aí, a compreensão de que o poder político, o poder estatal, desenvolve três funções fundamentais: a legislativa, a executiva e a jurisdicional, que podem ser exercidas por um órgão só - e temos, então, a concentração de poderes - ou por mais de um órgão - e podemos, aí, chegar até a chamada divisão ou separação de poderes. O que não devemos confundir é a distinção de funções com a divisão de poderes. Se aquelas funções distintas (a de criar normas gerais, impessoais etc., chamada legislativa, a de executar e administrar e de solucionar conflitos de interesse) estiverem concentradas num único órgão, ou sob o domínio de um único órgão, elas podem até, estar, digamos, formal e abstratamente separadas, entregues a mais de um órgão, mas sob o domínio de um deles, que poderá até extinguir os outros à vontade; em verdade, não ocorre, aí, uma divisão de poderes. Para que se verifique a separação de poderes, no sentido posto por Montesquieu, são necessários dois elementos: especialização funcional e independência orgânica. Pela primeira as funções especializadas (legislativa, executiva e jurisdicional) são entregues a órgãos separados, enquanto a segunda garante autonomia a esses órgãos separados (daí falar-se em separação de poderes).

Não se trata, logo se vê, de uma divisão de poderes abstrata, de uma divisão do poder do Estado em si mesmo considerada (que seria impossível), mas de uma divisão concreta, organizadora do Direito, ou como forma de organização jurídica das manifestações do poder.

\footnotetext{
${ }^{46} \mathrm{Na}$ mesma linha de Aristóteles, afirma Montesquieu (2010, p. 167): "Mas é uma experiência eterna que todo homem que tem poder é levado a abusar dele. Vai até encontrar os limites. Quem diria? A própria virtude precisa de limites".
} 
$[\ldots]$

O governo é, então, o conjunto de órgãos mediante os quais a vontade do Estado é formulada, expressada e realizada, ou o conjunto de órgãos supremos a que incumbe o exercício das funções do poder político. Este se manifesta mediante suas funções, que são exercidas e cumpridas pelos órgãos de governo. Vale dizer, portanto, que o poder político, uno, indivisível e indelegável, se desdobra e se compõe de várias funções, fato que permite falar em distinção das funções, que fundamentalmente são três: a legislativa, a executiva e a jurisdicional.

A função legislativa consiste na edição de regras gerais, abstratas, impessoais e inovadoras da ordem jurídica, denominadas leis. A função executiva resolve os problemas concretos e individualizados, de acordo com as leis; não se limita à simples execução das leis, como às vezes se diz; comporta prerrogativas, e nela entram todos os atos e fatos jurídicos que não tenham caráter geral e impessoal; por isso, é cabível dizer que a função executiva se distingue em função de governo, com atribuições politicas, colegislativas e de decisão, e função administrativa, com suas três missões básicas: intervenção, fomento e serviço público. A função jurisdicional tem por objeto aplicar o Direito aos casos concretos, a fim de dirimir conflitos de interesse.

Montesquieu, porém, não prega uma separação absoluta das funções estatais entre os três poderes, mas a mencionada diferenciação entre elas para convivência em equilíbrio, admitindo suas interpenetrações para que haja mútua fiscalização entre os poderes, como observado pelos "pais fundadores" dos Estados Unidos da América (Founding Fathers of the United States) Alexander Hamilton, James Madison e John Jay (2003, pp. 299 a 305).

Como afirmado pelo Ministro Joaquim Barbosa em seu voto na Ação Direta de Constitucionalidade (ADI) n 3367, “em realidade, [...] a expressão 'separação de poderes', nos dias atuais, para que se capte com precisão seu sentido verdadeiro, há de ser entendida como dispersão/difusão de poderes".

Essa separação das funções estatais para contenção do poder, de fato, não é absoluta em nosso sistema constitucional, pois há previsão de diversas situações em que um dos Poderes exerce funções que, pela lição montesquiana, seriam de outro Poder, o que se justifica exatamente para evitar que qualquer um deles se sobressaia aos demais. 
Assim, como doutrina Michel Temer (1996, p. 120 e 121), “cada órgão do Poder exerce, preponderantemente, uma função, e secundariamente, as duas outras. Da preponderância advém a tipicidade da função; da secundariedade, a atipicidade".

A respeito, o Ministro Cezar Peluso se manifestou em seu voto na Ação Direta de Constitucionalidade $n^{\circ} 3367$ :

O constituinte desenhou a estrutura institucional dos Poderes de modo a garantir-lhes a independência no exercício das funções típicas, mediante previsão de alto grau de autonomia orgânica, administrativa e financeira. Mas tempera-o com a prescrição doutras atribuições, muitas das quais de controle recíproco, e cujo conjunto forma, com as regras primárias, verdadeiro sistema de integração e cooperação, preordenado a assegurar equilíbrio dinâmico entre os órgãos, em benefício do escopo último, que é a garantia da liberdade.

Esse quadro normativo constitui expressão natural do princípio na arquitetura política dos freios e contrapesos. À Constituição repugna-lhe toda exegese que reduza a independência dos poderes a termos absolutos, os quais, aliás de todo estranhos aos teóricos de sua fórmula, seriam contraditórios com a ideia que a concebeu como instrumento políticoliberal.

Confirma-o rápido percurso pelo texto constitucional. Não são poucos os institutos cuja disciplina revela ostensiva existência de mecanismos predispostos ao controle mútuo entre os Poderes e, até, ao desempenho anômalo, por um deles, de função típica de outro. Basta mencionar veto (art. 66, $\S 1^{\circ}$, e 84 , inc. V)), o impeachment (arts. 52, 85 e 86), o controle de constitucionalidade das leis (arts. 102, I, letra $a$, e 103), as medidas provisórias (art. 62), as leis delegadas (art. 68), o poder conferido ao Legislativo de sustar atos normativos do Executivo (art. 49, inc. V), bem como de lhe fiscalizar e controlar seus atos (inc. X), controle das contas públicas pelo Congresso Nacional e pelo Tribunal de Contas (arts. 70, 71, cc. 49, inc. IX), o Conselho da República (art. 89), o poder do Presidente da República de conceder indulto e comutar penas (art. 84, inc. XII). Não menos significativa é a previsão do procedimento de elaboração conjunta do orçamento de cada Poder, por meio da lei de diretrizes orçamentárias e da própria lei orçamentária (arts. 48, inc. II, 99, 165 a 168). 
No que concerne à vida orgânica do Judiciário, merece atenção especial a competência do Executivo para nomear parte dos membros do Poder, como se dá com integrantes da Justiça Eleitoral (arts. 119, inc. II, e 120, inc. III), dos Tribunais Regionais Federais, dos Tribunais estaduais e do Distrito Federal, por via do chamado quinto constitucional (art. 94), e dos próprios Ministros desta Casa, cuja investidura depende ainda de aprovação do Senado (art. 101, § único).

O Conselho Nacional de Justiça foi criado pela Emenda Constitucional $n^{\circ} 45 / 2004$ como um órgão de administração superior do Judiciário, porém, como será detalhado, não lhe foi atribuído o exercício da função típica do Poder Judiciário, a jurisdição. O CNJ Conselho exerce apenas funções atípicas na estrutura do Poder que integra.

\subsection{Os elementos constitucionais característicos do Conselho Nacional de Justiça.}

Por se tratar de criação do direito positivo, através de manifestação do Poder Constituinte derivado reformador ${ }^{47}$, a busca dos elementos constitucionais característicos do Conselho Nacional de Justiça deve partir do próprio texto introduzido na Constituição Federal. Deve-se considerar, também, as razões históricas que levaram à sua criação ${ }^{48}$ e as abalizadas posições doutrinárias sobre o novel Órgão. Por fim, não se pode ignorar o teor das decisões proferidas pelo Supremo Tribunal Federal no exercício do controle dos atos praticados pelo Colegiado, em especial daquela prolatada na Ação Direta de Inconstitucionalidade $n^{\circ}$ 3367, movida pela Associação dos Magistrados Brasileiros (AMB) para impugnar os textos que exteriorizavam as normas relativas ao Conselho Nacional de Justiça previstas na Emenda Constitucional $n^{\circ} 45$, de 30 de dezembro de $2004^{49}$, porque trazem importantes informações para distingui-lo no ordenamento,

\footnotetext{
${ }^{47}$ Alexandre de Moraes (2013b, p. 27) assinal que "o Poder Constituinte derivado reformador, denominado por parte da doutrina de competência reformadora, consiste na possibilidade de alterar-se o texto constitucional, respeitando-se a regulamentação especial prevista na própria Constituição Federal e será exercitado por determinados órgãos com caráter representativo".

${ }^{48}$ Expostas no Capítulo 1.

${ }^{49}$ Conforme consta no relatório do Ministro Cezar Peluso, os fundamento jurídicos do pedido deduzido pela Associação dos Magistrados Brasileiros para questionar a constitucionalidade da criação do CNJ circunscreveram-se a três argumentos materiais essenciais: a) violação do princípio da separação e da independência dos poderes $\left(\mathrm{CF}\right.$, art. $2^{\circ}$ ), de que são corolários o autogoverno dos tribunais e a sua autonomia administrativa, financeira e orçamentária (CF, arts. 96, 99 e parágrafos, e 168), por ser o CNJ composto por membros, na origem, alheios ao Poder Judiciário; b) ofensa ao pacto federativo (CF, arts. 18, 25 e 125), por submeter a EC n ${ }^{\circ}$ 45/2004 os órgãos do Poder Judiciário dos Estados a uma supervisão administrativa,
} 
estabelecer seu espaço institucional e, consequentemente, as fronteiras constitucionais de sua atuação.

Como exposto ${ }^{50}$, as alterações trazidas pela Emenda Constitucional $n^{0}$ 45/2004 à Constituição Federal estabeleceram que o Conselho Nacional de Justiça é órgão do Poder Judiciário (art. 92, I-A), composto de quinze membros (art. 103-B, caput), responsável pelo controle da sua atuação administrativa e financeira e do cumprimento dos deveres funcionais dos juízes (art. 103-B, § $4^{\circ}$ ).

Ao Conselho Nacional de Justiça cabe, além de outras atribuições que lhe forem conferidas pelo Estatuto da Magistratura: a) zelar pela autonomia do Poder Judiciário e pelo cumprimento do Estatuto da Magistratura, podendo expedir atos regulamentares, no âmbito de sua competência, ou recomendar providências (art. 103-B, $\S 4^{\circ}, \mathrm{I}$ ); b) zelar pela observância do art. 37 da Constituição Federal e apreciar, de ofício ou mediante provocação, a legalidade dos atos administrativos praticados por membros ou órgãos do Poder Judiciário, podendo desconstituí-los, revê-los ou fixar prazo para que se adotem as providências necessárias ao exato cumprimento da lei, sem prejuízo da competência do Tribunal de Contas da União (art. 103-B, § 4 , II); c) receber e conhecer das reclamações contra membros ou órgãos do Poder Judiciário, inclusive contra seus serviços auxiliares, serventias e órgãos prestadores de serviços notariais e de registro que atuem por delegação do poder público ou oficializados, sem prejuízo da competência disciplinar e correicional dos tribunais, podendo avocar processos disciplinares em curso e determinar a remoção, a disponibilidade ou a aposentadoria com subsídios ou proventos proporcionais ao tempo de serviço e aplicar outras sanções administrativas, assegurada ampla defesa (art. 103-B, § $4^{\circ}$, III); d) representar ao Ministério Público, no caso de crime contra a administração pública ou de abuso de autoridade (art. 103-B, $\S 4^{\circ}$, IV); e) rever, de ofício ou mediante provocação, os processos disciplinares de juízes e membros de tribunais julgados há menos de um ano (art. 103-B, $\left.\S 4^{\circ}, \mathrm{V}\right)$; f) elaborar semestralmente relatório estatístico sobre processos e sentenças prolatadas, por unidade da Federação, nos diferentes órgãos do Poder Judiciário (art. 103-B, $\S 4^{\circ}$, VI); e, g) elaborar relatório anual, propondo as providências que julgar necessárias, sobre a situação do Poder Judiciário no País e as atividades do Conselho, o qual deve integrar mensagem do Presidente do Supremo

orçamentária, financeira e disciplinar de órgão da União Federal; c) inconstitucionalidade formal do art. 103$\mathrm{B}, \S 4^{\circ}$, III, pois sua redação final não foi submetida à discussão e votação nas duas Casas do Congresso Nacional, mas apenas no Senado Federal.

${ }^{50}$ Vide item 1.3. 
Tribunal Federal a ser remetida ao Congresso Nacional, por ocasião da abertura da sessão legislativa (art. 103-B, $\S 4^{\circ}$, VII).

A singela leitura do texto constitucional revela a miríade de competências do Conselho Nacional de Justiça, a dificultar a busca de seus elementos característicos e, consequentemente, sua conceituação.

Para Alexandre de Moraes (2013b, p. 534), o Conselho Nacional de Justiça é órgão de cúpula administrativa do Poder Judiciário, porém sem funções jurisdicionais.

Manoel Gonçalves Ferreira Filho (2012a, p. 292) também inclui o Conselho Nacional de Justiça na cúpula do Poder Judiciário. Após informar que o Colegiado surgiu da "luta [...] promovida pela Ordem dos Advogados do Brasil e por alguns grupos políticos, para o estabelecimento de um controle 'externo' do Poder Judiciário” (2012a, p. 296), esclarece que, da leitura do artigo 103-B da Constituição, extrai-se que o Conselho Nacional de Justiça "não pode examinar senão atos administrativos, jamais decisões jurisdicionais, e não pode impor senão sanções administrativas, jamais sanções penais” (2012a, p. 297).

Para Gilmar Ferreira Mendes e Paulo Gustavo Gonet Branco (2011, pp. 1034 e 1038), o Conselho Nacional de Justiça tem atribuições de efetivar a supervisão da atuação administrativa e financeira do Poder Judiciário, mas não submete o Supremo Tribunal Federal às suas deliberações.

José Adércio Leite Sampaio (2007, pp. 263 e 264) conceitua o Conselho Nacional de Justiça como "órgão administrativo-constitucional do Poder Judiciário da República Federativa do Brasil com status semi-autônomo ou de autonomia relativa" porque previsto na Constituição Federal, com autonomia e atribuições administrativas, porém sem autonomia orçamentária e financeira plena, pois vinculado, neste ponto, ao Supremo Tribunal Federal.

De acordo com Nelson Nery Junior e Rosa Maria de Andrade Nery (2013, p. 710),

Conselho Nacional de Justiça. Natureza jurídica. O CNJ é órgão do Poder Judiciário (CF 92 I-A), mas sem jurisdição, vale dizer, é órgão judicial, mas não jurisdicional. Órgão administrativo de controle externo do Poder Judiciário e da atividade da Magistratura (CF 103-B 4. ${ }^{\circ}$ ), o CNJ não tem função jurisdicional, cabendo-lhe fiscalizar a gestão financeira e administrativa do Poder Judiciário e o cumprimento do dever funcional dos juízes. Os Conselheiros não são investidos de jurisdição e, portanto, as decisões do CNJ não têm autoridade de coisa julgada. Ao CNJ não 
cabe controlar a função jurisdicional do Poder Judiciário e de seus membros, razão por que não pode rever nem modificar decisão judicial, isto é, não tem competência recursal. Os atos administrativos do $\mathrm{CNJ}$ podem ser controlados judicialmente, apenas por meio de ação $(\mathrm{CF}$, art. 5. ${ }^{\circ} \mathrm{XXXV}$ ), que será processada e julgada pelo STF (CF 102 I r). Não há previsão constitucional de recurso administrativo, para o STF, das decisões do CNJ. Nos crimes de responsabilidade, os membros do CNJ são julgados pelo Senado Federal (CF 52 II). O CNJ tem editado verbetes que denomina enunciados administrativos, que formam a súmula de sua jurisprudência predominante.

Antonio Rulli Neto (2007, p. 201) considera o Conselho Nacional de Justiça órgão de controle externo da Magistratura, com feição político-constitucional, pois retira dos tribunais estaduais sua autonomia administrativa e disciplinar. Defende sua inconstitucionalidade, pois, em síntese: a) em sua composição atuam membros estranhos ao Poder Judiciário; b) sua atuação viola o pacto federativo, com a extinção da autogestão dos tribunais.

Mas, quanto à expressão controle externo, utilizada para caracterizar o $\mathrm{CNJ}$, adverte José Afonso da Silva (2013, p. 570):

Esta expressão peca por sua má significação, porque transmite a ideia de que o Poder Judiciário seria controlado por um órgão externo. Isso seria inconcebível, porque então este órgão externo é que seria o Poder. Isso não exclui a necessidade de um órgão não judiciário para o exercício de certas funções de controle administrativo, disciplinar e de desvios de condutas da magistratura, como é previsto em Constituições de vários países: Conselho Superior da Magistratura, na Itália (art. 105); França (art. 65); Portugal (art. 223); Espanha (art. 122); Turquia (arts. 143-144); Colômbia (arts. 254-257); Venezuela (arts. 217).

Ao julgar a constitucionalidade dos dispositivos da Emenda Constitucional no 45/2004 que instituíram o Conselho Nacional de Justiça, o Supremo Tribunal Federal apresentou diversos elementos para sua conceituação. 
Dada a relevância, transcreve-se, na íntegra, a ementa ${ }^{51}$ do acórdão da Ação Direta de Inconstitucionalidade $\mathrm{n}^{\circ} 3367$ daquela da Corte Suprema Brasileira:

1. AÇÃO. Condição. Interesse processual, ou de agir. Caracterização. Ação direta de inconstitucionalidade. Propositura antes da publicação oficial da Emenda Constitucional n ${ }^{\circ}$ 45/2004. Publicação superveniente, antes do julgamento da causa. Suficiência. Carência da ação não configurada. Preliminar repelida. Inteligência do art. 267, VI, do CPC. Devendo as condições da ação coexistir à data da sentença, considera-se presente o interesse processual, ou de agir, em ação direta de inconstitucionalidade de Emenda Constitucional que só foi publicada, oficialmente, no curso do processo, mas antes da sentença.

2. INCONSTITUCIONALIDADE. Ação direta. Emenda Constitucional $n^{0}$ 45/2004. Poder Judiciário. Conselho Nacional de Justiça. Instituição e disciplina. Natureza meramente administrativa. Órgão interno de controle administrativo, financeiro e disciplinar da magistratura. Constitucionalidade reconhecida. Separação e independência dos Poderes. História, significado e alcance concreto do princípio. Ofensa a cláusula constitucional imutável (cláusula pétrea). Inexistência. Subsistência do núcleo político do princípio, mediante preservação da função jurisdicional, típica do Judiciário, e das condições materiais do seu exercício imparcial e independente. Precedentes e súmula 649. Inaplicabilidade ao caso. Interpretação dos arts. $2^{\circ}$ e $60, \S 4^{\circ}$, III, da CF. Ação julgada improcedente. Votos vencidos. São constitucionais as normas que, introduzidas pela Emenda Constitucional $n^{0} 45$, de 8 de dezembro de 2004, instituem e disciplinam o Conselho Nacional de Justiça, como órgão administrativo do Poder Judiciário nacional.

3. PODER JUDICIÁRIO. Caráter nacional. Regime orgânico unitário. Controle administrativo, financeiro e disciplinar. Órgão interno ou externo. Conselho de Justiça. Criação por Estado membro. Inadmissibilidade. Falta de competência constitucional. Os Estados

\footnotetext{
${ }^{51}$ José Augusto Chaves Guimarães (2004, p. 62) esclarece que "a ementa, embora fisicamente gerada junto com o acórdão (sendo originalmente publicada no alto daquele) não é parte, mas sim documento contíguo àquele". E Atienza (1981, p. 31, apud GUIMARÃES, 2004, p. 61) ensina que "a ementa deve facilitar o trabalho de pesquisa quando da procura ou busca da informação, possibilitando, também, o conhecimento do assunto que está sendo objeto de pronunciamento judicial, dando uma idéia geral do que o documento contém".
} 
membros carecem de competência constitucional para instituir, como órgão interno ou externo do Judiciário, conselho destinado ao controle da atividade administrativa, financeira ou disciplinar da respectiva Justiça.

4. PODER JUDICIÁRIO. Conselho Nacional de Justiça. Órgão de natureza exclusivamente administrativa. Atribuições de controle da atividade administrativa, financeira e disciplinar da magistratura. Competência relativa apenas aos órgãos e juízes situados, hierarquicamente, abaixo do Supremo Tribunal Federal. Preeminência deste, como órgão máximo do Poder Judiciário, sobre o Conselho, cujos atos e decisões estão sujeitos a seu controle jurisdicional. Inteligência dos art. 102, caput, inc. I, letra "r", e $\S 4^{\circ}$, da CF. O Conselho Nacional de Justiça não tem nenhuma competência sobre o Supremo Tribunal Federal e seus ministros, sendo esse o órgão máximo do Poder Judiciário nacional, a que aquele está sujeito.

5. PODER JUDICIÁRIO. Conselho Nacional de Justiça. Competência. Magistratura. Magistrado vitalício. Cargo. Perda mediante decisão administrativa. Previsão em texto aprovado pela Câmara dos Deputados e constante do Projeto que resultou na Emenda Constitucional n ${ }^{\circ}$ 45/2004. Supressão pelo Senado Federal. Reapreciação pela Câmara. Desnecessidade. Subsistência do sentido normativo do texto residual aprovado e promulgado (art. 103-B, § $4^{\circ}$, III). Expressão que, ademais, ofenderia o disposto no art. 95, I, parte final, da CF. Ofensa ao art. 60, § $2^{\circ}$, da CF. Não ocorrência. Argüição repelida. Precedentes. Não precisa ser reapreciada pela Câmara dos Deputados expressão suprimida pelo Senado Federal em texto de projeto que, na redação remanescente, aprovada de ambas as Casas do Congresso, não perdeu sentido normativo.

6. PODER JUDICIÁRIO. Conselho Nacional de Justiça. Membro. Advogados e cidadãos. Exercício do mandato. Atividades incompatíveis com tal exercício. Proibição não constante das normas da Emenda Constitucional $n^{\circ} 45 / 2004$. Pendência de projeto tendente a torná-la expressa, mediante acréscimo de $\S 8^{\circ}$ ao art. 103-B da CF. Irrelevância. Ofensa ao princípio da isonomia. Não ocorrência. Impedimentos já previstos à conjugação dos arts. $95, \S$ único, e 127, § 5º II, da CF. Ação direta de inconstitucionalidade. Pedido aditado. Improcedência. Nenhum dos advogados ou cidadãos membros do Conselho Nacional de Justiça pode, durante o exercício do mandato, exercer atividades incompatíveis 
com essa condição, tais como exercer outro cargo ou função, salvo uma de magistério, dedicar-se a atividade político-partidária e exercer a advocacia no território nacional.

A partir das disposições constitucionais, das manifestações doutrinárias e do teor do referido julgado, entendemos que o Conselho Nacional de Justiça ostenta as seguintes características:

a) Integra Poder Judiciário;

b) Forma um colegiado;

c) É um órgão de controle;

d) Realiza controle interno;

e) Exerce controle da atuação administrativa e financeira do Poder Judiciário;

f) Ocupa-se também do controle do cumprimento dos deveres funcionais dos juízes;

g) É um órgão de sobreposição na estrutura do Poder Judiciário.

Passa-se à análise, em itens distintos, de cada um dos elementos constitucionais característicos mencionados e dos limites que trazem à atuação do Conselho Nacional de Justiça.

\subsection{1. Órgão integrante do Poder Judiciário.}

O Conselho Nacional de Justiça é um órgão judicial, pois integra o Poder Judiciário.

A Emenda Constitucional $n^{\circ} 45 / 2004$, ao acrescentar o inciso I-A ao artigo 92 da Constituição Federal, expressamente incluiu o Conselho entre os órgãos do referido Poder e disciplinou-o no artigo 103-B, inserto no Título IV (da Organização dos Poderes), Capítulo III (do Poder Judiciário), Seção II (do Supremo Tribunal Federal) ${ }^{52}$ da Carta Política, atribuindo-lhe competência para o controle da atuação administrativa e financeira do Poder Judiciário e do cumprimento dos deveres funcionais dos juízes (CF, art. 103-B, $\S$ $\left.4^{\circ}\right)$.

Ademais, o Conselho Nacional de Justiça é composto, majoritariamente, por $\operatorname{magistrados}^{53}$ e o Supremo Tribunal Federal, no julgamento da Ação Direta de

\footnotetext{
${ }^{52}$ Nota-se que a EC no 45/2004 não acrescentou uma sessão específica para tratar do Conselho Nacional de Justiça e preferiu, de forma assistemática, regulá-lo na mesma sessão que discorre sobre o Supremo Tribunal Federal.

${ }^{53}$ Como será explicitado no item 2.3.2.1, nove dos quinze membros do Conselho Nacional de Justiça são escolhidos dentre magistrados.
} 
Inconstitucionalidade $n^{\circ} 3367$, expressamente reconheceu-o como integrante do Poder Judiciário $^{54}$.

Assim, além de não ser objeto deste trabalho, não há mais sentido, respeitados posicionamentos divergentes ${ }^{55}$, em se insistir na afirmação de que o Conselho Nacional de Justiça não integra o Poder Judiciário Brasileiro.

O que importa neste estudo é apresentar, em razão dessa característica (ser o CNJ órgão judicial), o primeiro limite constitucional para sua atuação: impossibilidade do Conselho exercer funções dos outros Poderes da República, ou mesmo de outras instituições essenciais à Justiça.

O Conselho Nacional de Justiça, como órgão judicial, mas não jurisdicional ${ }^{56}$, deve limitar-se ao exercício das competências expressamente fixadas na Constituição Federal e naquelas porventura previstas na Lei Orgânica da Magistratura Nacional ou no futuro Estatuto da Magistratura ${ }^{57}$.

Logo, não pode o $\mathrm{CNJ}$ exercer qualquer uma das competências exclusivas do Congresso Nacional (CF, art. 49), e privativas da Câmara dos Deputados (CF, art. 51), do Senado Federal (CF art. 52) e do Presidente da República (CF, art. 84).

Também não pode, apesar de sua competência disciplinar, promover ação penal pública, atribuição privativa do Ministério Público (CF, art. 129, I), prestar consultoria e assessoramento jurídico ao Poder Executivo, encargo da Advocacia Pública (CF, arts. 131 e 132) ou promover orientação jurídica e defesa dos necessitados, função da Defensoria Pública (CF, art. 134).

O Conselho Nacional de Justiça, ainda, por ser órgão do Poder Judiciário, não pode se imiscuir nas competências dos outros Poderes dos demais Entes da Federação (Estados,

\footnotetext{
${ }^{54}$ Reitera-se, pela pertinência, transcrição de parte da ementa do acórdão: "INCONSTITUCIONALIDADE. Ação Direta. Emenda Constitucional no 45/2004. Poder Judiciário. Conselho Nacional de Justiça. Instituição e disciplina. Natureza meramente administrativa. Órgão interno de controle administrativo, financeiro e disciplinar da magistratura. Constitucionalidade reconhecida. [...] São constitucionais as normas que, introduzidas pela Emenda Constitucional $n^{0} 45$, de 8 de dezembro de 2004, instituem e disciplinam o Conselho Nacional de Justiça, como órgão administrativo do Poder Judiciário nacional".

${ }^{55}$ Não se pode deixar de prestar homenagem à Tese de Doutorado apresentada em 2007 por Antonio Rulli Neto, sob a orientação da Professora Doutora Odete Medauar, à banca examinadora da Faculdade de Direito da Universidade de São Paulo sob o título "Controle Externo do Poder Judiciário no Brasil", onde o autor defende, com vigorosos fundamentos, que o Conselho Nacional de Justiça é órgão de controle externo do Poder Judiciário e, pois, inconstitucional.

${ }^{56}$ Conforme será exposto detalhadamente no item 2.3.5.1.

${ }^{57}$ Enquanto não for promulgado o Estatuto da Magistratura, permanecem vigentes, naquilo que foi recepcionado pela Constituição Federal, as disposições da Lei Complementar nº 35, de 14 de março de 1979, conhecida como Lei Orgânica da Magistratura Nacional (LOMAN).
} 
Municípios, Distrito Federal) ${ }^{58}$.

Sob outro prisma, cumpre mencionar que, além do limite à atuação do Conselho Nacional Justiça apresentado, outro deflui da sua condição de órgão integrante do Poder Judiciário, devido às vedações constitucionais estabelecidas aos magistrados.

Ao tratar das garantias da Magistratura previstas na Constituição Federal, Alexandre de Moraes (2013b, p. 515 a 524) as divide em institucionais e aos seus membros. As primeiras são as autonomias funcional, administrativa e financeira (art. 99) e relativa à escolha dos dirigentes dos tribunais (art. 96, I, “a”). As garantias aos membros da Magistratura são as atinentes à liberdade dos magistrados (vitaliciedade, inamovibilidade e irredutibilidade de subsídios - art. 95, I a III) e as garantias de sua imparcialidade, consubstanciadas em vedações aos juízes (art. 95, parágrafo único, I a V).

Em relação a estas últimas, prescrevem as normas constantes do art. 95, parágrafo único, da Constituição Federal ser defeso aos juízes: a) exercer, ainda que em disponibilidade, outro cargo ou função, salvo uma de magistério (inc I) ; b) receber, a qualquer título ou pretexto, custas ou participação em processo (inc. II); c) dedicar-se à atividade político-partidária (inc. III); d) receber, a qualquer título ou pretexto, auxílios ou contribuições de pessoas físicas, entidades públicas ou privadas, ressalvadas as exceções previstas em lei (inc. IV); e) exercer a advocacia no juízo ou tribunal do qual se afastou, antes de decorridos três anos do afastamento do cargo por aposentadoria ou exoneração (inc. $\mathrm{V})^{59}$.

Como o Conselho Nacional de Justiça é órgão judicial, referidas proibições também alcançam seus Conselheiros. A leitura do termo "juízes” do dispositivo constitucional em comento deve ser extensiva, de forma a atingir todos os integrantes do Poder Judiciário, pois a ratio da norma é salvaguardar a imparcialidade de seus membros.

Essa interpretação foi corroborada no julgamento da Ação Direta de Inconstitucionalidade $n^{\circ}$ 3367. O relator, Ministro Cezar Peluso, ao final de seu voto, expressamente mencionou que a autora da ação, a Associação dos Magistrados Brasileiros, formulara pedido de aditamento à inicial para sustentar que, ante a não apreciação, na Câmara dos Deputados, de proposta de acréscimo de um parágrafo $8^{\circ}$ ao artigo 103-B da Constituição Federal, que vedava aos membros do Conselho o exercício, durante seus

\footnotetext{
${ }^{58}$ Sobre as competências dos entes da federação, cumpre destacar o excelente trabalho da Professora Doutora Fernanda Dias Menezes de Almeida intitulado "Competências na Constituição Federal de 1988", já na sua $5^{\text {a }}$ edição (São Paulo: Saraiva, 2010).

${ }^{59}$ As vedações previstas nos incisos IV e V do parágrafo único do artigo 95 da Constituição Federal foram incluídas pela Emenda Constitucional no $45 / 2004$.
} 
mandatos, de outro cargo ou função, salvo uma de magistério, dedicação a atividade político-partidária e o exercício, em todo o território nacional, da advocacia, haveria um tratamento desigual entre eles, pois essas proibições já atingem aqueles Conselheiros oriundos das carreiras da Magistratura e do Ministério Público e não alcançariam os advogados e cidadãos integrantes do órgão. A alegação, porém, foi afastada pelo Supremo Tribunal Federal porque a pendência da proposta de emenda constitucional não deixaria de sujeitar os membros do Conselho Nacional de Justiça às vedações constitucionais.

Como consta no voto:

Basta juízo analógico baseado nos arts. $95, \S$ único, e $128, \S 5^{\circ}$, inc. II, da Constituição Federal, para tirar-se a limpo que ninguém pode desempenhar atividades incompatíveis com a função de membro do Conselho, tais como as previstas naquele projeto e independentemente de sua conversão em regra constitucional específica. Da ausência desta não se infere inconstitucionalidade daquele, por insulto ao princípio isonômico ${ }^{60}$.

Em relação aos Conselheiros do $\mathrm{CNJ}$, pois, as vedações constitucionais previstas no dispostivo citado devem ser observadas sob dois aspectos: a) aplicam-se aos Conselheiros não integrantes das carreiras da Magistratura e do Ministério Público, enquanto perdurarem seus mandatos e, quanto ao disposto no art. 95, parágrafo único, $\mathrm{V}$, nos três anos subsequentes aos seus términos; e, b) continuam a ser aplicadas aos Conselheiros oriundos das carreiras da Magistratura e do Ministério Público ${ }^{61}$, mesmo afastados de suas

\footnotetext{
${ }^{60}$ Apesar do afirmado, cumpre destacar que Marçal Justen Filho não classifica os Conselheiros do CNJ oriundos dos quadros da advocacia e indicados como cidadãos de notável saber jurídico e reputação ilibada pelas Casas Legislativas (CF, art. 103-B, XII e XIII) como magistrados. O professor paranaense divide os agentes do Poder Judiciário em servidores e não servidores. No primeiro grupo inclui aqueles que percebem remuneração dos cofres públicos, diferenciando-os em magistrados, servidores estatutários e servidores não estatutários. Os primeiros, segundo o doutrinador, "são agentes estatais não políticos, integrantes do respectivo Poder Judiciário, titulares do exercício da função jurisdicional. São subordinados ao regime jurídico constitucional dos servidores, mas com diferenças relevantes que estão previstas, basicamente, nos arts. 93 e 95 da CF/1988. No nível infraconstitucional, aplica-se-lhes a disciplina da LC 35/1979 (Lei Orgânica da Magistratura)". Os servidores estatutários, conforme pontifica, "são os titulares de cargos públicos não exercentes de funções juridicionais propriamente ditas. São investidos de competências para o desempenho de funções administrativas necessárias e acessórias em relação à atuação jurisdicional" (2014, pp. 899/900).

${ }^{61} \mathrm{O}$ art. 128, $\S 5^{\circ}$, II, da Constituição Federal prevê as seguintes vedações aos membros do Ministério Público: a) receber, a qualquer título e sob qualquer pretexto, honorários, percentagens ou custas processuais; b) exercer a advocacia; c) participar de sociedade comercial, na forma da lei; d) exercer, ainda que em disponibilidade, qualquer outra função pública, salvo uma de magistério; e) exercer atividade políticopartidária; e, f) receber, a qualquer título ou pretexto, auxílios ou contribuições de pessoas físicas, entidades públicas ou privadas, ressalvadas as exceções previstas em lei. Ainda determina o $\S 6^{\circ}$ do mesmo dispositivo
} 
atividades funcionais originárias ${ }^{62}$.

Em síntese, o Conselho Nacional de Justiça é órgão integrante do Poder Judiciário. Logo: a) não pode exercer funções dos outros Poderes da República, ou mesmo de outras instituições essenciais à Justiça; b) aos seus Conselheiros também alcançam as vedações constitucionais aos magistrados previstas nas regras mencionadas nos incisos do art. 95, parágrafo único, da Lei Fundamental.

Apesar das afirmações feitas, apresentar-se-ão, nos dois próximos itens, exemplos de normas que mostram como: a) resolução do Conselho pode invadir a esfera de competência de outros Poderes; e; b) regra regimental do órgão violou a "quarentena" imposta pela Emenda Constitucional no 45/2004 aos membros do Poder Judiciário.

\subsubsection{Estudo de norma: Resolução CNJ $n^{0}$ 140/2011 - Invasão de competência do Poder Legislativo}

Em 26 de setembro de 2011 foi editada a Resolução do Conselho Nacional de Justiça $\mathrm{n}^{\mathrm{o}} 140$

Referido ato normativo proíbe, em todo o território nacional, a atribuição de "nome de pessoa viva a bem público sob a administração de órgãos do Poder Judiciário" (art. $1^{\circ}$ ). Fundamenta a determinação no disposto na Lei ${ }^{0}$ 6.454, de 24 de outubro de 1977, que proíbe atribuir nome de pessoa viva ou que tenha se notabilizado pela defesa ou exploração de mão de obra escrava, a bem público, de qualquer natureza, pertencente à União ou às pessoas jurídicas da administração indireta (art. $1^{\circ}$, com a redação dada pela Lei $n^{\circ} 12.781$, de 10 de janeiro de 2013) e na norma inserta no artigo 37, § $1^{\circ}$, da Constituição Federal, que estabelece que a publicidade dos atos, programas, obras, serviços e campanhas de órgãos públicos deverá ter caráter educativo, informativo ou de orientação social, proibindo que dela constem nomes, símbolos ou imagens que caracterizem promoção pessoal de autoridades ou servidores públicos.

A regra constitucional revela uma das vertentes do princípio da impessoalidade no

constitucional, aplicar-se aos membros do Ministério Público a proibição do exercício da advocacia no juízo ou tribunal do qual se afastou, antes de decorridos três anos do afastamento do cargo por aposentadoria ou exoneração, conforme previsto no art 95, parágrafo único, V, da Lei Maior.

${ }^{62} \mathrm{O}$ art. $17, \S \S 1^{\mathrm{o}}$ e $2^{\mathrm{o}}$, do atual Regimento Interno do Conselho Nacional de Justiça, aprovado pela Resolução $\mathrm{n}^{\circ}$ 67, de 3 de março de 2009, dispõe que "a qualidade de Conselheiro não é incompatível com o exercício do cargo em virtude do qual foram indicados os magistrados", mas estes "poderão afastar-se de suas atividades funcionais". 
âmbito da Administração Pública: "evitar que esta apresente-se com a marca pessoal do ocupante momentâneo do poder ou outra fórmula de identificação de sua pessoa" $\left(\right.$ TAVARES, 2013, p. 1064) ${ }^{63}$. Destina-se, no entanto, somente a autoridades e servidores públicos.

Quanto à Lei nº 6.454/1977, suas disposições são aplicáveis somente à Administração Pública da União (lei federal, não nacional) ${ }^{64}$, pois compete aos Estados, aos Municípios e ao Distrito Federal legislar privativamente sobre seus próprios.

Como ressalta Fernanda Dias Menezes de Almeida (2010, p. 102), ao tratar das competências legislativas dos Municípios, mas cuja lição também se aplica, mutatis mutandis, aos Estados e ao Distrito Federal,

no âmbito de sua competência constitucional o Município exerce a função de legislar sem submissão hierárquica, sendo inconstitucionais a lei estadual e a lei federal que, desbordando dos limites das respectivas competências, invadirem o campo da competência municipal.

No Estado de São Paulo, por exemplo, a Constituição Estadual estabelece competir à Assembleia Legislativa legislar sobre "bens do domínio do Estado e proteção do patrimônio público" (art. 19, VII). A Lei Estadual Paulista no 14.707, de 8 de março de

\footnotetext{
${ }^{63}$ O princípio da impessoalidade, previsto no art. 37, caput, da Constituição Federal, é lido de modo diverso pelos doutrinadores constitucionalistas e administrativistas brasileiros (vide item 3.1.3).

${ }^{64}$ Sobre a distinção entre lei federal e lei nacional, transcreve-se elucidativo trecho constante da Dissertação de Mestrado apresentada por Douglas Camarinha Gonzales, sob a orientação da Professora Doutora Anna Cândida da Cunha Ferraz, à Banca Examinadora da Faculdade de Direito da Universidade de São Paulo sob o título "Competência legislativa dos entes federados; conflitos e interpretação constitucional" (2011, pp. 20 a 21): "[...] a União é um ente federado tal como os Estados-membros, os Municípios e o Distrito Federal, e não se confunde com a República Federativa do Brasil. Essa divisão torna-se mais clara quando a União legisla para seus servidores ou para sua polícia (federal). Contudo, a União também age em nome da Federação quando mantém relações com os Estados estrangeiros, assegura a defesa nacional ou decreta estado de sítio e a intervenção federal (art. 21, I, II e IV da CF). Justamente por essa dupla atribuição, Michel Temer observa que a União é uma figura de duas faces, que tanto age em nome próprio como em nome da Federação. Ora se manifesta por si, como pessoa jurídica de capacidade política, ora em nome do Estado Federal (TEMER, Michel. Elementos de direito constitucional. 10ª ed. São Paulo: Malheiros Ed., 1993, p. 77. Também nesse sentido, Cf. ARAÚJO; NUNES JÚNIOR, 2009, p. 281). Daí o sentido de dizer que as leis federais alcançam somente a União (como quando legisla para seus servidores), ao passo que as leis nacionais alcançam toda a Federação (quando legisla em nome da Federação). Frise-se, pois, que quanto as normas firmadas pela União, a divisão entre normas ditas nacionais ou federais tem por base não o critério territorial de validade, mas sim o critério pessoal de validade da norma, consoante preconiza Hans Kelsen (KELSEN, Hans. Teoria Geral do Direito e do Estado. $2^{\mathrm{a}}$ ed. Tradução de Luís Recaséns Siches e Justino de Azcárate. Barcelona: Bosch, 1934, p. 435), ao pontuar que as normas provindas da União, embora tenham [ou possam ter] todas a mesma esfera territorial de validade, tendem a diferir quanto às suas esferas pessoais de validade. As normas nacionais apresentam validade pessoal para todos os entes federados; já as normas tidas como federais, vinculam somente a União, geralmente voltadas para seu corpo administrativo, como seus servidores ou sua própria regulação administrativa".
} 
2012, ao dispor sobre a denominação de prédios, rodovias e repartições públicas, permite que se homenageie pessoa viva, desde que conte com mais de sessenta e cinco anos de idade (art. $\left.1^{\mathrm{o}}, \mathrm{I}, b\right)$, preenchidos outros requisitos ${ }^{65}$.

Por outro lado, a Lei Orgânica do Município de São Paulo prevê caber à Câmara Municipal "autorizar, nos termos da lei, a alteração de denominação de próprios, vias e logradouros públicos" (art. 13, XVII, com a redação dada pela Emenda n 10/1991). A Lei Municipal Paulistana n ${ }^{0}$ 14.454, de 27 de junho de 2007, responsável pela consolidação da legislação municipal sobre a denominação e a alteração da denominação de vias, logradouros e próprios municipais, veda a designação de próprio municipal com o nome de personalidade viva (art. $\left.7^{\circ}, \mathrm{I}\right)^{66}$.

Verifica-se, por esses dois exemplos, que a Resolução CNJ no 140/2011, ao determinar que nenhum bem público sob a administração de órgãos do Poder Judiciário seja intitulado com o nome de pessoa viva, invade competência legislativa privativa dos Entes da Federação.

Basta imaginar um imóvel de propriedade do Estado de São Paulo, administrado pelo Tribunal de Justiça ou cedido para uso ao Tribunal Regional Federal da $3^{\text {a }}$ Região ou aos

${ }^{65}$ Artigo $1^{\text {o }}$ (Lei Estadual Paulista $n^{\text {o }} 14.707 / 2012$ ) - Poderão ser atribuídos nomes de personalidades nacionais ou estrangeiras a prédios, rodovias e repartições públicas estaduais, desde que:

I - a proposta seja acompanhada de:

a) biografia e relação das obras e ações do homenageado;

b) documento que comprove ser o homenageado pessoa falecida ou com mais de 65 (sessenta e cinco) anos de idade;

c) documento referente ao próprio a ser denominado, expedido pelo órgão responsável, no qual conste que o prédio, rodovia ou repartição pública pertence ao Estado e está em condições de receber denominação, bem como sua exata localização;

d) abaixo-assinado com, no mínimo, 400 (quatrocentas) assinaturas de moradores da região atendida pela escola ou manifestação de apoio do Conselho de Escola, no caso de denominação de estabelecimento de ensino;

II - não haja outro prédio, rodovia ou repartição pública estadual com o nome da mesma pessoa que se pretende homenagear;

III - o homenageado tenha prestado serviços relevantes à sociedade, à Pátria ou à humanidade e, preferencialmente, tenha vínculos com o próprio a ser denominado e sua população circunvizinha.

${ }^{66}$ Art. $7^{\circ}$ (Lei Municipal Paulistana $\mathrm{n}^{\circ}$ 14.454/2007) Os próprios municipais, especialmente quando neles se localizam repartições e serviços públicos, poderão ser denominados com nomes de personalidades nacionais ou estrangeiras, atendidas as seguintes condições:

I - que a personalidade a ser homenageada seja pessoa já falecida;

II - que não exista outro próprio municipal com o nome da personalidade que se pretende homenagear;

III - que a proposta contenha uma justificativa que inclua a biografia de quem se pretende homenagear e a relação de suas obras e ações meritórias e relevantes;

IV - que se utilize exclusivamente a língua nacional, exceto quando referente a nomes próprios de brasileiros de origem estrangeira ou para homenagear personalidades reconhecidas por terem prestado relevantes serviços ao Município, ao Brasil ou à Humanidade.

Parágrafo único. Só poderão ser homenageadas, com seus nomes denominando próprios municipais, personalidades que tenham prestado importantes serviços à Humanidade, à Pátria, à Sociedade ou à Comunidade e, neste caso, que possua vínculos com o logradouro, com a repartição ou o serviço nele instalado ou com a população circunvizinha. 
Tribunais Regionais do Trabalho da $2^{\mathrm{a}}$ ou da $15^{\mathrm{a}}$ Região. Não poderia a Assembleia Legislativa, com a sanção do Governador, observados os requisitos da Lei Estadual $n^{o}$ 14.707/2012, atribuir, por lei, o nome de pessoa viva ao prédio, ante o teor da resolução comentada? Por outro lado, os vereadores da Capital Bandeirante estarão impedidos, ante o teor da Resolução CNJ no 140/2011, de, eventualmente, alterar a Lei Municipal $n^{\text {o }}$ 14.454/2007, para permitir homenagens a pessoas vivas, desde que não haja afronta à Constituição Federal, caso admitam a denominação em prédios públicos cedidos para uso do Poder Judiciário? É evidente que a resposta a essas duas indagações é negativa ante o disposto nos artigos $25, \S 1^{\circ}$, e $30, \mathrm{I}$, ambos da Constituição Federal.

Em suma, a Resolução CNJ no 140/2011, ao proibir, em todo o território nacional, a atribuição de nome de pessoa viva a bem público sob a administração de órgãos do Poder Judiciário, é exemplo de ato normativo que extrapola os limites constitucionais de atuação do Conselho Nacional de Justiça, pois, como órgão do Poder Judiciário, não pode o Colegiado dispor sobre assunto privativo dos Legislativos dos Entes da Federação.

\subsubsection{Estudo de norma: RICNJ, art. 11, $\S 4^{\circ}$ - Violação da "quarentena" constitucional}

Como afirmado $^{67}$, o Conselho Nacional de Justiça é órgão integrante do Poder Judiciário e, por esse motivo, além de não exercer funções dos outros Poderes da República, ou mesmo de outras instituições essenciais à Justiça, seus Conselheiros também estão sujeitos às vedações aos magistrados previtas no art. 95, parágrafo único, I a V, da Carta Política.

Não cabe, neste momento, analisar detalhadamente as vedações impostas pela Lei Maior para garantia da imparcialidade dos Conselheiros do CNJ e de todos os magistrados).

Mas não se pode deixar de abordar, neste ponto, a atuação do Conselho na elaboração de seus Regimentos Internos em cotejo com a proibição prevista no art. 95, parágrafo único, V, da Constituição Federal, porque explicita violação, pelo Colegiado, de fronteira à sua competência determinada pela Carta Política ao integrá-lo como órgão do Poder Judiciário.

O Conselho Nacional de Justiça, por força da norma inserta no artigo $5^{\circ}, \S 2^{\circ}$, da

\footnotetext{
${ }^{67}$ Vide item 2.3.1.
} 
Emenda Constitucional no 45/2004 - "Até que entre em vigor o Estatuto da Magistratura, o Conselho Nacional de Justiça, mediante resolução, disciplinará seu funcionamento e definirá as atribuições do Ministro-Corregedor” - e ante a disposição contida no artigo 96, I, “a”, da Constituição Federal - "Compete privativamente [...] aos tribunais [...] eleger seus órgãos diretivos e elaborar seus regimentos internos, com observância das normas de processo e das garantias processuais das partes, dispondo sobre a competência e o funcionamento dos respectivos órgãos jurisdicionais e administrativos" - , aplicável ao órgão, no que for compatível, por integrar o Poder Judiciário, através da Resolução $\mathrm{n}^{\circ} 2$, de 16 de agosto de 2005, elaborou seu primeiro Regimento Interno, posteriormente revogado pela Resolução $n^{\circ}$ 67, de 3 de março de 2009, que aprovou o novo Regimento Interno do Colegiado (RICNJ).

O primeiro Regimento Interno do Conselho, para explicitar que as garantias e vedações aos juízes previstas na Constituição Federal também se estendiam aos seus membros, estabelecia, em seu art. $5^{\circ}, \S 1^{\circ}$, que "os Conselheiros terão as mesmas prerrogativas, impedimentos constitucionais, suspeições e incompatibilidades que regem a carreira da magistratura, enquanto perdurar o mandato". Nota-se que a norma, corretamente, não fazia qualquer distinção entre Conselheiros oriundos ou não da carreira da Magistratura, justamente porque o regramento constitucional atingia a todos.

E, consentâneo à norma inserta no art. 95, parágrafo único, V, da Constituição Federal, previa o anterior Regimento Interno do CNJ, em seu art. $5^{\circ}, \S 4^{\circ}$, que aos Conselheiros era vedado o exercício da advocacia perante o órgão nos três anos subseqüentes ao término dos seus mandatos.

O novo Regimento Interno (RICNJ), porém, inovou as redações das normas em comento: de forma equivocada, quanto ao primeiro regramento, e com violação à última disciplina constitucional citada, em relação à segunda normatização.

Reza o art. 11, $\S 3^{\circ}$, do novel diploma regimental que, no que couber, enquanto durarem seus mandatos, terão os mesmos direitos, prerrogativas, deveres, impedimentos constitucionais e legais, suspeições e incompatibilidades que regem a carreira da magistratura os Conselheiros que não a integrem ${ }^{68}$.

A referida norma explicita que os Conselheiros também estão sujeitos aos

\footnotetext{
${ }^{68}$ Art. 11 (RICNJ). [...]

$\S 3^{\circ}$ Os Conselheiros não integrantes das carreiras da magistratura terão os mesmos direitos, prerrogativas, deveres, impedimentos constitucionais e legais, suspeições e incompatibilidades que regem a carreira da magistratura, no que couber, enquanto perdurar o mandato.
} 
impedimentos previstos em lei (como os constantes dos códigos processuais), mas restringe seu alcance aos Conselheiros não integrantes das carreiras da Magistratura.

Ocorre que, como exposto alhures ${ }^{69}$, os Conselheiros integrantes das carreiras da Magistratura continuam, da mesma forma, a manter os mesmos predicados durante seus mandatos no Conselho Nacional de Justiça, justamente porque o órgão integra o Poder Judiciário.

A redação do novo Regimento Interno do Conselho, nesse ponto, não foi feliz, ainda que, pelos motivos apresentados, não gere maiores consequências.

Houve sobre o tema, porém, outra inovação no novo Regimento Interno do CNJ, essa maculada de inconstitucionalidade: a alteração do tempo de proibição do exercício de advocacia perante o Colegiado após o término do mandato dos Conselheiros.

$\mathrm{O}$ art. $11, \S 4^{\mathrm{o}}$, do referido diploma normativo veda aos Conselheiros, nos dois anos seguintes ao término dos seus mandatos, advogar junto ao Conselho Nacional de Justiça ${ }^{70}$.

O novo Regimento Interno, pois, reduziu em um ano o prazo tratado em relação ao diploma revogado.

Ocorre, como já mencionado, que a Constituição Federal veda o exercício da advocacia perante o órgão judicial do qual se afastou o membro do Poder Judiciário, antes de decorridos três anos do afastamento do cargo (art. 95, parágrafo único, V).

Trata-se de inovação trazida pela Emenda Constitucional $n^{\circ} 45 / 2004$, denominada pela doutrina de "quarentena",

\footnotetext{
${ }^{69}$ Vide item 2.3.1.

${ }^{70}$ Art. 11 (RICNJ). [...]

$\S 4^{\circ}$ Aos Conselheiros é vedado o exercício da advocacia perante o CNJ nos dois (2) anos subsequentes ao término do mandato.

${ }^{71} \mathrm{O}$ termo "quarentena" remete ao numeral quarenta e origina-se da reclusão, inicialmente por quarenta dias, de pessoas ou animais sadios que tiveram contato com doenças quarentenárias, de grande transmissibilidade, como cólera ou febre amarela. Muitas vezes é determinada pela Vigilância Sanitária em relação a navios, quando constatada a presença de passageiro ou tripulante com moléstia contagiosa, para que não ancorem no porto, a fim de se evitar sua introdução em regiões indenes (GASPARINI, 2011, p. 291; Glossário do Portal da Saúde e Cidadania do Governo do Estado de Santa Catarina. Disponível em: $<$ http://portalses.saude.sc.gov.br/arquivos/sala_de_leitura/saude_e_cidadania/ed_07/10.html $>$. Acesso em 23.06.2013).

${ }^{72}$ Preferiu-se, neste trabalho, a utilização da expressão "tráfico de influência" no lugar de "exploração de prestígio", também adotada pela doutrina, ante a alteração da rubrica e da redação do artigo 332 do Código Penal, trazida pela Lei $\mathrm{n}^{\circ}$ 9.127, de 16 de novembro de 1995, a saber:
}

"Tráfico de influência".

Art. 332. Solicitar, exigir, cobrar ou obter, para si ou para outrem, vantagem ou promessa de vantagem, a pretexto de influir em ato praticado por funcionário público no exercício da função.

Pena - Reclusão, de dois a cinco anos, e multa. 
Judiciário.

É certo que a redação do dispositivo em comento poderia levar à equivocada leitura (decorrente de pura aplicação do método jurídico clássico e interpretação meramente gramatical do texto ${ }^{73}$ ) de que o prazo de três anos de "quarentena" não atinge os Conselheiros do $\mathrm{CNJ}$, pois deixam o órgão após o cumprimento de mandato e não devido a exoneração ou aposentadoria. Ademais, o Conselho não é juízo ou tribunal.

A imprecisão, porém, não justifica afastar a disposição constitucional do seu real alcance. A respeito lecionam Gilmar Ferreira Mendes e Paulo Gustavo Gonet Branco (2011, pp. 971 e 972):

A EC n. 45/2004 inovou nas vedações, ao estabelecer a proibição de o ex-ocupante de cargo na magistratura exercer atividade advocatícia perante o juízo ou tribunal do qual se afastou, salvo se decorridos três anos do afastamento. Tem-se aqui a aplicação da chamada "quarentena" no âmbito do Poder Judiciário, com o objetivo de evitar situações geradoras de um estado de suspeição quanto ao bom funcionamento do Judiciário. Embora a matéria tenha suscitado alguma polêmica, tendo em vista a restrição que se impõe sobre direitos individuais, a decisão afigura-se plenamente respaldada na ideia de reforço de independência e da imparcialidade dos órgãos judiciais.

Eventuais críticas ao modelo adotado centraram-se na limitação ao exercício livre de atividade profissional. Por outro lado, a previsão procura afastar suposto perigo evidenciado pela odiosa prática do revolving doors, como se denomina no Direito norte-americano o trânsito entre setores públicos e privado.

Parágrafo único. A pena é aumentada da metade, se o agente alega ou insinua que a vantagem é também destinada ao funcionário.

${ }^{73}$ J. J. Gomes Canotilho (2003, pp. 1210 e 1211) assinala que o método jurídico, também denominado método hermenêutico clássico, "parte da consideração de que a constituição é, para todos os efeitos, uma lei. Interpretar a constituição é interpretar uma lei (tese da identidade: interpretação constitucional = interpretação legal). Para se captar o sentido da lei constitucional devem utilizar-se os cânones ou regras tradicionais da hermenêutica. O sentido das normas constitucionais desvenda-se através da utilização como elementos interpretativos: (i) do elemento filológico (= literal, gramatical, textual); (ii) do elemento lógico (= elemento sistemático); (iii) do elemento histórico; (iiii) do elemento teleológico (= elemento racional); (iiiii) do elemento genético. A articulação destes vários factores hermenêuticos conduzir-nos-á a uma interpretação jurídica (= método jurídico) da constituição em que o princípio da legalidade (= normatividade) constitucional é fundamentalmente salvaguardado pela dupla relevância atribuída ao texto: (1) ponto de partida para a tarefa de mediação ou captação de sentido por parte dos concretizadores das normas constitucionais; (2) limite da tarefa de interpretação, pois a função do intérprete será a de desvendar o sentido do texto sem ir para além, e muito menos contra, o teor literal do preceito". 
Refere-se a profissional que detém segredo e prestígio por conta de determinada atividade e que, em tese, exploraria o savoir-faire e o bom nome, em benefício próprio ou de terceiros.

Assim, como a regra constitucional visa evitar o tráfico de influência por ex-membros do Poder Judiciário nos órgãos dos quais se apartaram, não se justifica, pois, restringir seu alcance somente àqueles se exoneram ou se aposentam, mas a todos aqueles que se afastam após exercerem funções, ainda que temporárias, em alguma de suas estruturas parcelares ${ }^{74}$.

No caso, para se extrair o real alcance da norma do texto constitucional mencionado, devem ser utilizados os métodos de interpretação denominados pela doutrina de

\footnotetext{
${ }^{74}$ Além do Conselheiros do CNJ, também exercem funções temporárias no Poder Judiciário, por exemplo, os membros da Justiça Eleitoral, como preceituam os artigos 118 a 121 da Constituição Federal e os artigos $8^{\circ}$ a 10 da LOMAN, sendo que o próprio Conselho Nacional de Justiça, em 25 de março de 2008, no julgamento do Pedido de Providências $\mathrm{n}^{\circ}$ 2007.10.000014851-1, relator Conselheiro Técio Lins e Silva, entendeu aplicável aos magistrados de Tribunais Eleitorais que ocupem vagas reservadas à classe de advogados (CF, arts. 119, inciso II, e 120, $1^{\circ}$, inciso III), a "quarentena" prevista na Constituição Federal, nas hipóteses em que a advocacia é exercida no próprio Tribunal Eleitoral do qual se afastaram. O Tribunal Superior Eleitoral (TSE), porém, posteriomente, em 8 de junho de 2010, no julgamento da Questão de Ordem na Petição ${ }^{\circ}$ 3020 (39253-74.2009.6.00.0000), relator Ministro Aldir Passarinho, posicionou-se no sentido de que "a restrição prevista no art. 95, parágrafo único, V, da Constituição não se aplica aos ex-membros de Tribunais Eleitorais, oriundos da classe dos juristas". Entenderam os Ministros da Corte Superior Eleitoral, à exceção do Ministro Marco Aurélio Mello, que a regra inserta no art. 95, parágrafo único, V, da Constituição Federal deve ser lida de forma restrita, pois restringe direitos, alcançando somente os magistrados que se afastam do cargo por aposentadoria ou exoneração, sobretudo porque os juízes eleitorais provenientes da advocacia encontram-se em situação peculiar, uma vez que percebem tão somente gratificação de presença e representação em obediência à Lei no 8.350 , de 28 de dezembro de 1991, razão pela qual não há impedimento para que advoguem durante o desempenho do mandato, excluindo a possibilidade apenas de patrocinarem causas perante a própria Justiça Eleitoral. Tanto é que restou decidido pelo Supremo Tribunal Federal, em 6 de outubro de 1994, no julgamento da Medida Cautelar na ADI n ${ }^{\circ} 1127$, da relatoria do Ministro Paulo Brossard, que a norma inserta no inciso II do artigo 28 da Lei no 8.906, de 4 de julho de 1994 - Estatuto da Advocacia - ao estabelecer ser incompatível com a advocacia, mesmo em causa própria, as atividades de membros de órgãos do Poder Judiciário, do Ministério Público, dos tribunais e conselhos de contas, dos juizados especiais, da justiça de paz, juízes classistas, bem como de todos os que exerçam função de julgamento em órgãos de deliberação coletiva da administração pública direta e indireta, não se estende aos advogados e membros da Justiça Eleitoral e aos Juízes Substitutos não remunerados, em respeito ao que dispõe os artigos 119, II, e 120, § $1^{\circ}$, da Constituição Federal (posteriormente, em 17 de maio de 2006, a decisão foi confirmada no julgamento final da ADI $n^{\circ} 1127$, relator Ministro Marco Aurélio Mello, relator para o acórdão Ministro Ricardo Lewandowski). O Ministro Marco Aurélio Mello, vencido no julgamento da Questão de Ordem na Petição ${ }^{\circ} 3020$ no TSE, ponderou que o preceito constitucional analisado versa apenas sobre a proibição da advocacia no Juízo ou Tribunal do qual o Juiz se afastou. E salientou: "visa-se preservar não só o perfil da Corte, como também impor ou afastar, melhor dizendo, o que poderia transparecer, na visão do leigo, uma concorrência desleal com os demais advogados, com os demais profissionais da advocacia. Sabemos que, na prática, principalmente quem está na província pensa que, credenciando um ex-integrante do Tribunal, terá ganho de causa, como se passasse a atuar, o ex-integrante, como uma pessoa que ocupasse cadeira voltada a relações públicas, como se passasse a atuar como verdadeira maçaneta, abrindo portas e, com isso, logrando algo que é incompatível com a missão sublime de julgar, o afastamento da equidistância". Assim, segundo Sua Excelência, deve haver uma interpretação integrativa do art. 95, parágrafo único, V, da Constituição Federal, incluindo-se na sua previsão o término do mandato para fins de "quarentena", a fim de preservar o perfil da Corte Eleitoral e impor tratamento igualitário aos profissionais da advocacia.
} 
hermenêutico-concretizador ${ }^{75}$ e valorativo ${ }^{76}$ (também intitulado de método científicoespiritual) $^{77}$. Ademais, como esclarece André Ramos Tavares (2013, pp. 182 e 183), após citar Celso Bastos (1999, p. 112), Peter Häberle (1997, pp. 13 e 42) e Francesco Ferrara (1987, p. 139), “a interpretação da Constituição deve operar, sempre, o mais próximo possível de seu povo", retirando-se dos seus vocábulos os sentidos empregados na linguagem comum.

Não há dúvida, após uma análise dos valores dominantes na sociedade brasileira que justificaram a introdução da disposição contida no art. 95, parágrafo único, $\mathrm{V}$, da Constituição Federal pela Emenda Constitucional $n^{0} 45 / 2004^{78}$, que o intuito do

\footnotetext{
${ }^{75}$ Quanto ao método de interpretação constitucional hermenêutico-concretizador, pontifica J. J. Gomes Canotilho (2003, p. 1212) que sua consideração "arranca da ideia de que a leitura de um texto normativo se inicia pela pré-compreensão do seu sentido através do intérprete. A interpretação da constituição também não foge a este processo: é uma compreensão de sentido, um preenchimento de sentido juridicamente criador, em que o intérprete efectua uma actividade prático-normativa, concretizando as norma para e a partir de uma situação histórica concreta. No fundo, este método vem realçar e iluminar vários pressupostos da tarefa interpretativa: (1) os pressupostos subjectivos, dado que o intérprete desempenha um papel criador (précompreensão) na tarefa de obtenção do sentido do texto constitucional: (2) os pressupostos objectivos, isto é, o contexto, actuando o intérprete como operador de mediações entre o texto e a situação em que se aplica: (3) relação entre o texto e o contexto com a mediação criadora do intérprete, transformando a interpretação em 'movimento de ir e vir' (círculo hermenêutico)".
}

${ }^{76}$ As premissas do método valorativo, também denominado de científico-espiritual ou sociológico, segundo J. J. Gomes Canotilho (2003, pp. 1212 e 1213), "baseiam-se na necessidade de interpretação da constituição dever ter em conta: (i) as bases de valoração (= ordem de valores, sistema de valores) subjacentes ao texto constitucional; (ii) o sentido e a realidade da constituição como elemento do processo de integração. $\mathrm{O}$ recurso à ordem de valores obriga a uma 'captação espiritual' do conteúdo axiológico último da ordem constitucional. A ideia de que a interpretação visa não tanto dar resposta ao sentido dos conceitos do texto constitucional, mas fundamentalmente compreender o sentido e realidade de uma lei constitucional, conduz à articulação desta lei com a integração espiritual real da comunidade (com os valores, com a realidade existencial do Estado)".

${ }^{77}$ Observado o ensinamento de Virgílio Afonso da Silva (2010, pp. 115 a 143), preferiu-se, neste trabalho, denominar o método hermenêutico apresentado por J. J. Gomes Canotilho de "valorativo" em vez de "científico-espiritual". Com efeito, como pontua o Professor Titular da Faculdade de Direito do Largo de São Francisco (2010, p. 134), o termo originou-se de equivocada tradução para o português da expressão alemã geisteswissenschaftliche Methode utilizada por Ernst Forsthoff (1959, p. 39 e 44) para denominar as teses interpretativas da Constituição apresentadas por Rudolf Smend. Forsthoff rejeitava as teses de Smend, pois defendia a utilização do método jurídico clássico para interpretação constitucional. Prossegue o Professor: “Ainda que Wissenschaft signifique 'ciência' e Geist signifique 'espírito', não se pode traduzir a expressão por 'método científico-espiritual' - e não só pela estranheza que o termo certamente causa, mas também porque a expressão Geisteswissenschaft tem um sentido próprio: ela denomina aquilo que no Brasil é chamado de 'ciências humanas'. Ocorre que na Alemanha o Direito não costuma ser considerado como parte das ciências humanas, e é justamente essa contraposição que Forsthoff queria salientar, criticando o uso de métodos estranhos ao direito, ainda que pertencentes às ciências humanas". Cumpre dizer que Virgílio Afonso da Silva $(2010$, p. 121) crítica a difusão pela doutrina dos princípios de interpretação constitucional pois, para ele "não desempenham papel relevante na interpretação da constituição [...]" uma vez que, no seu pensamento, "[...] a irrelevância desses princípios é revelada quando se percebe que alguns deles em nada se diferenciam do cânones tradicionais de interpretação [...]" e "[...] pode basear-se também na impossibilidade de aplicação desses princípios em conjunto com outras práticas ou métodos de interpretação constitucional".

${ }^{78}$ O Poder Executivo considerou como um dos pontos prioritários da Reforma Constitucional implementada pela EC no 45/2004 a instituição da "quarentena" para magistrados e membros do Ministério Público, como pode ser constatado no sítio eletrônico do Ministério da Justiça. Foi apresentada a seguinte justificativa 
Constituinte Reformador foi o de impedir, de forma ampla, o tráfico de influência em todos os órgãos do Poder Judiciário por seus ex-membros, através do exercício da advocacia, antes de decorrido o prazo de três anos, e não apenas aquele eventualmente realizado por juízes exonerados ou aposentados ${ }^{79}$.

A interpretação da disposição contida no art. 95, parágrafo único, V, da Constituição Federal, apesar dos termos utilizados ${ }^{80}$, pois, indica que o prazo de três anos de

oficial: "no sentido de garantir a isonomia das partes nas relações processuais, defende-se a instituição de período em que magistrados e membros do Ministério Público não podem exercer a advocacia no âmbito da área de atuação. Isto porque o conhecimento das práticas jurídicas e das autoridades dos órgãos judicantes, por parte do egresso da magistratura ou do Ministério Público local, poderia configurar vantagem ou privilégio em relação aos demais operadores do direito que nunca integraram os quadros funcionais em questão. Trata-se de medida de valorização da advocacia e da própria magistratura, impedindo constrangimentos desnecessários". Disponível em: <http://portal.mj.gov.br/main.asp?View=\{BB93AF2526C9-4EB2-A4CC-0E5F80657034\}>. Acesso em 30.06.2013.

${ }^{79}$ Releva mencionar que André Ramos Tavares (2013, p. 956) critica a instituição da "quarentena" pelo constituinte reformador poque: a) falta-lhe proporcionalidade, pois juízes e promotores (estes ante o disposto no art. $128, \S 6^{\circ}$, da Constituição Federal) podem valer-se de outras pessoas para exercer a advocacia em seus nomes e o mero decurso do período de três anos não fará desaparecer laços de amizade e influência que mantenham nos juízos e tribunais; b) há uma presunção sinistra de que juízes e promotores, "até então responsáveis pela prestação da Justiça, no dia seguinte passariam a adotar atitudes imorais e desonestas, para atenderem a interesses pessoais e escusos"; e, c) a norma implica em restrição de direitos individuais, "o que só tem sentido se for para salvaguardar o interesse público, o que não parece ser facilmente demonstrável no caso em tela".

${ }^{80}$ A norma inserta no art. 95, parágrafo único, V, da Constituição Federal, sem dúvida, não foi redigida de forma técnica. Alexandre de Moraes (2013b, p. 523) aponta uma outra imperfeição na sua redação: "Em relação à quarentena, importante ressaltar a imprecisão da redação da $E C n^{\circ} 45 / 04$, pois ao estabelecer a vedação ao exercício da advocacia, pelo prazo de três anos, pelo magistrado aposentado ou exonerado no juízo ou tribunal do qual se afastou, poderá permitir interpretações que tornem sem efeito essa importante norma de moralidade administrativa, no tocante a juízes de $1^{\circ}$ grau, em comarcas que não sejam de Vara única. Ora, se a finalidade de inovação constitucional foi impedir eventual tráfico de influência ou exploração de prestígio, fortalecendo as normas de moralidade administrativa, a expressão 'no juízo do qual se afastou' deve ser interpretada, em relação aos juízes de $1^{\text {o }}$ grau aposentados ou exonerados, como na 'Comarca da qual se afastou', pois seria de absoluta inutilidade proibir-se, por exemplo, o juiz aposentado da $3^{\text {a }}$ Vara Cível da Comarca de São Paulo de advogar somente nessa Vara, permitindo-lhe a advocacia em todas as outras Varas da Comarca da Capital do Estado de São Paulo”. Sobre o assunto, o Conselho Nacional de Justiça, ao decidir, em 21 de novembro de 2006, o Pedido de Providências no 929, relatado pela Conselheira Ruth Lies Scholte Carvalho, asseverou que; a) os Juízes dos Tribunais Regionais Federais e do Trabalho, os Desembargadores dos Tribunais Estaduais e os Ministros dos Tribunais Superiores e do Supremo Tribunal Federal exonerados ou aposentados estão sujeitos à vedação do exercício da advocacia somente no específico tribunal de onde se afastaram; e, b) os Juízes de primeiro grau não podem advogar somente no juízo de onde se afastaram. Gilmar Mendes e Paulo Gustavo Gonet Branco (2011, p. 972), ao comentar a mencionada decisão, afirmam que a Conselheira Ruth Carvalho entendeu "que a denominada 'quarentena' se restringia aos limites territoriais da jurisdição onde o magistrado aposentado atuava". No voto, porém, não consta expressamente essa limitação. Cumpre destacar ainda que, em 23 de maio de 2014, a $8^{\text {a }}$ Turma do Tribunal Regional Federal da 1. ${ }^{a}$ Região, ao julgar o Mandado de Segurança n ${ }^{\circ}$ 0017722-56.2012.4.01.3300, da relatoria do Desembargador Federal Novély Vilanova, assegurou ao impetrante, juiz aposentado que exerceu a Magistratura de primeiro grau até 31 de maio de 2011 em juizado da Comarca de Salvador, Estado da Bahia, o direito ao exercício da advocacia perante os órgãos judiciários de primeiro grau de todas as comarcas do referido Estado, inclusive no seu Tribunal de Justiça, exceto na Comarca Soteropolitana, onde o requerente se aposentou ("Juiz de direito que se aposentou na comarca de Salvador pode exercer a advocacia no estado da Bahia", disponível em: <http://portal.trf1.jus.br/portaltrf1/comunicacaosocial/imprensa/noticias/juiz-de-direito-que-se-aposentou-na-comarca-de-salvador-pode-exercer-a-advocacia -no-estado-da-bahia.htm\#>. Acesso em 05.07.2014). 
"quarentena" também deve ser imposto aos ex-Conselheiros do Conselho Nacional de Justiça, órgão que integra o Poder Judiciário. O vocábulo "exoneração" constante do texto normativo constitucional, de utilização técnica pelo Direito Administrativo ${ }^{81}$, deve ser lido em sentido comum e observados os valores da sociedade que justificaram a emenda constitucional, como sinônimo da expressão "qualquer outro desligamento" 82 , inclusive aquele decorrente do término do exercício de mandato por Conselheiro no Colegiado Administrativo Judiciário.

Em resumo, o Conselho Nacional de Justiça, ao deliberar, através da Resolução CNJ $n^{\text {o }} 67 / 2009$, alterar seu Regimento Interno e dispor, no novo diploma normativo, precisamente no art. $11, \S 4^{\circ}$, que aos seus Conselheiros é vedado o exercício da advocacia perante o Colegiado nos dois anos subsequentes ao término do mandato, violou limite constitucional de sua atuação, pois ignorou tratar-se o CNJ de órgão do Poder Judiciário e, como tal, estarem seus membros sujeitos ao prazo de "quarentena" de três anos estabelecido no art. 95, parágrafo único, V, da Constituição Federal.

\subsection{2. Órgão colegiado.}

\subsubsection{A estrutura do Conselho Nacional de Justiça.}

O Conselho Nacional de Justiça é um colegiado.

Compõe-se, segundo dispõe o art. 103-B, da Constituição Federal, de quinze membros: a) o Presidente do Supremo Tribunal Federal, que o presidirá, salvo nas suas

\footnotetext{
${ }^{81}$ O vocábulo "exoneração", em Direito Administrativo, expressa uma das formas de extinção do vínculo entre a Administração Pública e o servidor, pessoa que ocupa cargo, emprego ou função pública. A exoneração decorre de pedido do servidor ou pode ser determinada de ofício nos cargos em comissão ou função de confiança, quando não satisfeitas as condições do estágio probatório, ou quando o servidor empossado não entrar em exercício no prazo estabelecido (Lei no 8112/1990, arts. 34 e 35). Implica em desinvestidura do cargo, emprego ou função pública, que torna-se vago (nesse sentido pronunciam-se, dentre outros, Hely Lopes Meirelles (1999, p. 392), Maria Sylvia Zanella di Pietro (2012, pp. 662 e 663) e Diogenes Gasparini (2011, pp. 302 e 303)).

${ }^{82}$ Já em sentido comum, o termo "exoneração", que se origina do verbo latino exonerare, significa descarregar, tirar a carga, livrar-se (SILVA, 2007, p. 584). Nos dicionários da língua portuguesa encontramse as seguintes definições para o substantivo e o verbo "exonerar": a) demissão ou destituição de uma função ou de um cargo; libertar ou libertar-se de uma obrigação ou de um dever; retirar ou retirar-se de uma função ou de um cargo (Dicionário Priberam da Língua Portuguesa, disponível em: $<$ http://www.priberam.pt/dlpo/default.aspx?pal=exoneração>. Acesso em 23.06.2013); b) ação de exonerar; demissão; dispensa; isenção; desobrigação (Dicionário online de português, disponível em: $<\mathrm{http}$ //www.dicio.com.br/exoneracao/>. Acesso em 23.06.2013); c) o mesmo que eximir e isentar; demitir(se); dispensar; aliviar, descarregar (Dicionário de Português Online Michaelis, disponível em $<$ http://michaelis.uol.com.br/moderno/portugues/definicao/exonerar\%20_963226.html $>$. Acesso em 23.06.2013).
} 
ausências e impedimentos, quando a presidência do órgão será exercida pelo VicePresidente do Supremo Tribunal Federal (art. 103-B, $\left.\S 1^{\circ}\right)^{83}$; b) um Ministro do Superior Tribunal de Justiça, indicado pelo respectivo tribunal, que exercerá a função de MinistroCorregedor (art.103-B, $\S 5^{\circ}$ ); c) um Ministro do Tribunal Superior do Trabalho, indicado pelo respectivo tribunal; d) um desembargador de Tribunal de Justiça, indicado pelo Supremo Tribunal Federal; e) um juiz estadual, indicado pelo Supremo Tribunal Federal; f) um juiz de Tribunal Regional Federal, indicado pelo Superior Tribunal de Justiça; g) um juiz federal, indicado pelo Superior Tribunal de Justiça; h) um juiz de Tribunal Regional do Trabalho, indicado pelo Tribunal Superior do Trabalho; i) um juiz do trabalho, indicado pelo Tribunal Superior do Trabalho; j) um membro do Ministério Público da União, indicado pelo Procurador-Geral da República; k) um membro do Ministério Público estadual, escolhido pelo Procurador-Geral da República dentre os nomes indicados pelo órgão competente de cada instituição estadual; 1) dois advogados, indicados pelo Conselho Federal da Ordem dos Advogados do Brasil ${ }^{84}$; e, m) dois cidadãos, de notável saber jurídico e reputação ilibada, indicados um pela Câmara dos Deputados e outro pelo Senado Federal $^{85}$.

$\mathrm{O}$ art. 103-B, $\S 3^{\circ}$, dispõe que "não efetuadas, no prazo legal, as indicações previstas neste artigo, caberá a escolha ao Supremo Tribunal Federal”.

André Ramos Tavares (2013, p. 940) afirma que esse prazo é de cento e oitenta dias, conforme previsto no art. $5^{\circ}$, caput, da $\mathrm{EC} \mathrm{n}^{\circ} 45 / 2004$.

Referida norma estabelece:

O Conselho Nacional de Justiça e o Conselho Nacional do Ministério Público serão instalados no prazo de cento e oitenta dias a contar da promulgação desta Emenda, devendo a indicação ou escolha de seus membros ser efetuada até trinta dias antes do termo final.

\footnotetext{
${ }^{83}$ Conforme exposto no item 1.3, no regramento inicialmente trazido pela EC $n^{\circ} 45 / 2004$, ficou estabelecido que o CNJ seria composto por quinze Conselheiros das mesmas classes mencionadas. Porém, havia limites mínimo e máximo de idade para ocupar o cargo (mais de trinta e cinco e menos de sessenta e seis anos de idade) e ainda foi inicialmente fixado que o órgão seria presidido por um Ministro indicado pelo Supremo Tribunal Federal, mas não necessariamente seu Presidente e que ele somente votaria em caso de empate, além de ficar excluído da distribuição de processos na Suprema Corte. Não havia, por outro lado, previsão de sua substituição por outro Ministro do STF nas suas ausências e impedimentos (art. 103-B, caput, I e CF).

${ }^{84} \mathrm{~A}$ indicação dos dois advogados é feita mediante eleição em sessão extraordinária do Conselho Federal da Ordem dos Advogados do Brasil, conforme prevê o Provimento (Prov.) no 113, de 10 de setembro de 2006, da referida Casa.

${ }^{85}$ Registre-se que, na composição do CNJ, não há membros oriundos da Justiça Eleitoral e da Justiça Militar.
} 
O primeiro parágrafo do dispositivo em comento determina:

Não efetuadas as indicações e escolha dos nomes para os Conselhos Nacional de Justiça e do Ministério Público dentro do prazo fixado no caput deste artigo, caberá, respectivamente, ao Supremo Tribunal Federal e ao Ministério Público da União realizá-las.

E o já mencionado art. $5^{\circ}, \S 2^{\circ}$, da EC 45/2004 reza: "Até que entre em vigor o Estatuto da Magistratura, o Conselho Nacional de Justiça, mediante resolução, disciplinará seu funcionamento e definirá as atribuições do Ministro-Corregedor”.

Assim, respeitado o entendimento apresentado, pensamos que o prazo de indicação, na verdade, é de cento e cinquenta dias, pois não há regra legal diversa e esse era o prazo máximo previsto para os órgãos legitimados apontarem os nomes dos primeiros membros do CNJ, que deveria ser instalado em cento e oitenta dias da data da publicação da $\mathrm{EC} \mathrm{n}^{\mathrm{o}}$ 45/2004. Caso não houvesse indicação até trinta dias antes da instalação, para evitar que o Colegiado iniciasse suas atividades incompleto, conferiu a emenda constitucional ao STF a prerrogativa de escolher seus integrantes, o que também restou estabelecido para as alterações futuras da composição do Conselho (art. 103-B, $\left.\S 3^{\circ}\right)^{86}$.

Esse prazo de indicação, a nosso ver, enquanto não entrar em vigor o Estatuto da Magistratura, por força da regra inserta no art. $5^{\circ}, \S 2^{\circ}$, da EC $n^{\circ} 45 / 2004$, inicia-se, conforme disciplinado pelo próprio CNJ no artigo 10 do seu atual Regimento Interno, da data do recebimento do ofício enviado pela Presidência do Conselho comunicando a proximidade do término do mandato do atual representante do órgão legitimado no Colegiado.

Como esse ofício, conforme previsto na regra citada, deve ser encaminhado até sessenta dias antes do término do mandato do Conselheiro, poderá, eventualmente, haver interrupção das representações, e o Conselho ficará incompleto por alguns meses, o que não é desejável.

\footnotetext{
${ }^{86}$ A Resolução STF ${ }^{0}$ 503, de 23 de maio de 2013, estabelece o procedimento de escolha e indicação, pelo Supremo Tribunal Federal, às vagas do CNJ destinadas a desembargador de Tribunal de Justiça e juiz estadual. As disposições dessa resolução, porém, na falta de ato normativo específico, também devem ser aplicadas na hipótese de indicação suplementar pelo STF de Conselheiro do CNJ, quando os órgãos legitimados originários deixem de fazê-la no prazo legal.
} 
Feitas as indicações, todos os membros do Conselho são nomeados pelo Presidente da República, após serem sabatinados pelo Senado Federal ${ }^{87}$, com exceção do Presidente do Supremo Tribunal Federal, não sujeito a arguição na Alta Casa Legislativa (art. 103-B, § $\left.2^{\circ}\right)$.

Os Conselheiros exercem mandato por um biênio, admitida uma recondução. Em relação ao Presidente do Supremo Tribunal Federal, todavia, isso não ocorre, pois ocupa a Presidência do Pretório Excelso por apenas dois anos, há proibição de reeleição para o período imediato, conforme previsto no artigo 12 do RISTF, e é tradição na Corte Suprema que haja rotatividade nos cargos direção entre os Ministros, sempre com a eleição do Ministro Vice-Presidente para exercer a Presidência no período subsequente ${ }^{88}$.

A seleção dos membros do $\mathrm{CNJ}$, pois, encerra ato administrativo complexo. A respeito, salutar a lição de Oswaldo Aranha Bandeira de Mello (2007, p. 541):

\begin{abstract}
$\mathrm{O}$ ato complexo é formado pela manifestação de vontade que se expressa pela participação de dois ou mais órgãos, cujas exteriorizações se verificam em uma só vontade. Há como um feixe unitário de impulsos volitivos, de forma que o ato jurídico é produto da ação conjugada da vontade desses órgãos. Nesse ato há unidade de conteúdo e unidade de fins de várias vontades que se congregam, operando em fases simultâneas ou sucessivas, para formar um único ato jurídico, como vontades concorrentes que cooperam na sua constituição.
\end{abstract}

Em síntese, o Conselho Nacional de Justiça é um órgão colegiado composto de quinze membros cuja seleção implica em ato complexo pois são: a) indicados por diversos órgãos legitimados mencionados Constituição Federal ou, supletivamente, pelo Supremo Tribunal Federal (caso a indicação não se realize no prazo de cento e cinquenta dias contados da data do recebimento do ofício enviado pela Presidência do CNJ comunicando a proximidade do término do mandato do atual representante do órgão legitimado no Colegiado); b) sabatinados pelo Senado Federal (com exceção do Presidente do Supremo Tribunal Federal, não sujeito a arguição na Alta Casa Legislativa); c) nomeados pelo Presidente da República para exercício de mandato por dois anos, admitida uma recondução.

\footnotetext{
${ }^{87}$ A Resolução do Senado Federal n ${ }^{\circ}$ 7, de 27 de abril de 2005, estabelece as normas para apreciação das indicações para composição do Conselho Nacional de Justiça e do Conselho Nacional do Ministério Público.

${ }^{88}$ Quanto à regra geral para eleição de cargos diretivos nos tribunais, vide item 3.1.2.1.
} 
A estrutura colegiada desenhada pela Constitução Federal para o Conselho Nacional de Justiça implica em duas importantes limitações à sua atuação: a) os critérios para composição do Colégio não podem ser alterados pelo próprio órgão; e, b) as decisões definitivas do Conselho devem ser tomadas no Plenário, pelo voto da maioria dos Conselheiros presentes, observado o quórum mínimo para reunião.

Quanto à primeira limitação, apresenta-se, a seguir, em subitem, exemplo de regra prevista no regimento interno do CNJ que alterou, indiretamente, critério constitucional para sua composição.

A segunda limitação demanda, antes da apresentação de exemplos, análise mais detalhada, pois refere-se à observância do princípio da colegialidade e os critérios para delegação de competências.

\subsection{Estudo de norma: RICNJ, art. $9^{\circ}, \S 6^{\circ}$ - Alteração de critérios para composição do CNJ}

Quanto à primeira limitação mencionada no último parágrafo do item anterior, cumpre afirmar que, como a Constituição Federal estabeleceu a forma de composição do Conselho Nacional de Justiça e relegou à lei somente a fixação de prazo para indicação dos membros do Colegiado pelos órgãos legitimados, sob pena da prerrogativa passar a ser exercida pelo Supremo Tribunal Federal, não pode o próprio Conselho modificá-la, quer diretamente, dispondo expressamente contra o texto constitucional, quer indiretamente, estabelecendo outros requisitos para a composição do Colegiado não previstos na Carta.

Não há registro de violação direta do regramento constitucional, que ocorreria, por exemplo, se o CNJ, por ato normativo próprio, alterasse o número, a forma de seleção ${ }^{89}$ ou o tempo de mandato de seus membros.

Mas há notícia de existência de norma que, indiretamente, modifica os critérios constitucionais mencionados.

Como já mencionado, o artigo $5^{\circ}, \S 2^{\circ}$, da Emenda Constitucional $n^{\circ} 45 / 2004$, determinou que o Conselho Nacional de Justiça, mediante resolução, disciplinasse seu funcionamento e definisse as atribuições do Ministro-Corregedor, até a entrada em vigor

\footnotetext{
${ }^{89}$ Uma hipótese que não se mostraria desarrazoada no senso comum, mas violaria diretamente a Constituição Federal, seria o CNJ, no processo de escolha de seus membros, dispensar a segunda sabatina dos Ministros indicados pelo Superior Tribunal de Justiça e pelo Tribunal Superior do Trabalho, porque já arguidos pelo Senado Federal quando indicados pelo Presidente da República para integrar as referidas Cortes, nos termos dos arts. 52, III, “a”, 104, parágrafo único, e 111-A, caput, todos da Lei Maior.
} 
do Estatuto da Magistratura. Em 16 de agosto de 2005 foi aprovado, pela Resolução nº 2, o Regimento Interno do Conselho, posteriormente revogado pela Resolução $n^{\circ} 67$, de 3 de março de 2009, que aprovou o novo Regimento Interno do Colegiado.

Em ambos os diplomas normativos ${ }^{90}$ foi previsto requisito não mencionado na Constituição Federal para a nomeação de Conselheiro: não ter a pessoa cumprido, na mesma classe ou em classe diversa ${ }^{91}$, dois mandatos, consecutivos ou não, no Conselho.

Dispõe o art. $9^{\circ}, \S 2^{\circ}$ do atual Regimento Interno do Colegiado: "Nenhum Conselheiro poderá voltar a integrar o Plenário na mesma classe ou em classe diversa após cumpridos dois mandatos, consecutivos ou não".

Ainda que salutar, pois democratiza a participação no órgão, entendemos que esse requisito é inconstitucional no que tange à impossibilidade de indicação da mesma pessoa em uma classe para compor o Conselho Nacional de Justiça, após o cumprimento de dois mandatos em outra classe.

É certo que o art. 103-B, caput, da Constituição Federal admite apenas uma recondução de membros indicados para o CNJ.

Mas a melhor interpretação da mencionada norma constitucional é concluir que o limite de até dois mandatos, decorrente da impossibilidade de mais de uma recondução, aplica-se somente para cada uma das classes de origem dos Conselheiros, a fim de não se restringir a faculdade de indicação dos órgãos legitimados, o que a aplicação da regra prevista no Regimento Interno do Conselho Nacional de Justiça enseja.

Por exemplo: a prevalecer a norma regimental, se um advogado for indicado pelo Conselho Federal da Ordem dos Advogados do Brasil para exercer no Conselho Nacional de Justiça dois mandatos de Conselheiro, não poderá, caso passe a integrar os quadros da Magistratura, por concurso ou por força do denominado "quinto constitucional" (CF, art. 94), ser novamente apontado para o órgão, ainda que os legitimados à indicação assim desejem.

Ademais, a regra regimental poderia inviabilizar o cumprimento da própria Constituição Federal. Basta imaginar, no exemplo anterior, que a pessoa previamente indicada na classe dos advogados para cumprir dois mandatos no Conselho se tornasse Presidente do Supremo Tribunal Federal ${ }^{92}$, membro nato do Colégio.

\footnotetext{
${ }^{90}$ Art. $2^{\mathrm{o}}, \S 2^{\mathrm{o}}$, do Regimento Interno de 2005 e art. $9^{\mathrm{o}}, \S 2^{\mathrm{o}}$, do Novo Regimento Interno de 2009.

${ }^{91}$ O termo "classe" refere-se a origem do Conselheiro de acordo com os incisos do art. 103-B, caput, da Constituição Federal.

${ }^{92}$ Apesar do novo Regimento Interno do Conselho Nacional de Justiça distinguir a figura do seu Presidente
} 
Em suma, a nosso ver, o art. $9^{\circ}, \S 2^{\circ}$ do atual Regimento Interno do Colegiado, ao impedir a indicação de Conselheiro de classe diversa daquela que tenha cumprido dois mandatos, importa em indireta alteração dos critérios de composição do CNJ, por estabelecer requisito não previsto na Constituição Federal. Trata-se de dispositivo que padece de inconstitucionalidade e que representa hipótese de violação praticada pelo Conselho aos limites constitucionais de sua atuação.

\subsubsection{Princípio da colegialidade e delegação de competências}

Em relação à segunda limitação mencionada (as decisões definitivas do Conselho devem ser tomadas no Plenário, pelo voto da maioria dos Conselheiros presentes, observado o quórum mínimo para reunião) cabe, por ser extremamente esclarecedor, primeiro transcrever o pontuado na obra "Direito Administrativo Brasileiro" de Hely Lopes Meirelles (1999, pp. 68 e 69) sobre a distinção entre órgãos singulares e coletivos:

Órgãos singulares ou colegiados: quanto à atuação funcional, os órgãos podem ser singulares ou colegiados.

Órgãos singulares ou unipessoais são os que atuam e decidem através de um único agente, que é seu chefe e representante. Esses órgãos podem ter muitos outros agentes auxiliares, como normalmente os têm, mas o que caracteriza sua singularidade ou unipessoalidade é o desempenho de sua função precípua por um só agente investido como seu titular. [...]

A formação e manifestação de vontade desses órgãos, ou seja, sua atuação funcional, não exigem formalidades nem procedimentos especiais, bastando a autenticação do Chefe para que se tornem eficazes nos limites de sua competência legal.

Órgãos colegiados ou pluripessoais são todos aqueles que atuam e

dos demais Conselheiros em seu art. $2^{\circ}$, II e IV, a Constituição Federal (art. 103-B) não faz essa distinção, sobretudo após a Emenda $\mathrm{n}^{\mathbf{0}}$ 61/2009, que estabeleceu o voto do Presidente do Conselho nas suas deliberações (antes da referida emenda constitucional o Presidente votava apenas em caso de empate (conforme CF, art. 103, $\S 1^{\circ}$, com a redação anterior à EC n ${ }^{\circ}$ 61/2009)). Ademais, o próprio Regimento Interno do Conselho prevê que seu Plenário é composto por todos os Conselheiros (art. $3^{\circ}$, caput) e presidido pelo Presidente (art. $6^{\circ}, \mathrm{IV}$ ). Mais evidente, ainda, a norma inserta no art. 45 do Diploma Regimental, que trata da distribuição de pedidos, propostas de atos normativos e processos no âmbito do CNJ: "A distribuição se fará entre todos os Conselheiros, inclusive os ausentes ou licenciados por até trinta dias, excetuando o Presidente e o Corregedor Nacional de Justiça”. Referida disposição demonstra que o Presidente do Supremo Tribunal Federal e o Corregedor Nacional de Justiça (Ministro do Superior Tribunal de Justiça) também são Conselheiros no Conselho Nacional de Justiça, porém não recebem distribuição de feitos no órgão. 
decidem pela manifestação conjunta e majoritária da vontade de seus membros. Nos órgãos colegiados não prevalece a vontade individual de seu Chefe ou Presidente, nem a de seus integrantes isoladamente: o que se impõe e vale juridicamente é a decisão da maioria, expressa na forma legal, regimental ou estatutária $\mathrm{A}$ atuação desses órgãos tem procedimento próprio, que se desenvolve nesta ordem: convocação, sessão, verificação de quórum e de impedimentos, discussão, votação e proclamação do resultado. Com a proclamação do resultado torna-se inalterável a deliberação colegial, só admitindo modificação ou correção através de novo pronunciamento do órgão, se cabível, por via recursal ou de ofício.

Como lecionava Ugo Gargiulo (1962, p. 62), o colégio consiste de uma reunião de pessoas que formam e manifestam uma deliberação, que é um ato com procedimento de formação (proposta, discussão, votação), regido por princípios especiais. Colégio e deliberação são duas noções correlatas e inseparáveis. O colégio, no entanto, não é um sistema que une, de um lado, as pessoas que o compõem, e, de outro, o que elas irão formar e manifestar: é, na verdade, uma unidade que expressa as razões da coexistência e do sistema em que as pessoas individualmente são organizadas e onde as vontades singulares se fundem; é uma unidade que institui, em si mesma, um sistema, que antecede e independe das pessoas e de suas vontades. Entendida dessa forma, a organização colegiada é uma organização deliberante, ou seja, uma reunião de pessoas, instituída e ordenada para manifestar - através de um processo especial, regido por princípios especiais - uma deliberação, que é o resultado das singulares vontades individuais ${ }^{93}$.

As vantagens das decisões proferidas por órgãos colegiados já eram pregadas por Aristóteles (2009, p. 111), no Livro III, Capítulo X, de “A Política”:

Sem dúvida, qualquer cidadão individualmente é inferior em comparação

\footnotetext{
${ }^{93}$ Nas palavras do doutrinador: "A nostro avviso, il collegio consiste in una riunione di persone che formano e manifestano uma deliberazione, cioè, un atto che ha un procedimento di formazione (proposta, discussione, voto), regolato da speciali principi [...]. Collegio e deliberazione sono due nozioni correlative ed inscindibili. Il collegio, però, non è un sistema che unifica, da un lato le persone che lo compongono, dall'altro le volontà che queste formano e manifestano: è invece una unità che esprime le ragioni della coesistenza e del sistema in cui le singole persone si organizzano e le singole volontà si fondono; è una unità che pone, essa stessa, il sistema, ed è antecedente e indipendente e dalle persone e dalle volontà, pur comprendendo le une e le altre. Così inteso, il collegio è organizzazione: organizzazione deliberante; ciò̀ riunione di persone, istituta ed ordinata allo scopo di manifestare - attraverso un particolare procedimento, retto da speciali principî - una deliberazione, che sia la risultante delle singole volontà individuali".
} 
com o melhor dos homens, mas uma cidade é constituída de muitos indivíduos, e da mesma forma que um banquete para o qual todos contribuem é mais fino que o jantar simples feito por uma só pessoa, na maioria das vezes um grupo julga melhor que uma única pessoa. A maioria também é mais difícil de corromper - tal como acontece com a água em maior quantidade, um número maior de pessoas é mais difícil de corromper que um número menor, e a faculdade de julgar de um indivíduo está sujeita a corromper-se quando ele é dominado pela cólera ou qualquer outra emoção; contrariamente, é uma tarefa difícil encolerizar um grande número de pessoas e levá-las a errar coletivamente.

Ao tratar da colegialidade das decisões dos recursos nos tribunais, em lição também aplicável às deliberações dos colégios administrativos, não desvia Pontes de Miranda do ensinamento aristotélico (1975, p. 11 apud PIERI, 2008, p. 70):

Colegialidade das decisões. - A regra, para os recursos, é a colegialidade das decisões. Quer dizer: a pluralidade de julgadores, com o fim político de assegurar diversos exames no mesmo tempo, além do duplo ou múltiplo exame, no tempo, pelo juiz do primeiro grau e os demais juízes superiores. A ciência ensina-nos, hoje, que a Assembleia não nos veio da reflexão: foi a reflexão que veio da assembleia. Portanto, o homem é que é produto da assembleia. Essa prioridade do exame múltiplo ao mesmo tempo, em relação ao exame de um só, se transforma em superioridade sempre que desejamos maior certeza. A colegialidade para a decisão dos recursos obedece a esse pendor íntimo do homem quando se deseja guiar pela "razão".

Como o Conselho Nacional de Justiça é um colegiado ${ }^{94}$, indissociável de sua natureza que suas decisões definitivas emanem da reunião de seus membros regularmente convocados para dela participarem, observados os quóruns necessários para aprovação das

\footnotetext{
${ }^{94}$ Em meados do século XX, M. S. Giannini (1961, p. 206), apud Lafayette Pondé (1972, p. 27), já revelava a importância dos órgãos colegiados, afirmando que a colegialidade, juntamente com a empresa, representava uma das estruturas jurídicas dominantes de sua época, e qualquer pessoa que pudesse penetrar na sua essência tornar-se-ia dono de uma das chaves do século. Nas palavras do doutrinador: "La collegialità, insieme all'impresa, constituisce una delle strutture giurisdiche dominanti della fase storica in cui viviamo, onde non è azzardato dire che chi riuscisse a penetrarne a fondo la sostanza, sarebbe padrone di una delle chiavi del secolo".
} 
matérias discutidas.

A Constituição Federal determina competir ao Conselho, portanto, ao órgão colegiado, o cumprimento das competências previstas em seu art. 103-B, $\S 4^{\circ}$. Confirmam essa assertiva as previsões contidas no art. 103-B, $\S 5^{\circ}$, da Lei Maior ${ }^{95}$, referentes às atribuições específicas do seu Ministro-Corregedor, órgão singular, na lição de Hely Lopes Meirelles suso mencionada. Ou seja, a própria Carta esclarece quais atos devem ser praticados pelo Colegiado e quais podem ser realizados pelo Corregedor Nacional de Justiça.

Logo, com exceção das atribuições conferidas pela Constituição Federal ao seu Ministro-Corregedor, impera no Conselho Nacional de Justiça o "princípio da colegialidade". O CNJ é um órgão pluripessoal. Portanto, pluripessoais devem ser suas decisões.

O princípio da colegialidade é muito citado pela doutrina processual, como corolário do princípio constitucional do juiz natural. A respeito, ensina Guilherme de Souza Nucci (2008):

A parte tem o direito não somente de recorrer a uma instância superior, mas de ter o seu recurso apreciado, como regra, por um órgão colegiado. Não foge à sistemática do processo brasileiro a exigência (assegurada, em grande parte, pelos Regimentos Internos dos Tribunais) de haver um colégio de juízes para julgar, em última decisão, de cada corte, os recursos de sua competência ${ }^{96}$.

Referido princípio também é aplicado no âmbito administrativo, quando o órgão detentor de determinado centro de poder for um colégio. Assim decidiu o Ministro Celso de Mello, em 12 de abril de 2000, ao deferir pedido de medida liminar no Mandado

\footnotetext{
${ }^{95}$ Dispõe o art. $103-\mathrm{B}, \S 5^{\circ}$, da Constituição Federal:

“\$ $5^{\circ} \mathrm{O}$ Ministro do Superior Tribunal de Justiça exercerá a função de Ministro-Corregedor e ficará excluído da distribuição de processos no Tribunal, competindo-lhe, além das atribuições que lhe forem conferidas pelo Estatuto da Magistratura, as seguintes:

I receber as reclamações e denúncias, de qualquer interessado, relativas aos magistrados e aos serviços judiciários;

II exercer funções executivas do Conselho, de inspeção e de correição geral;

III requisitar e designar magistrados, delegando-lhes atribuições, e requisitar servidores de juízos ou tribunais, inclusive nos Estados, Distrito Federal e Territórios".

${ }^{96}$ Texto publicado no jornal Carta Forense, sob o título "O Princípio da Colegialidade" em 10.03.2008. Disponível em: <http://www.cartaforense.com.br/conteudo/colunas/o-principio-da-colegialidade/1 148>. Acesso em 29.06.2013.
} 
Segurança $n^{\circ} 23669$ impetrado perante o Supremo Tribunal Federal contra ato praticado por Comissão Parlamentar de Inquérito, entendendo que a validade jurídica de seus atos depende da deliberação da maioria dos seus membros ${ }^{97}$, sobretudo no caso levado a julgamento (quebra de sigilo bancário do impetrante) diante do então disposto no art. 38 , $\S$ $4^{\text {o, da Lei }} \mathrm{n}^{\mathrm{o}} 4.595 / 1964^{98}$.

Em relação ao Conselho Nacional de Justiça, colegiado administrativo, a aplicação do princípio da colegialidade importa concluir que suas decisões devem ser tomadas em

\footnotetext{
${ }^{97}$ Reproduz-se parte da ementa da decisão monocrática:

"O PRINCÍPIO DA COLEGIALIDADE CONDICIONA A EFICÁCIA DAS DELIBERAÇÕES DE QUALQUER COMISSÃO PARLAMENTAR DE INQUÉRITO, ESPECIALMENTE EM TEMA DE QUEBRA DO SIGILO BANCÁRIO. - O princípio da colegialidade traduz diretriz de fundamental importância na regência das deliberações tomadas por qualquer Comissão Parlamentar de Inquérito, notadamente quando esta, no desempenho de sua competência investigatória, ordena a adoção de medidas restritivas de direitos, como aquela que importa na revelação das operações financeiras ativas e passivas de qualquer pessoa. $\mathrm{O}$ necessário respeito ao postulado da colegialidade qualifica-se como pressuposto de validade e de legitimidade das deliberações parlamentares, especialmente quando estas - adotadas no âmbito de Comissão Parlamentar de Inquérito - implicam ruptura, sempre excepcional, da esfera de intimidade das pessoas. A quebra do sigilo bancário, que compreende a ruptura da esfera de intimidade financeira da pessoa, quando determinada por ato de qualquer Comissão Parlamentar de Inquérito, depende, para revestir-se de validade jurídica, da aprovação da maioria absoluta dos membros que compõem o órgão de investigação legislativa (Lei no $4.595 / 64$, art. $38, \S 4^{\circ}$ )".
}

${ }^{98}$ A Lei no ${ }^{\circ} 4595 / 1964$ dispõe sobre a política e as instituições monetárias, bancárias e creditícias. O art. 38 do referido Diploma Legal previa:

Art. 38. As instituições financeiras conservarão sigilo em suas operações ativas e passivas e serviços prestados.

$\S 1^{\circ}$ As informações e esclarecimentos ordenados pelo Poder Judiciário, prestados pelo Banco Central da República do Brasil ou pelas instituições financeiras, e a exibição de livros e documentos em Juízo, se revestirão sempre do mesmo caráter sigiloso, só podendo a eles ter acesso as partes legítimas na causa, que deles não poderão servir-se para fins estranhos à mesma.

$\S 2^{\circ} \mathrm{O}$ Banco Central da República do Brasil e as instituições financeiras públicas prestarão informações ao Poder Legislativo, podendo, havendo relevantes motivos, solicitar sejam mantidas em reserva ou sigilo.

$\S 3^{\circ}$ As Comissões Parlamentares de Inquérito, no exercício da competência constitucional e legal de ampla investigação (art. 53 da Constituição Federal e Lei n ${ }^{\circ}$ 1579, de 18 de março de 1952), obterão as informações que necessitarem das instituições financeiras, inclusive através do Banco Central da República do Brasil.

$\S 4^{\circ}$ Os pedidos de informações a que se referem os $\S \S 2^{\circ}$ e $3^{\circ}$, deste artigo, deverão ser aprovados pelo Plenário da Câmara dos Deputados ou do Senado Federal e, quando se tratar de Comissão Parlamentar de Inquérito, pela maioria absoluta de seus membros.

O art. 38 da Lei 4595/1964 foi, após a decisão proferida pelo Ministro Celso de Mello no Mandado Segurança $\mathrm{n}^{\circ}$ 23669-MC, revogado pela Lei Complementar $\mathrm{n}^{\circ} 105$, de 10 de janeiro de 2001, que dispõe sobre o sigilo das operações de instituições financeiras. Este diploma normativo, em seu artigo $4^{\circ}$, contém disposição semelhante, a saber:

Art. $4^{\circ} \mathrm{O}$ Banco Central do Brasil e a Comissão de Valores Mobiliários, nas áreas de suas atribuições, e as instituições financeiras fornecerão ao Poder Legislativo Federal as informações e os documentos sigilosos que, fundamentadamente, se fizerem necessários ao exercício de suas respectivas competências constitucionais e legais.

$\S 1^{\circ}$ As comissões parlamentares de inquérito, no exercício de sua competência constitucional e legal de ampla investigação, obterão as informações e documentos sigilosos de que necessitarem, diretamente das instituições financeiras, ou por intermédio do Banco Central do Brasil ou da Comissão de Valores Mobiliários.

$\S 2^{\circ}$ As solicitações de que trata este artigo deverão ser previamente aprovadas pelo Plenário da Câmara dos Deputados, do Senado Federal, ou do plenário de suas respectivas comissões parlamentares de inquérito. 
Plenário, pelo voto da maioria de seus Conselheiros, observado o quórum mínimo de membros presentes para a reunião.

Ressalte-se que o atual Regimento Interno do CNJ estabelece quórum mínimo de dez integrantes para a instalação de sessões plenárias ${ }^{99}$, além de dispor que as decisões do órgão serão tomadas pelo voto da maioria dos $\operatorname{presentes}^{100}$, salvo disposição constitucional, legal ou regimental diversa ${ }^{101}$.

Mas o princípio da colegialidade não pode ser lido em termos absolutos em relação ao Conselho Nacional de Justiça (ou mesmo a qualquer órgão pluripessoal), porque o Colegiado, por sua natureza, não opera de modo contínuo, pois depende de convocação de seus membros para deliberação em sessão.

Nesse sentido afirmava Maurice Hauriou (1914, pp. 154 e 155), haver notável diferença entre os órgãos deliberantes (colegiados) e os órgãos executivos (singulares), porque aqueles não funcionam de forma permanente, mas apenas durante certos períodos de tempo prescritos pela lei, quando as reuniões são designadas, ao contrário destes, que atuam permanentemente, dia e noite e até nos feriados, pois não necessitam de sessões para $\operatorname{agir}^{102}$.

Logo, devido às exigências de celeridade e de racionalização do processo decisório ${ }^{103}$, determinados atos do Conselho devem ser delegados a órgãos singulares de atuação perene.

Aplicável, para esses atos, a regra inserta no art. 12 da Lei $n^{0} 9.784$, de 29 de janeiro de 1999, que regula o processo administrativo no âmbito da administração pública federal

\footnotetext{
${ }^{99}$ Art. $3^{\circ}$ O Plenário do CNJ, seu órgão máximo, é constituído por todos os Conselheiros empossados e se reúne validamente com a presença de no mínimo dez (10) de seus integrantes.

${ }^{100}$ Art. 121. As decisões do Plenário do CNJ e das Comissões serão tomadas pelo voto da maioria simples dos Conselheiros presentes, observado o quorum regimental, exceto nos casos em que haja exigência de quorum qualificado.

${ }^{101} \mathrm{O}$ art. 93, VIII e X, da Constituição Federal exige quórum qualificado (maioria absoluta) para imposição de sanções disciplinares a magistrados. O Regimento Interno do CNJ impõe o voto da maioria absoluta dos Conselheiros para: a) afastamento provisório de magistrado ou servidor de suas funções, caso instaurado contra ele processo administrativo disciplinar (art. 75, parágrafo único); b) instauração, de ofício, de revisão de processo disciplinar de magistrados (art. 86); c) atribuição de caráter normativo geral à consulta de interesse e repercussão gerais concernentes a material de competência do Plenário (art. 89, § $2^{\circ}$ ); d) edição de atos normativos pelo Plenário (art. 102); e, e) aprovação de emenda regimental (art. 136).

${ }^{102}$ Nas palavras do autor: "Il y a une autre différence remarquable entre les organes exécutifs et les organes délibérants, qui est la suivante: les organes délibérants ne siègent pas en permanence, mais seulement pendant certaines périodes de temps déterminées par la loi et qui s'appelent sessions; au contraire, les organes exécutifs sont en fonction d'une façon permanente. Non seulement il n'y a pas de sessions qui limitent leur compétence, mais il n'y a pas de jours féries, il n'y a même pas à distinguer la nuit du jour".

${ }^{103}$ Palavras utilizadas pelo Ministro do STF Celso de Mello, ao proferir, em 25.03.2013, decisão monocrática na Medida Cautelar em HC no 117170.
} 
e permite a delegação de competência de um órgão administrativo a outros, "ainda que estes não lhe sejam hierarquicamente subordinados, quando for conveniente, em razão de circunstâncias de índole técnica, social, econômica, jurídica ou territorial”.

Regis Fernandes de Oliveira (2005, p. 56 a 57) define "delegação" como a "transferência do exercício de competência, constitucional ou legal, de um órgão ou agente a outro, no interior ou fora de uma pessoa jurídica, em caráter precário"104.

Em seguida, o autor apresenta os requisitos para a delegação (2005, p. 60), previstos no art. 14 da Lei $n^{\circ} 9.784 / 99^{105}$ :

a) norma constitucional ou legal autorizativa; b) competência explícita do delegante, ou seja, que esteja ele investido na competência que transfere; c) dois órgãos ou agentes indicados na lei ou Constituição; d) forma expressa e escrita do ato; e) matéria passível de delegação; f) necessidade da transferência das atribuições, de acordo com as finalidades encampadas no ordenamento jurídico; e g) publicação do ato.

No que tange ao Conselho Nacional de Justiça, a EC n ${ }^{\circ} 45 / 2004$, em seu art. $5^{\circ}, \S 2^{\circ}$, expressamente o autorizou a disciplinar seu funcionamento mediante resolução até a entrada em vigor do Estatuto da Magistratura.

Pode o Colegiado (órgão indicado na Constituição Federal), portanto, delegar a Conselheiro (agente também apontado na Carta, pois membro do CNJ) parte de suas competências por resolução (ato expresso e escrito, devidamente publicado), para que seu

\footnotetext{
${ }^{104}$ A doutrina não destoa desse entendimento. Hely Lopes Meirelles (1999, p. 106) e José Cretella Júnior (1978, p. 172 apud OLIVEIRA, 2005, p. 57) apresentam conceito mais singelos de delegação. O primeiro assinala que "delegar é conferir a outrem atribuições que originalmente competiam ao delegante". O segundo afirma que "delegação é a transferência de atribuições de um órgão a outro no aparelhamento administrativo". Diógenes Gasparini (2011, p. 105) traz uma definição mais ampla e pontua que "por meio da competência de delegar, as competências recebidas são atribuídas a outrem, geralmente um subordinado, com o objetivo de assegurar maior rapidez e eficiência às decisões, colocando-as, desse modo, na proximidade dos fatos o agente competente para dar o necessário atendimento". Releva destacar ainda que, segundo Hely Lopes Meirelles (1999, p. 106), "as delegações dentro do mesmo Poder são, em princípio, admissíveis, desde que o delegado esteja em condições de bem exercê-las. O que não se admite, no nosso sistema constitucional, é a delegação de atribuições de um Poder a outro, como também não se permite delegação de atos de natureza política, como a do poder de tributar, a sanção e o veto de lei".

${ }^{105}$ Dispõe o art. 14 da Lei ${ }^{\circ} 9.784 / 1999$ :

"Art. 14. O ato de delegação e sua revogação deverão ser publicados no meio oficial.

$\S 1^{\circ} \mathrm{O}$ ato de delegação especificará as matérias e poderes transferidos, os limites da atuação do delegado, a duração e os objetivos da delegação e o recurso cabível, podendo conter ressalva de exercício da atribuição delegada.

$\S 2^{\circ} \mathrm{O}$ ato de delegação é revogável a qualquer tempo pela autoridade delegante.

$\S 3^{\circ}$ As decisões adotadas por delegação devem mencionar explicitamente esta qualidade e considerar-se-ão editadas pelo delegado".
} 
funcionamento não sofra solução de continuidade (necessidade de transferência de atribuições para que o Conselho cumpra suas missões constitucionais a contento).

Evidente, porém, que não são todas as matérias de competência do Colegiado passíveis de delegação. Se isso ocorresse, o princípio da colegialidade restaria completamente esvaziado.

A Lei $n^{0}$ 9.784/1999 apresenta as restrições à delegação de competência administrativa. Seu art. 13 a proíbe quanto: a) à edição de atos de caráter normativo; b) à decisão de recursos administrativos; e, c) às matérias de competência exclusiva do órgão ou autoridade ${ }^{106}$.

Não há, no âmbito das competências outorgadas pela Constituição Federal ao Conselho Nacional de Justiça, delegação, por ato interno, de emissão de atos de caráter normativo $^{107}$, pois compete ao Plenário editá-los, conforme dispõem os artigos $4^{\circ}$, I, XXIV e $\mathrm{XXV}^{108} ; 89, \S 2^{\text {o109}} ; 102$, caput $^{110}$; e 135 e $136^{111}$ todos do atual Regimento Interno do

${ }^{106}$ A respeito do dispositivo, leciona Regis Fernandes de Oliveira (2005. p. 97), também citado por Francisco Cláudio de Almeida Santos (2011, p. 29): "Os atos normativos, normalmente, são intransferíveis, uma vez que impõe estudos, análises do todo, para que possam ser editados. Normalmente, destinam-se a dar eficácia à aplicação da lei. Logo, próprio das autoridades que podem editar providências. A decisão, no âmbito recursal, também impede a delegação, uma vez que significaria que o delegado decidiria sobre a matéria que foi por ele apreciada e a exclusividade do exercício da competência pressupõe sua indelegabilidade”.

${ }^{107}$ A competência atribuída ao Corregedor Nacional de Justiça no art. $8^{\circ}$, X, do RICNJ insere-se entre aquelas outorgadas pelo artigo $103-\mathrm{B}, \S 5^{\circ}$ da Constituição Federal a órgão singular integrante do Colégio. Estabelece o dispositivo:

Art. $8^{\circ}$ (RICNJ) Compete ao Corregedor Nacional de Justiça, além de outras atribuições que lhe forem conferidas pelo Estatuto da Magistratura:

$[\ldots]$

X - expedir Recomendações, Provimentos, Instruções, Orientações e outros atos normativos destinados ao aperfeiçoamento das atividades dos órgãos do Poder Judiciário e de seus serviços auxiliares e dos serviços notariais e de registro, bem como dos demais órgãos correicionais, sobre matéria relacionada com a competência da Corregedoria Nacional de Justiça] insere-se entre aquelas outorgadas pelo artigo 103-B, $\S 5^{\circ}$ da Constituição Federal a órgão singular integrante do Colégio.

${ }^{108}$ Art. $4^{\circ}$ (RICNJ) Ao Plenário do CNJ compete o controle da atuação administrativa e financeira do Poder Judiciário e do cumprimento dos deveres funcionais dos magistrados, cabendo-lhe, além de outras atribuições que lhe forem conferidas pelo Estatuto da Magistratura, o seguinte:

I - zelar pela autonomia do Poder Judiciário e pelo cumprimento do Estatuto da Magistratura, podendo expedir atos regulamentares, no âmbito de sua competência, ou recomendar providências;

$[\ldots]$

XXIV - alterar o Regimento Interno;

$\mathrm{XXV}$ - resolver as dúvidas que forem submetidas pela Presidência ou pelos Conselheiros sobre a interpretação e a execução do Regimento ou das Resoluções, podendo editar Enunciados interpretativos com força normativa;

${ }^{109}$ Art. 89 (RICNJ). O Plenário decidirá sobre consultas, em tese, de interesse e repercussão gerais quanto à dúvida suscitada na aplicação de dispositivos legais e regulamentares concernentes à matéria de sua competência.

$[\ldots]$

$\S 2^{\circ} \mathrm{A}$ resposta à consulta, quando proferida pela maioria absoluta do Plenário, tem caráter normativo geral.

${ }^{110}$ Art. 102 (RICNJ). O Plenário poderá, por maioria absoluta, editar atos normativos, mediante Resoluções, Instruções ou Enunciados Administrativos e, ainda, Recomendações. 
Conselho.

Quanto aos recursos administrativos, prevê o atual Regimento Interno do CNJ, em seus artigos $4^{\mathrm{o}}$, XXI e $\S 1^{\mathrm{o}^{112}}$; e $115, \S \S 5^{\mathrm{o}}$ e $6^{\mathrm{o}^{113}}$, competir ao seu Plenário decidi-los, quando cabíveis. A decisão do Colegiado substitui a decisão recorrida e dela não cabe outro recurso administrativo

Há, porém, dispositivo - art. $25, \mathrm{IX}^{114}$ - que atribui a Conselheiro relator dos diversos procedimentos do Colegiado o poder de indeferir recurso intempestivo ou manifestamente incabível.

Também consta no Regimento Interno do Conselho - art. 115, caput e $\S 1^{\circ}$, com a redação dada pela Emenda Regimental 1, de 9 de março de $2010^{115}$ - previsão que restringe a possibilidade de interposição de recursos administrativos ao Plenário.

Quanto à primeira regra (art. 25, IX, do RICNJ), entendemos, ante a necessidade de observância do princípio da colegialidade, que não têm o condão de impedir a interposição de outro recurso administrativo ao Plenário do CNJ para questionar a decisão de Conselheiro relator que indefere processamento de recurso administrativo que considere intempestivo ou manifestamente incabível. E, nessa hipótese, não poderá haver novo indeferimento monocrático do recurso, pois a palavra final das questões de competência do

${ }^{111}$ Art. 135 (RICNJ). A iniciativa de proposta de emenda regimental cabe a qualquer Conselheiro ou Comissão do CNJ.

Parágrafo único. Recebida a proposta pela Presidência, será imediatamente autuada e encaminhada à Comissão de Reforma do Regimento Interno, que terá prazo de cento e vinte (120) dias para apreciá-la e encaminhá-la para o Plenário.

Art. 136 (RICNJ). As emendas considerar-se-ão aprovadas se obtiverem o voto favorável da maioria absoluta do Plenário do CNJ.

${ }^{112}$ Art. $4^{\circ}$ (RICNJ) Ao Plenário do CNJ compete o controle da atuação administrativa e financeira do Poder Judiciário e do cumprimento dos deveres funcionais dos magistrados, cabendo-lhe, além de outras atribuições que lhe forem conferidas pelo Estatuto da Magistratura, o seguinte:

$[\ldots]$

XXI - decidir, na condição de instância revisora, os recursos administrativos cabíveis;

$[\ldots]$

$\S 1^{\mathrm{o}}$ Dos atos e decisões do Plenário não cabe recurso.

113 Art. 115 (RICNJ) [...]

$\S 5^{\circ}$ A decisão final do colegiado substitui a decisão recorrida para todos os efeitos.

$\S 6^{\circ}$ Dos atos e decisões do Plenário não cabe recurso.

${ }^{114}$ Art. 25 (RICNJ). São atribuições do Relator:

IX - indeferir, monocraticamente, recurso quando intempestivo ou manifestamente incabível;

${ }^{115}$ Art. 115 (RICNJ). A autoridade judiciária ou o interessado que se considerar prejudicado por decisão do Presidente, do Corregedor Nacional de Justiça ou do Relator poderá, no prazo de cinco (5) dias, contados da sua intimação, interpor recurso administrativo ao Plenário do CNJ.

$1^{\circ}$ São recorríveis apenas as decisões monocráticas terminativas de que manifestamente resultar ou puder resultar restrição de direito ou prerrogativa, determinação de conduta ou anulação de ato ou decisão, nos casos de processo disciplinar, reclamação disciplinar, representação por excesso de prazo, procedimento de controle administrativo ou pedido de providências. 
Conselho Nacional de Justiça deve ser dada pelo Colegiado ${ }^{116}$.

Já a segunda disposição, eivada, no nosso sentir, de inconstitucionalidade, pois impede que decisão definitiva sobre matéria constitucionalmente atribuída à competência do Colegiado seja decidida pelo seu Plenário, será analisada a seguir ${ }^{117}$, pois demanda maior fundamentação.

Por fim, quanto à aplicação, no âmbito do Conselho Nacional de Justiça, da última proibição de delegação de competência administrativa mencionada no art. 13 da Lei $\mathrm{n}^{\mathrm{o}}$ 9.784/1999, observa-se que as atribuições previstas no art. 103-B, $\S 4^{\mathrm{o}}$ e incisos, da Constituição Federal, são exclusivas do Conselho Nacional de Justiça, enquanto órgão colegiado. Logo, não podem ser delegadas.

Nesse sentido, posiciona-se Francisco Cláudio de Almeida Santos (2011, p. 29):

\begin{abstract}
Entendemos que se pode extrair serem as atribuições primárias e específicas do Conselho indelegáveis. Na verdade, as matérias de sua competência são exclusivas e especiais, e, absolutamente, indelegáveis, por força de sua condição de órgão do Poder Judiciário, da escolha e nomeação de natureza especialíssima de seus agentes e da forma de deliberação em colegiado.
\end{abstract}

Admissível, porém que atos administrativos internos e atos preparatórios e instrutórios à deliberação final do Colegiado sobre qualquer assunto de sua competência sejam delegados a órgão singular, para que suas realizações não fiquem subordinadas a constantes votações em Plenário.

As execuções das deliberações do Colégio também podem ser acometidas a órgão singular, pois implicam em mero cumprimento das decisões manifestadas pelo Pleno.

116 Transcreve-se, pela pertinência, trecho da decisão prolatada no Superior Tribunal de Justiça, no
julgamento do Agravo Regimental do Mandado de Segurança no $9945 / \mathrm{DF}$, Rel. Min. Luiz Fux, julgado em
10.11 .2004 , cujo ensinança também é aplicável ao colegiado administrativo: "É da natureza dos tribunais
superiores o exercício colegiado da jurisdição. Consectariamente, se a lei ou o Regimento conferem a um dos
membros do Tribunal, por razões de urgência e de abreviação do serviço judiciário, o exercício de função
jurisdicional, ele a desempenha em nome do colegiado, mas sem poder tolher o acesso do jurisdicionado ao
colegiado, que é o juiz natural da causa. Por isso, jamais se cogitou de considerar inconstitucional a previsão
de agravos nos regimentos internos dos tribunais". No julgado afastou-se a incidência da Súmula STF no 622
afirmando-se que ela conflitava com o artigo 317 do Regimento Interno do Supremo Tribunal Federal e
infringia o princípio da colegialidade. A redação da Súmula STF no 622 é a seguinte: "Não cabe agravo
regimental contra decisão do relator que concede ou indefere liminar em mandado de segurança". Na norma
inserta no artigo 317, caput, do RISTF consta: "Ressalvadas as exceções previstas neste Regimento, caberá
agravo regimental, no prazo de cinco dias de decisão do Presidente do Tribunal, de Presidente de Turma ou
do Relator, que causar prejuízo ao direito da parte". ${ }^{117}$ Vide item 2.3.2.2.2. 
Por fim, medidas urgentes e acauteladoras, que muitas vezes não podem aguardar a reunião do Colegiado, também devem restar delegadas para decisão singular no âmbito do Conselho Nacional de Justiça.

Neste último caso, porém, ante o caráter decisório da medida aplicada, deve ser analisada, com a maior brevidade possível, pelo Plenário do CNJ, para ratificação ou modificação, em respeito ao princípio da colegialidade.

Inclusive, também em acatamento ao princípio mencionado, deve-se admitir recurso administrativo ao pleno contra referidas decisões singulares urgentes e mesmo contra atos singulares preparatórios, instrutórios ou executórios, pois podem extrapolar os limites da delegação do Colegiado.

Aplicável, mutatis mutandis, salutar lição do âmbito jurisdicional apresentada pela Ministra Eliana Calmon do Superior Tribunal de Justiça, em voto-vista no Agravo Regimental no Mandado de Segurança n 11961, julgado em 16 de maio de 2007:

\footnotetext{
A partir da visão ontológica do funcionamento dos Tribunais, tem-se como regra as decisões colegiadas. Entretanto, pela necessidade de dar-se maior velocidade na tramitação dos feitos, estabelecem os regimentos internos poderes para os relatores agirem isoladamente. O relator age, então, como delegado do colegiado.

Quando a parte não se conforma com o ato isolado do relator, não se pode furtar dela a oportunidade de chegar ao juiz natural, o colegiado. Se assim não for, estar-se-á dando ao delegado poderes absolutos, tornando irrecorrível o seu agir, omitindo-se o colegiado de julgar.
}

Em síntese, como o Conselho Nacional de Justiça é um órgão colegiado, suas deliberações definitivas devem ser pautadas pelo princípio da colegialidade e, portanto, devem ser feitas, em Plenário, pelo voto da maioria de seus membros. Admite-se, no entanto, a relativização desse princípio, pois o Colegiado não pode funcionar ininterruptamente, podendo ser delegados atos preparatórios, instrutórios e executórios, bem como decisões sobre medidas urgentes e acauteladoras a seus membros, órgãos singulares. Em todos os casos, porém, sempre caberá revisão dos atos e decisões singulares pelo Pleno.

2.3.2.2.1. Estudo de norma: RICNJ, arts. $6^{\circ}$, XXVI, e 25, XI - Reexame necessário pelo Plenário de decisões monocráticas singulares 
Assentadas essas ideias, cumpre expor que o atual Regimento Interno do Conselho Nacional de Justiça delega diversas competências ao Presidente e aos demais Conselheiros do Colegiado Administrativo ${ }^{118}$.

A maioria das competências delegadas ao Presidente do Conselho refere-se à prática de atos administrativos internos ${ }^{119}$ ou executórios das decisões do Plenário ${ }^{120}$. Há, ainda, previsão de subdelegação ${ }^{121}$ e norma genérica para a prática de outros atos previstos em lei ou no próprio Regimento Interno ${ }^{122}$. Constam, por fim, duas atribuições de cunho decisório e uma destinada a realização de medidas urgentes: a) decidir questões de ordem (art. $6^{\circ}$, VII $)^{123}$; b) apreciar liminarmente, antes da distribuição, os pedidos e requerimentos anônimos ou estranhos à competência do CNJ (art. $6^{\circ} \mathrm{XXX}$ ); e, c) praticar, em caso de urgência, ato administrativo de competência do Plenário, submetendo-o ao referendo deste na primeira sessão que se seguir (art. $6^{\circ}, \mathrm{XXVI)}$.

Aos Conselheiros relatores dos diversos procedimentos criados pelo próprio Regimento Interno do CNJ foram delegadas, em sua maioria, competências para atos preparatórios e instrutórios à deliberação final do Colegiado ${ }^{124}$. Há, também, norma genérica para a prática de outros atos previstos em lei ou no próprio Regimento Interno ${ }^{125}$.

Por fim, constam sete delegações aos Conselheiros relatores relativas a atos decisórios, sendo uma delas também referente à prática de medidas urgentes e

${ }^{118}$ As competências do Corregedor Nacional de Justiça previstas no Regimento Interno do CNJ serão analisadas separadamente (vide item 3.2), pois decorrem diretamente das normas previstas no art. 103-B, § $5^{\circ}$, da Constituição Federal e no art. $5^{\circ}$, $\S 2^{\circ}$, da Emenda Constitucional $n^{\circ} 45 / 2004$. São, portanto, competências originárias, não delegadas.

${ }^{119}$ Art. $6^{\circ}$ (RICNJ), I, II, III, IV, V, VI, VIII, IX, X, XI, XII, XIII, XV, XVI, XVII, XVIII, XIX, XX, XXI, XXII, XXIII, XXIV, XXVII, XXVIII, XXIX, XXXI, XXXII, XXXIII e XXXIV.

${ }^{120}$ Art. $6^{\circ}$ (RICNJ), XIV.

${ }^{121}$ Art. $6^{\circ}$ (RICNJ), XXV. Sobre a subdelegação, Caio Tácito (apud OLIVEIRA, 2005, p. 120), ensina que "a delegação de competência não comporta subdelegações. O delegado poderá exercer a competência delegada, mas não poderá transmiti-la a terceiros, salvo se a isto está expressamente autorizado". Como o art. $5^{\circ}, \S 2^{\circ}$, da $\mathrm{EC} \mathrm{n}^{\circ} 45 / 2004$ permitiu que o próprio CNJ, até a entrada em vigor do Estatuto da Magistratura, disciplinasse seu funcionamento mediante resolução, não há qualquer vício na disposição mencionada, que permite ao Presidente delegar a prática de atos de sua competência singular aos demais Conselheiros ou ao Secretário-Geral do CNJ.

${ }^{122}$ Art. $6^{\circ}$ (RICNJ), XXXV.

${ }^{123}$ A "questão de ordem" refere-se à observância, na condução dos trabalhos, das disposições constantes do Regimento Interno. O Presidente deve decidi-las, mas não pode impedir que sua decisão, se houver requerimento, seja submetida à apreciação do Plenário. O art. $6^{\circ}$, VII, do RICNJ estabelece que o Presidente decide as questões de ordem, ou submetê-as ao Plenário, quando entender necessário.

${ }^{124}$ Art. 25 (RICNJ), I, II, III, IV, parte final, V, VI, VII, parte final, VIII e XIII.

${ }^{125}$ Art. 25 (RICNJ), XIV. 
acauteladoras: a) decidir os incidentes que não dependerem de pronunciamento do Plenário (art. 25, IV, primeira parte); b) proferir decisões monocráticas (art. 25, VII, primeira parte); c) indeferir, monocraticamente, recurso quando intempestivo ou manifestamente incabível (art. 25, IX); d) determinar o arquivamento liminar do processo quando a matéria for flagrantemente estranha às finalidades do CNJ, bem como a pretensão for manifestamente improcedente, despida de elementos mínimos para sua compreensão ou quando ausente interesse geral (art. 25, X); e) deferir monocraticamente pedido em estrita obediência a Enunciado Administrativo ou entendimento firmado pelo CNJ ou pelo Supremo Tribunal Federal (art. 25, XII); f) indeferir, de plano, o pedido de revisão que se mostre intempestivo, manifestamente sem fundamento ou improcedente; e, g) deferir medidas urgentes e acauteladoras, motivadamente, quando haja fundado receio de prejuízo, dano irreparável ou risco de perecimento do direito invocado, determinando a inclusão em pauta, na sessão seguinte, para submissão ao referendo do Plenário (art. 25, XI).

Quanto às questões urgentes, nota-se que o Regimento Interno do CNJ impôs, tanto ao seu Presidente, quando praticar atos administrativos urgentes de competência exclusiva do Plenário (art. $\left.6^{\circ}, \mathrm{XXVI}\right)^{126}$, quanto a Conselheiro relator, quando deferir medidas urgentes e acauteladoras (art. 25, $\mathrm{XI}^{127}$ ), a submissão de suas decisões monocráticas ao referendo do Colegiado na primeira sessão que se seguir.

Em relação ao Conselheiro relator, a determinação foi reafirmada na seção do Regimento Interno que trata especificamente do "Pedido de Previdências", procedimento utilizado para o trâmite no órgão de propostas e sugestões tendentes à melhoria da eficiência e eficácia do Poder Judiciário e dos expedientes que não tenham classificação específica no CNJ (art. $99^{128} 129$ ).

\footnotetext{
${ }^{126}$ Art. $6^{\circ}$ (RICNJ) São atribuições do Presidente, que pode delegá-las, conforme a oportunidade ou conveniência, observadas as disposições legais:

$[\ldots]$

XXVI - praticar, em caso de urgência, ato administrativo de competência do Plenário, submetendo-o ao referendo deste na primeira sessão que se seguir;

${ }^{127}$ Art. 25 (RICNJ). São atribuições do Relator:

$[\ldots]$

XI - deferir medidas urgentes e acauteladoras, motivadamente, quando haja fundado receio de prejuízo, dano irreparável ou risco de perecimento do direito invocado, determinando a inclusão em pauta, na sessão seguinte, para submissão ao referendo do Plenário;

${ }^{128}$ Art. 99 (RICNJ). Em caso de risco de prejuízo iminente ou de grave repercussão, o Plenário do CNJ, o Presidente ou o Relator poderão, no âmbito de sua competência e motivadamente, adotar providências acauteladoras sem a prévia manifestação da autoridade, observados os limites legais.

Parágrafo único. Quando a medida cautelar for deferida pelo Relator, será submetida a referendo do Plenário na primeira sessão ordinária seguinte.
} 
Essas previsões de reexames necessários ${ }^{130}$ imediatos de decisões dos órgãos singulares pelo Colegiado harmonizam-se com o princípio da colegialidade. Neste ponto, houve nítida evolução em relação ao revogado Regimento Interno do CNJ.

Com efeito, o Regimento Interno aprovado pela Resolução CNJ nº 2/2005 previa somente em relação ao ato urgente de competência do Plenário praticado pelo Presidente a necessidade de submetê-lo ao referendo do Colegiado na primeira sessão que se seguisse (art. 29, XXVIII). Em relação aos atos de Conselheiro relator, o antigo Regimento estabelecia apenas que suas determinações de medidas urgentes deveriam ser referendadas pelo Plenário, mas não exigia que isso ocorresse com brevidade (art. 45, XI).

Salutar, pois, a alteração Regimental que prestigia o princípio da colegialidade e evita que os efeitos de decisões administrativas monocráticas se prolonguem indefinidamente, sem apreciação da questão pelo Colegiado constitucionalmente competente ${ }^{131}$.

\subsection{Estudo de norma: RICNJ, arts. $115, \S 1^{0}$ - Restrições à interposição de recursos administrativos ao Plenário}

Se o atual Regimento Interno do CNJ avançou na previsão de reexame necessário pelo Colegiado de medidas administrativas cautelares deferidas por Conselheiro relator, pecou

${ }^{129}$ A norma inserta no art. 99, parágrafo único, do RICNJ apresenta aparente contradição com a prevista no art. $6^{\circ}, \mathrm{XXVI}$, do RICNJ. A atenta leitura dos dispositivos, porém, indica que, se o Presidente praticar atos administrativos em caso de urgência de competência do Plenário, também deverá submetê-los a imediato referendo deste. Se, por outro lado, praticar outros atos administrativos urgentes dentro de sua esfera de competência delegada, não precisará fazê-lo.

${ }^{130}$ A expressão foi importada da doutrina processual civil, que a utiliza para definir a exigência de duplo grau de jurisdição para que produza efeitos a sentença proferida contra a União, o Estado, o Distrito Federal, o Município e as respectivas autarquias e fundações de direito público, bem como aquela que julgar procedentes, no todo em parte, os embargos à execução de dívida ativa da Fazenda Pública, desde que, em ambas as hipóteses, o direito controvertido for de valor certo superior a sessenta salários mínimos e a decisão não estiver fundada em jurisprudência do plenário do Supremo Tribunal Federal ou em súmula deste Tribunal ou do tribunal superior competente (CPC, art. 475). Porém, no Conselho Nacional de Justiça, ao contrário das sentenças proferidas na esfera cível nas hipóteses mencionadas, a decisão monocrática urgente ou acautelatória proferida pelo Presidente ou por Conselheiro relator da Casa produz efeitos administrativos imediatos, podendo ser revogada posteriormente pelo Plenário.

${ }^{131}$ No julgamento realizado em 29 de outubro de 2010 do Mandado de Segurança $n^{\circ} 27708$, impetrado no STF pelo Estado da Bahia contra ato do Conselheiro relator do Procedimento de Controle Administrativo $\mathrm{n}^{\circ}$ 20080000013000 do CNJ, que determinara o pagamento de precatório olvidando sua alteração cronológica em razão de acordos judiciais, o Ministro relator Marco Aurélio Mello afirmou, em seu voto, que o Conselheiro, ainda sob a égide do Regimento Interno anterior do CNJ, agiu individualmente quando a questão tratada deveria ter sido enfrentada pelo Colegiado o que, por certo, não ocorreu porque, na época, não havia a exigência de submissão de decisões urgentes de Conselheiros ao Plenário na primeira sessão ordinária seguinte. A ordem no mandado de segurança impetrado na Corte Suprema, porém, foi concedida por outro motivo considerado mais relevante: a maioria dos Ministros acompanhou o voto do relator que entendeu ter o Conselheiro alterado termo de conciliação e de compromisso judicial abrangente e, pois, extravasado os limites de suas atribuições administrativas (vide item 2.3.5.1.1). 
ao restringir a possibilidade de interposição de recursos administrativos ao Plenário, em violação ao princípio da colegialidade.

O revogado Regimento Interno do Conselho admitia a interposição de recurso administrativo sem qualquer restrição por todo aquele que se considerasse prejudicado por decisão de um de seus órgãos singulares. Dispunha seu o artigo 103, caput:

Art. 103. A parte ou o interessado que se considerar prejudicado por decisão do Presidente, do Ministro-Corregedor ou do Relator poderá, no prazo de dez dias, contados da sua intimação, interpor recurso administrativo, a fim de que o Plenário conheça da decisão, confirmandoa ou reformando-a.

$\mathrm{Na}$ sua redação original, o atual Regimento Interno do CNJ restringiu a possibilidade de interposição de recursos administrativos. Previa a redação original do art. 115, caput e $\S$ $1^{\mathrm{o}}$ :

Art. 115. A autoridade judiciária ou o interessado que se considerar prejudicado por decisão do Presidente, do Corregedor Nacional de Justiça ou do Relator poderá, no prazo de cinco (5) dias, contados da sua intimação, interpor recurso administrativo ao Plenário do CNJ.

$\S 1^{\circ}$ São recorríveis apenas as decisões de que manifestamente resultar ou puder resultar restrição de direito ou prerrogativa, determinação de conduta ou anulação de ato ou decisão, nos casos de processo disciplinar, reclamação disciplinar, representação por excesso de prazo, procedimento de controle administrativo ou pedido de providências.

Essa disposição permitia duas interpretações, ambas violadoras do princípio da colegialidade, pois retiravam do Plenário a palavra final sobre atos delegados aos membros do Colegiado.

Uma das leituras possíveis seria concluir que havia impedimento à interposição de recursos administrativos por autoridade judiciária ou interessado contra todos os atos praticados singularmente por membros do Conselho, exceto para combater as decisões monocráticas proferidas nos processos disciplinares, reclamações disciplinares, representações por excesso de prazo, procedimentos de controle administrativo ou pedidos de providências e desde que essas decisões resultassem ou pudessem resultar em manifesta 
restrição de direito ou prerrogativa, determinação de conduta ou anulação de ato ou decisão.

Outra interpretação seria admitir que, em regra, caberia recurso administrativo de todos os atos praticados singularmente por membros do CNJ. Porém, das decisões monocráticas proferidas nos procedimentos mencionados, somente se admitiria recurso administrativo se manifestamente resultassem ou pudessem resultar restrição de direito ou prerrogativa, determinação de conduta ou anulação de ato ou decisão.

A redação do parágrafo $1^{\circ}$ do dispositivo regimental analisado foi modificada em 9 de março de 2010 pela Emenda Regimental n ${ }^{\circ}$ 1, aprovada em Sessão Plenária ${ }^{132}$. A norma passou a ter a seguinte redação, atualmente vigente:

Art. 115. A autoridade judiciária ou o interessado que se considerar prejudicado por decisão do Presidente, do Corregedor Nacional de Justiça ou do Relator poderá, no prazo de cinco (5) dias, contados da sua intimação, interpor recurso administrativo ao Plenário do CNJ.

$1^{\circ}$ São recorríveis apenas as decisões monocráticas terminativas de que manifestamente resultar ou puder resultar restrição de direito ou prerrogativa, determinação de conduta ou anulação de ato ou decisão, nos casos de processo disciplinar, reclamação disciplinar, representação por excesso de prazo, procedimento de controle administrativo ou pedido de providências.

A disposição alterada, mais uma vez, permite duas interpretações que infringem o princípio da colegialidade, pois impedem que a autoridade judiciária ou o interessado levem ao colegiado seu inconformismo com a prática de algum ato ou decisão prolatada por membro singular do Conselho Nacional de Justiça.

Pela atual redação da regra regimental, pode-se depreender haver impedimento à interposição de recursos administrativos contra os todos os atos praticados singularmente por membros do Conselho, exceto em oposição às decisões monocráticas terminativas

\footnotetext{
${ }^{132}$ Conforme consta na Ata da $100^{\circ}$ Sessão Ordinária do CNJ, realizada nos dias 9 e 10 de março de 2010, a Emenda Regimental $\mathrm{n}^{\circ}$ 1/2010 foi aprovada no julgamento do ATO $\mathrm{n}^{\circ}$ 0001485-16.2010.2.00.0000. Não foi possível, porém, investigar os fundamentos das alterações regimentais, em especial da realizada no art. 115, § $1^{\circ}$, pois na pesquisa do referido processo no sistema de consulta de processos eletrônicos do CNJ consta tratar-se de feito sigiloso, de relatoria do então Corregedor Nacional de Justiça, Ministro Gilson Dipp. Disponível em <http://www.cnj.jus.br/atos-administrativos/atos-da-presidencia/atas-da-presidencia/11137certidoes-de-julgamento-da-100o-sessao-ordinaria-09-10-de-marco-de-2010>. Acesso em 30 de junho de 2013.
} 
proferidas nos processos disciplinares, reclamações disciplinares, representações por excesso de prazo, procedimentos de controle administrativo ou pedidos de providências e desde que essas decisões resultem ou possam resultar em manifesta restrição de direito ou prerrogativa, determinação de conduta ou anulação de ato ou decisão.

Também, pela atual redação da regra inserta no art. 115, $\S 1^{\circ}$, do Regimento Interno do $\mathrm{CNJ}$, pode-se entender que a autoridade judiciária ou o interessado pode recorrer administrativamente ao Plenário do Conselho de todos os atos praticados singularmente pelo Presidente, Corregedor Nacional de Justiça ou do Conselheiro relator, exceto das decisões monocráticas proferidas nos procedimentos aludidos de que, manifestamente, não resultarem ou puderem resultar restrição de direito ou prerrogativa, determinação de conduta ou anulação de ato ou decisão.

Além da dúvida que pode gerar o advérbio "manifestamente" inserto na norma, que a carrega de elevado subjetivismo, qualquer uma das interpretações mencionadas, como dito, leva à violação do princípio da colegialidade, pois retira do Plenário a análise dos atos realizados e das decisões proferidas por seus órgãos singulares.

Não se pode perder de vista, inclusive, como será exposto ${ }^{133}$, que os próprios atos e decisões dos membros do Conselho Nacional de Justiça também estão sujeitos ao controle administrativo do Colegiado, pois seus membros são integrantes do Poder Judiciário. Logo, ainda que se pudesse considerar válida a atual disposição do Regimento Interno analisada, qualquer decisão do Presidente, do Corregedor Nacional de Justiça ou de Conselheiro relator de procedimento no Conselho Nacional de Justiça também pode ser questionada no Plenário do órgão ${ }^{134}$.

Em síntese, a redação do art. 115, $\S 1^{\circ}$, do atual Regimento Interno do CNJ viola a Constituição Federal, que, ao estruturar o Conselho como um órgão Colegiado e conferirlhe diversas competências, evidenciou a necessidade de se observar o princípio da colegialidade nas suas deliberações. Trata-se de mais uma hipótese de violação, pelo CNJ, dos limites constitucionais de sua atuação.

\footnotetext{
${ }^{133}$ Vide item 2.3.7.5.

${ }^{134} \mathrm{O}$ indeferimento de recurso de decisão administrativa monocrática proferida em qualquer procedimento em trâmite no Conselho sem análise do mérito, com base na disposição constante no art. 115 , $\S 1^{\circ}$, do RICNJ, pode levar, pois, em tese, a um insólito surgimento de outro procedimento administrativo naquela Casa Administrativa, movido pelos interessados em razão de suposto ato irregular praticado pelo Conselheiro no procedimento anterior, exceto no caso de ato determinado pelo Presidente, por ser Ministro do Supremo Tribunal Federal e, portanto, como será visto no item 2.3.7.5, não sujeito ao controle disciplinar do CNJ.
} 


\subsection{3. Órgão de controle.}

Apresentados os dois primeiros elementos constitucionais característicos do Conselho Nacional de Justiça - órgão interno do Poder Judiciário com estrutura colegiada - passa-se ao estudo do terceiro: O Conselho Nacional de Justiça é órgão tipicamente de controle.

A norma inserta no artigo 103-B, $\S 4^{\circ}$, da Constituição Federal expressamente definiu competir ao Conselho Nacional de Justiça o controle da atuação administrativa e financeira do Poder Judiciário e do cumprimento dos deveres funcionais dos juízes.

Dessa característica extrai-se importante limitação constitucional à atuação do $\mathrm{CNJ}$ : por ser órgão controlador, somente excepcionalmente deve agir em substituição aos demais órgãos do Poder Judiciário.

A palavra "controle", segundo dicionários da língua portuguesa, significa vigilância, exame minucioso, inspeção, fiscalização, verificação administrativa, ato de dirigir qualquer serviço, fiscalizando-o do modo mais conveniente ${ }^{135}$.

Gérard Bergeron (1965, pp. 76 a 78), citado por Odete Medauar (2012, pp. 20 a 21), ensina que o termo "controle" tem acepções diferentes nas línguas inglesa (control) e francesa (contrôle), tendo alcance mais forte na primeira e mais fraco na segunda. Apresenta, com exemplos, os seguintes seis sentidos para a palavra, ressaltando que os três primeiros correspondem mais ao inglês control (alcance forte) e os três últimos se aproximam mais do francês contrôle (alcance fraco): $1^{\circ}$ ) dominação; $2^{\circ}$ ) direção; $3^{\circ}$ ) limitação; $4^{\circ}$ ) vigilância (fiscalização); $5^{\circ}$ ) verificação; e, $6^{\circ}$ ) registro (duplo registro; confrontação). Ressalta Bergeron, porém, que o último sentido apresentado -registro - foi o originalmente utilizado para a palavra francesa contrôle, em português controle ${ }^{136}$, e

\footnotetext{
${ }^{135}$ Dicionário Priberam da Língua Portuguesa, Dicionário online de português e Dicionário de Português Online Michaelis, disponíveis, respectivamente, em: $<$ http://www.priberam.pt/dlpo/default.aspx?pal=controle $>; \quad<$ http://www.dicio.com.br/controle/ $>\quad$ e $<$ http://michaelis.uol.com.br/moderno/portugues/definicao/controle.html $>$. Acesso em 01.05.2014.

${ }^{136}$ Etimologicamente, a palavra "controle" deriva do francês contrôle, mas tem origem na mercancia da Veneza Medieval nos séculos XIII e XIV, que criou o método de contabilidade de Partidas Dobradas, divulgado em 1494 na obra do Frei Luca Pacioli denominada "La Summa de Arithmetica, Geometria, Proportioni et Proportionalitá". Basicamente, esse método, ainda utilizado, consiste em corresponder para cada lançamento contábil de débito outro de crédito de igual valor e vice-versa, podendo também haver um lançamento de débito para diversos créditos que, somados, atinjam o valor debitado e, por outro lado, um lançamento de crédito para diversos débitos cuja soma correponda ao valor creditado. Ocorre que, para a execução do método, os mercadores venezianos utilizavam dois rolos de papel: o devedor, designado em latim de rotulus, e o credor, intitulado em latim de contrarotulus, e que se destinava à verificação. Em francês, contrarotulus tornou-se contrerôlle e, posteriormente, por haplologia (fenômeno fonéticomorfológico que suprime sílabas iguais ou muito semelhantes de uma palavra para facilitar sua pronúncia), contrôle (Portal da Contabilidade, Assim Mesmo e Dicionário de Português Online Michaelis, disponíveis, respectivamente, $\quad$ em: $\quad<$ http://www.cosif.com.br/mostra.asp?arquivo=contabil07partidas $>$;
} 
representa a menor intensidade do ato de controle, mas também a mais rica em significado, pois todos as outras acepções implicam um reforço da gravação etimológica da ideia de registro. Na verdade, controle, para todos os sentidos implica em uma confrontação de registros ${ }^{137}$.

$<$ http://letratura.blogspot.com.br/2006/02/controlo-grafia-e-etimologia.html >

$<$ http://michaelis.uol.com.br/moderno/portugues/index.php?lingua=portugues-portugues\&palavra=haplologia >. Acesso em 01.05.2014).

${ }^{137}$ Nas palavras de Gérard Bergeron: "Avant de désarticuler le mot, mettons-nous à l'écoute du langage courant, français et anglais. Qu'est-ce qu'un contrôle? Qu'est-ce que contrôler? On a déjà attiré notre attention sur le fait que "contrôle» a un sens plus faible que «control». Mais des usagers récents, dont plusieurs ont des origines politiques ou économiques (en finances, en commerce), tendent à faire accepter par le français et d'autres langues européennes les sens forts du «control», tandis que l'anglais ignore de moins en moins les sens plus faibles des langues continentales. Au lieu de constituer une difficulté majeure, cette gradation de sens permet de retracer un large continuum sémantique qui contraste avec l'étroitesse et l'ambiguïté de signification du "pouvoir», enserré entre ses deux connotations, séparées par un hiatus, de «puissance» ou «énergie» et de faculté morale, juridique ou naturelle pour agir. Nos relevés - qui n'ont certes pas la prétention d'une étude sémantique - nous suggèrent de grouper en six principales acceptions l'usage du mot "contrôle - control». Dans cette gradation descendante des six sens, les trois premiers correspondent plutôt au "control» qu'au "contrôle» et vice-versa pour les trois derniers. Ces six sens sont: $1^{\circ}$ domination; $2^{\circ}$ direction; $3^{\circ}$ limitation; $4^{\circ}$ surveillance; $5^{\circ}$ vérification; $6^{\circ}$ enregistrement ou, préférablement, collation. Dans le sens de domination citons comme exemples. "contrôler» un parti politique, une banque, une société anonyme; "contrôler» un pays militairement ou économiquemen; une équipe de foot-ball ou un joueur qui «contrôle» le jeu; un démagogue, un dictateur qui «contrôle» un peuple; le «self-control» ou domination de soi-même. C'est l'acception la plus forte du mot «contrôle». Elle est surtout courante en anglais; en français, quoique les dictionnaires ne lui donnent pas ordinairement ce sens, les exemples que nous venons de citer suffisent à démontrer que l'usage vulgaire tend de plus en plus à le lui conférer. Dans le sens de direction, les mêmes exemples peuvent être cités en enlevant la nuance ordinairement péjorative ou abusive de domination. Le contrôle s'entend alors dans le sens d'exercer une influence déterminante, avoir la direction effective, être le maître dans une situation: politique (ou économie) de "contrôles»; "contrôler» une administration, une entreprise, la production, les investissements, l'épargne, le ravitaillement ; un joueur de tennis qui «contrôle» bien sa balle; un coureur qui «contrôle» sa course, etc. ... Contrôler au sens de dominer et de diriger fait surtout voir l'aspect positif du contrôle. Contrôler au sens de limiter et de surveiller en fait voir l'aspect négatif, restrictif ou inhibitif. Citons comme exemples dans le sens de limitation: "contrôler» les importations, les changes, le commerce extérieur; "contrôler» par l'apposition d'un veto, d'une interdiction, d'une défense; le «birth control», etc. ... Contrôler au sens de surveiller implique surtout l'idée de continuité: «contrôler» les finances, la gestion d'un gérant, d'un administrateur d'un caissier; "contrôler» les agissements de quelqu'un, i. e. le critiquer, le censurer. Le contrôle au sens de vérification n'évoque pas, de soi, l'idée de continuité comme le contrôle au sens de surveillance. Il implique plutôt le sens d'examen sur un ou plusieurs objets précis: "contrôler» un bilan; l'activité du "contrôleur» du chemin de fer, du métro, d'un théâtre; le "contrôle» de l'état sur la frappe des monnaies; le «contrôle» ou la marque gravée avec un poinçon sur les ouvrages d'or et d'argent "pour faire foi qu'ils ont payé les droits et qu'ils sont au titre fixé par la loi», etc. ... Enfin, le mot contrôle peut signifier un simple acte d'enregistrement ou de collation. Il signifie alors inscrire en double registre. C'est, semble-t$i l$, le sens premier et originaire du mot contrôle: "À partir de 1654, nombre d'actes juridiques devaient être "contrôlés", c'est-à-dire résumés sur des registres spéciaux, moyennant le paiement d'une taxe. Ils acquéraient ainsi date certaine, avantage précieux de droit privé C'est le système du contrôle, que nous appelons aujourd'hui enregistrement». Nous croyons ce sens originaire parce qu'il est le seul à nous révéler l'étymologie du mot: "contre-rôle» dont le «contrôle» est une contraction. Selon Littré, qui le tient de Vaugelas, Ronsard fut le premier à écrire "contrôler», "contrôleur» au lieu de "contre-rôler», "contrerôleur». Selon le Quillet, le rôle est: $1^{\circ}$ une "pièce de parchemin plus ou moins longue, roulée ou non, sur laquelle on écrivait des actes, des titres»; ou $2^{\circ}$ "feuillet, registre, officiel où l'on inscrit des noms, des états, etc.»; $3^{\circ}$ en termes de marine, le rôle d'un équipage est la «liste de l'état civil de l'équipage». Le contrôle est le registre tenu en double qui sert à vérifier, dater ou faire preuve d'authenticité de divers actes. Ce sixième sens désigne la plus faible intensité de l'acte de contrôle; mais il est aussi le plus riche en signification. Tous les autres sens (vérification, surveillance, limitation direction, domination) impliquent un renforcement de 
Como conceitua Hely Lopes Meirelles (1999, p. 598), “controle', em tema de administração pública, é a faculdade de vigilância, orientação e correção que um Poder, órgão ou autoridade exerce sobre a conduta funcional de outro".

Ainda prossegue o saudoso administrativista (1999, p. 599):

Como faculdade onímoda, o controle é exercitável em todos e por todos os Poderes do Estado, estendendo-se a toda a Administração e abrangendo todas as atividades e agentes. Bem por isso, diversifica-se em variados tipos e formas de atuação para atingir os seus objetivos.

O vocábulo "controle" foi introduzido no direito pátrio na obra "O Controle dos Atos Administrativos pelo Poder Judiciário” de Seabra Fagundes. No Direito Administrativo, o "controle" tem por finalidade assegurar que "a Administração atue em consonância com os príncipios que lhe são impostos pelo ordenamento jurídico" (DI PIETRO, 2012, p. 791). A palavra também é utilizada como sinônimo de "tutela" e, nesse caso, refere-se ao princípio pelo qual se assegura a Administração Pública Direta o direito de fiscalizar as atividades das entidades da Administração Indireta para garantir que observem suas finalidades institucionais (DI PIETRO, 2012, p. 70).

No Direito Financeiro, o termo refere-se ao controle da execução orçamentária que implica em "acompanhar e obter condições para, se for o caso, otimizar os meios de arrecadação da receita pública, de um lado, e adotar medidas de contenção de gastos, de outro lado, ainda no decorrer do exercício. Trata-se de verificar a compatibilidade entre o planejado e o que está sendo executado" (HARADA, 2013, p. 97).

Para o Direito Constitucional, o vocábulo é usualmente empregado na expressão "controle de constitucionalidade" que, como pontua Alexandre de Moraes (2013b, p. 720), "significa verificar a adequação (compatibilidade) de uma lei ou de um ato normativo com a constituição, verificando seus requisitos formais e materiais".

Odete Medauar (2012, p. 30) apresenta duas acepções para "controle" no âmbito da Administração Pública. Em sentido restrito, "controle da Administração Pública é a verificação da conformidade da atuação desta a um cânone, possibilitando ao agente controlador a adoção de medida ou proposta em decorrência do juízo formado". Já em

l'idée étymologique d'enregistrement ou de collation. En effet, en quoi consiste le contrôle selon les divers sens que nous venons de relever si ce n'est de faire une comparaison en vue d'une recherche d'adéquation ou d'équivalence entre un "rôle» et un «contre-rôle»? Si cela est, nous sommes justifiés à y voir le formel de l'acte de contrôle, le contrôle à l'état «pur»". 
acepção ampla, "o controle significa a verificação da conformidade da atuação da Administração Pública a certos parâmetros, independentemente de ser adotada, pelo controlador, medida que afete, do ponto de vista jurídico, a decisão ou o agente"138.

Para chegar a essas acepções, Odete Medauar (2012, pp. 25 a 30) analisa os pensamentos sobre a caracterização de "controle" de Ugo Forti, Gérard Bergeron, Massimo Severo Giannini Umberto Allegretti, Manin Carabba, Gaetano D’Auria e Roberta Lombardi. Merecem destaque os dois primeiros.

O jurista italiano Ugo Forti (1915, pp. 608 e 609) indicou os seguintes atributos do controle como instituto de direito público: a) diferenciação de órgãos e de vontades; b) atividade precedente; e, c) juízo lógico.

Odete Medauar (2012, pp. 25 e 26) critica o primeiro atributo apontado por Forti, pois há exemplos de órgão da Administração Pública que fiscalizam seus próprios atos (autocontrole).

Quanto ao segundo atributo mencionado pelo italiano Forti - atividade precedente ressalta Odete Medauar (2012, p. 26):

[...] em grande parte das situações, o controle pressupõe uma atividade, ato ou comportamento anterior sobre o qual é exercido; mas, por vezes, incide sobre simples iniciativa ou proposta de realizar certa medida, ou seja, antes de ato, atividade ou conduta efetivamente realizados, com o objetivo de evitá-los (controle preventivo).

Sobre o último atributo apontado por Ugo Forti - juízo lógico -, Medauar (2012, pp. 26 e 27) informa que o doutrinador o considera a característica essencial do controle, pois através dele

[...] o órgão controlador declara que a atividade controlada corresponde a determinadas normas, princípios ou padrão, o que acarreta efeitos jurídicos positivos sobre a eficácia da própria atividade; se não há correspondência, o controlador tende a garantir a observância das

\footnotetext{
${ }^{138}$ Essa acepção importa menos ao presente trabalho. Nela, segundo Odete Medauar (2012, pp. 30 e 31), inclui-se o chamado controle social. A autora exemplifica-o com a hipótese de representação de cidadão contra irregularidades administrativas dirigida a Tribunal de Contas, pois o representante "náo adota medidas jurídicas relativas a decisões ou a agentes, de forma direta, mas pode desencadear a atividade do órgão de controle".
} 
normas, princípios ou padrão, o que é obtido influindo em sentido negativo sobre a eficácia da atividade controlada.

Mas, pondera Medauar, (2012, p. 27), a falta de correspondência da atividade controlada a determinadas normas, princípios ou padrões nem sempre implica na adoção de medida pelo órgão controlador para influir na sua eficácia porque pode já ter se consolidado ou exaurido "no momento de sua realização, restando somente a possibilidade de impor medidas sancionadoras".

Gérard Bergeron (1965, p. 120), por seu turno, indica quatro componentes no controle: a) um ato concreto a ser controlado; b) um padrão, uma medida, um critério de valores, para servir como um ponto de comparação para o controle; c) "a aproximação desses dois primeiros termos, que significa propriamente o ato de controle" (MEDAUAR, 2012, p. 27); e, d) a justificativa, o objetivo do controle. Agrega ainda a esses componentes outros dois elementos, de acordo com o primeiro atributo de Forti: "o agente do controle, o controlador; o agente do ato que é objeto do controle, o controlado" (MEDAUAR, 2012, p. 27), o que, como salientado por Odete Medauar, não prevalece em caso de autocontrole ${ }^{139}$.

Diante do exposto, pode-se afirmar, como elemento comum na ideia de "controle" no âmbito do Direito Público, a incidência, sobre uma conduta da Administração Pública, genericamente aqui denominada de "atividade" 140 , de um ato diverso para sua verificação, orientação, fiscalização ou correção, em razão de um paradigma estabelecido em normas, princípios, valores ou cânones. E, apesar do "controle" poder ser exercido pelo próprio

\footnotetext{
${ }^{139}$ Nas palavras do doutrinador canadense: "Voilà le minimum qu'il convient de dire sur le contrôle en tant qu'acte formel. Nous voilà donc en présence de quatre éléments: $1^{\circ}$ un terme concret à l'occasion duquel ou sur lequel portera le contrôle; $2^{\circ}$ un étalon, une mesure, une aune de valeurs, un «rôle» justement, qui servira de point de comparaison pour contrôler; $3^{\circ}$ le rapprochement de ces deux premiers termes, ce qui constitue proprement l'acte de contrôle; $4^{\circ}$ la raison d'être, le but du contrôle. Mais il manque encore à la notion précédente un double élément, l'un moteur, l'autre passif: l'agent du contrôle, par qui se fera le contrôle, le contrôleur; l'agent de l'acte qui est l'objet de contrôle, le contrôlé. Le contrôle a donc besoin de deux agents différenciés irréductibles même en un certain sens, dont l'un est selon un ordre de suprématie fonctionnelle, sinon nécessairement de supériorité hiérarchique, vis-à-vis de l'autre: un agent dont l'action est contrôlée; un autre qui fait l'acte de contrôler - et son acte, son rôle, sa fonction pourront s'appeler indifféremment un "contrôle». D'où le contrôle ne peut être que social, non pas seulement parce qu'il nécessite une pluralité d'agents d'une part, mais encore et surtout qu'il implique, d'autre part, des valeurs d'appréciation qui ne peuvent être également que sociales, puisque, même tout en valant ou pouvant valoir pour elles-mêmes, le fait qu'elles sont invoquées par un agent social pour l'appréciation de l'acte d'un agent social, leur confère obligatoirement une valeur sociale. Mais cette caractéristique du contrôle est en intime liaison avec le quatrième élément que nous venons de dégager de la sémantique du mot, i. e. ce que nous avons appelé «le but», la «raison d'être» du contrôle".

${ }^{140}$ Apesar do termo utilizado, é possível haver controle sobre a omissão. O melhor exemplo é ação direta de inconstitucionalidade por omissão ( $\mathrm{CF}$, art. $103, \S 2^{\circ}$ ), instrumento pelo qual o Poder Judiciário, mais especificamente o Supremo Tribunal Federal, é acionado para controlar eventual conduta negativa do Poder Público incompatível com conduta positiva exigida pela Constituição (MORAES, 2013b, p. 790).
} 
agente ou órgão que realiza a "atividade" (autocontrole), normalmente é efetuado por outro, surgindo, assim, as figuras do "controlado" (aquele que executa a "atividade") e do “controlador" (aquele que controla a "atividade").

Ressalte-se que o "controle" pode ser prévio, concomitante ou subsequente à "atividade" do "controlado". No primeiro caso - controle prévio -, inclusive, o ato do "controlado" sequer pode vir a ser praticado, ante a verificação ou orientação antecedente do "controlador".

Precisa a lição de Hely Lopes Meirelles (1999, p. 601):

Controle prévio ou preventivo (“a priori”) - É o que antecede a conclusão ou operatividade do ato, como requisito para sua eficácia. Exemplos: a liquidação da despesa, para oportuno pagamento; a autorização do Senado Federal para a União, O Estado-membro ou o Município contrair empréstimo externo.

Controle concomitante ou sucessivo - É todo aquele que acompanha a realização do ato para verificar a regularidade de sua formação, como, p. ex., a realização de auditoria durante a execução do orçamento; o seguimento de um concurso pela corregedoria competente; a fiscalização de um contrato em andamento.

Controle subseqüente ou corretivo ("a posteriori”) - É o que se efetiva após a conclusão do ato controlado, visando a corrigir-lhe eventuais defeitos, declarar sua nulidade ou dar-lhe eficácia. Exemplos: a homologação do julgamento de uma concorrência; o visto das autoridades superiores em geral. Observe-se que o controle judicial dos atos administrativos é, normalmente, subseqüente ou corretivo, salvo em mandado de segurança preventivo, em ação civil pública e em ação popular, que, em alguns casos, antecede a conclusão do ato impugnado.

No que tange ao Conselho Nacional de Justiça, como a Constituição expressamente afirmou competir-lhe "o controle da atuação administrativa e financeira do Poder Judiciário e do cumprimento dos deveres funcionais dos juízes" (art. 103, § $4^{\circ}$ ), conclui-se que trata-se de órgão eminentemente "controlador".

Logo, salvo se constitucionalmente excepcionado, não cabe ao CNJ agir, mas - e naquilo que também lhe foi atribuído pela Lei Maior - prévia, concomitante ou 
subsequentemente, verificar, orientar, fiscalizar ou corrigir, mediante o "controle" que exerce, a "atividade" de outros membros e órgãos do Poder Judiciário.

Cumpre dizer que as "atividades" desenvolvidas pelos demais órgãos do Poder Judiciário ocorrem das mais diversas formas: exercício da jurisdição (CF, art. 29, X; art. 53, $\S 1^{\circ}$, art. 93, IX; art. 96, III; art. 98, I; art. 102, I, II e III; art. 103-A, $\S 3^{\text {o; }}$ art. 105, I, II e III; art. 108, I e II; art. 109; art. 114, art. 124; e art. 125, caput e $\S \S 4^{\circ}$ e $5^{\circ}$ ); iniciativa para deflagração do processo legislativo (CF, art. 61; art. 93; art. 96, I, “d”, e II; e art. 125, $\S \S 1^{\circ}$ e $3^{\circ}$ ); aplicação de sanções disciplinares (CF, art. 93, VIII e X; e art. 95, I); constituição de Órgão Especial (CF, art. 93, XI); formação de listas tríplices para preechimento dos lugares reservados ao quinto constitucional ( $\mathrm{CF}$, art. 94); eleição de órgãos diretivos (CF, art. 96, I, "a"); elaboração de regimentos internos (CF, art. 96, I, "a"); tratamento das competências e funcionamento dos seus órgãos jurisdicionais e administrativos (CF, art. 96, I, “a”); organização das suas secretarias e serviços auxiliares (CF, art. 96, I, "b"); exercício de atividade correicional (CF, art. 96, I, "b"); provimento dos cargos de juiz de carreira $(\mathrm{CF}$, art. 96, I, “c"); provimento dos cargos necessários à administração da Justiça (CF, art. 96, I, “e”); concessão de licenças, férias e outros afastamentos (CF, art. 96, I, " $\mathrm{f}$ "); exercício de autonomia administrativa e financeira (CF, 99); elaboração de propostas orçamentárias (CF, art. 99); administração das eleições (CF, art. $17, \S 2^{\circ}$; e art. 121); indicação de membros para compor o Conselho Nacional de Justiça e o Conselho Nacional do Ministério Público (CF, art. 103-B; e art. 130-A, IV); criação de câmaras regionais e varas especializadas ( $\mathrm{CF}$, art. 125, § 6 ; e art. 126); instalação de justiça intinerante $\left(\mathrm{CF}\right.$, art. $\left.125, \S 7^{\circ}\right)$. Nem todas essas "atividades", porém, adianta-se, estão sujeitas ao "controle" exercido pelo Conselho Nacional de Justiça, como será exposto alhures ${ }^{141}$.

No voto do Ministro Cezar Peluso na ADI no 3367, inclusive, restou expressamente afirmado que a competência de "controle" atribuída ao Conselho Nacional de Justiça não atinge o autogoverno do Judiciário, porque seus demais órgãos continuam com suas competências para realização de "atividades" previstas constitucionalmente.

Consta no voto:

\footnotetext{
${ }^{141}$ Pode-se classificar em cinco ordens as "atividades" dos órgãos do Poder Judiciário: jurisdicionais, políticas, administrativas, financeiras e disciplinares. Como será tratado nos itens 2.3.5 e 2.3.6, o CNJ pode exercer controle somente sobre as três últimas ("atividades" administrativas, financeiras e disciplinares). A EC n ${ }^{\circ}$ 45/2004 não conferiu ao Conselho, porém, competência para controle das "atividades" jurisdicionais e políticas praticadas pelos órgãos do Poder Judiciário). Por outro lado, como será exposto no item 2.3.7, o $\mathrm{CNJ}$ não exerce controle sobre todos os órgãos e membros do Poder Judiciário.
} 
Da totalidade das competências privativas dos tribunais, objeto do disposto no art. 96 da Constituição da República, nenhuma lhes foi castrada a esses órgãos, que continuarão a exercê-las todas com plenitude e exclusividade, elaborando os regimentos internos, elegendo os corpos diretivos, organizando as secretarias e serviços auxiliares, concedendo licenças, férias e outros afastamentos a seus membros, provendo os cargos de juiz de carreira, assim como os necessários à administração da justiça, etc, sem terem perdido o poder de elaborar e encaminhar as respectivas propostas orçamentárias.

Mas, apesar de sua competência de "controle", nos incisos do parágrafo $4^{\circ}$ do artigo 103-B da Constituição Federal estão relacionadas "atividades" a serem desempenhadas pelo Conselho Nacional de Justiça: a) expedição de atos regulamentares no âmbito de sua competência (inc. I); b) representação ao Ministério Público, no caso de crime contra a administração pública ou de abuso de autoridade (inc. IV); c) elaboração de relatório semestral estatístico sobre processos e sentenças prolatadas, por unidade da Federação, nos diferentes órgãos do Poder Judiciário (inc. VI); e, d) elaboração de relatório anual, propondo as providências que julgar necessárias, sobre a situação do Poder Judiciário no País e as atividades do Conselho (inc. VII). O dispositivo em comento ainda permite que outras "atividades" sejam conferidas ao Conselho Nacional de Justiça pelo Estatuto da Magistratura. Também prevê o artigo $5^{\circ}, \S 2^{\circ}$, da Emenda Constitucional $n^{\circ} 45 / 2004$ competir ao CNJ, mediante resolução, disciplinar seu funcionamento e definir as atribuições do seu Ministro-Corregedor, sendo que algumas já estão fixadas no parágrafo $5^{\circ}$ do artigo 103- B da Carta Política ${ }^{142}$.

Ainda que o rol apresentado seja extenso ${ }^{143}$, não se pode perder de vista que o Conselho Nacional de Justiça é um órgão tipicamente de "controle". Portanto, imposto esse limite constitucional à sua atuação, o CNJ deverá sempre observá-lo, não lhe competindo agir em substituição aos demais órgãos do Poder Judiciário, salvo nas hipóteses excepcionadas pela Constituição Federal, no artigo $5^{\circ}, \S 2^{\circ}$, da Emenda Constitucional $n^{\circ} 45 / 2004$ e naquelas que venham a ser eventualmente previstas no Estatuto da Magistratura.

\footnotetext{
${ }^{142}$ Vide item 3.2 .

${ }^{143}$ Vide itens 3.1.6, 3.1.7 e 3.1.8.
} 
E mesmo nessas hipóteses, entendemos, a "atividade" constitucionalmente autorizada ao Conselho Nacional de Justiça não pode invadir o campo de "atividade" constitucionalmente garantido aos demais órgãos do Poder Judiciário, salvo se também expressamente permitido na Carta Política pois, caso contrário, a "atividade" desempenhada pelo CNJ substituiria aquela que deveria ser originalmente realizada por outro órgão do Poder (o que violaria a distribuição de competências prevista na Constituição Federal) e somente eventualmente controlada pelo Conselho ${ }^{144}$.

Assim, o Conselho Nacional de Justiça pode, por expressa autorização constitucional, "agir" e expedir atos regulamentares $\left(\mathrm{CF} \text {, art. 103-B, } \S 4^{\circ}, \mathrm{I}\right)^{145}$, porém esses atos não podem anular o campo da "atividade" garantido constitucionalmente aos demais órgãos do Poder Judiciário, porque devem se restringir ao âmbito da competência do Conselho, que é tipicamente de "controle" (por exemplo, o Conselho não pode pretender, através de ato normativo próprio, padronizar os regimentos internos dos tribunais, porque anularia o espaço de competência constitucionalmente atribuído a esses órgãos do Poder Judiciário CF, art. 96, I, “a”).

Logo, conclui-se que o Conselho Nacional de Justiça, em regra, controla as ações dos demais órgãos do Poder Judiciário. Excepcionalmente, se assim previsto na Constituição Federal, age, mas ao realizar alguma "atividade" não pode aniquilar o campo de “atividades" garantido àqueles órgãos, exceto se essa possibilidade também estiver contemplada na Carta Política.

\subsubsection{Estudo de norma: Resolução CNJ no 130/2011 - Fixação de horário uniforme de expediente forense}

Em 8 de setembro de 2009, o Conselho Nacional de Justiça editou a Resolução no 88 que dispõe sobre a jornada de trabalho no âmbito do Poder Judiciário, o preenchimento de cargos em comissão e o limite de servidores requisitados.

Quanto ao primeiro tema, procurou o $\mathrm{CNJ}$ "fixar parâmetros uniformes para o funcionamento dos órgãos do Poder Judiciário quanto à jornada de trabalho de seus servidores" e estabeleceu, na regra inserta no art. $1^{\mathrm{o}}$ do referido ato normativo, ser de oito horas diárias e quarenta horas semanais, facultada a fixação de sete horas ininterruptas e

\footnotetext{
${ }^{144}$ Como já afirmado na nota de rodapé $\mathrm{n}^{\circ} 141$, nem todas as "atividades" dos órgãos do Poder Judiciário estãos sujeitas ao controle do Conselho Nacional de Justiça.

${ }^{145}$ Vide item 3.1.8.
} 
ressalvada a existência de legislação local ou especial disciplinando a matéria de modo diverso, o período de trabalho dos servidores do Poder Judiciário (caput). Determinou, também, que o pagamento de horas extras, em qualquer dos casos, somente poderia ocorrer após a oitava hora diária, até o limite de cinquenta horas semanais trabalhadas, vedada a jornada ininterrupta na hipótese de sobrejornada $\left(\S 1^{\circ}\right)$. E, ainda, ordenou que os Tribunais de Justiça dos Estados em que a legislação local disciplinasse a jornada de trabalho de forma diversa encaminhassem projeto de lei, no prazo de 90 (noventa) dias, para adequação ao horário fixado, proibindo o envio de projeto de lei para fixação de horário diverso $\left(\S 2^{\circ}\right)$.

No que se refere ao segundo assunto, ante "as distorções verificadas quanto à ocupação de cargos em comissão, em descompasso com os ditames do art. 37, IV e V, da Constituição Federal e considerados os parâmetros do art. 5º $\S 7^{\circ}$, da Lei 11.416/06 ", dispôs o art. $2^{\circ}$ da resolução em comento que referidos cargos estão ligados às atribuições de direção, chefia e assessoramento, sendo vedado seu provimento para atribuições diversas (caput), devendo haver exoneração daqueles que ocupassem esses cargos fora daquelas hipóteses $\left(\S 1^{\circ}\right)$. Determinou, também, que os Tribunais de Justiça dos Estados que ainda não tivessem regulamentado os dispositivos constitucionais mencionados, encaminhassem projetos de lei de regulamentação da matéria, com observância da destinação de percentual mínimo de 50\% (cinquenta por cento) dos cargos em comissão a servidores das carreiras judiciárias $\left(\S 2^{\circ}\right)$.

Quanto ao último ponto, constatado "o funcionamento atual de vários órgãos de primeira instância do Poder Judiciário basicamente na dependência de servidores requisitados de Prefeituras e diferentes órgãos estaduais e federais", a regra prevista no artigo $3^{\circ}$ da Resolução tratada estabeleceu o limite de servidores requisitados ou cedidos de órgãos não pertencentes ao Poder Judiciário em $20 \%$ (vinte por cento) do total do quadro de cada tribunal, salvo disciplina diversa da matéria em legislação local ou especial (caput). Ordenou, também, que a substituição dos servidores requisitados ou cedidos por servidores do quadro, deveria ocorrer no prazo máximo de 4 (quatro) anos, na proporção mínima de 20\% (vinte por cento) por ano, até atingimento do limite fixado, exceto em relação aos órgãos que o próprio $\mathrm{CNJ}$, em análise concreta, já tivesse determinado a devolução dos requisitados ou cedidos $\left(\S \S 1^{\circ}\right.$ e $\left.2^{\circ}\right)$. Prescreveu, ainda, que os Tribunais de Justiça dos Estados em que houvesse legislação local estabelecendo percentual superior ao limite de servidores requisitados ou cedidos de outros órgãos ao Poder Judiciário fixado pelo Conselho, encaminhassem projeto de lei para adequação à fronteira de $20 \%$ (vinte por 
cento), proibido o envio de projeto de lei para fixação de percentual superior $\left(\S 3^{\circ}\right)$.

Verifica-se, pois, que a Resolução CNJ no 88/2009, apesar de conter disposições que também, no nosso sentir, ultrapassam os limites de atuação do $\mathrm{CNJ}^{146}$, não dispôs sobre o assunto mencionado na rubrica do presente item: fixação de horário uniforme de expediente forense.

Mas, em 28 de abril de 2011, o Conselho Nacional de Justiça, com a justificativa de que a fixação de parâmetros uniformes para o funcionamento dos órgãos jurisdicionais somente quanto à jornada de trabalho dos servidores fez com que houvesse multiplicidade de horário de expediente, inclusive em relação a alguns dias da semana, o que teria gerado prejuízo ao jurisdicionado, exigindo o caráter nacional do Poder Judiciário a fixação de horário de funcionamento uniforme pelo menos em relação a um determinado período do dia, mas tendo em vista a insuficiência de recursos e a necessidade de respeito a costumes locais, editou a Resolução $\mathrm{n}^{\circ} 130$, que acrescentou os parágrafos $3^{\circ}$ e $4^{\circ}$ ao artigo $1^{\circ}$ da Resolução $\mathrm{CNJ}^{\circ}$ n $^{88 / 2009}$, com entrada em vigor sessenta dias após sua publicação.

O dispositivo citado passou a ter a seguinte redação:

Art. $1^{\circ}$ A jornada de trabalho dos servidores do Poder Judiciário é de 8 horas diárias e 40 horas semanais, salvo se houver legislação local ou especial disciplinando a matéria de modo diverso, facultada a fixação de 7 horas ininterruptas.

$\S 1^{\circ}$ - O pagamento de horas extras, em qualquer dos casos, somente se dará após a $8^{\text {a }}$ hora diária, até o limite de 50 horas trabalhadas na semana, não se admitindo jornada ininterrupta na hipótese de prestação de sobrejornada.

$\S 2^{\circ}$ - Deverão os Tribunais de Justiça dos Estados em que a legislação local disciplinar a jornada de trabalho de forma diversa deste artigo encaminhar projeto de lei, no prazo de 90 (noventa) dias, para adequação ao horário fixado nesta resolução, ficando vedado envio de projeto de lei para fixação de horário diverso do nela estabelecido.

$\S 3^{\circ}$ - Respeitado o limite da jornada de trabalho adotada para os servidores, o expediente dos órgãos jurisdicionais para atendimento ao público deve ser de segunda a sexta-feira, das $9 \mathrm{~h}$ às $18 \mathrm{~h}$, no mínimo.

$\S 4^{\circ}$ - No caso de insuficiência de recursos humanos ou de necessidade de respeito a costumes locais, deve ser adotada a jornada de $8 \mathrm{~h}$ diárias, em

${ }^{146}$ Vide itens 2.3.5.2.1, 2.3.7.3 e 2.3.7.3.1. 
dois turnos, com intervalo para o almoço.

Ocorre que, além de contrariar deliberações de composições anteriores, as normas acrescentadas ao artigo $1^{\circ}$ da Resolução CNJ n ${ }^{\circ}$ 88/2010 pela Resolução CNJ nº 130/2011 representam típica hipótese em que o Conselho Nacional de Justiça deixou de exercer sua função constitucional de controle e agiu no lugar dos demais órgãos do Poder Judiciário, violando, consequentemente, limite constitucional de sua atuação.

Para perfeita compreensão do que se afirma, cumpre, primeiro, fazer uma exposição cronológica de outras deliberações do Conselho que trataram do mesmo tema, além de decisões do Supremo Tribunal Federal sobre o assunto.

Poucos meses após a instalação do Conselho Nacional de Justiça ${ }^{147}$, em 13 de setembro de 2005, a Seccional de Mato Grosso da Ordem dos Advogados do Brasil, através do Pedido de Providências (PP) $n^{0} 73$, pleiteou junto ao órgão a unificação do horário de atendimento do Poder Judiciário, com atendimento externo entre as oito horas e as dezoito horas.

O pedido foi distribuído à Conselheira Germana Moraes que determinou a realização de levantamento acerca dos horários de funcionamento dos órgãos do Poder Judiciário ${ }^{148} \mathrm{e}$ votou pela improcedência do pleito, reconhecendo "a autonomia privativa dos tribunais para organizar o funcionamento dos órgãos e secretarias vinculadas, incluindo a fixação do horário que melhor atenda as peculiaridades locais".

Argumentou Sua Excelência que: a) a fixação de horário unificado pelo CNJ violaria a competência privativa atribuída aos tribunais pela Constituição Federal para dispor sobre o funcionamento dos seus órgãos jurisdicionais e administrativos e organizar suas secretarias e serviços auxiliares e os dos juízos que the forem vinculados (CF, art. 96, I, "a " e "b "); b) o artigo 19 da Lei $n^{\circ} 8.112$, de 11 de dezembro de 1990 , com a redação dada pela Lei $\mathrm{n}^{\circ}$ 8.270, de 17 de dezembro de 1991, estabelece que "os servidores cumprirão jornada de trabalho fixada em razão das atribuições pertinentes aos respectivos cargos, respeitada a duração máxima do trabalho semanal de quarenta horas e observados os limites mínimo e máximo de seis horas e oito horas diárias, respectivamente". Logo, cabe a cada administrador, e não ao órgão central, estabelecer os horários dos servidores, sobretudo por inexistir qualquer indício de desvio de finalidade ou abuso de poder dos tribunais ao fixar o

\footnotetext{
${ }^{147}$ O Conselho Nacional de Justiça foi instalado em 14 de junho de 2005.

${ }^{148}$ No voto da Conselheira, foi apresentada a tabela de horários de expediente forense nos diversos órgãos do Poder Judiciário.
} 
horário que for mais conveniente às peculiaridades locais; e, c) além de tais peculiaridades locais (climáticas, geográficas, etc.), a fixação do horário resulta da acomodação de vários interesses, como os dos advogados, magistrados, membros do Ministério Público e servidores, através de soluções dialogadas e consensuais.

A primeira composição do Conselho Nacional de Justiça ${ }^{149}$, em 29 de maio de 2007, por onze votos a um $^{150}$, julgou improcedente o Pedido de Providências $n^{\text {o }} 73$, nos termos do voto da Conselheira Relatora, vencido apenas o Conselheiro Paulo Lôbo, que o julgava procedente.

Menos de um mês depois, em 20 de junho de 2007, o Tribunal de Justiça de Sergipe (TJSE) aprovou a Resolução $n^{\circ} 24$ que estabeleceu horário de expediente forense das sete às treze horas, na Comarca de Aracaju, e das oito às catorze horas, nas Comarcas do Interior do Estado de Sergipe (art. 1 ${ }^{\circ}$, I e II), regrando, ainda, que o funcionamento interno de cada órgão judiciário, fora do expediente forense, ficaria a critério do respectivo titular, observada a necessidade do serviço, as normas pertinentes aos servidores e o horário-limite das dezessete horas. Nos consideranda do ato normativo consta que a modificação visava observar o princípio da eficiência administrativa, reduzir custos e impactos ambientais com consumo de água e energia elétrica e fixar horário consentâneo com as peculiaridades climáticas e culturais daquele Estado.

A Ordem dos Advogados do Brasil - Seccional Sergipe insurgiu-se perante o CNJ contra referida resolução através do Procedimento de Controle Administrativo (PCA) $n^{o}$ 0000798-44.2007.2.00.0000, distribuído originalmente ao Conselheiro Joaquim Falcão, integrante da segunda composição do $\mathrm{CNJ}^{151}$, que, em $1^{\circ}$ de agosto de 2007 , liminar e monocraticamente, suspendeu o ato normativo até julgamento em Plenário. Argumentou na sua decisão que: a) apesar da autonomia dos tribunais para dispor sobre o funcionamento dos seus órgãos jurisdicionais e administrativos e do teor da decisão proferida no $\mathrm{PP} \mathrm{n}^{\mathrm{o}} 73$, como não há direitos absolutos em uma sociedade democrática marcada pela diversidade de interesses sociais, essa autonomia não pode ser exercida de

\footnotetext{
149 Biênio 2005-2007, disponível em: <http://www.cnj.jus.br/sobre-o-cnj/composicao/composicoesanteriores-2012/composicao-2005-2007>. Acesso em 11.05.2014.

${ }^{150}$ Estiverem presentes na sessão os Conselheiros Marcus Faver, Jirair Aram Meguerian, Douglas Rodrigues, Cláudio Godoy, Germana Moraes, Paulo Schmidt, Eduardo Lorenzoni, Ruth Carvalho, Oscar Argollo, Paulo Lôbo e Alexandre de Moraes. Ausentes, justificadamente, os Conselheiros Ellen Gracie (Presidente), Antônio de Pádua Ribeiro (Corregedor Nacional de Justiça), Vantuil Abdala e Joaquim Falcão (conforme certidão de julgamento da $41^{\mathrm{a}}$ Sessão Ordinária do $\mathrm{CNJ}$ ).

151 Biênio 2007-2009, disponível em: <http://www.cnj.jus.br/sobre-o-cnj/composicao/composicoesanteriores-2012/composicao-2007-2009>. Acesso em 11.05.2014.
} 
modo a prejudicar outros direitos constitucionalmente garantidos; e, b) o Tribunal de Justiça de Sergipe mudou, no prazo de um mês, horário de funcionamento estabelecido há mais de cinquenta anos, sem consultar e preocupar-se com os usuários e os profissionais que dependem da administração da justiça, podendo a alteração prejudicá-los.

A decisão proferida pelo Conselheiro Joaquim Falcão, porém, foi suspensa em sede de apreciação de liminar, no Mandado de Segurança $n^{\circ} 26835$ impetrado perante o Supremo Tribunal Federal, pelo Ministro Ricardo Lewandowski em 3 de agosto de 2007, ficando restabelecidos os efeitos da Resolução TJSE nº 24/2007 até o julgamento de mérito do writ $^{152}$. Argumentou o Ministro, em sua decisão, que: a) a Constituição Federal conferiu competência privativa aos Tribunais, em seu artigo 96, inciso I, alíneas "a" e "b", para dispor sobre o funcionamento dos respectivos órgãos jurisdicionais e administrativos; b) o próprio Conselho Nacional de Justiça, nos autos do PP $n^{\circ} 73$, consagrou entendimento no sentido de que a fixação de horário unificado para todo o Poder Judiciário viola o disposto no artigo 96 da Constituição; c) a suspensão da Resolução TJ/SE n ${ }^{\circ}$ 24/2007 geraria instabilidade na Justiça Sergipana, pois diversos júris, audiências e sessões foram designados com base no novo horário estabelecido no ato normativo; e, d) todos os atos processuais necessários à implementação do novo expediente forense foram projetados com 40 (quarenta) dias de antecedência no sentido de minimizar a mudança.

Poucos dias depois, em 14 de agosto de 2007, a segunda composição do Conselho Nacional de Justiça, por unanimidade, indeferiu o Pedido de Providências $n^{\circ} 1436$, relatado pela Conselheira Andréa Pachá ${ }^{153}$. Tratava-se de requerimento feito por advogado inscrito na $\mathrm{OAB}$ do Estado de Goiás que pediu providência em face do Tribunal de Justiça daquele Estado, alegando que houve fixação temporária de expediente do fórum na capital,

\footnotetext{
${ }^{152}$ Cumpre dizer que o Mandado de Segurança $\mathrm{n}^{\mathrm{0}} 26835$ foi distribuído no STF à relatoria do Ministro Luiz Fux, mas o pedido de liminar foi apreciado pelo Ministro Ricardo Lewandowski nos termos da norma inserta no artigo 38, I, do RISTF, com a redação anterior à Emenda Regimental n ${ }^{\circ} 42$, de 2 de dezembro de 2010, que dispunha sobre a substituição, para deliberação sobre medida urgente, do relator pelo revisor, se houvesse, ou pelo Ministro imediato em antiguidade, dentre os do Tribunal ou da Turma, conforme a competência, em caso de ausência ou impedimento eventual. O "mandamus", até 26 de dezembro de 2014, ainda não havia sido julgado (disponível em: $<$ http://www.stf.jus.br/portal/processo/verProcessoAndamento.asp?incidente=2543845>. Acesso em 26.12.2014). Quanto ao PCA $\mathrm{n}^{\mathrm{o}}$ 0000798-44.2007.2.00.0000, em $1^{\circ}$ de outubro de 2007, foi determinada a suspensão de seu andamento até o julgamento do MS 26835 do STF e, em 16 de maio de 2013, foi homologado pedido de desistência do procedimento formulado pela requerente (disponível em: $<$ https://www.cnj.jus.br/ecnj/consulta_eproc.php?filtro=a $>$. Acesso em 11.05.2014).

${ }^{153}$ Estiverem presentes na sessão os Conselheiros Francisco Cesar Asfor Rocha, Gelson de Azevedo, Rui Stoco, Mairan Gonçalves Maia Júnior, Altino Pedrozo dos Santos, Andréa Maciel Pachá, Jorge Maurique, Antonio Umberto de Souza Junior, José Adonis Callou de Araújo Sá, Felipe Locke Cavalcanti, Paulo Lôbo e Técio Lins e Silva. Ausentes, justificadamente, os Conselheiros Ellen Gracie (Presidente) e Joaquim Falcão (conforme certidão de julgamento da $45^{\text {a }}$ Sessão Ordinária do CNJ).
} 
Goiânia, das $8 \mathrm{~h}$ às $18 \mathrm{~h}$, com intervalo das $11 \mathrm{~h}$ às $13 \mathrm{~h}$ para economia de energia elétrica em virtude do "apagão" que ocorreu no país, porém, superado o problema, os horários continuam os mesmos, prejudicando interesses das partes. Prestadas informações pela Corte Estadual Goiana, o pleito foi indeferido porque: a) o expediente forense no Estado de Goiás foi estabelecido no Código de Organização Judiciária daquele Estado, Lei Estadual $\mathrm{n}^{\circ}$ 9.129, de 22 de dezembro de $1981^{154}$, e não por razões emergenciais; e, b) compete privativamente aos Tribunais organizar suas secretarias e o funcionamento delas, pois trata-se de questão que deve ser adequadamente analisada e equacionada por cada um deles, dentro da gestão que lhes cabe e dos interesses e circunstâncias locais que os oriente, e não pelo CNJ, órgão de planejamento do Poder Judiciário.

Cumpre reproduzir, por utilizar termos que remetem às ponderações já apresentadas, trecho do voto da Conselheira Andréa Pachá que trata do segundo motivo para indeferimento do Pedido de Providências $n^{\circ}$ 1436. Os termos que remontam às ideias de "atividade" e "controle" foram destacados no texto:

Não cabe a este Conselho, sem profundo conhecimento sobre todos os aspectos que orientaram a ampliação do horário de expediente forense em mais duas horas diárias, decidir sobre questão, especialmente porque não se trata de caso em que o TJ-GO esteja agindo em desconformidade com os princípios ou as normas que regem a matéria, já que total são oito horas diárias de atendimento ao público.

Em síntese, não há qualquer controle a ser feito pelo $\mathrm{CNJ}$ no presente caso, devendo a matéria ser suscitada perante o próprio Tribunal de Justiça de Goiás que, querendo e entendendo oportuno, pode modificar o horário de atendimento aos advogados e às partes, em virtude do crescimento da cidade e do aumento de demandas.

No dia seguinte, 15 de agosto de 2007, foi apreciado pelo CNJ outro requerimento relativo a horário de expediente forense. Tratava-se do Procedimento de Controle

\footnotetext{
${ }^{154}$ Art. 158 (Lei Estadual Goiana $n^{\circ}$ 9.129/1981) - Seraá o seguinte o horário do expediente forense, ressalvado o disposto no art. 66:

I - das oito às onze horas;

II - das treze às dezoito horas.

Parágrafo único - Aos sábados, domingos e feriados, os cartórios de Registro Civil de Pessoas Naturais funcionarão no horário das oito às treze horas.
}

Art. 66 (Lei Estadual Goiana n 9.129/1981) - O tabelião de notas poderá lavrar os atos de seu ofícios em qualquer hora do dia útil, no cartório ou fora dele, e os de causa mortis mesmo em dias feriados. 
Administrativo $\mathrm{n}^{\mathrm{o}}$ 611, da relatoria do Conselheiro Mairan Gonçalves Maia Júnior, onde foi questionada a suspensão de expediente forense no Tribunal de Justiça de São Paulo (TJSP) no dia 8 de junho de 2007, oficializada pelo Provimento TJSP n ${ }^{\circ} 1318$, de 4 de junho de 2007, sob a alegação de violação do princípio da continuidade dos serviços públicos, moralidade e eficiência administrativas, sendo requerida a proibição, em todas as esferas do Poder Judiciário, de atos que suspendam o expediente de trabalho nos dias imediatamente anteriores ou posteriores aos feriados.

Após a apresentação das informações requeridas ao Tribunal Estadual Paulista, o pleito foi julgado, por unanimidade ${ }^{155}$, improcedente, reconhecendo o Conselho, mais uma vez, que questões afetas ao expediente forense inserem-se no âmbito da autonomia dos tribunais $^{156}$.

Em 2007 ainda foi julgado, pela segunda composição do Conselho Nacional de Justiça, o Recurso Administrativo no Pedido de Providências no 2007.10.00001086-9, relatado pela Conselheira Andreá Pachá e no qual insurgiu-se Promotor de Justiça contra decisão monocrática proferida por Sua Excelência em 28 de setembro de 2007 que não conheceu de requerimento formulado pelo recorrente para adoção de providências para eficiente gerenciamento no meio judicial e melhor atendimento ao público, onde argumentou faltar, no Poder Judiciário, delegação de funções pelo juiz e período maior de atendimento ao público, entendendo que deva ser aumentado o tempo diário de atendimento para oito horas.

O Colegiado, em 23 de outubro de 2007, por unanimidade ${ }^{157}$, negou provimento ao

\footnotetext{
${ }^{155}$ Estiverem presentes na sessão os Conselheiros Francisco Cesar Asfor Rocha, Rui Stoco, Mairan Gonçalves Maia Júnior, Altino Pedrozo dos Santos, Andréa Maciel Pachá, Jorge Maurique, Antonio Umberto de Souza Junior, José Adonis Callou de Araújo Sá, Paulo Lôbo e Técio Lins e Silva. Ausentes, justificadamente, os Conselheiros Ellen Gracie (Presidente), Gelson de Azevedo, Felipe Locke Cavalcanti e Joaquim Falcão (conforme certidão de julgamento da $45^{\text {a }}$ Sessão Ordinária do CNJ).

${ }^{156} \mathrm{O}$ julgado recebeu a seguinte ementa:

"PROCEDIMENTO DE CONTROLE ADMINISTRATIVO - SUSPENSAO DO EXPEDIENTE FORENSE - ATO DO CONSELHO SUPERIOR DA MAGISTRATURA - AUTONOMIA DOS TRIBUNAIS REQUERIMENTO DE MEDIDA ESTRANHA AS FINALIDADES DO CNJ (ART. 103, § 4º, DA CF/88) SITUAÇÃO FÁTICA QUE ENSEJA PERDA DO OBJETO - INDEFERIMENTO.

I. Inviável interferir na gerência do expediente do Tribunal no que tange à determinação de datas sem expediente.

II. A questão enquadra-se no âmbito da autonomia dos Tribunais, os quais hão de observar a necessidade de regime plantonista, nas datas sem expediente normal, nos termos do art. 93, inciso XII, da CF/88. Indevida ingerência sobre atos de autogoverno e administração.

III. Requerimento estranho às finalidades do CNJ (art. 103, § $\left.4^{\circ}, \mathrm{DA} C F / 88\right)$. Situação fática que revela falta de interesse superveniente dos requerentes.

IV. Procedimento de controle administrativo, indeferido".

${ }^{157}$ Estiverem presentes na sessão os Conselheiros Francisco Cesar Asfor Rocha, Rui Stoco, Mairan Gonçalves Maia Júnior, Altino Pedrozo dos Santos, Andréa Maciel Pachá, Jorge Maurique, José Adonis
} 
recurso, reafirmando a competência privativa dos tribunais para estabelecer horário de funcionamento de suas secretarias ${ }^{158}$.

Posteriormente, em 4 de junho de 2008, no julgamento da Ação Direta de Inconstitucionalidade $\mathrm{n}^{\mathbf{0}}$ 2907, Relator Ministro Ricardo Lewandowski, interposta para questionar a constitucionalidade da Portaria $n^{\circ}$ 94/2001, da Presidência do Tribunal de Justiça do Estado de Amazonas, que fixou horário único de expediente forense nas serventias e demais órgãos daquele tribunal das oito às catorze horas ${ }^{159}$, o Supremo Tribunal Federal firmou entendimento que a disciplina de expediente administrativo dos servidores do Poder Judiciário pode ser regulada pelos tribunais, desde que o façam por decisão colegiada ${ }^{160}$ e desde que não haja alteração da jornada de trabalho ${ }^{161162}$.

Callou de Araújo Sá, Felipe Locke Cavalcanti, Paulo Lôbo, Técio Lins e Silva e Joaquim Falcão. Ausentes, justificadamente, os Conselheiros Ellen Gracie (Presidente), João Oreste Dalazen e Antonio Umberto de Souza Júnior (conforme certidão de julgamento da $50^{\mathrm{a}}$ Sessão Ordinária do CNJ).

${ }^{158}$ Esta é a ementa que recebeu o julgado:

"RECURSO ADMINISTRATIVO. Decisão monocrática. Pedido de providências para determinar delegação de atos ordinatórios e fixação de horário do expediente forense. Arquivamento liminar.

I - A delegação de atos ordinatórios no processo está previsto no Código de Processo Civil, sendo desnecessária determinação administrativa neste sentido.

II - O horário de atendimento ao público nos fóruns depende de interesses e costumes locais e está afeto a competência privativa dos tribunais".

${ }^{159}$ Nos consideranda do ato normativo consta que a alteração de horário de expediente administrativo foi motivada pela necessidade de racionalizar os gastos com material, energia elétrica e pessoal e que houve manifestação de concordâbcia dos Juízes de Direito, Ministério Público e Defensoria Pública do Estado.

${ }^{160}$ Sobre princípio da colegialidade, vide item 2.3.2.2.

${ }^{161}$ O STF assentou que a alteração da carga horária semanal de trabalho dos servidores do Poder Judiciário tem que ser tratada em lei de iniciativa reservada do Chefe do Poder Executivo (ADIMC n ${ }^{\circ} 2308$, Relator Ministro Moreira Alves, j. 25.4.2001; ADIMC n 2400, Relator Ministro Ilmar Galvão, j. 19.4.2001), por força da norma inserta no artigo $61, \S 1^{\circ}$, II, "c", da Constituição Federal, aplicável compulsoriamente aos Estados-membros (ADI n ${ }^{\circ}$ 120, Relator Ministro Moreira Alves, j. 20.3.96; ADI no 227, Relator Ministro Maurício Corrêa, j. 19.11.91; ADI n§ 822, Relator Ministro Octavio Gallotti, j. 25.4.96), uma vez que dispõe sobre o regime jurídico de servidores públicos, expressão que, na lição apresentada pelo Ministro Celso de Mello no julgamento da ADIMC n ${ }^{\circ} 766$, em 3 de setembro de 1992, "exterioriza o conjunto de normas que disciplinam os diversos aspectos das relações estatutárias ou contratuais, mantidas pelo Estado com os seus agentes" e "compreende todas as regras pertinentes (a) às formas de provimento; (b) às formas de nomeação; (c) à realização do concurso; (d) à posse; (e) ao exercício, inclusive as hipóteses de afastamento, de dispensa de ponto e de contagem de tempo de serviço; (f) às hipóteses de vacância; (g) à promoção e respectivos critérios, bem como avaliação do mérito e classificação final (cursos, títulos, interstícios mínimos); (h) aos direitos e às vantagens de ordem pecuniária; (i) às reposições salariais e aos vencimentos; (j) ao horário de trabalho e ao ponto, inclusive os regimes especiais de trabalho; (k) aos adicionais por tempo de serviço, gratificações, diárias, ajudas de custo e acumulações remuneradas; (l) às férias, licenças em geral, estabilidade, disponibilidade, aposentadoria; (m) aos deveres e proibições; (n) às penalidades e sua aplicação; (o) ao processo administrativo.

${ }^{162}$ O acórdão da Ação Direta de Inconstitucionalidade nº 2907, Relator Ministro Ricardo Lewandowski, recebeu a seguinte ementa:

“AÇÃO DIRETA DE INCONSTITUCIONALIDADE. PORTARIA 954/2001 DO TRIBUNAL DE JUSTIÇA DO ESTADO DO AMAZONAS, ATO NORMATIVO QUE DISCIPLINA O HORÁRIO DE TRABALHO DOS SERVIDORES DO JUDICIÁRIO. VÍCIO DE NATUREZA FORMAL. OFENSA AO 
A segunda composição do Conselho Nacional de Justiça voltou a apreciar pleitos semelhantes formulados pela Seccionais da Ordem dos Advogados do Brasil dos Estados da Bahia (OAB/BA) e de Alagoas (OAB/AL) em março de 2009.

No Procedimento de Controle Administrativo $\mathrm{n}^{\mathrm{o}}$ 0001470-18.2008.2.00.0000 a OAB/BA requereu a revogação do Ato $n^{0}$ 80, de 29 de abril de 2008, da Presidência do Tribunal Regional do Trabalho da $5^{\text {a }}$ Região, que limitou o horário de expediente das oito horas às dezesseis horas, apesar de alguns servidores continuarem a laborar internamente após este período.

No julgamento concluído em 17 de março de $2009^{163}$, após as informações prestadas pelo Tribunal Regional da Justiça Obreira, o Conselho Nacional de Justiça, por maioria ${ }^{164}$, julgou parcialmente procedente o pedido para reconhecer a autonomia dos tribunais para fixação do horário de expediente forense, porém determinar a observância da norma inserta no artigo $7^{\circ}$, VI, “c”, da Lei no 8.906, de 4 de jullho de 1994, que garante aos advogados ingressar livremente "em qualquer edifício ou recinto em que funcione repartição judicial ou outro serviço público onde o advogado deva praticar ato ou colher prova ou informação útil ao exercício da atividade profissional, dentro do expediente ou fora dele, e ser atendido, desde que se ache presente qualquer servidor ou empregado"165.

ART. 96, I, a e b, da CF. AÇÃO JULGADA PROCEDENTE COM EFEITOS EX NUNC.

I. Embora não haja ofensa ao princípio da separação dos poderes, visto que a Portaria em questão não altera a jornada de trabalho dos servidores e, portanto, não interfere com o seu regime jurídico, constata-se, na espécie, vício de natureza formal.

II. Como assentou o Plenário do STF nada impede que a matéria seja regulada pelo Tribunal, no exercício da autonomia administrativa que a Carta Magna garante ao Judiciário.

III. Mas a forma com que o tema foi tratado, ou seja, por portaria ao invés de resolução, monocraticamente e não por meio de decisão colegiada, vulnera o art. 96, I, a e b, da Constituição Federal. IV. Ação julgada procedente, com efeitos ex nunc".

É importante registrar que, quanto ao mérito da ADI no 2907, restaram vencidos os Ministros Marco Aurélio Mello, Menezes Direito, Cármen Lúcia e Eros Grau que julgavam improcedente o pedido por considerarem que a matéria tratada (horário de expediente forense) poderia, inclusive, ser disciplinada por ato normativo da Presidência do Tribunal de Justiça do Amazonas.

${ }^{163}$ Estiverem presentes na sessão os Conselheiros Gilson Dipp, João Oreste Dalazen, Rui Stoco, Mairan Gonçalves Maia Júnior, Altino Pedrozo dos Santos, Andréa Maciel Pachá, Jorge Maurique, Antonio Umberto de Souza Junior, José Adonis Callou de Araújo Sá, Felipe Locke Cavalcanti, Paulo Lôbo, Técio Lins e Silva, Marcelo Nobre e Joaquim Falcão (conforme certidão de julgamento da $80^{a}$ Sessão Ordinária do CNJ).

${ }^{164}$ Ficaram vencidos parcialmente os Conselheiros Altino Pedrozo dos Santos (Relator), Andréa Maciel Pachá, Jorge Maurique, João Oreste Dalazen, Rui Stoco e Mairan Gonçalves Maia Júnior. O acórdão foi lavrado pelo Conselheiro Antonio Umberto de Souza Junior (conforme certidão de julgamento da $80^{\text {a }}$ Sessão Ordinária do CNJ).

${ }^{165}$ Cumpre registrar que o acórdão administrativo reafirmou o decidido na ADI no 2907 mencionada quanto à autonomia dos tribunais para fixação do horário de expediente forense, tendo recebido a seguinte ementa:

"PROCEDIMENTO DE CONTROLE ADMINISTRATIVO. HORÁRIO DE EXPEDIENTE. FIXAÇÃO. 1. ATO DO PRESIDENTE. VALIDADE. Incensurável a iniciativa de edição de ato monocrático pela Presidência de tribunal quando o Regimento Interno, aprovado por seus membros efetivos, lhe confira tal 
Já a Seccional da Ordem dos Advogados do Brasil dos Estado de Alagoas (OAB/AL), através do Procedimento de Controle Administrativo $\mathrm{n}^{\mathrm{o}}$ 0001461-56.2008.2.00.0000, requereu a desconstituição da Resolução ${ }^{0}$ 7, de 26 de fevereiro de 2008, do Tribunal de Justiça do mesmo Estado, que, em atenção à Recomendação n ${ }^{0} 11$, de 22 de maio de 2007, oriunda do Conselho Nacional de Justiça para os Tribunais adotarem políticas públicas visando a formação e recuperação de um ambiente ecologicamente equilibrado, em especial com a utilização sustentável de energia, e considerando a expressiva economia anual no que tange ao custeio do consumo de energia elétrica utilizada para a manutenção das sedes dos órgãos administrativos e jurisdicionais, alterou para das sete e trinta às treze e trinta o horário de expediente forense.

Fornecidas as informações pedidas à Justiça Estadual Alagoana, o Conselho Nacional

delegação. 2. HORÁRIO DE EXPEDIENTE. AUTONOMIA PARA FIXAÇÃO. Aos tribunais concedeu a Constituição Federal autorização para disciplinarem o funcionamento de seus órgãos (CF, art. 96, I, a), aí abrangida a fixação do horário de expediente (STF, ADI 2.907, LEWANDOWSKI). Ato de fixação de horário de expediente deve ser preservado pelo Conselho Nacional de Justiça, zelador constitucional que é da autonomia dos tribunais (CF, art. 103-B, $\left.\S 4^{\circ}, \mathrm{I}\right)$. 3. EXPEDIENTE FORENSE. PRERROGATIVA LEGAL DOS ADVOGADOS. ADEQUAÇÃO. Dado o relevo constitucional da atuação profissional dos advogados, indispensáveis à administração da Justiça (CF, art. 133), a autonomia dos tribunais para estipulação do horário de expediente deve ser conjugada com a garantia de atendimento dos advogados enquanto haja nos recintos forenses a presença de serventuário (Lei $\mathrm{n}^{\circ}$ 8.906/94, art. $7^{\circ}$, VI, c). 4. PORTARIA REVOCATÓRIA DA PORTARIA IMPUGNADA. PREJUDICIALIDADE. INOCORRÊNCIA. A edição de nova portaria substitutiva e revocatória de portaria objeto de ataque inicial não prejudica o exame da matéria quando, ainda que atenuando os vícios originais, persista a incompatibilidade de seu texto com disposição legal expressa. Pedido conhecido e parcialmente acolhido para, mantendo intacto o ato administrativo sucessor do ato atacado, determinar que as Secretarias das Varas do Trabalho da Bahia atendam advogados enquanto houver serventuário em atividade, ainda que aquém ou além do horário de expediente fixado pela Presidência".

Saliente-se que o Ato $\mathrm{n}^{\circ}$ 80/2008 foi posteriormente revogado pelo Ato $\mathrm{n}^{\circ} 377$, de 6 de outubro de 2008, também da Presidência do TRT da $5^{\text {a }}$ Região. E este foi, em 13 de fevereiro de 2009, também revogado pela mesma autoridade através do Ato $\mathrm{n}^{\circ} 24 / 2009$, ainda em vigor, que fixa o horário de expediente das nove às dezessete horas, nas Secretarias das Varas do Trabalho integrantes do Tribunal Regional do Trabalho da $5^{\text {a }}$ Região (art. $2^{\circ}$ ), estabelece que os serviços de protocolo deverão ser prestados até as dezoito horas, nas Secretarias das Varas do Trabalho onde não há setor correspondente (art. $3^{\circ}$ ) e determina, quando realizadas audiências fora do horário de expediente, que deverá ser designado, pelo menos, um servidor para prestar atendimento às partes e advogados que dela participarem, além daquele responsável por secretariar as audiências, ficando garantido o acesso a informações na Secretaria da Vara do Trabalho (art, $4^{\circ}$ ). O CNJ entendeu que, apesar da revogação do ato impugnado, deveria apreciar o mérito do pedido porque sua atuação não se limita ao plano corretivo, mas também preventivo. Como assinalou o Conselheiro Antonio Umberto de Souza Junior redator do acórdão, "se os novos atos houverem consigo a estrita observância prática da regra legal alusiva ao atendimento de advogados pela Justiça do Trabalho baiana, qualquer determinação deste Conselho no mesmo sentido não é impertinente nem perturbadora, mas meramente redundante; ao contrário, se do novo ato não resultou mudança de postura, soa mais conveniente aproveitar a existência deste procedimento para resolver a questão, evitando a reiteração de pleitos e a persistência de um indesejável clima de animosidade". No caso, entendeu o Conselho Administrativo que o Ato no 24/2009 assegurou atendimento aos advogados durante expediente interno exclusivamente no horário coincidente de audiências e apenas para os profissionais nelas presentes, o que afronta o disposto no artigo $7^{\circ}$, VI, "c", da Lei $n^{\circ} 8.906 / 1994$. 
de Justiça, por maioria ${ }^{166}$, também em julgamento concluído em 17 de março de $2009^{167}$, julgou improcedente o pedido. Reconheceu, pois, novamente, a autonomia administrativa dos tribunais para fixação do horário de expediente forense, recomendando apenas ao Tribunal de Justiça do Estado de Alagoas estender o horário de atendimento nas centrais de protocolo para além do horário de expediente fixado na Resolução n $n^{\circ}$ 07/2008, de preferência, até as dezoito horas, como forma de melhorar o acesso mínimo do jurisdicionado à justiça ${ }^{168}$.

Na sequência, já após o advento da Resolução $n^{\circ} 88$, de 8 de setembro de 2009 , foi formulada consulta ao Conselho Nacional de Justiça sobre a possibilidade de órgão monocrático de tribunal, a exemplo da presidência ou corregedoria, editar atos normativos que disciplinem os horários de funcionamento dos órgãos do Poder Judiciário estadual e expediente forense (Consulta $\mathrm{n}^{\mathrm{o}}$ 0006013-30.2009.2.00.0000).

A terceira composição do Conselho Administrativo ${ }^{169}$, em 24 de novembro de 2009, por unanimidade ${ }^{170}$, nos termos do voto do Relator, Conselheiro Paulo de Tarso Tamburini Souza, responde à referida no sentido de que cabe à Presidência do Tribunal de Justiça

\footnotetext{
${ }^{166}$ Ficaram vencidos os Conselheiros Paulo Lôbo, Técio Lins e Silva, Marcelo Nobre e Joaquim Falcão (conforme certidão de julgamento da $80^{\mathrm{a}}$ Sessão Ordinária do CNJ).

${ }^{167}$ Estiverem presentes na sessão os Conselheiros Gilson Dipp, João Oreste Dalazen, Rui Stoco, Mairan Gonçalves Maia Júnior, Altino Pedrozo dos Santos, Andréa Maciel Pachá, Jorge Maurique, Antonio Umberto de Souza Junior, José Adonis Callou de Araújo Sá, Felipe Locke Cavalcanti, Paulo Lôbo, Técio Lins e Silva, Marcelo Nobre e Joaquim Falcão (conforme certidão de julgamento da 80a Sessão Ordinária do CNJ).

${ }^{168}$ Eis a ementa do julgado:
}

"HORÁRIO DE EXPEDIENTE FORENSE. ALTERAÇÃO. COMPETÊNCIA PRIVATIVA. ARTIGO 96, INCISO I, DA CONSTITUIÇÃO FEDERAL. ATO VÁLIDO. INTERESSE PÚBLICO. RECOMENDAÇÃO. AMPLIAÇÃO DO HORÁRIO DE EXPEDIENTE DO SERVIÇO DE PROTOCOLO.

1. A fixação do horário de expediente dos respectivos órgãos encontra-se no âmbito da autonomia administrativa conferida a cada Tribunal, conforme inteligência do artigo 96, inciso I, alínea "a", da Constituição Federal.

2. Não há falar em ilegalidade ou inconstitucionalidade da Resolução do Tribunal de Justiça do Estado de Alagoas que altera o horário de expediente forense externo, se, editada com vistas ao interesse público, não contém vícios que a maculem.

3. Constatando-se, no entanto, a ausência de horário mais amplo destinado ao serviço de protocolo, é recomendável que o Tribunal aumente o horário de atendimento nas respectivas centrais para além do horário de expediente fixado na Resolução, como forma de melhorar a qualidade do acesso mínimo do jurisdicionado à justiça.

Procedimento de Controle Administrativo de que se conhece e a que se julga improcedente, com recomendação ao Tribunal”.

169 Biênio 2009-2011, disponível em: <http://www.cnj.jus.br/sobre-o-cnj/composicao/composicoesanteriores-2012/composicao-2009-2011>. Acesso em 15.05.2014.

${ }^{170}$ Estiverem presentes na sessão os Conselheiros Gilson Dipp, Ives Gandra, Milton Augusto de Brito Nobre, Leomar Barros Amorim de Sousa, Nelson Tomaz Braga, Paulo de Tarso Tamburini Souza, Walter Nunes da Silva Júnior, Morgana de Almeida Richa, José Adonis Callou de Araújo Sá, Felipe Locke Cavalcanti, Jefferson Luis Kravchychyn, Jorge Hélio Chaves de Oliveira, Marcelo Nobre e Marcelo Neves (conforme certidão de julgamento da $95^{\mathrm{a}}$ Sessão Ordinária do $\mathrm{CNJ}$ ). 
editar atos normativos que disciplinem horários de funcionamento dos órgãos do Poder Judiciário Estadual, salvo nos casos em que a Lei de Organização Judiciária ou o Regimento Interno da respectiva Corte disponha expressamente de outra maneira, atribuindo a outro órgão monocrático ou coletivo tal competência.

Nota-se que, mais uma vez, apesar de contrariar a decisão do Supremo Tribunal Federal proferida na ADI $n^{\circ} 2907$, que estabeleceu a necessidade da matéria ser tratada por ato colegiado, o CNJ reconheceu competir aos Tribunais de Justiça a disciplina de seus horários de expediente forense.

Esse entendimento foi confirmado pela terceira composição do CNJ no julgamento do Procedimento de Controle Administrativo $\mathrm{n}^{\mathrm{o}}$ 0007128-86.2009.2.00.0000 onde a Ordem dos Advogados do Brasil - Seccional de Mato Grosso requereu a suspensão liminar dos efeitos da Resolução $n^{0}$ 140, de 23 de novembro de 2009, do Tribunal Regional do Trabalho da $23^{\mathrm{a}}$ Região, que fixou o horário de funcionamento do protocolo e do distribuidor do tribunal para o horário compreeendido entre $7 \mathrm{~h} 30 \mathrm{~min}$ e $17 \mathrm{~h} 30 \mathrm{~min}^{171}$.

Apresentados esclarecimentos pelo Tribunal Regional Trabalhista, o Conselho Nacional de Justiça, em 26 de janeiro de 2010, por maioria, nos termos do voto do Relator, Conselheiro Paulo Tamburini, vencidos os Conselheiros Leomar Amorim e Jefferson Kravchychyn $^{172}$, julgou improcedente o pedido, por entender que a Resolução TRT23 no 140/2009 não violou o teor da redação original da Resolução CNJ n ${ }^{\circ}$ 88/2009, pois o estabelecimento do expediente forense é matéria que se encontra dentro da autonomia administrativa de cada um dos tribunais, o horário de funcionamento fixado é razoável e a medida, conforme justificativa apresentada, proporcionará razoável economia de recursos públicos.

E, agora no segundo semestre de 2010, o CNJ, mais uma vez apreciou questionamento quanto a fixação de horário de expediente funcionamento estabelecido por órgão do Poder

${ }^{171}$ A Resolução TRT23 n ${ }^{\text {o }}$ 140/2009 fixou, a partir de 07 de janeiro de 2010, o horário de funcionamento dos órgão da Justiça do Trabalho da $23^{\mathrm{a}}$ Região da seguinte forma: a) expediente interno e atendimento ao público em geral das 07h30min às 14h30min; b) atendimento, na Capital e no Foro Trabalhista de Rondonópolis, nas seções de Protocolo, Distribuição e Central de Atendimento ao Jurisdicionado das 07h30min às $17 \mathrm{~h} 30 \mathrm{~min}$; e, c) limite máximo para funcionamento de todos os computadores, elevadores e aparelhos de ar-condicionado individuais às 17h30min. O CNJ apreciou somente o pedido de suspensão dos efeitos do ato administrativo normativo e razão da fixação de funcionamento do protocolo e do distribuidor do tribunal mencionado no item "b"supra.

${ }^{172}$ Estiverem presentes na sessão os Conselheiros Gilson Dipp, Ives Gandra, Milton Augusto de Brito Nobre, Leomar Barros Amorim de Sousa, Nelson Tomaz Braga, Paulo de Tarso Tamburini Souza, Walter Nunes da Silva Júnior, José Adonis Callou de Araújo Sá, Jefferson Luis Kravchychyn, Marcelo Nobre e Marcelo Neves. Ausentes, justificadamente, os Conselheiros Gilmar Mendes, Morgana de Almeida Richa, Felipe Locke Cavalcanti e Jorge Hélio Chaves de Oliveira (conforme certidão de julgamento da 97 ${ }^{\mathrm{a}}$ Sessão Ordinária do CNJ). 
Judiciário.

No Pedido de Providências $n^{0}$ 0005477-82.2010.2.00.0000, da relatoria do Conselheiro Jorge Hélio Chaves de Oliveira, a Ordem dos Advogados do Brasil Seccional de Rondônia, requereu a revogação da Resolução n ${ }^{0}$ 29, de 26 de julho de 2010, do Tribunal de Justiça do mesmo Estado, que estabeleceu o horário de expediente forense dos órgãos do Poder Judiciário Estadual entre sete e catorze horas, ininterruptamente ${ }^{173}$.

Fornecidas informações pelo Tribunal Estadual Rondoniense, o Conselho Nacional de Justiça, em 14 de setembro de 2010, ao julgar referido pedido, novamente, por unanimidade $^{174}$, confirmou o entendimento de que os tribunais têm autonomia para organizar o funcionamento de seus órgãos jurisdicionais e administrativos, inclusive a fixação do horário de expediente forense, nos termos das norma prescrita pelo artigo 96, inciso I, alínea "a”, da Constituição Federal. Expediu apenas, em homenagem ao princípio da eficiência e com apoio na decisão anteriormente proferida no Procedimento de Controle Administrativo $\mathrm{n}^{\mathrm{o}}$ 0001461-56.2008.2.00.0000, recomendação geral a todos os tribunais cujo expediente se concentrasse preponderantemente pela manhã, para estender o horário de funcionamento do protocolo de petições, com estrutura simplificada, até, ao menos, as dezoito horas, para evitar prejuízos aos jurisdicionados, para que não tivessem apenas apenas o período matutino para praticar atos, cumprir prazos processuais, devolver autos, protocolar pedidos urgentes etc ${ }^{175}$.

${ }^{173} \mathrm{~A} \mathrm{OAB} / \mathrm{RO}$ relatou que o expediente forense no Tribunal de Justiça de Rondônia funcionava anteriormente de $07 \mathrm{~h} 00$ às $13 \mathrm{~h} 00$, voltando a funcionar de $16 \mathrm{~h} 00$ às $18 \mathrm{~h} 00$, e que a alteração ocorreu sem que houvesse ampla divulgação, tendo sido aprovada em sessão no dia 26 de julho de 2010 e entrado em vigor no dia 02 de agosto do mesmo ano. Para impugnar o ato normativo, sustentou: a) violação ao princípio da legalidade, gravado no artigo $5^{\circ}$, inciso II e caput do artigo 37 da Constituição Federal, e ao artigo $1^{\circ}$ da Lei de Introdução às Normas do Direito Brasileiro (Decreto-Lei no 4.657, de 4 de setembro de 1942, com a redação da ementa dada pela Lei ${ }^{0} 12.376$, de 30 de dezembro de 2010); b) ofensa ao interesse público, pois o novo expediente passou a impedir serviços judiciais a partir das catorze horas, salvo urgências legais, sendo necessário, no mínimo, o aumento do horário de atendimento aos serviços de protocolo, para um acesso mais amplo à justiça; c) equivocada fundamentação da Resolução TJRO no 29/2010, pois elaborada nos termos da redação original da Resolução $\mathrm{CNJ}^{\circ}{ }^{\circ}$ 88/2009 que tratava apenas da jornada de trabalho e não do expediente forense, regulado pelo Código de Processo Civil e pelas Leis de Organização Judiciárias; d) violação da norma inserta no artigo $5^{\circ}, \mathrm{XXXV}$, da Constituição Federal, pois a Resolução em comento restringe acesso aos serviços forenses, e, por conseqüência, à justiça.

${ }^{174}$ Estiverem presentes na sessão os Conselheiros Cezar Peluso, Eliana Calmon, Ives Gandra, Milton Augusto de Brito Nobre, Leomar Barros Amorim de Sousa, Nelson Tomaz Braga, Paulo de Tarso Tamburini Souza, Walter Nunes da Silva Júnior, José Adonis Callou de Araújo Sá, Felipe Locke Cavalcanti, Jefferson Luis Kravchychyn, Jorge Hélio Chaves de Oliveira, Marcelo Nobre e Marcelo Neves. Ausente, justificadamente, a Conselheira Morgana de Almeida Richa (conforme certidão de julgamento da $112^{\text {a }}$ Sessão Ordinária do $\mathrm{CNJ})$.

${ }^{175}$ Segue a ementa do julgado:

TRIBUNAL DE JUSTIÇA DO ESTADO DE RONDÔNIA - RESOLUÇÃO CNJ 88 - HORÁRIO EXPEDIENTE - PROTOCOLO. 1. Conquanto assente o entendimento de que a fixação do horário do 
Nota-se, pois, quanto aos diversos questionamentos relativos à fixação de horário de expediente forense pelos vários tribunais do país que, durante mais de cinco anos e mesmo após editar a Resolução $n^{\circ}$ 88/2009, o Conselho Nacional de Justiça, manteve o entedimento, também firmado pelo Supremo Tribunal Federal no julgamento da Ação Direta de Inconstitucionalidade $\mathrm{n}^{\mathrm{o}} 2907$, no sentido de competir aos Tribunais, por força das normas insertas no artigo 96, I, "a" e "b", da Constituição Federal, no exercício de suas autonomias administrativas, dispor sobre o assunto.

Assim, quanto ao estabelecimento do horário de expediente forense, no período mencionado, enquanto os tribunais que integram o Judiciário Brasileiro realizaram "atividades" (órgãos controlados) de acordo com a competência administrativa que lhes foi conferida pela Carta Política (CF, art. 96, I, "a" e "b"), editando diversos atos normativos sobre o tema no âmbito de suas esferas de competência, o Conselho Nacional de Justiça limitou-se a atuar de acordo com a característica que lhe foi atribuída também pela Constituição Federal (CF, art. 103-B, § $\left.4^{\circ}\right)$ e apenas exerceu o "controle" (órgão controlador) dos atos editados, pois: a) verificou, individualmente, cada ato normativo; b) convalidou - à exceção do ocorrido no Procedimento de Controle Administrativo $\mathrm{n}^{\mathrm{o}}$ 0000798-44.2007.2.00.0000, em que a decisão monocrática de Conselheiro suspendendo a Resolução TJSE $n^{0}$ 24/2007, foi também suspensa em sede de apreciação de liminar no Mandado de Segurança ${ }^{\circ} 26835$ impetrado perante o Supremo Tribunal Federal - todos os atos normativos, por considerá-los em conformidade com os princípios e normas constitucionais que regem a matéria; c) efetuou correção pontual somente no Procedimento de Controle Administrativo $\mathrm{n}^{\mathrm{o}}$ 0001470-18.2008.2.00.0000 (determinou garantia de atendimento aos advogados enquanto houver serventuário em atividade os recintos forenses do Tribunal Regional do Trabalho da $5^{\text {a }}$ Região independentemente do horário de expediente fixado); d) orientou, individualmente, órgão controlado no Procedimento de Controle Administrativo $\mathrm{n}^{\mathrm{o}}$ 0001461-56.2008.2.00.0000 (recomendou ao Tribunal de Justiça do Estado de Alagoas estender o horário de atendimento nas centrais de protocolo para além do horário de expediente fixado na Resolução nº 07/2008, de preferência, até as dezoito horas, como forma de melhorar o acesso mínimo do jurisdicionado à justiça); e)

expediente forense esteja inserida no âmbito de competência dos tribunais, o funcionamento do protocolo de petições apenas pela manhã pode causar prejuízos ao jurisdicionado. 2. Ofensa ao Princípio da Eficiência, cujo dever de zelo foi conferido constitucionalmente a este Conselho Nacional de Justiça. 3. Pedido conhecido como Pedido de Providências e julgado parcialmente procedente para recomendar a todos os Tribunais do País cujo expediente se concentre preponderantemente pela manhã que estendam o horário de funcionamento do protocolo de petições até, ao menos, as $18 \mathrm{~h} 00$ ". 
expediu, com base na recomendação anterior, orientação geral a todos os órgãos controlados no Pedido de Providências $n^{\circ}$ 0005477-82.2010.2.00.0000 (instruiu todos os tribunais cujo expediente se concentrasse no período matutino a estender o horário de funcionamento do protocolo de petições até, ao menos, as dezoito horas); e, f) absteve-se de fixar horário e datas de expediente forense unificados (Pedido de Providências $n^{0} 73$, Procedimento de Controle Administrativo $\mathrm{n}^{\circ} 611$ e Recurso Administrativo no Procedimento de Controle Administrativo no 2007.10.00001086-9).

Nos meses de março e abril de 2011, porém, toda essa orientação foi desconsiderada com a edição, ainda pela terceira composição do Conselho Nacional de Justiça, da Resolução $n^{\circ} 130$, de 28 de abril de 2011 que, como dito, acrescentou os parágrafos $3^{\circ}$ e $4^{\circ}$ ao artigo $1^{\circ}$ da Resolução $\mathrm{CNJ} n^{0}$ 88/2009 e fixou horário de expediente uniforme aos órgãos jurisdicionais para atendimento ao público de segunda a sexta-feira, das nove às dezoito, no mínimo, facultando apenas, no caso de insuficiência de recursos humanos ou de necessidade de respeito a costumes locais, a adoção de jornada de oito diárias, em dois turnos, com intervalo para o almoço.

A referida resolução originou-se do procedimento denominado Ato Normativo $\mathrm{n}^{\mathrm{o}}$ 0001464-06.2011.2.00.0000. O procedimento foi instaurado de ofício pelo Conselho Nacional de Justiça em 29 de março de 2011, distribuído ao Conselheiro Walter Nunes da Silva Júnior na mesma data e incluído no mesmo dia na pauta de julgamento da $123^{\mathrm{a}}$ Sessão Ordinária do CNJ, nos termos do disposto no artigo 120, $\S 1^{\circ}$, do seu Regimento Interno (Resolução $n^{0}$ 67/2009) ${ }^{176}$. sendo aprovada, por unanimidade ${ }^{177}$, a edição da norma, mas apenas com o acréscimo do parágrafo $3^{\circ}$ ao artigo $1^{\circ}$ da Resolução $\mathrm{CNJ} \mathrm{n}^{\mathrm{o}}$ 88/2009. Na sessão seguinte (124 ${ }^{\text {a }}$ Sessão Ordinária do CNJ), realizada em 12 de abril de 2011, houve reinclusão do procedimento na pauta, mais uma vez com a invocação do prescrito no artigo $120, \S 1^{\circ}$, do RICNJ, sendo novamente aprovada, porém por maioria ${ }^{178}$,

\footnotetext{
${ }^{176}$ Art. 120 (RICNJ). As pautas do Plenário serão organizadas pela Secretaria-Geral, com aprovação da Presidência, encaminhando-se previamente aos Conselheiros os dados pertinentes aos pontos incluídos em pauta.

$\S$ 1o Poderão ser apresentados em mesa, pela relevância, urgência ou conveniência, assuntos que não se encontrem inscritos na pauta da sessão.

${ }^{177}$ Estiverem presentes na sessão os Conselheiros Cezar Peluso, Ives Gandra, Milton Augusto de Brito Nobre, Nelson Tomaz Braga, Paulo de Tarso Tamburini Souza, Walter Nunes da Silva Júnior, Morgana de Almeida Richa, José Adonis Callou de Araújo Sá, Felipe Locke Cavalcanti, Jefferson Luis Kravchychyn, Jorge Hélio Chaves de Oliveira e Marcelo Nobre. Ausentes, justificadamente, os Conselheiros Eliana Calmon, Leomar Barros Amorim de Sousa e Marcelo Neves (conforme certidão de julgamento da $123^{\mathrm{a}}$ Sessão Ordinária do CNJ).

${ }^{178}$ Estiverem presentes na sessão os Conselheiros Cezar Peluso, Ives Gandra, Milton Augusto de Brito Nobre, Nelson Tomaz Braga, Paulo de Tarso Tamburini Souza, Walter Nunes da Silva Júnior, Morgana de
} 
vencidos os Conselheiros Jorge Hélio e Jefferson Kravchychyn, a alteração da Resolução $\mathrm{CNJ} n^{\circ} 88 / 2009$, com a inclusão dos parágrafos $3^{\circ}$ e $4^{\circ}$ ao seu artigo $1^{\circ}$.

Consta nos consideranda da Resolução $\mathrm{n}^{\mathrm{o}}$ 130/2011 os motivos que levaram o Conselho Nacional de Justiça a sua aprovação: a) a fixação de parâmetros uniformes para o funcionamento dos órgãos do Poder Judiciário pela Resolução CNJ nº 88/2009, apenas quanto à jornada de trabalho de seus servidores, fez com que houvesse multiplicidade de horário de expediente dos órgãos jurisdicionais; b) a existência de vários horários de expediente adotados pelos tribunais, inclusive em relação a alguns dias da semana, gera prejuízo ao jurisdicionado; c) o caráter nacional do Poder Judiciário exige a fixação de horário de funcionamento uniforme pelo menos em relação a um determinado período do dia; e, d) deve-se observar a insuficiência de recursos e a necessidade de respeito a costumes locais.

A nosso ver, porém, as regras trazidas pela edição da Resolução CNJ n 130/2011 extrapolaram os limites constitucionais de atuação do Conselho como órgão de controle do Poder Judiciário.

Se a fixação do expediente forense pode ser regulada pelos tribunais, no exercício da autonomia administrativa que lhes é conferida pelas regras previstas no artigo 96, I, "a" e "b" , da Constituição Federal, como assentado pelo Supremo Tribunal Federal no julgamento da Ação Direta de Inconstitucionalidade $n^{0}$ 2907, compete a esses órgãos do Poder Judiciário, realizar essa "atividade" e disciplinar o assunto.

Ao Conselho Nacional de Justiça cabe, como órgão de "controle", apenas, verificar a regularidade de cada ato normativo expedido pelos tribunais, corrigindo eventuais ilegalidades ${ }^{179}$. Não pode o Conselho Administrativo, porém, desviar-se de sua característica constitucional de órgão tipicamente controlador para substituir a "atividade" realizada pelos tribunais, estabelecer, por ato normativo próprio, horário de expediente forense uniforme para todos os órgãos do Poder Judiciário de oito horas diárias, em dois turnos, com intervalo para almoço, preferencialmente das nove às dezoito horas e, praticamente, aniquilar qualquer campo residual de "atividade" dos Tribunais sobre o

Almeida Richa, José Adonis Callou de Araújo Sá, Felipe Locke Cavalcanti, Jefferson Luis Kravchychyn, Jorge Hélio Chaves de Oliveira, Marcelo Nobre e Marcelo Neves. Ausente, justificadamente, o Conselheiro Leomar Barros Amorim de Sousa. Ausente, circunstancialmente, a Conselheira Eliana Calmon (conforme certidão de julgamento da $124^{\mathrm{a}}$ Sessão Ordinária do CNJ).

${ }^{179}$ Vide itens 3.1.4 e 3.1.4.4. 
assunto $^{180}$

A aplicação das disposições trazidas pela Resolução CNJ no 130/2011 no âmbito do Tribunal de Justiça de Sergipe, inclusive, leva à indireta violação da decisão monocrática proferida pelo Ministro Ricardo Lewandowski em sede de apreciação de liminar no Mandado de Segurança $n^{\circ} 26835$ impetrado perante o Supremo Tribunal Federal, uma vez que Sua Excelência, ao suspender a decisão liminar proferida no Procedimento de Controle Administrativo $\mathrm{n}^{\mathrm{o}}$ 0000798-44.2007.2.00.0000 pelo Conselheiro Joaquim Falcão, restabeleceu os termos da Resolução TJSE $n^{0}$ 24/2007, que fixou expediente forense de sete horas diárias, sem intervalo para almoço, no Poder Judiciário Sergipano (das sete às treze horas, na Comarca de Aracaju, e das oito às catorze horas, nas Comarcas do Interior do Estado).

E o estabelecimento de horário uniforme por meio de ato normativo pelo Conselho Nacional de Jutiça para substituir o controle que o Colégio Administrativo deveria exercer individualmente sobre cada ato praticado pelos órgãos controlados impede, por outro lado, que estes, através das Procuradorias-Gerais de cada Estado ou da Advocacia-Geral da União, se insurjam, como o Estado de Sergipe o fez, contra a decisão administrativa proferida pelo Colegiado junto ao Supremo Tribunal Federal através do manejo de mandados de segurança, pois incabível contra ato normativo, conforme aplicação, por analogia, da Súmula 266 do Supremo Tribunal Federal, que reza: "não cabe mandado de segurança contra lei em tese"

Ressalte-se que a justificativa da necessidade de fixação de horário de expediente uniforme pelo Conselho Nacional de Justiça dado o caráter nacional do Poder Judiciário não convence. Como destacou o Ministro Cezar Peluso em seu voto na ADI nº 3367, ainda

\footnotetext{
${ }^{180}$ A Resolução CNJ n ${ }^{\circ} 130 / 2011$, ao acrescer os parágrafos $3^{\circ}$ e $4^{\circ}$ ao artigo $1^{\circ}$ da Resolução $\mathrm{CNJ} \mathrm{n}^{\circ}$ 88/2009 reduziu drasticamente o âmbito de ação dos Tribunais no que se refere à fixação de horário de expediente forense, pois, pelas novas regras, não podem, por exemplo: a) estabelecer jornada inferior a oito horas diárias; b) fixar jornada ininterrupta; c) instituir expediente em períodos diversos daqueles que necessariamente englobem o matutino e o vespertino; d) ordenar, esclusivamente, intervalo diverso daquele reservado para almoço. Para os casos que não se enquadrem nas hipóteses previstas no $\S 4^{\circ}$ mencionado (ou seja, para tribunais sem insuficiência de recursos humanos e justificativa de existência de costumes locais), o campo de ação ficou ainda mais limitado, pois devem, necessariamente, estabelecer horário de expediente forense mínimo das nove às dezoito horas, de segunda a sexta-feira. Não podem, pois, iniciar a jornada de trabalho mais cedo e terminá-la mais tarde, ou vice-versa, e também não lhes é facultado deixar de trabalhar um dia da semana entre segunda e sexta-feira para estabelecer jornada aos sábados ou domingos.

${ }^{181}$ Para ilustrar a hipótese mencionada, pode-se citar a decisão monocrática proferida em 14 de dezembro de 2009 pelo Ministro Eros Grau no Mandado de Segurança n 28380 impetrado no Supremo Tribunal Federal pelo Sindicato dos Servidores do Poder Judiciário do Estado de Alagoas - SERJAL - contra a Resolução CNJ $\mathrm{n}^{\circ}$ 88/2009. Na decisão, Sua Excelência afirmou que, como ato impugnado disciplina situações gerais e abstratas cuja aplicabilidade depende da edição de outros atos normativos, no âmbito de cada Estadomembro, não era possível a impetração de mandado segurança, assemelhando-se, a hipótese, à de impetração de writ contra lei em tese, vedada pela Súmula STF nº 266
} 
que o CNJ, pela Emenda Constitucional n ${ }^{\circ} 45 / 2004$, tenha, mais que o encargo de controle, recebido "uma alta função política de aprimoramento do autogoverno do Judiciário, cujas estruturas burocráticas dispersas inviabilizam o esboço de uma estratégia políticoinstitucional de âmbito nacional", o princípio federativo também tem "repercussão na fisionomia constitucional do Judiciário", tanto é que a Carta Política "delega aos Estadosmembros competência exclusiva para organizar sua Justiça”, conforme preceitua a norma constante do seu artigo 125, tocando-lhes "definir a competência residual de seus tribunais, distribuí-las entre os vários órgãos de grau inferior, bem como administrá-la na forma prevista no art. 96”. A Constituição Federal, inclusive, estabelece ser de iniciativa do Tribunal de Justiça a lei de organização judiciária nos Estados ( $\mathrm{CF}$, art. 125, § $\left.1^{\circ}\right)$. Assim, não pode o Conselho Nacional de Justiça afastar-se de sua característica constitucional de órgão de controle para disciplinar, em nome da unidade do Poder Judiciário, matéria que constitucionalmente deve ser tratada de forma atomizada pelos demais órgãos do Judiciário, essencialmente para que sejam observadas as diferenças históricas, geográficas, climáticas e culturais peculiares de cada região do território nacional.

Cumpre ressaltar que a Associação dos Magistrados Brasileiros, em 11 de maio de 2011, ajuizou ação direta de inconstitucionalidade com pedido de medida cautelar contra o artigo $1^{\circ}$ da Resolução CNJ n ${ }^{\circ} 130 / 2011$, que acrescentou os parágrafos $3^{\circ}$ e $4^{\circ}$ ao artigo $1^{\circ}$ da Resolução CNJ nº 88/2009 perante o Supremo Tribunal Federal.

A referida ação foi registrada sob número 4598 e distribuída à relatoria do Ministro Luiz Fux que, em 2 de junho de 2011, determinou a adoção do rito do artigo 12 da Lei ${ }^{\circ}$ 9.868 , de 10 de novembro de $1999^{182}$, porque a matéria arguida tem relevância social por questionar a validade de resolução do Conselho Nacional de Justiça, impondo-se seu julgamento definitivo em homenagem à segurança jurídica e à autoridade do CNJ e diante dos efeitos erga omnes e vinculantes da decisão a ser proferida. Sua Excelência, na mesma decisão, ainda determinou a expedição de ofícios para consulta aos tribunais quanto a duas questões relacionadas à Resolução $\mathrm{CNJ}^{\circ}$ 130/2011: a) se a obrigação de atendimento ao público nos órgãos jurisdicionais no horário de 09:00 às 18:00 horas, é de viável implementação ou traz mais transtornos e dificuldades para uma regular prestação jurisdicional do que benefícios, diante dos escassos recursos financeiros e humanos que o

\footnotetext{
${ }^{182}$ Art. 12 (Lei n 9.868/1999). Havendo pedido de medida cautelar, o relator, em face da relevância da matéria e de seu especial significado para a ordem social e a segurança jurídica, poderá, após a prestação das informações, no prazo de dez dias, e a manifestação do Advogado-Geral da União e do Procurador-Geral da República, sucessivamente, no prazo de cinco dias, submeter o processo diretamente ao Tribunal, que terá a faculdade de julgar definitivamente a ação.
} 
Poder Judiciário possui?; e, b) se a aplicação da norma contribuiu para a a eficiência e a produtividade dos órgãos judiciários ou a celeridade nos julgamentos?

Prestadas informações por diversos Tribunais brasileiros, o Ministro Luiz Fux, em 30 de junho de 2011, ad referendum do Plenário, deferiu a medida cautelar pleiteada para suspender os efeitos da Resolução CNJ no 130/2011 até o julgamento definitivo da ADI n ${ }^{\circ}$ 4598. Argumentou que: a) a aplicação imediata do novo horário de atendimento ao público poderá causar prejuízos irreversíveis aos cofrres públicos diante da possibilidade de reconhecimento da procedência do pedido; b) vários presidentes de tribunais brasileiros informaram ser inviável a implementação imediata da ampliação do horário de expediente forense, inclusive devido ao aumento de despesas que a medida provocaria; c) há controvérsia sobre a competência do CNJ para disciplinar o tema; e, d) a Resolução CNJ n ${ }^{\circ}$ $130 / 2011$ pode ofender a autonomia dos tribunais e o princípio da legalidade ${ }^{183}$.

Em suma, o Conselho Nacional de Justiça, ao editar a Resolução CNJ nº 130/2011 ultrapassou os limites constitucionais de sua atuação como órgão de controle interno do Poder Judiciário, pois a fixação de horário de expediente forense é matéria que deve ser regulada pelos tribunais, no exercício da autonomia administrativa que lhes é conferida pelas normas insertas no artigo 96, I, "a" e "b" , da Constituição Federal. Ao Conselho Nacional de Justiça compete, como órgão de "controle", apenas verificar a regularidade de cada ato normativo expedido pelos Tribunais para disciplina do tema, corrigindo eventuais ilegalidades ou inconstitucionalidades. Não pode, porém, ainda que através da prática de "atividade" que lhe é garantida pela Constituição Federal - expedição de atos regulamentares -, esvaziar o campo de "atividade" dos demais órgãos do Poder Judiciário e estabelecer, por ato normativo próprio, horário de expediente forense uniforme para todos os seus órgãos.

\subsection{4. Órgão que realiza controle interno.}

\footnotetext{
${ }^{183}$ Até 26 de dezembro de 2014, a decisão liminar e o mérito da ADI no 4598 ainda não haviam sido apreciados pelo Plenário do Supremo Tribunal Federal. Cumpre ressaltar que, devido a solicitação feita pelo Conselho Federal da OAB, que ingressou na ação como amicus curiae e pleiteou, ante a notícia de redução de horário de atendimento à população imposta pela Resolução n ${ }^{\circ}$ 350/2013 do Tribunal de Justiça do Estado de Pernambuco, a manutenção do horário de expediente forense nos tribunais brasileiros, o Ministro Luiz Fux, em 26 de junho de 2013, determinou a manutenção, até decisão definitiva do STF, do horário de atendimento ao público em vigor adotado nos diversos tribunais no início do ano de 2013, para evitar prejuízo aos usuários do serviço público da justiça, uma vez que a decisão liminar que prolatara objetivou evitar uma mudança súbita nos horários de expediente forense, mas não visou permitir ou estimular suas reduções.
} 
Assentadas as ideias relativas aos três primeiros elementos constitucionais característicos do Conselho Nacional de Justiça - órgão interno do Poder Judiciário com estrutura colegiada, tipicamente controlador - adentra-se, agora, no estudo da sua quarta característica: O Conselho Nacional de Justiça é órgão que, em regra, realiza controle interno no âmbito do Poder Judiciário.

Como estabelece a regra prevista no artigo 103-B, $\S 4^{\circ}$, da Constituição Federal, "compete ao Conselho o controle da atuação administrativa e financeira do Poder Judiciário e do cumprimento dos deveres funcionais dos juízes".

Portanto, o controle realizado pelo CNJ dirige-se, em regra, ao próprio Poder que integra e aos seus membros.

Pode-se afirmar, ademais, que, como o Conselho integra o Poder Judiciário, trata-se de um órgão interno para controle interno desse Poder.

Dessa característica extrai-se mais uma limitação constitucional à atuação do CNJ: por ser órgão controlador interno, não lhe compete exercer o controle de outros órgãos, estranhos ao Poder que integra, exceto em hipótese constitucionalmente admitida.

Com efeito, na Administração Pública, o controle pode ser interno ou externo, e isto dependerá da posição do órgão controlador em relação ao órgão controlado.

Se o "controlador" for agente ou órgão da mesma organização administrativa da qual emanou o ato praticado pelo "controlado", haverá controle interno. Se o "controlador", porém, for agente ou órgão estranho à organização administrativa à qual pertence o “controlado", dar-se-á controle externo.

Cita-se, mais uma vez, a ensinança de Hely Lopes Meirelles (1999, p. 600):

Controle interno - É todo aquele realizado pela entidade ou órgão responsável pela atividade controlada, no âmbito da própria Administração. Assim, qualquer controle efetivado pelo Executivo sobre seus serviços ou agentes é considerado interno, como interno será também o controle do Legislativo ou do Judiciário, por seus órgãos de administração, sobre o seu pessoal e os atos administrativos que pratique.

A Constituição de 1988 determina que os três Poderes de Estado mantenham sistema de controle interno de forma integrada. E, mais, que os responsáveis pelo controle interno, ao tomarem conhecimento de qualquer irregularidade, dela deverão dar ciência ao Tribunal de Contas, sob pena de responsabilidade solidária (art. $74, \S 1^{\circ}$ ). 
Controle externo - É o que se realiza por órgão estranho à Administração responsável pelo ato controlado, como, p. ex., a apreciação das contas do Executivo e do Judiciário pelo Legislativo; a auditoria do Tribunal de Contas sobre a efetivação de determinada despesa do Executivo; a anulação de um ato do Executivo por decisão do Judiciário; a sustação de ato normativo do Executivo pelo Legislativo (CF, art. 49, V).

O autor argentino José Roberto Dromi (1973, p. 92) e o doutrinador uruguaio Jorge Silva Censio (1976, p. 18) denominam de "intraorgânico" o controle que "ocorre dentro da organização jurídico-administrativa interna do órgão" (MEDAUAR, 2012, p. 36), em contraposição aos controles "interorgânico”, que se verifica entre os Poderes da República, e "extraorgânico", que "ocorre fora da relação orgânica como é o caso do controle exercido por associações (MEDAUAR, 2012, p. 36) ${ }^{184}$.

Essa classificação, como pontua Odete Medauar (2012, p. 36), foi inspirada em Karl Loewenstein (1957, p. 164). O professor alemão, em sua obra Political power and the Governmental process, ao tratar das técnicas de controle de poder, as estrutura em dois tipos: os controles intraorgânicos (intra-organ controls), que se desenvolvem dentro da organização de um detentor de poder individual, e os controles interorgânicos (interorgan controls), que operam entre vários detentores de poder ${ }^{185}$.

Já foi esclarecido que o Conselho Nacional de Justiça é um órgão judicial, pois integra o Poder Judiciário ${ }^{186}$. Ante, por outro lado, previsão da norma inserta no art. 103-B, $\S 4^{\circ}$ da Constituição Federal (competir ao Conselho o controle da atuação administrativa e financeira do Poder Judiciário e do cumprimento dos deveres funcionais dos juízes), conclui-se que se trata de um órgão somente para controle interno do Judiciário.

\footnotetext{
${ }^{184}$ Afirma o Professor Dromi: “Los controles intraorgánicos (dentro del órgano) son los que resultan cuando las instituciones operan dentro de la organización jurídico-administrativa interna del órgano. Los controles interorgánicos (entre órganos) se refieren al mutuo y recíproco control que tienen los órganos ejecutivo, legislativo y jurisdiccional en el ejercicio del poder. Los extraorgánicos (fuera de la relación orgánica), comprenden tanto el control de los orgános del poder, como extrapoderes y demás sujetos auxiliares del Estado; tales como los partidos políticos, cuerpo electoral, sindicatos y asociaciones intermedias, etcétera".

${ }^{185}$ Nas palavras do doutrinador alemão: "If the control devices operate within the organization of an individual power holder, they are spoken of as intra-organ controls. If, however, they operate between the several interacting power holders, they are called interorgan controls. The terms 'intra-organ' and 'interorgan' controls are modeled on the familiar distinction of the American constitution between intra- and interstate jurisdiction".

${ }^{186}$ Vide item 2.3.1.
} 
Importa porém destacar que, sob o ponto de vista do Judiciário enquanto Poder da República, o controle exercido pelo Conselho Nacional de Justiça é, como dito, interno, pois realizado por órgão que integra sua organização jurídico-administrativa. Porém, não se pode olvidar que, sob a perspectiva da estrutura do Poder Judiciário, o CNJ exerce um controle externo em relação aos demais órgãos que a compõe, que também realizam seu próprio controle interno.

Fenômeno semelhante, quanto ao controle exercido pela Administração Direta sobre as entidades da Administração Indireta, foi identificado por Celso Antônio Bandeira de Mello (2009, p. 927), e sua lição é igualmente aplicável, mutatis mutandis, ao controle exercido pelo Conselho Nacional de Justiça sobre os demais órgãos do Poder Judiciário:

Em relação às entidades da Administração indireta e fundacional (sem
prejuízo dos controles externos), haveria um duplo controle interno:
aquele que é efetuado por órgãos seus, que lhe componham a intimidade
e aos quais assista esta função, e aqueloutro procedido pela
Administração direta. A este último talvez se pudesse atribuir a
denominação, um tanto rebarbativa ou paradoxal, reconheça-se, de
controle interno exterior.

De fato, após a Emenda Constitucional n $n^{\circ} 45 / 2004$, passou a existir um duplo controle interno administrativo, financeiro e disciplinar no âmbito do Poder Judiciário. Aquele exercido, no seu seio, pelos próprios tribunais, e aqueloutro, que também pode ser denominado de "controle interno exterior", exercido pelo Conselho Nacional de Justiça sobre os órgão que estruturam esse Poder.

Ao Conselho Nacional de Justiça, porém, não cabe exercer o controle de pessoas e órgãos que não integram o Poder Judiciário.

Como o CNJ é órgão judicial, não pode exercer competências exclusivas de outras Poderes ou entes previstas na Constituição Federal, conforme já afirmado ${ }^{187}$.

Por outro lado, por não ser órgão jurisdicional ${ }^{188}$, e ter suas competências de controle expressamente previstas na Constituição Federal, não cabe ao CNJ realizar o controle (externo) de órgãos administrativos estranhos ao Judiciário, pertencentes ao Executivo ou

\footnotetext{
${ }^{187}$ Vide item 2.3.1.

${ }^{188}$ Vide item 2.3.5.1.
} 
ao Legislativo, ou de entes da Administração Indireta, apesar dessa atribuição ser exercida pelos demais órgãos que compõe o Poder que integra, quando do exercício da jurisdição ${ }^{189}$.

Também não cabe ao Conselho fiscalizar atividades privadas individuais ou coletivas.

Não compete ao CNJ, pois, exercer qualquer controle em outros Poderes ou sobre pessoas e instituições públicas ou privadas, que não integram a estrutura administrativa do Poder Judiciário.

Não pode o Conselho Nacional de Justiça, por exemplo, exercer fiscalização contábil, financeira e orçamentária de outras pessoas públicas ou privadas, atividade afeta ao Tribunais de Contas ${ }^{190}$.

Da mesma forma, não the compete o controle administrativo, financeiro e disciplinar do Ministério Público, atividades atribuídas ao Conselho Nacional do Ministério Público, também criado pela Emenda Constitucional no 45/2004 (CF, art. 130-A).

Igualmente, o Conselho Nacional de Justiça não pode exercer qualquer controle sobre outras atividades, públicas ou privadas, estranhas ao Poder Judiciário, estejam elas ou não submetidas a alguma fiscalização estatal ${ }^{191}$.

Há apenas uma exceção expressamente prevista na Constituição: a norma inserta no art. 103-B, $\S 4^{\circ}$, III, da Constituição Federal prevê também competir ao Conselho Nacional de Justiça receber e conhecer das reclamações contra órgãos prestadores de serviços notariais e de registro que atuem por delegação do poder público ou oficializados, sem prejuízo da competência disciplinar e correicional dos tribunais.

\footnotetext{
${ }^{189}$ A respeito pontua Odete Medauar (2012, p. 186): "No quadro geral dos controles que incidem sobre a atividade da Administração Pública, o controle jurisdicional se insere, no geral, entre os controles externos, a posteriori, repressivos ou corretivos. É desencadeado por provocação e realizado por juízes dotados de independência".

${ }^{190}$ os Tribunais de Contas da União e dos Estados também fiscalizam o Poder Judiciário, apesar da atuação do Conselho Nacional de Justiça, conforme expressamente dispõe o art. 103-B, $\S 4^{\circ}$, III, da Constituição Federal, ("zelar pela observância do art. 37 e apreciar, de ofício ou mediante provocação, a legalidade dos atos administrativos praticados por membros ou órgãos do Poder Judiciário, podendo desconstituí-los, revêlos ou fixar prazo para que se adotem as providências necessárias ao exato cumprimento da lei, sem prejuízo da competência do Tribunal de Contas da União") (vide item 3.1.4.3).

${ }^{191}$ Alguns exemplos de órgãos estatais que controlam atividades públicas e privadas são: a) o Conselho Administrativo de Defesa Econômica (CADE), autarquia federal, nos termos da Lei 8.884, de 11 de junho de 1994; b) o Conselho Monetário Nacional (CMN) e o Banco Central do Brasil (BACEN ou BCB), previstos na Lei $\mathrm{n}^{\mathrm{o}} 4.595$, de 31 de dezembro de 1964; c) o Instituto Nacional de Estudos e Pesquisas Educacionais (INEP), transformado em autarquia federal, nos termos da Lei $\mathrm{n}^{\circ}$ 9.448, de 14 de março de 1997; d) as agências reguladoras (Anatel, ANP, Aneel, ANS, Anvisa, ANA, Ancine, Antaq, ANTT e Anac), criadas, respectivamente, pelas Lei $\mathrm{n}^{\circ}$ 9472, de 16 de julho de 1997; Lei $\mathrm{n}^{\circ}$ 9.478, de 6 de agosto de 1997; Lei $\mathrm{n}^{\circ}$ 9.427, de 26 de dezembro de 1996; Lei $\mathrm{n}^{\circ}$ 9.961, de 28 de janeiro de 2000; Lei ${ }^{\circ}$ 9782, de 26 de janeiro de 1999; Lei no 9.984, de 17 de julho de 2000; Medida Provisória $n^{\circ}$ 2.228-1, de 6 de setembro de 2001; Lei ${ }^{\circ}$ 10.233, de 5 de junho de 2001 (Antaq e ANTT); e, Lei no 11.182, de 27 de setembro de 2005.
} 
No modelo atual ${ }^{192}$, os serviços notariais e de registro surgiram na Idade Média, ante a necessidade de elaboração de contratos escritos em uma sociedade pouco letrada, para garantir segurança jurídica, evitar litigios, dar publicidade de fatos relevantes, dispensar provas e conservar a memória dos negócios.

A respeito se pronunciam Molinaro, Pansieri e Sarlet (2013, p. 2160):

[...] no formato em que conhecemos hoje, a atividade notarial e registral é produto da Idade Média. No medievo, a partir do século XIII, efetivamente, nascem os registros e as atividades notariais para atender uma necessidade pública, até mesmo pelo fato que grande parte da população era analfabeta, e a cultura refugiava-se nos monastérios. Contudo, na vida civil, os contratos entre particulares, os censos e as atividades mercantis exigiam que se elaborassem documentos escritos, até mesmo para os litígios sempre frrequentes nas relações verbais do tráfico negocial e, mesmo, político. Atente-se que os "notários" apenas sabiam ler e escrever; todavia, na medida em que vão se especializando na grafia da memória, passam a adquirir conhecimentos de direito (especialmente os canônicos) e passam a prstar, também, assistência jurídica àqueles que os procuravam; mais tarde, vão "conservar" os documentos originais que elaboravam, entregando às partes as pertinentes cópias.

A Constituição Federal prescreve, na norma inserta no seu artigo 236, que os serviços notarias e de registro são exercidos em caráter privado, por delegação do Poder Público (caput). Expressamente, também, prevê que a regulação de suas atividades deve ser estabelecida em lei, que também deve definir a fiscalização de seus atos, acometida ao Poder Judiciário $\left(\S 1^{\circ}\right)$. Ainda estabelece que o ingresso na atividade notarial e de registro depende de concurso público de provas e títulos $\left(\S 3^{\circ}\right)$.

$\mathrm{O}$ artigo 32 do Ato das Disposições Constitucionais Transitórias, porém, ressalva a não aplicação da norma mencionada aos serviços notariais e de registro que já tivessem sido oficializados pelo Poder Público quando do advento da Constituição Cidadã ${ }^{193}$.

\footnotetext{
${ }^{192}$ Conforme esclarecem Carlos Alberto Molinaro, Flávio Pansieri e Ingo Wolfgang Sarlet (2013, pp. 2159 e 2160), há registros de notariado na Antiguidade, na Suméria, Babilônia, Cadeia e Creta, com finalidades tributária, econômica e principalmente de defesa política (manutenção da unidade territorial).

${ }^{193}$ A Emenda Constitucional no 7, de 13 de abril 1977, à Constituição Federal (CF) de 1967, alterada pela Emenda Constitucional $n^{\circ} 1$, de 17 de outubro de 1969, estabeleceu a oficialização dos serviços notariais e de
} 
A Lei $\mathrm{n}^{\mathrm{o}} 8.935$, de 18 de novembro de 1994, regulamenta o dispositivo constitucional em comento ( $\mathrm{CF}$, art. 236), detalhando as atribuições dos notários e dos oficiais de registros (arts. $5^{\circ}$ ao 13), os requisitos para a delegação (arts. 14 a 19) e a físcalização pelo Poder Judiciário dos Estados e do Distrito Federal (arts. 37 e 38).

E no julgamento da ADI $n^{\circ}$ 3151, relator Ministro Carlos Britto, realizado em 8 de junho de 2005, restou estabelecido que, nos termos do artigo 236 da Constituição Federal, as atividades dos serviços notariais e de registro, exceto os oficializados, apesar de tipicamente estatais, são exercidas, por delegação, por particulares, pessoas naturais habilitadas em concurso público de provas e títulos, sob fiscalização exclusiva do Poder Judiciário $^{194}$.

registro (integrantes das denominadas serventias extrajudiciais), "mediante remuneração de seus servidores exclusivamente pelos cofres públicos", sendo mantida a determinação pela Emenda Constitucional no 22 , de 29 de junho de 1982. No Estado da Bahia, por exemplo, as Leis Estaduais no ${ }^{\circ}$ 1.909, de 3 de junho de 1963, e 3.075, de 7 de dezembro de 1972, já haviam determinado a oficialização desses serviços, passando os oficiais e suboficiais de Registro de Imóveis, de Registro das Pessoas Naturais e de Registro de Títulos e Documentos e tabeliães e subtabeliães de Notas e de Protestos de Títulos a serem servidores investidos nesses cargos e pertencentes ao quadro do Tribunal de Justiça da Bahia. Mas, após o advento da Constituição de 1988, a Lei Estadual Baiana ${ }^{\circ}$ 12.352, de 8 de setembro de 2011 determinou a desoficialização dos serviços notariais e de registro daquele Estado. Cumpre registrar, porém, que o Procurador-Geral da República ajuizou no Supremo Tribunal Federal a ADI $\mathrm{n}^{\circ} 4851$ para questionar a constitucionalidade do caput e dos $\S \S 1^{\circ}, 4^{\circ}$ e $5^{\circ}$ do artigo $2^{\circ}$ do referido Diploma Legal do Estado da Bahia por, segundo ele, possibilitar "aos servidores do Poder Judiciário baiano a delegação de serviços notariais e de registro sem o necessário concurso público de provas e títulos". A ADI foi distribuída à relatoria do Ministro Dias Toffoli que determinou seu processamento nos termos do procedimento abreviado previsto no artigo 12 da Lei $\mathrm{n}^{\circ}$ 9.868/99. Ainda não foi apreciada pelo Plenário do Pretório Excelso (Notícias STF - "ADI questiona norma baiana sobre ingresso em atividade notarial" disponível em: $<$ http://www.stf.jus.br/portal/cms/verNoticiaDetalhe.asp?idConteudo=218485 $>$. Acesso em 04.05.2014).

${ }^{194}$ Segue a ementa do acórdão:

AÇÃO DIRETA DE INCONSTITUCIONALIDADE. LEI No N $^{\circ} .033 / 2003$, DO ESTADO DO MATO GROSSO, QUE INSTITUIU O SELO DE CONTROLE DOS ATOS DOS SERVIÇOS NOTARIAIS E DE REGISTRO, PARA IMPLANTAÇÃO DO SISTEMA DE CONTROLE DAS ATIVIDADES DOS NOTÁRIOS E DOS REGISTRADORES, BEM COMO PARA OBTENÇÃO DE MAIOR SEGURANÇA JURÍDICA QUANTO À AUTENTICIDADE DOS RESPECTIVOS ATOS. I - Iniciativa: embora não privativamente, compete ao Tribunal de Justiça deflagrar o processo de elaboração de leis que disponham sobre a instituição do selo de controle administrativo dos atos dos serviços notariais e de registro (alínea "d" do inciso II do art. $96 \mathrm{c} / \mathrm{c} \S 1^{\circ}$ do art. 236 da Carta Federal). II - Regime jurídico dos serviços notariais e de registro: a) trata-se de atividades jurídicas próprias do Estado, e não simplesmente de atividades materiais, cuja prestação é traspassada para os particulares mediante delegação. Traspassada, não por conduto dos mecanismos da concessão ou da permissão, normados pelo caput do art. 175 da Constituição como instrumentos contratuais de privatização do exercício dessa atividade material (não jurídica) em que se constituem os serviços públicos; b) a delegação que lhes timbra a funcionalidade não se traduz, por nenhuma forma, em cláusulas contratuais; c) a sua delegação somente pode recair sobre pessoa natural, e não sobre uma empresa ou pessoa mercantil, visto que de empresa ou pessoa mercantil é que versa a Magna Carta Federal em tema de concessão ou permissão de serviço público; d) para se tornar delegatária do Poder Público, tal pessoa natural há de ganhar habilitação em concurso público de provas e títulos, não por adjudicação em processo licitatório, regrado pela Constituição como antecedente necessário do contrato de concessão ou de permissão para o desempenho de serviço público; e) são atividades estatais cujo exercício privado jaz sob a exclusiva fiscalização do Poder Judiciário, e não sob órgão ou entidade do Poder Executivo, sabido que por órgão ou entidade do Poder Executivo é que se dá a imediata fiscalização das empresas concessionárias ou permissionárias de serviços públicos. Por órgãos do Poder Judiciário é que se marca a 
Assim, o Conselho Nacional de Justiça, quando recebe e conhece de reclamações contra órgãos prestadores de serviços notariais e de registro que atuem por delegação do poder público, exerce controle externo de atividade privada fiscalizada pelo Poder Judiciário $^{195}$.

Em suma, o Conselho Nacional de Justiça é um órgão tipicamente de controle interno. Portanto, não lhe compete, exercer qualquer controle de pessoas e órgãos estranhos ao Poder Judiciário, exceto dos prestadores de serviços notariais e de registro que atuem por delegação do poder público (CF, art. 103-B, $\S 4^{\circ}$, III).

\subsubsection{Casuística: impossibilidade de controle de ex-juiz no exercício da advocacia e de ato de governador de Estado.}

Passa-se, neste item, à apresentação de dois casos em que o Conselho Nacional de Justiça, no nosso sentir, observou a sua característica constitucional de órgão de fiscalização interna do Judiciário, reconhecendo sua incompetência para controle dos deveres de pessoas estranhas aos quadros do referido Poder.

Como já exposto, o Conselho Nacional de Justiça é um órgão tipicamente de controle interno. Não é órgão jurisdicional e suas competências de controle estão expressamente

presença do Estado para conferir certeza e liquidez jurídica às relações inter-partes, com esta conhecida diferença: o modo usual de atuação do Poder Judiciário se dá sob o signo da contenciosidade, enquanto o invariável modo de atuação das serventias extra-forenses não adentra essa delicada esfera da litigiosidade entre sujeitos de direito; f) as atividades notariais e de registro não se inscrevem no âmbito das remuneráveis por tarifa ou preço público, mas no círculo das que se pautam por uma tabela de emolumentos, jungidos estes a normas gerais que se editam por lei necessariamente federal. III - Taxa em razão do poder de polícia: a Lei mato-grossense $n^{\circ} 8.033 / 2003$ instituiu taxa em razão do exercício do poder de polícia. Poder que assiste aos órgãos diretivos do Judiciário, notadamente no plano da vigilância, orientação e correição da atividade em causa, a teor do $\S 1^{\circ}$ do art. 236 da Carta-cidadã. É constitucional a destinação do produto da arrecadação da taxa de fiscalização da atividade notarial e de registro a órgão público e ao próprio Poder Judiciário. Inexistência de desrespeito ao inciso IV do art. 150; aos incisos I, II e III do art. 155; ao inciso III do art. 156 e ao inciso III do art. 153, todos da Constituição Republicana de 1988. IV - Percepção integral dos emolumentos: a tese de que o art. 28 da Lei federal $n^{\circ}$ 8.935/1994 (Lei dos Cartórios) confere aos notários e registradores o direito subjetivo de recebem integralmente os emolumentos fixados em lei jaz circunscrita às fronteiras do cotejo entre normas subconstitucionais. Assim, por se constituir em confronto que só é direto no plano infraconstitucional mesmo, insuscetível se torna para autorizar o manejo de um tipo de ação de controle de constitucionalidade que não admite intercalação normativa entre o diploma impugnado e a Constituição República. V - Competência legislativa e registros públicos: o $\S 1^{\mathrm{o}}$ do art. $2^{\mathrm{o}}$ do diploma legislativo em estudo cria um requisito de validade dos atos de criação, preservação, modificação e extinção de direito e obrigações. Imiscuindo-se, ipso facto, na competência legislativa que a Carta Federal outorgou à União (CF inciso XXV art. 22). Ação julgada parcialmente procedente, para declarar a inconstitucionalidade, tão-somente, do $\S 1^{\circ}$ do art. $2^{\circ}$ da Lei $n^{\circ} 8.033 / 03$, do Estado do Mato Grosso (ADI 3151, Relator(a): Min. CARLOS BRITTO, Tribunal Pleno, julgado em 08/06/2005, DJ 28-04-2006).

${ }^{195}$ Quando o CNJ aprecia reclamações contra serviços notarias e de registro oficializados, o controle é interno, pois esses órgãos integram a estrutura do próprio Poder Judiciário e seus titulares são funcionários públicos. 
previstas na Constituição Federal. E, pelo que reza a norma constitucional, (CF, art. 103-B, $\S 4^{\circ}$ ), não lhe não compete exercer qualquer controle de pessoas ou órgãos estranhos ao Poder Judiciário, exceto dos prestadores de serviços notariais e de registro que atuem por delegação do poder público (CF, art. 103-B, $\S 4^{\circ}$, III).

Esse limite constitucional à atuação do CNJ, no nosso sentir, foi observado no julgamento do Pedido de Providências $n^{\circ}$ 1230, relatado pelo Conselheiro Marcus Faver, ocorrido em 13 de fevereiro de 2007, bem como no julgamento do Procedimento de Controle Administrativo $\mathrm{n}^{\mathrm{o}}$ 2008.10.00.001769-8, relator Conselheiro Felipe Locke Cavalcanti, realizado em 23 de setembro de 2008.

No Pedido de Providências $n^{0} 1230$ requereu-se a cassação da aposentadoria de juiz aposentado que passou a exercer a advocacia por adulteração dolosa de título de crédito.

O pleito foi liminarmente arquivado pela Presidência do Conselho Nacional de Justiça, através de decisão proferida pelo Juiz Auxiliar Pedro de Araújo Yung-Tay Neto em 9 de janeiro de 2007, fundamentada na impossibilidade de atuação do Conselho em relação a ato praticado por ex-juiz, no exercício da advocacia.

Houve interposição de recurso contra referida decisão monocrática e o caso foi levado ao Plenário do Conselho Nacional de Justiça que, por unanimidade, nos termos do voto do relator, negou-lhe provimento ${ }^{196}$, por não competir ao órgão tomar providências a respeito de conduta de advogado, no exercício de suas atividades profissionais, mesmo que este, anteriormente, tenha sido Juiz de Direito. Ademais, os fatos imputados não poderiam produzir efeitos retroativos para atingir a aposentação do reclamado ${ }^{197}$.

A decisão do Conselho Nacional de Justiça, a nosso ver, mostrou-se correta.

Com a extinção do vínculo entre a pessoa natural que exercia a judicatura e o Poder Judiciário (Administração Pública), aquela deixa de ser magistrado, pois desaparece o liame jurídico institucional e as partes retornam "à situação de alheamento que antes existia entre elas" (JUSTEN FILHO, 2014, p. 301). Assim, cessam seus deveres funcionais como juiz. E se não há mais dever funcional a controlar, não tem o Conselho Nacional de

\footnotetext{
${ }^{196}$ Estiverem presentes na sessão os Conselheiros Vantuil Abdala, Marcus Faver, Douglas Rodrigues, Cláudio Godoy, Germana Moraes, Eduardo Lorenzoni, Oscar Argollo, Paulo Lôbo, Alexandre de Moraes e Joaquim Falcão. Ausentes, justificadamente, os Conselheiros Ellen Gracie, Antônio de Pádua Ribeiro, Jirair Aram Meguerian, Paulo Schmidt e Ruth Carvalho (conforme certidão de julgamento da $34^{\text {a }}$ Sessão Ordinária do CNJ).

${ }^{197}$ Segue a ementa do julgado:

"Pedido de providências. Juiz aposentado há vários anos inscrito na OAB/SP. Imputação de suposto ato fraudulento. Adulteração de nota promissória. Ato que teria sido praticado na condição de advogado. A conduta ética dos advogados deve ser analisada pelo órgão da classe. Incompetência do CNJ para a análise da questão. Recurso desprovido e arquivamento do pedido".
} 
Justiça competência para adotar qualquer providência administrativa ou disciplinar contra ex-juiz, uma vez que não pode exercer controle de atividade externa ao Poder Judiciário, salvo dos prestadores de serviços notariais e de registro que atuem por delegação do poder público.

Por outro lado, não é demais lembrar que a Constituição Federal trata da advocacia no título da Organização dos Poderes do Estado (Título IV), porém em capítulo autônomo (Capítulo IV), desvinculado daquele que trata da estrutura do Poder Judiciário (Capítulo III). A advocacia, pública ou privada, assim como o Ministério Público e a Defensoria Pública são consideradas "Funções Essenciais à Justiça", e o advogado, em especial, é declarado pela Carta Política, como "indispensável à administração da justiça” (CF, art. 133). Não há qualquer subordinação dos advogados ao Poder Judiciário (art. $6^{\circ}$ da Lei $n^{\circ}$ 8.906, de 4 de julho de 1994 - Estatuto da Advocacia e da Ordem dos Advogados do Brasil). Assim, não compete ao Conselho Nacional de Justiça zelar pelo cumprimento dos deveres dos advogados previstos nos artigos 31 a 33 da Lei $n^{\circ} 8.906 / 1994$ e no Código de Ética e Disciplina da Ordem dos Advogados do Brasil (OAB), cabendo a esta entidade "promover, com exclusividade, a representação, a defesa, a seleção e a disciplina dos advogados em todo a República Federativa do Brasil” (Lei no 8.906/1994, art. 44, II) ${ }^{198}$.

\footnotetext{
${ }^{198}$ No julgamento da ADI n ${ }^{\circ}$ 3026, relator Ministro Eros Grau, em 8 de junho de 2006, em que o ProcuradorGeral da República requereu que fosse dada interpretação conforme a Constituição (CF, art. 37, II) ao trecho final da norma inserta no parágrafo $1^{\circ}$ do artigo 79 da Lei $n^{\circ} 8.906 / 1994$ para estabelecer a necessidade de concurso público para provimento dos cargos da Ordem dos Advogados do Brasil, o Supremo Tribunal Federal afirmou que a $\mathrm{OAB}$ é um serviço público sui generis independente, com finalidade institucionais, não sujeito a controle, relação ou dependência de qualquer órgão público. Eis a ementa do julgado:
}

AÇÃO DIRETA DE INCONSTITUCIONALIDADE. $\S 1^{\circ}$ DO ARTIGO 79 DA LEI N. 8.906, $2^{\mathrm{a}}$ PARTE. "SERVIDORES" DA ORDEM DOS ADVOGADOS DO BRASIL. PRECEITO QUE POSSIBILITA A OPÇÃO PELO REGIME CELESTISTA. COMPENSAÇÃO PELA ESCOLHA DO REGIME JURÍDICO NO MOMENTO DA APOSENTADORIA. INDENIZAÇÃO. IMPOSIÇÃO DOS DITAMES INERENTES À ADMINISTRAÇÃO PÚBLICA DIRETA E INDIRETA. CONCURSO PÚBLICO (ART. 37, II DA CONSTITUIÇÃO DO BRASIL). INEXIGÊNCIA DE CONCURSO PÚBLICO PARA A ADMISSÃO DOS CONTRATADOS PELA OAB. AUTARQUIAS ESPECIAIS E AGÊNCIAS. CARÁTER JURÍDICO DA OAB. ENTIDADE PRESTADORA DE SERVIÇO PÚBLICO INDEPENDENTE. CATEGORIA ÍMPAR NO ELENCO DAS PERSONALIDADES JURÍDICAS EXISTENTES NO DIREITO BRASILEIRO. AUTONOMIA E INDEPENDÊNCIA DA ENTIDADE. PRINCÍPIO DA MORALIDADE. VIOLAÇÃO DO ARTIGO 37, CAPUT, DA CONSTITUIÇÃO DO BRASIL. NÃO OCORRÊNCIA. 1. A Lei n. 8.906, artigo $79, \S 1^{\circ}$, possibilitou aos "servidores" da OAB, cujo regime outrora era estatutário, a opção pelo regime celetista. Compensação pela escolha: indenização a ser paga à época da aposentadoria. 2. Não procede a alegação de que a OAB sujeita-se aos ditames impostos à Administração Pública Direta e Indireta. 3. A OAB não é uma entidade da Administração Indireta da União. A Ordem é um serviço público independente, categoria ímpar no elenco das personalidades jurídicas existentes no direito brasileiro. 4. A OAB não está incluída na categoria na qual se inserem essas que se tem referido como "autarquias especiais" para pretender-se afirmar equivocada independência das hoje chamadas "agências". 5. Por não consubstanciar uma entidade da Administração Indireta, a $\mathrm{OAB}$ não está sujeita a controle da Administração, nem a qualquer das suas partes está vinculada. Essa não-vinculação é formal e materialmente necessária. 6. A OAB ocupa-se de atividades atinentes aos advogados, que exercem função constitucionalmente privilegiada, na medida em que são indispensáveis à administração da Justiça [artigo 133 da CB/88]. É entidade cuja 
Quanto ao Procedimento de Controle Administrativo no 2008.10.00.001769-8, verifica-se que foi instaurado em face do Tribunal de Justiça de Minas Gerais (TJMG) para impugnar ato datado de 21 de novembro de 1997, do então Governador do Estado, Dr. Eduardo Azeredo, que removera, nos termos do artigo 258 da Resolução TJMG n ${ }^{\circ}$ 61, de 8 de dezembro de 1975, Oficial do Registro de Comarca de entrancia inicial (Jacuí), para o cargo de Oficial de Registro de Imóveis de Comarca de entrância final (Passos), sem a realização de concurso para provimento ou remoção na atividade notarial e de registro.

O pedido foi, de plano, indeferido pelo Conselheiro relator Felipe Locke Cavalcanti, em decisão monocrática proferida em 30 de julho de 2008, porque visava anular ato de remoção levado a termo pelo Governador do Estado de Minas Gerais e uma vez que a matéria já havia sido debatida em ações judiciais ${ }^{199}$.

Houve interposição de recurso e o caso foi levado ao plenário do Conselho Nacional de Justiça que, por unanimidade, nos termos do voto do relator, negou-lhe provimento ${ }^{200}$, pelos fundamentos expostos na decisão monocrática e porque, não compete ao Conselho Nacional de Justiça, como pleiteado pelo recorrente, aconselhar ao Poder Executivo a anulação de um ato que realizara ${ }^{201}$.

Entendemos que essa decisão do Conselho Nacional de Justiça também foi acertada.

Apesar do Conselho Nacional de Justiça ter competência, por expressa ressalva

finalidade é afeita a atribuições, interesses e seleção de advogados. Não há ordem de relação ou dependência entre a OAB e qualquer órgão público. 7. A Ordem dos Advogados do Brasil, cujas características são autonomia e independência, não pode ser tida como congênere dos demais órgãos de fiscalização profissional. A OAB não está voltada exclusivamente a finalidades corporativas. Possui finalidade institucional. 8. Embora decorra de determinação legal, o regime estatutário imposto aos empregados da OAB não é compatível com a entidade, que é autônoma e independente. 9. Improcede o pedido do requerente no sentido de que se dê interpretação conforme o artigo 37, inciso II, da Constituição do Brasil ao caput do artigo 79 da Lei n. 8.906, que determina a aplicação do regime trabalhista aos servidores da OAB. 10. Incabível a exigência de concurso público para admissão dos contratados sob o regime trabalhista pela OAB. 11. Princípio da moralidade. Ética da legalidade e moralidade. Confinamento do princípio da moralidade ao âmbito da ética da legalidade, que não pode ser ultrapassada, sob pena de dissolução do próprio sistema. Desvio de poder ou de finalidade. 12. Julgo improcedente o pedido.

${ }^{199}$ A impossibilidade do CNJ rever o conteúdo de decisões judiciais será abordada no item 2.3.5.1.

${ }^{200}$ Estiverem presentes na sessão os Conselheiros Gilson Dipp, João Oreste Dalazen, Rui Stoco, Mairan Gonçalves Maia Júnior, Altino Pedrozo dos Santos, Andréa Pachá, JOrge Maurique, Antonio Umberto de Souza Júnior, José Adonis Callou de Araújo Sá, Felipe Locke Cavalcanti, Paulo Lobo, Joaquim Falcão e Marcelo Nobre.Ausentes, justificadamente, os Conselheiros Gilmar Mendes e Técio Lins e Silva (conforme certidão de julgamento da $70^{\mathrm{a}}$ Sessão Ordinária do CNJ).

${ }^{201} \mathrm{O}$ julgado recebeu a seguinte ementa:

Recurso Administrativo no Procedimento de Controle Administrativo. Ato de remoção de oficial de registro praticado pelo Governador do Estado de Minas Gerais. Questão já jurisdicionalizada. O Conselho Nacional de Justiça, como órgão interno de cúpula da administração do Poder Judiciário, não pode se imiscuir na regulação de Atos do Poder Executivo. Ademais, segundo entendimento pacificado por este Conselho Nacional de Justiça, uma vez jurisdicionalizada a questão, não cabe ao CNJ examiná-la, sob pena de, por vias transversas, imprimir ineficácia à decisão judicial ou esvaziar seu objeto. Recurso a que se nega provimento. 
constitucional, para fiscalizar as serventias extrajudiciais, não pode anular ato, ainda que inconstitucional, emanado por Governador, Chefe de outro Poder (Executivo), estranho ao Poder Judiciário.

Em resumo, por ser órgão de controle interno do Judiciário, falece competência ao Conselho Nacional de Justiça para exercer controle sobre cumprimento de deveres de exjuiz no exercício da advocacia, seja porque não há mais vínculo jurídico da pessoa natural com o referido Poder, seja porque não cabe ao CNJ promover a representação disciplina dos advogados, função, no Brasil, afeta à $\mathrm{OAB}^{202}$. Também não cabe ao $\mathrm{CNJ}$, ainda que, excepcionalmente possa fiscalizar as serventias extrajudiciais, controlar ato realizado por Governador do Estado, pois atingiria o Chefe do Poder Executivo Estadual, que não integra a estrutura do Poder Judiciário.

\subsection{5. Órgão que exerce controle da atuação administrativa e financeira do Poder Judiciário.}

Como já exposto, o Conselho Nacional de Justiça é um órgão interno do Judiciário, com estrutura colegiada, tipicamente de controle interno desse Poder.

O controle exercido pelo CNJ sobre os demais órgãos e sobre os membros do Poder Judiciário não é, porém, irrestrito.

Segundo prescreve o artigo 103-B, $\S 4^{\circ}$, da Constituição Federal, compete ao

\footnotetext{
${ }^{202}$ Cumpre registrar que, em 10 de janeiro de 2012, a Associação dos Juízes Federais do Brasil (AJUFE) divulgou nota sugerindo a fiscalização da $\mathrm{OAB}$ pelo $\mathrm{CNJ}$, o que, conforme exposto, seria inconstitucional, por não competir ao Conselho exercer controle de órgãos e entidades estranhos ao Poder Judiciário, observada, em especial, no caso, a natureza jurídica da $\mathrm{OAB}$ mencionada na nota anterior. Para conhecimento, segue o teor da nota: "Com relação à notícia de que o presidente da Ordem dos Advogados do Brasil, Ophir Cavalcante, pretende realizar ato em defesa das atribuições do Conselho Nacional de Justiça (CNJ), a Associação dos Juízes Federais do Brasil (AJUFE), vem a público informar à população que o papel do CNJ é fundamental no aperfeiçoamento do Estado Democrático de Direito, com vistas a conferir maior eficiência ao Poder Judiciário e na apuração de eventuais irregularidades. Tal missão, por outro lado, deve ser desempenhada dentro dos estritos limites legais e constitucionais, mas sempre visando a absoluta transparência institucional. Nessa linha, sendo a $\mathrm{OAB}$, autarquia imprescindível à administração da justiça, nos termos do art. 133 da Constituição da República, é imperativo que igualmente aquela instituição esteja sujeita à fiscalização pelo CNJ, inclusive sob o aspecto disciplinar. Entende, pois, a AJUFE, que ante o caráter público da $\mathrm{OAB}$, os recursos por ela administrados e a atuação dos seus membros mereceria total atenção do Conselho Nacional da Justiça. Isso evitaria, sem sombra de dúvida, a imensa quantidade de queixas por apropriações indébitas praticadas por advogados contra os cidadãos comuns, permitindo ao CNJ punir os maus advogados, honrando, assim, a imensa maioria dos causídicos honestos e que tanto lutam pelo aperfeiçoamento da democracia brasileira, mas que têm a consciência de que a intimidação de juízes e familiares por meios ilegais em nada contribui para esse objetivo. Fabrício Fernandes de Castro. Presidente Interino da Associação dos Juízes Federais do Brasil (AJUFE)" (Nota sobre a OAB realizar ato em defesa das atribuições do CNJ, disponível em: < http://www.ajufe.org/imprensa/noticias/nota-sobre-a-oab-realizarato-em-defesa-das-atribuicoes-do-cnj/>. Acesso em 02.06.2014).
} 
Conselho somente o controle da atuação administrativa e financeira do Judiciário e o controle do cumprimento dos deveres funcionais dos juízes.

Nota-se, pois, como pontua Alexandre de Moraes (2013, p. 541), que "a atuação do Conselho Nacional de Justiça direciona-se para duas importantes missões". Ambas configuram elementos constitucionais característicos do Conselho Nacional de Justiça.

A primeira dessas missões é o controle exercido pelo Colegiado, enquanto órgão de sobreposição $^{203}$, sobre a atuação administrativa e financeira dos demais entes do Judiciário. Essa vigilância, pois, será exercida sobre os atos praticados pelas demais instituições que integram a estrutura do Poder Judiciário, através de seus órgãos singulares ou colegiados $^{204}$. A fiscalização é realizada sobre as instituições e não sobre as pessoas naturais que a integram.

A segunda missão do CNJ é exercer o controle do cumprimento dos deveres funcionais dos juízes. Aqui age o Conselho como vigilante disciplinar dos magistrados, pessoas naturais investidas do poder judicante, e não das instituições a que pertencem.

Este item será dedicado à análise da primeira dessas missões mencionada e dos limites constitucionais dela decorrentes: o controle exercido pelo Conselho da atuação administrativa e financeira do Judiciário. O controle realizado pelo $\mathrm{CNJ}$ sobre o cumprimento dos deveres funcionais dos juízes será objeto de estudo posterior ${ }^{205}$.

Para melhor exposição, o tema será apresentado em dois subitens distintos, o primeiro relativo à impossibilidade do $\mathrm{CNJ}$ exercer o controle da atividade típica do Judiciário - a jurisdição - e o segundo referente às limitações ao controle exercido pelo Colegiado sobre as atividades atípicas desenvolvidas nesse Poder. Cada subitem será acrescido de ramificação tópica para exemplificação dos assuntos abordados.

\subsubsection{Impossibilidade do CNJ exercer controle da jurisdição}

Da característica do Conselho Nacional de Justiça em estudo logo se percebe um

\footnotetext{
${ }^{203}$ Essa característica será analisada no item 2.3.7.

${ }^{204}$ Todos os atos praticados pelos Presidentes dos Tribunais no exercício das atribuições que lhe são conferidas pelos respectivos Regimentos Internos de cada Corte, são exemplos de atuações administrativas exercidas por órgãos singulares em nome das instituições que chefiam, integrantes da estrutura do Poder Judiciário Brasileiro e, portanto, passíveis de controle pelo CNJ. Os atos administrativos determinados pelos Tribunais Plenos ou por seus Órgãos Especiais (CF, art. 93, XI) ilustram casos em que a atuação dos entes que compõe o Poder Judiciário Nacional, sujeita à fiscalização do Alto Conselho Administrativo, é realizada por seus órgãos colegiados.

${ }^{205}$ Vide item 2.3.6.
} 
primeiro limite constitucional à sua atuação relacionado diretamente à separação dos Poderes e das funções estatais: se cabe ao Colegiado somente a fiscalização da atuação administrativa e financeira do Judiciário, não lhe compete o controle da atuação jurisdicional exercida pelos diversos órgãos do Poder Judiciário.

Como já observado ${ }^{206}$, o poder soberano do Estado é uno, tendo a Constituição Federal consagrado a clássica divisão da separação das funções estatais não absoluta ao dispor, em seu artigo $2^{\circ}$, que "são Poderes da União, independentes e harmônicos entre si, o Legislativo, o Executivo e o Judiciário". Dessa forma, como doutrina Alexandre de Moraes, "cada um dos Poderes possui uma função predominante, que o caracteriza como detentor de parcela da soberania nacional estatal, além de outras funções previstas no texto constitucional. São as chamadas funções típicas e atípicas” (2013b, p. 423).

A função típica do Poder Judiciário é julgar (função jurisdicional). Suas funções atípicas são administrar e legislar.

Julgar é solucionar um conflito de interesses através da aplicação da lei ao caso controvertido, substituindo, definitivamente, a vontade das partes em litígio. É exercer a jurisdição, a função jurisdicional.

Para André Ramos Tavares, jurisdição é “a atividade pela qual determinados órgãos pronunciam-se, em caráter cogente, sobre a aplicação do Direito" (2013, p. 929).

A função jurisdicional, típica do Poder Judiciário, pois, consiste em “julgar, aplicando a lei a um caso concreto, que lhe é posto, resultante de um conflito de interesses" (MORAES, 2013b, p. 515).

Por esse motivo, Tavares define o Poder Judiciário, do ponto de vista de sua função típica, como “o conjunto de órgãos públicos que detêm o exercício da função jurisdicional $^{207, "}(2013$, p. 929).

Essa função jurisdicional é realizada, segundo o mesmo autor (2013, p. 929), "por meio da obediência a um procedimento previamente determinado, ao final e ao cabo do

\footnotetext{
${ }^{206}$ Vide item 2.2.

${ }^{207}$ Cintra, Grinover e Dinamarco (2007, pp. 151 a 154) apontam os seguintes princípios inerentes à juridição: a) investidura: apenas quem for regularmente investido como juiz poderá exercê-la; b) aderência ao território: os limites territorias do Estado demarcam a autoridade dos magistrados, de modo geral, sendo que, singularmente, "cada juiz só exerce a sua autoridade nos limites do território sujeito à sua jurisdição"; c) indelegabilidade: as atribuições do Judiciário, enquanto Poder, e dos juízes, individualmente considerados, não podem ser delegadas, pois fixadas pela Constituição e uma vez que a jurisdição, como função pública, não é exercida em nome próprio; d) inevitabilidade: as partes do processo de sujeitam à autoridade dos órgãos jurisdicionais; e) inafastabilidade: a todos é garantido o acesso ao Poder Judiciário para apreciação de lesão ou ameaça a direito (CF, art. $\left.5^{\circ}, \mathrm{XXXV}\right)$; e, f) juiz natural: "assegura que ninguém pode ser privado do julgamento por juiz independente e imparcial, indicado pelas normas constitucionais e legais".
} 
qual se alcança uma decisão que é revestida do caráter da imutabilidade, vale dizer, faz coisa julgada entre as partes" 208 .

Esse procedimento é a exteriorização dos atos de um processo que interliga os sujeitos cujos interesses conflitam e viabiliza o exercício da função jurisdicional ${ }^{209}$.

Porém, ante a massa existente de processos e a previsão, no ordenamento, de diversos órgãos do Poder Judiciário, pontuam Cintra, Grinover e Dinamarco (2007, p. 246):

\begin{abstract}
Como são inúmeros os processos que podem ser instaurados em decorrência dos conflitos interindividuais que surgem em um país e múltiplos também os órgãos jurisdicionais, é facilmente compreensível a necessidade de distribuir esses processos entre esses órgãos. A jurisdição como expressão do poder estatal é uma só, não comportando divisões ou fragmentações: casa juiz, cada tribunal, é plenamente investido dela. Mas o exercício da jurisdição é distribuído, pela Constituição e pela lei ordinária, entre os muitos órgãos jurisdicionais; cada qual então a exercerá dentro de determinados limites (ou seja, com referência a determinado grupo de litígios).

Chama-se competência a quantidade de jurisdição cujo exercício é atribuído a cada órgão ou grupo de órgãos (Liebman).
\end{abstract}

\footnotetext{
${ }^{208} \mathrm{Um}$ dos principais escopos da coisa julgada é a segurança jurídica. Sobre o assunto, doutrina Luiz Guilherme Marinoni (2008, p. 68): “A coisa julgada, enquanto instituto jurídico, tutela o princípio da segurança jurídica em sua dimensão objetiva, deixando claro que as decisões judiciais são definitivas e imodificáveis. Frise-se que a coisa julgada expressa a necessidade de estabilidade das decisões judiciais. Na outra dimensão do princípio da segurança jurídica, quando importa a proteção da confiança, a coisa julgada garante ao cidadão que nenhum outro ato estatal poderá modificar ou violar a decisão que definiu o litígio. Neste sentido, sabe o cidadão que, uma vez produzida a coisa julgada material, nada mais será possível fazer para se alterar a decisão e, assim, que o ato judicial de solução do litígio merece plena confiança".

${ }^{209}$ Sobre a distinção entre procedimento e processo, ensinam Cintra, Grinover e Dinamarco (2007, p. 295): "Etimologicamente, processo significa marcha avante ou caminhada (do latim, procedere = seguir adiante). Por isso, durante muito tempo ele foi confundido com a simples sucessão de atos processuais (procedimento), sendo comuns as definições que o colocavam nesse plano. Contudo, desde 1868, com a obra de Bulow (Teoria dos pressupostos processuais e das exceções dilatórias), apercebeu-se a doutrina de que há, no processo, uma força que motiva e justifica a prática dos atos do procedimento, interligando os sujeitos processuais. O processo, então, pode ser encarado pelo aspecto dos atos que the dão corpo e das relações entre eles e igualmente pelo aspecto das relações entre seus sujeitos. O procedimento é, nesse quadro, apenas meio extrínseco pelo qual se instaura, desenvolve-se e termina o processo; é a manifestação extrínseca deste, a sua realidade fenomenológica perceptível. A noção de processo é essencialmente teleológica, porque ele se caracteriza por sua finalidade de exercício do poder (no caso, jurisdicional). A noção de procedimento é puramente formal, não passando da coordenação de atos que se sucedem. Conclui-se, portanto, que o procedimento (aspecto formal do processo) é o meio pelo qual a lei estampa os atos e fórmulas da ordem legal do processo. O processo é indispensável À função jurisdicional exercida com vistas ao objetivo de eliminar conflitos e fazer justiça mediante a atuação da vontade concreta da lei. É, por definição, o instrumento através do qual a jurisdição opera (instrumento para a positivação do poder)".
} 
Os órgãos do Poder Judiciário, pois, são estruturados pela Constituição Federal e pelas leis, que lhes atribuem as suas competências, ou seja, suas "quantidades" de jurisdição. Há duas ordens de organizações, federal e estadual, e os diversos órgãos do Judiciário exercem competências especializadas ou comuns, originárias ou recursais (TAVARES, 2013, pp. 930 a 932).

Por vincular-se à ideia de controle, discorre-se sobre a competência recursal.

A competência recursal refere-se à apreciação de recursos manejados no processo contra decisões judiciais, em razão do inconformismo da parte perdedora. Essa competência é normalmente atribuída aos tribunais, órgãos colegiados. Através dela, o vencido busca a reforma da decisão que lhe desfavoreceu, por outra que lhe beneficie. A competência recursal prestigia o denominado princípio constitucional processual do duplo grau de jurisdição ${ }^{210}$.

Segundo Cássio Scarpinella Bueno (2013, p. 138), pelo princípio constitucional do duplo grau de jurisdição ${ }^{211}$ garante-se "a revisibilidade ampla das decisões judiciais, quaisquer decisões, por magistrados preferencialmente diversos e localizados em nível hierárquico diverso".

O duplo grau de jurisdição permite que haja um reexame da matéria decidida por juízes mais experientes, em colegiado, de forma mais aprofundada e independente ${ }^{212}$.

O controle, pois, é o essencial mote para justificar o duplo grau de jurisdição. Seja o controle psicológico a que fica submetido o juiz de primeiro grau, que "se cerca de maiores cuidados no julgamento quando sabe que sua decisão poderá ser revista pelos tribunais da jurisdição superior” (CINTRA, GRINOVER E DINAMARCO, 2007, p. 81). Seja o controle para "fiscalização dos atos estatais em geral visando ao seu aprimoramento" (BUENO, 2013, p. 138). Seja, por fim, o controle de conotação política da atividade jurisdicional.

Sobre este último controle, pontuam CINTRA, GRINOVER E DINAMARCO (2007,

\footnotetext{
${ }^{210}$ A respeito confira-se CINTRA, GRINOVER E DINAMARCO (2007, pp. 187 e 256).

${ }^{211}$ O autor destaca (2013, p. 137) que o princípio constitucional do duplo grau de jurisdição é o mais difícil de ser identificado pois "não há consenso na doutrina sobre sua extensão e significado, o que é agravado porque a Constituição não se refere a ele expressamente"

${ }^{212}$ A corrente doutrinária contrária ao princípio do duplo grau de jurisdição argumenta que ele não se justifica porque: a) pode levar à reforma de uma decisão justa por outra injusta, uma vez que os juízes de jurisdição superior também erram; b) o tempo despendido para reexame da matéria decidida é contrário às ideias de economia e celeridade processuais; c) a decisão em grau jurisdicional superior que confirma a de grau inferior mostra-se inútil; e, d) a decisão em grau jurisdicional superior que reforma a de grau inferior é nociva, pois revela a falibilidade dos julgadores e desprestigia o Poder Judiciário. Nesse sentido, confira-se BUENO (2013, p. 138) e CINTRA, GRINOVER E DINAMARCO (2009, pp. 80 e 81).
} 
p. 81):

[...] o principal fundamento para a manutenção do princípio do duplo grau é de natureza política: nenhum ato estatal pode ficar imune aos necessários controles. O Poder Judiciário, principalmente onde seus membros não são sufragrados pelo povo, é, dentre todos, o de menor representatividade. Não o legitimaram as urnas, sendo o controle popular sobre o exercício da função jurisdicional ainda incipiente em muitos ordenamentos, como o nosso. É preciso, portanto, que se exerça ao menos o controle interno sore a legalidade e a justiça das decisões judiciárias. Eis a conotação política do princípio do duplo grau de jurisdição

O princípio constitucional processual do duplo grau de jurisdição, pois, com o perdão da redundância, permite o controle interno da jurisdição pela jurisdição.

Assim, no exercício da competência jurisdicional recursal, os diversos órgãos superiores do Judiciário exercem verdadeira atividade de controle sobre a atuação juridicional dos outros órgãos inferiores do Poder, pois reapreciam as decisões proferidas, podendo mantê-las ou alterá-las.

Esse controle jurisdicional também é feito pelos órgãos do Poder Judiciário através do manejo de outros técnicas constitucionais ou processuais de verificação do acerto das decisões judiciais, como o habeas corpus, o mandado de segurança, a revisão criminal, a ação rescisória etc.

E, como, no Brasil, foi adotado o modelo da unidade de jurisdição na organização do Poder Judiciário, todas essas técnicas de controle, todas as "jurisdições”, como pontua José Levi Mello do Amaral Júnior (2009, p. 1174), “convergem para um mesmo órgão de cúpula, o Supremo Tribunal Federal"213.

Porém, instituído pela Emenda Constitucional no 45/2004 como órgão do Judiciário, não foi atribuído o exercício da função típica do Poder - a função juridicional - ao

\footnotetext{
${ }^{213}$ José Levi Mello do Amaral Júnior (2009, pp. 1173 e 1174) ensina que, no constitucionalismo ocidental, o Poder Judiciário é organizado como base em dois modelos básicos: unidade de jurisdição e pluralidade de jurisdições. E doutrina: "A unidade de jurisdição é associada ao modelo de suprema corte, ou seja, ainda que haja jurisdições especializadas identificáveis, todas elas convergem para um único órgão de cúpula. Este modelo predomina na América. A pluralidade de jurisdições desconhece um único órgão de cúpula. As eventuais jurisdições especializadas havidas atuam de modo independente. Este modelo é próprio da Europa, inclusive nos países que adotam um tribunal constitucional (que é considerado uma jurisdição especializada ou, até mesmo, um novo Poder)".
} 
Conselho Nacional de Justiça.

Com efeito, a norma prevista no art. 92, caput, da Constituição Federal estabelece quais são os órgão do Poder Judiciário Brasileiro.

A singela cisão em dois parágrafos do antigo parágrafo único do referido dispositivo constitucional promovida pela Emenda Constitucional n $n^{o} 45 / 2004$ já demostra que o Conselho Nacional de Justiça não foi dotado, pelo Constituinte Reformador, do exercício da jurisdição.

A redação anterior do art. 92, parágrafo único dispunha que "o Supremo Tribunal Federal e os Tribunais Superiores têm sede na Capital Federal e jurisdição em todo o território nacional".

Após a Emenda Constitucional no 45/2004, o artigo 92 da Constituição Federal passou a contar com dois parágrafos com as seguintes redações: “ $\S 1^{\circ} \mathrm{O}$ Supremo Tribunal Federal, o Conselho Nacional de Justiça e os Tribunais Superiores têm sede na Capital Federal; $\S 2^{\circ}$ O Supremo Tribunal Federal e os Tribunais Superiores têm jurisdição em todo o território nacional".

O Constituinte Reformador, pois, deliberadamente, separou o dispostivo constitucional que tratava de dois assuntos distintos (local da sede do Supremo Tribunal Federal e dos Tribunais Superiores e abrangência de suas jurisdições) para definir que o Conselho Nacional de Justiça, assim como o Supremo Tribunal Federal e os Tribunais Superiores, também teria sede na Capital Federal, mas esclarecer que a jurisdição nacional continuava a ser atributo somente destes Tribunais.

Trata-se do denominado "silêncio eloquente"214 a indicar não exercer o Conselho Nacional de Justiça a função típica do Poder Judiciário, a jurisdição.

\footnotetext{
${ }^{214}$ Sobre este tema (silêncio eloquente), Karl Larenz (1997, p. 524 a 526), leciona, ao analisar o Código Civil alemão, e destrinçar os conceitos de lacuna e de silêncio eloquente: “(...) Mas, quando existe uma «lacuna da lei», tal carece de uma explicação mais concreta. Poderia pensar-se que existe uma lacuna só quando e sempre que a lei - entendida esta, doravante, como uma expressão abreviada da totalidade das regras jurídicas susceptíveis de aplicação dadas nas leis ou no Direito consuetudinário - não contenha regra alguma para uma determinada configuração no caso, quando, portanto, «se mantém em silêncio». Mas existe também um «silêncio eloquente» da lei." E exemplifica KARL LARENZ, ainda distinguindo entre o silêncio da lei e a lacuna, através de exemplos do direito privado alemão (casa de morada), com algo que faz lembrar do chamado bem de família do atual direito brasileiro: "A modo de exemplo, o facto de não conter qualquer disposição sobre a propriedade da casa de morada (no sentido actual), não foi uma lacuna do Código Civil na sua formulação originária. É que o legislador do BGB não quis admitir um tal direito especial sobre uma casa ou uma parte do edifício, que em princípio lhe não era desconhecido, por razões da disposição das relações jurídicas sobre bens imóveis e, por isso, intencionalmente não incluiu na lei disposições a esse respeito. (...) «Lacuna» e «silêncio da lei» não são, portanto, pura e simplesmente o mesmo. O termo «lacuna» faz referência a um carácter incompleto. Só se pode falar de «lacunas» de uma lei quando esta aspira a uma regulação completa em certa medida, para um determinado sector. $\mathrm{O}$ acentuar do conceito de lacuna está, pois, também em estreita conexão com as aspirações a uma codificação global completa do direito, que se suscitaram no século XVIII e tiveram o seu ponto alto no século XIX".
} 
O teor das disposições constantes no artigo 103-B da Lei Maior confirma essa afirmação. Não há qualquer atribuição de competência ao Conselho Nacional de Justiça para o julgamento de demandas jurisdicionais originárias ou recursos decorrentes de decisões judiciais. Mesmo na atribuição prevista no art. 103-B, $\S 4^{\circ}$, V ("rever, de ofício ou mediante provocação, os processos disciplinares de juízes e membros de tribunais julgados há menos de um ano”), preocupou-se o Constituinte Reformador em utilizar o verbo "rever", apesar de, evidentemente, tratar-se de hipótese de revisão de julgamento, porém de processo administrativo-disciplinar, não jurisdicionalizado ${ }^{215}$.

Essa singular característica do Conselho Nacional de Justiça - ser órgão judicial, mas desvestido da função jurisdicional -, apesar de não constar expressamente na ementa do acórdão $^{216}$, foi reconhecida em diversas passagens no julgamento da Ação Direta de Inconstitucionalidade $\mathrm{n}^{\mathrm{o}} 3367$.

Com efeito, em seu voto na referida ação, o Ministro Cezar Peluso, para refutar a alegação da $\mathrm{AMB}$ no sentido de que a criação do $\mathrm{CNJ}$ implicou em violação à independência do Poder Judiciário, consignou:

\footnotetext{
${ }^{215}$ Rápido giro pelas demais normas constitucionais Judiciário indica que, aos outros órgãos do Poder Judiciário, foi conferido o exercício de sua função típica (julgar), como estabelecem expressamente os artigos 102, I e II (em relação ao Supremo Tribunal Federal), 105, I, II e III (em relação ao Superior Tribunal de Justiça), 108, I e II, (em relação aos Tribunais Regionais Federais), 109 (em relação aos juízes federais); 114 (em relação à Justiça do Trabalho) e 124 (em relação à Justiça Militar).

${ }^{216}$ A questão é indiretamente tratada nos segundo e quarto itens da ementa do acórdão da ADI $n^{\circ} 3367$. O segundo item da ementa do julgado menciona que não há inconstitucionalidade na instituição do Conselho Nacional de Justiça porque sua atuação não ofende o princípio da separação e independência dos poderes, pois preserva-se a função jurisdicional, típica do Judiciário, e as condições materiais de seu exercício imparcial e independente. Na quarta parte da ementa, afirma-se que o CNJ tem atribuição de controle da atividade administrativa, financeira e disciplinar da magistratura, exceto sobre o Supremo Tribunal Federal e seus Ministros. Em nenhuma delas, porém, consta expressamente que o Conselho não exerce função jurisdicional, limitando-se apenas a dizer que trata-se de órgão de natureza exclusivamente administrativa. Seguem os trechos citados da ementa:
}

2. INCONSTITUCIONALIDADE. Ação direta. Emenda Constitucional $\mathrm{n}^{\circ}$ 45/2004. Poder Judiciário. Conselho Nacional de Justiça. Instituição e disciplina. Natureza meramente administrativa. Órgão interno de controle administrativo, financeiro e disciplinar da magistratura. Constitucionalidade reconhecida. Separação e independência dos Poderes. História, significado e alcance concreto do princípio. Ofensa a cláusula constitucional imutável (cláusula pétrea). Inexistência. Subsistência do núcleo político do princípio, mediante preservação da função jurisdicional, típica do Judiciário, e das condições materiais do seu exercício imparcial e independente. Precedentes e súmula 649. Inaplicabilidade ao caso. Interpretação dos arts. $2^{\circ}$ e 60 , $4^{\circ}$, III, da CF. Ação julgada improcedente. Votos vencidos. São constitucionais as normas que, introduzidas pela Emenda Constitucional $\mathrm{n}^{\circ} 45$, de 8 de dezembro de 2004, instituem e disciplinam o Conselho Nacional de Justiça, como órgão administrativo do Poder Judiciário nacional. [...]

4. PODER JUDICIÁRIO. Conselho Nacional de Justiça. Órgão de natureza exclusivamente administrativa. Atribuições de controle da atividade administrativa, financeira e disciplinar da magistratura. Competência relativa apenas aos órgãos e juízes situados, hierarquicamente, abaixo do Supremo Tribunal Federal. Preeminência deste, como órgão máximo do Poder Judiciário, sobre o Conselho, cujos atos e decisões estão sujeitos a seu controle jurisdicional. Inteligência dos art. 102, caput, inc. I, letra "r", e $\S 4^{\circ}$, da CF. O Conselho Nacional de Justiça não tem nenhuma competência sobre o Supremo Tribunal Federal e seus ministros, sendo esse o órgão máximo do Poder Judiciário nacional, a que aquele está sujeito. 
[...] é sobremodo importante notar que o Conselho não julga causa alguma, nem dispõe de nenhuma atribuição, de nenhuma competência, cujo exercício fosse capaz de inter ferir no desempenho da função típica do Judiciário, a jurisdicional. Pesa-lhe, antes, abrangente dever constitucional de "zelar pela autonomia" do Poder (art. 103-B, § 4", inc. I). E não seria lógico nem sensato levantar suspeitas de que, sem atribuição jurisdicional, possa comprometer independências que jamais se negou a órgãos jurisdicionais integrados por juízes cuja nomeação compete ao Poder Executivo, como ou sem colaboração do Legislativo.

O Ministro Eros Grau, por ocasião do julgamento da ADI $\mathrm{n}^{\circ}$ 3367, assim se pronunciou sobre o Conselho Nacional de Justiça:

Embora órgão integrante do Poder Judiciário --- razão pela qual desempenha autêntico controle interno --- não exerce função jurisdicional.

Também no julgamento da ADI n ${ }^{\circ}$ 3367, a Ministra Ellen Gracie, ainda que para refutar, no seu entender, a constitucionalidade da participação de membros de origem estranha ao Poder Judiciário no Conselho Nacional de Justiça, posicionamento que ficou vencido, disse:

Levando-se em conta a competência não somente gerencial, mas também invasiva do Conselho recém-criado e por se tratar de órgão do Judiciário que tem como campo de atuação, ainda que despojado de função jurisdicional, o funcionamento do próprio Judiciário, a participação daqueles que não são membros deste Poder choca-se frontalmente com a já referida independência qualificada do Poder Judiciário.

Mesmo o Ministro Marco Aurélio Mello, único a considerar inconstitucional a criação do Conselho Nacional de Justiça, pontuou, quando julgada a ação direta em comento:

Ilações me ocorrem: a primeira é de termos um superórgão - vou dizer por que entendo haver surgido um superórgão administrativo - que não terá - ainda bem - jurisdição, ou seja, o ofício judicante, jurisdicional 
propriamente dito (p. 117).

Não resta dúvida, que, apesar de ser órgão do Poder Judiciário, não exerce o Conselho Nacional de Justiça a função jurisdicional, originária ou recursal. Assim, de outra banda, não lhe compete qualquer controle sobre o exercício dessa função pelos demais órgãos do Poder Judiciário.

Portanto, o Conselho Nacional de Justiça atua somente no âmbito administrativo. Não lhe cabe, pois, rever decisões judiciais ou analisar incorreções na apreciação de provas em meios judicialiformes, devendo a parte que se julgar prejudicada valer-se de medidas e recursos processuais para impugná-las. Caso contrário, estará o $\mathrm{CNJ}$ usurpando as atribuições e a independência dos demais órgãos do Poder Judiciário.

Trata-se de importante limitação à sua atuação, pois não pode o Conselho julgar demandas judiciais originárias ou em grau de recurso, ou mesmo rescindir ou rever decisões judiciais, ainda que contrárias às suas deliberações.

Por outro lado, as decisões do Conselho Nacional de Justiça, mesmo se enfrentarem o mérito de alguma questão administrativa ou disciplinar, não fazem coisa julgada material e, portanto, podem ser revistas pelo Poder Judiciário ${ }^{217}$.

Percebe-se, pois, porque a Emenda Constitucional no 45/2004 estabeleceu várias competências administrativas ao Conselho Nacional de Justiça e ainda abriu a possibilidade de outras lhe serem conferidas pelo Estatuto da Magistratura: se o órgão, por integrar o Poder Judiciário, não pode, em regra, exercer funções típicas de outros Poderes e se não exerce a função típica do Poder a que pertence (a jurisdição), seria totalmente inútil sua criação se, desde logo, não lhe fossem conferidas várias missões (todas exclusivamente administrativas) pelo Constituinte Reformador.

O Conselho, inclusive, diante dessa característica, desde sua criação, tem, reiteradamente, deixado de conhecer pleitos relacionados a questões administrativas do Poder Judiciário jurisdicionalizadas mas ainda não julgadas, para não causar o esvaziamento do conteúdo da tutela jurisdicional, e evitar a alteração do curso normal das competências jurisdicionais, além do conflito de decisões, causador de insegurança aos jurisdicionados.

Paradigma desse entendimento foi o posicionamento externado pelo Conselheiro Alexandre de Moraes em 26 de setembro de 2006 quando da apreciação, para referendo, de

${ }^{217}$ Vide Capítulo 4. 
decisão liminar proferida no Procedimento de Controle Administrativo $\mathrm{n}^{\mathrm{o}}$ 201, da relatoria do Conselheiro Oscar Argollo.

O PCA n 201 tratou de representação formulada por Magistrado que se insurgiu contra a preterição de sua opção operada em concurso de promoção realizado em 27 de dezembro de 2005 pelo Órgão Especial do Tribunal de Justiça do Estado de São Paulo. Após o indeferimento, o interessado ajuizou, na data de 24 de julho de 2006, o Mandado de Segurança ${ }^{\circ}$ 137657-0/2 contra o ato do Órgão Especial do TJ/SP, tendo sido negada a liminar pleiteada pelo Desembargador Relator Ivan Sartori.

Em seu voto, o Conselheiro Alexandre de Moraes suscitou questão de ordem para não conhecimento do procedimento. Argumentou que, apesar das instâncias administrativa e jurisdicional serem autônomas, a admissão da dupla possibilidade de impugnação de atos administrativos dos órgãos do Judiciário - uma, jurisdicional, perante as instâncias ordinárias do Poder e através dos meios processuais cabíveis, e outra, administrativa, junto ao Conselho Nacional de Justiça - pode implicar na modificação, a critério dos interessados, do curso normal das competências jurisdicionais e consequente violação do princípio do Juiz Natural, pois compete ao Supremo Tribunal Federal processar e julgar originalmente as ações contra o Conselho Nacional de Justiça (CF, art. 102, I, "r") ${ }^{218}$.

\footnotetext{
${ }^{218}$ Reproduz-se, a seguir, trecho do voto proferido pelo Conselheiro Alexandre de Moraes: "Não nego, obviamente, que a clássica consagração da autonomia de instâncias administrativa e jurisdicional possibilita dupla revisão dessas questões, conforme se verifica em pacífica jurisprudência do SUPREMO TRIBUNAL FEDERAL (Pleno, MS 22.438-0/SP, Rel. Min. Moreira Alves, Diário da Justiça, Seção I, 6 fev. 1998, p. 8). Porém, entendo importante analisarmos a peculiar circunstância do Conselho Nacional de Justiça como órgão administrativo do próprio Poder Judiciário, em face dessa dupla possibilidade de impugnação de atos administrativos dos órgãos do judiciário, em especial dos Tribunais e de seus órgãos de direção, ser utilizado para alterar o curso normal das competências jurisdicionais. E assim o faço, por uma questão de possibilidade de desvirtuamento da própria função do CNJ, além do perigo de se permitir que os requerentes possam, a partir de suas próprias conveniências, escolher o juízo que, em princípio, melhor lhe convenha, alterando o curso do Juízo Natural. A presente hipótese demonstra claramente essa possibilidade. O requerente optou, inicialmente, por ajuizar mandado de segurança no próprio Órgão Especial. Opção legal e legítima. Porém, uma vez negada a medida liminar pleiteada, ao invés de manter o curso jurisdicional normal, pleiteou administrativamente no $\mathrm{CNJ}$ - em idêntica petição e omitindo o anterior mandado de segurança - a concessão da liminar. As possibilidades constitucional e legal existem, porém, qualquer que seja a decisão do CNJ salvo entender prejudicado o presente PCA - haverá alteração do Juízo Natural para a decisão da questão objeto do mandado de segurança, pois eventuais impugnações obrigatoriamente serão perante o SUPREMO TRIBUNAL FEDERAL (CF, art. 102, I, "r"). Dessa forma, enquanto o PRIMEIRO CAMINHO escolhido pelo próprio requerente levaria ao julgamento do Mandado de Segurança pelo Órgão Especial do TJ/SP, com possibilidade de recurso ordinário constitucional ao SUPERIOR TRIBUNAL DE JUSTIÇA, caso fosse denegada a segurança (CF, art. 105, II, "b"), o SEGUNDO CAMINHO - requerimento ao CNJ -, caso admitido, determinará a prejudicialidade do Mandado de Segurança, uma vez que a nova autoridade coatora, em tese, será o próprio CNJ ("para figurar no pólo passivo da ação de segurança, autoridade coatora é aquela que ordena, que determina ou pratica o ato, ou, ainda, a que defende a prevalência deste (ato coator), assumindo, embora a posteriori, a posição de coator" - STJ, $1^{\text {a }}$ Seção, MS 4085, Rel. Min. Demócrito Reinaldo), determinando a competência do SUPREMO TRIBUNAL FEDERAL para eventuais impugnações. Torno a repetir a possibilidade constitucional e legal para tanto, mas também, entendo importante analisarmos a conveniência do CONSELHO NACIONAL DE JUSTIÇA passar a ser utilizado
} 
Apesar de, na ocasião, ter ficado vencido ${ }^{219}$, sua tese, posteriomente, tornou-se vencedora e passou a ser adotada em vários outros julgados do Conselho Nacional de Justiça $^{220}$, inclusive em hipóteses de judicialização superveniente de questões administrativas do Poder Judiciário levadas ao conhecimento do Colégio Administrativo 221 .

Em suma, não compete ao Conselho Nacional de Justiça controlar a função jurisdicional típica do Judiciário, exercida pelos seus demais órgãos através dos meios e recursos processuais pertinentes, sob pena de usurpação de atribuições e da independência dos demais órgãos do Poder. O próprio Conselho, por outro lado, no que tange a questões

rotineiramente como instrumento de alteração de competência jurisdicional, a fim de, por via oblíqua, afastar decisões jurisdicionais contrárias aos interesses dos requerentes, sem que haja motivo de interesse público a justificar a atuação desse Colegiado".

${ }^{219}$ Conforme se extrai da certidão de julgamento do PCA n ${ }^{\circ} 201$, realizado na $26^{\text {a }}$ Sessão Ordinária do CNJ, o Conselho decidiu, na ocasião: a) por maioria, conhecer do procedimento de controle administrativo, vencidos os Conselheiros Alexandre de Moraes, Joaquim Falcão e Marcus Faver, que não admitiam o cabimento do procedimento; e, b) por maioria, referendar a liminar concedida pelo Relator, com os efeitos mantidos até o julgamento do PCA ou do mandado de segurança impetrado perante o TJSP, vencidos os Conselheiros Alexandre de Moraes, Joaquim Falcão, Marcus Faver, Douglas Rodrigues e Ruth Carvalho, que não referendavam o ato. Declarou-se impedido o Conselheiro Cláudio Godoy. Estiverem presentes na sessão os Conselheiros Ellen Gracie,Vantuil Abdala, Marcus Faver, Jirair Aram Meguerian, Douglas Rodrigues, Cláudio Godoy, Germana Moraes, Paulo Schmidt, Eduardo Lorenzoni, Ruth Carvalho, Oscar Argollo, Alexandre de Moraes e Joaquim Falcão. Ausentes, justificadamente, os Conselheiros Antônio de Pádua Ribeiro e Paulo Lôbo.

${ }^{220}$ A título exemplificativo: a) Procedimento de Controle Administrativo. A autonomia das instâncias administrativa e jurisdicional consagra a competência constitucional do CNJ, por força do artigo 103-B da Constituição, mesmo existindo ação judicial sem decisão judicial transitada em julgado; Tendo o requerente optado pela via judicial e tendo obtido decisão liminar ou de mérito, ainda que provisória, antes de instaurado o processo administrativo no CNJ, este não será conhecido (CNJ - PCA 213 - Rel. Cons. Paulo Lobo - Voto vencedor do Cons. Alexandre de Moraes - 38 Sessão - j. 10.04.2007 - Ementa não oficial); b) Procedimento de Controle Administrativo. Matéria sub judice. - "Inarredável a competência deste Conselho para controle da atuação administrativa do Poder Judiciário, nos termos do parágrafo $4^{\circ}$ do artigo 103-B da Constituição Federal, mas não deve o CNJ avançar no debate de sorte a atingir eventual decisão judicial, ou nela intervir, por razão de segurança jurídica e respeito à função jurisdicional, evitando-se possíveis pronunciamentos conflitantes" (CNJ - PCA 631 - Rel. Cons. Altino Pedrozo - 44a Sessão - j. 31.07.2007 - DOU 17.08.2007 Ementa não oficial); c) RECLAMAÇÃO DISCIPLINAR. RECURSO ADMINISTRATIVO. DECISÃO QUE DETERMINOU O ARQUIVAMENTO DO FEITO. MATÉRIA JURISDICIONALIZADA. AUSÊNCIA DE INDÍCIOS DE IRREGULARIDADES POR PARTE DE DESEMBARGADORA QUE ATUOU EM AÇÃO RESCISÓRIA. INSURGÊNCIA CONTRA ATO COM CONTEÚDO DECISÓRIO. INCOMPETÊNCIA DA CORREGEDORIA. 1. A jurisdicionalização da matéria e a ausência de elementos de irregularidades perpetradas por membro do Poder Judiciário que atuou no feito obstam a atuação da Corregedoria Nacional de Justiça, devendo ser confirmada a decisão que determinou o arquivamento do presente procedimento. 2. Recurso administrativo não provido (CNJ - RA - Recurso Administrativo em RD Reclamação Disciplinar - 0004382-46.2012.2.00.0000 - Rel. ELIANA CALMON - 153 ${ }^{\mathrm{a}}$ Sessão - j. 04/09/2012).

${ }^{221}$ Nesse sentido: PROCEDIMENTO DE CONTROLE ADMINISTRATIVO - SUBSTITUIÇÃO DE NOTÁRIO AFASTADO - JURISDICIONALIZAÇÃO SUPERVENIENTE. I. Questão jurisdicionalizada ao longo da apreciação do pleito por meio de impetração de mandado de segurança perante o TJPR (MS $n^{\circ}$ 430565-3/PR). II. Procedimento de controle administrativo não-conhecido.(CNJ - PCA - Procedimento de Controle Administrativo - 0001263-53.2007.2.00.0000 - Rel. Mairan Gonçalves Maia Júnior - 53 ${ }^{\mathrm{a}}$ Sessão - j. 04/12/2007). 
administrativas do Judiciário judicializadas mas ainda não julgadas, tem se autolimitado, deixando de conhecê-las para evitar a alteração do curso normal das competências jurisdicionais e conflito de decisões.

\subsection{Casuística: alteração de acordo judicial e retirada de eficácia de decisões proferidas em writs pelo CNJ.}

Como abordado, o Conselho Nacional de Justiça não foi contemplado constitucionalmente com a missão de promover a função típica do Judiciário, ou seja, o exercício da jurisdição, de modo que não lhe compete rever decisões judiciais ou analisar incorreções na apreciação de provas em meios judicialiformes, sob pena de usurpação de atribuições e da independência dos demais órgãos do Poder.

A competência do $\mathrm{CNJ}$ é, pois, restrita ao âmbito administrativo, sendo um órgão jurisdicionalmente estéril ${ }^{222}$.

Não obstante, por vezes o Supremo Tribunal Federal foi acionado para afastar decisões do Conselho Nacional de Justiça que ultrapassaram os limites de suas atribuições constitucionais e invadiram esfera de competência jurisdicional.

Os dois casos a seguir apresentados bem ilustram o afirmado.

O primeiro refere-se à decisão exarada no Procedimento de Controle Administrativo $\mathrm{n}^{\mathrm{o}}$ 0001300-46.2008.2.00.0000 no qual três titulares de precatório de natureza alimentar do Estado da Bahia afirmaram que, segundo lista publicada pelo Tribunal de Justiça Baiano em 7 de novembro de 2006, estavam na $18^{\text {a }}$ colocação da ordem cronológica de pagamento. Porém, em 2007, após o Núcleo Auxiliar de Conciliação de Precatórios do TJBA realizar acordo com os credores do Estado para pagamento dos precatórios com descontos, com o qual não concordaram os requerentes, em nova lista publicada em 20 de março de 2008, foi desmembrado seu precatório em três, um para cada postulante, sendo eles reposicionados da $18^{\mathrm{a}}$ colocação para as posições $516^{\mathrm{a}}, 518^{\mathrm{a}}$ e $520^{\mathrm{a}}$ da lista, além de ter sido aplicado $53 \%$ de deságio ao valor original.

Argumentaram que esse ato violou a ordem cronológica de pagamento de precatórios, determinada pelo art. 100 da Constituição Federal, além de infringir o princípio da isonomia (CF, art. $\left.5^{\circ}, \mathrm{II}\right)$.

Requereram: a) a desconstituição dos atos administrativos - lista e termo de

\footnotetext{
${ }^{222}$ Expressão utilizada no voto do Conselheiro Antonio Umberto de Souza Júnior apresentado no Recurso Administrativo no Procedimento de Controle Administrativo no 2007.10.00.001276-3
} 
conciliação - citados; b) o reposicionamento do seu precatório na $18^{\text {a }}$ colocação; e, c) a determinação, ao TJBA, de pagamento dos requerentes no valor integral a que tinham direito.

Na decisão monocrática proferida em 25 de agosto de 2008 no PCA n n $^{\circ} 0001300$ 46.2008.2.00.0000, o Conselheiro Joaquim Falcão, primeiro, afastou alegação do Tribunal de Justiça da Bahia de que a impugnada nova lista de ordem cronológica de pagamento de precatórios decorreu de ato jurisdicional. Afirmou que referida listagem é ato administrativo consoante entendimento do Supremo Tribunal Federal firmado na ADI $\mathrm{n}^{\mathrm{o}}$ $1098^{223}$ e do Conselheiro Paulo Schmidt no Pedido de Providências no $201^{224}$. Em seguida, reconheceu a inconstitucionalidade da alteração da ordem cronológica de pagamento de precatórios $^{225}$, mesmo decorrente de conciliação e acordo judicial e determinou, ante a

${ }^{223}$ Segue a ementa do julgado:

PRECATÓRIO - OBJETO. Os preceitos constitucionais direcionam à liquidação dos débitos da Fazenda. O sistema de execução revelado pelos precatórios longe fica de implicar a perpetuação da relação jurídica devedor-credor. PRECATÓRIO - TRAMITAÇÃO - REGÊNCIA. Observadas as balizas constitucionais e legais, cabe ao Tribunal, mediante dispositivos do Regimento, disciplinar a tramitação dos precatórios, a fim de que possam ser cumpridos. PRECATÓRIO - TRAMITAÇÃO - CUMPRIMENTO - ATO DO PRESIDENTE DO TRIBUNAL - NATUREZA. A ordem judicial de pagamento $\left(\S 2^{\circ}\right.$ do artigo 100 da Constituição Federal), bem como os demais atos necessários a tal finalidade, concernem ao campo administrativo e não jurisdicional. A respaldá-la tem-se sempre uma sentença exeqüenda. PRECATÓRIO VALOR REAL - DISTINÇÃO DE TRATAMENTO. A Carta da República homenageia a igualação dos credores. Com ela colide norma no sentido da satisfação total do débito apenas quando situado em certa faixa quantitativa. PRECATÓRIO - ATUALIZAÇÃO DE VALORES - ERROS MATERIAIS - INEXATIDÕES CORREÇÃO - COMPETÊNCIA. Constatado erro material ou inexatidão nos cálculos, compete ao Presidente do Tribunal determinar as correções, fazendo-o a partir dos parâmetros do título executivo judicial, ou seja, da sentença exeqüenda. PRECATÓRIO - ATUALIZAÇÃO - SUBSTITUIÇÃO DE ÍNDICE. Ocorrendo a extinção do índice inicialmente previsto, o Tribunal deve observar aquele que, sob o ângulo legal, vier a substituí-lo. PRECATÓRIO - SATISFAÇÃO - CONSIGNAÇÃO - DEPÓSITO. Não se há de confundir a consignação de créditos, a ser feita ao Poder Judiciário, com o depósito do valor do precatório, de responsabilidade da pessoa jurídica devedora à qual são recolhidas, materialmente, 'as importâncias respectivas' ( $§ 2^{\circ}$ do artigo 100 da Constituição Federal)" (ADI 1098, Relator Min. MARCO AURÉLIO, Tribunal Pleno, julgado em 11/09/1996, DJ 25-10-1996).

${ }^{224}$ Afirmou o Conselheiro Paulo Schmidt em decisão monocrática proferida no Pedido de Providências $n^{\circ}$ 201 em 13 de junho de 2006: "Desde logo, sublinho que tem natureza administrativa o ato do Presidente do Tribunal que formaliza a requisição de pagamento de condenação judicial mediante precatório. Assim, eventual demanda que questiona o descumprimento ou a quebra da ordem cronológica reclama decisão de mesma natureza, o que legitima o CNJ ao conhecimento da matéria em questão".

${ }^{225} \mathrm{Na}$ decisão foram citadas as ementas de dois julgados do Supremo Tribunal Federal sobre o tema a seguir reproduzidas:

a) Rcl 1893 / RN - EMENTA: RECLAMAÇÃO. PRECATÓRIO. CONCILIAÇÃO. QUEBRA DA ORDEM. SEQÜESTRO. AFRONTA À DECISÃO PROFERIDA NA ADI 1662- SP. INEXISTÊNCIA. 1. Ordem de seqüestro fundada no vencimento do prazo para pagamento do precatório ( $\S 4^{\circ}$ do artigo 78 do $\mathrm{ADCT} / 88$, com redação dada pela EC 30/00), bem como na existência de preterição do direito de precedência. Embora insubsistente o primeiro fundamento, conforme decidido na Ação Direta de Inconstitucionalidade 1662-SP, remanesce motivação suficiente a legitimar o saque forçado de verbas públicas. 2. Quebra da cronologia de pagamentos comprovada pela quitação de dívida mais recente por meio de acordo judicial. A conciliação, ainda que resulte em vantagem financeira para a Fazenda Pública, não possibilita a inobservância, pelo Estado, da regra constitucional de precedência, com prejuízo ao direito 
impossibilidade fática de recolocar os requerentes em sua posição original na ordem de pagamentos, que, uma vez pagos os dezessete primeiros precatórios da nova lista, fossem satisfeitos os precatórios desmembrados decorrentes do precatório dos postulantes, em seu valor integral.

Para impugnar a decisão mencionada, o Estado da Bahia impetrou, perante o Supremo Tribunal Federal, o Mandado de Segurança $n^{\circ}$ 27708. Alegou nulidade do processo administrativo, ante a inobservância do devido processo legal, consideradas a ausência de sua oitiva e a atuação monocrática do Conselheiro relator.

$\mathrm{O}$ writ foi distribuído à relatoria do Ministro Marco Aurélio Mello que, em 8 de novembro de 2008, deferiu a liminar pleiteada e suspendeu a decisão prolatada no

preferencial dos precatórios anteriores. 3. A mutação da ordem caracteriza violação frontal à parte final do $\S$ 2 do artigo 100 da Constituição Federal, legitimando a realização do seqüestro solicitado pelos exeqüentes prejudicados. 4. Reclamação julgada improcedente. DJ 08-03-2002;

b) RE 132031 / SP - EMENTA: EXECUÇÃO CONTRA A FAZENDA PÚBLICA - QUANTIA CERTA REGIME CONSTITUCIONAL DOS PRECATÓRIOS - DESRESPEITO À ORDEM CRONOLÓGICA SEQÜESTRO DETERMINADO - PRETENSÃO AO PAGAMENTO PARCELADO (ADCT/88, ART. 33) - IMPOSSIBILIDADE - RE NÃO CONHECIDO. - O regime constitucional de execução por quantia certa contra o Poder Público - qualquer que seja a natureza do crédito exequendo (RTJ 150/337) - impõe a necessária extração de precatório, cujo pagamento deve observar, em obséquio aos princípios ético-juridícos da moralidade, da impessoalidade e da igualdade, a regra fundamental que outorga preferência apenas a quem dispuser de precedência cronológica (prior in tempore, potior in jure). A exigência constitucional pertinente à expedição de precatório - com a conseqüente obrigação imposta ao Estado de estrita observância da ordem cronológica de apresentação desse instrumento de requisição judicial de pagamento - tem por finalidade (a) assegurar a igualdade entre os credores e proclamar a inafastabilidade do dever estatal de solver os débitos judicialmente reconhecidos (RTJ 108/463), (b) impedir favorecimentos pessoais indevidos e (c) frustrar tratamentos discriminatórios, evitando injustas perseguições ditadas por razões de caráter políticoadministrativo. PODER PÚBLICO - PRECATÓRIO - INOBSERVÂNCIA DA ORDEM CRONOLÓGICA DE SUA APRESENTAÇÃO. - A Constituição da República não quer apenas que a entidade estatal pague os seus débitos judiciais. Mais do que isso, a Lei Fundamental exige que o Poder Público, ao solver a sua obrigação, respeite a ordem de precedência cronológica em que se situam os credores do Estado. - A preterição da ordem de precedência cronológica - considerada a extrema gravidade desse gesto de insubmissão estatal às prescrições da Constituição - configura comportamento institucional que produz, no que concerne aos Prefeitos Municipais, (a) consequências de caráter processual (seqüestro da quantia necessária à satisfação do débito - $\mathrm{CF}$, art. 100, par. 2.), (b) efeitos de natureza penal (crime de responsabilidade, punível com pena privativa de liberdade - DL n. 201/67, art. 1., XII) e (c) reflexos de índole político-administrativa (possibilidade de intervenção do Estado no Município, sempre que essa medida extraordinária revelar-se essencial à execução de ordem ou decisão emanada do Poder Judiciário - CF, art. 35, IV, in fine). PAGAMENTO ANTECIPADO DE CREDOR MAIS RECENTE - ALEGAÇÃO DE VANTAGEM PARA O ERARIO PÚBLICO - QUEBRA DA ORDEM DE PRECEDÊNCIA CRONOLÓGICA - INADMISSIBILIDADE. - O pagamento antecipado de credor mais recente, em detrimento daquele que dispõe de precedência cronológica, não se legitima em face da Constituição, pois representa comportamento estatal infringente da ordem de prioridade temporal assegurada a todos os credores do Estado, de maneira objetiva e impessoal, pela Carta Politica. O legislador constituinte, ao editar a norma inscrita no art. 100 da Carta Federal, teve por objetivo evitar a escolha de credores pelo Poder Público. Eventual vantagem concedida ao erario público por credor mais recente não justifica, para efeito de pagamento antecipado de seu crédito, a quebra da ordem constitucional de precedência cronológica. $\mathrm{O}$ pagamento antecipado que daí resulte - exatamente por caracterizar escolha ilegítima de credor - transgride o postulado constitucional que tutela a prioridade cronológica na satisfação dos débitos estatais e autoriza, em conseqüência - sem prejuízo de outros efeitos de natureza jurídica e de caráter político-administrativo -, a efetivação do ato de seqüestro. DJ 19-04-1996. 
Procedimento de Controle Administrativo CNJ $\mathrm{n}^{\mathrm{o}}$ 0001300-46.2008.2.00.0000, do Conselho Nacional de Justiça.

Levado a jugamento em 29 de outubro de 2010, por maioria, o Pleno do Supremo Tribunal Federal, concedeu a ordem pleiteada no Mandado de Segurança $n^{\circ} 27708$ e, assentando a impropriedade da atuação do CNJ, declarou insubsistente a decisão proferida no referido.

A maioria dos Ministros ${ }^{226}$ acompanhou o voto do relator, Ministro Marco Aurélio Mello, que entendeu ter o Conselheiro alterado termo de conciliação e de compromisso judicial abrangente e, pois, extravasado os limites de suas atribuições administrativas, uma vez que envolveu aspectos substanciais de execuções contra a Fazenda Pública ${ }^{227}$.

Durante os debates, após ponderação do Ministro Dias Toffoli, que disse ter restado demonstrado no caso que houve invasão, pelo $\mathrm{CNJ}$, de relação jurídica já formatada, o que não era de sua competência, o Ministro relator ainda afirmou que, se aceita a atuação do Colegiado, "em todo e qualquer caso de satisfação de precatório com preterição, atendendo-se credores mais antigos, abrir-se-á a porta para correção perante o Conselho, deixando o tema, quanto às consequências, de ser jurisdicional propriamente dito", uma vez que, como também lembrado por ele e pelo Ministro Cezar Peluso, poderiam os interessados formular, judicialmente, pedido de sequestro. E a Ministra Cármen Lúcia salientou que, no caso de preterição de pagamento de precatório, há outras vias no próprio Poder Judiciário para restauração do direito violado, mas não se mostra correto o caminho trilhado ao Conselho Nacional de Justiça, que não exerce atividade jurisdicional e, portanto, não diz o direito no caso concreto, "menos ainda dizendo sobre algo que foi dito pelo próprio Poder Judiciário".

$\mathrm{Na}$ ementa do referido acórdão do STF constou expressamente que "detendo o Conselho Nacional de Justiça atribuições simplesmente administrativas, revela-se imprópria declaração a alcançar acordo judicial”228.

\footnotetext{
${ }^{226}$ Conforme extrato de ata, participaram do julgamento os Ministros Celso de Mello, Marco Aurélio Mello, Ellen Gracie, Cezar Peluso, Carlos Britto, Eros Grau, Cármen Lúcia e Dias Toffoli. Ficaram vencidos os Ministra Celso de Melo e Ellen Gracie. Não participaram do julgamento os Ministros Joaquim Barbosa (licenciado), Ricardo Lewandowski (justificadamente) e Gilmar Mendes (Presidente).

${ }^{227}$ O Ministro Marco Aurélio Mello, em seu voto, também demonstrou acolher os argumentos da impetrante ao afirmar que o Conselho Nacional de Justiça, existente situação jurídica constituída, deveria ter ouvido previamente os interessados antes de desfazer o ajustado e, por outro lado, a decisão não poderia ter sido proferida individualmente, pois competia ao colegiado enfrentar o versado no processo administrativo (vide item 2.3.2.2).

${ }^{228}$ Segue a ementa completa do acórdão proferido pelo STF no Mandado de Segurança no 27708 :
}

CONSELHO NACIONAL DE JUSTIÇA - ATRIBUIÇÃO - ACORDO JUDICIAL - 
Nota-se, pois, que o Supremo Tribunal Federal, mesmo em caso de alteração de classificação de precatórios por Tribunal de Justiça, entendeu que o Conselho Nacional de Justiça atuou além da sua competência constitucional, pois, ao determinar o desarranjo de transação judicial, exerceu indevido controle jurisdicional ${ }^{229}$.

O segundo caso refere-se à decisão proferida em 11 de dezembro de 2009 no Pedido de Providências $n^{\mathrm{o}}$ 0006179-62.2009.2.00.0000 pelo Corregedor Nacional de Justiça, Conselheiro Gilson Dipp, que resolveu "tornar sem efeito" ${ }^{\text {230 }}$ decisões concessivas em mandados de segurança proferidas pelo Tribunal de Justiça do Estado do Maranhão, reconhecedoras de direito adquirido à efetivação na titularidade do cartório, ainda que em vaga surgida após a Constituição Federal de 1988, de substitutos de serventias extrajudiciais, ante o preenchimento dos requisitos previstos no art. 208 da Constituição Federal de 1967, com a redação conferida pela Emenda Constitucional no 22, de 29 de

INTANGIBILIDADE. Detendo o Conselho Nacional de Justiça atribuições simplesmente administrativas, revela-se imprópria declaração a alcançar acordo judicial.

${ }^{229}$ Cumpre esclarecer que o Conselho Nacional de Justiça acabou por firmar entendimento no sentido de que não the cabe conhecer de questões relacionadas à expedição, ao processamento e ao cumprimento de precatórios judiciais, ainda que ostentem natureza administrativa, pois essa atribuição é da competência da respectiva Corte em que se processa o título e a eventual atuação do CNJ como instância ordinária revisora das decisões proferidas nesses casos inviabilizaria o exercício de sua missão constitucional. Nesse sentido, pode-se conferir os seguintes julgados administrativos:

a) PRECATÓRIO. SEQUESTRO DE VALOR. ALEGAÇÃO DE DESCUMPRIMENTO DA ORDEM CRONOLÓGICA. NATUREZA ADMINISTRATIVA DA DECISÃO. A natureza administrativa da atividade desenvolvida no processamento de precatórios não torna o $\mathrm{CNJ}$ instância ordinária de revisão das decisões proferidas nesses procedimentos (...) (PCA 2007.10.00.0008462, Rel. Cons. José Adonis Callou de Araújo Sá, j. 14.9.2007);

b) RECURSO ADMINISTRATIVO EM PROCEDIMENTO DE CONTROLE ADMINISTRATIVO. PRECATÓRIO. INCOMPETÊNCIA DO CNJ. A jurisprudência recente do CNJ entende ser incompetente o Conselho para revisar decisões acerca da expedição ou cumprimento de precatórios, apesar do caráter administrativo da matéria" (PCA 2008.10.00.000824-7, Rel. Cons. Paulo Lôbo, j. 24.6.2008);

c) RECURSO ADMINISTRATIVO. PEDIDO DE PROVIDÊNCIAS. TRIBUNAL DE JUSTIÇA DO ESTADO DA BAHIA. REGIME DE PRECATÓRIOS. NÃO COMPETÊNCIA DO CNJ. PRECEDENTES. RECURSO CONHECIDO. NEGADO PROVIMENTO. 1) Consoante a jurisprudência atual do Conselho Nacional de Justiça, não cabe a este imiscuir-se nos procedimentos alusivos à expedição e cumprimento de precatórios judiciais, ainda que ostentem nítido viés administrativo, pois funcionar como instância ordinária revisora das decisões nestes proferidas inviabilizaria o exercício de suas demais competências cometidas constitucionalmente. Procedimento de controle administrativo não conhecido; Precedentes do CNJ. 2) Recurso conhecido e negado provimento. (Recurso Administrativo no PP $\mathrm{n}^{\circ}$ PCA 000566337.2012.2.00.0000, Rel. Cons. José Roberto Neves Amorim, 158 a Sessão Ordinária, j. 13.11.2012 e PCA 0003350-69.2013.2.00.0000, Rel. Cons. Jefferson Kravchychyn, 173ª Sessão Ordinária, j. 6.8.2013).

${ }^{230}$ Não foi possível acessar a íntegra da decisão porque o Pedido de Providências $\mathrm{n}^{\circ}$ 000617962.2009.2.00.0000 tramitou em caráter sigiloso, sendo a informação obtida através da leitura das decisões concessivas de liminares proferidas pelo Ministro Celso de Mello em 8 de junho de 2010 nos Mandados de Segurança $n^{\circ} \mathrm{s} 28598$ e 28611 impetrados junto ao STF. 
junho de $1982^{231}$, e o escoamento do lapso temporal previsto no art. 54 da Lei $\mathrm{n}^{\mathrm{o}}$ 9.784/1999 232 sem a interposição de qualquer medida anulatória ou revogatória dos atos administrativos de nomeação de anterior Governador do Estado e/ou de anterior Presidente do Tribunal de Justiça ${ }^{233}$.

Foram impetrados perante o Supremo Tribunal Federal, os Mandados de Segurança $n^{\circ}$ s 28598 e 28611 contra o mencionado ato do Corregedor Nacional de Justiça, sendo distribuídos ao Ministro Celso de Mello que, em 8 de junho de 2010, deferiu os pedidos de liminares para, em relação às partes impetrantes, suspender cautelarmente, até final julgamento dos writs, os efeitos da decisão proferida Pedido de Providências $n^{0}$ 000617962.2009.2.00.0000, uma vez que a atuação do Corregedor Nacional de Justiça excedeu as atribuições institucionais outorgadas pela Constituição Federal ao Conselho Nacional de Justiça, que não exerce jurisdição e, portanto, não pode controlar ou interferir em decisões judiciais, modificando ou inibindo suas eficácias.

Interpostos agravos regimentais pela União, o Pleno do Supremo Tribunal Federal, por unanimidade, em julgamento conjunto realizado em 14 de outubro de 2010, manteve as liminares deferidas pelo Ministro Celso de Mello, corroborando o entendimento supramencionado.

$\mathrm{Na}$ ementa do acórdão da Suprema Corte restou expressamente consignado que o Conselho Nacional de Justiça, embora integrado a estrutura constitucional do Poder Judiciário, é instituição de caráter eminentemente administrativo e, portanto, não dispõe de atribuições funcionais que lhe permitam, monocratica ou colegialmente, "fiscalizar, reexaminar e suspender os efeitos decorrentes de atos de conteúdo jurisdicional emanados de magistrados e Tribunais em geral" 234 .

\footnotetext{
${ }^{231}$ Art. 208 (CF/1967). Fica assegurada aos substitutos das serventias extrajudiciais e do foro judicial, na vacância, a efetivação, no cargo de titular, desde que, investidos na forma da lei, contem ou venham a contar cinco anos de exercício, nessa condição e na mesma serventia, até 31 de dezembro de 1983.

${ }^{232}$ Art. 54 (Lei no 9.784/1999). O direito da Administração de anular os atos administrativos de que decorram efeitos favoráveis para os destinatários decai em cinco anos, contados da data em que foram praticados, salvo comprovada má-fé.

${ }^{233}$ Os mandados de segurança maranhenses foram interpostos contra ato do então Presidente do Tribunal de Justiça daquele Estado, que, em cumprimento à Resolução do Conselho Nacional de Justiça $n^{\circ} 80$, de 9 de junho de 2009, autorizou a divulgação de edital noticiando concurso público para a outorga de delegação de serviços notariais e de registros, declarando vaga, dentre outras, as serventias ocupadas pelos impetrantes (Nesse sentido: TJMA, Tribunal Pleno, Mandado de Segurança n. ${ }^{\circ}$ 023340-2008-Barra do Corda/MA, Rel. Des. José Bernardo Silva Rodrigues (voto divergente), maioria, DJMA de 26 de agosto de 2009).

${ }^{234}$ Segue a ementa completa do acórdão proferido pelo STF nos Agravos Regimentais nos Mandados de Segurança $\mathrm{n}^{\circ} \mathrm{s} 28598$ e 28611 : 
Quanto ao Mandado de Segurança n ${ }^{\circ}$ 28598, cumpre relatar que o writ foi, por decisão monocrática proferida pelo Ministro Celso de Mello em 15 de agosto de 2011, julgado prejudicado por carência superveniente ${ }^{235}$ uma vez que o acordão do Tribunal de Justiça do Maranhão atingido pela decisão proferida no PP $\mathrm{n}^{\circ}$ 0006179-62.2009.2.00.0000 foi reformado por decisão monocrática do Ministro Humberto Martins do Superior Tribunal de Justiça proferida em 10 de agosto de 2010 no Recurso Especial $n^{\circ} 1.199 .896$, transitada em julgado em 02 de setembro de 2010, fundada em diversos julgados dessa Corte.

Para justificar a decisão monocrática proferida ${ }^{236}$ com fundamento no artigo 557, § $1^{\text {o- }}$ A, do Código de Processo Civil ${ }^{237}$ no Recurso Especial no 1.199 .896 , o Ministro Humberto Martins mencionou diversos precedentes do Superior Tribunal de Justiça ${ }^{238}$ que estabeleceram a necessidade de realização de concurso público para a delegação com fim

CONCESSIVA DE MANDADO DE SEGURANÇA -INADMISSIBILIDADE - ATUAÇÃO "ULTRA VIRES” DO CORREGEDOR NACIONAL DE JUSTIÇA, PORQUE EXCEDENTE DOS ESTRITOS LIMITES DAS ATRIBUIÇÕES MERAMENTE ADMINISTRATIVAS POR ELE TITULARIZADAS INCOMPETÊNCIA ABSOLUTA DO CONSELHO NACIONAL DE JUSTIÇA, NÃO OBSTANTE ÓRGÃO DE CONTROLE INTERNO DO PODER JUDICIÁRIO, PARA INTERVIR EM PROCESSOS DE NATUREZA JURISDICIONAL - IMPOSSIBILIDADE CONSTITUCIONAL DE O CONSELHO NACIONAL DE JUSTIÇA (QUE SE QUALIFICA COMO ÓRGÃO DE CARÁTER EMINENTEMENTE ADMINISTRATIVO) FISCALIZAR, REEXAMINAR E SUSPENDER OS EFEITOS DECORRENTES DE ATO DE CONTEÚDO JURISDICIONAL, COMO AQUELE QUE CONCEDE MANDADO DE SEGURANÇA - PRECEDENTES DO SUPREMO TRIBUNAL FEDERAL - MAGISTÉRIO DA DOUTRINA - RECURSO DE AGRAVO A QUE SE NEGA PROVIMENTO. - O Conselho Nacional de Justiça, embora integrado a estrutura constitucional do Poder Judiciário como órgão interno de controle administrativo, financeiro e disciplinar da magistratura - excluídos, no entanto, do alcance de referida competência, o próprio Supremo Tribunal Federal e seus Ministros (ADI 3.367/DF) -, qualifica-se como instituição de caráter eminentemente administrativo, não dispondo de atribuições funcionais que the permitam, quer colegialmente, quer mediante atuação monocrática de seus Conselheiros ou , ainda, do Corregedor Nacional de Justiça, fiscalizar, reexaminar e suspender os efeitos decorrentes de atos de conteúdo jurisdicional emanados de magistrados e Tribunais em geral, razão pela qual mostra-se arbitrária e destituída de legitimidade jurídico-constitucional a deliberação do Corregedor Nacional de Justiça que , agindo " ultra vires”, paralise a eficácia de decisão que tenha concedido mandado de segurança. Doutrina. Precedentes (MS 28.598- MC-Agr/DF, Rel. Min. Celso de Mello, Pleno, v.g. ).

${ }^{235}$ Até 20 junho de 2014, o Mandado de Segurança n 28611 ainda não havia sido julgado pelo Pretório Excelso.

${ }^{236}$ A decisão referida recebeu a seguinte ementa:

ADMINISTRATIVO - SERVENTIA CARTORIAL - NECESSIDADE DE CONCURSO PÚBLICO NOMEAÇÃO - ATO NULO - DECADÊNCIA DO DIREITO DE AUTOTUTELA DA ADMINISTRAÇÃO - NÃO OCORRÊNCIA - RECURSO ESPECIAL PROVIDO.

${ }^{237}$ Art. 557 (CPC). O relator negará seguimento a recurso manifestamente inadmissível, improcedente, prejudicado ou em confronto com súmula ou com jurisprudência dominante do respectivo tribunal, do Supremo Tribunal Federal, ou de Tribunal Superior.

$[\ldots]$

$\S 1^{\circ}$-A Se a decisão recorrida estiver em manifesto confronto com súmula ou com jurisprudência dominante do Supremo Tribunal Federal, ou de Tribunal Superior, o relator poderá dar provimento ao recurso.

${ }^{238}$ AgRg no REsp 969.090/SC, Rel. Min. Mauro Campbell Marques, Segunda Turma, julgado em 16.3.2010, DJe 30.3.2010; AgRg no REsp 930.484/SC, Rel. Min. Humberto Martins, Segunda Turma, julgado em 20.8.2009, DJe 8.9.2009; REsp 966.086/SC, Rel. Min. José Delgado, Primeira Turma, julgado em 1.4.2008, DJe 5.5.2008. 
de investidura no cargo de titular de serventia cartorária após o advento da Constituição Federal de 1988.

As decisões do Superior Tribunal de Justiça, por seu turno, foram embasadas em outros diversos julgados do Supremo Tribunal Federal que, em sede de controle concentrado e abstrato, reconheceram a inconstitucionalidade de normas insertas em Constituições Estaduais que efetivaram nos cargos de titular vagos os substitutos das serventias extrajudiciais, preenchidos certos requisitos ${ }^{239}$.

${ }^{239}$ Nesse sentido:

a) 1. Por não implicar criação, extinção ou transformação de cargos, não é inconstitucional o parágrafo único do art. 13 do ADCT de Rondônia. 2. Por preterição de exigência de licitação, são incompatíveis, com o art. 175 da Constituição Federal, o art. 32, e seu parágrafo único, daquele mesmo ADCT estadual. 3. Por tornar privado o exercício de serventias, sem observância do requisito temporal do art. 32 do ADCT da República e investir serventuários independentemente, de concurso público, na titularidade de cartórios (art. 236, paragrafo 3., da CF), é inconstitucional o art. 266 da Constituição de Rondônia. 4. Por ser decorrência da competência assegurada nos artigos 127, paragrafo $3^{\circ}$ e 168 da Constituição Federal, não é com esta incompatível o art. 98 (caput) da Carta de Rondônia, que tornou explicita a autonomia financeira do Ministério Público. 5. Por se conter na iniciativa para a criação de cargos, não é inconstitucional o inciso I do mesmo art. 98, que tornou explícita a competência do Ministério Público para propor a fixação de vencimentos (ADI 126, Relator Min. OCTAVIO GALLOTTI, Tribunal Pleno, julgado em 29/08/1991, DJ 05-06-1992 PP-08427 EMENT VOL-01664-01 PP-00033 RTJ VOL-00138-02 PP-00357);

b) Direito Constitucional. Serventias notariais e de registro. Concurso público de provas e titulos (art. 236, par. 3., da Constituição Federal). 1. O ingresso na atividade notarial e de registro depende de concurso público de provas e títulos, nos termos do par. 3. do art. 236 da Constituição Federal. 2. Ofende esse princípio constitucional o disposto no par. 3. do art. 16 do A.D.C.T. da Constituição do Estado do Rio de Janeiro, que, sem prévio concurso de provas e titulos, torna efetivo, em caso de vacância, o direito a titularidade dos serviços notariais e de registro, em favor do substituto, desde que, legalmente investido, tenha ingressado na atividade, há mais de cinco anos, até a data da promulgação da C.F. 3. Ação Direta de Inconstitucionalidade (de tal dispositivo estadual) julgada procedente pelo S.T.F. Precedentes (ADI 552, Relator Min. SYDNEY SANCHES, Tribunal Pleno, julgado em 07/06/1995, DJ 25-08-1995 PP-26020 EMENT VOL-01797-01 PP-00018);

c) Direito Constitucional. Serventias judiciais, notariais e de registro. Concurso público de provas e títulos. 1 . Viola o princípio do inciso II do art. 37 da Constituição Federal o disposto no art. 22 do A.D.C.T. da Constituição do Estado de Goiás, no ponto em que, sem concurso prévio de provas e títulos, assegura aos substitutos das serventias judiciais, na vacância, o direito de acesso a titular, desde que legalmente investidos na função até 5 de outubro de 1988, obrigados, apenas, a se submeterem a prova específica de conhecimento das funções, na forma da lei. 2. Ofende, por outro lado, o princípio do par. 3. do art. 236 da Constituição Federal o disposto no referido art. 22 do A.D.C.T. da C.E. de Goiás, na parte em que, nas mesmas condições, independentemente de concurso de provas e títulos, assegura o mesmo direito a substitutos, nas serventias notariais e de registro. Precedente. 3. Ação Direta julgada procedente, pelo Supremo Tribunal Federal, declarando a inconstitucionalidade do art. 22 do A.D.C.T. da Constituição do Estado de Goiás (ADI 690, Relator Min. SYDNEY SANCHES, Tribunal Pleno, julgado em 07/06/1995, DJ 25-08-1995 PP-26021 EMENT VOL-01797-01 PP-00030); e, d) Direito Constitucional. Serventias judiciais e extrajudiciais. Concurso público: artigos 37, II, e 236, par. 3., da Constituição Federal. Ação Direta de Inconstitucionalidade do art. 14 do A.D.C.T. da Constituição do Estado de Santa Catarina, de 5.10.1989, que diz: "Fica assegurada aos substitutos das serventias, na vacância, a efetivação no cargo de titular, desde que, investidos na forma da lei, estejam em efetivo exercício, pelo prazo de três anos, na mesma serventia, na data da promulgação da Constituição". 1. É inconstitucional esse dispositivo por violar o princípio que exige concurso público de provas ou de provas e titulos, para a investidura em cargo público, como é o caso do Titular de serventias judiciais (art. 37, II, da C.F.), e também para o ingresso na atividade notarial e de registro (art. 236, par. 3.). 2. Precedentes do S.T.F. 3. Ação Direta de Inconstitucionalidade julgada procedente (ADI 363, Relator Min. SYDNEY SANCHES, Tribunal Pleno, julgado em 15/02/1996, DJ 03-05-1996 PP-13897 EMENT VOL01826-01 PP-00025). 
Nota-se, mais uma vez, que o Supremo Tribunal Federal, mesmo diante de vários precedentes da própria Corte e também do Superior Tribunal de Justiça contrários às decisões proferidas nos mandados de segurança julgados pelo Tribunal de Justiça do Estado do Maranhão, entendeu que o Conselho Nacional de Justiça, na pessoa do seu Corregedor, extrapolou os limites constitucionais de sua atuação ao torná-las sem efeito no Pedido de Providências $n^{\text {o }}$ 0006179-62.2009.2.00.0000, exercendo controle jurisdicional que não lhe compete.

\subsubsection{Limitações ao controle sobre funções atípicas desempenhadas no Judiciário}

Estudada a impossibilidade do Conselho Nacional de Justiça realizar controle de jurisdição, função típica do Judiciário, este item será dedicado à análise das limitações ao controle exercido pelo Colegiado sobre as funções atípicas desenvolvidas pelos órgãos desse Poder.

No nosso sentir, também não cabe ao CNJ exercer o controle de todas as chamadas funções atípicas exercidas no âmbito do Poder Judiciário, porque a Constituição lhe conferiu apenas o controle da atuação administrativa e financeira do Poder.

Necessário, pois, estabelecer, neste momento, o exato alcance dessa expressão: “controle da atuação administrativa e financeira do Poder Judiciário".

Para tanto importa, primeiro, distinguir os conceitos de atos da administração e atos administrativos. Em seguida, cumpre cotejá-los com a ideia de atividade financeira do Estado e, assim, definir quais atos praticados pelos órgãos do Poder Judiciário no exercício de funções atípicas estão sujeitos ao controle do Conselho Nacional de Justiça.

Oswaldo Aranha Bandeira de Melo (2010, p. 475) distingue os atos da administração dos atos administrativos. Ressalta que aqueles enfeixam qualquer ato da Administração Pública, material ou jurídico, praticado enquanto Poder Público ou nas condições de um particular. Os atos administrativos são apenas os atos jurídicos praticados pelos órgãos administrativos, "enquanto Poder Público, isto é, em que há manifestação da vontade autoritária estatal".

Esse caminho também é traçado por Celso Antônio Bandeira de Melo (2009, pp. 378 a 380), ao enumerar os seguintes atos da administração que não podem, porém, ser considerados atos administrativos: atos regidos pelo Direito Privado, atos materiais, atos políticos ou de governo. Em seguida, afirma o doutrinador haver atos não praticados pela Administração Pública, "mas que devem ser incluídos entre os atos administrativos, 
porquanto se submetem à mesma disciplina jurídica aplicável aos demais atos da Administração, habitualmente reputados como atos administrativos", incluindo os praticados pelas autoridades dos Poderes Legislativo e Judiciário.

Mas, se os órgãos desses Poderes, ainda que atipicamente, também exercem função administrativa, injustificável defender que não pratiquem atos da administração, apesar de realizarem atos administrativos, até porque esses órgãos também executam atos materiais e jurídicos disciplinados pelo Direito Privado, nas mesmas condições de particulares, além de atos políticos.

Assiste, pois, razão à Professora Maria Sylvia Zanella Di Pietro ao doutrinar que "todo ato praticado no exercício da função administrativa é ato da Administração" (2012, p. 197). Logo, os Poderes Legislativo e Judiciário, no desempenho de suas atípicas funções de administrar, também praticam atos da administração.

A administrativista apresenta os seguintes atos que podem ser exercidos pela Administração, não importa a que Poder pertença o órgão que os pratique (2012, pp. 197 e 198):

1. os atos de direito privado, como doação, permuta, compra e venda, locação;

2. os atos materiais da Administração, que não contêm manifestação de vontade, mas que envolvem apenas execução, como a demolição de uma casa, a apreensão de mercadoria, a realização de um serviço;

3. os atos políticos, que estão sujeitos a regime jurídico-constitucional;

4. os contratos;

5. os atos normativos da Administração, abrangendo decretos, portarias, resoluções, regimentos, de efeitos gerais e abstratos;

6. os atos administrativos propriamente ditos.

Também esclarece a autora que os diversos atos da administração podem ou não produzir efeitos jurídicos. Inclui, nessa última categoria, que não se amolda ao seu conceito de ato administrativo propriamente dito, os seguintes (2012, pp. 203 e 204):

1. os atos materiais, de simples execução, como a reforma de um prédio, um trabalho de datilografia, a limpeza de ruas, etc;

2. os despachos de encaminhamento de papéis e processos;

3. os atos enunciativos ou de conhecimento, que apenas atestam ou 
declaram a existência de um direito ou situação, como os atestados, certidões, declarações, informações;

4. os atos de opinião, como os pareceres e laudos.

A professora do Largo de São Francisco, assim, define ato administrativo (propriamente dito) "como a declaração do Estado ou de quem o represente, que produz efeitos jurídicos imediatos, com observância da lei, sob regime jurídico de direito público e sujeita a controle pelo Poder Judiciário"240 (2012, p. 203).

Não há similitude, pois, entre ato da administração e ato administrativo. Este, na verdade, é uma espécie daquele.

Neste ponto indaga-se: $\mathrm{O}$ controle da atuação administrativa e financeira exercido pelo Conselho Nacional de Justiça atinge todos os atos da administração? Ou abrange apenas os atos administrativos praticados pelos órgãos do Poder Judiciário?

A resposta a ambas as questões, ao nosso ver, é negativa. Mas, para responder o porquê dessa conclusão deve-se, antes, conceituar o que é atividade financeira do Estado, uma vez que, segundo a regra inserta no art. 103-B $\S 4^{\circ}$, da Constituição Federal, também compete ao CNJ o controle da atuação financeira do Poder Judiciário.

Aliomar Baleeiro reza que "a atividade financeira consiste em obter, criar, gerir e despender o dinheiro indispensável às necessidades, cuja satisfação o Estado assumiu ou cometeu àqueloutras pessoas de direito público" $(1969$, p. 18).

Kiyoshi Harada conceitua atividade financeira do Estado "como sendo a atuação estatal voltada para obter, gerir e aplicar os recursos financeiros necessários à consecução das finalidades do Estado que, em última análise, se resumem na realização do bem comum" (2013, p. 4).

Diante desses conceitos, poder-se-ia, açodadamente, concluir que, se ao Conselho Nacional de Justiça compete o controle da atuação administrativa e financeira do Judiciário, cabe-lhe exercer o controle sobre todos os atos de administração praticados pelos diversos órgãos desse Poder e não apenas sobre os atos administrativos propriamente ditos, pois não só estes implicam na obtenção, gerenciamento ou aplicação de recursos financeiros para a consecução das suas finalidades.

De fato, para exemplificar, se órgão do Poder Judiciário celebra contrato de locação regido pelo direito privado, este contrato está sujeito ao controle do $\mathrm{CNJ}$ pois, ainda que

\footnotetext{
${ }^{240} \mathrm{O}$ controle referido pela autora é o jurisdicional, que pode também ser exercido pelo próprio Poder Judiciário em relação a atos administrativos praticados por seus órgãos internos.
} 
não tenha sido praticado ato administrativo propriamente dito, há, no caso, atividade financeira estatal.

Mas, como será exposto, algumas atos praticados no exercício de função administrativa pelos órgãos do Poder Judiciário não envolvem a obtenção, gerenciamento ou aplicação de recursos financeiros. Por outro lado, há atos de administração realizados no seio desse Poder que, por suas próprias características, não podem se sujeitar a controle do Conselho Nacional de Justiça.

Necessário, pois, analisar cada uma das espécies de atos da administração mencionadas e verificar se compete ao Conselho Nacional de Justiça controlá-las.

a) Atos administrativos (propriamento ditos):

Não há dúvida que os atos administrativos (propriamente ditos) praticados pelos diversos órgãos do Poder Judiciário estão sujeitos ao controle do Conselho Nacional de Justiça, pois produzem efeitos jurídicos imediatos e devem ser realizados com observância da lei. Ademais, na maioria das vezes, esses atos têm repercussão financeira. O CNJ, por exemplo, pode rever as decisões administrativas que concedam ou neguem o pagamento de diárias como indenização pelo custeio de alimentação, hospedagem e locomoção urbana a magistrados que, eventual e transitoriamente, tenham que se deslocar de suas sedes por motivo de interesse público ${ }^{241}$.

b) Atos de direito privado:

Uma vez que, apesar de não serem exercidos sob regime de direito público, também devem ser praticados com observância da lei, produzem efeitos jurídicos imediatos e implicam atividade financeira, estão sujeitos ao controle do Conselho os atos de direito privado realizados pelos órgão do Poder Judiciário. O CNJ pode, ilustrativamente, controlar se doações de equipamentos de informática obsoletos realizadas pelos tribunais $^{242}$ estão de acordo com os ditames legais ${ }^{243}$.

\footnotetext{
${ }^{241}$ A Resolução CNJ n ${ }^{\text {0 }} 73$, de 28 de abril de 2009, dispõe sobre a concessão e pagamento de diárias no âmbito do Poder Judiciário.

${ }^{242}$ Sob o título "TJMT faz doação de 100 computadores para entidades sociais", o próprio CNJ noticiou, em 16 de novembro de 2010, a inicitativa do Tribunal de Justiça do Mato Grosso de encerrar o ano de 2010 com a doação de conjuntos completos de computadores usados inservíveis para o Poder Judiciário a entidades filantrópicas sem fins lucrativos (Disponível em: <http://www.cnj.jus.br/noticias-gerais/10226-tjmt-faz-
} 
c) Contratos administrativos:

Os contratos administrativos também estão sujeitos ao controle do Conselho Nacional de Justiça, pois, celebrados “sob regime jurídico publicístico, derrogatório e exorbitante do direito comum" (DI PIETRO, 2012, p. 269), criam obrigações financeiras e devem obedecer a forma prescrita em lei, com prévio processo licitatório, salvo hipótese em que é dipensada ou inexigível ${ }^{244}$.

d) Atos materiais:

Os atos materiais praticados pelos órgãos do Poder Judiciário também são passíveis de controle pelo Conselho Nacional de Justiça. Hely Lopes Meirelles (1999, p. 133) os denomina de fatos administrativos e assim pontifica:

Fato administrativo é toda realização material da Administração em cumprimento de alguma decisão administrativa, tal como a construção de uma ponte, a instalação de um serviço público etc. O fato administrativo, como materialização da vontade administrativa, é do domínio da técnica e só reflexamente interessa ao Direito, em razão das consequências jurídicas que dele possam advir para a Administração e para os administrados. O que convém fixar é que o ato administrativo não se confunde com o fato administrativo, se bem que estejam intimamente relacionados, por ser este consequência daquele. $\mathrm{O}$ fato administrativo resulta sempre do ato administrativo ${ }^{245}$ que o determina.

doacao-de-100-computadores-para-entidades-sociais $>$. Acesso em 18.04.2014). A ratificação da iniciativa também é um exemplo de exercício de controle pelo Conselho, no caso sobre a ação do Tribunal Matogrossense.

${ }^{243}$ A norma inserta no art. 17, II, "b”, da Lei n ${ }^{\circ}$ 8.666, de 21 de junho de 1993, permite a doação de bens móveis da Administração Pública com dispensa de licitação "exclusivamente para fins e uso de interesse social, após avaliação de sua oportunidade e conveniência sócio-econômica, relativamente à escolha de outra forma de alienação".

${ }^{244}$ As normas insertas nos arts. 24 e 25 da Lei no 8.666, de 21 de junho de 1993, tratam das hipóteses de dispensabilidade e inexigibilidade de licitação.

${ }^{245}$ Cumpre lembrar que Hely Lopes Meirelles (1999, p. 132) não faz distinção ampla entre atos da administração e atos administrativos, diferenciando estes somentes dos atos de direito privado, dos contratos administrativos e dos atos materiais (fatos administrativos). Assim, conceitua ato administrativo como "toda manifestação unilateral de vontade da Administração Pública que, agindo nessa qualidade, tenha por fim 
Diogenes Gasparini (2011, p. 109), que denomina os atos materiais de atos ajurídicos, não destoa desse entendimento. Para ele, esses atos não visam produzir qualquer efeito jurídico. E assim prossegue na sua doutrina:

Não expressam uma manifestação de vontade, juízo ou conhecimento da Administração Pública sobre dada situação. Traduzem mero trabalho ou operação técnica dos agentes públicos. não têm, portanto, laivos de juridicidade. Com isso não se está afirmando que deles não possa decorrer efeito de natureza jurídica, a exemplo do direito à indenização que o administrado tem se, ao ser operado, o cirurgião servidor público atuou negligentemente e lhe causou um dano estético. São exemplos de atos materiais os de dar aula e os de varrer rua.

Assim, apesar de não produzirem efeitos jurídicos, os atos materiais, como visto, concretizam a vontade administrativa e sua execução pode produzir efeitos jurídicos. Portanto, compete ao Conselho Nacional de Justiça controlá-los, inclusive para monitorar a precisa execução de suas próprias decisões.

O atual Regimento Interno do Conselho Nacional de Justiça (Resolução CNJ no 67, de 3 de março de 2009) até estabelece, como uma das classes processuais de feitos do órgão, o "Acompanhamento de Cumprimento de Decisão" (art. 43, XIII) e, quanto a ela, disciplina caber à Secretaria-Geral o acompanhamento do fiel cumprimento dos atos e decisões do Colegiado, e à Secretaria da Corregedoria Nacional de Justiça, o das deliberações do seu (art. 104). Ainda prevê que, comprovada a resistência ao cumprimento da decisão proferida pelo Conselho em mais de 30 dias além do prazo estabelecido, o Plenário, o Presidente ou o Corregedor Nacional de Justiça, de ofício ou por reclamação de interessado, adotará as providências que entenderem cabíveis à sua imediata efetivação, sem prejuízo da instauração do competente procedimento disciplinar contra a autoridade recalcitrante e, quando for o caso, do envio de cópias ao Ministério Público para a adoção das providências pertinentes (art. 105).

Para exemplificar, cumpre lembrar que no mencionado Procedimento de Controle Administrativo $\mathrm{n}^{\mathrm{o}}$ 0001470-18.2008.2.00.0000, onde o Conselho Nacional de Justiça 
reconheceu a autonomia dos tribunais para fixação do horário de expediente forense, mas determinou às Secretarias das Varas do TRT da $5^{\text {a }}$ Região - Bahia - a prestação de atendimento aos advogados enquanto houver serventuário em atividade, ainda que aquém ou além do horário de expediente fixado pela Presidência daquela Corte, em atenção à norma inserta no artigo $7^{\circ}$, VI, “c”, da Lei n ${ }^{\circ} 8.906$, de 4 de jullho de $1994^{246}$. O fiel cumprimento dessa decisão passou a depender da consecução de atos materiais (abertura das portas das serventias, recepção dos profissionais, busca de autos etc) também sujeitos aos controle do Conselho Nacional de Justiça ${ }^{247248}$.

e) Atos enunciativos ou de conhecimento:

O Conselho Nacional de Justiça, no nosso sentir, também exerce controle sobre os denominados atos enunciativos ou de conhecimento, pois, apesar desses atos não ensejarem manifestação de vontade da Administração e, portanto, não produzirem, por si só, efeitos jurídicos imediatos, reflexamente podem gerar consequências jurídicas, uma vez que certificam, atestam ou declaram atos e situações ou direitos ${ }^{249}$.

\footnotetext{
${ }^{246}$ Vide item 2.3.3.1.

${ }^{247}$ No caso, devido à recepção de várias reclamações pelo não atendimento fora dos horários oficiais (ausência de atos materiais), houve denuncia pela Ordem dos Advogados do Brasil - Secção Bahia ao redator designado do acórdão do PCA n ${ }^{\circ}$ 0001470-18.2008.2.00.0000, Conselheiro Antonio Umberto de Souza Júnior, quanto ao desrespeito à decisão plenária do CNJ, sob a alegação de não ter o Presidente do TRT da $5^{\mathrm{a}}$ Região editado ato normativo para conformar-se o atendimento dos advogados antes e depois do horário de expediente fixado por aquela Corte. $\mathrm{O}$ dirigente daquele tribunal, porém, com apoio em manifestação de vários diretores de secretaria de varas do trabalho, afirmou o cumprimento da decisão do Conselho. $\mathrm{O}$ Conselheiro redator, por decisão monocrática proferida em 3 de junho de 2009, reconheceu que criou-se uma confusão de leituras do acórdão, porque, no último parágrafo da fundamentação, constou a necessidade da edição de novo ato normativo para explicitar a obrigatoriedade de atendimento dos advogados independetemente do horário oficial de funcionamento dos órgãos jurisdicionais trabalhistas baianos e, no dispositivo, consignou-se apenas a ordem de estrita observância (com a execução, pois, de atos materiais) do disposto no art. $7^{\circ}$, VI, “c”, da Lei 8.906/1994, inclusive antes e depois do horário de expediente fixado em ato normativo, desde que presente qualquer servidor na secretaria da Corte. A postulação, porém, foi julgada prejudicada porque, em 3 de junho de 2009, o Corregedor Regional da Justiça do Trabalho da $5^{\text {a }}$ Região expediu o Aviso $\mathrm{n}^{\circ} 32$ assegurando aos advogados o direito de acesso aos espaços das secretarias e setores das Varas do Trabalho e do Tribunal e atendimento, havendo, em qualquer horário, serventuário, nos termos da norma mencionada.

${ }^{248}$ Outro exemplo de controle de ato material pelo CNJ é o tratado na nota 512 do item 3.1.4.4, sobre o controle de distribuição de processos criminais no Tribunal de Justiça de São Paulo.

249 Hely Lopes Meirelles (1999, pp. 175/177) conceitua o que denomina de "atos administrativos enunciativos" (como exposto na nota de rodapé no 245 , o administrativista não distingue claramente atos da administração de atos administrativos) como "todos aqueles em que a Administração se limita a certificar ou a atestar um fato, ou emitir uma opinião sobre determinado assunto, sem se vincular ao seu enunciado". O doutrinador, pois, também não diferencia os atos enunciativos dos atos de opinião, tanto é que inclui os pareceres entre as espécies mais comuns de "atos administrativos enunciativos", junto com as certidões, atestados e apostilas. Importa sobremaneira, neste trabalho, porém, diferenciar os atos enunciativos
} 
Por exemplo, basta imaginar a emissão de certidões falsas de objeto e pé de processos judiciais, com informações inverídicas sobre o teor dos feitos e a fase ("pé”) em que se encontram $^{250}$ para gerar as mais diversas consequências jurídicas, como, ilustrativamente, permitir a participação de interessado em certame licitatório ${ }^{251}$. Compete, pois, ao CNJ fiscalizar a prática desses atos e administrativamente, se necessário, invalidá-los, sem prejuízo da adoção de providências administrativas disciplinares e criminais em face do seu emissor.

\section{f) Atos normativos:}

Os atos normativos expedidos pela Administração Pública são também denominados de atos regulamentares ou, simplesmente, regulamentos.

Segundo Hely Lopes Meirelles (1999, p. 161), “atos administrativos normativos são aqueles que contêm um comando geral do Executivo, visando a correta aplicação da lei”.

Também sobre os atos normativos, denominando-os de regulamentares, Luciano Ferreira Leite (1986, pp. 22 e 25) doutrina:

(certidões, atestados, apostilas) dos atos de opinião (pareceres e laudos), pois, como será exposto, quanto a estes não cabe controle do Conselho Nacional de Justiça sobre seu conteúdo.

${ }^{250}$ Ilustrativamente, pode ser citada notícia veiculada na imprensa no dia 30 de junho de 2014 sobre prisões efetuadas no Poder Judiciário da Comarca de Campinas, Estado de São Paulo, ocorridas em virtude de investigação sobre suposto esquema de fraudes na emissão de certidões civis e criminais, tanto no que diz respeito ao recolhimento das taxas cobradas pelos cartórios para conceder as certidões, quanto no que tange à legitimidade dos documentos emitidos. Nesse sentido pode ser conferidas as matérias publicadas sob os seguintes títulos:"Polícia prende 8 e apura fraudes em certidões do Judiciário de Campinas" (Disponível em: $<$ http://g1.globo.com/sp/campinas-regiao/noticia/2014/06/policia-civil-de-campinas-investiga-esquema-defalsificacao-de-certidoes.html>. Acesso em 30.08.2014); "Grupo é preso por falsificação de certidões" (Disponível em: <http://portal.tododia.uol.com.br/_conteudo/2014/06/cidades/31482-grupo-e-preso-porfalsificacao-de-certidoes.php>. Acesso em 30.08.2014); e, "Polícia Civil descobre esquema de fraude em cartórios e prende oito pessoas em Campinas" (Disponível em: $<$ http://www2.policiacivil.sp.gov.br/x2016/modules/news/article.php?storyid=5699>. Acesso em 30.08.2014).

${ }^{251}$ A Lei no 8.666, de 21 de junho de 1993, exige dos interessados em participar de licitações, dentre outros requisitos, documentação pertinente à qualificação econômico-financeira e à regularidade fiscal e trabalhista (art. 27, III e IV). Para conprovação da qualificação econômico-financeira há necessidade de apresentação de certidão negativa de falência ou concordata expedida pelo cartório distribuidor da sede da pessoa jurídica, ou de execução patrimonial, expedida no domicílio da pessoa física (art. 31, II). Para demonstrar a regularidade fiscal e trabalhista, exige-se a prova de regularidade para com a Fazenda Federal, Estadual e Municipal do domicílio ou sede do licitante, ou outra equivalente, na forma da lei (art. 29, III) e a prova de inexistência de débitos inadimplidos perante a Justiça do Trabalho (art. 29, V). A primeira prova pode ser feita através da apresentação da denominada "certidão positiva com efeitos de negativa", expedida nos termos do artigo 206 do Código Tributário Nacional, que pode ser obtida mediante entrega de documento que demostre haver cobrança executiva de tributo em que tenha sido efetivada a penhora ou com decisão suspendendo sua exigibilidade. A segunda prova que é realizada através da apresentação da Certidão Negativa de Débitos Trabalhistas (CNDT), prevista no artigo 642-A da Consolidação das Leis do Trabalho. 
Os atos regulamentares constituem-se, tanto quanto as demais categorias (atos individuais quanto aos destinatários ou concretos quanto a estrutura) em comandos complementares da lei, possibilitando, ao contrário dos atos concretos, repetidas aplicações, na medida em que reiterarem as hipóteses neles previstas. [...]

A única forma possível de se estabelecer nítida distinção, entre ato legislativo e ato regulamentar decorre de que o primeiro se constitui em criação do direito. Em outras palavras, através da função legislativa o Estado inova primariamente a ordem jurídica.

Nota-se que os atos normativos se assemelham aos atos legislativos, tipicamente emanados do Poder Legislativo, pois contém normas gerais, abstratas e impessoais, mas são editados pela Administração Pública. Em regra, não podem inovar no Ordenamento Jurídico $^{252}$, pois devem obediência à lei e à Constituição.

Como podem produzir efeitos jurídicos e materiais, compete ao Conselho Nacional de Justiça também exercer o controle dos atos normativos expedidos pelos órgãos do Poder Judiciário.

Esse controle, porém, como será exposto ${ }^{253}$, não pode objetivar o afastamento da incidência da própria lei que fundamenta a validade do ato normativo expedido, pois não compete ao CNJ a verificação da compatibilidade de lei com a Constituição. Assim, o CNJ não pode a invalidar atos normativos expedidos por órgãos do Judiciário que se limitem a dar cumprimento a lei. O controle que o Colégio Administrativo exerce é da legalidade dos atos regulamentares editados pelos seus órgãos controlados, e não da constitucionalidade da lei em que eles se respaldam.

Também não compete ao Conselho, como abordaremos adiante ${ }^{254}$, o controle das atos normativos expedidos pela Justiça Eleitoral para disciplinar suas matérias específicas, ante as particularidades desse braço do Poder Judiciário, bem como o controle das sentenças normativas trabalhistas, pois emanadas no exercício da função jurisdicional.

g) Atos de opinião:

\footnotetext{
${ }^{252} \mathrm{O}$ Supremo Tribunal Federal reconheceu, no julgamento da $\mathrm{ADC} \mathrm{n}^{\mathrm{o}} 12$, que Conselho Nacional de Justiça, através do manejo do seu poder normativo previsto no art. 103-B, § $4^{\circ}$, I, da Carta da República, pode, no âmbito de suas competências, expedir ato regulamentar de conteúdo primário, inovador na ordem jurídica. Vide item 3.1.8.

${ }^{253}$ Vide item 3.1.4.4.

${ }^{254}$ Vide itens 2.3.7.3 e 2.3.7.4.
} 
O controle da atuação administrativa e financeira realizado pelo Conselho Nacional de Justiça sobre os denominados atos de opinião praticados no âmbito do Poder Judiciário no exercício da função administrativa não é pleno.

Para esclarecer essa afirmação, necessário se faz, primeiro, definir e apresentar as principais espécies de atos de opinião.

Em sentido estrito, atos de opinião seriam somente os pareceres, atos pelos quais órgãos da administração manifestam seus entendimentos, suas ideias, seus pensamentos sobre determinados assuntos submetidos às suas avaliações.

Adotar-se-á neste trabalho, porém, um conceito mais amplo mais para englobar, entre os atos de opinião, também os atos em que a administração manifesta um desejo ou faz uma sugestão.

Assim, nesta investigação, ato de opinião é o ato pelo qual a administração manifesta seu entedimento, sua ideia, seu pensamento ou seu desejo, ou faz uma sugestão sobre determinado assunto.

Observado esse conceito, podem ser destacados, dentre as espécies de atos de opinião, o parecer, a proposta, o voto e a denúncia.

Parecer é o ato pelo qual a administração manifesta sua opinião fundamentada sobre assuntos jurídicos, técnicos e administrativos submetidos à sua consideração ${ }^{255}$.

Proposta é o ato pelo qual um órgão da administração "faz sugestão a outro para a prática de determinado ato jurídico" (MELLO, 2010, p. 585).

Voto é o ato pelo qual os membros de um colégio se pronunciam para formação da vontade colegiada, a deliberação.

Denúncia é o ato "de agente público ou de particular, informando a órgão da Administração Pública de dada situação de fato, que lhe serve de elemento para poder atuar nos termos da sua competência, em atenção ao interesse da coletividade e à ordem pública” (MELLO, 2010, p. 585).

Cumpre destacar que, como os atos de opinião não produzem efeitos jurídicos

\footnotetext{
${ }^{255}$ Nesse sentido Oswaldo Aranha Bandeira de Mello (2010, p. 583), Hely Lopes Meirelles (1999, p. 176), Maria Sylvia Zanella Di Pietro (2012, p. 237) e Diogenes Gasparini (2011, p. 143). Cumpre ainda destacar que, em 5 de setembro de 2002, no julgamento do Mandado de Segurança $\mathrm{n}^{\circ}$ 24.073, impetrado perante o Supremo Tribunal Federal, o relator, Ministro Carlos Velloso, expressamente afirmou em seu voto vencedor, em relação ao parecer emitido por procurador ou advogado (mas a lição também se aplica, por analogia, aos demais pareceres administrativos), que o parecer "não é ato administrativo. Nada mais é do que a opinião emitida pelo operador do direito, opinião técnico-jurídica, que orientará o administrador na tomada da decisão, na prática do ato administrativo, que se constitui na execução 'ex officio'da lei”.
} 
imediatos $^{256}$ e não traduzem atividade material administrativa, aqueles praticados no âmbito do Poder Judiciário não estão sujeitos, em princípio, ao controle de atuação administrativa e financeira exercido pelo Conselho Nacional de Justiça.

Com efeito, o controle exercido pelo CNJ deve ocorrer sobre a decisão administrativa e o ato da administração dela decorrente e não sobre os atos de opinião que lhe serviram de suporte.

Por exemplo, se um órgão administrativo de Tribunal do Poder Judiciário propõe a adoção de determinada rotina de trabalho para melhoria do atendimento ao jurisdicionado e o Presidente da Corte, convencido pelos argumentos apresentados, determina sua adoção, o Conselho Nacional de Justiça exercerá controle sobre o ato presidencial e os atos materiais dele decorrentes, e não sobre a proposta administrativa.

Somente estarão sujeitos ao controle de atuação administrativa e financeira do CNJ os atos de opinião que passem a integrar a decisão que determine a realização de outro ato da administração, por consistirem na sua própria motivação ${ }^{257}$.

E, mesmo nessa hipótese, o controle da atuação administrativa e financeira realizado pelo Conselho Nacional de Justiça não permite a esse órgão que imponha a realização de ato de opinião em determinado sentido.

A Constituição Federal inclui, no rol dos direitos e garantias fundamentais $(\mathrm{CF}$, art. $5^{\circ}$ ), a liberdade da manifestação de pensamento, vedado o anonimato (inc. IV), a liberdade de expressão da atividade intelectual, artística, científica e de comunicação, independente de censura ou licença (inc. IX), a liberdade no exercício de qualquer trabalho, ofício ou

\footnotetext{
${ }^{256}$ Mesmo o voto, singularmente considerado, não produz efeitos jurídicos imediatos. O que produz efeitos jurídicos é o ato do colegiado, a deliberação, extraída pelo computo dos votos singulares. Um voto vencido, por exemplo, pode nunca produzir qualquer efeito jurídico, exceto se o tema exigir unanimidade ou maioria qualificada de votos, ou se o voto vencido permitir o manejo de algum meio de impugnação da deliberação tomada pela maioria (como no caso dos embargos infringentes previstos nas leis processuais - CPC, arts. 496, III; 498; 500, II; 508; 530 a 534; 551, caput; e, 553; CPP, art. 609, parágrafo único; e, CLT, art. 894, I). Ugo Gargiulo (1962, pp. 221/222) leciona que, através do voto, o colégio exprime sua proposta, após a discussão. $\mathrm{O}$ voto, última fase do procedimento deliberativo, é a indicação da solução adotada pelo colegiado. $\mathrm{Na}$ votação, deve-se distinguir as normas que regram as manifestações referentes aos votos singulares dos componentes do colégio, ou seja, os vários sistemas de votação (aberto ou secreto), das normas que disciplinam os critérios segundo os quais todos os votos se unem ou se fundem, formando o ato colegiado. Nas palavras do doutrinador: "L'aspetto più caratteristico del funzionamento collegiale consiste nel voto che il collegio esprime sulla proposta, definitivamente rielaborata in seguito alla discussione. Il voto, così inteso, è la indicazione della soluzione che il collegio adotta, e costituisce una fase essenziale, $e$ l'ultima, del procedimento deliberativo. Con esso si esprime la volontà del collegio. Nel voto si distinguono le norme che disciplinano le manifestazioni dei singoli voti dei componenti, e cioè i vari sistemi di votazione, e le norme che disciplinano i criteri secondo i quali i voti stessi si uniscono o si fondono, formando l'atto collegiale".

${ }^{257}$ Nesse sentido, aplicável, por similitude, a lição de Maria Silvia Zanella di Pietro (2012, p. 237) ao tratar dos pareceres facultativos.
} 
profissão, atendidas as qualificações profissionais que a lei estabelecer (inc. XIII).

Como o ato de opinião é um ato de pensamento no exercício de atividade intelectual, técnica ou científica, não pode o CNJ impor, em sede de controle de atuação administrativa e financeira, que seja novamente realizado em outro sentido predeterminado pelo Colegiado, ainda que esse ato tenha sido inicialmente praticado com má-fé.

Dois exemplos podem esclarecer o afirmado.

Primeiro: no exercício do controle da atuação administrativa e financeira, o Conselho Nacional de Justiça pode considerar irregular contrato administrativo celebrado com dispensa de licitação para execução de obras em determinado tribunal do Poder Judiciário com base em decisão proferida com fundamento em proposta que passou a integrá-la. Assim, poderá o Conselho rever a decisão, desconsiderar a proposta, determinar a rescisão unilateral do contrato e a suspensão dos atos materiais e execução da obra. Os termos da proposta que integraram a decisão, no caso, também são submetidos ao controle de atuação administrativa e financeira do $\mathrm{CNJ}$. A decisão é modificada pelo $\mathrm{CNJ}$, que desconsidera a proposta que a integrou e determina os efeitos jurídicos e materiais da sua própria decisão, proferida em sede de controle. Inadmissível, porém, que o Colegiado, na situação, determine a elaboração de outra proposta em sentido que estabelecer, para que outra decisão seja proferida com base nos seus termos (predeterminados pelo Conselho), ainda que a primeira tenha sido elaborada de má-fé, pois, nesse caso, estaria a violar os dispositivos constitucionais mencionados. A eventual ação dolosa do proponente ficará, no entanto, sujeita a controle administrativo disciplinar.

Segundo: deliberação administrativa colegiada de órgão do Poder Judiciário que concede benefício financeiro a magistrado pode ser modificada ${ }^{258}$ pelo Conselho Nacional de Justiça, que pode determinar a suspensão dos atos materiais para pagamento do benefício ao magistrado. Não pode o Conselho, porém, impor ao órgão colegiado controlado que prolate outra decisão em sentido predeterminado, pois o voto, ainda que proferido dolosamente, é manifestação do pensamento e, portanto, inviolável.

Nesse ponto, cumpre destacar o peculiar controle que deve ser realizado pelo CNJ sobre a atuação administrativa e financeira em relação a pareceres emitidos no âmbito do Poder Judiciário.

A doutrina classifica os pareceres administrativos em facultativos, obrigatórios e

\footnotetext{
${ }^{258}$ Como os votos que amparam a deliberação colegiada necessariamente a integram, o CNJ, ao modificá-la, além de exercer controle administrativo e financeiro sobre ato administrativo (a deliberação colegiada), também controla os atos de opinião que o formaram.
} 
vinculantes ${ }^{259}$.

Parecer facultativo é o opcionalmente solicitado por autoridade administrativa antes da realização de um ato. Não há norma que determine sua feitura prévia ao ato a ser realizado e sua emissão não vincula a prática desse ato subsequente às suas conclusões.

Parecer obrigatório é o solicitado por autoridade administrativa antes da realização de um ato por determinação legal, como pressuposto para a sua prática. Como na hipótese anterior, a prática do ato ulterior não está adstrita aos termos do parecer.

Parecer vinculante, também denominado parecer conforme, é aquele que deve ser solicitado e suas conclusões devem, necessariamente, ser seguidas pela autoridade solicitante.

O Supremo Tribunal Federal, em 9 de agosto de 2007, ao julgar o Mandado de Segurança $\mathrm{n}^{\mathrm{o}}$ 24631, relatado pelo Ministro Joaquim Barbosa ${ }^{260}$, decidiu, quanto a pareceres técnico-jurídicos, que: a) o parecer facultativo não vincula a decisão a ser proferida pela autoridade administrativa que o solicita; b) no parecer obrigatório, a autoridade administrativa se obriga a emitir o ato tal como apresentado à consultoria, com parecer favorável ou contrário, e se pretender praticá-lo com conteúdo e forma diversos da submetida ao parecerista, deverá requerer a feitura de novo $\operatorname{parecer}^{261}$; e, c) o parecer vinculante impõe que a decisão exarada siga suas conclusões ${ }^{262263}$.

\footnotetext{
${ }^{259}$ Nesse sentido: Oswaldo Aranha Bandeira de Mello (2010, pp. 583/584) e Maria Sylvia Zanella Di Pietro (2012, p. 237). Cita-se, ainda, o denominado parecer normativo, que, segundo Hely Lopes Meirelles (1999, p. 176), é "aquele que, ao ser aprovado pela autoridade competente, é convertido em norma de procedimento interno, tornando-se impositivo e vinculante para todos os órgãos hierarquizados à autoridade que o aprovou. Tal parecer, para o caso que o propiciou, é ato individual e concreto; para os casos futuros, é ato geral e normativo". Nessa linha também leciona na Maria Sylvia Zanella Di Pietro (2012, p. 239), esclarecendo que o objetivo do parecer normativo "é garantir uniformidade de orientação na esfera administrativa e até o de evitar consultas repetitivas que exijam novas manifestações do órgão consultivo".

${ }^{260}$ O Mandado de Segurança $n^{\circ} 24631$ foi impetrado por procurador autárquico contra ato do Tribunal de Contas da União que aprovou auditoria realizada no extinto Departamento Nacional de Estradas de Rodagem (DNER) para verificar sua atuação nos processos relativos a desapropriações e acordos extrrajudiciais para pagamento de precatórios e ações em andamento, e incluiu o impetrante em processo administrativo entre os responsáveis por irregularidades encontradas.

${ }^{261}$ Pois, conforme anota o Ministro Joaquim Barbosa no seu voto-vista no Mandado de Segurança $n^{\circ} 24584$, relatado pelo Ministro Marco Aurélio Mello e julgado no Supremo Tribunal Federal também em 9 de agosto de 2007 se a autoridade administrativa "submeter à consultoria a minuta ou esboço de um ato com um determinado conteúdo e, ao tomar a decisão, publicar ato de conteúdo diverso, estará burlando a obrigatoriedade do parecer prévio, que nada mais é do que um mecanismo adicional de controle da administração".

${ }^{262}$ Cumpre destacar que, apesar de ter sido deferida a ordem no Mandado de Segurança $\mathrm{n}^{\mathrm{o}} 24631$ por unanimidade pelos Ministros do STF, houve ressalvas individuais ao voto do relator pelos Ministros Carlos Britto e Marco Aurélio Mello, que não concordaram com a posição apresentada pelo Ministro Joaquim Barbosa em seu voto, ao defender que "nos casos em que o parecer favorável de órgão consultivo é, por força de lei, pressuposto de perfeição do ato, há efetiva 'partilha do poder de decisão' entre a autoridade executiva e o órgão consultivo" e, logo, "o parecerista pode vir a ter que responder conjuntamente com o
} 
Apesar da decisão proferida restringir-se a pareceres administrativos jurídicos, não há porque deixar de estender o entendimento exarado aos outros pareceres técnicos emitidos no âmbito da Administração Pública, porque, conforme doutrina Hely Lopes Meirelles (1999, p. 176), parecer técnico

é o que provém de órgão ou agente especializado na matéria, não

administrador, pois ele também é administrador nesse caso". Segue a ementa do julgado:

CONSTITUCIONAL. ADMINISTRATIVO. CONTROLE EXTERNO. AUDITORIA PELO TCU. RESPONSABILIDADE DE PROCURADOR DE AUTARQUIA POR EMISSÃO DE PARECER TÉCNICO-JURÍDICO DE NATUREZA OPINATIVA. SEGURANÇA DEFERIDA. I. Repercussões da natureza jurídico-administrativa do parecer jurídico: (i) quando a consulta é facultativa, a autoridade não se vincula ao parecer proferido, sendo que seu poder de decisão não se altera pela manifestação do órgão consultivo; (ii) quando a consulta é obrigatória, a autoridade administrativa se vincula a emitir o ato tal como submetido à consultoria, com parecer favorável ou contrário, e se pretender praticar ato de forma diversa da apresentada à consultoria, deverá submetê-lo a novo parecer; (iii) quando a lei estabelece a obrigação de decidir à luz de parecer vinculante, essa manifestação de teor jurídica deixa de ser meramente opinativa e o administrador não poderá decidir senão nos termos da conclusão do parecer ou, então, não decidir. II. No caso de que cuidam os autos, o parecer emitido pelo impetrante não tinha caráter vinculante. Sua aprovação pelo superior hierárquico não desvirtua sua natureza opinativa, nem o torna parte de ato administrativo posterior do qual possa eventualmente decorrer dano ao erário, mas apenas incorpora sua fundamentação ao ato. III. Controle externo: É lícito concluir que é abusiva a responsabilização do parecerista à luz de uma alargada relação de causalidade entre seu parecer e o ato administrativo do qual tenha resultado dano ao erário. Salvo demonstração de culpa ou erro grosseiro, submetida às instâncias administrativo-disciplinares ou jurisdicionais próprias, não cabe a responsabilização do advogado público pelo conteúdo de seu parecer de natureza meramente opinativa. Mandado de segurança deferido.

${ }^{263}$ Em seu voto, o Ministro Joaquim Barbosa expressamente citou lição do Professor René Chapus (2001, pp. 1113 a 1115) a respeito da natureza jurídica do parecer na esfera administrativa, centrando sua análise na obrigação que a lei impõe ou não ao administrador de proceder à consulta antes de praticar o ato. Seguem as palavras do Professor Emérito da Universidade de Paris Panthéon-Assas: "La portée des avis. - Elle varie selon qu'il y a ou non obligation de consulter; et elle est particulièrement contraignante dans le cas où la décision ne peut être prise que "sur avis conforme» de l'organisme consultatif. $1^{\circ}$ ) Quand la consultation est facultative, l'autorité qui l'a provoquée ne saurait s'estimer liée par l'avis émis, même dans le cas où elle a spécialement institué (v. No 868) l'organisme consulté (v., par exemple, CE 30 juin 1997, Cornebois, p. 897). Et sa liberté de décision n'est rien limitée par l'avis. Elle conserve la faculté d'apporter à son projet « toutes les modifications qui lui paraissent utiles, quelle qu'en soit l'importance, sans avoir l'obligation de sisir à nouveau " l'organisme consulté. $2^{\circ}$ ) Au, contraire, en cas de consultation obligatoire, l'autorité consultante (si elle ne renonce pas à toute décision, et si l'avis s'est traduit par une proposition de décision différente) est enfermée dans une alternative : ou bien prendre la décision même dont le projet avait été soumis à la consultation; ou bien décider conformément ao texte en faveur duquel l'organisme consultatif s'était prononcé. Parallèlement, si l'organisme a été consulté sur des questions, l'autorité administrative, si elle ne $s$ 'en tient pas à son propre projet, doit se conformer aux positions adoptées relativement à ces questions et s'abstenir d'inclure dans sa décision des dispositions liées à des questions non soumises à l'organisme consultatif. Enfin, si l'organisme a émis un avis défavorable sans proposer de texte de remplacement, l'autorité administrative ne peut que, soit s'abstenir de décider, soit s'en tenir au texte soumis à la consultation. Tout cela est dans la logique du caractère obligatoire de la consultation: adopter des dispositions différant à la fois de celles soumises à l'organisme consultatif et de celles proposées par ce dernier serait adopter des dispositions dont il n'a pas eu à connaître (v., de même. $N^{o} 1220-1^{\circ}$ ). En conséquence, quand l'autorité administrative envisage l'adoption de dispositions nouvelles, elle doit saisir de nouveau l'organisme consultatif pour qu'il se prononce sur elles. $3^{\circ}$ ) Enfin, lorsque l'obligation est celle de décider sur avis conforme, l'autorité consultante ne peut décider que conformément à l'avis (v. de même, $\left.n^{\circ} 1220-2^{\circ}\right)$. S'il est défavorable à la décision projetée, elle ne pourra que renoncer à la décision. En d'autres termes, l'autorité administrative ne peut prendre la décision projetée qu'avec l'accord de l'organisme consultatif, qui se trouve ainsi étroitement associé à l'exercise du pouvoir de décision". 
podendo ser contrariado por leigo ou, mesmo, por superior hierárquico. Nessa modalidade de parecer ou julgamento não prevalece a hierarquia administrativa, pois não há subordinação no campo da técnica.

Assim, como não pode ser contrariado por leigo, o parecer técnico vinculante, não pode ser desconsiderado pela autoridade administrativa. $\mathrm{Na}$ hipótese de parecer obrigatório, a autoridade administrativa pode, justificadamente, praticar ato de forma contrária às suas conclusões, desde que o faça como o assunto foi apresentado à consultoria pois, se pretender praticá-lo com conteúdo e forma diversos, deverá previamente submeter o assunto a novo parecer. Nos casos de parecer facultativo, não há qualquer submissão da autoridade administrativa, que pode desconsiderá-lo e decidir e praticar o ato inclusive de forma diversa da submetida à consulta.

Logo, no âmbito do controle exercido pelo Conselho Nacional de Justiça sobre a atuação administrativa e financeira do Poder Judiciário, pode o Conselho, na hipótese de assunto que não exija a elaboração de prévio parecer à prática do ato, desconsiderar eventual ato de opinião apresentado e exercer a fiscalização sobre o ato da administração realizado independentemente dos termos do parecer, que somente será analisado caso integre a decisão sujeita a verificação.

Quanto a lei exige a emissão de parecer obrigatório para a realização de ato pela administração, o CNJ, em sede do controle mencionado, poderá decidir, justificadamente, de forma contrária aos seus termos, desde que o faça como o assunto foi apresentado à consultoria. Se pretender decidir com conteúdo e forma diversos do que foi consultado, deverá previamente submeter o assunto a novo parecer.

Por fim, não pode o Colégio Administrativo, no exercício do controle referido, como regra, desconsiderar o teor de pareceres técnicos vinculantes. Em outras palavras, deverá o Conselho Nacional de Justiça, quanto aos pareceres vinculantes, seguir suas conclusões, exceto se comprovadamente elaborados de má-fé ${ }^{264}$ pois, nesse caso, há, pelos pareceristas, violação do princípio constitucional da moralidade administrativa $(\mathrm{CF} \text {, art. } 37 \text {, caput })^{265}$. Nessa última hipótese, o Conselho deve reconhecer o vício e poderá desconsiderar o parecer, mas deverá requerer a emissão de outro e, posteriormente, acolher seus termos,

\footnotetext{
${ }^{264}$ Maria Sylvia Zanella Di Pietro (2012, p. 249), ao tratar dos vícios dos atos da administração, afirma que haverá vício relativo ao objeto se ele não for "lícito, possível (de fato e de direito), moral e determinado". E, ao cuidar do vício relativo a objeto imoral, exemplica com o "parecer emtido sob encomenda, apesar de contrário ao entendimento de quem o profere".

${ }^{265}$ Vide item 3.1.3.
} 
exceto se também viciado.

Por exemplo, na concessão de aposentadoria por invalidez a magistrado, há necessidade de apresentação de laudo ${ }^{266}$ médico (parecer técnico vinculante) e o tribunal a que está vinculado o magistrado é obrigado a decidir de acordo com a conclusão pericial. Da mesma forma, no exercício do controle da atuação administrativa e financeira, o Conselho Nacional de Justiça está vinculado aos termos do parecer médico e somente pode desconsiderá-lo se constatada má-fé na sua elaboração. Nesse caso, deverá reconhecer o vício, desconsiderar o laudo e determinar a feitura de outro, ficando novamente vinculado à sua conclusão, ainda que idêntica a do primeiro parecer elaborado.

Em resumo, quanto aos atos de opinião emitidos no âmbito do Poder Judiciário, pode se afirmar que o controle da atuação administrativa e financeira do Conselho Nacional de Justiça não é pleno pois: a) somente sujeitam-se ao referido controle os atos de opinião que passem a integrar decisão que determine a realização de outro ato da administração, por consistirem na sua própria motivação; b) o controle realizado pelo CNJ sobre atos de opinião não pode implicar na imposição da sua elaboração em sentido predeterminado pelo Conselho; c) o CNJ, quanto a lei exigir a emissão de parecer obrigatório deverá, se pretender decidir com conteúdo e forma diversos do que foi consultado, requerer a feitura de novo parecer sobre o assunto; e, d) o Conselho Administrativo não pode, em regra, desconsiderar o teor de parecer técnic vinculantes. Assim, deverá o Colegiado seguir suas conclusões, exceto se reconhecer vício na elaboração do referido atos de opinião, hipótese em que deverá requerer a emissão de outro parecer e, posteriormente, acolher seus termos, exceto se este último também estiver viciado.

\footnotetext{
${ }^{266} \mathrm{O}$ termo "laudo" é utilizado como sinônimo de parecer técnico, normalmente no âmbito da medicina. Segundo Joffre Marcondes de Rezende (2010, pp. 228 a 330), “laudo' provém do verbo latino 'laudo', 'laudare', que significa elogiar, enaltecer, exaltar. De 'laudare' derivam 'louvar', em português; 'lodare', em italiano; 'louer', em francês, e as formas divergentes 'loar' e 'laudar', em espanhol. [...] Do presente do indicativo do verbo latino 'laudo' (eu louvo) procede o substantivo 'laudo'. Houaiss define 'laudo' como 'texto contendo parecer técnico (de médico, engenheiro etc.)' e, por metonímia, 'suporte (p.ex., folha de papel, documento) em que está exarado tal parecer' (Houaiss A, Villar MS. Dicionário Houaiss da língua portuguesa. Rio de Janeiro, Objetiva, 2001)". A palavra latina que exprime louvor passou ao português com o sentido de parecer e também de opinião e sentença porque, pela diacronia, "o primeiro registro da palavra laudo, segundo Houaiss, data de 1858. Os dicionários mais antigos (Domingos Vieira, 1874; Caldas Aulette, 1881; Cândido de Figueiredo, 1899; Simões da Fonseca, 1926) definem laudo como parecer, voto, decisão do juiz louvado. $\mathrm{O}$ juiz encarregado de julgar, de dar uma sentença, era chamado de juiz louvado ou simplesmente louvado. Por extensão semântica, a qualificação de louvado estendeu-se aos árbitros e peritos em geral, conforme se documenta na décima edição do Dicionário de Moraes Silva, de 1954: 'Louvado. Indivíduo nomeado especialmente para avaliar e examinar qualquer coisa e dar o seu laudo ou informação; perito, árbitro' (Morais Silva A. Grande dicionário da língua portuguesa. 10.ed., vol. 6, Lisboa, Confluência, 1954)".
} 
h) Atos políticos:

$\mathrm{Na}$ sequência, cumpre analisar se o Conselho Nacional de Justiça pode exercer controle sobre a atuação administrativa e financeira relativo aos atos políticos ${ }^{267}$ praticados no seio do Poder Judiciário.

Atos políticos, nas palavras de Carlos Blanco de Morais (2006, p. 512), são aqueles atos que exprimem "a sua eficácia e a imperatividade dos respectivos comandos no circuito interno das relações institucionais entre órgãos de poder político, não projectando directamente as suas consequências jurídicas na esfera dos cidadãos”268.

Como esclarece Celso Antônio Bandeira de Mello (2009, p. 379), são atos praticados “com margem de discrição e diretamente em obediência à Constituição, no exercício de função puramente política".

A função política é uma atividade de direção, de gestão superior dos negócios públicos em busca da realização do bem comum. Os atos políticos, pois, observa Hely Lopes Meirelles (1999, p. 636), "se fundam na ampla liberdade de apreciação da conveniência ou oportunidade de sua realização, sem se aterem a critérios jurídicos preestabelecidos" 269 .

Por outro lado, apesar de existir uma preponderância do Executivo no exercício da

${ }^{267}$ Conforme esclarecem José Cretella Júnior (1988, p. 8) e Odete Medauar (1993, pp. 69 e 70), a teoria do ato político ou de governo tem origem na França no século XIX, em decisões do Conselho de Estado que rejeitavam apreciar certos atos do Poder Executivo, fundadas no art. 26, da lei de 24 de maio de 1872, com a seguinte fórmula: "atos cuja interpretação e execução não podiam lhe ser atribuídas pela via contenciosa".

${ }^{268}$ Não há consenso doutrinário quanto à melhor denominação do instituto em exame, sendo comum a utilização das expressões "ato político" ou "ato de governo". Em estudo intitulado "Ato de Governo" (1993, pp. 67 a 85), Odete Medauar esclarece que José Cretella Júnior e Manoel de Oliveira Sobrinho utilizam as expressões "ato de governo" e "ato político" como sinônimas, enquanto Seabra Fagundes e Ada Pellegrini Grinover adotam o termo "ato político". Já a doutrina francesa prefere a denominação "ato de governo" (acte de gouvernement), enquanto no direito norte-americano utiliza-se a locução "questões políticas" (political questions) e no direito inglês "ato de estado" (act of state). Ainda pontua a doutrinadora que "a considerar o sentido de atuação do poder estatal, seria político todo o ato que a expresse, tal como deflui das afirmações de Candido Dinamarco, ao caracterizar a sentença como ato político por expressar o exercício da jurisdição como poder [...]. Assim políticos seriam também os atos parlamentares e todos os atos administrativos porque expressam atuação de poderes estatais". Entende a professora, porém, que é melhor a utilização da expressão "ato de governo", por tratar do ato originário do Poder Executivo, embora reconheça, citando Miguel Marienhoff (1966, p. 699), que o conceito de governo engloba as atividades do Executivo, Legislativo e do Judiciário. Preferiu-se neste trabalho adotar a terminologia "ato político", pois realizado no exercício de função política e, no caso, por órgãos do Poder Judiciário.

${ }^{269}$ É importante registrar que Hely Lopes Meirelles nega a existência de ato político como entidade autônoma distinta do ato administrativo, pois, para ele, o fundamento político pode apenas informar o ato administrativo, legislativo ou judiciário (1999, p. 39). José Cretella Júnior também considera o ato político “"espécie' em que se desdobra o 'gênero' ato administrativo" (1988, p. 10). Odete Medauar (2011, p. 32) ainda informa que "incluem os atos de governo ou atos políticos entre os atos administrativos, por exemplo: Diogo de Figueiredo Moreira Neto e Odete Medauar; não incluem, dentre outros: Virga, Maurer, Maria Sylvia Zanella Di Pietro e Almiro do Couto e Silva". 
função política (DI PIETRO, 2012, p. 54) ${ }^{270}$, como não há uma separação rígida das funções Estatais entre os Poderes, atos políticos também são realizados pelo Legislativo e pelo Judiciário. Assim, doutrina Hely Lopes Meirelles:

Todos os Poderes do Estado são autorizados constitucionalmente a praticar determinados atos, e determinadas circunstâncias, com fundamento político. Nesse sentido, pratica ato político o Executivo quando veta projeto de lei, quando nomeia Ministro de Estado, quando concede indulto; pratica-o o Legislativo quando rejeita veto, quando aprova contas, quando cassa mandato; pratica o Judiciário quando propõe a criação de tribunais inferiores, quando escolhe advogado e membro do Ministério Público parar compor o quinto constitucional. Em todos esses exemplos são as conveniências do Estado que comandam o ato e infundem-lhe caráter político que o torna insuscetível de controle judicial quanto à valoração de seus motivos.

Tem-se entendido que, mesmo em sede de controle jurisdicional, somente há revisão pelo Poder Judiciário do ato político se acarretar lesão ao ameaça a direito, ante o princípio da inafastabilidade da jurisdição $\left(\mathrm{CF} \text {, art. } 5^{\circ}, \mathrm{XXXV}\right)^{271}$.

Como já pontuava José Cretella Júnior, ao tratar do tema ainda sob a égide da Constituição de 1967/1969 (1988, p. 13), mas em lição ainda plenamente aplicável à Ordem Constitucional vigente,

Dentro de nosso sistema constitucional de freios e contra-pesos, a
afirmação de que "os atos exclusivamente políticos sao imunes à
apreciação jurisdicional" precisa ser entendida em seu sentido exato, que
é: "os atos exclusivamente políticos sao imunes a apreciação jurisdicional
apenas no que encerram de político", porque, integrando a ordem

${ }^{270}$ Costuma-se citar como exemplos de atos políticos (ou atos de governo, dependendo da terminologia adotada): a apresentação e retirada de projeto de lei; sanção ou veto a projetos de lei, convocação de sessão extraordinária do Congresso Nacional; decretação e execução de intervenção federal; concessão de indulto; celebração de tratados e convenções internacionais. Nesse sentido, confira-se Celso Antônio Bandeira de Mello (2009, pp. 379/380) e Odete Medauar (2012, p. 215).

\footnotetext{
${ }^{271}$ Nesse sentido: Odete Medauar (2012, pp. 215 e 216), Seabra Fagundes (1979, p. 164) e Ada Pellegrini Grinover (1973, pp. 145 e 146). Odete Medauar destaca que "as constituições de 1934 e 1937, nos arts. 68 e 97, respectivamente, previam, de modo explícito, a exclusão dos atos de governo da apreciação do Judiciário; 'É vedado ao Poder Judiciário conhecer questões exclusivamente políticas'. A partir de 1946 passou a vigorar o princípio da inafastabilidade do controle jurisdicional a qualquer lesão de direito. Em decorrência, se o ato de governo acarretar lesão a direito, poderá ser impugnado perante o Judiciário" (2012, p. 215).
} 
jurídica, a qual se submetem e adaptam, como atos jurídicos que são, devem concretizar-se de harmonia com o princípio da legalidade e conforme competência constitucional.

Nessa linha, entendemos que o Conselho Nacional de Justiça não pode exercer controle de atuação administrativa e financeira sobre o ato político praticado no seio do Poder Judiciário naquilo que tem de essencialmente, com o perdão da redundância, político, porque realizado com ampla discricionariedade no âmbito de atividade de gestão superior outorgada pela Constituição Federal aos diversos órgãos do Judiciário para defesa institucional do próprio Poder e garantia institucional da sua independência para o exercício da jurisdição ${ }^{272}$.

Assim, admitir-se controle do Conselho sobre atuação política dos órgãos do Judiciário, exercida com ampla liberdade de apreciação da conveniência e oportunidade de sua realização, implicaria, por certo, na supressão da autonomia administrativa e financeira do Poder, garantida pela Constituição Federal (CF, art. 99) e que compete ao próprio CNJ zelar (CF, art. 103-B, § 4 , I).

Não obstante, permanece o $\mathrm{CNJ}$, mesmo em relação ao atos políticos realizados no âmbito do Poder Judiciário, com a competência para exercer o controle do seu revestimento jurídico-administrativo, da sua legalidade perante a ordem jurídica porque, nesse ponto, poderão violar direitos individuais ou da própria coletividade ${ }^{273}$.

\footnotetext{
${ }^{272}$ Como pontua Alexandre de Moraes (2013b, p. 516), as garantias conferidas ao Poder Judiciário, institucionais ou aos seus membros, têm "como condão conferir à instituição a necessária independência para o exercício da Jurisdição, reguardando-a das pressões do Legislativo e do Executivo", sendo "imprescindíveis ao exercício da democracia, à perpetuidade da Separação de Poderes e ao respeito aos direitos fundamentais, configurando suas ausências, supressões ou mesmo reduções, obstáculos inconstitucionais ao Poder Judiciário". O exercício da jurisdição deve ficar salvaguardado de pressões dos demais Poderes, inclusive para que atos políticos realizados pelo Legislativo e pelo Executivo também possam ser controlados se causarem prejuízo a direitos e garantias individuais e coletivas.
}

273 José Cretella Júnior esclarece que "a discricionariedade do ato político é maior do que a discricionariedade do ato administrativo. Ambas, porém, tem barreiras ou limitações, tais como as prerrogativas individuais, as liberdades públicas, os direitos subjetivos públicos". E prossegue: “o ato de governo, assim, nem direta, nem reflexamente atingirá os direitos adquiridos, as liberdades públicas, as prerrogativas individuais, expressas em lei, e caso, por inadvertência, por abuso, excesso ou desvio de poder, a providência do Governo interfira na esfera circunscrita a tais prerrogativas, estará inquinada de vício patente que a desnatura, tornando-a vulnerável aos remedia juris correspondentes para o reexame do esdrúxulo pronunciamento governamental pelo Poder Judiciário" (1988, vol. 627, p. 10). Ruy Barbosa (1983, pp. 114 e 120), citado por Odete Medauar (2012, p. 215), já ensinava no início do século XX: "Quais as questões meramente, unicamente, exclusivamente políticas? Óbvio é que as relativas ao exercício de poderes, mera, única e exclusivamente políticos. Quais são, porém, os poderes exclusiva e meramente políticos? Evidentemente os que não são limitados por direitos correlativos nas pessoas, individuais ou coletivas, sobre que tais poderes se exercem (...). Eis o terreno meramente político, defeso como tal à ingerência dos tribunais. Contraposto a este se estende, como divisas claras e sensíveis, o terreno da justiça, assinalado exatamente pela característica oposta de que questões de sua alçada, em vez de obedecerem à apreciação de 
Para concluir este item pode-se afirmar, em síntese, que a Constituição Federal, no que tange ao exercício das funções atípicas pelos órgãos do Poder Judiciário, conferiu ao Conselho Nacional de Justiça (I) o controle amplo dos atos administrativos (propriamente ditos), atos de direito privado, contratos administrativos, atos materiais, atos enunciativos ou de conhecimento. (II) Quanto aos atos normativos, o controle realizado pelo CNJ também é amplo, mas não pode implicar em afastar a incidência das próprias leis que fundamentem suas validades e também pode se voltar àqueles emanados pela Justiça Eleitoral para disciplinar suas matérias específicas e às sentenças normativas trabalhistas. (III) No que se refere aos atos de opinião, o controle não é pleno pois: a) destina-se apenas àqueles integram decisão determinante da realização de outro ato da administração, por consistirem na sua própria motivação; b) não pode implicar na imposição da elaboração de ato de opinião em determinado sentido; c) quanto aos pareceres obrigatórios, o Colegiado só poderá decidir com conteúdo e forma diversos do consultado após requerer a emissão de novo parecer sobre o assunto; e, d) o Conselho Administrativo não pode, em regra, desconsiderar o teor de parecer técnico vinculante, devendo seguir suas conclusões, exceto se reconhecer vício na sua feitura, caso em que deverá requerer a emissão de outro parecer e, posteriormente, acolher seus termos, exceto se este último também estiver viciado. (IV) Por fim, em relação aos atos políticos, cabe ao CNJ exercer apenas o controle do seu revestimento jurídico-administrativo, ante a possibilidade de violação de direitos individuais ou coletivos, não lhe competindo controlar o aspecto puramente político desses atos.

\subsection{Estudo de norma: Resoluções CNJ nº 48/2007 e 88/2009 - Controle sobre iniciativa lei}

Estabelecido o alcance constitucional do controle exercido pelo Conselho Nacional de Justiça sobre as funções atípicas desenvolvidas pelos órgãos do Poder Judiciário, passa-se à apresentação de disposições normativas que, no nosso sentir, extrapolaram os limites de atuação do Colegiado, pois visam o controle de atos exclusivamente políticos.

conveniências, mais ou menos gerais, entendem com a aplicação de direito legal aos casos particulares, de ordem individual ou coletiva. Onde quer que surja um problema jurídico desta natureza, embora não seja estreme de elementos políticos, desde que exclusivamente político não é, tem de receber a solução legal do poder constituído para dar efeito às garantias constitucionais e com elas valer a toda individualidade, natural ou moral, lesada no seu direito". 
As hipóteses tratam de determinações do Conselho para encaminhamento, pelos Tribunais de Justiça Estaduais, de projetos de lei para adequação das legislações locais aos termos de seus atos normativos.

Na Resolução CNJ no 48, de 18 de dezembro de 2007, o Conselho Nacional de Justiça determinou que os Tribunais passassem a exigir, como requisito para provimento do cargo de Oficial de Justiça, a conclusão de curso superior, preferencialmente em Direito (art. $1^{\circ}$ ). Ordenou, ainda, que os Tribunais, no prazo de sessenta dias, informassem as medidas adotadas para cumprimento da norma mencionada ${ }^{274}$.

Nos consideranda na referida resolução constou que sua edição se justificava pois o CNJ deve orientar os demais órgãos do Poder Judiciário quanto aos meios para garantir uma concreta prestação juridicional, sendo a atividade dos Oficiais de Justiça, nesse contexto, essencial para a dinamização do trâmite processual e observância de princípios constitucionais processuais. Útil, pois, que esses servidores possuam conhecimentos jurídicos para adequado desempenho de seus ofícios ${ }^{275}$.

O próprio Conselho Nacional de Justiça, porém, passou a "mitigar" (termo utilizado em decisões proferidas pelo CNJ) a aplicação da referida determinação ao constatar que legislações estaduais, por extrema necessidade de pessoal para o Poder Judiciário ou por dificuldades orçamentárias, estabeleciam o nível escolar médio como requisito para a investidura no cargo de Oficial de Justiça ${ }^{276}$.

\footnotetext{
${ }^{274}$ Determinação semelhante foi feita pela Resolução CNJ no 58 , de 12 de agosto de 2008 , em relação ao provimento do cargo de Escrivão Judicial ou equivalente.

${ }^{275}$ Reproduz-se os dois consideranda da Resolução CNJ n ${ }^{\circ}$ 48/2007:

CONSIDERANDO haver sido confiada ao Conselho Nacional de Justiça a missão de orientar os órgãos jurisdicionais no implemento de meios capazes de facilitar o acesso à Justiça, racionalizar o serviço prestado e viabilizar o aumento da produtividade dos servidores, com vistas a garantir a efetividade da prestação jurisdicional;
}

CONSIDERANDO o papel dos Oficiais de Justiça na concretização da atividade jurisdicional como elemento de dinamização do trâmite processual à luz dos princípios do contraditório, ampla defesa e da duração razoável do processo, bem como a utilidade de deterem conhecimentos técnico-jurídicos diante de ocorrência de situações imprevistas, durante o cumprimento de mandados, e o disposto no artigo 144 do Código de Processo Civil.

${ }^{276}$ No Estado de São Paulo, por exemplo, assim dispunha a Lei Estadual no 9.884, de 31 de outubro de 1967 (art. $2^{\circ}$, II), e estabelece a Lei Complementar Estadual no 516, de 9 de junho de 1987 (art. $5^{\circ}, \S 2^{\circ}$ ). É certo que a Lei Estadual no 12.237, de 23 de janeiro de 2006, alterou a disposição da Lei Estadual no 9.884/1967, para passar a exigir, para inscrição em concurso para provimento de cargo de Oficial de Justiça, a apresentação, pelo candidato, de diploma de conclusão de nível superior ou equivalente, expedido por estabelecimento de ensino oficial ou oficializado. Mas, como o projeto que deu origem à Lei Estadual $\mathrm{n}^{\mathrm{o}}$ 12.237/2006 foi apresentado pelo Deputado Estadual Campos Machado (Projeto de Lei Estadual $\mathrm{n}^{\mathrm{o}}$ 660/2002) e não foi modificada a Lei Complementar Estadual $n^{\circ}$ 516/1987, o Tribunal de Justiça de São Paulo continuou a exigir nível escolar médio para investidura no cargo citado. Cumpre registrar que, em 14 de novembro de 2013, a Presidência da Corte Bandeirante encaminhou à Assembleia Legislativa do Estado o Projeto de Lei Complementar Estadual $n^{\circ}$ 56, para que se passe a exigir, para ingresso no cargo de Oficial de 
Nesse sentido, por exemplo, foi a decisão proferida, por unanimidade, em 4 de agosto de 2009, no julgamento do Recurso Administrativo no Procedimento de Controle Administrativo $\mathrm{n}^{\mathrm{o}}$ 2009.10.00.002904-8, da relatoria do Conselheiro Marcelo Nobre ${ }^{277}$ :

O Conselho Nacional de Justiça, apercebendo-se que a "mitigação" da única determinação constante da Resolução CNJ no 48/2007 significava, na verdade, seu descumprimento, mas considerando que o ato normativo em comento não estabeleceu regra de transição para adaptação das legislações estaduais, inseriu, por força da decisão proferida em 16 de dezembro de 2009, no Ato Normativo ${ }^{\circ}$ 0007097-66.2009.2.00.0000, da relatoria do Conselheiro Ives Gandra ${ }^{278}$, dispositivo na referida resolução para determinar aos Tribunais de Justiça dos Estados em que a legislação local disciplinasse de forma diversa dos seus termos quanto à escolaridade mínima para o provimento de cargos de oficial de justiça, que encaminhassem projeto de lei, no prazo de noventa dias, para adequação ao fixado, ficando proibido o envio de projeto de lei para fixação de critério diverso (art. $\left.1^{\mathrm{o}}-\mathrm{A}\right)^{279}$.

Justiça, diploma de graduação de nível superior ou habilitação legal correspondente. Segundo a justificativa apresentada no referido projeto, o requisito é objeto de recomendação do Conselho Nacional de Justiça (Resolução $\mathrm{n}^{\circ}$ 48/07) (apesar do referido ato normativo, como será exposto, já estar revogado quando do encaminhamento do projeto de lei) e deve ser ajustada a situação jurídica existente, uma vez que a Lei ${ }^{\circ}$ 12.237/2006, promulgada após a derrubada de veto do Exmo. Sr. Governador, padece de flagrante inconstitucionalidade, dado o vício de iniciativa existente. Ademais, a propositura revaloriza gratificação específica, de modo a resgatar em parte o benefício instituído pela Lei $\mathrm{n}^{\circ}$ 516/1987, antigo pleito da classe.

${ }^{277} \mathrm{O}$ julgado recebeu a seguinte ementa:

RECURSO ADMINISTRATIVO. EDITAL DE CONCURSO QUE CONTRARIA A RESOLUÇÃO No 48 DESTE CNJ. EXIGÊNCIA DE ENSINO MÉDIO PARA OFICIAIS DE JUSTIÇA. "A decisão, por maioria, do Plenário deste CNJ, mitigou a Resolução 48, autorizando que os tribunais abram concursos para oficiais de justiça exigindo apenas ensino médio, não havendo qualquer correção a ser feita no edital do TJ-PR. Recurso improvido.”.

Estiverem presentes na sessão os Conselheiros Gilmar Mendes, Gilson Dipp, Ives Gandra, Milton Augusto de Brito Nobre, Leomar Barros Amorim de Sousa, Nelson Tomaz Braga, Paulo de Tarso Tamburini Souza, Walter Nunes da Silva Júnior, Morgana de Almeida Richa, José Adonis Callou de Araújo Sá, Felipe Locke Cavalcanti, Jefferson Luis Kravchychyn, Jorge Hélio Chaves de Oliveira, Marcelo Nobre e Marcelo Neves (conforme certidão de julgamento da $87^{\mathrm{a}}$ Sessão Ordinária do CNJ).

${ }^{278}$ Estiverem presentes na sessão os Conselheiros Gilson Dipp, Ives Gandra, Milton Augusto de Brito Nobre, Leomar Barros Amorim de Sousa, Nelson Tomaz Braga, Walter Nunes da Silva Júnior, Morgana de Almeida Richa, José Adonis Callou de Araújo Sá, Felipe Locke Cavalcanti, Jefferson Luis Kravchychyn e Marcelo Neves. Ausentes, justificadamente, os Conselheiros Gilmar Mendes, Paulo Tamburini, Jorge Hélio e Marcelo Nobre (conforme certidão de julgamento da $96^{\text {a }}$ Sessão Ordinária do CNJ).

${ }^{279}$ Segue a ementa do julgado:

RESOLUÇÃO 48/07 DO CNJ - EXIGÊNCIA DE NÍVEL SUPERIOR PARA INVESTIDURA NO CARGO DE OFICIAL DE JUSTIÇA - ACRÉSCIMO DE DISPOSITIVO À RESOLUÇÃO - REGRA DE TRANSIÇÃO PARA AS LEGISLAÇÕES ESTADUAIS EM SENTIDO CONTRÁRIO AO ATO NORMATIVO DO CONSELHO. 1. A Resolução 48/07 do CNJ estatuiu a necessidade de observância do nível superior, preferencialmente em Direito, para a investidura no cargo público de oficial de justiça (art. $1^{\circ}$ ), tendo em consideração o zelo pela eficiência do serviço público, pela celeridade e pela efetividade das decisões judiciais. Com efeito, o oficial de justiça é o executor dos mandados judiciais, bem assim o 
No voto condutor ficou consignado que a regra de transição das legislações estaduais inserta na Resolução CNJ $n^{\circ}$ 48/2007 inpirava-se nos termos da redação original da Resolução do Conselho Nacional de Justiça no 88, de 8 de setembro de 2009.

Originalmente, a já mencionada Resolução CNJ n ${ }^{\circ} 88 / 2009^{280}$, estabeleceu, dentre outras determinações: a) jornada ordinária de trabalho do servidor público do Poder Judiciário em oito horas diárias e quarenta horas semanais, facultada a fixação de sete horas ininterruptas (art. $1^{\circ}$, caput); b) destinação de pelo menos cinquenta por cento dos cargos em comissão nos Tribunais de Justiça para servidores das carreiras judiciárias (art. $2^{\circ}, \S 2^{\circ}$ ); e, c) limite de vinte por cento do total do quadro de funcionários de cada tribunal para requisição de servidores de órgãos não pertencentes ao Poder Judiciário (art. $3^{\circ}$, caput).

Em relação às citadas determinações, dispôs também o ato normativo em comento que deveriam os tribunais encaminhar projetos de lei para alteração das legislações locais, a fim de refletir a observância dos seus termos, estabelecendo prazo de noventa dias para envio dos projetos em relação à jornada ordinária de trabalho $\left(\operatorname{art.} 1^{\circ}, \S 2^{\mathrm{o}}\right.$; art. $2^{\mathrm{o}}, \S 2^{\mathrm{o}}$; e art. $\left.3^{\circ}, \S 3^{\circ}\right)^{281}$.

intérprete do alcance e dos limites da decisão que objetiva cumprir, sendo, portanto, necessário que conheça a lei. 2. No entanto, a Resolução em liça ressentiu-se, quando editada, de previsão de regra de transição para que as legislações estaduais, muitas das quais estabeleceram o nível de escolaridade médio como condição para a investidura no cargo referido (seja por extrema necessidade de pessoal do Judiciário, seja por dificuldades orçamentárias), adaptassem-se ao seu conteúdo, vindo o CNJ, em julgados recentes, a mitigar, em razão disso, a sua aplicação. 3. Ocorre, todavia, que a mitigação da única determinação constante da Resolução significa o seu absoluto descumprimento, não podendo ser aceita, senão com desprezo à atribuição constitucionalmente cometida ao $\mathrm{CNJ}$, de estabelecimento de diretrizes uniformizadoras da atividade administrativo-judiciária da Magistratura, com seus órgãos e auxiliares (Constituição Federal, art. 103-B, I). 4. Nessa linha, a medida mais pertinente a ser tomada é a de inserção de dispositivo na Resolução 48/07, assentando prazo razoável para que os Tribunais de Justiça promovam, mediante iniciativa de seus Presidentes, o encaminhamento de projeto de lei no sentido da Resolução deste Conselho.

${ }^{280}$ Vide item 2.3.3.1.

${ }^{281}$ Seguem os dispositivos da redação original da Resolução CNJ nº 88/2009:

Art. $1^{\circ} \mathrm{A}$ jornada de trabalho dos servidores do Poder Judiciário é de 8 horas diárias e 40 horas semanais, salvo se houver legislação local ou especial disciplinando a matéria de modo diverso, facultada a fixação de 7 horas ininterruptas.

$\S 1^{\circ}$ - O pagamento de horas extras, em qualquer dos casos, somente se dará após a $8^{\mathrm{a}}$ hora diária, até o limite de 50 horas trabalhadas na semana, não se admitindo jornada ininterrupta na hipótese de prestação de sobrejornada.

$\S 2^{\circ}$ - Deverão os Tribunais de Justiça dos Estados em que a legislação local disciplinar a jornada de trabalho de forma diversa deste artigo encaminhar projeto de lei, no prazo de 90 (noventa) dias, para adequação ao horário fixado nesta resolução, ficando vedado envio de projeto de lei para fixação de horário diverso do nela estabelecido.

Art. $2^{\circ}$ Os cargos em comissão estão ligados às atribuições de direção, chefia e assessoramento, sendo vedado seu provimento para atribuições diversas.

$\S 1^{\circ}$ - Os ocupantes de cargos em comissão que não se enquadrem nos requisitos do caput deste artigo deverão ser exonerados no prazo de 90 dias 
Ocorre que, pensamos, não poderia o Conselho Nacional de Justiça determinar aos tribunais, nas Resoluções n ${ }^{\circ}$ s 48/2007 e 88/2009, o envio de projetos de lei para adequação das legislações locais às suas respectivas disposições, pois a iniciativa de propositura de lei é ato político que não pode sujeitar-se ao controle do Conselho.

A respeito da iniciativa de lei, leciona Alexandre de Moraes (2013b, p. 662):

Iniciativa de lei é a faculdade que se atribui a alguém ou a algum órgão para apresentar projetos de lei ao Legislativo, podendo ser parlamentar ou extraparlamentar e concorrente ou exclusiva.

Diz-se iniciativa parlamentar a prerrogativa que a Constituição confere a todos os membros do Congresso Nacional (Deputados Federais/Senadores da República) de apresentação de projetos de lei. Diz-se, por outro lado, iniciativa de lei extraparlamentar aquela conferida ao Chefe do Poder Executivo, aos Tribunais Superiores, ao Ministério Público e aos cidadãos (iniciativa popular de lei).

Por sua vez, a iniciativa concorrente é aquela pertencente a vários legitimados de uma só vez (por exemplo: parlamentares e Presidente da República), enquanto iniciativa exclusiva é aquela reservada a determinado cargo ou órgão (por exemplo: $\mathrm{CF}$, art. $61, \S 1^{\circ}$ ).

$\S 2^{\circ}$ - Para os Estados que ainda não regulamentaram os incisos IV e V do art. 37 da Constituição Federal, pelo menos 50\% (cinquenta por cento) dos cargos em comissão deverão ser destinados a servidores das carreiras judiciárias, cabendo aos Tribunais de Justiça encaminharem projetos de lei de regulamentação da matéria, com observância desse percentual.

Art. $3^{\circ} \mathrm{O}$ limite de servidores requisitados ou cedidos de órgãos não pertencentes ao Poder Judiciário é de $20 \%$ (vinte por cento) do total do quadro de cada tribunal, salvo se a legislação local ou especial disciplinar a matéria de modo diverso.

$\S 1^{\circ}$ - Os servidores requisitados ou cedidos deverão ser substituídos por servidores do quadro, no prazo máximo de 4 (quatro) anos, na proporção mínima de $20 \%$ (vinte por cento) por ano, até que se atinja o limite previsto no caput deste artigo.

$\S 2^{\circ}$ - O disposto no parágrafo anterior não se aplica aos órgãos em relação aos quais este Conselho, em análise concreta, já determinou a devolução dos requisitados ou cedidos.

$\S 3^{\circ}$ - Deverão os Tribunais de Justiça dos Estados em que houver legislação local estabelecendo percentual superior ao do caput deste artigo encaminhar projeto de lei para adequação a esse limite, ficando vedado envio de projeto de lei para fixação de limite superior.

Art. $4^{\circ}$ Os tribunais deverão fazer chegar ao $\mathrm{CNJ}$, por meio eletrônico, no prazo de 60 dias:

I - o valor de cada uma das verbas que compõem a remuneração dos cargos efetivos e em comissão;

II - o quantitativo e a denominação dos cargos em comissão, com descrição das respectivas atribuições;

III - o quantitativo dos cargos em comissão ocupados por servidores do quadro, por servidores requisitados ou cedidos, e por servidores sem vínculo com a administração pública; e

IV - o quantitativo e a relação dos servidores requisitados ou cedidos de órgão não pertencentes ao Judiciário, com o nome, matrícula e órgão de origem.

Parágrafo único. As informações deverão ser enviadas segundo o modelo de dados fornecido pelo Departamento de Tecnologia da Informação do Conselho Nacional de Justiça.

Art. $5^{\circ} \mathrm{A}$ presente resolução entra em vigor na data de sua publicação. 
A iniciativa de lei, como visto, deflagra o processo legislativo. Trata-se, pois, de ato político, praticado com ampla discricionariedade, pelos legitimados constitucionalmente, no âmbito das relações institucionais, que não atinge ou ameaça direitos individuais ou coletivos.

Como observa Manoel Gonçalves Ferreira Filho (2012b, p. 95):

A elaboração da lei, no Direito Constitucional clássico, obedece a um processo complexo, até certo ponto espelho da própria natureza da lei.

De fato, essa elaboração se desdobra em três fases distintas. A primeira é meramente introdutória: é a fase da iniciativa. A segunda é a fundamental, é a fase constitutiva da lei. A ultima é complementar, integra a eficácia da lei.

Chama-se iniciativa o poder de propor a adoção de uma lei como também a apresentação do projeto junto ao órgão competente.

Embora se use dizer que ela é uma fase do processo legislativo, juridicamente não o é, embora politicamente o seja. Não o é no plano estrito do Direito, porque se resume num ato, o depósito do projeto. Assim, mais correto seria afirmar que a iniciativa é o ato que desencadeia o processo de elaboração ou de adoção da lei.

No plano político, todavia, a preparação do projeto é de alta importância. Ante de um projeto ser depositado, um trabalho muitas vezes longo e penoso se desenvolve. E trabalho que demanda pesquisa, apreciação de conveniência e redação precisa, o que não é fácil de levar a cabo. Por outro lado, essa fase de gestação do projeto, onde se admite que o legislador faça a lei e não simplesmente reproduza o direito não escrito, é a cheia de perigo e tentações, já que é nela sobretudo que a pressão de interesses particulares se faz sentir preponderantemente.

No caso do Poder Judiciário, a iniciativa de lei para as matérias conferidas pela Constituição $^{282}$ é exclusiva, também denominada reservada, cujo aspecto fundamental,

${ }^{282} \mathrm{CF}$, art. 93, caput (iniciativa do STF para o Estatuto da Magistratura); CF, art. 96, II (iniciativa do STF, dos Tribunais Superiores e dos Tribunais de Justiça para leis que tratem sobre: a) alteração do número de membros de tribunais inferiores; b) criação e extinção de cargos e remuneração dos seus serviços auxiliares e dos juízos que lhes forem vinculados, bem como fixação do subsídio de seus membros e dos juízes, inclusive dos tribunais inferiores, onde houver; c) criação ou extinção de tribunais inferiores; e, d) alteração da organização e da divisão judiciárias); e, CF, art. 125, $\S 1^{\circ}$ (iniciativa dos Tribunais de Justiça para as leis de organização judiciária nos Estados). 
conforme também leciona Manoel Gonçalves Ferreira Filho (2012b, p. 230), citado por José Levi Mello do Amaral (2009, p. 1213), “está em resguardar a seu titular a decisão de propor direito novo em matérias confiadas à sua especial atenção, ou de seu interesse preponderante".

Logo, as determinações de envio de projetos de lei pelos tribunais ao Poder Legislativo para adequação da legislação a resoluções expedidas pelo Conselho Nacional de Justiça extrapolam os limites constitucionais de atuação do órgão, que não pode exercer o controle desses atos políticos.

Correta mostrou-se, pois, a revogação da Resolução CNJ nº 48/2007 promovida em 28 de setembro de 2010 pela Resolução CNJ n ${ }^{\circ} 119$, por força da decisão proferida, por maioria, na mesma data, no julgamento do Procedimento de Controle Administrativo $\mathrm{n}^{\mathrm{o}}$ 0000387-93.2010.2.00.0000, relatado pelo Conselheiro Marcelo Nobre (vencido) ${ }^{283}$.

Ainda que nos consideranda da Resolução CNJ no $119 / 2010^{284}$ não tenha sido expressamente mencionado que a revogação da Resolução CNJ no 48/2007 também se justificava ante a impossibilidade do Conselho realizar o controle do ato político dos tribunais relativo à iniciativa de lei, extrai-se do voto condutor da decisão, lavrado pelo

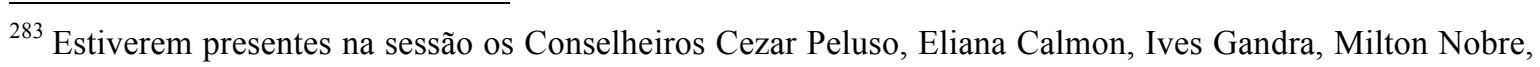
Leomar Barros Amorim, Nelson Tomaz Braga, Paulo Tamburini, Walter Nunes, Morgana Richa, José Adonis Callou de Araújo Sá, Felipe Locke Cavalcanti, Jefferson Luis Kravchychyn, Jorge Hélio Chaves de Oliveira, Marcelo Nobre e Marcelo Neves (conforme certidão de julgamento da $113^{\mathrm{a}}$ Sessão Ordinária do CNJ). Ficaram vencidos no julgamento os Conselheiros Walter Nunes, Marcelo Nobre e Jorge Hélio que votaram pela conversão da Resolução em Recomendação aos Tribunais para se exigir curso superior para o cargo de oficial de justiça (conforme certidão de julgamento da $114^{\mathrm{a}}$ Sessão Ordinária do CNJ que retificou a certidão proferida na sessão anterior).

${ }^{284}$ Segue a íntegra da Resolução $\mathrm{n}^{\circ} 119$, de 28 de setembro de 2010 :

Resolução n ${ }^{\circ} 119$, de 28 de setembro de 2010.

Dispõe sobre a revogação da Resolução $\mathrm{n}^{\circ} 48$, de 16 de dezembro de 2007, alterada pelo Ato Normativo 0007097-66.2009.2.00.0000, julgado na 96 $6^{\mathrm{a}}$ Sessão Ordinária, em 16 de dezembro de 2009.

O PRESIDENTE DO CONSELHO NACIONAL DE JUSTIÇA, no uso de suas atribuições constitucionais e regimentais, e

CONSIDERANDO as peculiaridades locais a respeito da alocação de recursos humanos para o provimento do cargo de Oficial de Justiça;

CONSIDERANDO as necessidades específicas dos tribunais em relação ao provimento do cargo de Oficial de Justiça;

CONSIDERANDO as especificidades orçamentárias de cada tribunal e das unidades da federação;

CONSIDERANDO que, por força das condições peculiares de desenvolvimento local e da estrutura peculiar das respectivas unidades administrativas do Judiciário, a exigência da conclusão de curso de nível superior para o provimento do cargo de Oficial de Justiça, enquanto padrão nacional único, pode ser prejudicial à administração judiciária em determinadas circunstâncias;

CONSIDERANDO o que foi deliberado pelo Plenário do Conselho Nacional de Justiça na sua $113^{\text {a }}$ Sessão Ordinária, realizada em 28 de setembro de 2010, no julgamento do Procedimento de Controle Administrativo $\mathrm{n}^{\circ}$ 0000387-93.2010.2.00.0000;

RESOLVE:

Art. $1^{\circ}$ Revogar a Resolução $\mathrm{n}^{\circ} 48$, de 18 de dezembro de 2007, alterada pelo Ato Normativo 000709766.2009.2.00.0000, julgado na $96^{\mathrm{a}}$ Sessão Ordinária, em 16 de dezembro de 2009.

Art. $2^{\circ}$. Esta Resolução entrará em vigor na data de sua publicação. 
Conselheiro Marcelo Neves, o seguinte trecho elucidativo:

A questão decorre de um obstáculo jurídico intransponível. A iniciativa de lei não é função administrativa, mas sim função legislativa dos tribunais. O CNJ não é competente para controlá-la, salvo se a iniciativa de lei ou a sua omissão esteja relacionada com desvios administrativos suscetíveis de sanção. Mas parece evidente que o $\mathrm{CNJ}$ não tem competência para impor a um tribunal a iniciativa de lei com um conteúdo pré-fixado. Não há, em princípio, sanção a ser aplicada em caso de descumprimento dessa determinação. A função legislativa é automotivada. O máximo que poderia admitir-se, nessa área de competência, seria uma recomendação, mas ela não resolveria o impasse gerado pela Resolução $n^{\circ} 48$.

E ainda no caso de admitida a sua obrigatoriedade, a iniciativa de lei, em princípio, não teria nenhum efeito prático relevante: o legislativo estadual tem competência constitucional de rejeitar ou não aprovar o respectivo projeto. Isso pode ocorrer efetivamente não apenas por força de um eventual "conluio" entre o Judiciário e o Legislativo estadual (que, em princípio, não se deve supor), mas também em virtude de decisão fundamentada do poder legiferante estadual, considerando as peculiaridades locais.

Entendemos que, na mesma linha, deve o Conselho Nacional de Justiça também revogar as disposições da sua Resolução no 88/2009 que determinam aos Tribunais de Justiça o envio de projetos de lei para adequação das legislações estaduais aos seus termos (art. $1^{\circ}, \S 2^{\circ}$; art. $2^{\circ}, \S 2^{\circ}$, in fine; e, art. $3^{\circ}, \S 3^{\circ}$ ), pois implicam em exercício de controle de prática de ato político pelo órgão, não admitido pela Constituição Federal.

Cumpre destacar que a Resolução CNJ $n^{\text {o }}$ 88/2009 padece de outra inconstitucionalidade, pois seu art. $1^{\circ}$, caput, fixa a jornada de trabalho dos servidores do Poder Judiciário (oito horas diárias e quarenta horas semanais, facultada a fixação de sete horas ininterruptas).

É certo que a mesma norma ressalva a hipótese de existência de legislação local ou especial disciplinando a duração do trabalho dos servidores do Poder Judiciário de modo diverso, mas, em seguida, no seu parágrafo $2^{\circ}$, como já mencionado, determina que os Tribunais de Justiça dos Estados, nessa hipótese, encaminhem projeto de lei, no prazo de 
90 (noventa) dias, para adequação ao horário fixado na resolução, proibindo o envio de projeto de lei para fixação de horário diverso do nela estabelecido.

Ocorre que o Supremo Tribunal Federal assentou que, apesar da disciplina de expediente forense poder ser regulada pelos tribunais, desde que o façam por decisão colegiada (ADI no 2907 da relatoria do Ministro Ricardo Lewandowski) ${ }^{285}$, a alteração da carga horária semanal de labor tem que ser tratada em lei de iniciativa reservada do Chefe do Poder Executivo (ADIMC $\mathrm{n}^{\circ}$ 2308, Relator Ministro Moreira Alves, j. 25.4.2001; ADIMC n 2400, Relator Ministro Ilmar Galvão, j. 19.4.2001), por força da norma inserta no artigo 61, § $1^{\circ}$, II, “c”, da Constituição Federal, aplicável compulsoriamente aos Estados-membros (ADI n ${ }^{\circ}$ 120, Relator Ministro Moreira Alves, j. 20.3.96; ADI $n^{\circ} 227$, Relator Ministro Maurício Corrêa, j. 19.11.91; ADI nº 822, Relator Ministro Octavio Gallotti, j. 25.4.96), uma vez que dispõe sobre o regime jurídico de servidores públicos ${ }^{286}$. Logo, além da norma prevista na cabeça do art. $1^{\text {o }}$ da Resolução CNJ no 88/2009 ser inconstitucional, pois trata de matéria reservada a lei de iniciativa exclusiva do Chefe do Executivo, quaisquer projetos de lei encaminhados pelos Tribunais de Justiça, em obediência à determinação contida no art. $1^{\circ}, \S 2^{\circ}$, do referido diploma normativo, para adequação da legislações estaduais aos seus termos, podem ser rejeitados já no exame realizado pelas Comissões de Constituição e Justiça das Assembleias Legislativas ${ }^{287}$.

\footnotetext{
${ }^{285}$ Vide item 2.3.3.1.

${ }^{286}$ A expressão "regime jurídico de servidores públicos", na lição apresentada pelo Ministro Celso de Mello no julgamento da ADIMC $\mathrm{n}^{\mathrm{o}}$ 766, em 3 de setembro de 1992, "exterioriza o conjunto de normas que disciplinam os diversos aspectos das relações estatutárias ou contratuais, mantidas pelo Estado com os seus agentes" e "compreende todas as regras pertinentes (a) às formas de provimento; (b) às formas de nomeação; (c) à realização do concurso; (d) à posse; (e) ao exercício, inclusive as hipóteses de afastamento, de dispensa de ponto e de contagem de tempo de serviço; (f) às hipóteses de vacância; (g) à promoção e respectivos critérios, bem como avaliação do mérito e classificação final (cursos, títulos, interstícios mínimos); (h) aos direitos e às vantagens de ordem pecuniária; (i) às reposições salariais e aos vencimentos; (j) ao horário de trabalho e ao ponto, inclusive os regimes especiais de trabalho; $(\mathrm{k})$ aos adicionais por tempo de serviço, gratificações, diárias, ajudas de custo e acumulações remuneradas; (1) às férias, licenças em geral, estabilidade, disponibilidade, aposentadoria; (m) aos deveres e proibições; (n) às penalidades e sua aplicação; (o) ao processo administrativo".

${ }^{287}$ Ao tratar da Comissão de Constituição e Justiça e de Cidadania (CCJC) da Câmara dos Deputados, Paulo Adib Casseb (2008, pp. 289 e 290) esclarece, em lição também aplicável a órgãos internos semelhantes das Casas Legislativas dos Estados, que ela é "dotada de competência para tratar dos aspectos constitucional, legal, jurídico, regimental e de técnica legislativa de todos os projetos, emendas e substitutivos que são apresentados ao Plenário e às comissões, o que proporciona a participação dessa Comissão no exame formal de todas as proposições, elevando sua visibilidade perante a sociedade, em virtude da constante divulgação de seus trabalhos pelos meios de comunicação social". No Estado de São Paulo, por exemplo, o Regimento Interno da Assembleia Legislativa, consolidado pelo Ato $\mathrm{n}^{\mathrm{o}}$ 15, de 17 de junho de 2011, confere ao Presidente da Casa a atribuição de deixar de aceitar proposições que lhe sejam encaminhadas (inclusive projetos de lei (art. 133)) caso não atendam as exigências regimentais ou constitucionais, cabendo recurso à Comissão de Constituição, Justiça e Redação (art. 18, II, “b”). Esta tem competência para manifestar-se a respeito de todos os assuntos quanto ao aspecto constitucional, legal e jurídico, apresentar a redação final das proposições, salvo nos casos em que essa incumbência estiver expressamente deferida pelo Regimento
} 
Em resumo, por não ter o Conselho Nacional de Justiça competência para exercer o controle de atos políticos, no que tange ao seu revestimento estritamente político, não pode determinar que os Tribunais de Justiça encaminhem, em prazos especificados, projetos de lei para adequação de legislações locais aos termos de suas resoluções. Logo, correta a revogação da Resolução CNJ n 48/2007 pela Resolução CNJ nº 119/2010, devendo também ser revogadas as normas previstas nos art. $1^{\circ}, \S 2^{\circ}$, art. $2^{\circ}, \S 2^{\circ}$, in fine; e, art. $3^{\circ}, \S$ $3^{\circ}$, todos da Resolução CNJ $n^{\circ}$ 88/2009, pois eivadas de semelhante inconstitucionalidade ${ }^{288289}$.

\subsection{6. Órgão que também se ocupa do controle do cumprimento dos deveres}

Interno a outra Comissão, e ainda manifestar-se quanto ao mérito das proposições em diversos casos, inclusive naqueles relacionados ao Poder Judiciário (art. $31, \S 1^{\circ}$ ). Uma proposição não admitida, pois reputada inconstitucional ou antirregimental, somente seguirá o trâmite regimental se a Comissão de Constituição, Justiça e Redação, ouvida, discordar da decisão (art. 135, § $2^{\circ}$ ).

${ }^{288}$ Cumpre registrar que a Mesa da Assembleia Legislativa do Estado de Pernambuco e a Associação Nacional dos Magistrados Estaduais (ANAMAGES) ajuizaram no Supremo Tribunal Federal, em 5 de outubro de 2009 e 9 de dezembro de 2009, respectivamente, as Ações Diretas de Inconstitucionalidade $n^{\circ} \mathrm{s}$ 4312 e 4355 para impugnar os termos da Resolução CNJ nº 88/2009. Ambas as ações estão apensadas e sob a relatoria do Ministro Celso de Mello. Não foram, porém, julgadas pela Suprema Corte Brasileira até o término deste trabalho.

${ }^{289}$ Também é relevante mencionar, por se tratar de mais uma atuação do Conselho Nacional de Justiça que implicou em controle de ato político, que a Associação dos Magistrados Brasileiros (AMB), a Associação dos Magistrados do Amapá (AMAAP) e a Associação dos Magistrados do Espírito Santo (AMAGES) impetraram perante o Supremo Tribunal Federal, em 15 de dezembro de 2012, o Mandado de Segurança $n^{\circ}$ 31667 para anular a decisão administrativa proferida, por unanimidade, nos Pedidos de Providências $n^{\circ} \mathrm{s}$ 0002421-70.2012.2.0000 e 0002254-53.2012.2.00.000 (relatora Conselheira Eliana Calmon) na $151^{\mathrm{a}}$ Sessão Ordinária do CNJ. Referida decisão determinou aos Tribunais de Justiça que informaram a existência de legislação em seus Estados com previsão de fixação do percentual de férias referido no art. $7^{\circ}$, inciso XVII, da Constituição Federal, superior a um terço do subsídio mensal auferido pelos Magistrados o envio de projetos de lei às Assembleias Legislativas com previsão de redução desse percentual, bem como ordenou a expedição da mesma determinação aos tribunais que eventualmente tenham encaminhado projetos de lei para a majoração em referência. Argumentaram as impetrantes que a decisão proferida: a) violou a competência privativa dos Tribunais para dispor sobre a elaboração e o envio de projeto de lei de sua competência ao Poder Legislativo e infringiram o princípio do autogoverno dos tribunais; b) implicou em desvio de finalidade, pois não detém o CNJ competência para reconhecer a inconstitucionalidade de leis; c) importou em invasão, por órgão federal, de competência privativa conferidas às Cortes de Justiça estaduais; e, d) não observou o teor da regra constitucional que estabelece a terça parte do salário como adicional mínimo a ser pago a título de "abono de férias", sendo legítimo o pagamento da vantagem em valor superior quando previsto em lei regularmente editada, uma vez que não há disposição a respeito na LOMAN. O mandado de segurança foi distribuído à relatoria do Ministro Dias Toffoli que, em 7 de novembro de 2012, deferiu o pedido de liminar para suspender os efeitos da decisão impugnada até final julgamento do writ por entender, em juízo de estrita delibação, existir plausibilidade na tese jurídica desenvolvida no no que diz respeito à extrapolação das atribuições conferidas ao Conselho Nacional de Justiça enquanto órgão de controle da atuação administrativa e financeira do Poder Judiciário. O Procurador-Geral de Justiça Rodrigo Janot Monteiro de Barros, em parecer ofertado em 3 de julho de 2014, opinou pela concessão da segurança pleiteada, pois "a determinação, por parte do CNJ, para que os Tribunais de Justiça dos Estados encaminhem aos respectivos Poderes Legislativos projetos de lei reduzindo o percentual de abono de férias previsto no art. 7o, XVII, da Constituição Federal, invade a competência privativa de iniciativa legislativa dos Tribunais, prevista no art. 96, II, “b” da CF”. Até o depósito desta dissertação, porém, o mandamus ainda não havia sido julgado definitivamente. 


\section{funcionais dos juízes}

Além do controle da atuação administrativa e financeira do Poder Judiciário, prescreve a norma inserta no art. 103-B, $\S 4^{\mathrm{o}}$, da Constituição Federal competir ao Conselho Nacional de Justiça o controle do "cumprimento dos deveres funcionais dos juízes".

Conforme salienta Alexandre de Moraes (2013b, p. 542), ao destacar trecho do voto do Ministro Cezar Peluso na ADI no 3367,

o controle ético-disciplinar a ser realizado pelo Conselho Nacional de Justiça, em relação a todos os membros da magistratura, "representa expressiva conquista do Estado democrático de direito a consciência de que os mecanismos de responsabilização dos juízes, por inobservância das obrigações funcionais, são imprescindíveis à boa prestação jurisdicional, sendo de reconhecer, como imperativo do regime republicano e da inteireza e serventia da função, a necessidade de convívio permanente entre a independência jurisdicional e instrumentos de responsabilização dos juízes que não sejam apenas formais, mas que cumpram, com efetividade, o papel que se lhes predica"

A respeito dessa característica do $\mathrm{CNJ}$, cumpre primeiro observar que, apesar da norma constitucional em comento utilizar a palavra "juízes", esse controle atinge todos os magistrados, inclusive os desembargadores dos Tribunais de Justiça e os Ministros dos Tribunais Superiores, com exceção dos Ministros do Supremo Tribunal Federal, conforme restou decidido na ADI $n^{\mathrm{o}} 3367^{290291}$.

Deve-se definir, por outro lado, qual o alcance da expressão "deveres funcionais dos juízes" pois eventual controle exercido pelo Conselho Nacional de Justiça sobre o cumprimento de outros deveres dos magistrados implica em violação aos limites

${ }^{290}$ Segue trecho da ementa da ADI n ${ }^{\circ} 3367$ :

4. PODER JUDICIÁRIO. Conselho Nacional de Justiça. Órgão de natureza exclusivamente administrativa. Atribuições de controle da atividade administrativa, financeira e disciplinar da magistratura. Competência relativa apenas aos órgãos e juízes situados, hierarquicamente, abaixo do Supremo Tribunal Federal. Preeminência deste, como órgão máximo do Poder Judiciário, sobre o Conselho, cujos atos e decisões estão sujeitos a seu controle jurisdicional. Inteligência dos art. 102, caput, inc. I, letra "r", e $\S 4^{\circ}$, da CF. O Conselho Nacional de Justiça não tem nenhuma competência sobre o Supremo Tribunal Federal e seus ministros, sendo esse o órgão máximo do Poder Judiciário nacional, a que aquele está sujeito".

${ }^{291}$ Vide item 2.3.7.1. 
constitucionais de sua atuação.

Para tanto, cumpre trazer à baila a ensinança de Sidnei Agostinho Beneti (2003, pp. 151 e 152). O autor doutrina que os "deveres do Juiz têm muito que ver com as relações entre o Juiz e a sociedade a que serve", pois o magistrado é, também, “um 'político', porque participa da direção comportamental da sociedade". Esclarece, em seguida, que "a sociedade fornece valores institucionais ao Juiz, por intermédio das normas jurídicas e mediante atuação direta da comunicação social". No entanto, muitas vezes os valores decorrentes dessa sociedade se confrontam com os ditames legais. Cabe ao magistrado, pois, filtrar os valores que lhe são exigidos decorrentes da interação social, cotejando-os com o imperativo da técnica ${ }^{292}$.

Beneti (2003, p. 154) divide, assim, os deveres do juiz em jurídicos e morais. Os primeiros, enumerados no direito positivo, constituem o "círculo mínimo de regras diante do círculo maior de regras morais em que se insere". Os últimos, por seu turno, decorrem "da exigência social das virtudes judiciais não constantes da lei”, e traduzem-se, na forma positiva , em mandamentos - virtudes essenciais ao bom juiz -, e, na formulação negativa, em verdadeiros pecados capitais do Juiz.

Quanto às sanções ante a não observância, pelos magistrados, do cumprimento de seus deveres jurídicos e morais, prossegue o jurista (2003, p. 154):

O rol de deveres não sancionados pela lei, mas de imensa relevância para o Juiz e a sociedade, é sancionado pela opinião pública, cuja adesão auxilia fortemente o efetivar das decisões de Magistrados de adequada virtude, ao mesmo tempo em que incentiva a desobediência a comandos jurisdicionais provindos de Magistrados portadores de imagem de descrédito. A despeito de não providos de sanção legal que leve à coactividade, esses deveres decorrentes de exigência social de virtudes devem ser referidos [...] mediante exposição das virtudes básicas e seus mandamentos e os defeitos componentes do rol de pecados capitais que corroem a figura do Juiz.

No que tange aos deveres jurídicos do juiz, após listar (2003, pp. 157 a 168) os

\footnotetext{
${ }^{292}$ O autor apresenta o seguinte exemplo (2003, p. 152): Diante do "choque entre a exigência de celeridade nas decisões e a demora, decorrente da observância das garantias processuais" deve prevalecer a última, "porque resulta de valores cristalizados na lei, relativamente aos quais, salvo o aproveitamento de atos irregulares sem nulidade, não resta nenhum espaço de discricionariedade ao Juiz”.
} 
previstos na Constituição Federal, na Lei Orgânica da Magistratura ${ }^{293}$ e nas Leis Processuais $^{294}$, assinala Beneti que os magistrados também estão submetidos a extenso rol

${ }^{293}$ Beneti (2003, pp. 157/161) arrola os seguintes deveres jurídicos do juiz previstos na Constituição Federal
e na Lei Orgânica da Magistratura: a) Residência na Comarca (CF, art. 93, VII; LOMAN, art. 35, V); b)
Publicidade das decisões (CF, art. 93, IX); c) Motivação das decisões (CF, art. 93, IX e X); d) Abstenção de
exercício de função (CF, art. 95, parágrafo único, I; LOMAN, art. 26, "a" e §§ $1^{\circ}$ e $2^{\circ}$ ); e) Abstenção de
percepção de custas ou participação em processo (CF, art. 95, parágrafo único, II; LOMAN, art. 26, II, "b");
f) Abstenção de atividade político-partidária (CF, art. 95, parágrafo único, III; LOMAN, art. 26, II, "c"); g)
Legalidade (LOMAN, art. 35, I); h) Efetividade (LOMAN, art. 35, I); i) Independência (LOMAN, art. 35, I);
j) Serenidade (LOMAN, art. 35, I); k) Exatidão (LOMAN, art. 35, I); 1) Respeito a prazos (LOMAN, art. 35,
II); m) Correcionalidade de subordinados (LOMAN, art. 35, III e VII); n) Urbanidade (LOMAN, 35, IV); o)
Atendimento urgente (LOMAN, art. 35, IV); p) Comparecimento pontual (LOMAN, art. 35, VI); q)
Permanência até o fim do expediente (LOMAN, art. 35, VI); r) Conduta pessoal irrepreensível (LOMAN, art.
35, VIII); s) Abstenção de atividade comercial (LOMAN, art. 36, I); t) Abstenção de exercício de cargo de
direção ou técnico (LOMAN, art. 36, II); u) Abstenção de manifestação de opinião sobre processo pendente
(LOMAN, art. 36, III); v) Informaçãa mensal de produção pessoal (LOMAN, art. 39); w) Propriedade de
linguagem (LOMAN, art. 41); x) Não-envolvimento criminal (LOMAN, art. 26, I); y) Abstenção de
exercício de cargo de direção ou técnico em estabelecimento de ensino (LOMAN, art. 26, §§ $1^{\circ}$ e $2^{\circ}$ ); e, z)
Prolação de voto (LOMAN, art. 121). ${ }^{294} \mathrm{O}$ autor (2003, pp. 164 a 167) enumera os seguintes deveres jurídicos do juiz previstos no Código de Processo Civil: a) Dever de exercício da jurisdição (CPC, art. $\left.1^{\circ}\right)$; b) Abstenção, em regra, de procedimento ex officio (CPC, art. $2^{\circ}$ ); c) Dever-poder de polícia nos excessos de linguagem (CPC, art. 15); d) Nãoadiamento injustificado de atos processuais, sob pena de pagamento de despesas resultantes da repetição (CPC, art. 29); e) Dever de reunião de ações conexas (CPC, art. 105); f) Dever de direção do processo segundo as disposições do Código de Processo (CPC, art. 125); g) Dever de garantir às partes igualdade de tratamento (CPC, art. 125, I); h) Dever de velar pela rápida solução do litígio (CPC, art. 125, II); i) Dever de prevenir ou reprimir qualquer ato contrário à dignidade da Justiça (CPC, art. 125, III); j) Dever de tentar, a qualquer tempo, conciliar as partes (CPC, art. 125, IV); k) Dever de sentenciar ou despachar, não podendo alegar lacuna ou obscuridade da lei (CPC, art.126); 1) Dever de julgar segundo as normas legais, recorrendo, se não as houver, à analogia, aos costumes e aos princípios gerais de direito (CPC, art. 126); $\mathrm{m}$ ) Dever de decidir por equidade apenas nos casos previstos em lei (CPC, art. 127); n) Dever de julgar a lide nos limites em que proposta (CPC, art. 128); o) Dever de coibir o uso do processo para praticar ato simulado ou conseguir fim proibido por lei (CPC, art. 129); p) Dever de "determinar provas necessárias à instrução do processo" (CPC, art. 130, $1^{\circ}$ parte); q) Dever de indeferir "as diligências inúteis ou meramente protelatórias" (CPC, art. $130,2^{\circ}$ parte); r) Dever de livre apreciação da prova "atendendo aos fatos e circunstâncias constantes dos autos, ainda que não alegados pelas partes" (CPC, art. 131); s) Dever de motivação, indicando, "na sentença, os motivos que lhe formaram o convencimento" (CPC, art. 131); t) Dever de julgar a lide se concluir a audiência - princípio da identidade física do Juiz (CPC, art. 132); u) Dever de abster-se de procedimento "com dolo ou fraude", sob pena de responder por perdas e danos (CPC, art. 133, I); v) Dever de não "recusar, omitir ou retardar, sem justo motivo, providência que deva ordenar de ofício, ou a requerimento da parte" (CPC, art. 133, II); w) Dever de declarar o impedimento ou suspeição (CPC, art. 134); x) Poder de polícia nos autos quanto a cotas marginais ou interlineares, mandando-as riscar o Juiz e impondo multa aos seus autores (CPC, art. 161); y) Dever de documentação mediante assinatura e rubrica (CPC, art. 164); z) Dever de observar prazos para despachos de expediente (2 dias) e decisões (10 dias) (CPC, art. 189), permitindo-se exceder esses prazos por motivo justificado (CPC, art. 187) e podendo as partes representar a respeito, e podendo o relator avocar o caso ou designar outro juiz (CPC, art. 198); aa) Dever de decretação da prescrição de ofício (CPC, art. $\left.219, \S 4^{\circ}\right)$; ab) Dever de impulso oficial do processo (CPC, art. 262); ac) Dever de declarar de imediato o impedimento ou suspeição (CPC, art. 313), podendo ser condenado nas custas (CPC, art. 314); ad) Dever do exercício do poder de polícia na audiência (CPC, art. 445), especialmente "mantendo a ordem e o decoro na audiência", ordenando "que se retirem da sala da audiência os que se comportarem inconvenientemente" e devendo "requisitar, quando necessário, a força policial" (CPC, art. 445); ae) Dever de "dirigir os trabalhos da audiência", de "proceder direta e pessoalmente à colheita das provas" e de "exortar os advogados e o órgão do Ministério Público a que discutam a causa com elevação e urbanidade" (CPC, art. 446); af) Dever de fixar os pontos controvertidos sobre que incidirá a prova (CPC, art. 451); ag) Dever de prolação da sentença assim que terminada a audiência ou no prazo de 10 dias (CPC, art. 456), ah) Dever de determinação de atos executivos pelo Juiz (CPC, art. 577); ai) Dever de iniciar inventário ex officio (CPC, art. 989); e, aj) Dever de decidir o processo de jurisdição voluntária em 10 
oriundo de outras leis, como os Códigos Judiciários Estaduais, e de atos normativos do tribunais (e, atualmente, também do Conselho Nacional de Justiça), de impossível exposição exauriente.

Sistematiza, pois, os deveres jurídicos previstas na Carta Política e na LOMAN em quatro espécies (2003, pp. 168 a 170): a) deveres pessoais: aqueles "incidentes sobre o modo de ser do cidadão juiz, características de personalidade, de comportamento profissional, de vida particular e pública" ${ }^{295}$; b) deveres administrativos: "decorrem da qualidade de ocupante de cargo público e, consequentemente, de agente político na direção da sociedade, nos limites reservados ao Magistrado" com subordinação hierárquica, pois não jurisdicionais ${ }^{296}$; c) deveres jurisdicionais gerais: “incidentes sobre o exercício da função de julgar típica do Poder Judiciário, relevando-se, neles, a não submissão a nenhuma hierarquia, nem mesmo às diretrizes do próprio Tribunal ou à jurisprudência mais elevada"297; e, d) deveres jurisdicionais processuais: decorrentes de "normas processuais cíveis, penais, trabalhistas, eleitorais e militares, cujos Códigos de regência reescrevem, com linguagem preceptiva específica a cada necessidade, os deveres jurisdicionais

dias, adotando a solução mais conveniente (CPC, art. 1.109). Em seguida (2003, pp. 167 e 168), apresenta os seguintes deveres jurídicos do juiz extraídos do Código de Processo Penal: a) Dever de remessa do inquérito ao Procurador-Geral no caso de arquivamento (CPP, art. 28); b) Dever de decretação da extinção da punibilidade ex officio no caso de óbito do acusado (CPP, art. 61); c) Dever de afirmar a suspeição por escrito (CPP, art. 97); d) Dever de agir diante de recusa pela parte (CPP, art. 98); e) Dever de sustar a marcha do processo diante da declaração de suspeição (CPP, art. 99); f) Dever de requisição da força pública (CPP, art. 251); g) Incumbência do Juiz (CPP, art. 251); h) Dever de afastar-se de processo (CPP, art. 252); i) Dever de afirmar espontaneamente a suspeição (CPP, art. 254); j) Dever de declaração de impedimento ou suspeição (CPP, art. 255); k) Dever de não declarar a suspeição (CPP, art. 256); 1) Dever de concessão de liberdade provisória no caso de pobreza do acusado (CPP, art. 350); m) Dever de designação de dia e hora para prosseguimento da instrução criminal no caso de adiamento (CPP, art. 372); n) Dever de expedir ordem de habeas corpus (CPP, art. 654); o) Dever do Juiz presidente do Tribunal do Júri (CPP, art. 692); p) Dever de motivar a concessão ou não de suspensão condicional da pena (CPP, art. 697); e, q) Prazo para despachos ou sentenças (CPP, art. 800).

$2951^{\circ}$ ) Independência (LOMAN, art. 35, I); $2^{\circ}$ ) Efetividade (LOMAN, art. 35, I); $3^{\circ}$ ) Serenidade (LOMAN, art. 35, I); $4^{\circ}$ ) Exatidão (LOMAN, art.35, I); $5^{\circ}$ ) Legalidade (LOMAN, art. 35, I); $6^{\circ}$ ) Urbanidade (LOMAN, art. 35, IV); $7^{\circ}$ ) Disponibilidade urgente (LOMAN, art. 35, IV); e, $8^{\circ}$ ) Conduta pessoal irrepreensível (LOMAN, art. 35, VIII).

$2961^{\text {o) }}$ Residência na Comarca (CF, art. 93, VII); $2^{\circ}$ ) Vedação de atividade político-partidária (CF, art. 92, parágrafo único, III); $3^{\circ}$ ) Motivação de decisões administrativas ( CF, art. 93, IX); $4^{\circ}$ ) Publicidade ou transparência (CF, art. 93, IX); $5^{\circ}$ ) Vedação de acumulação de cargos, exceto atividade docente (CF, art. 95, parágrafo único, I; LOMAN, art. 26, $\left.\S 1^{\circ}\right) ; 6^{\circ}$ ) Correcionalidade de subordinados (LOMAN, art. 35, VII); $7^{\circ}$ ) Vedação de exercício do comércio e de participação societária (LOMAN, art. 36, I); $8^{\circ}$ ) Vedação de participação diretiva (LOMAN, art. 36, II); e, $9^{\circ}$ ) Vedação de emissão de opinião em matéria jurisdicional (LOMAN, art. 36, III).

${ }^{297} 1^{\text {o}}$ ) Motivação das decisões (CF, art. 93, IX); $2^{\circ}$ ) Publicidade da atuação (CF, art. 93, IX); $3^{\text {o }}$ ) Vedação de recebimento por processo (CF, art. 95, parágrafo único, II; LOMAN, art. 26, II, “b”); e, $4^{\circ}$ ) Correcionalidade de subordinados (LOMAN, art. 35, VII). 
gerais ${ }^{298}$.

Em seguida, quanto aos deveres morais do juiz, Sidnei Agostinho Beneti (2003, pp. 171 a 175) apresenta extenso rol de virtudes do magistrado, dividindo-as em quatro espécies: a) deveres pessoais ${ }^{299}$; b) deveres sociais ${ }^{300}$; c) deveres organizacionais ${ }^{301}$; e, d) deveres jurisdicionais ${ }^{302}$.

Por fim, ainda no que tange aos deveres morais do juiz, Beneti (2003, p. 175 a 179) arrola trinta e sete condutas que entende não deverem ser adotadas pelos magistrados ${ }^{303}$.

Verifica-se que diversos deveres morais mencionados pelo autor também são citados como deveres jurídicos do magistrado ou, ao menos, muito se aproximam, em sua definição, de condutas positivadas como, por exemplo, os deveres de cordialidade (a LOMAN trata da urbanidade - art. 35, IV), independência (LOMAN, art. 35, I), distância político-partidária (CF, art. 95, parágrafo único, III; LOMAN, art. 26, II, “c”); pontualidade (LOMAN, art. 35, VI); correicionalidade (LOMAN, art. 35, III e VII) e motivação das decisões (CF, art. 93, IX e X).

Outros deveres morais relacionados por Beneti, em sua pureza, não podem ser

$2981^{\circ}$ ) Respeito aos prazos (LOMAN, art. 35, III); $2^{\circ}$ ) Correcionalidade (LOMAN, art. 35, VII); e, $3^{\circ}$ ) Presença pontual ao expediente ou sessão (LOMAN, art. 35, VI).

$2991^{\circ}$ ) Cordialidade no trato pessoal; $2^{\circ}$ ) Sentimento de Justiça; $3^{\circ}$ ) Firmeza no decidir; $4^{\circ}$ ) Independência; $5^{\circ}$ ) Prudência no decidir e no executar; $6^{\circ}$ ) Cultura; $7^{\circ}$ ) Idealismo; $8^{\circ}$ ) Realismo; $9^{\circ}$ ) Senso crítico; $10^{\circ}$ ) Ausência de preconceitos no agir; $11^{\circ}$ ) Pluralismo para conviver com os opostos e assegurar-lhes os direitos; $12^{\circ}$ ) Exação econômica; $13^{\circ}$ ) Sobriedade pessoal em cada momento da vida; $14^{\circ}$ ) Organização; $15^{\circ}$ ) Obediência à lei; $16^{\circ}$ ) Comunicabilidade; $17^{\circ}$ ) Coragem pessoal; $18^{\circ}$ ) Perseverança; $19^{\circ}$ ) Compreensão para com os que têm direito; $20^{\circ}$ ) Reta intenção; e, $21^{\circ}$ ) Altruísmo.

${ }^{300} 1^{\circ}$ ) Sintonia social; $2^{\circ}$ ) Desvinculação; $3^{\circ}$ ) Idoneidade familiar do cônjuge, filhos e parentes próximos; $4^{\circ}$ ) Imagem pública de ser e parecer comprometido com os valores da justiça; $5^{\circ}$ ) Distância político-partidária; $6^{\circ}$ ) Atuação comunitária; e, $7^{\circ}$ ) Igualdade de tratamento de desfavorecidos e poderosos.

${ }^{301} 1^{\text {o }}$ ) Pontualidade; $2^{\circ}$ ) Senso de direção na organização do serviço; $3^{\circ}$ ) Correcionalidade permanente; $4^{\circ}$ ) Justiça na direção organizacional; e, $5^{\circ}$ ) Liderança do pessoal cartorário.

$3021^{\circ}$ ) Presteza nas decisões e providências; $2^{\circ}$ ) Motivação das decisões; $3^{\circ}$ ) Aplicação aos casos; e, $4^{\circ}$ ) Disposição de Justiça.

${ }^{303} 1^{\text {o) }}$ Trato pessoal agressivo; $2^{\circ}$ ) Descortesia; $3^{\circ}$ ) Displicência no ouvir e no atender; $4^{\circ}$ ) Desrespeito a prerrogativas profissionais; $5^{\circ}$ ) Falta de educação; $6^{\circ}$ ) Recusa de atendimento; $7^{\circ}$ ) Deboche no comportamento; $8^{\circ}$ ) Desregramento familiar, próprio ou de familiares; $9^{\circ}$ ) Amizades de comportamento duvidoso; $10^{\circ}$ ) Abuso de bebida alcoólica; $11^{\circ}$ ) Informalidade excessiva; $12^{\circ}$ ) Conduta pessoal desregrada; $13^{\circ}$ ) Indumentária inadequada no trabalho ou fora dele; $14^{\circ}$ ) Linguagem verbal inadequada; $15^{\circ}$ ) Linguagem inadequada nos auto; $16^{\circ}$ ) Residência fora da Comarca; $17^{\circ}$ ) Ausência da Comarca; $18^{\circ}$ ) Impontualidade de audiências e em compromissos em geral; $19^{\circ}$ ) Atraso no serviço; $20^{\circ}$ ) Descontrole pessoal em atividades desportivas em geral; $21^{\circ}$ ) Frequência a locais de desregramento de costumes; $22^{\circ}$ ) Incontinência libertina; $23^{\circ}$ ) Descontrole financeiro; 24 ) Ataque crítico a decisões de Tribunais ou outros Juízes; $25^{\circ}$ ) permeabilidade a influências; $26^{\circ}$ ) Temor diante da pressão da mídia e de forças sociais componentes da Comunicação social; $27^{\circ}$ ) Devassamento de segredo de ofício; $28^{\circ}$ ) Submissão ao poder; $29^{\circ}$ ) Hostilização gratuita; $30^{\circ}$ ) Preconceitos em geral; $31^{\circ}$ ) Ironia; $32^{\circ}$ ) Mau tratamento ou falta de consideração para com funcionários; $33^{\circ}$ ) Formalismo excessivo; $34^{\circ}$ ) Reduzida produção jurisdicional; $35^{\circ}$ ) Designação de audiências para datas extremamente distantes; $36^{\circ}$ ) Recebimento de dádivas; e, $37^{\circ}$ ) Realização de favores jurisdicionais. 
classificados entre os deveres positivados e não os tangenciam de forma evidente. Sua violação, pois, apenas indiretamente pode implicar também na infringência de algum dever jurídico. Para ilustrar, pode-se citar os deveres morais de prudência, cultura, idealismo, realismo, senso crítico, pluralismo, exação econômica, sobriedade pessoal, organização, comunicabilidade, coragem pessoal compreensão, altruísmo, liderança, etc.

Observada a classificação proposta por Beneti (deveres jurídicos e morais do juiz), entendemos, uma vez que o descumprimento de deveres morais pode ser sancionado pela opinião pública, ao passo que a violação a deveres jurídicos é sancionada pela lei, apesar de alguns daqueles se confundirem com estes, que não compete ao $\mathrm{CNJ}$ exercer controle sobre deveres morais que não tenham correspondência ou relação com algum dever jurídico do magistrado.

Em outras palavras, quando a Constituição atribuiu ao Conselho Nacional de Justiça competência para o controle "do cumprimento dos deveres funcionais dos juízes" referiuse aos deveres jurídicos positivados. Não compete ao Conselho, porém, exercer um controle social da conduta do magistrado (fiscalizando o cumprimento de deveres estritamente ou puramente morais dos juízes, que não correspondam a qualquer dever previsto em norma).

Por exemplo se um magistrado não é, perante a sociedade, reputado corajoso, mas cumpre todos os seus deveres jurídicos, não compete ao $\mathrm{CNJ}$ exercer qualquer controle sobre sua atuação, até porque o próprio conceito de coragem varia no espaço e no tempo.

Da mesma forma, se a falta de encanto cultural do magistrado, indicada, por exemplo, pelo completo desinteresse em frequentar cursos oficiais das Escolas de Magistratura de inscrição facultativa, não importar em violação de deveres positivados, não pode o Conselho, da mesma forma, sancioná-lo.

Assim, pensamos que a expressão “deveres funcionais dos juízes” inserta no art. 103$\mathrm{B}, \S 4^{\mathrm{o}}$, refere-se exclusivamente aos deveres jurídicos dos magistrados, positivados, consubstaciem estes ou não também deveres morais. Logo, o Conselho Nacional de Justiça infringirá seus limites constitucionais de atuação se pretender exercer controle sobre o cumprimento de deveres puramente morais exigidos pela sociedade dos magistrados.

Mas, mesmo no exercício do controle do cumprimento dos deveres jurídicos dos magistrados, a atuação do Conselho Nacional de Justiça encontra outro limite constitucional: a independência dos juízes, entendida em sua dimensão individual, ou seja, "a independência do juiz enquanto protagonista principal" do Poder Judiciário (Sébastien 
Conan $(2005 \text {, p. 68) })^{304}$.

Já foi exposto que não compete ao Conselho Nacional de Justiça o exercício da atividade jurisdicional. Não lhe cabe, pois, modificar decisões judiciais, como instância originária ou recursal $^{305}$.

De outra banda, também não pode o Conselho, a pretexto de exercer o controle administrativo do cumprimento dos deveres funcionais dos juízes, pressionar ou direcionar suas decisões, atingindo a independência da Magistratura e, por conseguinte, a própria imparcialidade dos provimentos judiciais.

Ao abordar as tristezas e heroísmos da vida dos juízes, trata Piero Calamandrei (2013, pp. 100 e 101) da independência da Magistratura:

Não conheço qualquer ofício em que, mais do que no do juiz, se exija tão grande noção de viril dignidade, esse sentimento que manda procurar na própria consciência, mas do que nas ordens alheias, a justificação do modo de proceder, assumindo as respectivas responsabilidades.

A independência dos juízes, isto é, aquele princípio institucional por força do qual, ao julgarem, se devem sentir desligados de qualquer subordinação hierárquica, é um privilégio duro, que impõe, a quem dele goza, a coragem de ficar só, consigo mesmo, sem que se possa comodamente arranjar um esconderijo por detrás de ordem superior.

Assinala Dalmo de Abreu Dallari (1996, pp. 45 a 47) que essa independência visa a imparcialidade da Magistratura e interessa a toda a sociedade:

Longe de ser um privilégio para os juízes, a independência da magistratura é necessária para o povo, que precisa de juízes imparciais para harmonização pacífica e justa dos conflitos de direitos. A rigor, pode-se afirmar que os juízes têm a obrigação de defender sua independência, pois sem esta a atividade jurisdicional pode, facilmente, ser reduzida a uma farsa, uma fachada nobre para ocultar do povo a realidade das discriminações e das injustiças. [...] A magistratura deve ser

\footnotetext{
${ }^{304}$ Sébastien Conan lembra (2005, pp. 68 a 69) que são reconhecidas duas dimensão no conceito de independência dos juízes: a institucional, relacionada à independência do Poder Judiciário "enquanto instituição do Estado democrático", e a dimensão individual, que considera terem os juiz o direito de gozar de independência no exercício de suas funções.

${ }^{305}$ Vide item 2.3.5.1.
} 
independente para que se possa orientar no sentido da justiça, decidindo com equidade os conflitos de interesses. O juiz não pode sofrer qualquer espécie de violência, de ameaça ou de constrangimento material, moral ou psicológico. Ele necessita da independência para poder desempenhar plenamente suas funções decidindo com serenidade e imparcialidade, cumprindo verdadeira missão no interesse da sociedade. Assim, pois, segundo essa visão ideal do juiz, mais do que este, individualmente, é a sociedade quem precisa dessa independência, o que, em última análise, faz o próprio magistrado incluir-se entre os que devem zelar pela existência da magistratura independente ${ }^{306}$.

Sébastien Conan (2005, p. 53) define a independência do juiz como a faculdade que tem de "exercer sua função a partir da análise objetiva dos fatos submetidos a seu julgamento, de acordo com seu entendimento da regra de direito, livre de qualquer influência externa, pressão, ameaça ou interferência, direta ou indireta, seja qual for a origem ou o motivo".

A relevância dispensada à independência do juiz é revelada pelo tratamento que lhe é dado por vários instrumentos internacionais, como as normas insertas: a) no art. $\mathrm{X}$ da

\footnotetext{
${ }^{306}$ O Grupo de Integridade Judicial (The Judicial Integrity Group), constituído sob os auspícios das Nações Unidas e composto por membros de cortes superiores e juízes seniores de diversas regiões do mundo, debateu, entre abril de 2000 (início em Viena, Aústria) e abril de 2001 (Bangalore, Índia), "o problema criado pela evidência de que, em vários países, em todos os continentes, muitas pessoas estavam perdendo a confiança em seus sistemas judiciais por serem tidos como corruptos ou parciais em algumas circunstâncias" (2008, p. 13). O grupo acabou por elaborar o denominado Bangalore Principles of Judicial Conduct, em português "Príncípios de Bangalore de Conduta Judicial" (2008, p. 1), oficialmente aprovados em novembro de 2002 em Haia, Países Baixos. Como destaca Gilson Dipp, "os Princípios de Conduta Judicial de Bangalore é um projeto de Código Judicial em âmbito global, elaborado com base em outros códigos e estatutos, nacionais, regionais e internacionais, sobre o tema, dentre eles a Declaração Universal dos Direitos Humanos, da ONU. Essa declaração de direitos prevê um julgamento igualitário, justo e público, por tribunal independente e imparcial, princípio de aceitação geral pelos Estados-Membros" (2008, p. 7). São, no total, seis princípios: independência, imparcialidade, integridade, idoneidade, igualdade (de tratamento) e competência/diligência. Esses princípios, pontifica Sébastien Conan (2005, p. 66), dirigem-se aos juízes e pretendem estabelecer padrões de conduta, "oferecendo-lhes orientações destinadas a guiá-los no desenvolvimento das suas funções. Também se destinam a outros atores, tais como os membros do Executivo, Legislativo, advogados e o público em geral a fim de melhor entenderem o papel e as atribuições do Judiciário". Quanto ao princípio da independência, restou estabelecido que "A independência judicial é um pré-requisito do estado de Direito e uma garantia fundamental de um julgamento justo. Um juiz, consequentemente, deverá apoiar e ser o exemplo da independência judicial tanto no seu aspecto individual quanto no aspecto institucional" $(2008$, p. 45) (Judicial independence is a prerequisite to the rule of law and a fundamental guarantee of a fair trial. A judge shall therefore uphold and exemplify judicial independence in both its individual and institutional aspects). Nota-se, pois, que a independência judicial deve, antes de tudo, ser cuidada pelos próprios juízes.
} 
Declaração Universal dos Direitos Humanos de $1948^{307}$; b) na primeira parte do art. 6(1) da Convenção Européia de Direitos Humanos e Liberdades Fundamentais de $1950^{308}$; c) na primeira parte do art. $14, \S 1^{\circ}$, do Pacto Internacional de Direitos Civis e Políticos de $1966^{309}$, no art. 8(1) da Convenção Interamericana de Direitos Humanos (Pacto de San José da Costa Rica) de $1969^{310}$; d) no item 1 dos Princípios Básicos sobre a Independência do Judiciário (adotados durante o $7^{\circ}$ Congresso das Nações Unidas para a Prevenção do Crime e o Tratamento dos Delinquentes, Milão, Itália, 1985, e endossados pela Assembléia Geral da ONU pelas resoluções 40/32 e 40/146 de 29.11.1985 e 13.12.1985) ${ }^{311}$; e) no parágrafo 27 da Declaração e Programa de Ação de Viena da Conferência Mundial sobre Direitos Humanos de $1993^{312}$, e no primeiro dos Princípios de Bangalore de Conduta Judicial de $2001^{313}$.

${ }^{307}$ Art. X (Declaração Universal dos Direitos Humanos). Toda pessoa tem direito, em plena igualdade, a uma audiência justa e pública por parte de um tribunal independente e imparcial, para decidir de seus direitos e deveres ou do fundamento de qualquer acusação criminal contra ele.

${ }^{308}$ Art. 6(1) (Convenção Européia de Direitos Humanos e Liberdades Fundamentais). Qualquer pessoa tem direito a que a sua causa seja examinada, equitativa e publicamente, num prazo razoável por um tribunal independente e imparcial, estabelecido pela lei, o qual decidirá, quer sobre a determinação dos seus direitos e obrigações de carácter civil, quer sobre o fundamento de qualquer acusação em matéria penal dirigida contra ela $[\ldots]$.

${ }^{309}$ Art. 14(1) (Pacto Internacional de Direitos Civis e Políticos). Todas as pessoas são iguais perante os Tribunais e as Cortes de Justiça. Toda pessoa terá o direito de ser ouvida publicamente e com as devidas garantias por um Tribunal competente, independente e imparcial, estabelecido por lei, na apuração de qualquer acusação de caráter penal formulada contra ela ou na determinação de seus direitos e obrigações de caráter civil $[\ldots]$

${ }^{310}$ Art. 8(1) (Convenção Interamericana de Direitos Humanos (Pacto de San José da Costa Rica)). Toda pessoa terá o direito de ser ouvida, com as devidas garantias e dentro de um prazo razoável, por um juiz ou Tribunal competente, independente e imparcial, estabelecido anteriormente por lei, na apuração de qualquer acusação penal formulada contra ela, ou na determinação de seus direitos e obrigações de caráter civil, trabalhista, fiscal ou de qualquer outra natureza.

${ }^{311}$ 1. (Princípios Básicos sobre a Independência do Judiciário). A independência da magistratura deve ser garantida pelo Estado e consagrada na Constituição ou na legislação nacional. É dever de todas as instituições, governamentais e outras, respeitar e acatar a independência da magistratura

31227 (Declaração e Programa de Ação de Viena da Conferência Mundial sobre Direitos Humanos). Todos os Estados deverão oferecer um quadro efetivo de soluções para reparar injustiças ou violações dos Direitos Humanos. A administração da justiça, incluindo os departamentos policiais e de ação penal e, especialmente, um poder judicial independente e um estatuto das profissões forenses em total conformidade com as normas aplicáveis constantes de instrumentos internacionais em matéria de Direitos Humanos, são essenciais para a concretização plena e não discriminatória dos Direitos Humanos e indispensáveis aos processos da democracia e do desenvolvimento sustentável. Neste contexto, deverão ser devidamente financiadas instituições que se dediquem à administração da justiça, devendo a comunidade internacional providenciar pela prestação de um maior apoio técnico e financeiro. Compete às Nações Unidas utilizar, com caráter prioritário, programas especiais de serviços consultivos com vista à obtenção de uma administração da justiça forte e independente.

${ }^{313}$ Valor 1 - Independência (Princípios de Bangalore de Conduta Judicial). A independência judicial é um pré-requisito do estado de Direito e uma garantia fundamental de um julgamento justo. Um juiz, consequentemente, deverá apoiar e ser o exemplo da independência judicial tanto no seu aspecto individual quanto no aspecto institucional. 
As Constituições de diversos Estados também consagram, explicitamente, a independência dos juízes.

A Lei Fundamental de Bonn da República Federal da Alemanha dispõe, em seu art. 97 (1), que os juízes são independentes e somente subordinados à lei ${ }^{314}$.

A Constituição Portuguesa contém disposição semelhante em seu artigo 203: "Os tribunais são independentes e apenas estão sujeitos à lei”.

A Constituição da República Italiana estabelece, em seus artigos 101 e 104, que os os juízes só estão sujeitos à lei e a magistratura constitui uma ordem autônoma e independente de qualquer outro poder ${ }^{315}$.

É certo que a Constituição de 1988 não trata, explicitamente, da independência dos juízes em sua dimensão individual.

A Carta Política Brasileira expressamente afirma a independência institucional do Poder Judiciário, ao prescrever, logo em seu art. $2^{\circ}$ que "são Poderes da União, independentes e harmônicos entre si, o Legislativo, o Executivo e o Judiciário".

Além disso, as garantias institucionais previstas no art. 96, I, “a” e 99 da Lei Maior conferem "a independência do Poder Judiciário no relacionamento com os demais poderes" (MORAES, 2013b, p. 517). São garantias que "concernem ao poder como um todo, resguardando-o da interferência de outros poderes" (MANOEL GONÇALVES FERREIRA FILHO, 2012, p. 276).

Não há na Constituição da República, porém, disposição semelhante às constantes das Constituições Alemã, Portuguesa e Italiana mencionadas. Explicitamente, pois, não consta norma na Carta Política declarando a independência dos juízes.

Mas não resta dúvida que essa independência sob a perspectiva individual dos órgãos principais do Poder Judiciário no exercício da função jurisdicional também é reconhecida pela Lei Maior Brasileira.

\footnotetext{
${ }^{314}$ Artikel 97 (1) (Grundgesetz für die Bundesrepublik Deutschland). Die Richter sind unabhängig und nur dem Gesetze unterworfen.

${ }^{315}$ Art. 101 (Costituzione della Repubblica Italiana). La giustizia è amministrata in nome del popolo. I giudici sono soggetti soltanto alla legge.

Art. 104 (Costituzione della Repubblica Italiana). La magistratura costituisce un ordine autonomo e indipendente da ogni altro potere. Il Consiglio superiore della magistratura è presieduto dal Presidente della Repubblica. Ne fanno parte di diritto il primo presidente e il procuratore generale della Corte di cassazione. Gli altri componenti sono eletti per due terzi da tutti i magistrati ordinari tra gli appartenenti alle varie categorie, e per un terzo dal Parlamento in seduta comune tra professori ordinari di università in materie giuridiche ed avvocati dopo quindici anni di esercizio. Il Consiglio elegge un vice presidente fra $i$ componenti designati dal Parlamento. I membri elettivi del Consiglio durano in carica quattro anni e non sono immediatamente rieleggibili. Non possono, finché sono in carica, essere iscritti negli albi professionali, né far parte del Parlamento o di un Consiglio regionale.
} 
Primeiro porque não haveria efetiva separação de poderes se os seus atores essenciais estivessem subordinados a outros do Executivo e do Legislativo. Logo, a ideia de independência institucional do Judiciário é indissociável da noção de independência no exercício da função típica do Poder dos seus principais protagonistas: os juízes.

Segundo porque, apesar da Constituição não explicitar que os juízes são independentes, estabelece regras que se consubstanciam em três garantias de liberdade aos magistrados (vitaliciedade, inamovibilidade e irredutibilidade de subsídios - art. 95, I a III), além de vedações para resguardo de sua imparcialidade (art. 95, parágrafo único, I a V).

Manoel Gonçalves Ferreira Filho (2012, p. 278) ensina que as garantias da vitaliciedade, inamovibilidade e irredutibilidade de subsídios dos juízes "completam as garantias do todo, o Judiciário", e "se destinam a resguardar a sua independência, contra pressões inclusive de outros órgãos judiciários".

Como pontua André Ramos Tavares (2012, pp. 240 a 242), com apoio em Pontes de Miranda e J. J. Gomes Canotilho, as regras mencionadas estão umbilicalmente relacionadas à independência dos juízes porque conectam-se com os princípios e subprincípios constitucionais, densificando-os ${ }^{316}$.

Não há dúvida pois, que a independência dos juízes é garantida pela Constituição Federal e não deve ser violada, mesmo por órgãos do próprio Poder Judiciário.

\footnotetext{
${ }^{316}$ Canotilho (2003, p. 1173) explica que "a articulação de princípios e regras, de diferentes tipos e características, iluminará a compreensão da constituição como um sistema interno assente em princípios estruturantes fundamentais que, por sua vez, assentam-se em subprincípios e regras constitucionais concretizadores desses mesmos princípios. Quer dizer: a constituição é formada por regras e princípios de diferente grau de concretização (= diferente densidade semântica)". Em seguida, o autor (2003, pp. 1173 a 1175) estrutura, em forma piramidal, esses princípios e regras constitucionais. Em primeiro lugar, no topo da pirâmide, apresenta os princípios estruturantes, "constitutivos e indicativos das ideias directivas básicas de toda a ordem constitucional", as "traves-mestras jurídico-constitucionais do estatuto jurídico do político". Para concretizar os princípios estruturantes, "iluminando o seu sentido jurídico-constitucional e políticoconstitucional" (2003, p. 1174), Canotilho apresenta, abaixo deles na estrutura piramidal, os princípios constitucionais gerais. Estes, por sua vez, são ainda mais densificados por princípios constitucionais especiais e por regras constitucionais, que, na pirâmide, situam-se, observada a ordem, descensionalmente, pouco acima e totalmente na base. Por fim, Canotilho ainda ressalta que este esquema é bi-direcional e de esclarecimento recíproco, podendo "ainda obter maior grau de concretização e densidade através da concretização legislativa e jurisprudencial” (2003, p. 1175). Observadas essas lições, TAVARES (2012, pp. 240 a 242) destaca que, na ordem constitucional brasileira, assim como na portuguesa (estudada por Canotilho), o princípio estruturante do Estado de Direito é densificado pelo princípio da independência dos tribunais que recebe nova densificação pelo princípio da separação e interdependência dos poderes (CF, art. $2^{\circ}$ ). Todos, por sua vez, são concretizados por regras, como as cláusulas de vitaliciedade, inamovibilidade e irredutibilidade de subsídios dos juízes.
} 
Mas essa independência, por outro lado pode servir de escudo protetivo ${ }^{317}$ para o descumprimento dos deveres funcionais dos juízes ou, pior, para prática de atividades ilícitas que impliquem responsabilidade civil ou penal.

Sobre a independência dos juízes, ressalta Luiz Flávio Gomes (1997, pp. 41 e 42), citando Belloch e Ibarra (1988, p. 21) ${ }^{318}$, que "não pode encarada como barreira impeditiva para tornar possível o controle da Magistratura e da atividade pública que ela desempenha", porque ela não visa estabelecer um "um tipo de privilégio de casta". Pelo contrário, trata-se de "um meio, um conceito instrumental em relação à imparcialidade". Assim, a independência judicial "não só não exclui a ideia de controle, senão que a pressupõe, ao mesmo tempo que a condiciona", pois "não pode ter outra finalidade que a de constituir um instrumento de garantia de que sua função será justa e livre de qualquer pressão, seja externa ou interna, direta ou indireta".

Os juízes exercem parcela de poder do Estado e "onde há poder deve haver responsabilidade: em uma sociedade organizada racionalmente, haverá uma relação diretamente proporcional entre poder e responsabilidade" (CAPPELLETTI, 1989, p. $18)^{319}$.

Assim, como destacou o Ministro Cezar Peluso em seu voto na ADI $n^{\circ} 3367$, “representa expressiva conquista do Estado democrático de direito, a consciência de que mecanismos de responsabilização dos juízes por inobservância das obrigações funcionais são também imprescindíveis à boa prestação jurisdicional”.

Lima Lopes (2002, p. 76) adverte que "o Poder Judiciário não pode ser independente, no sentido de irresponsável, ou não prestar contas a sociedade, aos cidadãos, no que diz respeito à máquina judicial”.

\footnotetext{
${ }^{317}$ A expressão "escudo protetivo" foi emprestada, dada a semelhança de situações, do ensinamento de Alexandre de Moraes (2013b, pp. 30 e 119) sobre a relatividade dos direitos e garantias individuais e coletivos previsto na Constituição Federal. Doutrina o Professor da Facudade de Direito do Largo de São Francisco que "os direitos humanos fundamentais, dentre eles os direitos e garantias individuais e coletivos consagrados no art. $5 .^{\circ}$ da Constituição Federal, não podem ser utilizados como um verdadeiro escudo protetivo da prática de atividades ilícitas, nem tampouco como argumento para afastamento ou diminuição da responsabilidade civil ou penal por atos criminosos, sob pena de total consagração ao desrespeito a um verdadeiro Estado de Direito".

${ }^{318}$ Nas palavras dos referidos doutrinadores: “ [...] la independencia judicial, que es el principio sobre el que nuclearmente se articula la relación del poder judicial con los demás poderes públicos, no puede verse como barrera impedltlva para hacer posible el control de la judicatura y de la actividad pública por ella desarrollada, respecto de su adecuación al papel constitucional encomendado a la misma, ya que, de otra forma, no estaríamos defendiendo la Independencia del juez sino una suerte de privilegio de casta".

${ }^{319}$ Como lembrado por Antonio Veloso Peleja Júnior (2011, p. 170), Cappelletti (1989, p. 17) doutrina que a expressão "responsabilidade judicial" tem significado "ambivalente: pode significar o poder dos juízes, como o dever de prestar contas (accountability, answerability) no exercício de tal poder-responsabilidade".
} 
O cumprimento dos deveres funcionais dos juízes deve, pois, ser controlado pelo Conselho Nacional de Justiça, como já era, antes de sua criação (e continua sendo) sujeito a controle pelas Corregedorias de Justiça de cada Tribunal.

Surge, pois, o seguinte problema: a independência dos juízes não pode ser restringida, mas compete ao Conselho Nacional de Justiça controlar os deveres funcionais dos juízes, inclusive para que não se valham da independência para se esquivarem da responsabilização pelo descumprimento desses deveres.

Como afirma Mauro Cappelletti (1989, p. 33), em trecho também constante do voto do Ministro Cezar Peluso na ADI n 3367, há, pois, "um problema de equilíbrio entre o valor de garantia e instrumental da independência, externa e interna, dos juízes, e o outro valor moderno (mas também antigo, como se viu) do dever democrático de prestar contas".

Esse dilema ainda se agrava em razão, como pondera André Ramos Tavares (2013, p. 944), da carga axiológica indeterminada de certos deveres funcionais dos juízes, o que pode implicar, para definição de seus parâmetros, em interpretações váriaveis do órgão controlador e, assim, sujeitar "o magistrado às (pré) compreensões, visões de mundo e ideologias de seu fiscalizador", além de possibilitar, diante de imprecisões conceituais, a perseguição política $^{320}$.

Entendemos que o Conselho Nacional de Justiça, por expressa disposição constitucional, deve exercer o controle dos deveres funcionais dos juízes, assim entendidos como aqueles deveres jurídicos positivados no ordenamento, inclusive para coibir ações ilícitas praticadas sob o manto da independência judicial. Porém, não pode o $\mathrm{CNJ}$, no exercício do seu mister, violar a independência dos juízes, interferindo, através do controle disciplinar, nas decisões exaradas ou influenciando aquelas que venham a ser proferidas, de modo que os magistrados se sintam intimidados, pressionados ou ameaçados, em razão de responsabilização anterior, própria ou de outros juízes, a não decidir de acordo com suas (livres) convicções da aplicação das regras de direito e quebrando, por consequência, sua imparcialidade.

Assevera André Ramos Tavares (2012, p. 328):

Livre convicção é, acima de tudo, uma garantia da sociedade contra ingerências externas, tornando o magistrado imune a orientações ou

\footnotetext{
${ }^{320}$ André Ramos Tavares apresenta como exemplo a norma inserta no art. 35, I, da LOMAN que dispõe ser dever do magistrado "cumprir e fazer cumprir, com independência, serenidade e exatidão as disposições legais e os atos de ofício" e indaga (2013, p. 944): "Há algum parâmetro fixo que seja capaz de assegurar a presença ou não de um atuar jurisdicional independente, sereno e exato?"
} 
determinações de outros Poderes, das partes ou mesmo de órgãos judiciais superiores, sobre o sentido a adotar nos processos pendentes de julgamento.

Não há dúvida que a tarefa de encontrar a tênue linha que divide o controle dos deveres funcionais dos juízes da interferência na indepedência judicial não é simples.

A nosso ver, essa tarefa passa, necessariamente, pela resposta às seguintes indagações: a) $\mathrm{O}$ ato controlado é daqueles em que o juiz deve agir de forma independente?; b) $\mathrm{O}$ magistrado valeu-se de sua independência para agir, de forma isenta e imparcial, de acordo com suas convicções pessoais e seus conhecimentos sobre a aplicação das regras de direito ou aproveitou-se dessa independência para descumprir seus deveres funcionais e, quiça, praticar atividades ilícitas?; e, c) A sanção imposta a magistrado pelo Conselho Nacional de Justiça interfere, intimida, ameaça ou pressiona outros juízes a agirem de acordo com suas convicções quando assim é possível, ainda que cumpram todos os deveres positivados?

Se o ato praticado pelo magistrado não for daqueles em que deva atuar de forma livre, como, por exemplo, os atos administrativos que executa, ou mesmo certos deveres processuais, como o de "não exceder injustificadamente os prazos para sentenciar ou despachar" (LOMAN, art. 35, I), a atuação fiscalizatória do Conselho Nacional de Justiça poderá ser realizada sem receio de interferência na independência judicial ${ }^{321}$.

Porém, se o ato praticado for daqueles em que, minimamente, se vislumbre que a atuação do juiz deva ser independente cumpre questionar, como já afirmado: o magistrado valeu-se dessa independência para agir, de forma isenta e imparcial, de acordo com suas convicções pessoais e seus conhecimentos sobre a aplicação das regras de direito ou aproveitou-se dessa independência para descumprir seus deveres funcionais e, quiça, praticar atividades ilícitas?

Importa ressaltar que a atuação independente do juiz não se circunscreve às decisões proferidas nos casos que lhe são submetidos a julgalmento. Pode revelar-se de várias outras formas, como, por exemplo, no controle da pauta de audiências da sua unidade

\footnotetext{
${ }^{321}$ O que não significa, necessariamente, que eventual decisão prolatada pelo Conselho Nacional de Justiça, mormente na hipótese de punição disciplinar ao magistrado, esteja correta, pois pode o Colegiado falhar na aplicação da regra de direito ao caso concreto.
} 
(designando audiências de questões urgentes e delicadas para datas mais próximas que outras) ou na organização dos seus trabalhos ${ }^{322}$.

Se a resposta a essa questão inclinar-se para a primeira opção, o controle do ato realizado pelo magistrado implicará em violação, pelo Conselho Nacional de Justiça, de seus limites constitucionais de atuação, pois importará em ingerência na sua livre convicção.

Todavia, se se concluir pela segunda opção, o controle disciplinar do Conselho Nacional de Justiça é legítimo, pois o magistrado visou, sob o manto da independência funcional, violar seus deveres e, possivelmente, praticar atividades ilícitas.

Mas, mesmo nessa última hipótese, ainda deve ser indagado se a decisão censória imposta pelo Conselho Nacional de Justiça interfere, intimida, ameaça ou pressiona outros juízes a agirem de acordo com suas convicções quando assim for possível, ainda que cumpram todos os deveres positivados? Em outras palavras, deve se questionar: o controle do CNJ foi excessivo, mesmo diante da pratica de ato violador dos deveres funcionais por

\footnotetext{
${ }^{322}$ O Projeto de Código de Processo Civil (Projeto de lei $\mathrm{n}^{\mathrm{o}}$ 166/2010 do Senado Federal e Projeto de lei $\mathrm{n}^{\mathrm{o}}$ 8.046/2010 da Câmara dos Deputados) prevê, em seu artigo 12, o que se tem denominado de "príncípio da observância da ordem cronológica de conclusão para a prolação de sentença/acórdão". Estabelece a redação dada ao referido projeto de dispositivo legal na Câmara dos Deputados (disponível em: $<$ http://www.camara.gov.br/proposicoesWeb/fichadetramitacao?idProposicao=490267>. Acesso em 01.08.2014) que "os juízes deverão proferir proferir sentenças e os tribunais deverão decidir os recursos obedecendo à ordem cronológica de conclusão" (art. 12, caput), disponibilizando-se, em cartório, lista de processos aptos a julgamento para consulta pública (art. 12, § $1^{\circ}$ ). Apesar de louvável essa inovação, pois visa evitar que processos fiquem esquecidos nos gabinetes, e mesmo considerando a previsão de hipóteses de exclusão da regra para as sentenças proferidas em audiência, homologatórias de acordo ou de improcedência liminar do pedido (art. 12, $\S 2^{\circ}$, I), o julgamento de processos em bloco para aplicação da tese jurídica firmada em incidente de resolução de demandas repetitivas ou em recurso repetitivo (art. 12, $\S 2^{\circ}$, II), a apreciação de pedido de efeito suspensivo ou de antecipação da tutela recursal (art. 12, § $2^{\circ}$, III), o julgamento de recursos repetitivos ou de incidente de resolução de demandas repetitivas (art. 12 , § $2^{\circ}$, IV), e as preferências legais $\left(\left(\operatorname{art} .12, \S 2^{\circ}, \mathrm{V}\right)\right.$, parece-nos que o dispositivo é demasiadamente fechado e pode violar o princípio constitucional da independência judicial, no que tange à organização dos trabalhos do magistrado, além do princípio constitucional da celeridade processual (CF, art. $5^{\circ}$, LXXVIII) que visa a norma projetada, em princípio, prestigiar. Basta imaginar, por exemplo, que o magistrado tenha em conclusão diversos processos e que o primeiro deles na ordem cronológica apresente questões de alta complexidade jurídica, sobre as quais o juiz ainda não formou convicção, enquanto os demais revelem-se de singela complexidade e possam ser decididos em curto espaço de tempo. A aplicação draconiana da regra, caso passe a integrar o ordenamento jurídico, poderá levar à paralisação do célere julgamento de todos os demais processos até que o magistrado forme seu convencimento sobre as complexas matérias discutidas no primeiro, quando poderia, desde que não excedesse demasiadamente o prazo para julgamento (e o atual Código de Processo Civil (art. 133), assim como o Projeto de Novo Código de Processo Civil (art. 123) prevêm até a responsabilização por perdas e danos do juiz que retarda, sem justo motivo, providência que deva ordenar no processo, quando instado pela parte), apreciar aqueloutros e, em momento mais tranquilo, debruçar-se sobre o primeiro. A pressão para julgamento, em razão da restrição na organização do trabalho do magistrado imposta pela estrita observância da ordem cronológica de sentenciamento, surgirá e poderá implicar na prolação de decisão desvestida de sereneidade e reflexão, orientada somente pela rápida solução da causa e não pela busca da Justiça.
} 
juiz, a ponto de causar temor aos demais magistrados em agir e decidir de determinada maneira de forma independente?

Se a resposta a essa última pergunta também for positiva, deve-se concluir que o Conselho Nacional de Justiça também violou, no exercício do controle disciplinar, os limites constitucionais de sua atuação, pois proferiu decisão que intimida os demais magistrados a agir e decidir de acordo com suas convicções.

Exemplo: juiz aceita receber dinheiro para reconhecer a inconstitucionalidade dos dispositivos introduzidos na Lei de Execução Penal (Lei n 7.210 , de 11 de julho de 1984) pela Lei $\mathrm{n}^{\mathrm{o}} 10.792$, de $1^{\mathrm{o}}$ de dezembro de 2003, referentes ao regime disciplinar diferenciado prisional, a fim de facilitar a fuga de preso de alto risco para a ordem e a segurança da sociedade. Nesse caso, a sanção imposta pelo Conselho Nacional de Justiça deve restringir-se ao ato ilícito praticado (receber dinheiro para decidir, sob o manto da independência judicial, de forma parcial e facilitar fuga de preso de alto risco). Não pode o Conselho, porém, sugerir, que apenas o reconhecimento da inconstitucionalidade da norma em comento já justificaria a censura do ato judicial, pois inibiria a atuação livre, independente e imparcial de outros magistrados no exercício do controle difuso de constitucionalidade da regra mencionada e, porventura, de outras, por receio de futura punição disciplinar.

Em suma, o Conselho Nacional de Justiça, no que tange à sua competência para controle dos deveres funcionais dos juízes, pode realizar exclusivamente o controle dos deveres jurídicos dos magistrados, positivados, consubstaciem estes ou não também deveres morais. Por outro lado, no exercício desse mister, a atuação do Conselho Nacional de Justiça não pode atingir a independência dos juízes no exercício da jurisdição, interferindo nas decisões prolatadas ou influenciando aquelas que venham a ser proferidas por outros magistrados, intimidando-os, pressionando-os ou ameaçando-os a não decidir com liberdade de convicção.

\subsubsection{Casuística: punição de magistrado por comportamento incompatível com o decoro de suas funções ${ }^{323}$.}

Em março de 2009, candidata do concurso para o cargo de juiz de direito substituto da

\footnotetext{
${ }^{323}$ Parte das informações apresentadas neste item não têm caráter oficial, pois extraídas de notícias veículadas na imprensa, uma vez que o procedimento disciplinar movido contra o magistrado, cuja identidade será preservada, assim como a da candidata, tramitou sob sigilo no Conselho Nacional de Justiça.
} 
entrância inicial do Tribunal de Justiça do Estado do Maranhão impetrou, junto ao Tribunal Pleno daquela Corte, o Mandado de Segurança ${ }^{\circ}$ 0008954-70.2009.8.10.0000 contra ato do presidente da comissão do certame.

O mandamus foi julgado em sessão plenária em 22 de julho de 2009. O Tribunal de Justiça do Maranhão, por maioria, nos termos do voto divergente do Desembargador Antonio Fernando Bayma Araújo, concedeu in totum a segurança pleiteada, anulou questões de prova realizada e determinou a recorreção de outra, individualmente, por dois avaliadores, um como relator e outro como revisor ${ }^{324}$.

Opostos embargos de declaração pela impetrante com natureza infringente em 22 de dezembro de 2009, os autos foram encaminhados, em 16 de agosto de 2010, à Relatora Substituta, Desembargadora Nelma Celeste Souza Silva Sarney Costa que determinou mais uma revisão da prova, através de consulta a apenas um integrante da banca revisora ${ }^{325}$.

Dois desembargadores do Tribunal de Justiça do Maranhão, entre eles aquele que fora posteriormente punido administrativamente, em 23 de março de 2011, pleitearam junto ao Conselho Nacional de Justiça a instauração do Pedido de Providências $n^{0}$ 000138187.2011.2.00.0000 contra o ato da relatora do mandado de segurança mencionado, que determinou nova correção da prova da candidata. Alegaram que a candidata não obteve nota suficiente para aprovação, mesmo após o pedido de revisão, e que, por ordem da relatora, nova revisão (a terceira) foi feita por intermédio de consulta a apenas um integrante da banca revisora. Requereram, liminarmente, a exclusão da candidata da lista dos aprovados do concurso público e, no mérito, a ratificação da recorreção da prova da candidata efetuada pela comissão de concurso, por meio de um relator e um revisor, onde restou constatada a insuficiência de pontuação para a sua aprovação, tendo em vista a manifesta incompetência de um único membro da Comissão para, modificando seu posicionamento anterior, efetuar nova revisão.

\footnotetext{
${ }^{324}$ Segue a ementa do julgado:

Mandado de Segurança. Concurso Público. Resolução e Edital. Observância. Obrigatoriedade. Prova discursiva. Correção não atrelada ao Princípio da Proporcionalidade. Recorreção nesta sede. Impossibilidade. I - De intransponível observância no conduzir de concurso público, os ditames insertos na Resolução e Edital se lhe regulamentadores, sob pena de que violado direito líquido e certo do candidato, reparável por esta via mandamental. II - Inconcebível que, por meio de mandamus, recorrigida, pelo Judiciário, questão de concurso público, eis que vedado imiscuir-se no mérito da correção proferida pela instituição condutora do certame, sobretudo quando não despontante, de plano, ilegalidade na sua elaboração, bem ainda demandante referida análise, de dilação probatória. III - Ordem concedida, com vistas a que nulificadas as questões nominadas 'despacho', bem ainda, individualmente, por um relator e um revisor, recorrigidas as provas do Grupo III. Por maioria.

${ }^{325}$ Apesar das diversas consultas realizadas na movimentação do Mandado de Segurança $\mathrm{n}^{\circ} 0008954$ 70.2009.8.10.0000, não foi possível verificar os motivos para a prolação da referida decisão.
} 
O pedido foi distribuído à relatoria do Conselheiro Paulo de Tarso Tamburini Souza que, por decisão monocrática proferida em 27 de abril de 2011, deixou de conhecê-1o ${ }^{326}$, por encontrar-se a matéria colacionada aos autos judicializada e porque o próprio Conselho Nacional de Justiça firmou entendimento que não lhe cabe se tornar mera instância revisora de atos de comissões de concursos ${ }^{327}$. Também determinou, em razão da notícia trazida nas informações prestadas pelo Tribunal de Justiça do Maranhão quanto a fatos bastante graves ocorridos durante a arguição da impetrante do writ por um dos requerentes do pedido de providências por ocasião da realização da prova oral do concurso, a remessa de cópias do procedimento à Corregedoria Nacional para apuração.

\footnotetext{
${ }^{326}$ A decisão foi confirmada, por unanimidade, em grau de recurso pelo Pleno do Conselho Nacional de Justiça em julgamento realizado em 21 de junho de 2011, recebendo a seguinte ementa:

RECURSO ADMINISTRATIVO EM SEDE DE PEDIDO DE PROVIDÊNCIAS. PEDIDO DE 'RATIFICAÇÃO DE RECORREÇÃO DE PROVA'. IMPOSSIBILIDADE. QUESTÃO SUB JUDICE. PRECEDENTES. RECURSO CONHECIDO PORÉM IMPROVIDO. 1. Pretensão veiculada de ratificar 'a recorreção da prova da candidata efetuada pela Comissão de Concurso, por meio de um Relator e um Revisor, onde restou constatada a insuficiência de pontuação para a sua aprovação, tendo em vista a manifesta incompetência de um único membro da Comissão para, modificando seu posicionamento anterior, efetuar nova revisão', ainda mais quando a recorreção foi determinada em sede de ação judicial, não merece ser conhecida. 2. Nos termos de reiterada jurisprudência deste Conselho Nacional de Justiça, não pode a parte interessada fazer uso, a um só tempo, dos procedimentos administrativos assegurados pelo art. 103-B, $\S 4^{\circ} \mathrm{da}$ $\mathrm{CF} / 88$ perante o $\mathrm{CNJ}$ e dos meios judiciais tendentes a obter a coisa julgada definitiva no âmbito do Poder Judiciário. 3. Recurso Administrativo conhecido, porquanto tempestivo, mas, no mérito, julgado improcedente.
}

Estiverem presentes na sessão os Conselheiros Cezar Peluso, Eliana Calmon, Ives Gandra, Milton Nobre, Nelson Tomaz Braga, Paulo Tamburini, Walter Nunes, Morgana Richa, José Adonis Callou de Araújo Sá, Felipe Locke Cavalcanti, Jefferson Luis Kravchychyn, Jorge Hélio Chaves de Oliveira, Marcelo Nobre e Marcelo Neves. Ausente, justificadamente, o Conselheiro Leomar Barros Amorim (conforme certidão de julgamento da $129^{\mathrm{a}}$ Sessão Ordinária do CNJ).

${ }^{327} \mathrm{Na}$ decisão prolatada são citados os seguintes precedentes do CNJ:

a) Concurso Público. Magistratura Militar do Estado de São Paulo. Edital. Vedação expressa de revisão das provas. Legalidade. - "I) Improcede a pretensão de rever, perante o Conselho Nacional de Justiça, ato administrativo praticado em estrita observância às normas do edital de concurso público para magistratura militar do estado de São Paulo, que é a lei do certame, no tocante à vedação expressa de revisão de provas" (CNJ - PCA 16598 - Rel. Cons. Min. João Oreste Dalazen - 55 $5^{\mathrm{a}}$ Sessão - j. 29.01.2008 - DJU 20.02.2008);

b) Procedimento de Controle Administrativo. Concurso público para Ingresso na Atividade Notarial e de Registro. Pedido de revisão e anulação de questões de prova objetiva. Interesse individual. - "A jurisprudência majoritária dos Tribunais Superiores é no sentido de que, somente nos casos de flagrante erro material perceptível de plano e, excepcionalmente, deve ser declarada nula questão de prova objetiva, sob pena de invadir-se a competência administrativa da Banca Examinadora. Por outro turno, o simples fato da Banca Examinadora alterar o gabarito preliminar, após a análise dos recursos dos candidatos, não caracteriza per se a ilegalidade sustentada pelo requerente, mas adequação administrativa ao julgamento dos recursos. A substituição ou anulação de questões eivadas de vícios na correção - ressalte-se, correção esta realizada após análise de todos os recursos dos candidatos insatisfeitos com o gabarito preliminar - foi fundamentada na opção de resposta admitida pela Banca, e que resultou no gabarito definitivo. O que se verifica, in casu, é a insurgência do requerente com a opção adotada pela Banca e que, à evidência, não autoriza este Conselho a rever as aludidas questões, sobretudo, porque caracteriza interesse meramente individual, sem repercussão institucional relevante para o Judiciário nacional" (CNJ - PCA 518 - Rel. Cons. Ruth Lies Scholte Carvalho - $11^{\mathrm{a}}$ Sessão Extraordinária - j. 09.05.2007 - DJU 18.05.2007 - Ementa não oficial). 
Os "fatos bastante graves", segundo noticiado ${ }^{328}$, consubstar-se-iam em um escândalo de assédio sexual, pois um desembargador membro da comissão examinadora do concurso para o cargo de juiz de direito substituto (e um dos requerentes do Pedido de Providências $\mathrm{n}^{\mathrm{o}}$ 0001381-87.2011.2.00.0000 junto ao CNJ), durante a prova oral, teria assediado a candidata (e impetrante do Mandado de Segurança $n^{\circ}$ 0008954-70.2009.8.10.0000 junto ao Tribunal de Justiça do Maranhão) com "cantadas indecorosas", reprovando-a injustamente por que a arguida não cedeu aos seus galanteios.

O caso, conforme também informado pela imprensa ${ }^{329}$, foi julgado pelo Conselho Nacional de Justiça em 3 de junho de 2014, sendo aplicada ao desembargador a pena de disponibilidade com vencimentos proporcionais ao tempo de serviço. O Conselho, pelo noticiado, afastou a configuração da conduta como assédio sexual porque a candidata correspondeu ao magistrado. O desembargador foi punido porque os Conselheiros entenderam que seu comportamento foi incompatível com o decoro de suas funções e porque deveria ter se declarado impedido de atuar em questões relacionadas à candidata por conta de "diálogos inadequados".

Nota-se, no exemplo mencionado, que uma conduta moralmente reprovada pela sociedade e, em princípio, muito grave (assédio sexual) foi, no julgamento do CNJ, abrandada para um comportamento social normalmente aceito (flerte, paquera), mas, em razão das exigências adicionais de certas virtudes judiciais e diante da situação em que foi realizada (por examinador em relação a candidata, durante concurso para ingresso na Magistratura) considerado violador também dos deveres jurídicos do magistrado.

Abstemo-nos de emitir opinião quanto à noticiada decisão - se o Conselho corretamente responsabilizou o magistrado por infringência de seus deveres funcionais ou se realizou indevido controle de cumprimento de deveres meramente morais - porque, devido ao necessário sigilo que resguardou o caso, não foi possível ter acesso aos autos e à íntegra do acórdão.

\footnotetext{
${ }^{328}$ Conforme notícia veiculada na edição eletrônica no 2170 da revista "Isto É", datada de 15 de junho de 2011, com o título "Cantadas indecorosas nos tribunais" (disponível em: $<$ http://www.istoe.com.br/reportagens/141509_CANTADAS+INDECOROSAS+NOS+TRIBUNAIS>. Acesso em 02.08.2014).

${ }^{329}$ De acordo com notícias veiculadas em 3 de junho de 2011, na edição eletrônica do revista "Folha de São Paulo" com o título "CNJ pune juiz por 'paquerar' candidata em banca de concurso" (disponível em: $<$ http://www1.folha.uol.com.br/poder/2014/06/1464552-cnj-pune-juiz-por-paquerar-candidata-em-banca-deconcurso.shtml $>$. Acesso em 02.08.2014) e no portal eletrônico "globo.com", com o título "Desembargador do MA é afastado após paquerar candidata de concurso" (disponível em: $<$ http:/g1.globo.com/ma/maranhao/noticia/2014/06/cnj-determina-afastamento-de-desembargadormaranhense.html>. Acesso em 02.08.2014).
} 


\subsection{7. Órgão de sobreposição}

Analisados seis elementos constitucionais característicos do Conselho Nacional de Justiça (órgão interno (1), com estrutura colegiada (2), tipicamente de controle (3) interno (4) da atuação administrativa e financeira do Poder Judiciário (5) e do cumprimento dos deveres funcionais dos juízes (6)), passa-se ao estudo da sua última característica: o CNJ é um órgão de sobreposição na estrutura do Poder Judiciário.

Como já afirmado, o Conselho Nacional de Justiça foi disciplinado no art. 103-B da Constituição Federal. O parágrafo $4^{\circ}$ do referido dispositivo atribuiu-lhe a competência para controle da atuação administrativa e financeira do Poder Judiciário e do cumprimento dos deveres funcionais dos juízes, sem estabelecer qualquer exceção ao alcance do seu comando.

Extrai-se dessa norma, pois, que o CNJ, diante das suas outras características estudadas, no âmbito de suas competências, apresenta-se, no modelo novo institucional do Poder Judiciário trazido pela $\mathrm{EC} \mathrm{n}^{\mathrm{o}}$ 45/2004, como um órgão de sobreposição administrativa. Ou seja, o Conselho é um órgão do Poder Judiciário hierarquicamente superior, que impõe suas deliberações aos demais, pois, caso contrário, não poderia exercer a vigilância, fiscalização, direção, orientação administrativa, financeira e disciplinar dos juízos e tribunais e dos seus membros.

Apesar dessa posição de destaque na estrutura do Poder Judiciário, não exerce o Colegiado controle administrativo, financeiro e disciplinar geral e irrestrito sobre todos os órgãos e membros do terceiro poder.

Assim, preferiu-se, neste trabalho, utilizar a expressão "órgão de sobreposição" para caracterizar o Conselho Nacional de Justiça, apesar de abalizada doutrina referir-se ao CNJ, para destacar sua posição proeminente no desenho institucional do Judiciário, como "órgão de cúpula",330.

\footnotetext{
${ }^{330}$ Conforme exposto, Alexandre de Moraes (2013b, p. 534) e Manoel Gonçalves Ferreira Filho (2012, pp. 292) expressamente afirmam que o Conselho Nacional de Justiça é órgão de cúpula do Poder Judiciário. Preferiu-se, porém, neste trabalho, caracterizar o Conselho como órgão de sobreposição pois, enquanto o verbo "sobrepor" significa "pôr em cima ou por cima de", a indicar algo que está em posição mais elevada que outra coisa, o que não impede, porém, que esteja abaixo de terceiro elemento, "cúpula", vocábulo também utilizado pela Arquitetura, para a Política significa "pessoa(s) que chefia(m) uma instituição, uma empresa = ADMINISTRAÇÃO" e "conjunto de pessoas que representam as autoridades máximas de uma instituição, um organismo, um país, etc" (Dicionário Priberam da Língua Portuguesa, disponível em: $<$ http://www.priberam.pt/dlpo/default.aspx?pal=sobreposição $>$ $<$ http://www.priberam.pt/dlpo/default.aspx?pal=cupula $>$. Acesso em 18.04.2014). Nesse sentido, cumpre
} 


\title{
2.3.7.1. Não sujeição do STF ao controle do CNJ
}

Apesar da norma constitucional em comento (CF, art. 103-B, $\left.\S 4^{\circ}\right)$, da Constituição Federal não estabelecer qualquer exceção à competência do Conselho Nacional de Justiça para controle da atuação administrativa e financeira do Poder Judiciário e do cumprimento dos deveres funcionais dos juízes, restou decidido na $\mathrm{ADI} \mathrm{n}^{\mathrm{o}}$ 3367, não exercer qualquer domínio sobre o Supremo Tribunal Federal.

Trata-se de importante limitação à sua atuação.

Entendeu o Pretório Excelso que, por ser a guardião da Constituição Federal e julgar as ações movidas contra o próprio Conselho Nacional de Justiça ${ }^{331}$ (CF, art. 102, I, "r"), não poderia ficar sujeita a seu controle administrativo e financeiro.

Afirmou o Ministro Cezar Peluso em seu voto:

Ninguém pode [...] alimentar nenhuma dúvida a respeito da posição constitucional de superioridade absoluta desta Corte, como órgão supremo do Judiciário e, como tal, armado de preeminência hierárquica sobre o Conselho, cujos atos e decisões, todos de natureza só administrativa, estão sujeitos a seu incontrastável controle jurisdicional.

Foi expressamente citada no referido voto a lição de Sérgio Bermudes (2005, p. 137):

\begin{abstract}
Não bastasse a natureza do STF que, na estrutura do estado brasileiro, se põe acima de qualquer outro órgão administrativo ou judiciário, incumbido da guarda da Constituição (art. 102, caput), a Emenda entregou a ele o controle jurisdicional das decisões do Conselho Nacional
\end{abstract}

trazer à baila a lição de Flávio Pansieri (2013, p. 1437) ao tratar das competências do CNJ: “esta roupagem constitucional poderia sugerir que o Conselho assumiria umas função de cúpula do Poder Judiciário brasileiro, haja vista que por ele passaria toda a função e planejamento administrativo e as funções correicionais do Judiciário. No entanto [...], o Supremo Tribunal Federal, decidindo a ADI 3367, firmou entendimento contrário, estabelecendo que a competência do CNJ é relativa apenas aos órgãos e juízes situados, hierarquicamente, abaixo do Supremo Tribunal Federal. A preeminência deste, como órgão máximo do Poder Judiciário, sobre o Conselho, cujos atos e decisões estão sujeitos a seu controle jurisdicional, decisão fundada na inteligência dos arts. 102, caput, I, $r$, e 103-B, $\S 4^{\circ}$, da CF. Assim, note-se que o Conselho Nacional de Justiça não tem nenhuma competência sobre o Supremo Tribunal Federal e seus ministros, sendo este o órgão de cúpula do Poder Judiciário nacional, a que aquele está sujeito (ADI 3367)”. Mais incisivo, BULOS (2010, p. 1319) afirma que o STF é o órgão de cúpula jurisdicional, administrativa, financeira e disciplinar do Poder Judiciário. "O CNJ é apêndice do STF, no sentido de parte acessória, mas distinta pela sua forma ou posição, de importância menor se comparada a ele, submetida à sua magnitude"

${ }^{331}$ Vide Capítulo 4. 
de Justiça, conferindo-lhe competência para as ações contra o órgão, mediante a adoção da alínea $r$ do inciso I do art. 102 da Constituição. Controlador do CNJ, não pode o Supremo ser, de nenhum modo, controlado por ele.

E consta na ementa do julgado:

Poder Judiciário. Conselho Nacional de Justiça. Órgão de natureza exclusivamente administrativa. Atribuições de controle da atividade administrativa, financeira e disciplinar da magistratura. Competência relativa apenas aos órgãos e juízes situados, hierarquicamente, abaixo do Supremo Tribunal Federal. Preeminência deste, como órgão máximo do Poder Judiciário, sobre o Conselho, cujos atos e decisões estão sujeitos a seu controle jurisdicional. Inteligência dos arts. 102, caput, I, letra $r$, e 103-B, $\S 4^{\circ}$, da CF. O Conselho Nacional de Justiça não tem nenhuma competência sobre o Supremo Tribunal Federal e seus ministros, sendo esse o órgão máximo do Poder Judiciário nacional, a que aquele está sujeito.

Com efeito, ao contrário da Emenda Constitucional no 7 à Constituição de 1967/1969, que, ao criar o Conselho Nacional da Magistratura, não estabeleceu qual seria o órgão do Poder Judiciário competente para o julgamento de ações contra ele movidas, certamente porque aquele Conselho era composto exclusivamente por Ministros do Supremo Tribunal Federal e com função puramente disciplinar, a Emenda Constitucional no 45/2004 definiu que o controle jurisdicional do Conselho Nacional de Justiça, de composição híbrida, é realizado pelo Supremo Tribunal Federal. Seria um contrassenso, pois, admitir-se que o órgão jurisdicional controlador se sujeitasse ao controle administrativo do próprio órgão controlado.

Nesse sentido manifestou-se o Conselheiro Alexandre de Moraes, relator do Procedimento de Controle Administrativo no 79, julgado no CNJ em 11 de abril de 2006:

Com a criação do Conselho Nacional de Justiça, a EC n $n^{0} 45 / 04$ estabeleceu a existência de um órgão de controle central, no Âmbito financeiro, administrativo e disciplinar do Poder Judiciário, integrante do próprio Poder. 
Porém, também estabeleceu que a legalidade de todas as decisões do Conselho Nacional de Justiça estará sujeita ao controle pelo órgão de cúpula do Poder Judiciário. reforçando e centralizando no Supremo Tribunal Federal o controle de legalidade administrativo, financeiro $e$ disciplinar de todo o Poder Judiciário (CF, art. 102, I, r).

Ilógico seria o texto constitucional permitir que o único controlador da constitucionalidade e legalidade dos atos do Conselho Nacional de Justiça - o Supremo Tribunal Federal -, pudesse por ele ser controlado disciplinar ou administrativamente, para logo após, poder rever suas decisões, em um círculo virtuoso que, porém, estaria ferindo a previsão constitucional do Supremo Tribunal Federal como órgão jurisdicional máximo do Poder Judiciário brasileiro.

Interessante notar que na ementa do acórdão da $\mathrm{ADI} \mathrm{n}^{\mathrm{o}} 3367$ consta que o Conselho Nacional de Justiça não tem nenhuma competência de controle administrativo e financeiro sobre o Supremo Tribunal Federal, enquanto órgão máximo do Poder Judiciário, e também não exerce qualquer controle disciplinar sobre seus Ministros, enquanto juízes da Suprema Corte Brasileira.

Ao reconhecer a constitucionalidade do Conselho Nacional de Justiça, o Ministro Cezar Peluso expressamente afirmou em seu voto na referida ação que o CNJ capacita o Poder Judiciário a exercer competência disciplinar no plano nacional sobre todos os juízes hierarquicamente situados abaixo do Supremo Tribunal Federal.

E, em nota de rodapé, afirma:

Os ministros do Supremo, órgão máximo do Judiciário brasileiro e guardião último da Constituição Federal, não estão, nem poderiam estar, como óbvio, sujeitos ao poder disciplinar do Conselho, cujos atos e decisões, sempre de natureza administrativa, é que são passíveis de controle jurisdicional desta Corte (art. 102, inciso I, letra "r", introduzido pela Emenda). O que dispõe a Emenda no art. 103-B, § $4^{\circ}$, não os apanha, como se percebe sem muito esforço.

Novamente é mencionado no voto o pensamento de Sérgio Bermudes (2005, p. 137):

Excluem-se da incidência desse $\S 4^{\circ}$ apenas os ministros do Supremo Tribunal Federal [...] A submissão dos ministros do Supremo Tribunal 
Federal ao Conselho Nacional de Justiça perturbaria a ordem constitucional, inclusive pela impossibilidade de repercutir, de algum modo, nos julgamentos do órgão supremo do Poder Judiciário.

Como a decisão proferida na ADI no 3367, julgada em 13 de abril de 2005, tem efeito vinculante em relação aos demais órgão do Poder Judiciário $\left(\mathrm{CF}\right.$, art. 102, § $2^{\circ}$, com a redação dada pela Emenda Constitucional 45, de 30 de dezembro de 2004), conclui-se que nenhuma das missões atribuídas pela Emenda Constitucional $n^{\circ} 45 / 2004$ ao Conselho Nacional de Justiça (controle da atuação administrativa e financeira dos órgãos Poder Judiciário e do cumprimento dos deveres funcionais dos seus juízes) é exercida em relação ao Supremo Tribunal Federal e seus Ministros.

O próprio Conselho Nacional de Justiça tem reiteradamente deixado de apreciar pedidos de fiscalização administrativa e financeira da Suprema Corte e pleitos de controle disciplinar em relação aos seus Ministros, por entender, ante os termos do julgamento da ADI $n^{\circ} 3367$, ser incompetente para deles conhecê-los.

Cumpre destacar, porém, que os Ministros do Supremo Tribunal Federal (assim como os próprios membros do Conselho Nacional de Justiça) respondem por seus atos, politicamente, perante o Senado Federal (CF, art. 52, II). E, caso pratiquem crimes comuns, os Ministros do STF estão sujeitos a julgamento pela própria Suprema Corte $(\mathrm{CF}$, art. 102, I, "b").

Em resumo, apesar de ser instituição de sobreposição do Poder Judiciário, o Conselho Nacional de Justiça não tem competência para controle da atuação administrativa e financeira do Supremo Tribunal Federal (realizada por seus órgãos singulares ou colegiados) e também não lhe compete fiscalizar o cumprimento dos deveres funcionais dos Ministros da Alta Corte Brasileira ${ }^{332}$.

\footnotetext{
${ }^{332}$ É importante registrar que Joaquim Falcão (2006, p. 117) alerta que "se considerarmos o nosso Supremo Tribunal Federal não do ponto de vista do seu poder jurisdicional, mas da perspectiva de seu poder administrativo, veremos que ele não detém competência para impor seu modelo de gestão aos demais tribunais do país. A hierarquia jurisdicional não se traduz em hierarquia gerencial". Nessa linha, em Dissertação de Mestrado apresentada à Universidade de Fortaleza, Pedro Rafael Malveira Deocleciano (2010, pp. 107 e 108) questiona porque a atuação do CNJ não alcança os Ministros do STF, se o órgão, incumbido de realizar controle administrativo, financeiro e disciplinar, pertence à própria estrutura do Judiciário. Sustenta que não há "alcance interpretativo lógico que afirme o poder implícito, outorgado pela Constituição, pertinente a definir que o Supremo detém a última palavra em organização judiciária e que, por consequência, não poderia se submeter às diretrizes de gestão administrativa do CNJ" e ainda afirma que "a limitação das atividades administrativas do CNJ é mais uma carta na manga (tirania de valores na acepção de Carl Schmitt) utilizada pelo Supremo, que engenhosamente confunde atribuições de última instância recursal com última instância administrativa". De fato, a interpretação reducionista realizada no julgamento da ADI no 3367 que alheou o STF do controle do CNJ não é imune a questionamentos, sobretudo porque o próprio Supremo, na referida decisão, reconheceu que o CNJ recebeu do constituinte derivado "uma alta
} 


\subsection{Casuística: não conhecimento de pleitos relativos ao STF}

Neste item serão apresentados casos em que o Conselho Nacional de Justiça deixou de apreciar pedidos de controle do Supremo Tribunal Federal e de seus Ministros.

Conforme pesquisa realizada no sítio eletrônico do $\mathrm{CNJ}^{333}$ foram encontrados diversas decisões prolatadas pelo Alto Conselho Administrativo, singulares ou colegiadas, sobre o tema. Em todas elas, o CNJ concluiu ser incompetente para apreciar as pretensões deduzidas, uma vez que STF e seus membros não estão subordinados ou submissos ao seu controle, ante o teor da decisão proferida na $\operatorname{ADI} n^{\circ} 3367$, e determinou o arquivamento dos pleitos.

A maior parte das decisões administrativas localizadas foram proferidas em pedidos de providências apresentados devido à demora excessiva no julgamento de ações judiciais que tramitavam no Supremo Tribunal Federal. Nesse sentido podem ser mencionados os pleitos deduzidos nos Pedidos de Providências $n^{0}$ s 876, 877, 1052, 1077, 1082, 1099 e 1106 e nos Recursos Administrativos nos 2007.10.00.000732-9, 200820000000525, 200820000000537 e 200820000000549.

Para ilustrar, cita-se a ementa do Recurso Administrativo no Procedimento de Controle Administrativo no $2007.10 .00 .000732-9^{334}$ :

função política de aprimoramento do autogoverno do Judiciário", a fím de viabilizar uma "estratégia políticoinstitucional de âmbito nacional", e que o órgão não exerce jurisdição e não representa risco à independência do Poder Judiciário no exercício de sua função típica.

${ }^{333}$ Disponível em <http://www.cnj.jus.br/InfojurisI2/JurisprudenciaSearch.seam>. Acesso em 17.4.2014.

${ }^{334} \mathrm{O}$ processo mencionado iniciou-se em razão da representação apresentada pela Federação das Indústrias no Estado de Mato Grosso (FIEMT) perante o Conselho Nacional de Justiça por alegado excesso de prazo de Ministro do Supremo Tribunal Federal, relator de duas ações diretas de inconstitucionalidade. O feito foi registrado no CNJ como Procedimento $\mathrm{n}^{\circ}$ 2007.20.00.000318-2, sendo determinado seu arquivamento liminar por decisão de Juiz Auxiliar da Presidência do Conselho em 28 de junho de 2007, por falta de competência do órgão para dele conhecê-lo, ante os termos do julgado na ADI $n^{\circ} 3367$. A FIEMT interpôs recurso adminstrativo alegando que, "embora o art. 102, II, "r", da CF, preveja caber ao STF o julgamento das ações contra o CNJ, não ficaram os Ministros da Suprema Corte excluídos do controle administrativo e disciplinar do Conselho eis que tal controle é exercido sobre todo o Poder Judiciário". Argumentou, ainda, que "integrando o STF o Poder Judiciário, não há como deixá-lo alheio ao controle exercido pelo CNJ". Por fim, sustentou entender "também necessário o controle por cumprir ao CNJ zelar pelo princípio da moralidade administrativa". O feito foi distribuído ao Conselheiro Antônio Umberto de Souza Júnior, sendo registrado sob $\mathrm{n}^{\mathrm{o}}$ 2007.10.00.000732-9, e foi julgado em 31 de julho de 2007, com improvimento do recurso nos termos do voto do relator, resumido na ementa citada. Destacou ainda o relator, no seu voto, enganar-se "a recorrente ao enxergar um quadro de invulnerabilidade dos Ministros do Supremo Tribunal Federal. A par do controle social exercido pela opinião pública e pela mídia, os magistrados supremos podem ser processados e punidos com a perda do cargo, pela prática de crime de responsabilidade, perante o Senado Federal (CF, art. 52, II) ou, pela prática de crimes comuns, perante o próprio STF (CF, art. 102, I, $b$ )". Em voto convergente, o Conselheiro Técio Lins e Silva afirmou que lhe ocorreram "dúvidas sobre uma possível similitude de natureza e legitimidade entre a previsão constitucional do controle externo desenvolvido pelo 


\section{RECURSO ADMINISTRATIVO. REPRESENTAÇÃO POR EXCESSO}

\section{DE PRAZO. INCOMPETÊNCIA FUNCIONAL DO CONSELHO} NACIONAL DE JUSTIÇA PARA CONTROLE DA ATUAÇÃO DO SUPREMO TRIBUNAL FEDERAL. O móbile constitucional, na definição das atribuições dos diversos órgãos políticos, é montado dentro do sistema de freios e contrapesos. A conclusão que se extrai da arquitetura institucional que concebeu o Conselho Nacional de Justiça é de que ele ocupa posição privilegiadíssima dentro da estrutura do Poder Judiciário, exercendo o controle administrativo, financeiro e disciplinar de magistrados e serventuários. Todavia, dentro da idéia republicana de controlabilidade do poder, confiou-se ao Supremo Tribunal Federal a tarefa de rever, quando necessário, os atos do Conselho Nacional de Justiça. Não faria sentido que houvesse a Constituição Federal programado a competência revisora dos atos do CNJ pelo STF e ficassem os atos deste tribunal sujeitos ao $\mathrm{CNJ}$, criando um ciclo vicioso. Precedente do STF (ADI 3367, PELUSO). Recurso conhecido e improvido.

Cumpre registrar que o $\mathrm{CNJ}$, em relação a outros questionamentos que the foram

Tribunal de Contas da União nas unidades administrativas do Poder Judiciário - inclusive sobre o Supremo Tribunal Federal -, e o controle administrativo" requerido pela FIEMT junto ao CNJ, uma vez que "o Supremo Tribunal Federal, não obstante possuir competência constitucional para rever a legalidade das decisões proferidas pelo Tribunal de Contas da União, está adstrito ao controle externo exercido por tal órgão" e, assim, "não haveria que se falar em círculo vicioso de decisões", como afirmou o Conselheiro relator, pois o próprio STF tem "competência para, em face da constatação de qualquer ilegalidade, rever e desconstituir as decisões a si dirigidas pelo TCU”. Conclui, porém, "que tal dinâmica não poderá ser importada à hipótese de controle administrativo externo do Supremo Tribunal Federal por este Conselho Nacional de Justiça, devido às diferenças de localização no sistema político brasileiro e de obediência hierárquica a que estão submetidos este último e o Tribunal de Contas da União ”. uma vez que "o Tribunal de Contas da União não possui função judicante e, ao contrário do Conselho Nacional de Justiça, não integra o Poder Judiciário", sendo, assim, "possível admitir que o TCU fiscalize a regularidade das contas do Supremo Tribunal Federal, sem que isso signifique qualquer tipo de desrespeito hierárquico e, ainda, que a possibilidade de tal decisão ser revista pelo próprio STF diante da presença de ilegalidades importe em um ciclo vicioso de decisões entre instâncias judiciais entre si subordinadas", ao passo que se deve "reconhecer que, dada a atual sistemática constitucional, segundo a qual o Supremo Tribunal Federal constitui uma verdadeira instância revisora das decisões deste Conselho - não seria coerente que o mesmo pudesse efetivar fiscalização no órgão que, ao final, dirá se o resultado de tal fiscalização, sobre ele mesmo, deve ser mantido" (disponível em: <https://www.cnj.jus.br/ecnj/>, opção "Consulta Pública, Tipo de Consulta: Número Original do Processo, 200710000007329. Acesso em 18.04.2014). Insatisfeita com a decisão, impetrou a FIEMT, em 24 de março de 2008, mandado de segurança perante o Supremo Tribunal Federal, registrado sob no 27222 e distribuído inicialmente ao Ministro Gilmar Mendes e, posteriormente, à Ministra Ellen Gracie que, por decisão monocrática proferida em 23 de março de 2010, reconheceu a perda do objeto do writ e julgou-o prejudicado, porque as duas ações diretas de inconstitucionalidade em que se alegava excesso de prazo para julgamento foram apresentadas pelo Ministro relator para apreciação no Plenário da Suprema Corte em 07 de agosto de 2009. 
apresentados, na mesma linha, também reconheceu sua incompetência para exercer controle sobre o Supremo Tribunal Federal e seus Ministros.

Com efeito, o Ministério Público Federal, no Procedimento de Controle Administrativo $\mathrm{n}^{\mathrm{o}} 79$, pleiteou que o Conselho Nacional de Justiça analisasse a compatibilidade legal da carga semanal prevista em lei em relação aos servidores públicos ocupantes de cargo de provimento efetivo do Supremo Tribunal Federal ${ }^{335}$.

No Pedido de Providências $n^{0} 423$ foi solicitada a decretação de nulidade dos atos judiciais praticados por Ministro do STF porque, supostamente, participou em julgamentos em que se discutia temática que já teria sido defendida por Sua Excelência quando exerceu a função de Advogado Geral da União.

Requereu-se, no Pedido de Providências n ${ }^{\circ}$ 957, a revisão de habeas corpus indeferido no Pretório Excelso porque o solicitante não teria cometido o crime pelo qual foi preso e condenado, sendo posteriormente expulso do país.

Representou-se a Ministra Presidente do Supremo no Pedido de Providências no 1166 porque ela, supostamente, impedia e retia petições protocoladas na Corte, deixando de distribuí-las e processá-las.

No Pedido de Providências n 1170 insurgiu-se delegado de polícia contra a legalidade

\footnotetext{
${ }^{335}$ O Ministério Público Federal formulou pedidos idênticos ao Conselho Nacional de Justiça em relação ao Conselho da Justiça Federal (PCA n $77 / 2005)$, o Tribunal de Justiça do Distrito Federal e Território (PCA $\mathrm{n}^{\mathrm{o}}$ 80/2005), o Tribunal Regional Federal da $1^{\text {a }}$ Região (PCA n ${ }^{\circ} 81 / 2005$ ), o Tribunal Regional Federal da $5^{\text {a }}$ Região (PCA n ${ }^{\circ}$ 82/2005) e o Tribunal Superior do Trabalho (PCA n ${ }^{\circ}$ 83/2005). Todos foram distribuídos ao Conselheiro Alexandre de Moraes, sendo apreciados pelo colegiado conjuntamente em 28 de março de 2006. Transcreve-se, a seguir, a ementa do julgado que bem demostra a posição adotada pelo CNJ de considerar-se incompetente para exercer qualquer controle sobre o Supremo Tribunal Federal, mas competente para fiscalizar os demais órgãos do Poder Judiciário:
}

CONSELHO NACIONAL DE JUSTIÇA. COMPETÊNCIAS CONSTITUCIONAIS. I - Competência constitucional do Conselho Nacional de Justiça para controlar e supervisionar financeira, administrativa e disciplinarmente todos os órgãos do Poder Judiciário, com exceção do Supremo Tribunal Federal. Inteligência dos arts. 102, I, 'r' e 103-B, § 4', da Constituição Federal. II - Não conhecimento do Pedido de Controle Administrativo em relação ao Supremo Tribunal Federal. Conhecimento em relação aos demais órgãos do Poder Judiciário. III - Possibilidade de controle da constitucionalidade, legalidade do ato administrativo discricionário e fiel observância aos princípios e preceitos do art. 37 do texto constitucional. IV - Possibilidade de controle do ato administrativo discricionário nas hipóteses de desvio de poder ou de finalidade e pela teoria dos motivos determinantes. V - ATOS NORMATIVOS DE TRIBUNAIS E DO CONSELHO DA JUSTIÇA FEDERAL QUE ALTERARAM HORÁRIO DE EXPEDIENTE DOS SERVIDORES PÚBLICOS OCUPANTES DE CARGOS DE PROVIMENTO EFETIVO. Regulamentação por atos administrativos discricionários dentro dos parâmetros fixados pela Lei $\mathrm{n}^{0}$ 8.112/90. VI INEXISTÊNCIA DE INCONSTITUCIONALIDADE OU ILEGALIDADE. VII - NÃO COMPROVAÇÃO DE FERIMENTO AO INTERESSE PÚBLICO OU A PRESTAÇÃO JURISDICIONAL. O Ministério Público Federal não apresentou provas ou meros indícios de ferimento ao princípio da eficiência pelas alterações administrativas realizadas. VIII - PEDIDOS CONHECIDOS EM PARTE (PCA 77, 80, 81, 82, 83) E INDEFERIDOS NA PARTE CONHECIDA. 
da Resolução STF no 296, de 22 de setembro de 2004, por, segundo o requerente, extrapolar matéria de competência específica, ante os termos da Lei $\mathrm{n}^{\circ} 10.826$, de 22 de dezembro de 2003, e ante a forma como redigida carteira funcional de servidor do Supremo Tribunal Federal, porque teria, hipoteticamente, extrapolado os termos da referida resolução. Argumentou o postulante que funcionários que desempenham a função de seguranças judiciários na Suprema Corte têm portado arma de fogo sem previsão legal.

Versou o Pedido de Providências no 1311 sobre reclamação de advogado em razão de supostos fatos ocorridos no prédio do STF. O requerente afirmou que adentrou no local às 17h50min, encontrou gabinete de Ministro fechado e foi tratado com indelicadeza e descortesia por serventuário.

Por fim, tratou o Recurso Administrativo no Pedido de Providências $\mathrm{n}^{\mathrm{o}}$ 0004478.27.2013.2.00.0000 de pretensão de controle de atos praticados pela TV Justiça, unidade vinculada à Secretaria de Comunicação Social do STF. Requereu-se que o canal de telecomunição se abstivesse de divulgar a biografia de Ministros do Supremo Tribunal Federal, por, supostamente, caracterizar promoção pessoal e, pois, violar o disposto na norma inserta no art. 37 , caput e $\S 1^{\circ}$, da Constituição Federal.

Como afirmado, em todas as decisões prolatadas nos processos citados, determinou o CNJ o arquivamento dos pedidos, após concluir falecer-lhe competência para conhecê-los, por, nos termos da decisão exarada na Ação Direta de Inconstitucionalidade n ${ }^{0}$ 3367, não exercer vigilância sobre o Supremo Tribunal Federal e seus Ministros.

\subsection{Casuística: representações contra o PGR no CNMP}

Cumpre apresentar, por também ilustrar o objeto desta pesquisa e mais especificamente o tema em comento, caso que levou à prolação da decisão monocrática pela Ministra Rosa Weber no Mandado de Segurança $n^{\circ} 31578$, impetrado no Supremo Tribunal Federal pelo Procurador-Geral da República em face do Conselho Nacional do Ministério Público.

Em 12 de junho de 2012, o Senador Fernando Affonso Collor de Mello ofertou representações perante o Conselho Nacional do Ministério Público $\left(\mathrm{n}^{\circ} \mathrm{s}\right.$ 0.00.000.000600/2012-10 e 0.00.000.000603/2012-53) nas quais atribuiu ao ProcuradorGeral da República inércia ou excesso de prazo no desempenho de sua função ao receber inquérito policial e medida cautelar de interceptação telefônica relativos à denominada “Operação Vegas” da Polícia Federal porque, supostamente, teria, junto com 
Subprocuradora-Geral da República, permanecido inerte quanto ao dever de investigar, permitindo que os delitos atribuídos ao grupo chefiado por Carlos Augusto de Almeida Ramos, conhecido como "Carlinhos Cachoeira", prosseguissem em execução, o que somente não ocorreu devido à atuação do Ministério Público de Goiás, nos autos de outro inquérito policial, na investigação denominada "Operação Monte Carlo". Argumentou que o Procurador-Geral da República poderia ter pleiteado diligências, requerido ao STF aprofundamento de investigação em relação a parlamentares envolvidos nos delitos ou concluído pelo arquivamento parcial do procedimento de investigação em relação às autoridades com prerrogativa de foro, porém "teria preferido 'o silêncio e a inércia', deixando de adotar qualquer medida". Pugnou, pois, pela adoção de providências pelo CNMP, para aplicação das sanções cabíveis.

Ambos os feitos foram distribuídos ao Conselheiro Almino Afonso Fernandes. Aberta oportunidade para manifestações dos representados, o Procurador-Geral da República alegou a impossibilidade de sua submissão ao controle exercido pelo CNMP por seu cargo gozar de status e prerrogativas análogos aos que são conferidos aos Ministros do Supremo Tribunal Federal e, conforme entendimento firmado na ADI n 3367 e em diversos procedimentos de controle administrativo, não estão estes submetidos ao controle do CNJ. O Conselheiro relator, porém, entendeu que, prima facie, os Processos $\mathrm{n}^{\circ} \mathrm{s}$ $0.00 .000 .000600 / 2012-10$ e $0.00 .000 .000603 / 2012-53$ não buscavam atribuir responsabilidade às autoridades representadas, mas apenas apurar as alegações constantes das representações, concluindo que a aferição da possibilidade do CNMP apreciar matéria disciplinar em relação ao Procurador-Geral da República deveria ser realizada pelo plenário do órgão administrativo, pois nunca enfretara o assunto. Determinou, pois, a realização de diligência inaugural para oitiva de Procuradores da República no Estado de Goiás, a fim de possibilitar a análise do mérito das representações.

Para impugnar referidas decisões que determinaram o processamento das representações, o Procurador-Geral da República impetrou o Mandado de Segurança $n^{\circ}$ 31578 perante o Supremo Tribunal Federal. Entre outros argumentos, voltou a alegar que deve-lhe ser aplicado, por similitude, o entendimento firmado na ADI n ${ }^{\circ}$ 3367, para não se submeter ao controle do Conselho Nacional do Ministério Público.

O feito foi distribuído à Ministra Rosa Weber que, por decisão monocrática proferida em 23 de agosto de 2012, deferiu o pedido liminar formulado e suspendeu o curso das representações mencionadas perante o CNMP.

Justificou Sua Excelência, para a concessão da liminar, que o Procurador-Geral da 
República, em relação ao Conselho Nacional do Ministério Público, mantém posição semelhante àquela dos Ministros do Supremo Tribunal Federal em face do Conselho Nacional de Justiça, uma vez que: a) chefia o Ministério Público da União (CF, art. 128, § $1^{\circ}$ ); b) é nomeado, reconduzido e exonerado no cargo por decisão do Presidente da República, com autorização do Senado Federal (CF, art. 128, $\left.\S 1^{\circ}\right)$; c) é processado e julgado, nos crimes de responsabilidade, pelo Senado Federal (CF, art. 52, II), e nos crimes comuns pelo Supremo Tribunal Federal CF, art. 102, I, "b"); d) preside o Conselho Nacional do Ministério Público (CF, art. 130-A, I); e) representa o Ministério Público (LC $n^{\circ} 75 / 1993$, art. 26, I) e, f) incumbe-lhe exercer as funções do Ministério Público junto ao Supremo Tribunal Federal ( $\mathrm{LC}^{\circ}$ 75/1993, art. 46). Logo, como os Ministros do STF não se submetem ao controle administrativo do CNJ, o Procurador-Geral da República, também não se sujeita ao controle administrativo do Conselho Nacional do Ministério Público.

Com a devida vênia, discordamos desse entendimento.

Na ADI no 3367 afastou-se o Supremo Tribunal Federal e seus Ministros do controle exercido pelo Conselho Nacional de Justiça porque compete àquela Corte a guarda da Constituição Federal e o julgamento das ações movidas contra o próprio CNJ.

Mas a posição do Procurador-Geral da República em relação ao Conselho Nacional do Ministério Público não é análoga àquela dos Ministros do Supremo Tribunal Federal em face do Conselho do Judiciário, uma vez que o Chefe do Ministério Público Federal (LC n ${ }^{\circ}$ 75/1993, art. 45) não julga as ações contra o CNMP, competência constitucionalmente também afeta ao STF (CF, art. 102, I, "r").

Logo, não há possibilidade, no caso de eventual controle realizado pelo Conselho Nacional do Ministério Público sobre a atuação do Procurador-Geral da República, de surgimento de qualquer círculo vicioso em que órgão controlador das atividades do órgão controlado também seja fiscalizado por este último.

\subsubsection{Não sujeição do TSE ao controle do CNJ}

Como visto, o Supremo Tribunal Federal, no julgamento ADI nº 3367, definiu, apesar da norma inserta no artigo 103-B, $\S 4^{\circ}$, da Constituição Federal não estabelecer qualquer exceção à competência do Conselho Nacional de Justiça, que o referido Colegiado não exerce controle sobre a atuação administrativa e financeira do próprio STF e quanto ao cumprimento dos deveres funcionais dos seus Ministros. 
Ocorre que a ressalva firmada na ADI nº 3367 quanto à amplitude da atuação realizada pelo CNJ acaba por implicar, também, em restrições ao controle realizado pelo Colegiado em relação a outro órgão do Poder Judiciário: o Tribunal Superior Eleitoral (TSE).

A Constituição Federal, na norma inserta em seu art. 118, define serem órgãos da Justiça Eleitoral: a) o Tribunal Superior Eleitoral; b) os Tribunais Regionais Eleitorais (TREs); c) os Juízes Eleitorais; e, d) as Juntas Eleitorais.

O Tribunal Superior Eleitoral, segundo dispõe a regra prevista no artigo 119 da Lei Maior, compõe-se de sete membros, sendo: a) três juízes dentre os Ministros do Supremo Tribunal Federal; b) dois juízes dentre os Ministros do Superior Tribunal de Justiça; e, c) dois juízes dentre seis advogados de notável saber jurídico e idoneidade moral, indicados pelo Supremo Tribunal Federal e nomeados pelo Presidente da República.

O comando do parágrafo único do art. 119 da Carta ainda preceitua que o TSE elegerá seu Presidente e Vice-Presidente dentre os Ministros do Supremo Tribunal Federal, e o Corregedor Eleitoral dentre os Ministros do Superior Tribunal de Justiça.

Por fim, a norma anunciada no art. 121, caput, da Constituição Federal estabelece que lei complementar disporá sobre a organização e competência dos tribunais, dos juízes de direito e das juntas eleitorais.

Como ainda não foi editado esse diploma normativo, o Código Eleitoral, Lei ${ }^{\circ} 4.737$, de 15 de julho de 1965, que disciplina os referidos assuntos, foi recepcionado pela Ordem Constitucional atual e passou a ter o status de lei complementar.

Segundo essa lei, o Tribunal Superior Eleitoral é o órgão de sobreposição na Justiça Eleitoral. Sua competência jurisdicional originária e recursal está definida no art. 22 do Código Eleitoral ${ }^{336}$ e sua competência administrativa está fixada no art. 23 do mesmo

\footnotetext{
${ }^{336}$ Art. 22 (Código Eleitoral). Compete ao Tribunal Superior:

I - Processar e julgar originariamente:

a) o registro e a cassação de registro de partidos políticos, dos seus diretórios nacionais e de candidatos à Presidência e vice-presidência da República;

b) os conflitos de jurisdição entre Tribunais Regionais e juizes eleitorais de Estados diferentes;

c) a suspeição ou impedimento aos seus membros, ao Procurador Geral e aos funcionários da sua Secretaria;

d) os crimes eleitorais e os comuns que lhes forem conexos cometidos pelos seus próprios juizes e pelos juizes dos Tribunais Regionais;

e) o habeas corpus ou mandado de segurança, em matéria eleitoral, relativos a atos do Presidente da República, dos Ministros de Estado e dos Tribunais Regionais; ou, ainda, o habeas corpus, quando houver perigo de se consumar a violência antes que o juiz competente possa prover sobre a impetração;

f) as reclamações relativas a obrigações impostas por lei aos partidos políticos, quanto à sua contabilidade e à apuração da origem dos seus recursos;

g) as impugnações á apuração do resultado geral, proclamação dos eleitos e expedição de diploma na eleição de Presidente e Vice-Presidente da República;

h) os pedidos de desaforamento dos feitos não decididos nos Tribunais Regionais dentro de trinta dias da
} 
Diploma Legal ${ }^{337}$. O TSE, órgão colegiado, delibera, por maioria de votos, em sessão pública, presentes, em regra, a maioria de seus membros, consoante prevê o art. 19 do Código Eleitoral ${ }^{338}$.

Por outro lado, seja por força da norma inserta no art. 96, I, da Constituição Federal, seja em razão daquela prevista no art. 23, I, do Código Eleitoral, compete ao Tribunal Superior Eleitoral elaborar seu Regimento Interno.

conclusão ao relator, formulados por partido, candidato, Ministério Público ou parte legitimamente interessada.

i) as reclamações contra os seus próprios juizes que, no prazo de trinta dias a contar da conclusão, não houverem julgado os feitos a eles distribuídos.

j) a ação rescisória, nos casos de inelegibilidade, desde que intentada dentro de cento e vinte dias de decisão irrecorrível, possibilitando-se o exercício do mandato eletivo até o seu trânsito em julgado.

II - julgar os recursos interpostos das decisões dos Tribunais Regionais nos termos do Art. 276 inclusive os que versarem matéria administrativa.

Parágrafo único. As decisões do Tribunal Superior são irrecorrível, salvo nos casos do Art. 281.

OBS.: A Resolução do Senado Federal no 132/1984 suspendeu, por inconstitucionalidade, nos termos da decisão definitiva proferida pelo Supremo Tribunal Federal, em sessão Plenária realizada em 31 de agosto de 1983, a execução da locução "ou mandado de segurança", constante da letra " $e$ " do inciso I do artigo 22, do Código Eleitoral

${ }^{337}$ Art. 23 (Código Eleitoral). Compete, ainda, privativamente, ao Tribunal Superior:

I - elaborar o seu regimento interno;

II - organizar a sua Secretaria e a Corregedoria Geral, propondo ao Congresso Nacional a criação ou extinção dos cargos administrativos e a fixação dos respectivos vencimentos, provendo-os na forma da lei;

III - conceder aos seus membros licença e férias assim como afastamento do exercício dos cargos efetivos;

IV - aprovar o afastamento do exercício dos cargos efetivos dos juizes dos Tribunais Regionais Eleitorais;

V - propor a criação de Tribunal Regional na sede de qualquer dos Territórios;

VI - propor ao Poder Legislativo o aumento do número dos juizes de qualquer Tribunal Eleitoral, indicando a forma desse aumento;

VII - fixar as datas para as eleições de Presidente e Vice-Presidente da República, senadores e deputados federais, quando não o tiverem sido por lei:

VIII - aprovar a divisão dos Estados em zonas eleitorais ou a criação de novas zonas;

IX - expedir as instruções que julgar convenientes à execução deste Código;

$\mathrm{X}$ - fixar a diária do Corregedor Geral, dos Corregedores Regionais e auxiliares em diligência fora da sede;

XI - enviar ao Presidente da República a lista tríplice organizada pelos Tribunais de Justiça nos termos do ar. 25 ;

XII - responder, sobre matéria eleitoral, às consultas que lhe forem feitas em tese por autoridade com jurisdição, federal ou órgão nacional de partido político;

XIII - autorizar a contagem dos votos pelas mesas receptoras nos Estados em que essa providência for solicitada pelo Tribunal Regional respectivo;

XIV - requisitar a força federal necessária ao cumprimento da lei, de suas próprias decisões ou das decisões dos Tribunais Regionais que o solicitarem, e para garantir a votação e a apuração;

$\mathrm{XV}$ - organizar e divulgar a Súmula de sua jurisprudência;

XVI - requisitar funcionários da União e do Distrito Federal quando o exigir o acúmulo ocasional do serviço de sua Secretaria;

XVII - publicar um boletim eleitoral;

XVIII - tomar quaisquer outras providências que julgar convenientes à execução da legislação eleitoral.

${ }^{338}$ Art. 19 (Código Eleitoral). O Tribunal Superior delibera por maioria de votos, em sessão pública, com a presença da maioria de seus membros.

Parágrafo único. As decisões do Tribunal Superior, assim na interpretação do Código Eleitoral em face da Constituição e cassação de registro de partidos políticos, como sobre quaisquer recursos que importem anulação geral de eleições ou perda de diplomas, só poderão ser tomadas com a presença de todos os seus membros. Se ocorrer impedimento de algum juiz, será convocado o substituto ou o respectivo suplente. 
O Regimento Interno do TSE (RITSE), Resolução n 4.510, de 29 de setembro de 1952, dispõe sobre as competências do Presidente e do Vice-Presidente dessa Corte em seus arts. $9^{\circ}$ e $10^{339}$.

A leitura dos referidos dispositivos regimentais revela que ao Presidente do Tribunal Superior Eleitoral compete dirigir e administrar a Corte, bem como geri-la financeiramente. Deve, ainda, cumprir e fazer cumprir as decisões do Tribunal. Ao VicePresidente compete substituir o Presidente em seus impedimentos ou faltas ocasionais.

Cumpre lembrar que o Presidente e o Vice-Presidente do Tribunal Superior Eleitoral, são Ministros do Supremo Tribunal Federal, assim como mais um dos membros do TSE. Nessa qualidade, como exposto, não estão submetidos a controle disciplinar do Conselho Nacional de Justiça.

Portanto, como não é possível cindir da mesma pessoa natural os cargos que exerce de Ministro do Supremo Tribunal Federal e, ao mesmo tempo, de Ministro do Superior Eleitoral, inconcebível vislumbrar qualquer controle do CNJ sobre a atuação administrativa e financeira do Tribunal Superior Eleitoral e sobre o cumprimento dos deveres funcionais do seu Presidente e do seu Vice-Presidente, assim como do seu terceiro membro oriundo

${ }^{339}$ Art. $9^{\circ}$ (RITSE) Compete ao presidente do Tribunal:

a) dirigir os trabalhos, presidir as sessões, propor as questões, apurar o vencido e proclamar o resultado;

b) convocar sessões extraordinárias;

c) tomar parte na discussão, e proferir voto de qualidade nas decisões do Plenário, para as quais o Regimento Interno não preveja solução diversa, quando o empate na votação decorra de ausência de Ministro em virtude de impedimento, suspeição, vaga ou licença médica, e não sendo possível a convocação de suplente, e desde que urgente a matéria e não se possa convocar o Ministro licenciado, excepcionado o julgamento de habeas corpus onde proclamar-se-á, na hipótese de empate, a decisão mais favorável ao paciente;

d) dar posse aos membros substitutos;

e) distribuir os processos aos membros do Tribunal, e cumprir e fazer cumprir as suas decisões;

f) representar o Tribunal nas solenidades e atos oficiais, e corresponder-se, em nome dele, com o presidente da República, o Poder Legislativo, os órgãos do Poder Judiciário, e demais autoridades;

g) determinar a remessa de material eleitoral às autoridades competentes, e, bem assim, delegar aos presidentes dos tribunais regionais a faculdade de providenciar sobre os meios necessários à realização das eleições;

h) nomear, promover, exonerar, demitir e aposentar, nos termos da Constituição e das leis, os funcionários da Secretaria;

i) dar posse ao diretor-geral e aos diretores de serviço da Secretaria;

j) conceder licença e férias aos funcionários do quadro e aos requisitados;

k) designar o seu secretário, o substituto do diretor-geral e os chefes de seção;

1) requisitar funcionários da administração pública quando o exigir o acúmulo ocasional ou a necessidade do serviço da Secretaria, e dispensá-los;

m) superintender a Secretaria, determinando a instauração de processo administrativo, impondo penas disciplinares superiores a oito dias de suspensão, conhecendo e decidindo dos recursos interpostos das que foram aplicadas pelo diretor-geral, e relevando faltas de comparecimento;

n) rubricar todos os livros necessários ao expediente;

o) ordenar os pagamentos, dentro dos créditos distribuídos, e providenciar sobre as transferências de créditos, dentro dos limites fixados pelo Tribunal.

Art. 10. Ao vice-presidente compete substituir o presidente em seus impedimentos ou faltas ocasionais. 
do $\mathrm{STF}^{340}$.

Primeiro, porque o colegiado formado no TSE para deliberações administrativas conta, em seu corpo, com a participação de Ministros do Supremo Tribunal Federal.

Como exposto $^{341}$, na lição de Ugo Gargiulo (1962, p. 62), o colegiado forma uma unidade que funde as vontades singulares das pessoas que o compõe.

Logo, se na composição do colegiado do TSE, há integrantes - Ministros oriundos do Supremo Tribunal Federal - que não se submetem a qualquer fiscalização do Conselho Nacional de Justiça -, ainda que outros dos seus componentes - Ministros originários do Superior Tribunal de Justiça ou da advocacia -, individualmente, estejam sujeitos ao controle disciplinar do $\mathrm{CNJ}$, não é admissível que a unidade do desse colegiado - o Tribunal Superior Eleitoral -, surgida pela fusão das vontades singulares de seus integrantes, e portanto, inclusive daquelas não submissas ao órgão controlador, fique submetida ao seu jugo. Caso contrário, haveria indireta ingerência do Conselho Nacional de Justiça sobre as vontades externadas por Ministros do STF.

Poder-se-ia argumentar, neste ponto, que a vontade administrativa manifestada em deliberação do Colegiado TSE é distinta da dos seus membros, ainda que obtida pela reunião das suas vontades individuais e, portanto, pode aquela ser submetida ao controle do CNJ. Ademais, é possível que determinada deliberação administrativa no Tribunal Superior seja pronunciada sem a participação, na votação, dos integrantes provenientes do Supremo Tribunal Federal ou mesmo que, na deliberação, todos estes fiquem vencidos, uma vez que, o Tribunal Superior conta com sete membros e delibera-se por maioria de votos, presentes a maioria de seus Ministros, exceto quanto às decisões que impliquem interpretação do Código Eleitoral em face da Constituição, relativas a cassação de registro de partidos políticos e em quaisquer recursos que importem anulação geral de eleições ou

\footnotetext{
${ }^{340}$ Ao editar a Resolução CNJ no 135 , de 13 de julho de 2011, que dispõe sobre a uniformização de normas relativas ao procedimento administrativo disciplinar aplicável aos magistrados, o próprio Conselho Nacional de Justiça reconheceu que não lhe compete exercer o controle do cumprimento dos deveres funcionais dos Ministros do TSE provenientes do STF, excluindo-os, para os efeitos do referido ato normativo, do conceito de magistrado, conforme dispõe a norma prescrita no art $1^{\circ}$ do texto, a seguir transcrito:

Art. $1^{\circ}$ (Resolução CNJ no 135/2011) Para os efeitos desta Resolução, são magistrados os Juízes Substitutos, os Juízes de Direito e os Desembargadores dos Tribunais de Justiça Estaduais, os Juízes Federais e dos Tribunais Regionais Federais, os Juízes do Trabalho e dos Tribunais Regionais do Trabalho, os Juízes Militares e dos Tribunais Militares, os Juízes Eleitorais e dos Tribunais Regionais Eleitorais, os Ministros do Superior Tribunal de Justiça, os Ministros do Tribunal Superior do Trabalho, os Ministros do Superior Tribunal Militar e os Ministros do Tribunal Superior Eleitoral, exceto aqueles que também integram o Supremo Tribunal Federal.

${ }^{341}$ Vide item 2.3.2.2.
} 
perda de diplomas, que dependem de quorum completo (Código Eleitoral, art. 19) ${ }^{342}$.

Mas, se compete ao Presidente do TSE a administração e o gerenciamento das finanças dessa Corte, bem como o cumprimento de suas decisões administrativas, podendo ser substituído, eventualmente, pelo Vice-Presidente, e sendo ambos Ministros do Supremo Tribunal Federal, despiciendo se mostra qualquer controle administrativo e financeiro que o Conselho Nacional de Justiça pretenda realizar sobre referido tribunal, porque, se houver descumprimento das determinações do $\mathrm{CNJ}$ exaradas com o intuito de realizar eventual controle de deliberações emanadas pelo TSE (da qual tenham participado e apresentado votos vencedores, ou não, Ministros oriundos do STF), não poderá o Colegiado Administrativo responsabilizar disciplinarmente, de qualquer forma, os dirigentes do TSE, pois integram a Suprema Corte Brasileira.

No caso, o Presidente do TSE (ou, na sua falta, o Vice-Presidente) sequer poderá ser responsabilizado pela prática do crime de responsabilidade previsto na norma inserta no art. 39, 4, da Lei $\mathrm{n}^{\mathrm{o}} 1.079$, de 10 de abril de $1950^{343}$, porque, ao deixar de observar determinação do CNJ para prestigiar decisão administrativa do TSE, estará a cumprir exatamente um dos deveres do seu cargo de Ministro do STF que é, ao estar na Chefia da Corte Superior da Justiça Eleitoral, executar, em razão de delegação desse Colegiado, as suas deliberações (RITSE, art. 9", “e”).

Logo, em relação ao Tribunal Superior Eleitoral, compete ao Conselho Nacional de Justiça somente o controle do cumprimento dos deveres funcionais dos quatro Ministros procedentes do Superior Tribunal de Justiça e dos quadros da advocacia.

Quanto aos dois primeiros - Ministros oriundos do STJ -, o controle disciplinar é amplo, pois integram órgão do Poder Judiciário sujeito à fiscalização do CNJ.

Quanto aos dois últimos - Ministros provenientes dos quadros da advocacia -, porém,

\footnotetext{
${ }^{342}$ Restou decidido pelo TSE em 26 de setembro de 2000 e em 29 de abril de 2004, respectivamente nas questões de ordem suscitadas no Recurso Especial Eleitoral no 16.684, relator Ministro Waldemar Zveiter, e no Recurso Contra Expedição de Diploma n ${ }^{\circ}$ 612, relator Ministro Carlos Velloso, ser possível o julgamento das matérias previstas no art. 19, parágrafo único, do Código Eleitoral com quorum incompleto em caso de suspeição ou impedimento de Ministro titular da classe de advogado e impossibilidade jurídica de convocação de juiz substituto. No caso de impedimento ou suspeição de Ministro da representação do STF ou do STJ e de seu substituto, pede-se a indicação, pelas respectivas Cortes, de outro Ministro para compor o TSE.

${ }^{343}$ Art. 39 (Lei n ${ }^{\circ}$ 1.079/1950). São crimes de responsabilidade dos Ministros do Supremo Tribunal Federal: 1- altera, por qualquer forma, exceto por via de recurso, a decisão ou voto já proferido em sessão do Tribunal;

2 - proferir julgamento, quando, por lei, seja suspeito na causa;

3 - exercer atividade político-partidária;

4 - ser patentemente desidioso no cumprimento dos deveres do cargo;

5 - proceder de modo incompatível com a honra dignidade e decôro de suas funções.
} 
o controle do cumprimento dos seus deveres funcionais pelo Conselho é restrito à atuação deles enquanto no exercício da judicatura eleitoral pois, como restou decidido pelo Supremo Tribunal Federal, no julgamento da Medida Cautelar na ADI n ${ }^{\circ} 1127$, da relatoria do Ministro Paulo Brossard, em 6 de outubro de 1994, a norma prevista no art. 28, II, da Lei $\mathrm{n}^{\mathrm{o}}$ 8.906, de 4 de julho de 1994 - Estatuto da Advocacia - ao estabelecer ser incompatível com a advocacia, mesmo em causa própria, as atividades de membros de órgãos do Poder Judiciário, não se estende aos advogados e membros da Justiça Eleitoral e aos Juízes Substitutos não remunerados, em respeito ao que dispõe os artigos 119, II, e $120, \S 1^{\text {o }}$, da Constituição Federal ${ }^{344}$.

${ }^{344} \mathrm{O}$ acórdão da $\mathrm{ADI} \mathrm{n}^{\mathrm{o}} 1127 \mathrm{MC}$ recebeu a seguinte ementa, grifada na parte correspondente à matéria em exame:

AÇÃO DIRETA DE INCONSTITUCIONALIDADE. ESTATUTO DA ADVOCACIA E DA ORDEM DOS ADVOGADOS DO BRASIL - Lei 8.906/94. Suspensão da eficácia de dispositivos que especifica. LIMINAR. AÇÃO DIRETA. Distribuição por prevenção de competência e ilegitimidade ativa da autora. QUESTÕES DE ORDEM. Rejeição. MEDIDA LIMINAR. Interpretação conforme e suspensão da eficácia até final decisão dos dispositivos impugnados, nos termos seguintes: Art. $1^{\circ}$, inciso I - postulações judiciais privativa de advogado perante os juizados especiais. Inaplicabilidade aos Juizados de Pequenas Causas, à Justiça do Trabalho e à Justiça de Paz. Art. $7^{\circ}$, $\S \S 2^{\circ}$ e $3^{\circ}$ - suspensão da eficácia da expressão 'ou desacato' e interpretação de conformidade a não abranger a hipótese de crime de desacato à autoridade judiciária. Art. $7^{\circ}$, $\S 4^{\circ}$ - salas especiais para advogados perante os órgãos judiciários, delegacias de polícia e presídios. Suspensão da expressão "controle" assegurado à OAB. Art. $7^{\circ}$, inciso II - inviolabilidade do escritório ou local de trabalho do advogado. Suspensão da expressão 'e acompanhada de representante da OAB' no que diz respeito à busca e apreensão determinada por magistrado. Art. $7^{\circ}$, inciso IV - suspensão da expressão 'ter a presença de representante da $\mathrm{OAB}$, quando preso em flagrante, por motivo ligado ao exercício da advocacia, para a lavratura do auto respectivo, sob pena de nulidade'. Art. $7^{\circ}$, inciso V - suspensão da expressão 'assim reconhecida pela $\mathrm{OAB}$ ', no que diz respeito às instalações e comodidades condignas da sala de Estado Maior, em que deve ser recolhido preso o advogado, antes de sentença transitada em julgado. Art. 20, inciso II - incompatibilidade da advocacia com membros de órgãos do Poder Judiciário. Interpretação de conformidade a afastar da sua abrangência os membros da Justiça Eleitoral e os juizes suplentes não remunerados. Art. 50 - requisição de cópias de peças e documentos pelo Presidente do Conselho da OAB e das Subseções. Suspensão da expressão 'Tribunal, Magistrado, Cartório e'. Art. $1^{\circ}, \S 2^{\circ}$ contratos constitutivos de pessoas jurídicas. Obrigatoriedade de serem visados por advogado. Falta de pertinência temática. Argüição, nessa parte, não conhecida. Art. $2^{\circ}, \S 3^{\circ}$ - inviolabilidade do advogado por seus atos e manifestação, no exercício da profissão. Liminar indeferida. Art. $7^{\circ}$, inciso IX - sustentação oral, pelo advogado da parte, após o voto do relator. Pedido prejudicado tendo em vista a sua suspensão na ADIn 1.105. Razoabilidade na concessão da liminar". Posteriormente, em 17 de maio de 2006, a referida decisão foi confirmada no julgamento final da ADI $n^{\circ} 1127$, relator Ministro Marco Aurélio Mello, relator para o acórdão Ministro Ricardo Lewandowski, que recebeu a seguinte ementa, também destacado o assunto abordado: "AÇÃO DIRETA DE INCONSTITUCIONALIDADE. LEI 8.906, DE 4 DE JULHO DE 1994. ESTATUTO DA ADVOCACIA E A ORDEM DOS ADVOGADOS DO BRASIL. DISPOSITIVOS IMPUGNADOS PELA AMB. PREJUDICADO O PEDIDO QUANTO À EXPRESSÃO 'JUIZADOS ESPECIAIS', EM RAZÃO DA SUPERVENIÊNCIA DA LEI 9.099/1995. AÇÃO DIRETA CONHECIDA EM PARTE E, NESSA PARTE, JULGADA PARCIALMENTE PROCEDENTE. I - O advogado é indispensável à administração da Justiça. Sua presença, contudo, pode ser dispensada em certos atos jurisdicionais. II - A imunidade profissional é indispensável para que o advogado possa exercer condigna e amplamente seu múnus público. III - A inviolabilidade do escritório ou do local de trabalho é consectário da inviolabilidade assegurada ao advogado no exercício profissional. IV - A presença de representante da OAB em caso de prisão em flagrante de advogado constitui garantia da inviolabilidade da atuação profissional. A cominação de nulidade da prisão, caso não se faça a comunicação, configura sanção para tornar efetiva a norma. V - A prisão do advogado em sala de Estado Maior é garantia suficiente para que fique provisoriamente detido em condições compatíveis com o seu múnus público. VI - A administração de 
Em síntese, entendemos que o Conselho Nacional de Justiça não tem competência para exercer o controle da atuação administrativa e financeira do Tribunal Superior Eleitoral porque seu corpo é integrado, em parte, por Ministros do Supremo Tribunal Federal, sendo que dois deles exercem as funções de Presidente e Vice-Presidente e são, pois, responsáveis pela direção, administração, gerenciamento financeiro e cumprimento das decisões da Corte Superior. Também não cabe ao CNJ exercer controle do cumprimento dos deveres funcionais dos três Ministros do TSE provenientes do $\mathrm{STF}^{345}$, podendo apenas realizar esse controle em relação aos demais Ministros da referida Corte, de forma ampla quanto àqueles oriundos do STJ e somente enquanto estiverem no exercício da judicatura eleitoral quanto aos Ministros nomeados dos quadros da $\operatorname{advocacia}^{346}$.

\subsubsection{Não sujeição parcial da Justiça Eleitoral ao controle do CNJ}

estabelecimentos prisionais e congêneres constitui uma prerrogativa indelegável do Estado. VII - A sustentação oral pelo advogado, após o voto do Relator, afronta o devido processo legal, além de poder causar tumulto processual, uma vez que o contraditório se estabelece entre as partes. VIII - A imunidade profissional do advogado não compreende o desacato, pois conflita com a autoridade do magistrado na condução da atividade jurisdicional. IX - O múnus constitucional exercido pelo advogado justifica a garantia de somente ser preso em flagrante e na hipótese de crime inafiançável. X - O controle das salas especiais para advogados é prerrogativa da Administração forense. XI - A incompatibilidade com o exercício da advocacia não alcança os juízes eleitorais e seus suplentes, em face da composição da Justiça eleitoral estabelecida na Constituição. XII - A requisição de cópias de peças e documentos a qualquer tribunal, magistrado, cartório ou órgão da Administração Pública direta, indireta ou fundacional pelos Presidentes do Conselho da OAB e das Subseções deve ser motivada, compatível com as finalidades da lei e precedida, ainda, do recolhimento dos respectivos custos, não sendo possível a requisição de documentos cobertos pelo sigilo. XIII - Ação direta de inconstitucionalidade julgada parcialmente procedente.

${ }^{345}$ Cumpre registrar a fala do Ministro Marco Aurélio Mello em 17 de agosto de 2010, durante a prolação do voto da Ministra Cármen Lúcia no julgamento, no Tribunal Superior Eleitoral, do Processo Administrativo $\mathrm{n}^{\circ}$ 2156-06.2010.0.00.0000, da relatoria do Ministro Ricardo Lewandowski, que demostra sua indignação quanto a aventada possibilidade de controle pelo CNJ de ato praticado por Presidente do TSE: "Vossa Excelência me permite retratar um fato? Certo Presidente desta Corte atuou na primeira hora e de forma ostensiva, durante eleições passadas, incomodando, assim, determinado Partido. Houve, contra esse Presidente, representação no Conselho Nacional de Justiça, imediatamente arquivada pela então Presidenta, Ministra Ellen Gracie. Mas os interessados, parlamentares desse Partido, interpuseram recurso. Um Conselheiro, que aponto sempre como um homem letrado, Professor de Direito, foi até o então Presidente, àquela altura o Ministro Gilmar Mendes, para que ele apresentasse, ao Colegiado, esse recurso. Sua Excelência, o Presidente, apegado ao que está estabelecido na Constituição Federal, ressaltando-se o fato de o Conselho Nacional de Justiça, topograficamente, ter sido colocado logo abaixo do Supremo, como Órgão do Judiciário, mostrou-se firme e se recusou a levar o recurso ao Colegiado, porque este não teria como atuar relativamente ao Presidente do Tribunal Superior Eleitoral, que, todos sabem, é integrante do Supremo".

${ }^{346}$ Como a decisão proferida na ADI no 1127 , mencionada notas 344, estende-se também aos dois juízes eleitorais integrantes dos Tribunais Regionais Eleitorais nomeados pelo Presidente da República dentre seis advogados de notável saber jurídico e idoneidade moral, indicados pelo Tribunal de Justiça (CF, art. 120, § $1^{\circ}$, III), o controle disciplinar exercido sobre eles pelo CNJ restringe-se, da mesma forma, à atuação no exercício judicante. 
Observado que o Conselho Nacional de Justiça é um órgão de sobreposição administrativa na estrutura do Poder Judiciário mas, conforme decidido na ADI $\mathrm{n}^{\mathrm{o}} 3367$, não controla o Supremo Tribunal Federal e seus Ministros e, consequentemente, por três deles o integrarem e dois o dirigirem, também não pode fiscalizar o Tribunal Superior Eleitoral, passa-se a outra importante limitação constitucional à $\mathrm{CNJ}$ : também não pode exercer controle sobre os órgãos da Justiça Eleitoral quanto às matérias que possuem disciplina específica nessa Justiça Especializada.

Com efeito, foi explicitado que o CNJ não tem competência jurisdicional, função típica do Judiciário $^{347}$. Sua missão se volta ao controle das funções atípicas desenvolvidas no seio dos diversos órgãos desse Poder, tendo a Constituição Federal conferido-lhe, nesse ponto, amplo campo de atuação para realizar a vigilância dos diversos atos praticados pela administração no Poder Judiciário, com ressalvas, como defendido, em relação aos denominados atos de opinião e atos políticos.

Ocorre que a "jurisdição eleitoral" não se limita aos contornos tradicionais da função de decidir uma controvérsia através da imposição da lei.

Surgida após a Revolução de Trinta pelo Decreto do Governo Provisório de Getúlio Vargas $n^{\circ} 21.076$, de 24 de fevereiro de 1932, e disciplinada em nível constitucional pela primeira vez no Brasil na Constituição de 1934 (arts. 82 e 83), a criação da Justiça Eleitoral objetivou a moralização do procedimento eleitoral (VELLOSO; AGRA, 2012, p. $33)$.

Como um dos pilares do Estado Democrático de Direito, a Justiça Eleitoral garante a legitimidade do processo eleitoral e o exercício do voto, concretizando o princípio da soberania popular inserto na norma do art. $1^{\circ}$, parágrafo único, da Constituição Federal, exercido através da Democracia representativa e da Democracia participativa.

Conforme mencionado no item anterior, na atual Ordem Constitucional, a regra anunciada no art. 121, caput, da Constituição Federal estabelece que lei complementar disporá sobre a organização e competência dos tribunais, dos juízes de direito e das juntas eleitorais. O Código Eleitoral disciplina esses assuntos, trazendo contornos próprios a esse braço do Judiciário. Cumpre dizer que referido Diploma Legal, em nenhum dispositivo, estabelece alguma competência eleitoral ao Conselho Nacional de Justiça (mesmo porque o órgão não existia em 1965).

Como esclarecem Carlos Mário da Silva Velloso e Walber de Moura Agra (2012, p.

${ }^{347}$ Vide item 2.3.5.1. 
34), a "Justiça Eleitoral, pela própria especificidade de sua seara de atuação, a captação da vontade da população, possui alguns standards que lhe são peculiares, destoando das demais searas do Direito".

Referidos autores (2012, p.35), com apoio em Olivar Coneglian (2003, pp. 57 a 74), apontam as seguintes diferenças da Justiça Eleitoral em relação aos outros ramos do Poder Judiciário:

a) é constituída por membros emprestados;

b) seus membros não são vitalícios, ou seja, são renovados periodicamente, essa renovação tem trazido benefícios bastantes para a justiça, visto que seus novos membros sempre agregam novos valores político-sociais;

c) é uma forma de justiça executiva, no sentido de que, além de julgar os recursos eleitorais, tem o dever de executar as eleições;

d) sua jurisdição ocorre em bloco e em tempo único.

Esclarecerem ainda (2012, pp. 35 e 36) que os prazos do Direito Eleitoral são dos mais exíguos e os órgãos da Justiça Eleitoral, ao contrário dos demais do Poder Judiciário, podem emitir opiniões, por intermédio de consultas, como dispõe as normas insertas nos arts. 23, XII, e 30, VIII, ambos do Código Eleitoral ${ }^{348}$. Por fim, destacam o poder normativo da Justiça Eleitoral (2012, pp. 36 a 38) previsto, especialmente, no art. 23, IX, do Código Eleitoral ${ }^{349}$, no art. 105, caput, da Lei $n^{\circ}$ 9.504, de 30 de setembro de 1997 (Lei Eleitoral) ${ }^{350}$ e no art. 61 da Lei no 9.096, de 19 de setembro de 1995 (Lei dos Partidos

${ }^{348}$ Art. 23 (Código Eleitoral). Compete, ainda, privativamente, ao Tribunal Superior: $[\ldots]$

XII - responder, sobre matéria eleitoral, às consultas que lhe forem feitas em tese por autoridade com jurisdição, federal ou órgão nacional de partido político;

Art. 30 (Código Eleitoral). Compete, ainda, privativamente, aos Tribunais Regionais:

$[\ldots]$

VIII - responder, sobre matéria eleitoral, às consultas que lhe forem feitas, em tese, por autoridade pública ou partido político;

${ }^{349}$ Art. 23 (Código Eleitoral). Compete, ainda, privativamente, ao Tribunal Superior:

$[\ldots]$

IX - expedir as instruções que julgar convenientes à execução deste Código;

${ }^{350}$ Art. 105 (Lei Eleitoral). Até o dia 5 de março do ano da eleição, o Tribunal Superior Eleitoral, atendendo ao caráter regulamentar e sem restringir direitos ou estabelecer sanções distintas das previstas nesta Lei, poderá expedir todas as instruções necessárias para sua fiel execução, ouvidos, previamente, em audiência pública, os delegados ou representantes dos partidos políticos. 
Políticos) $)^{351}$.

A ativa atuação administrativa da Justiça Eleitoral é revelada em rápido giro pela Legislação Eleitoral. A título de exemplo, podem ser citadas as disposições constantes de diversos incisos do artigo 35 do Código Eleitoral que atribuem competência aos Juízes Eleitorais para: a) fazer as diligências que julgar necessárias a ordem e presteza do serviço eleitoral (inc. IV); b) tomar conhecimento das reclamações que the forem feitas verbalmente ou por escrito, reduzindo-as a termo, e determinando as providências que cada caso exigir (inc. V); c) dirigir os processos eleitorais e determinar a inscrição e a exclusão de eleitores (inc. VIII); d) expedir títulos eleitorais e conceder transferência de eleitor (inc. IX); e) dividir a zona em seções eleitorais (inc. X); f) mandar organizar, em ordem alfabética, relação dos eleitores de cada seção, para remessa a mesa receptora, juntamente com a pasta das folhas individuais de votação (inc. XI); g) ordenar o registro e cassação do registro dos candidatos aos cargos eletivos municipais e comunicá-los ao Tribunal Regional (inc. XII); h) designar, até 60 (sessenta) dias antes das eleições os locais das seções (inc. XIII); i) nomear, 60 (sessenta) dias antes da eleição, em audiência pública anunciada com pelo menos 5 (cinco) dias de antecedência, os membros das mesas receptoras (inc. XIV); j) instruir os membros das mesas receptoras sobre as suas funções (inc. XV); k) providenciar para a solução das ocorrências que se verificarem nas mesas receptoras (inc. XVI); 1) tomar todas as providências ao seu alcance para evitar os atos viciosos das eleições (inc. XVII); m) fornecer aos que não votaram por motivo justificado e aos não alistados, por dispensados do alistamento, um certificado que os isente das sanções legais (inc. XVIII); e, n) comunicar, até às 12 horas do dia seguinte a realização da eleição, ao Tribunal Regional e aos delegados de partidos credenciados, o número de eleitores que votarem em cada uma das seções da zona sob sua jurisdição, bem como o total de votantes da zona (inc. XIX).

Sobre essa vertente de atuação administrativa da Justiça Eleitoral, doutrina Torquato $\operatorname{Jardim}(1998$, p. 40):

Embora montada em modelo tipicamente judiciário - estrutura, forma, pessoal, vestes talares e jargão judiciário - sua tarefa é essencialmente administrativa, e só eventualmente jurisdicional. Processo eleitoral é um processo administrativo, e o que o singulariza é a unicidade do órgão

\footnotetext{
${ }^{351}$ Art. 61 (Lei dos Partidos Políticos). O Tribunal Superior Eleitoral expedirá instruções para a fiel execução desta Lei.
} 
administrativo executor e do órgão judiciário incumbido do seu controle judicial.

E, tratando do poder normativo conferido à Justiça Eleitoral, preleciona Olivar Conegliani (2002, p. 39): “Assim como cabe ao Poder Executivo a regulamentação das leis ordinárias, ao Poder Judiciário cabe, como Poder Executivo das eleições, regulamentar as leis eleitorais".

Diante do exposto, entendemos que o Conselho Nacional de Justiça não tem competência para exercer controle sobre os órgãos da Justiça Eleitoral quanto às matérias que possuem disciplina específica nessa Justiça Especializada pois: a) a Constituição Federal determinou que Lei Complementar estabelece-se a organização e a competência dos Tribunais, dos juízes de direito e das Juntas Eleitorais; b) o Código Eleitoral fixa essas competências e, em nenhum momento, confere alguma ao Conselho Nacional de Justiça; c) a "jurisdição", no âmbito eleitoral, não consiste apenas em aplicar a lei e decidir um caso concreto e controvertido, mas compreende, também, funções adminstrativas e normativas; d) as especificidades da matéria eleitoral e seu escopo maior - a efetivação da Democracia - não recomendam que mais de um órgão de sobreposição a regulamente, sobretudo quando um deles - o CNJ - não tem a experiência acumulada ao longo de anos de administração de eleições; e, e) qualquer determinação do CNJ relativa a matéria eleitoral dirigida a órgão da Justiça Especializada pode ser modificada pelo Tribunal Superior Eleitoral - competente para expedir instruções para a execução de matéria eleitoral, responder consultas sobre matéria eleitoral e tomar quaisquer outras providências que julgar convenientes à execução da legislação eleitoral (Código Eleitoral, art. 23, IX, XII e XVIII) - e, como visto, não pode o Conselho controlar o TSE, composto e dirigido por Ministros do Supremo Tribunal Federal ${ }^{352}$.

\footnotetext{
${ }^{352}$ Cumpre transcrever trecho da manifestação do Ministro Ricardo Lewandowski sobre a ingerência do CNJ nas atividades específicas da Justiça Eleitoral feita durante os debates para julgamento do referendo da decisão liminar proferida pelo Ministro Marco Aurélio Mello na ADI no 4638, após a prolação do voto do Ministro Dias Toffoli entendendo inaplicável a Resolução CNJ n ${ }^{\circ}$ 135/2011 ao referido ramo do Judiciário: "Vossas Excelências não sabem a dificuldade que tive nas eleições gerais de 2010, com interferência indevida do CNJ no processo eleitoral. Quiseram interferir no pagamento dos mesários, do vale-refeição, dizendo que no Brasil todos só podiam ser, na diária, com "ticket" vale-refeição, inclusive no interior da Amazônia; entre o primeiro e o segundo turno quiseram que nós devolvêssemos os funcionários requisitados e abríssemos concurso em sessenta dias. Isso, quando, deste 1932, a Justiça Eleitoral, por ser sazonal, trabalha com funcionários requisitados e há inúmeros outros exemplos”. O Ministro Lewandowski, no entanto, fez questão de frisar, na ocasião, que a ingerência do CNJ na Justiça Eleitoral não partiu do Presidente do Conselho e Presidente do STF, Ministro Cezar Peluso, mas de outros conselheiros e juízes auxiliares: "Eu queria apenas esclarecer que Vossa Excelência [Ministro Cezar Peluso], na condução do CNJ, jamais interferiu nas eleições e sempre colaborou para que elas corressem da melhor forma possível. As decisões às quais eu me referi foram isoladas, de conselheiros e de juízes auxiliares. Quero fazer esse
} 


\subsection{Casuística: requisição de servidores pelo TRE/RS}

Definido que não compete ao Conselho Nacional de Justiça o controle dos órgãos da Justiça Eleitoral no que tange aos seus assuntos específicos, apresenta-se, neste item, caso que ilustra embate entre o CNJ e TSE relativo ao afirmado.

Primeiro cumpre lembrar, conforme mencionado ${ }^{353}$, que a Resolução CNJ no 88/2009, originalmente, fixou, no âmbito de todo o Poder Judiciário: a) jornada ordinária de trabalho do servidor público do Poder Judiciário; b) número mínimo para destinação dos cargos em comissão para servidores das carreiras judiciárias; e, c) limite para requisição de servidores de órgãos não pertencentes ao Poder Judiciário (art. $3^{\circ}$, caput).

Quanto ao último tema, estabeleceu o art. $3^{\circ}$, caput e $\S 1^{\circ}$, da referida Resolução:

Art. $3^{\circ} \mathrm{O}$ limite de servidores requisitados ou cedidos de órgãos não pertencentes ao Poder Judiciário é de $20 \%$ (vinte por cento) do total do quadro de cada tribunal, salvo se a legislação local ou especial disciplinar a matéria de modo diverso.

$\S 1^{\circ}$ - Os servidores requisitados ou cedidos deverão ser substituídos por servidores do quadro, no prazo máximo de 4 (quatro) anos, na proporção mínima de $20 \%$ (vinte por cento) por ano, até que se atinja o limite previsto no caput deste artigo.

Diante dessa norma, membro do "Movimento Nacional pela Criação de Cargos para a Justiça Eleitoral" apresentou, perante o Conselho Nacional de Justiça, pedido de providências em face do Tribunal Regional Eleitoral do Rio Grande do Sul (TRE/RS). Alegou, em síntese, existir elevado número de servidores cedidos na Justiça Eleitoral Gaúcha, o que compromete a qualidade do serviço prestado e desfalca a estrutura administrativa dos municípios. Argumentou, ainda, que a prática viola o disposto no art. 30, incisos XIII e XIV, do Código Eleitoral ${ }^{354}$, pois não há acúmulo ocasional de serviço e

registro".

${ }^{353}$ Vide item 2.3.3.1.

${ }^{354}$ Art. 30 (Código Eleitoral). Compete, ainda, privativamente, aos Tribunais Regionais:

$[\ldots]$

XIII - autorizar, no Distrito Federal e nas capitais dos Estados, ao seu presidente e, no interior, aos juizes eleitorais, a requisição de funcionários federais, estaduais ou municipais para auxiliarem os escrivães eleitorais, quando o exigir o acúmulo ocasional do serviço; 
afronta o pacto federativo $\left(\mathrm{CF}\right.$, art. $1^{\circ}$, caput, c.c. art. $\left.60, \S 4^{\circ}, \mathrm{I}\right)$, por gerar impactos negativos no orçamento e nos recursos humanos dos entes federativos dos quais os servidores são requisitados, Por fim, aduziu que a requisição desnecessária e ilegal de servidores para atuar no TRE/RS viola os princípios constitucionais da eficiência, da moralidade, da impessoalidade, do concurso público e da dignidade da pessoa humana. Requereu, pois, que o CNJ determinasse a devolução imediata dos servidores requisitados pelo TRE/RS de outros órgãos públicos e a elaboração e implementação de plano estratégico para substituição de todos.

O pleito foi registrado como Pedido de Providências $n^{\circ}$ 0003311-77.2010.2.00.0000 e distribuído ao Conselheiro Jefferson Kravchychyn. Em informações prestadas, o Tribunal Regional Eleitoral Gaúcho afirmou não ter cometido qualquer ilegalidade porque observou os limites para requisição de servidores estabelecidos no art. $2^{\circ}, \S 1^{\circ}$ e art. $3^{\circ}$ da Lei n. ${ }^{\circ}$ 6.999, de 7 de junho de $1982^{355}$.

O Conselheiro Jefferson Kravchychyn, por decisão monocrática proferida em 6 de agosto de 2010, julgou procedente o pedido formulado e determinou que o Tribunal Regional Eleitoral do Estado do Rio Grande do Sul, divulgasse, no prazo de 30 (trinta) dias, plano de trabalho para substituição dos servidores cedidos/requisitados junto a outros poderes, por servidores efetivos do quadro próprio do judiciário local, até que se alcança-se o limite imposto pelo artigo $3^{\circ}$ da Resolução CNJ no 88/2009.

Afirmou, para justificar sua decisão, que a constante requisição de servidores pelas Cortes Eleitorais "acarreta grave problema no trâmite administrativo desses Tribunais e expõe a falta de quadro próprio em sua esfera" expondo-os e sujeitando-os a proximidade

XIV - requisitar funcionários da União e, ainda, no Distrito Federal e em cada Estado ou Território, funcionários dos respectivos quadros administrativos, no caso de acúmulo ocasional de serviço de suas Secretarias;

${ }^{355}$ Art. $2^{\circ}$ (Lei n ${ }^{\circ}$ 6.999/1982). As requisições para os Cartórios Eleitorais deverão recair em servidor lotado na área de jurisdição do respectivo Juízo Eleitoral, salvo em casos especiais, a critério do Tribunal Superior Eleitoral.

$\S 1^{\circ}$ - As requisições serão feitas pelo prazo de 1 (um) ano, prorrogável, e não excederão a 1 (um) servidor por 10.000 (dez mil) ou fração superior a 5.000 (cinco mil) eleitores inscritos na Zona Eleitoral.

$\S 2^{\circ}$ - Independentemente da proporção prevista no, parágrafo anterior, admitir-se-á a requisição de 1 (um) servidor.

Art. $3^{\circ}$ (Lei $n^{\circ}$ 6.999/1982). No caso de acúmulo ocasional de serviço na Zona Eleitoral e observado o disposto no art. $2^{\circ}$ e seus parágrafos desta Lei, poderão ser requisitados outros servidores pelo prazo máximo e improrrogável de 6 (seis) meses.

$\S 1^{\mathrm{o}}$ - Os limites estabelecidos nos parágrafos do artigo anterior só poderão ser excedidos em casos excepcionais, a juízo do Tribunal Superior Eleitoral.

$\S 2^{\circ}$ - Esgotado o prazo de 6 (seis) meses, o servidor será desligado automaticamente da Justiça Eleitoral, retomando a sua repartição de origem.

$\S 3^{\circ}$ - Na hipótese prevista neste artigo, somente após decorrido 1 (um) ano poderá haver nova requisição do mesmo servidor. 
tamanha com órgãos de outros Poderes, principalmente das administrações públicas municipais, o que dificulta suas independências funcionais e quase sempre "malfazeja à boa prestação da jurisdição eleitoral” (como decidido no PP $\mathrm{n}^{\mathrm{o}}$ 000733403.2009.2.00.0000) $)^{356}$. Disse, também, que as normas jurídicas constantes da Lei $\mathrm{n}^{\mathbf{0}}$ 6.999/1982 invocadas pelo TRE/RS não justificam a existência de servidores requisitados por períodos indeterminados nas zonas eleitorais, para desempenharem serviços atinentes à Justiça Eleitoral de forma continuada, ausente o requisito do acúmulo de serviço, pois sua interpretação sistemática indica que "as requisições devem estar adstritas a uma situação de excepcionalidade, e provisoriedade". Sustentou, ainda, transcrevendo decisão proferida pelo Conselheiro Walter Nunes no julgamento do PP n ${ }^{\circ}$ 0007334-03.2009.2.00.0000, que, apesar de admissível a prorrogação de prazo, pelo Tribunal Superior Eleitoral, na hipótese de requisição de servidor lotado fora da área de jurisdição do respectivo juízo eleitoral (cujo pleito deve ser submetido ao TSE, com justificativa feita pelo Tribunal Regional acerca das necessidades), ante o disposto nas normas previstas no art. $7^{\circ}$, caput e parágrafo único, da Resolução TSE $\mathrm{n}^{\mathrm{o}}$ 20.753, de 07 de dezembro de $2001^{357}$, o mesmo ato

\footnotetext{
${ }^{356}$ Segue a ementa do referido julgado:

PEDIDO DE PROVIDÊNCIAS. SERVIDORES CEDIDOS E REQUISITADOS. JUSTIÇA ELEITORAL. ART. 30, INCISO XII E XIV DO CÓDIGO ELEITORAL. LEI 6.999/82. RESOLUÇÕES DO TSE. TEMPORARIEDADE E EXCEPCIONALIDADE DO VOLUME DE SERVIÇO. LEI N. ${ }^{\circ} 10.842$, DE 2002 E RESOLUÇÃO N. . 21.832, DE 2004, DO TSE. ESTRUTURA MÍNIMA DAS ZONAS ELEITORAIS. RESOLUÇÃO N. ${ }^{\circ} 88$, DE 2009, DO CNJ. APLICABILIDADE A TODO O PODER JUDICIÁRIO. PLANO DE TRABALHO PARA SUBSTITUIÇÃO DOS SERVIDORES REQUISITADOS E CEDIDOS POR SERVIDORES EFETIVOS. PROCEDÊNCIA PARCIAL.

1. A utilização, em caráter permanente, de mão-de-obra cedida e requisitada junto a outros Poderes gera relação de dependência estrutural do Poder Judiciário, quase sempre malfazeja à boa prestação da jurisdição eleitoral, daí por que, para evitar que isso ocorra, a legislação eleitoral especial aplicável ao instituto da requisição de servidores é marcada pela estipulação de prazos para sua duração e pela presença do requisito da excepcionalidade do volume de serviço para sua formalização.

2. No intuito de dar impulso ao processo de consolidação da independência da Justiça Eleitoral em todo o país foram editadas a Lei . $^{\circ} 10.842$, de 2002 e Resolução n. $^{\circ} 21.832$, de 2004, do TSE, a qual instituiu estrutura mínima de pessoal efetivo para o funcionamento das Zonas Eleitorais.

3. O Conselho Nacional de Justiça, por meio da Resolução n. ${ }^{\circ} 88$, de 2009, estabeleceu percentual máximo de servidores cedidos e requisitados em relação ao quadro efetivo de todos os Tribunais do país, não havendo exceção em relação aos Tribunais Regionais Eleitorais, pois a regra estabelecida pelo CNJ não conflita com o disciplinamento dado à matéria pela legislação especial eleitoral.

4. Necessidade de apresentação de Plano de Trabalho para substituição dos servidores cedidos e requisitados por servidores efetivos do próprio Tribunal Regional Eleitoral de Goiás até que se atinja o limite do artigo $3^{\circ}$ da Resolução n. ${ }^{\circ} 88$, de 2009, deste Conselho. Precedentes do CNJ.

5. Procedência parcial. (CNJ - PP 0007334-03.2009.2.00.0000 - Rel. Cons. Walter Nunes - 99a Sessão - j. 24.02.2010).

${ }^{357}$ Artigo $7^{\circ}$ (Resolução TSE nº 20.753/2001). Quando o servidor estiver lotado fora da área de jurisdição do respectivo juízo eleitoral, o pedido deverá ser submetido ao Tribunal Superior Eleitoral, devidamente justificado, pelo Tribunal Regional Eleitoral, nos termos do artigo $8^{\circ}$ desta Resolução (Lei n. 6.999, art. $2^{\circ}$ ). Parágrafo único - O Tribunal Superior Eleitoral, ao deferir o pedido, fixará o prazo da requisição. Esgotado o prazo, o servidor será desligado automaticamente, retornando à sua repartição de origem.
} 
normativo traz, em seu art. $10^{358}$, “a ideia de que as requisições tem prazo certo e determinado de vigência". Asseverou, na sequência, que "a excepcionalidade e o caráter provisório das requisições no âmbito da justiça eleitoral são confirmados pela Lei $\mathrm{n}^{\mathrm{o}}$ 10.842/2004", que criou quadro próprio de servidores para os Tribunais Regionais Eleitorais. Por fim, asseverou que a Resolução CNJ n ${ }^{\circ} 88 / 2009$, em seu art. $3^{\circ}$, caput e $\S$ $1^{\mathrm{o}}$, fixou percentual máximo de servidores requisitados no âmbito de todo o Poder Judiciário e estabeleceu obrigação de redução anual mínima de servidores requisitados pelos Tribunais, até alcance da marca firmada.

Diante da decisão proferida, o Tribunal Regional Eleitoral Gaúcho adotou duas medidas: a) solicitou orientações e providências ao Tribunal Superior Eleitoral; e, b) interpôs recurso administrativo ao Pleno do Conselho Nacional de Justiça.

No pleito endereçado ao Tribunal Superior, o TRE/RS solicitou orientação e providências, uma vez que a decisão do CNJ poderia interferir no bom andamento do processo eleitoral.

O pedido, registrado no TSE como Processo Administrativo $n^{0}$ 253374.2010.6.00.0000, ficou sob a relatoria do Ministro Ricardo Lewandowski e foi apreciado pelo Pleno daquela Corte em 26 de agosto de 2010.

Em seu voto condutor, o Ministro Ricardo Lewandowski salientou que o Conselho Nacional de Justiça não pode se imiscuir na administração da Justiça Eleitoral, pois, ao

Artigo $8^{\circ}$ (Resolução TSE $n^{\circ}$ 20.753/2001). Os pedidos enviados ao Tribunal Superior Eleitoral deverão ser acompanhados, obrigatoriamente:

a) de formulário de requisição de servidor constante do Anexo I, devidamente preenchido, devendo dele constar:

I - justificativa acerca das necessidades enfrentadas pelo cartório eleitoral, bem como a relação entre as atividades desenvolvidas pelo servidor no seu órgão de origem e aquelas a serem desempenhadas no serviço eleitoral;

II - informação sobre o número de eleitores inscritos na respectiva zona eleitoral, sobre o número de funcionários do cartório eleitoral e se este já conta com servidores requisitados e, em caso afirmativo, o respectivo quantitativo;

b) da anuência do órgão cedente.

Parágrafo único - Na hipótese de não haver concordância do órgão cedente, o Tribunal Superior Eleitoral poderá autorizar a requisição, considerando a justificativa apresentada pelo presidente do Tribunal Eleitoral interessado, que deverá especificar a tarefa a ser executada e a notória capacitação daquele servidor em desempenhá-la.

${ }^{358}$ Artigo 10 (Resolução TSE $\mathrm{n}^{\circ}$ 20.753/2001). As requisições serão feitas pelo prazo de um ano, prorrogável, e não excederão a um servidor por dez mil ou fração superior a cinco mil eleitores inscritos na zona eleitoral (Lei n. 6.999, art. $2^{\circ}, \S 1^{\circ}$ ).

$\S 1^{\circ}$ - Independentemente da proporção prevista neste artigo admitir-se-á a requisição de um servidor em cada cartório eleitoral (Lei n. 6.999, art. $2^{\circ}, \S 2^{\circ}$ ).

$\S 2^{\circ}$ - Os limites quantitativos estabelecidos no caput deste artigo somente poderão ser excedidos em casos excepcionais, a juízo do Tribunal Superior Eleitoral, órgão ao qual deverão ser submetidas as solicitações, pelos Tribunais Regionais Eleitorais, devidamente instruídas com as justificativas pertinentes (Lei n. 6.999, art. $\left.3^{\circ}, \S 1^{\circ}\right)$. 
fazê-lo, invade "a competência privativa, exclusiva, que o Poder Constituinte Originário confiou aos órgãos desta Justiça Especializada para dirigir as eleições”.

Também ressaltou:

\begin{abstract}
A missão constitucional confiada à Justiça Eleitoral é a de garantir que a soberania popular se manifeste de forma mais livre e democrática possível. Para isso, o constituinte de 1988 fixou a atribuição exclusiva dessa Justiça para administrar as eleições, sob a direção do TSE, uma Corte eminentemente constitucional que, por essa razão, é presidida e integrada por membros do Supremo Tribunal Federal.
\end{abstract}

Asseverou, pois, que o CNJ não se substitui aos tribunais eleitorais, que detêm autonomia administrativa e financeira, especialmente ao TSE que é composto por três Ministros do Supremo Tribunal Federal e, assim, não possui o Conselho competência administrativa em matéria eleitoral, cuja atribuição é exclusiva da Justiça Especializada. Argumentou, ainda, que a matéria abordada - requisição de servidores pelo TRE/RS - está regulada por legislação especial - Lei nº 6.999/1982 - e é regulamentada pela Resolução TSE $n^{\circ} 23.255 / 2010$, que tem força de lei em sentido material e estabeleceu critérios específicos, diferentes dos genericamente fixados pela Resolução CNJ nº 88/2009, que não pode sobrepô-la. Concluiu propondo à Corte o encaminhamento de ofício ao Presidente CNJ para informar que as requisições no âmbito da Justiça Eleitoral possuem regulamentação própria prevista na Lei no 6.999/1982 e na Resolução $n^{0}$ 23.255/2010, editada pelo Tribunal Superior Eleitoral no exercício de sua competência normativa, cujo regramento afasta o disposto nas Resoluções do $\mathrm{CNJ}$ que cuidam da matéria ${ }^{359}$.

O Pleno do TSE, por votação unânime ${ }^{360}$, autorizou a expedição do ofício ao Presidente do Conselho Nacional de Justiça, nos termos do voto do relator ${ }^{361}$.

\footnotetext{
${ }^{359}$ Cumpre destacar a posição manifestada pelo Ministro Dias Toffoli durante os debates no julgamento do PA n ${ }^{\circ}$ 2533-74.2010.6.00.0000 que sugeriu, para reflexão, estabelecer orientação a todo o Poder Judiciário Eleitoral de "ignorar resolução, orientação ou qualquer determinação vinda do CNJ e o encaminhamento ao Tribunal Superior Eleitoral para as eventuais providências possíveis" e, se for o caso, até de judicializar a questão por meio da impetração de mandado de segurança no Supremo Tribunal Federal, por entender, conforme manifestou-se no julgamento no TSE da Questão de Ordem na Petição $\mathrm{n}^{\circ} 3020$ (3925374.2009.6.00.0000) que o CNJ "não tem competência sobre nenhum órgão de jurisdição do Poder Judiciário Eleitoral".

${ }^{360}$ Conforme extrato de ata do PA $\mathrm{n}^{\circ}$ 2533-74.2010.6.00.0000, participaram do julgamento os Ministros Ricardo Lewandowski (STF), Cármen Lúcia (STF), Dias Toffoli (STF), Aldir Passarinho Junior (STJ), Hamilton Carvalhido (STJ), Marcelo Ribeiro (OAB) e Arnaldo Versiani (OAB).

${ }^{361}$ Segue a ementa do julgado:
} 
Posteriormente, em 22 de setembro de 2010, o Conselho Nacional de Justiça julgou, em Plenário, o recurso administrativo interposto no Pedido de Providências no 0003311 77.2010.2.00.0000.

No referido recurso o Tribunal Regional Eleitoral do Rio Grande do Sul requereu a reconsideração da decisão monocrática proferida pelo Conselheiro Jefferson Kravchychyn porque: a) foi proferida decisão pelo TSE nos autos do PA n ${ }^{\circ}$ 2533-74.2010.6.00.0000, contrária à incidência da Resolução CNJ no 88/2009 à Justiça Eleitoral; b) a matéria já se encontrava já regulada pela Lei $n^{\circ}$ 6.999/1982 e pela Resolução TSE nº 23.255/2010, sendo incompatível a aplicação da referida resolução no âmbito da Justiça Eleitoral; c) seria inviável o cumprimento da determinação para elaboração de plano de trabalho no prazo de trinta dias, haja vista a proximidade das eleições em 2010; d) haveria necessidade de lei ordinária para a criação de cargos no TRE/RS, sendo insuficientes os criados pela Lei n. ${ }^{\circ} 10.842 / 2004$ para o cumprimento de todo o serviço nos cartórios eleitorais, em especial nas épocas de eleição.

O Conselho Nacional de Justiça, por unanimidade ${ }^{362}$, nos termos do voto do relator, deu provimento ao recurso e julgou improcedente o pedido que lhe fora inicialmente endereçado.

Em seu voto condutor, o Conselheiro Jefferson Kravchychyn, ratificou os argumentos que lançara na decisão monocrática proferida, porém, embora tenha enfatizado que o CNJ tem competência para controlar a legalidade de todos os atos administrativos praticados no

PROCESSO ADMINISTRATIVO. REQUISIÇÃO E CESSÃO DE SERVIDORES NO ÂMBITO DA JUSTIÇA ELEITORAL. CONSELHO NACIONAL DE JUSTIÇA. ATUAÇÃO DIRETA PERANTE TRIBUNAL REGIONAL ELEITORAL E INTERFERÊNCIA NA ADMINISTRAÇÃO DAS ELEIÇÕES. IMPOSSIBILIDADE. COMPETÊNCIA EXCLUSIVA DA JUSTIÇA ELEITORAL. PROCESSO RESOLVIDO.

I - A missão constitucional confiada à Justiça Eleitoral é a de garantir que a soberania popular se manifeste da forma mais livre e democrática possível.

II - O Conselho Nacional de Justiça não tem competência para se imiscuir direta ou indiretamente na administração das eleições em virtude da atribuição exclusiva que o Poder Constituinte Originário confiou, privativamente, aos órgãos da Justiça Eleitoral.

III - As matérias que possuem disciplina específica na Justiça Eleitoral não se inserem na competência do CNJ, de modo que não lhe incumbe regulamentá-las nem determinar sua aplicação no âmbito desta Justiça Especializada.

IV - As requisições realizadas no âmbito da Justiça Eleitoral possuem regulamento próprio, consubstanciado na Lei 6.999/1982 e na Resolução 23.255/2010 editada no exercício regular da competência normativa da Justiça Eleitoral.

V - Processo administrativo resolvido.

${ }^{362}$ Estiverem presentes na sessão os Conselheiros Cezar Peluso, Eliana Calmon, Ives Gandra, Milton Nobre, Leomar Barros Amorim, Nelson Tomaz Braga, Paulo Tamburini, Walter Nunes, Morgana Richa, José Adonis Callou de Araújo Sá, Felipe Locke Cavalcanti, Jefferson Luis Kravchychyn, Jorge Hélio Chaves de Oliveira, Marcelo Nobre e Marcelo Neves (conforme certidão de julgamento da $113^{a}$ Sessão Ordinária do $\mathrm{CNJ})$. 
âmbito da Justiça Eleitoral, concluiu que a prudência recomendava que a matéria fosse analisada previamente pelo TSE, ante o complexo universo de disposições e providências direcionadas à gerência do processo eleitoral e tendo em vista que a alteração do quadro de servidores resultaria em "vultoso prejuízo na organização e execução do iminente pleito eleitoral"363.

Nota-se, pois, que o Conselho Nacional de Justiça, apesar de afirmar exercer controle sobre toda a atuação administrativa praticados no terreno da Justiça Eleitoral, inclusive sobre o Tribunal Superior Eleitoral ${ }^{364}$, reconheceu que a especificidade e importância para

\footnotetext{
${ }^{363}$ Segue a ementa do voto:

RECURSO ADMINISTRATIVO EM PEDIDO DE PROVIDÊNCIAS. INCIDÊNCIA DA RESOLUÇÃO $\mathrm{N}^{\circ} 88$ DO CNJ NO ÂMBITO DA JUSTIÇA ELEITORAL. GRADATIVA SUBSTITUIÇÃO DOS SERVIDORES TEMPORÁRIOS, REQUISITADOS E CEDIDOS. ENCAMINHAMENTO AO TRIBUNAL SUPERIOR ELEITORAL PARA PROVIDÊNCIAS. RECURSO CONHECIDO E PROVIDO.
}

- A requisição de servidores pelos Tribunais Regionais Eleitorais é medida temporária e condicionada à existência de excepcional acúmulo do volume de serviços.

- A excepcionalidade e o caráter provisório das requisições no âmbito da justiça eleitoral são confirmados pela Lei n. ${ }^{\circ}$ 10.842/2004, que criou e transformou "cargos e funções nos Quadros de Pessoal dos Tribunais Regionais Eleitorais, destinados às Zonas Eleitorais".

- Mencionado diploma tem por escopo criar quadro próprio de servidores para os TRE's, de modo que os mesmos não precisem se valer de requisições para ter funcionamento adequado. Dessa forma, busca-se findar a deficiência estrutural da Justiça Eleitoral, para que esta possa se ver livre da relação de dependência que tinha em relação aos outros poderes.

- Alinhando-se a esse contexto, o CNJ, em 08 de setembro de 2009, editou a Resolução n. ${ }^{\circ} 88$ com o intuito de fixar percentual máximo de servidores requisitados no âmbito não apenas da Justiça Eleitoral, mas de todo o Poder Judiciário.

- No entanto, embora entenda pela coadunação entre a Resolução n. ${ }^{\circ}$ 88/2009 do CNJ e a legislação especial eleitoral, a prudência recomenda que essa matéria seja analisada previamente pelo Tribunal Superior Eleitoral.

- Há que se ressaltar que não se está afastando a competência do CNJ para controlar a legalidade dos atos administrativos praticados no âmbito eleitoral, em seus diversos órgãos, contudo, o que se sopesa é o complexo universo de disposições e providências direcionadas à gerência do processo eleitoral.

- A organização do pleito eleitoral, que por si só revela exaustivo trabalho do judiciário especializado, somada ao crescente número de demandas, com destaque àquelas que versam acerca de registros de candidaturas, faz inoportuna a tomada de medidas com tamanha repercussão administrativa.

- Reconsidero a posição por mim adotada anteriormente e que norteou a decisão monocrática ora recorrida, por entender em uma reflexão mais apurada que a possível alteração do quadro de servidores no momento presente resultará em vultoso prejuízo na organização e execução do iminente pleito eleitoral.

- Recurso conhecido e provido para julgar improcedente o pedido formulado, determinando que o presente procedimento seja encaminhado, por meio de ofício, ao Tribunal Superior Eleitoral, para que adote as providências que julgar necessárias.

${ }^{364}$ Mais incisiva foi a decisão proferida em 14 de dezembro de 2010 pelo CNJ no Pedido de Providências ${ }^{\circ}$ 0004834-27.2010.2.00.0000, em que se postulou o não pagamento em pecúnia de auxílio-alimentação a mesários escalados para trabalhar nas eleições de 2010, no âmbito do Tribunal Regional Eleitoral do Paraná. O Tribunal Superior Eleitoral, ao ser cientificado do pleito, decidiu, em 17 de agosto de 2010, no Processo Administrativo $\mathrm{n}^{\mathrm{o}}$ 2156- 06.2010.6.00.0000, de relatoria do Min. Ricardo Lewandowski, à unanimidade, pelo encaminhamento de ofício ao CNJ, ressaltando que a matéria discutida seria de competência exclusiva da Justiça Eleitoral. O Conselho, porém, apesar de julgar prejudicado o pedido, ante a realização das eleições, afirmou ter competência, à exceção do STF, para controle administrativo, financeiro e disciplinar sobre o todos os órgãos do Poder Judiciário, inclusive o TSE, consignando não vislumbrar qualquer ilegalidade no ato práticado. Segue a ementa do voto condutor:

PEDIDO DE PROVIDÊNCIAS - TRE-PR - SUBSTITUIÇÃO DO AUXÍLIO-ALIMENTAÇÃO DOS 
a Democracia de assuntos eleitorais recomendava a apreciação do assunto primeiro pelo seu órgão superior ${ }^{365}$.

\subsubsection{Impossibilidade de controle das sentenças normativas trabalhistas}

Apesar de competir ao Conselho Nacional de Justiça o controle dos atos normativos expedidos pelos órgãos do Poder Judiciário ${ }^{366}$, no âmbito da Justiça Trabalhista há atos dessa natureza que são emanados no exercício da função jurisdicional e, portanto, não estão sujeitos ao jugo do Colegiado Administrativo.

Tratam-se das denominadas sentenças normativas proferidas pelo Tribunal Superior do Trabalho e por Tribunais Regionais do Trabalho no julgamento de dissídios coletivos com fundamento nas normas insertas nos $\S \S 2^{\circ}$ e $3^{\circ}$ do art. 114 da Constituição ${ }^{367368}$ e 858

MESÁRIOS POR VALOR EM PECÚNIA - DECISÃO DO TSE - COMPETÊNCIA DO CNJ PARA APRECIAR A LEGALIDADE DO ATO ADMINISTRATIVO DO TRE-PR - PERDA DO OBJETO PELO DECURSO DAS ELEIÇÕES DE 2010.

1. Nos termos do art. 103-B, $\S 4^{\circ}$, da CF e da decisão proferida pelo STF na ADI 3.367 (Rel. Min. Cezar Peluso, DJ 22/09/06), o CNJ tem o controle administrativo, financeiro e disciplinar de todo o Poder Judiciário, à exceção do próprio STF, o qual revê, jurisdicionalmente, as decisões do Conselho. Assim, os atos de gestão administrativa dos Tribunais Superiores, entre eles os do Tribunal Superior Eleitoral e da Justiça Eleitoral, estão naturalmente sujeitos ao controle administrativo do CNJ.

2. Nesse sentido, a determinação de pagamento em pecúnia do auxílio- alimentação aos mesários paranaenses pelo TRE-PR, ao invés do vale-alimentação, ao ser contestada perante o CNJ, não refoge ao seu controle administrativo, não se vislumbrando, na hipótese, ilegalidade no ato, pela razoabilidade das razões aduzidas pelo Tribunal Requerido (dificuldade de aceitação do vale-refeição por muitos estabelecimentos comerciais), a par de restar prejudicado o pedido, em face da realização das eleições de 2010.

Pedido de Providências prejudicado. (CNJ - PP 0004834-27.2010.2.00.0000 - Rel. Cons. Ives Gandra - $118^{\mathrm{a}}$ Sessão - j. 14.12.2010).

${ }^{365}$ Registre que o Supremo Tribunal Federal já decidiu que “[...] cumpre aos tribunais eleitorais preencher os cargos existentes no quadro funcional, fazendo cessar a prática das requisições, de modo a atender as balizas da Lei $\mathrm{n}^{\circ}$ 6.999/82 [...] (MS 25206, Relator(a): Min. MARCO AURÉLIO, Tribunal Pleno, julgado em 09/06/2005, DJ 02-09-2005).

${ }^{366}$ Vide item 2.3.5.2.

${ }^{367} \mathrm{O}$ art. 114 da Constituição Federal foi modificado pela Emenda Constitucional no 45/2004. Antes da alteração constitucional, seu parágrafo $2^{\circ}$ dizia: "Recusando-se qualquer das partes à negociação ou à arbitragem, é facultado aos respectivos sindicatos ajuizar dissídio coletivo, podendo a Justiça do Trabalho estabelecer normas e condições, respeitadas as disposições convencionais e legais mínimas de proteção ao trabalho" (grifo nosso). O poder normativo da Justiça Obreira era extraído da expressão destacada no texto. O referido parágrafo, porém, após a EC n 45/2004, passou a ter a seguinte redação: "Recusando-se qualquer das partes à negociação coletiva ou à arbitragem, é facultado às mesmas, de comum acordo, ajuizar dissídio coletivo de natureza econômica, podendo a Justiça do Trabalho decidir o conflito, respeitadas as disposições mínimas legais de proteção ao trabalho, bem como as convencionadas anteriormente" (grifo nosso). Foi retirada, pois, a expressão do texto constitucional relacionada ao poder normativo da Justiça Trabalhista. Por esse motivo, Amauri Mascaro Nascimento (2011, pp. 432 e 433) passou a afirmar que a "Emenda Constitucional no 45/2004 alterou o poder normativo da Justiça do Trabalho. Manteve o dissídio coletivo econômico desde que proposto de comum acordo entre as partes, mas retirou do Judiciário trabalhista, o poder de criar normas e condições de trabalho, com o que desapareceram da sentença normativa algumas das suas características. O dissídio coletivo econômico, com essa ressalva, foi mantido, mas as suas decisões, a rigor, já não são sentenças normativas, embora possam ser chamadas sentenças coletivas porque 
a 875 da Consolidação das Leis do Trabalho (CLT) (Decreto-lei n ${ }^{\circ} 5.452$, de $1^{\circ}$ de maio de 1943).

Os dissídios coletivos são processo judiciais de competência originária dos órgãos jurisdicionais da Justiça do Trabalho de segunda instância ${ }^{369}$ onde, em procedimento mais simplificado, pois não há instrução probatória, grupos econômicos e profissionais, abstratamente considerados, representados por organizações, discutem conflitos de natureza coletiva ${ }^{370}$. Neles há uma contraposição de interesses que afetam as categorias de

são aplicadas genericamente a uma coletividade de pessoas. Todos os trabalhadores são representados pela entidade sindical, que figura como sujeito do processo; efeito que terá, também, o dissídio coletivo jurídico, mantido pela mesma reforma cuja decisão não é normativa, sob a perspectiva acima assinalada, aproximando-se mais de uma decisão de tipo declaratório, para dirimir dúvidas sobre a interpretação de cláusula de contrato coletivo de trabalho". Luciano Martinez (2012, p. 998), no entanto, pondera: "A despeito de a alteração ter atingido a expressão elementar que sempre esteve relacionada ao poder normativo "estabelecer normas e condições" -, a nova redação do dispositivo deu aos sujeitos coletivos a faculdade de "ajuizar dissídio coletivo de natureza econômica", justamente aquele dissídio que objetiva a criação, alteração ou revisão das normas concernentes às condições gerais de trabalho. Diante do imbróglio, o poder normativo da Justiça do Trabalho permaneceu existente, assim como toda a sistemática que diz respeito à ação coletiva produtora da sentença normativa, sendo essa a posição do TST na medida em que tratou do tema em seu Regimento Interno, publicado em 9-5-2008. O tema aqui em análise tem, portanto, um sistema normativo que inclui não apenas o precitado $\S 2^{\circ}$ do art. 114 da Constituição da República, mas também os arts. 856 a 875 da CLT e, com algumas adaptações, a Lei n. 4.725, de 13 de julho de 1965 (que estabelece normas para o processo dos dissídios coletivos), e a Lei n. 7.783/89 (que trata da greve). Completam o sistema de fontes disciplinadoras o Regimento Interno do TST e o dos TRTs, bem como seus precedentes normativos".

${ }^{368}$ Cumpre ainda registrar que tramitam no Supremo Tribunal Federal diversas ação diretas de inconstitucionalidade (ADIs. $n^{\circ}$ S 3392, 3423, 3431, 3432 e 3520), todas sob a relatoria do Ministro Gilmar Mendes, ainda não julgadas, que questionam a expressão "de comum acordo" prevista na nova redação do art. 114, § $2^{\circ}$, da Constituição Federal impositora, para o ajuizamento do dissídio coletivo de natureza econômica na Justiça Trabalhista, de acordo entre as partes envolvidas em conflito coletivo de trabalho, "condicionando-a ao mútuo consentimento das partes, o que equivale a dizer que o impulso processual é agora bilateral e não unilateral como antes" (NASCIMENTO, 2011, p. 1419). Argumenta-se, principalmente, ofensa ao princípio da razoabilidade, à garantia de livre acesso à Justiça (art. $5^{\circ}$, inciso XXXV) e ao direito fundamental dos trabalhadores ao reconhecimento estatal das convenções e acordos coletivos de trabalho (art. $7^{\circ}$, inciso XXVI).

${ }^{369}$ Luciano Martinez (2012, p. 995) salienta: “a palavra 'dissídio', muitas vezes referida no texto da CLT, significa não mais do que 'divergência', 'dissensão', 'desavença'. Assim, o 'dissídio coletivo' é, em última análise, uma desavença, uma divergência entre os sujeitos coletivos que, em tese, não mais permitiria imaginar a obtenção de uma solução por via amistosa, seja pela negociação coletiva direta, seja pela atuação persuasiva de mediadores, seja pela eleição de árbitros. Parece relevante anotar, também, que, apesar de o exato sentido da palavra 'dissídio' não se relacionar necessariamente com 'ação judicial', essa variável semântica tem sido constantemente encontrada na prática forense. É muito comum ouvir dizer que o sindicato 'ajuizou o dissídio coletivo' em vez de que o sindicato, por conta do dissídio coletivo, 'ajuizou ação coletiva tendente a obter uma sentença que estabeleça novas e melhores condições de trabalho aplicáveis às relações individuais'. Por uma adstrição à linguagem costumeira, até mesmo o legislador constitucional utilizou a imprecisa expressão 'ajuizar dissídio coletivo' no art. 114 da Carta Magna”.

${ }^{370}$ Os dissídios coletivos podem ser de natureza econômica ou de natureza jurídica. O primeiro, também denominado "dissídio de interesse" é "aquele em que predominam as contendas que dizem respeito à instituição de novas e melhores condições de trabalho aplicáveis às relações individuais. Esses dissídios podem ser originários (quando inexistentes ou em vigor normas e condições especiais de trabalho, decretadas em sentença normativa) ou de revisão (quando destinados a reavaliar normas e condições coletivas de trabalho preexistentes, que se hajam tornado injustas ou ineficazes pela modificação das circunstâncias que as ditaram). Contrariamente, o dissídio de natureza jurídica (ou de interpretação) é aquele em que 
empregados e empregadores coletivamente considerados. Busca-se, nos dissídios coletivos, a constituição de sentenças normativas e a extensão ou revisão de regulamentos coletivos existentes, decisões que constituem importante mecanismo de criação, pelos tribunais trabalhistas, de normas e condições de trabalho (NASCIMENTO, 2013, pp. 548 a 550).

Afirma Amauri Mascaro Nascimento (1993, p. 381):

Há semelhanças entre a regulamentação coletiva jurisdicional de que resulta a sentença normativa, e a lei elaborada pelo Poder Legislativo. Ambas as figuras têm a natureza de norma jurídica trabalhista, elaborada para prever hipóteses a serem aplicáveis às relações de trabalho. Porém, a lei é mais geral e a regulamentação coletiva jurisdicional é mais restrita, aplicando-se sobre uma parcela do grupo social. O processo de elaboração da lei desenvolve-se perante o Poder Legislativo, enquanto o processo de elaboração da regulamentação coletiva jurisdicional tramita perante o Poder Judiciário. A iniciativa da elaboração da lei é condicionada ao critério do Estado, ao passo que a iniciativa do processo coletivo é também um poder dos interessados diretos. A lei é de constituição mais lenta, o processo é mais célere. Os efeitos da lei são gerais e os efeitos da sentença normativa são mais restritos.

As sentenças normativas da Justiça do Trabalho, pois, também destoam do clássico conceito de jurisdição, pois não se limitam a apenas aplicar as leis em um concreto conflito de interesses, uma vez que criam normas abstratas para reger certas relações trabalhistas ${ }^{371}$.

Apesar do Conselho Nacional de Justiça, em regra, poder fiscalizar os atos normativos expedidos pelos diversos órgãos do Poder Judiciário, não pode exercer qualquer controle

prevalecem as discussões no tocante à aplicação ou à interpretação de normas preexistentes. Essas normas preexistentes não podem, entretanto, ser de caráter genérico, mas sim fontes criadas especificamente para disciplinar as relações coletivas entre os sujeitos em embate (cláusulas de sentenças normativas, de instrumentos de negociação coletiva, acordos e convenções coletivas, de disposições legais particulares de categoria profissional ou econômica e de atos normativos a estes correlatos)" (MARTINEZ, 2012, p. 995).

${ }^{371} \mathrm{O}$ poder normativo na Justiça Obreira não é ilimitado. O Supremo Tribunal Federal, no julgamento do Recurso Extraordinário n ${ }^{\circ}$ 197.911-9, da relatoria do Ministro Octávio Gallotti, ocorrido em 24 de setembro de 1996, definiu, ao interpretar a norma inserta no art. 114, § $2^{\circ}$ da Carta, em sua redação original, que a Justiça do Trabalho não pode produzir normas ou condições contrárias à Constituição ou à lei. A sentença normativa "é fonte formal de direito objetivo [...], porém, somente suscetível de operar no vazio legislativo, como regra subsidiária ou supletiva subordinada à supremacia da lei”. Por outro lado, o Tribunal Superior do Trabalho, em 19 de novembro de 2003, editou a Súmula 190 que reza: "Ao julgar ou homologar ação coletiva ou acordo nela havido, o Tribunal Superior do Trabalho exerce o poder normativo constitucional, não podendo criar ou homologar condições de trabalho que o Supremo Tribunal Federal julgue iterativamente inconstitucionais". 
sobre as sentenças normativas da Justiça Trabalhista.

Primeiro porque essas sentenças normativas, em regra, atingem grupos econômicos e profissionais que não se sujeitam ao controle do $\mathrm{CNJ}$, órgão de vigilância interna do Poder Judiciário.

Segundo porque, mesmo na hipótese da sentença normativa destinar-se a categorias que estão sujeitas ao crivo do Conselho Nacional de Justiça, falecerá competência ao órgão para exercer qualquer controle sobre ela, pois, ainda que se consubstancie em um ato normativo, foi proferida em processo judicial no exercício da função típica do Judiciário e, portanto, somente pode ser revista através do manejo dos mecanismos processuais cabíveis, por órgão do Poder com competência jurisdicional ${ }^{372}$.

É o caso, por exemplo, de uma decisão normativa exarada para reger litígio coletivo em que são partes, representativas de suas respectivas categorias, sindicato de notários e registradores e sindicato de empregados notariais e registrais ${ }^{373374}$. O Conselho Nacional de Justiça pode, por expressa ressalva constitucional, fiscalizar as serventias extrajudiciais

\footnotetext{
${ }^{372}$ Cabe recurso ordinário com efeito, em regra, apenas devolutivo ao Tribunal Superior do Trabalho das sentenças normativas exaradas pelos Tribunais Regionais do Trabalho, podendo ser concedido efeito suspensivo pelo Presidente do TST (CLT, arts. 702, II, "a", e 899, caput; Lei nº7.701/1988, arts. $7^{\circ}$, caput e $\S$ $6^{\circ}$, e $9^{\circ}$; Lei n ${ }^{\circ} 10.192 / 2001$, art. 14).

${ }^{373}$ Em São Paulo há o SINOREG-SP - Sindicato dos Notários e Registradores do Estado de São Paulo - e o SEANOR - Sindicato dos Escreventes e Auxiliares Notariais e Registrais do Estado de São Paulo.

${ }^{374}$ Conforme anota Alexandre de Moraes (2013a, p. 1559), quanto às causas envolvendo a Administração e seus servidores estatutários, observa-se que, por decisão monocrática proferida em 27 de janeiro de 2005 pelo então Presidente do STF, Ministro Nelson Jobim, na ADI n 3395, foi suspensa "ad referendum, toda e qualquer interpretação dada ao inciso I do art. 114 da CF, na redação dada pela EC 45/2004, que inclua, na competência da Justiça do Trabalho, a '... apreciação ... de causas que ... sejam instauradas entre o Poder Público e seus servidores, a ele vinculados por típica relação de ordem estatutária ou de caráter jurídicoadministrativo". O Plenário do STF, em sessão realizada em 5 de abril de 2006, por maioria, vencido apenas o Ministro Marco Aurélio Mello, referendou a liminar concedida nos termos do voto do relator, Ministro Cezar Peluso. Segue a ementa do julgado:
}

"INCONSTITUCIONALIDADE. Ação direta. Competência. Justiça do Trabalho. Incompetência reconhecida. Causas entre o Poder Público e seus servidores estatutários. Ações que não se reputam oriundas de relação de trabalho. Conceito estrito desta relação. Feitos da competência da Justiça Comum. Interpretação do art. 114, inc. I, da CF, introduzido pela EC 45/2004. Precedentes. Liminar deferida para excluir outra interpretação. O disposto no art. 114, I, da Constituição da República, não abrange as causas instauradas entre o Poder Público e servidor que lhe seja vinculado por relação jurídico-estatutária" (ADI 3395 MC, Relator(a): Min. CEZAR PELUSO, Tribunal Pleno, julgado em 05/04/2006).

Cumpre registrar que, em São Paulo, o Regimento Interno do Tribunal de Justiça (RITJSP) permite a formulação, perante aquela Corte, de "pedido de instauração de dissídio coletivo por greve, envolvendo servidores de vínculos não regidos pela Consolidação das Leis do Trabalho" (art. 239), a ser julgado pelo Órgão Especial do Tribunal de Justiça Bandeirante (art. 241, caput). De duvidosa constitucionalidade, porém, a disposição posta no art. 245 do referido Regimento Interno, que determina, concluído o julgamento, a proclamação de decisão normativa, pois a Constituição Federal não autoriza sua emanação pela Justiça Comum Estadual. 
$\left(\mathrm{CF} \text {, art. 103-B, } \S 4^{\mathrm{o}}, \mathrm{III}\right)^{375}$, mas não poderá imiscuir-se no teor da sentença normativa proferida, por não exercer jurisdição.

Em suma, como as sentenças normativas são emanadas no exercício da função típica do Poder Judiciário e regulam interesses de categorias de empregados e empregadores, não podem ser controladas pelo Conselho Nacional de Justiça.

\subsubsection{Sujeição dos membros do CNJ ao controle do Colegiado}

Defendemos que as vedações previstas na norma inserta no art. 95, parágrafo único, da Constituição Federal alcançam os Conselheiros do CNJ, porque trata-se de órgão do Poder Judiciário e a ratio da disposição é salvaguardar a imparcialidade de seus membros, tendo essa interpretação sido confirmada no julgamento da ADI $n^{\circ} 3367^{376}$.

Pelos mesmos motivos, as garantias estabelecidas aos magistrados na cabeça do referido dispositivo constitucional também se aplicam, no que couber, aos membros do Conselho Administrativo, mesmo àqueles indicados pela Conselho Federal da Ordem dos Advogados do Brasil e pelas Casas Legislativas.

A norma inserta no parágrafo $3^{\circ}$ do art. 11 do Regimento Interno do CNJ expressamente dispõe, em relação aos Conselheiros não integrantes das carreiras da magistratura, que eles "terão os mesmos direitos, prerrogativas, deveres, impedimentos constitucionais e legais, suspeições e incompatibilidades que regem a carreira da magistratura, no que couber, enquanto perdurar o mandato".

A respeito leciona Flávio Pansieri (2013, p. 1437):

Aos conselheiros se aplicam as mesmas regras de prerrogativas, impedimentos, incompatibilidades e suspeições dos magistrados, por todo o período que durar o mandato. Assim são garantias constitucionais dos Conselheiros, desde a posse: inamovibilidade, neste caso conectada à ideia de preservação do juiz natural para os processos administrativos e irredutibilidade de subsídios. Será vedado constitucionalmente aos Conselheiros: i. exercício, ainda que em disponibilidade, de outro cargo ou função, salvo uma de magistério; [...]; ii. receber, a qualquer título ou pretexto, custas ou participação em processo; iii. dedicar-se à atividade

\footnotetext{
${ }^{375}$ Vide item 2.3.4.

${ }^{376}$ Vide item 2.3.1.
} 
político-partidária; iv. receber, a qualquer título ou pretexto, auxílios ou contribuições de pessoas físicas, entidades públicas ou privadas, ressalvadas as exceções previstas em lei; v. exercer a advocacia perante o Conselho, antes de decorridos três anos do afastamento do cargo [...].

Por tudo isso, pode-se afirmar que os Conselheiros do CNJ continuam a ser magistrados (se oriundos das carreiras da Magistratura) e tornam-se magistrados (se provenientes de outras origens) durante o exercício de seus mandatos e, nessa condição, também estão sujeitos ao controle administrativo, financeiro e disciplinar do próprio Colegiado que integram.

Esse controle pode ocorrer em relação a atuação administrativa dos Conselheiros nos diversos feitos submetidos às suas relatorias ${ }^{377}$ e às atividades desenvolvidas nas comissões para as quais hajam sido eleitos ${ }^{378}$, ou à própria pessoa dos Conselheiros pelo não cumprimento de seus deveres funcionais ${ }^{379}$.

Também dirige-se a fiscalização realizada pelo Colegiado ao cumprimento das atribuições do seu Conselheiro Corregedor Nacional de Justiça, por ser Ministro do Superior Tribunal de Justiça, tanto no aspecto administrativo (correção da sua atuação administrativa) ${ }^{380}$, quanto no âmbito disciplinar (cumprimentos dos deveres positivados) $)^{381}$.

\footnotetext{
${ }^{377}$ Os arts. 25 e 26 do RICNJ tratam das atribuições dos Conselheiros relatores no CNJ.

${ }^{378}$ Os arts. 28 e 29 do RICNJ disciplinam as atribuições das Comissões e dos respectivos Presidentes no CNJ.

${ }^{379}$ Além dos Conselheiros estarem sujeitos, naquilo que couber, aos mesmos deveres funcionais dos Magistrados, o Regimento Interno do CNJ prevê, em seu art. 18, deveres específicos a eles afetos:
}

Art. 18 (RICNJ). Os Conselheiros têm os seguintes deveres:

I - participar das sessões plenárias para as quais forem regularmente convocados;

II - despachar, nos prazos legais, os requerimentos ou expedientes que lhes forem dirigidos;

III - desempenhar as funções de Relator nos processos que lhes forem distribuídos;

IV - desempenhar, além das funções próprias do cargo, as que lhes forem delegadas pelo Regimento, pelo Plenário, pelo Presidente ou pelo Corregedor Nacional de Justiça;

$\mathrm{V}$ - guardar sigilo dos seus atos, das suas deliberações e das providências determinadas pelo CNJ, ou pelos seus órgãos, que tenham caráter reservado na forma deste Regimento;

VI - declarar motivadamente os impedimentos, as suspeições ou as incompatibilidades que lhes afetem, comunicando-os de imediato à Presidência.

Parágrafo único. Não são cabíveis impedimentos, suspeições ou incompatibilidades quando se tratar de atos normativos.

${ }^{380} \mathrm{O}$ art. 103-B, $\S 5^{\circ}$, da Constituição Federal e o art. $8^{\circ}$ do RICNJ tratam das atribuições do Corregedor Nacional de Justiça no CNJ (vide item 3.2).

${ }^{381}$ Como magistrado e Conselheiro do CNJ, o Corregedor Nacional de Justiça está sujeito, naquilo que couber, aos mesmos deveres funcionais dos Magistrados e também aos deveres específicos dos integrantes do Colégio Administrativo insertos no art. 18 do RICNJ. 
Quanto ao Presidente do Conselho Nacional de Justiça, porém, por se tratar também do Presidente do Supremo Tribunal Federal, ante o decidido na ADI n ${ }^{\circ} 3367$, o controle realizado pelo Colegiado não é tão amplo.

Tal qual ocorre na hipótese em que Ministro do STF integre o TSE, não é possível separar da mesma pessoa natural os cargos que exerce de Presidente do Supremo Tribunal Federal e, ao mesmo tempo, de Presidente do Conselho Nacional de Justiça.

Logo, o Presidente do CNJ não está sujeito a controle disciplinar pelo Colégio Administrativo que chefia, uma vez que esse órgão não pode exercer vigilância quanto ao cumprimento de deveres funcionais de Ministros do STF.

Entendemos, porém, que a atuação administrativa e financeira do Presidente do CNJ também fica submetida ao crivo do Colegiado que integra.

Conforme exposto $^{382}$, o Conselho Nacional de Justiça é um colegiado e, portanto, suas decisões definitivas devem emanar da reunião de seus membros. O Presidente do CNJ, ainda que seja também Presidente do Supremo, exerce competências delegadas pelo Regimento Interno daquele órgão ${ }^{383}$, que não podem, pois, ser subtraídas da apreciação do Pleno.

É certo que, em tese, pode o Presidente do CNJ ignorar as deliberações do Plenário, deixando de executá-las e fazer executá-las (RICNJ, art. 6º XIV) e, mesmo assim, não estará sujeito ao controle disciplinar do órgão que integra, por também ser Presidente do Supremo Tribunal Federal.

Mas, nesse caso, poderá responder pela prática do crime de responsabilidade previsto na norma inserta no art. 39, 4 e 5, da Lei $\mathrm{n}^{\text {o }} 1.079$, de 10 de abril de $1950^{384}$, porque, ao deixar de observar determinação do Colegiado Administrativo que integra por também ser Presidente do Pretório Excelso e para o qual age por delegação, está a proceder de modo patentemente desidioso no cumprimento dos deveres do seu cargo e de maneira incompatível com a honra, dignidade e decoro de suas funções ${ }^{385}$.

\footnotetext{
${ }^{382}$ Vide item 2.3.2.2.

${ }^{383} \mathrm{O}$ art. $6^{\circ}$ do RICNJ trata das atribuições do Presidente do CNJ.

${ }^{384}$ Art. 39 (Lei n ${ }^{\circ}$ 1.079/1950). São crimes de responsabilidade dos Ministros do Supremo Tribunal Federal: [...]

4 - ser patentemente desidioso no cumprimento dos deveres do cargo;

5 - proceder de modo incompatível com a honra dignidade e decôro de suas funções.

${ }^{385}$ Essa situação não se confunde com a hipótese de descumprimento de determinação do CNJ pelo Presidente do TSE exposto no item 2.3.7.2. Na hipótese mencionada alhures, o Presidente do TSE, também Ministro do STF, não deve responder por crime de responsabilidade porque age como longa manus do Colegiado que integra, composto por ele mesmo e por outros Ministros do STF. Cumpre, pois, o dever de cargo, ou seja, executar as deliberações do TSE, ainda que contrárias a outras emanadas do CNJ.
} 
Em suma, por serem magistrados, os Conselheiros do CNJ estão também sujeitos ao controle de suas atuações administrativas e do cumprimento de seus deveres funcionais pelo Colegiado que integram, com exceção do Presidente do CNJ que, por também ser Presidente do Supremo Tribunal Federal, não se submete ao controle disciplinar do Conselho Nacional de Justiça, mas, caso descumpra as decisões pluripessoais emanadas, poderá responder por crime de responsabilidade.

\subsection{Estudo de norma: Resolução CNJ n ${ }^{0}$ 135/2011, art. $1^{\circ}$ - Injustificado silêncio eloquente}

Para uniformizar as normas relativas ao procedimento administrativo disciplinar aplicável ao magistrados, o Conselho Nacional de Justiça editou as Resoluções $n^{\circ}$ s 30 , de 7 de março de 2007, e 135, de 13 de julho de 2011.

A Resolução CNJ n ${ }^{o}$ 30/2007 não tratou da competência do Conselho Nacional de Justiça para os processos disciplinares contra magistrados e para a aplicação das penalidades previstas em lei. Explicitou apenas que suas regras eram aplicáveis na persecução de infrações administrativas praticadas pelos magistrados que integram a Justiça Federal, a Justiça do Trabalho, a Justiça Eleitoral, a Justiça Militar, a Justiça dos Estados e a do Distrito Federal e Territórios (art. 25), excluindo, portanto, por não integrarem qualquer um desses braços do Judiciário, sua incidência sobre os membros do Supremo Tribunal Federal, órgão de cúpula, e sobre os próprios Conselheiros do CNJ.

Em 5 de julho de 2011, sob a justificativa da necessidade de compatibilizar o regime jurídico disciplinar aplicável à Magistratura, surgido durante a diatura militar, com os princípios democráticos previstos na Carta de 1988, e ante a conveniência de revisar e atualizar os termos da Resolução CNJ nº 30/2007, o Conselheiro Walter Nunues da Silva Júnior, relator do Pedido de Providências $n^{\circ}$ 0002655-23.2010.2.00.0000, apresentou ao Plenário do $\mathrm{CNJ}$ os termos de novo ato normativo para disciplinar a matéria ${ }^{386}$. A proposta foi aprovada por unanimidade ${ }^{387}$, sendo editada a Resolução CNJ n ${ }^{\circ}$ 135/2011.

${ }^{386}$ Segue a ementa do voto:

PEDIDO DE PROVIDÊNCIAS. ATO NORMATIVO. RESOLUÇÃO. PROCEDIMENTO ADMINISTRATIVO DISCIPLINAR. MAGISTRADOS. CONSTITUIÇÃO DE $1988 . \quad$ DEVIDO PROCESSO LEGAL. LOMAN. RELEITURA. MAGISTRATURA. CARÁTER NACIONAL.

1. Ao longo dos 6 (seis) anos de funcionamento do Conselho Nacional de Justiça, uma das maiores dificuldades enfrentadas pelo órgão para o bom desempenho das competências a ele confiadas pelo legislador constituinte derivado tem sido compatibilizar o regime jurídico disciplinar aplicável à magistratura, 
Os dois primeiros dispositivos do referido ato regulamentar apresentam definições gerais aplicáveis a toda a Resolução CNJ n 135/2011, esclarecendo os destinatários dos seus comandos, para, segundo justificou o relator do Pedido de Providências $n^{\circ} 0002655$ 23.2010.2.00.0000, evitar que magistrados sejam processados sem a observância do rito comum definido. $\mathrm{O}$ art. 12 afirma a competência do Conselho Nacional de Justiça em matéria correcional-disciplinar.

Rezam as normas previstas nos arts. $1^{\circ}, 2^{\circ}$ e 12 da Resolução CNJ nº 135/2011:

Art. $1^{\circ}$ Para os efeitos desta Resolução, são magistrados os Juízes Substitutos, os Juízes de Direito e os Desembargadores dos Tribunais de Justiça Estaduais, os Juízes Federais e dos Tribunais Regionais Federais, os Juízes do Trabalho e dos Tribunais Regionais do Trabalho, os Juízes Militares e dos Tribunais Militares, os Juízes Eleitorais e dos Tribunais Regionais Eleitorais, os Ministros do Superior Tribunal de Justiça, os Ministros do Tribunal Superior do Trabalho, os Ministros do Superior Tribunal Militar e os Ministros do Tribunal Superior Eleitoral, exceto aqueles que também integram o Supremo Tribunal Federal.

Art. $2^{\circ}$ Considera-se Tribunal, para os efeitos desta resolução, o Conselho Nacional de Justiça, o Tribunal Pleno ou o Órgão Especial, onde houver, e o Conselho da Justiça Federal, no âmbito da respectiva competência administrativa definida na Constituição e nas leis próprias.

Art. 12. Para os processos administrativos disciplinares e para a aplicação de quaisquer penalidades previstas em lei, é competente o Tribunal a que pertença ou esteja subordinado o Magistrado, sem prejuízo da atuação do Conselho Nacional de Justiça.

concebido sob um regime de exceção que vigorava no país no ano de 1979, com os princípios que norteiam o devido processo legal no contexto da Constituição de 1988.

2. Faz-se necessário adequar as conquistas já alcançadas desde a edição da Resolução no 30, de 2007, deste Conselho, às necessidades e vicissitudes surgidas ao longo dos seus 4 (quatro) anos de aplicação, bem como uniformizar procedimentos cuja gravidade é notória, porquanto colocam em jogo garantias dos juízes, cláusulas pétreas da magistratura, ressaltando-se o caráter nacional do Poder Judiciário, tantas vezes afirmado pelo Supremo Tribunal Federal.

${ }^{387}$ Estiverem presentes na sessão os Conselheiros Cezar Peluso, Eliana Calmon, Ives Gandra, Milton Nobre, Leomar Barros Amorim, Nelson Tomaz Braga, Paulo Tamburini, Walter Nunes, Morgana Richa, José Adonis Callou de Araújo Sá, Felipe Locke Cavalcanti, Jefferson Luis Kravchychyn, Jorge Hélio Chaves de Oliveira, Marcelo Nobre e Marcelo Neves (conforme certidão de julgamento da $130^{\text {a }}$ Sessão Ordinária do CNJ). 
A leitura atenta das referidas normas revela que o Conselho Nacional de Justiça, ao editar a Resolução CNJ no 135/2011 e procurar uniformizar as normas relativas ao procedimento administrativo disciplinar aplicável ao magistrados, reconheceu ter competência concorrente a dos tribunais para exercer o controle do cumprimento dos deveres funcionais de todos os magistrados, exceto dos Ministros do STF, dos Ministros do TSE oriundos do STF e dos próprios Conselheiros do CNJ (pois não mencionados no art. $1^{\mathrm{o}}$ do diploma normativo).

Ressalte-se que, no mês seguinte à publicação do referido ato normativo, a AMB ajuizou, no Supremo Tribunal Federal, a ADI $\mathrm{n}^{\mathrm{o}} 4638$ para questionar a constitucionalidade de toda a Resolução CNJ nº 135/2011 e também, pontualmente, de diversos de seus dispositivos ${ }^{388}$.

Dentre as alegações da $\mathrm{AMB}$, interessa mencionar as seguintes:

a) Inconstitucionalidade de toda a Resolução CNJ nº 135/2011, uma vez que a competência para dispor sobre o processo disciplinar nos tribunais (CF., art. 96, I e II), quanto às penas de censura e advertência, é das próprias cortes e, quanto às demais sanções, do legislador complementar (CF., art. 93, caput, VIII e X);

b) Inconstitucionalidade do art. $2^{\circ}$ da Resolução CNJ $n^{\circ} 135 / 2011$ porque emprestou a denominação de "tribunal" ao Conselho Nacional de Justiça e ao Conselho da Justiça Federal, o que resulta em modificação da natureza normativa dos órgãos, que podem considerar-se habilitados a promover atos típicos da atividade-fim do Poder Judiciário, apesar da Carta da República terlhes conferido apenas atribuição administrativa; e,

c) Inconstitucionalidade do art. 12 da Resolução CNJ no 135/2011 porque estabelece competência "concorrencial" entre o CNJ e os Tribunais para os processos disciplinares contra magistrados, apesar da regra insertas no art. 103B, $\S 4^{\circ}$, III, da Constituição Federal prever competência subsidiária do Colégio Administrativo.

Não foi impugnada, especificamente, a disposição constante do art. $1^{\circ}$ da Resolução CNJ no $135 / 2011$.

\footnotetext{
${ }^{388}$ A Resolução CNJ n ${ }^{\text {o } 30 / 2007 ~ t a m b e ́ m ~ f o i ~ a l v o ~ d e ~ a c ̧ a ̃ o ~ d i r e t a ~ d e ~ i n c o n s t i t u c i o n a l i d a d e ~ m o v i d a ~ n o ~ S T F ~}$ pela Associação Nacional dos Magistrados da Justiça do Trabalho (ANAMATRA) - ADI n 3392. O relator, Ministro Joaquim Barbosa, em 6 de março de 2012, julgou prejudicada referida ação direta ante o advento da Resolução CNJ n ${ }^{\circ}$ 135/2011 e o indeferimento de medida cautelar na ADI n 4638 contra diversos dos seus dispositivos normativos.
} 
A ADI no 4638 foi distribuída ao Ministro Marco Aurélio Mello que, em decisão liminar proferida em 19 de dezembro de 2011, acolheu, das três alegações mencionadas, apenas a última ${ }^{389}$, para conferir à cabeça do artigo 12 da Resolução CNJ no 135/2011 interpretação conforme, de modo a assentar a competência subsidiária do Conselho Nacional de Justiça em âmbito disciplinar ${ }^{390}$.

Porém, no julgamento do referendo da mencionada decisão liminar, concluído em 8 de fevereiro de 2012, o Plenário do STF, por maioria, manteve a competência originária e concorrente do Conselho Nacional de Justiça para investigar magistrados, prevista no artigo 12 da Resolução CNJ no 135/2011 ${ }^{391}$.

Portanto, até ao menos o julgamento definitivo da ADI n 4638 no Supremo Tribunal Federal, de acordo com a Resolução CNJ nº 135/2011, o Conselho Nacional de Justiça tem competência originária e concorrente a dos tribunais para os processos administrativos disciplinares e para a aplicação de penalidades em relação a todos os magistrados ${ }^{392}$, exceto aos Ministros do STF, aos Ministros do TSE provenientes do STF e aos próprios Conselheiros do CNJ.

A exclusão dos Ministros do Supremo e dos Ministros do TSE oriundos do STF revela-se correta, ante o teor da decisão proferida na $\mathrm{ADI} \mathrm{n}^{\circ} 3367$.

\footnotetext{
389 O primeiro argumento mencionado (inconstitucionalidade de toda a Resolução CNJ no 135/2011) não foi acolhido porque, apesar do Ministro Marco Aurélio ter ficado vencido no julgamento da Medida Cautelar na Ação Declaratória de Constitucionalidade ${ }^{\circ}$ 12, da relatoria do Ministro Ayres Britto, (acórdão publicado em $1^{\circ}$ de setembro de 2006), a maioria do Plenário do STF concluiu estar o CNJ dotado de competência para editar atos de caráter geral e abstrato. $\mathrm{O}$ segundo argumento (inconstitucionalidade do art. $2^{\circ}$ da Resolução $\mathrm{CNJ} \mathrm{n}^{\mathrm{o}}$ 135/2011) não foi aceito porque o dispositivo questionado não encerra, relativamente ao Conselho Nacional de Justiça e ao Conselho da Justiça Federal, a qualificação de Tribunal, pois o vocábulo "tribunal" nele contido revela tão somente que as normas da Resolução CNJ no 135/2011 são aplicáveis também aos referidos Conselhos Administrativos. O Pleno do STF, em $1^{\circ}$ de fevereiro de 2012, por maioria, referendou o indeferimento da liminar em relação ao art. $2^{\circ}$ do ato regulamentar, vencidos ps Ministros Cezar Peluso e Luiz Fux que davam, cada qual, interpretação conforme ao dispositivo.

${ }^{390}$ A decisão, por completo, também suspendeu a eficácia do $\S 1^{\circ}$ do art. $3^{\circ}$, do art. $8^{\circ}$, do $\S 2^{\circ}$ do art. $9^{\circ}$, do art. 10, do parágrafo único do art. 12 , do caput do art. 14 e dos respectivos $\S \S 3^{\circ}, 7^{\circ}, 8^{\circ}$ e $9^{\circ}$, do artigo 17 , caput, incisos IV e V, do $\S 3^{\circ}$ do art. 20 , do $\S 1^{\circ}$ do art. 15 e do parágrafo único do artigo 21 , todos da Resolução CNJ $n^{\circ} 135 / 2011$. Ainda, quanto ao $\S 3^{\circ}$ do art. $9^{\circ}$ do mencionado ato normativo, foi suspensa a eficácia da norma apenas quanto à divisão de atribuições, de modo a viabilizar aos tribunais a definição, por meio do regimento interno, dos responsáveis pelo cumprimento das obrigações ali versadas.

${ }^{391}$ Em relação ao art. 12 da Resolução CNJ n ${ }^{\circ}$ 135/2011, negaram referendo à liminar a maioria composta pelos Ministros Gilmar Mendes, Ayres Britto, Joaquim Barbosa, Cármen Lúcia Dias Toffoli e Rosa Weber. Restaram vencidos os Ministros Marco Aurélio (relator), Luiz Fux, Celso de Mello e Cezar Peluso, que referendavam, quanto à regra mencionada, a decisão monocrática. Também ficou vencido o Ministro Ricardo Lewandowski, que deferia a liminar para conferir interpretação conforme ao dispositivo, de modo a assentar que a competência correicional do CNJ é de natureza material ou administrativa comum, nos termos do artigo 23, I, da Constituição Federal, tal como aquela desempenhada pelas corregedorias dos tribunais, cujo exercício depende de decisão motivada apta a afastar a competência disciplinar destes, nas situações anômalas caracterizadas no voto do Ministro Celso de Mello n ${ }^{\circ}$ MS 28.799.
}

${ }^{392}$ Vide item 3.1.5. 
Injustificado, porém, no nosso sentir, o eloquente silêncio ${ }^{393}$ da norma inserta no art.

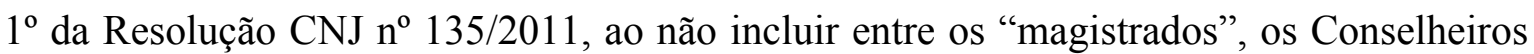
do CNJ, com exceção do seu Presidente (também Presidente do STF) de modo a indicar que o ato regulamentar a eles não se aplica.

Primeiro porque, os Conselheiros também são magistrados durante o exercício de seus mandatos, ainda que não sejam originários dos quadros da Magistratura.

Segundo porque a própria Resolução CNJ nº 135/2011 conferiu ao CNJ competência para processos administrativos disciplinares contra magistrados e, no caso deles se dirigirem contra Conselheiros, ainda que oriundos da Magistratura, a atuação do Conselho Nacional de Justiça deve ser originária, uma vez que voltada à apuração de desvio de conduta de seus próprios membros.

Terceiro porque nenhum outro ato normativo prevê regras procedimentais para aplicação de sanções disciplinares aos Conselheiros do CNJ. O Regimento Interno do Conselho (Resolução CNJ no 67/2009) dispõe apenas que que os Conselheiros perderão os seus mandatos (art. 16): a) em virtude de condenação, pelo Senado Federal, em crime de responsabilidade (inc. I); b) devido a sentença judicial transitada em julgado (inc. II); e, c) em razão de declaração, pelo Plenário, de perda do mandato por invalidez (inc. III), hipótese em que a Presidência do CNJ levará o fato ao conhecimento do Colegiado (art. 13), que instaurará e julgará o processo para verificação do estado de saúde do Conselheiro (art. $\left.4^{\circ}, X\right)$.

Em síntese, pensamos que, apesar do silêncio da norma prevista no seu art. $1^{\circ}$, a Resolução CNJ n ${ }^{0}$ 135/2011 também deve ser aplicada nos processos administrativos disciplinares eventualmente movidos contra os próprios Conselheiros do Conselho Nacional de Justiça, exceto seu Presidente, por também chefiar o Supremo Tribunal Federal.

\subsection{Nosso conceito para o $\mathbf{C N J}$}

Estudados os elementos constitucionais característicos do $\mathrm{CNJ}$ e as fronteiras que ele trazem à sua atuação institucional, é possível conceituá-lo.

Assim, conceituamos o Conselho Nacional de Justiça como órgão de sobreposição do Judiciário, colegiado, incumbido de realizar o controle interno da atuação administrativa e

\footnotetext{
${ }^{393}$ Sobre silêncio eloquente, vide nota 214 do item 2.3.5.1.
} 
financeira dos demais órgãos do mesmo Poder e do cumprimento dos deveres jurídicos dos magistrados, exceto do Supremo Tribunal Federal e dos seus ministros, e do Tribunal Superior Eleitoral, cabendo-lhe também efetuar o controle externo dos órgãos prestadores de serviços notariais e de registro que atuem por delegação do poder público. 


\section{CAPÍTULO 3 - LIMITES DECORRENTES DAS COMPETÊNCIAS CONSTITUCIONAIS ESPECÍFICAS DO CNJ}

Investigados os elementos constitucionais característicos do Conselho Nacional de Justiça, passa-se, neste capítulo, ao estudo de suas competências constitucionais específicas, previstas nos incisos do art. 103-B, $\S 4^{\mathrm{o}}$, da Constituição, extraindo-se delas outras fronteiras de atuação do Colegiado Administrativo. Também serão analisadas as competências singulares específicas do Corregedor Nacional de Justiça estabelecidas no art. 103-B, $\S 5^{\circ}$ e incisos, da Carta Política, e os limites delas derivados.

\subsection{Competências constitucionais específicas do CNJ}

De acordo com a lição de André Ramos Tavares (2012, pp. 190 a 194), as competências constitucionais específicas do CNJ são atribuições instrumentais às atribuições primárias do órgão estabelecidas no parágrafo $4^{\circ}$ do art. 103-B da Constituição Federal: a) exercer o controle da atuação administrativa do Judiciário; b) exercer o controle da atuação financeira desse Poder; e, c) exercer o controle do cumprimento dos deveres funcionais dos magistrados.

Explica o doutrinador (2012, p. 193):

\footnotetext{
Diz-se que uma atribuição é instrumental ou secundária porquanto (i) decorre, a bem da verdade, das atribuições primárias, ou (ii) trata-se, na realidade, de procedimento necessário à efetivação do exercício das atribuições principais.

Em outras palavras, as atribuições secundárias findam por ser, tão apenas,

(i) desdobramentos complementares das atribuições das quais se tratou acima, ou (ii) procedimentos instrumentais que buscam efetivá-las.
}

Preferimos, ante a linha de investigação deste trabalho, tratar essas atribuições instrumentais como competências constitucionais específicas do Conselho Nacional de Justiça, pois, apesar de serem complementos às características primárias do órgão, sem dúvida indicam as tarefas que o Colegiado deve desempenhar e os meios para efetivá-las. Assim, por conseguinte, também revelam outros limites de atuação do CNJ, restringindo aqueles decorrentes das suas características primárias. 
As competências específicas estão previstas nas normas prescritas nos diversos incisos do art. 103-B, $\S 4^{\circ}$, da Constituição, que têm a seguinte redação:

Art. 103-B (CF) [...]

$\S 4^{\circ}$ Compete ao Conselho o controle da atuação administrativa e financeira do Poder Judiciário e do cumprimento dos deveres funcionais dos juízes, cabendo-lhe, além de outras atribuições que lhe forem conferidas pelo Estatuto da Magistratura:

I - zelar pela autonomia do Poder Judiciário e pelo cumprimento do Estatuto da Magistratura, podendo expedir atos regulamentares, no âmbito de sua competência, ou recomendar providências;

II - zelar pela observância do art. 37 e apreciar, de ofício ou mediante provocação, a legalidade dos atos administrativos praticados por membros ou órgãos do Poder Judiciário, podendo desconstituí-los, revêlos ou fixar prazo para que se adotem as providências necessárias ao exato cumprimento da lei, sem prejuízo da competência do Tribunal de Contas da União;

III - receber e conhecer das reclamações contra membros ou órgãos do Poder Judiciário, inclusive contra seus serviços auxiliares, serventias e órgãos prestadores de serviços notariais e de registro que atuem por delegação do poder público ou oficializados, sem prejuízo da competência disciplinar e correicional dos tribunais, podendo avocar processos disciplinares em curso e determinar a remoção, a disponibilidade ou a aposentadoria com subsídios ou proventos proporcionais ao tempo de serviço e aplicar outras sanções administrativas, assegurada ampla defesa;

IV - representar ao Ministério Público, no caso de crime contra a administração pública ou de abuso de autoridade;

$\mathrm{V}$ - rever, de ofício ou mediante provocação, os processos disciplinares de juízes e membros de tribunais julgados há menos de um ano;

VI - elaborar semestralmente relatório estatístico sobre processos e sentenças prolatadas, por unidade da Federação, nos diferentes órgãos do Poder Judiciário;

VII - elaborar relatório anual, propondo as providências que julgar necessárias, sobre a situação do Poder Judiciário no País e as atividades do Conselho, o qual deve integrar mensagem do Presidente do Supremo 
Tribunal Federal a ser remetida ao Congresso Nacional, por ocasião da abertura da sessão legislativa.

A leitura dos dispositivos constitucionais mencionadas revela as seguintes competências específicas do Conselho Nacional de Justiça:

a) Guarda da autonomia do Poder Judiciário (inc. I);

b) Guarda do cumprimento do Estatuto da Magistratura (inc. I);

c) Regulamentar (inc. I);

d) Guarda da observância dos princípios que regem a Administração Pública (inc. II);

e) Controle da legalidade dos atos administrativos praticados por membros ou órgãos do Poder Judiciário (inc. II);

f) Controle disciplinar (inc. III e V);

g) Dever de representação (V); e,

h) Dever de elaboração de relatórios com proposta de providências ao parlamento (incs. VI e VII).

Cumpre, pois, analisar cada uma dessas competências constitucionais do Conselho Nacional de Justiça e delas também extrair os limites de sua atuação.

Por razões didáticas, uma vez que influenciada por todas outras, a competência regulamentar será estudada após cuidarmos das demais.

\subsubsection{Guarda da autonomia do Poder Judiciário}

Segundo dispõe o art. 103-B, $\S 4^{\mathrm{o}}$, I, primeira parte, da Constituição Federal, a inaugural competência específica do Conselho Nacional de Justiça é "zelar pela autonomia do Poder Judiciário".

Não deixa de ser paradoxal a Carta da República estabelecer que um Conselho criado com características de órgão de controle interno do Judiciário tenha, como primeira atribuição específica, a guarda da autonomia do Poder que integra.

Duas perguntas despertam:

Se o controle exercido pelo CNJ dirige-se ao próprio Poder que integra, como pode esse Conselho zelar pela autonomia do Judiciário? 
Por outro lado, como o CNJ pode zelar pela autonomia do Judiciário ao mesmo tempo que tem que exercer o controle da atuação administrativa e financeira dos órgãos desse Poder, bem como do cumprimento dos deveres funcionais dos juízes?

Para responder a essas indagações, necessário se faz rememorar qual a autonomia que a Lei Maior confere ao Poder Judiciário.

As garantias da Magistratura previstas na Constituição Federal revelam o grau de independência do Poder Judiciário em nosso Ordenamento.

Como destaca José Adércio Leite Sampaio (2007, pp. 129, 130, 140 e 141):

Tanto em teoria quanto na prática, a independência do Judiciário tem um aspecto institucional ou orgânico, externo ou coletivo, ao lado de outro dito subjetivo, particular, interno. Seus parâmetros e até mesmo regras com alto grau de definição estão estabelecidos no texto constitucional, sendo, em regra, auto-aplicáveis.

A independência "externa", "objetiva", "institucional", "orgânica" ou "coletiva" refere-se à autonomia do Judiciário como Poder em face das forças exteriores, sejam elas os outros poderes, os partidos políticos, a imprensa ou mesmo a sociedade civil. Sua proteção imediata é o autogoverno judiciário e, mediatamente, a independência do juiz.

[...]

A independência "interna", "decisória", "subjetiva", "funcional" ou "particular" é, como o nome está a dizer, a do juiz em face de seus pares, seja os de mesmo nível, seja os de nível superior, e ainda das entidades ou de outros órgãos do próprio Judiciário, não podendo sofrer pressões ou influências, além de sua consciência e do direito, na hora de decidir ou na condução dos processos sob sua responsabilidade, sujeitando-se apenas ao poder revisional previsto em lei.

Como mencionado no capítulo anterior, a Constituição Federal atribui diversas competências ao Poder Judiciário ${ }^{394}$.

${ }^{394}$ Exercício da jurisdição (CF, art. 29, X; art. 53, $\S 1^{\circ}$, art. 93, IX; art. 96, III; art. 98, I; art. 102, I, II e III;
art. 103-A, $\S 3^{\circ}$; art. 105, I, II e III; art. 108, I e II; art. 109; art. 114, art. 124; e art. 125, caput e $\S \S 4^{\circ}$ e $5^{\circ}$ );
iniciativa para deflagração do processo legislativo (CF, art. 61; art. 93; art. 96, I, "d", e II; e art. 125, $\S \S 1^{\circ}$ e
$3^{\circ}$ ); aplicação de sanções disciplinares (CF, art. 93, VIII e X; e art. 95, I); constituição de Órgão Especial
(CF, art. 93, XI); formação de listas tríplices para preechimento dos lugares reservados ao quinto
constitucional (CF, art. 94); eleição de órgãos diretivos (CF, art. 96, I, "a"); elaboração de regimentos
internos (CF, art. 96, I, "a"); tratamento das competências e funcionamento dos seus órgãos jurisdicionais e
administrativos (CF, art. 96, I, "a"); organização das suas secretarias e serviços auxiliares (CF, art. 96, I, 
Assim, quanto à independência do Judiciário em seu aspecto institucional, verifica-se que os tribunais gozam de autonomia administrativa, orçamentária e financeira $(\mathrm{CF}$, art. 99) pois: a) elegem seus órgãos diretivos (CF, art. 96, I, “a”); b) elaboram seus regimentos internos (CF, art. 96, I, "a"); c) tratam das competências e do funcionamento dos seus órgãos jurisdicionais e administrativos (CF, art. 96, I, “a”); d) organizam suas secretarias e serviços auxiliares (CF, art. 96, I, "b”); e) exercem atividade correicional (CF, art. 96, I, “b”); f) proveem os cargos de juiz de carreira e os necessários à administração da Justiça (CF, art. 96, I, "c" e "e"); g) tem iniciativa para deflagração do processo legislativo sobre os assuntos do seu próprio governo (CF, art. 61; art. 93; art. 96, I, “d”, e II; e art. 125, $\S 1^{\circ}$ e $3^{\circ}$ ); h) concedem licenças, férias e outros afastamentos (CF, art. 96, I, “f”); e, i) elaboram suas propostas orçamentárias $\left(\mathrm{CF}\right.$, art. $\left.99, \S 1^{\circ}\right)$.

Interessante observar que o próprio Conselho Nacional de Justiça não goza da mesma autonomia institucional atribuída ao tribunais pois: a) não elege seus órgãos diretivos, uma vez que a Constituição Federal determina que o chefia o Presidente do Supremo Tribunal Federal e, nas suas ausências e impedimentos, o Vice-Presidente do Supremo Tribunal Federal (CF, art. 103-B, $\left.\S 1^{\circ}\right)$ e nele exerce a função de Corregedor Nacional de Justiça o Ministro do Superior Tribunal de Justiça que o integrar (CF, art. 103-B, $\S 5^{\circ}$ ); e b) a disciplina de seu funcionamento e as atribuições de seu Corregedor Nacional de Justiça, além daquelas estabelecidas na Lei Maior, devem ser reguladas pelo Estatuto da Magistratura, podendo o Colegiado fixá-las somente até o advento da referida lei complementar de iniciativa do Supremo Tribunal Federal (CF, art. 93, caput; EC ${ }^{\circ}$ $45 / 2004$, art. $\left.5^{\mathrm{o}}, \S 2^{\mathrm{o}}\right)^{395}$.

No que se refere-se à independência do Judiciário em seu aspecto interno, ou seja, a independência dos magistrados na exercício da atividade juridiscional, como já pontuado $^{396}$, ela decorre da necessidade dos atores essenciais do Judiciário não estarem

\footnotetext{
"b"); exercício de atividade correicional (CF, art. 96, I, "b"); provimento dos cargos de juiz de carreira (CF, art. 96, I, "c"); provimento dos cargos necessários à administração da Justiça (CF, art. 96, I, "e"); concessão de licenças, férias e outros afastamentos (CF, art. 96, I, "f"); exercício de autonomia administrativa e financeira (CF, 99); elaboração de propostas orçamentárias (CF, art. 99); administração das eleições (CF, art. $17, \S 2^{\circ}$; e art. 121); indicação de membros para compor o Conselho Nacional de Justiça e o Conselho Nacional do Ministério Público (CF, art. 103-B; e art. 130-A, IV); criação de câmaras regionais e varas especializadas (CF, art. 125, § $6^{\circ}$; e art. 126); instalação de justiça intinerante (CF, art. 125, $\left.\S 7^{\circ}\right)$.

${ }^{395}$ Paulo José Leonesi Maluf, em Dissertação de Mestrado apresentada à Universidade de São Paulo, (2013, p. 162) destaca que o CNJ sofre forte influência do STF, pois é presidido pelo mesmo Ministro Presidente da Suprema Corte brasileira, que ainda indica dois de seus Conselheiros. Ademais (como será visto no Capítulo 4), decide "em única e última instância, sobre a conformidade das decisões do Conselho com a Constituição"

${ }^{396}$ Vide item 2.3.6.
} 
subordinados aos outros Poderes, a fim de que o próprio Poder que integram deles seja independente, e se revelam nas normas constitucionais que consubstanciam três garantias de liberdade aos magistrados (vitaliciedade, inamovibilidade e irredutibilidade de subsídios - art. 95, I a III), além de vedações para resguardo de sua imparcialidade (art. 95, parágrafo único, I a V).

O Conselho Nacional de Justiça zela por essas dimensões da independência do Poder Judiciário quando, como afirma José Adércio Leite Sampaio (2007, pp. 274 e 275), adota “o papel de gestor estratégico dos recursos administrativos, humanos, logísticos e financeiros do Judiciário", promovendo estudos e pesquisas para diagnosticar as deficiências da máquina judiciária e estabelecer, com a participação dos demais entes da estrutura do Poder, um gerenciamento profissionalizado dos recursos disponíveis ${ }^{397}$.

Também, como ressalta o referido autor (2007, pp. 276 e 277), o CNJ tutela a autonomia do Poder Judiciário quando, enquanto órgão de poder, adota "as medidas necessárias contra as ameaças e as violações advindas dos outros Poderes e, com certas cautelas, de setores da sociedade, em defesa da soberania judiciária”.

Afirmou o Ministro Cezar Peluso em seu voto na Ação Declaratória de Inconstitucionalidade $\mathrm{n}^{\mathrm{o}} 3367$ :

A bem da verdade, mais que encargo de controle, o Conselho recebeu aí
uma alta função política de aprimoramento do autogoverno do Judiciário,
cujas estruturas burocráticas dispersas inviabilizam o esboço de uma
estratégia político-institucional de âmbito nacional. São antigos os
anseios da sociedade pela instituição de um órgão superior, capaz de
formular diagnósticos, tecer críticas construtivas e elaborar programas
que, nos limites de suas responsabilidades constitucionais, dêem
respostas dinâmicas e eficazes aos múltiplos problemas comuns em que
se desdobra a crise do Poder. [...] A instituição do Conselho, que, sob a
rubrica das atribuições inerentes ao poder de controle da atuação
administrativa e financeira do Judiciário (art. 103-B, § $4^{\circ}$ ), assume o
dever jurídico de diagnosticar problemas, planejar políticas e formular
projetos, com vistas ao aprimoramento da organização judiciária e da
prestação jurisdicional, em todos os níveis, como exigência da própria

${ }^{397}$ Afirma José Adércio Leite Sampaio (2007, p. 275): “É, exatamente, a transformação em centro de gestão de excelência, sem trocadilho, o ponto nevrálgico do $\mathrm{CNJ}$, por meio da racionalização das estruturas e do funcionamento dos serviços auxiliares, gerenciado por objetivos e metas, definindo diretrizes da política administrativa e planos de desenvolvimento dos recursos humanos, físicos e logísticos". 
feição difusa da estrutura do Poder nas teias do pacto federativo. [...] Somente um órgão de dimensão nacional e de competências centralizadas pode, sob tais aspectos, responder aos desafios da modernidadee às deficiências oriundas de visões e práticas fragmetárias na administração do Poder.

Salienta Deocleciano (2010, p. 70), que, embora o CNJ não disponha de "poder político autônomo e, muito menos, de poder jurisdicional, restando-lhe autonomias administrativas e fiscalizatórias", esse fato "não o descredencia como instrumento fundamental aos rumos da independência funcional dos juízes e da dignidade da justiça. Como órgão interno do Judiciário, o CNJ fomenta a função política desse Poder”.

No cumprimento das suas missões, porém, o Conselho Nacional de Justiça não pode descurar que ele mesmo deve respeitar a autonomia dos órgãos e dos membros do Poder Judiciário.

Em outras palavras, não pode o CNJ, para defender a independência do Judiciário, desconsiderar as garantias conferidas pela Constituição aos órgãos e aos membros do Poder que integra.

A respeito das duas dimensões da autonomia do Poder Judiciário, institucional e interna, cotejadas com as missões conferidas pelo Constituinte Reformador ao Conselho Nacional de Justiça, defendeu-se que ${ }^{398}$ : a) ao CNJ cabe, em regra, controlar as ações dos demais órgãos do Poder Judiciário, não podendo agir em substituição aos demais órgãos do Poder Judiciário, salvo se autorizado constitucionalmente e, mesmo assim, sem poder aniquilar o campo de "atividades" garantido àqueles órgãos, exceto se essa possibilidade também estiver contemplada na Carta Política; b) não compete ao Colegiado Administrativo rever decisões judiciais ou analisar incorreções na apreciação de provas em meios judicialiformes; e, c) também não pode o Conselho, a pretexto de exercer o controle do cumprimento dos deveres funcionais dos juízes, pressionar ou direcionar suas decisões.

Pode-se acrescentar ainda que, na defesa da independência do Judiciário e no exercício regular do controle da atuação administrativa e financeira dos órgãos desse Poder, como compete ao Conselho Nacional de Justiça zelar pelas suas autônomias e uma vez que as competências desses órgãos também estão previstas na Constituição da República, deve o Colegiado Administrativo preocupar-se em não deliberar de modo a que suas decisões prevaleçam sobre aquelas que competiam originalmente aos tribunais

${ }^{398}$ Vide itens $2.3 .3,2.3 .5 .1$ e 2.3.6. 
estabelecer, subtraindo-lhes qualquer espaço da competência constitucional que lhes foi conferida.

A adoção, pois, de medidas estratégicas, metas, programas e políticas administrativas pelo Conselho Nacional de Justiça deve, pois, ser precedida da oitiva dos demais órgãos do Poder Judiciário, pois podem implicar em alterações nas competências e no funcionamento dos órgãos jurisdicionais e administrativos dos tribunais (CF, art. 96, I, “a”), ou na organização de suas secretarias e serviços auxiliares (CF, art. 96, I, "b”), com eventual necessidade de alterações legislativas cuja iniciativa compete a esses órgãos (CF, art. 61; art. 93; art. 96, I, “d”, e II; e art. 125, $\S \S 1^{\circ}$ e $3^{\circ}$ ) e repercussão nas suas propostas orçamentárias (CF, art. 99, $\left.\S 1^{\circ}\right)$.

O controle da atuação administrativa e financeira realizado pelo Conselho, de outra banda, não pode tornar letra morta as normas constitucionais que garantem o autogoverno nos tribunais, esmiuçando-se, sem justificativa, mesmo na hipótese de correção de atos praticados, em particularidades que engessem a atuação dos órgãos atomizados do Poder Judiciário.

\subsubsection{Estudo de norma: RICNJ, art. $4^{\circ}$ e $8^{\circ}$ - Provisoriedade da autodisciplina de funcionamento e de atribuições do Ministro-Corregedor}

Como afirmado, apesar do Conselho Nacional de Justiça dever zelar pela autonomia do Poder Judiciário, o próprio Colegiado não foi contemplado com as mesmas garantias institucionais conferidas aos tribunais, pois não elege seus órgãos de direção e ainda restou estabelecido na norma prevista no art. $5^{\circ}, \S 2^{\circ}$, da $E C n^{\circ} 45 / 2004$ que o órgão, pode, mediante resolução, disciplinar seu funcionamento e definir as atribuições do Corregedor Nacional de Justiça, mas somente até a entrada em vigor do Estatuto da Magistratura, lei complementar de iniciativa do Supremo Tribunal Federal.

Com efeito, reza a norma mencionada:

Art. $5^{\circ}\left(\mathrm{EC} \mathrm{n}^{\mathrm{o}} 45 / 2004\right)[\ldots]$

$\S 2^{\circ}$ Até que entre em vigor o Estatuto da Magistratura, o Conselho Nacional de Justiça, mediante resolução, disciplinará seu funcionamento e definirá as atribuições do Ministro-Corregedor. 
$\mathrm{O}$ art. $4^{\mathrm{o}}$ do Regimento Interno do Conselho Nacional de Justiça ${ }^{399}$ fixou, em trinta e seis incisos, as competências do seu Plenário e o art. $8^{\circ}$ do mesmo ato normativo ${ }^{400}$ estabeleceu, em vinte e um incisos, as diversas atribuições do Corregedor Nacional de Justiça.

Prescrevem as cabeças dos referidos dispositivos regimentais:

Art. $4^{\circ}$ (RICNJ) Ao Plenário do CNJ compete o controle da atuação administrativa e financeira do Poder Judiciário e do cumprimento dos deveres funcionais dos magistrados, cabendo-lhe, além de outras atribuições que lhe forem conferidas pelo Estatuto da Magistratura, o seguinte:

Art. $8^{\circ}$ (RICNJ) Compete ao Corregedor Nacional de Justiça, além de outras atribuições que the forem conferidas pelo Estatuto da Magistratura:

A leitura das referidas disposições regimentais revela que seus redações estão eivadas de inconstitucionalidade, porque, ao utilizarem a expressão "além de outras atribuições que lhe forem conferidas pelo Estatuto da Magistratura" induzem o intérprete a crer que as e atribuições definidas nos seus respectivos incisos ao Plenário do CNJ e ao Corregedor Nacional de Justiça permanecerão vigentes mesmo após a edição da lei complementar prevista no art. 93, caput, da Constituição Federal, sem prejuízo de outras que, porventura, venham a ser por esta estabelecidas. No entanto, a regra prevista no art. $5^{\circ}$ da Emenda Constitucional $n^{\circ} 45 / 2004$ impõe, como limite temporal à autodisciplina de funcionamento do CNJ e das atribuições do Corregedor Nacional de Justiça por resolução do próprio Colegiado, a entrada em vigor do Estatuto da Magistratura.

Em tese, o Estatuto da Magistratura, lei complementar de iniciativa do STF, repita-se, pode alterar a regulamentação de funcionamento do CNJ e modificar as atribuições estabelecidas no Regimento Interno do órgão ao seu Plenário e ao Ministro-Corregedor, respeitadas apenas as prescrições previstas no art. 103-B da Carta Política, tornando letra

\footnotetext{
${ }^{399}$ Art. $4^{\circ}$ (RICNJ) Ao Plenário do CNJ compete o controle da atuação administrativa e financeira do Poder Judiciário e do cumprimento dos deveres funcionais dos magistrados, cabendo-lhe, além de outras atribuições que lhe forem conferidas pelo Estatuto da Magistratura, o seguinte:

${ }^{400}$ Art. $8^{\circ}$ (RICNJ) Compete ao Corregedor Nacional de Justiça, além de outras atribuições que lhe forem conferidas pelo Estatuto da Magistratura:
} 
morta diversas disposições contidas nos incisos dos arts. $4^{\circ}$ e $8^{\circ}$ do RICNJ.

\subsubsection{Estudo de norma: Resolução CNJ n⿳ $185 / 2013$ - Sistema único de processo judicial eletrônico}

Em 18 de dezembro de 2013, o Plenário do Conselho Nacional de Justiça aprovou a edição da Resolução n 185, para instituir “o Sistema Processo Judicial Eletrônico - PJe como sistema de processamento de informações e prática de atos processuais e estabelece os parâmetros para sua implementação e funcionamento" ${ }^{401}$.

Referido ato normativo determinou que os Tribunais constituíssem Comitê Gestor e adotassem as providências para a implantação gradativa do $\mathrm{PJe}^{402}$ a partir do ano de 2014 (no mínimo, dez por cento dos órgãos julgadores de primeiro e segundo graus), tornando-a integral até o ano de 2018 (art. 34) ${ }^{403}$.

Também proibiu, a partir da sua vigência, admitindo relativização das regras pelo Plenário do CNJ, a criação, desenvolvimento, contratação ou implantação de sistema ou módulo de processo judicial eletrônico diverso do PJe, ressalvadas as manutenções corretivas e evolutivas necessárias ao funcionamento de sistemas já implantados ou ao

401 Conforme ementa da Resolução CNJ no 185/2013 (disponível em <http://www.cnj.jus.br/atosnormativos?documento=1933>. Acesso em 28 de setembro de 2014). A referida resolução foi aprovada, por unanimidade, nos termos do voto apresentado pelo Conselheiro Rubens Curado Silveira no procedimento registrado como Ato Administrativo $\mathrm{n}^{\circ}$ 0004441-97.2013.2.00.000. Foram, porém, apresentadas algumas ressalvas pelos Conselheiros Gisela Gondin, Paulo Teixeira, Emmanoel Campelo, Fabiano Silveira e Maria Cristina Peduzzi. Estiverem presentes na sessão os Conselheiros Joaquim Barbosa, Francisco Falcão, Maria Cristina Peduzzi, Ana Maria Duarte Amarante Brito, Guilherme Calmon, Flavio Sirangelo, Deborah Ciocci, Saulo Casali Bahia, Rubens Curado Silveira, Luiza Frischeisen, Gilberto Martins, Paulo Teixeira, Gisela Gondin Ramos, Emmanoel Campelo e Fabiano Silveira (conforme certidão de julgamento da $181^{\text {a }}$ Sessão Ordinária do $\mathrm{CNJ})$.

${ }^{402}$ O PJe foi criado pela empresa Infox Tecnologia da Informação Ltda. (conforme notícia disponível em $<$ http://www.infox.com.br/ler_noticia.wsp?tmp.tipo_noticia=no\&tmp.noticia_cod=8>. Acesso em 29 de setembro de 2014).

${ }^{403}$ Art. 34 (Resolução CNJ no 185/2013). As Presidências dos Tribunais devem constituir Comitê Gestor e adotar as providências necessárias à implantação do PJe, conforme plano e cronograma a serem previamente aprovados pela Presidência do CNJ, ouvido o Comitê Gestor Nacional.

$\S 1^{\circ}$ Os Tribunais encaminharão à Presidência do CNJ e, quando houver, à do Conselho de seu segmento do Poder Judiciário, no prazo de 120 (cento e vinte) dias, cópias do ato constitutivo do Comitê Gestor, do plano e do cronograma de implantação do PJe.

$\S 2^{\circ} \mathrm{O}$ plano deve descrever as ações e contemplar informações sobre os requisitos necessários à implantação, como infraestrutura de tecnologia da informação e capacitação de usuários, observado modelo a ser disponibilizado pelo $\mathrm{CNJ}$.

$\S 3^{\circ} \mathrm{O}$ cronograma deve relacionar os órgãos julgadores de $1^{\circ}$ e $2^{\circ}$ Graus em que o PJe será gradualmente implantado, a contar do ano de 2014, de modo a atingir 100\% (cem por cento) nos anos de 2016, 2017 ou 2018, a depender do porte do Tribunal no relatório Justiça em Números (pequeno, médio ou grande porte, respectivamente).

$\S 4^{\circ}$ No ano de 2014, o PJe deve ser implantado em, no mínimo, 10\% (dez por cento) dos órgãos julgadores de $1^{\mathrm{a}}$ e $2^{\mathrm{a}}$ Graus. 
cumprimento de determinações do CNJ, sem prejuízo da implantação gradativa do PJe $(\text { arts. } 44 \text { e } 45)^{404}$.

Em suma, a Resolução CNJ n 185/2013 impôs aos órgãos do Poder Judiciário a implantação integral do sistema eletrônico denominado "Processo Judicial Eletrônico PJe" para processamento das ações judiciais até o ano de 2018.

Ocorre que, no nosso sentir, apesar da inegável intenção de racionalizar a utilização de recursos orçamentários e uniformizar o sistema eletrônico para processos judiciais em todo o Brasil, a Resolução CNJ no 185/2013 terminou por extrapolar os limites constitucionais de atuação do Conselho Nacional de Justiça, pois atentou contra a autonomia dos tribunais que o próprio Conselho deveria zelar.

Primeiro porque determina às cortes a constituição de "Comitê Gestor" para adotar as providências necessárias à implantação do PJe, o que representa indevida ingerência do CNJ na organização dos órgãos administrativos, secretarias e serviços auxiliares dos tribunais, pois impõe a designação de magistrados e servidores para tratar desse específico assunto administrativo, com violação às regras insertas nos arts. 96, I, "a" e "b", da Constituição Federal ${ }^{405}$.

Segundo porque impõe aos tribunais a adoção exclusiva do PJe e sua implantação integral até o ano de 2018, com a proibição de contratação de sistema diverso de processo judicial eletrônico e a exclusão gradual de outros sistemas atualmente porventura utilizados, o que, além de infringir as regras constitucionais já mencionadas ${ }^{406}$, também

\footnotetext{
${ }^{404}$ Art. 44 (Resolução CNJ no 185/2013). A partir da vigência desta Resolução é vedada a criação, desenvolvimento, contratação ou implantação de sistema ou módulo de processo judicial eletrônico diverso do PJe, ressalvadas a hipótese do art. 45 e as manutenções corretivas e evolutivas necessárias ao funcionamento dos sistemas já implantados ou ao cumprimento de determinações do CNJ.

Parágrafo único. A possibilidade de contratação das manutenções corretivas e evolutivas referidas no caput deste artigo não prejudica o integral cumprimento do disposto no art. 34 desta Resolução.

Art. 45 (Resolução CNJ no 185/2013). O Plenário do CNJ pode, a requerimento do Tribunal, relativizar as regras previstas nos arts. 34 e 44 desta Resolução quando entender justificado pelas circunstâncias ou especificidades locais.

${ }^{405}$ A palavra "comitê", derivada do francês "comité", significa a reunião de um número relativamente pequeno de pessoas, destacadas de um corpo maior, responsável por tratar de assunto específico. Segue a primeira definição de "comité" constante do "dictionnaire Littré" (disponível em $<$ http://www.littre.org/definition/comité>. Acesso em 28 de setembro de 2014): Réunion d'un nombre relativement restreint de personnes, ou, plus spécialement, de membres d'un corps plus nombreux, d'une assemblée, laquelle réunion est chargée de s'occuper d'affaires déterminées, de donner un avis, de préparer une délibération.

${ }^{406}$ Cumpre lembrar que a Lei $n^{\circ} 11.419$, de 19 de dezembro de 2006, que trata do processo judicial eletrônico, apenas facultou sua utilização pelos órgão do Poder Judiciário, consoante dispõe a norma inserta em seu art. $8^{\circ}$, caput, a seguir reproduzida:
} 
representa interferência nos orçamentos das cortes, além de implicar em desperdício dos recursos financeiros até então utilizados na implantação desses outros sistemas ${ }^{407}$, em violação ao princípio da eficiência administrativa previsto no caput do art. 37 da Carta da República, que também deve ser tutelado pelo Conselho Nacional de Justiça (CF, art. 103$\left.\mathrm{B}, \S 4^{\mathrm{o}}, \mathrm{II}\right)^{408409}$.

Como o desenvolvimento de sistemas de informatização de tramitação de processos judiciais está necessariamente vinculado às peculiaridades de cada órgão do Judiciário e à forma como se estruturam e dispõem, privativamente, quanto à competência e ao funcionamento dos seus órgãos juridicionais e quanto à organização das suas secretarias e serviços auxiliares, não poderia o Conselho Nacional de Justiça impor aos tribunais a adoção de sistema eletrônico único, que, inclusive, implica na criação de uma de mercado $^{410}$.

No caso, a solução para uniformização do sistema eletrônico processamento das ações judiciais em todo o Brasil sem violação da autonomia dos tribunais já havia sido

Art. $8^{\circ}$ (Lei n $\left.{ }^{\circ} 11.419 / 2006\right)$ Os órgãos do Poder Judiciário poderão desenvolver sistemas eletrônicos de processamento de ações judiciais por meio de autos total ou parcialmente digitais, utilizando, preferencialmente, a rede mundial de computadores e acesso por meio de redes internas e externas.

${ }^{407}$ É o caso do Tribunal de Justiça de São Paulo que investiu, desde 2006, mais de trezentos milhões de reais para implantação do sistema de processo digital SAJ PG5 (Sistema de Automação da Justiça desevolvido pela empresa catarinense Softplan), tendo seu Presidente, ainda antes da edição da Resolução CNJ $n^{\circ}$ 185/2013), sugerido, em ofício encaminhado ao CNJ em 2 de outubro de 2013, a alteração da redação do art. 44 do referido ato normativo, para possibilitar a manutenção e a realização de investimentos nos sistemas adotados pelos tribunais antes do PJe, surgido somente em 2009, sob pena de "gravíssimos prejuízos ao erário e ao interesse público", uma vez que a migração de sistema "seria um processo caro, demorado e traumático, além de contraditório com outros esforços do próprio CNJ" (disponível em $<$ http://s.conjur.com.br/dl/oficio-tj-sp-cnj-processo-eletronico.pdf $>$. Acesso em 29 de setembro de 2014).

${ }^{408}$ Como afirma Diogenes Gasparini (2011, p. 76), o princípio da eficiência é tratado pelos italianos como o “dever de boa administração" e, assim, "impõe à Administração Pública direta e indireta a obrigação de realizar suas atribuições com rapidez, perfeição e rendimento, além por certo, de observar outras regras, a exemplo do princípio da legalidade" . De sua parte, Marçal Justen Filho (2014, pp. 221 a 223), esclarece que a Administração deve otimizar os recursos públicos, evitando o desperdício e a falha. "É necessário obter o máximo de resultados com a menor quantidade possível de desembolsos".

${ }^{409}$ Vide item 3.1.3.

${ }^{410}$ Em 10 de fevereiro de 2014, a FENAINFO - Federação das Empresas de Informática impetrou perante o Supremo Tribunal Federal o Mandado de Segurança no 32767 para impugnar a Resolução CNJ nº 185/2013. Alegou, em síntese, representar, em conjunto, 121.000 empresas de informática do Brasil, dentre elas as que desenvolvem soluções de informática para a informatização da Justiça brasileira e que prestam serviços a tribunais pátrios para desenvolver sistemas de processo judicial eletrônico. Sustentou que o sistema PJe imposto pelo CNJ é deficiente e a obrigatoriedade de sua adoção por todos os tribunais viola o princípio da livre iniciativa, implica em criação de reserva de mercado e desrespeita as disposições da Lei n 11.419/2006, que estabelece competir aos tribunais a contratação de soluções de informática mais adequadas às suas realidades locais. $\mathrm{O}$ writ, com pedido liminar, foi distribuído à relatoria da Ministra Rosa Weber que, em 12 de fevereiro de 2014, determinou, nos termos do art. 22, $\S 2^{\circ}$, da Lei $n^{\circ} 12.016 / 2009$, a prévia oitiva do representante judicial da pessoa jurídica de direito público em 72 (setenta e duas) horas. Foram prestadas as informações mas, até a entrega deste trabalho, a liminar ainda não havia sido apreciada por Sua Excelência. 
apresentada pelo próprio Conselho Nacional de Justiça em 29 de setembro de 2009, através da Resolução CNJ no 90, que "dispõe sobre os requisitos de nivelamento de tecnologia da informação no âmbito do Poder Judiciário" e estabelece regras para a contratação de sistemas de informação, entre as quais sua portabilidade e interoperabilidade, além da obediência a padrões recomendados pelo Comitê Nacional de Gestão de Tecnologia da Informação e Comunicação do Poder Judiciário ${ }^{411}$ e aprovados pela Comissão de Tecnologia e Infraestrutura do CNJ ${ }^{412}$ (Resolução CNJ no 90/2009, art. $\left.6^{\circ}\right)^{413}$.

Em suma, deveria o Conselho Nacional de Justiça, ter se limitado a estabelecer as regras gerais previstas na Resolução CNJ no 90/2009 para a comunicação dos sistemas de automação dos processos contratados pelas cortes. Ao determinar, porém, através da Resolução CNJ n 185/2013, a implantação necessária do sistema eletrônico denominado "Processo Judicial Eletrônico - PJe" em todos os órgãos do Poder Judiciário até o ano de 2018, com a criação, no âmbito dos tribunais, de "Comitês Gestores", o Conselho Nacional de Justiça ultrapassou os limites constitucionais de atuação, pois, ao invés de zelar pela autonomia dos tribunais, restringiu-a, seja por tratar de questões intimamente atreladas à competência e ao funcionamento dos órgãos juridicionais e à organização das secretarias e

\footnotetext{
${ }^{411}$ O Comitê Nacional de Gestão de Tecnologia da Informação e Comunicação do Poder Judiciário, criado pela Portaria $\mathrm{CNJ}^{\circ}$ 222, de 3 de dezembro de 2010 e reconstituído pela Portaria $\mathrm{CNJ} \mathrm{n}^{\circ} 47$, de 4 de abril de 2014, "objetiva diagnosticar a situação de toda a rede informatizada do Poder Judiciário e apresentar sugestões para a uniformização e padronização desse sistema" (disponível em $<$ http://www.cnj.jus.br/programas-de-a-a-z/eficiencia-modernizacao-e-transparencia/comite-nacional-datecnologia-da-informacao-e-comunicacao-do-poder-judiciario>. Acesso em 29 de setembro de 2014).

${ }^{412}$ Como informado no sítio eletrônico do Conselho Nacional de Justiça, "trata-se de comissão permanente que, analisando o funcionamento do Poder Judiciário em suas várias instâncias, propõe-se a adotar medidas tendentes a: - Buscar infraestrutura adequada ao funcionamento desejado para o Poder Judiciário; - Criar Planejamento estratégico em TI para garantir tecnologia apropriada ao bom desempenho das atividades dos tribunais e interoperabilidade entre os diversos sistemas e para o aperfeiçoamento e implantação do processo eletrônico; - Implantar Processo eletrônico" (disponível em <http://www.cnj.jus.br/sobre-o$\mathrm{cnj} /$ comissoes/comissao-de-tecnologia-da-informacao-e-infraestrutura $>$. Acesso em 29 de setembro de 2014).

413 Art. $6^{\circ}$ (Resolução CNJ no 90/2009) Os sistemas de automação deverão atender a padrões de desenvolvimento, suporte operacional, segurança da informação, gestão documental, interoperabilidade e outros que venham a ser recomendados pelo Comitê Nacional de Gestão de Tecnologia da Informação e Comunicação do Poder Judiciário e aprovados pela Comissão de Tecnologia e Infraestrutura do CNJ. (Redação dada pela Resolução ${ }^{\circ} 136$, de 13.07.11)

$\S 1^{\circ}$ As novas aplicações de sistemas de automação de procedimentos judiciais deverão:

I - ser portáveis e interoperáveis;

II - manter documentação atualizada;

III - ser homologadas antes de entrar em produção;

IV - oferecer suporte para assinatura baseado em certificado emitido por Autoridade Certificadora credenciada na forma da Infraestrutura de Chaves Públicas Brasileira - ICP Brasil;

V - o Modelo de Requisitos para Sistemas Informatizados de Acompanhamento e Gestão de Processos e de Documentos Eletrônicos da Justiça aprovado pelo CNJ; e

VI - os padrões de interoperabilidade do Governo Federal - e-PING.

$\S 2^{\circ}$ Facultativamente, aplicar-se-á o parágrafo anterior aos sistemas de automação de procedimentos administrativos dos tribunais.
} 
serviços auxiliares das cortes, seja por propiciar, ante a determinação indireta de abandono de outros sistemas utilizados pelos órgãos do Poder Judiciário, a desnecessária dissipação de recursos orçamentários caros aos tribunais.

\subsubsection{Guarda do cumprimento do Estatuto da Magistratura}

A norma prevista no art. 103-B, § 4 , I, segunda parte, da Constituição da República, também estabelece competir ao Conselho Nacional de Justiça zelar pelo cumprimento do Estatuto da Magistratura.

O art. 93, caput, da Carta da República reza que o Estatuto da Magistratura será disposto em lei complementar de iniciativa do Supremo Tribunal Federal, devendo observar os princípios mencionados em seus diversos incisos. Porém, ressalta Alexandre de Moraes (2013a, p. 1322), “em virtude da característica de autoaplicabilidade da maioria dos incisos do art. 93, a não edição da espécie normativa indicada não impede a utilização dos preceitos constitucionais básicos que regem a magistratura" ${ }^{414}$.

Ademais, enquanto não for editado o Estatuto da Magistratura, permanecem vigentes, naquilo que foi recepcionado pela Constituição Federal, as disposições da Lei Complementar $\mathrm{n}^{\mathrm{o}}$ 35, de 14 de março de 1979, conhecida como Lei Orgânica da Magistratura Nacional ou LOMAN.

A LOMAN foi recebida formalmente pela Constituição de 1988, sendo "afastadas as normas incompatíveis com a nova disciplina constitucional do Poder Judiciário" (MORAES, 2013a, p. 1324).

\footnotetext{
${ }^{414}$ Quanto a autoaplicabilidade da maioria dos princípios insertos no art. 93 da CF/1988, cumpre mencionar a lição trazida pelo Ministro Celso de Mello no voto que prolatou, como relator, na ADI n ${ }^{\circ} 189$, julgada no STF em 9 de outubro de 1991: "A norma constitucional em questão estabelece que lei complementar, de iniciativa do Supremo Tribunal Federal, disporá sobre o Estatuto da Magistratura, observados os princípios que enumera. Esses princípios, em sua maioria, estabelecem critérios objetivos referentes ao ingresso na Magistratura e ao desenrolar da carreira judiciária, até a aposentadoria. A natureza estritamente objetiva dessas regras traduz-se na sua eficácia plena e em sua aplicabilidade imediata, e torna dispensável - mediante adequada interpositio legislatoris - qualquer integração normativa. Tais regras muito mais traduzem diretrizes, de observância compulsória pelo Congresso Nacional, quando da elaboração do Estatuto da Magistratura, do que normas dependentes, para sua efetiva aplicação, de ulterior providência legislativa. A eficiácia e a aplicabilidade das normas consubstanciadas no art. 93 da Carta Federal não dependem, portanto, para que possam operar e atuar concretamente, da promulgação e edição do Estatuto da Magistratura. Constituem, na realidade, pressupostos condicionadores da própria ação normativa do Congresso Nacional, que não poderá prescindir, na concretização do comando constitucional referido, dos princípios que nele se acham proclamados".
} 
Compete ao Conselho Nacional de Justiça, pois, até o advento do Estatuto da Magistratura $^{415}$, zelar pela observância, no âmbito do Poder Judiciário, das regras insertas na Lei Orgânica da Magistratura Nacional.

No cumprimento desse mister, contudo, o CNJ não pode olvidar que a LOMAN foi editada em pleno regime autoritário e centralizador, durante a Ditadura Militar, em razão da Emenda Constitucional n ${ }^{\mathrm{o}}$ 7, de 13 de abril de $1977^{416}$ que alterou a redação do art. 112, parágrafo único, da Constituição de 1967/1969 417.

Cabe ao Conselho, pois, ante de determinar a aplicação cega de qualquer disposição constante da LOMAN, verificar se ela se harmonizam com a nova Ordem Constitucional Democrática introduzida pela Carta de 1988, em especial com os princípios regentes do Poder Judiciário insculpidos em seu art. 93.

Para tanto, e uma vez que compete ao Supremo Tribunal Federal a guarda da Constituição (CF, art. 102, caput), a determinação de aplicação da regras da LOMAN no âmbito administrativo deve manter sintonia com as orientações e com eventuais mudanças de orientações apresentadas nos julgados da Alta Corte Brasileira.

Em resumo, compete ao Conselho Nacional de Justiça zelar pela observância, nos órgãos do Poder Judiciário, enquanto não for editado o Estatuto da Magistratura, das regras insertas na Lei Orgânica da Magistratura Nacional, desde que elas se harmonizem com os preceitos da Constituição de 1988, observadas as orientações trazidas nos julgamentos proferidos pelo Supremo Tribunal Federal, guarda da Lei Maior.

\footnotetext{
${ }^{415}$ Até 10 de novembro de 2003 tramitava na Câmara dos Deputados o Projeto de Lei Complementar $n^{\circ}$ 144/1992 do STF que dispunha sobre o Estatuto da Magistratura Nacional. Na referida data, porém, foi deferido pela Casa Legislativa pedido do próprio Supremo para retirada do projeto, para atualização dos seus termos, conforme deliberado na Sessão Administrativa do STF de 3 de outubro de 2003. O Supremo Tribunal Federal, posteriormente, através da Portaria $n^{\circ}$ 47, de 18 de fevereiro de 2013, instituiu a Comissão de Estudo e Redação de Anteprojeto de Lei Complementar sobre o Estatuto da Magistratura, presidida pelo Ministro Gilmar Mendes e composta ainda pelos Ministros Ricardo Lewandowski e Luiz Fux, para apresentar minuta de anteprojeto da lei complementar do novo estatuto e com competência para recuperar a memória dos trabalhos com o mesmo propósito realizados por Comissões ou individualmente por Ministros da Alta Corte.

${ }^{416}$ A EC no 7/1977 foi editada com base no Ato Institucional $n^{\circ}$ 5/1968 e integrou o denominado pela imprensa "Pacote de Abril", apresentado pelo então Presidente Ernesto Beckmann Geisel ante a perspectiva de vitória da oposição nas eleições marcadas para 15 de novembro de 1977. Dentre outras medidas distantes de um regime democrático, o "Pacote de Abril" fechou temporariamente o Congresso Nacional, instituiu a figura dos "Senadores Biônicos" (indicados pelo Presidente da República), impôs a eleição indireta de governadores, estendeu o mandado presidencial (de cinco para seis anos) e alterou o quórum para aprovação de emendas constitucionais (de dois terços para maioria absoluta das Casas Legislativas).

${ }^{417}$ A iniciativa de edição da LOMAN sequer partiu do Supremo Tribunal Federal, como atualmente exige o art. 93, caput, da Constituição de 1988, apesar de sua concepção ter ocorrido naquela Corte. Seu anteprojeto foi redigido pelo Ministro Rodrigues de Alckimin (conforme mencionado no voto do Ministro Cezar Peluso na $\mathrm{ADI} \mathrm{n}^{\mathrm{o}} 3976$, relator Ministro Ricardo Lewandowski, julgada em 14 de novembro de 2007).
} 


\subsubsection{Estudo de norma e casuística: LOMAN, art. 102 - Eleição de cargos diretivos nos tribunais}

Como regra geral para eleição de cargos diretivos nos tribunais ${ }^{418}$, prevê o art. 102 da LOMAN que os titulares dos cargos de direção dos tribunais serão eleitos, pela maioria dos seus membros efetivos, por votação secreta, dentre seus Juízes mais antigos, em número correspondente ao dos cargos, com mandato por dois anos, proibida a reeleição, não podendo figurar entre os elegíveis o magistrado que tiver exercido quaisquer cargos de direção por quatro anos, ou o de presidente, até que se esgotem todos os nomes, na ordem de antigüidade, sendo obrigatória a aceitação do cargo, salvo recusa manifestada e aceita antes da eleição ${ }^{419}$.

Apesar da regra citada estar inserta no Capítulo II do Título VIII da LOMAN, que trata da Justiça dos Estados e da composição dos seus Tribunais de Justiça, e de algumas tentativas, através de disposições previstas em Regimento Internos de Tribunais e Leis Estaduais, de alterá-la, o Supremo Tribunal Federal diversas vezes decidiu que a norma contida no art. 102 da LOMAN foi recepcionada pela Constituição Federal e aplicar-se-ia a outros tribunais $^{420}$, em especial quanto a universalidade dos elegíveis ${ }^{421}$.

\footnotetext{
${ }^{418}$ Em relação ao STF, o art. 12 do seu Regimento Interno estabelece que o Presidente da Suprema Corte Brasileira exerce mandato de dois anos, proibida a reeleição para o período imediato.

${ }^{419}$ Art. 102 (LOMAN). Os Tribunais, pela maioria dos seus membros efetivos, por votação secreta, elegerão dentre seus Juízes mais antigos, em número correspondente ao dos cargos de direção, os titulares destes, com mandato por dois anos, proibida a reeleição. Quem tiver exercido quaisquer cargos de direção por quatro anos, ou o de Presidente, não figurará mais entre os elegíveis, até que se esgotem todos os nomes, na ordem de antigüidade. É obrigatória a aceitação do cargo, salvo recusa manifestada e aceita antes da eleição.

Parágrafo único - O disposto neste artigo não se aplica ao Juiz eleito, para completar período de mandato inferior a um ano.

${ }^{420}$ Quanto ao Tribunal Superior do Trabalho e aos Tribunais Regionais do Trabalho, o art. 94 da LOMAN expressamente prevê que lhes sejam aplicadas as disposições contidas no art. 102 e parágrafo único do mesmo Diploma Legal. No que tange ao Tribunal Superior Eleitoral, a Constituição Federal estabelece que seus presidente e vice-presidente serão eleitos dentre os Ministros do Supremo Tribunal Federal que o integram, e seu Corregedor Eleitoral dentre os Ministros do Superior Tribunal de Justiça que o compõe (art. 119, parágrafo único). Em relação aos Tribunais Regionais Eleitorais, a Carta da República reza que seus presidentes e vice-presidentes serão eleitos dentre os desembargadores que os integram (art. 120, $\S 2^{\circ}$ ).

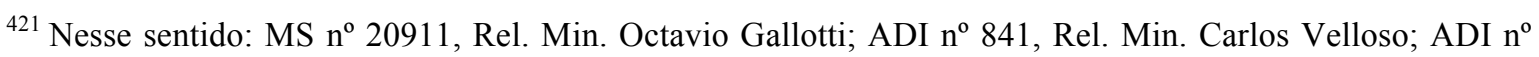
1152-MC, Rel. Min, Celso de Mello; ADI n 1385-MC, Rel. Min. Néri da Silveira; ADI no 1422, Rel. Min. Ilmar Galvão; ADI n 2370-MC, Rel. Min. Sepúlveda Pertence; ADI no 1503, Rel. Min. Maurício Corrêa). Segue a ementa do acórdão proferido pelo Supremo Tibunal Federal em 10 de maio de 1989, no julgamento do Mandado de Segurança n ${ }^{\circ}$ 20911, da relatoria do Ministro Octavio Gallotti:
}

MANDADO DE SEGURANÇA CONTRA O ATO DE TRIBUNAL DE JUSTIÇA, QUE REELEGEU SEU PRESIDENTE. COMPETÊNCIA ORIGINARIA DO SUPREMO TRIBUNAL, PARA O PROCESSO E JULGAMENTO DO FEITO, POR INTERESSE GERAL E DIRETO DOS MEMBROS DO TRIBUNAL ESTADUAL, NOS TERMOS DO ART. 102, I, 'N', DA CONSTITUIÇÃO. SEGURANÇA DEFERIDA, POR AFRONTA AO ART. 102 DA LEI ORGÂNICA DA MAGISTRATURA NACIONAL, QUE NÃO É 
Entendeu a Suprema Corte Brasileira que o preceito em comento não era incompatível com a Constituição de 1988 porque inspirado no princípio de propiciar, através de rodízio nos cargos diretivos pela eleição dos mais antigos, vedada a reeleição, a oportunidade de todos os integrantes dos tribunais exercerem os postos de chefia, sem a politização nas cortes que poderia surgir com a formação de grupos políticos que denegririam seu prestígio.

Após a Emenda Constitucional $n^{\circ} 45 / 2004$, foi ajuizada perante o Supremo Tribunal Federal pelo Procurador-Geral da República a ADI no 3566 para questionar a constitucionalidade da expressão "eleitos na conformidade do que dispuserem os respectivos Regimentos Internos”, constante do art. $4^{\mathrm{o}}$, caput, da Lei $\mathrm{n}^{\mathrm{o}} 7.727$, de 9 de janeiro de 1989 , e todo o $\S 1^{\circ}$ do mesmo art. $4^{\circ}$, bem como para impugnar as expressões “dentre os Desembargadores Federais integrantes do Órgão Especial" contida no caput do art. $3^{\circ}$ do Regimento Interno do Tribunal Regional Federal da $3^{\text {a }}$ Região, e, "dentre os membros do Órgão Especial” inserida no art. 11, I, “a”, também do referido Regimento Interno $^{422}$.

A $\mathrm{ADI} \mathrm{n}^{\mathrm{o}} 3566$ foi distribuída à relatoria do Ministro Joaquim Barbosa e julgada em 15 de fevereiro de 2007. Em seu voto, o relator argumentou que seria possível estabelecer a eligibilidade para cargos de direção de tribunal de todos os integrantes do órgão especial porque a nova redação do artigo 93, XI, da Constituição Federal, trazida pela EC n ${ }^{\circ}$ $45 / 2004$, definiu que os órgãos especiais de tribunais devem ser compostos tanto por juízes mais antigos como por juízes eleitos, que podem não ser os mais antigos, tornando incompatível o preceito contido no art. 102 da LOMAN que reserva os cargos de direção dos tribunais apenas aos juízes mais antigos, porque o mesmo dispositivo constitucional

INCOMPATÍVEL COM A CARTA POLÍTICA DE 1988. (MS 20911, Relator(a): Min. OCTAVIO GALLOTTI, Tribunal Pleno, julgado em 10/05/1989, DJ 30-06-1989)

${ }^{422}$ Seguem as redações dos dispositivos atacados:

Art. $4^{\circ}$ (Lei $\left.{ }^{\circ} 7.727 / 1989\right)$ Os Tribunais Regionais Federais serão instalados pelo Presidente do Tribunal Federal de Recursos e presididos pelo magistrado mais antigo, oriundo da carreira de juiz federal, até a posse do Presidente e do Vice-Presidente, eleitos na conformidade do que dispuserem os respectivos Regimentos Internos.

$\S 1^{\circ} \mathrm{O}$ Vice-Presidente exercerá também a função de Corregedor da Justiça Federal na respectiva jurisdição.

Art. $3^{\circ}$ (RITRF3) O Presidente, o Vice-Presidente e o Corregedor-Geral são eleitos pelo Plenário, dentre os Desembargadores Federais integrantes do Órgão Especial.

Art. 11 (RITRF3) Compete:

I - ao Plenário:

a) eleger o Presidente, o Vice-Presidente e o Corregedor-Geral, bem assim os membros efetivos e suplentes do Conselho da Justiça Federal da $3^{\text {a }}$ Região, do Conselho de Administração e o Diretor da Revista, dentre os membros do Órgão Especial, bem como lhes dar posse; 
alterado dispõe expressamente que as atribuições administrativas e jurisdicionais exercidas pelo órgão especial das cortes são da competência do pleno e, assim, "na instituição de órgão especial por um tribunal está implícito que sobre qualquer dos membros do órgão pode recair a incumbência de dirigir o tribunal", pois, "a função de direção que exerce o órgão especial é mesmo elemento integrante da atividade administrativa delegada pelo Pleno" e "o critério de antiguidade não poderia desvirtuar esse elemento integrante".

Prevaleceu, porém, a divergência aberta pelo Ministro Cezar Peluso, no sentido de que a matéria tratada é institucional, típica do objeto constitucional do Estatuto da Magistratura (não é própria de tribunais locais que atenda "a especificidades ou particularidades que poderiam ser objeto de disposições de cada regimento interno"), pois visa o tratamento uniforme da Magistratura, a sua unidade nacional, e, portanto, deve prevalecer, enquanto aquele não for editado, a regra prevista no artigo 102 da LOMAN, que procurou evitar a politização nos tribunais. Ressaltou Sua Excelência que a Constituição Federal prevê, na norma inserta no art. 96, I, “a”, competir aos tribunais eleger seus órgãos diretivos, mas não especificou quais são e não atribuiu ao regimento o poder de criar esses órgãos. A Lei Maior, segundo Peluso, “diz 'elaborar seus regimentos' e, em seguida, 'dispondo sobre a competência e o funcionamento dos respectivos órgãos jurisdicionais e administrativos' não sobre os diretivos" $" 423$.

O Conselho Nacional de Justiça, pois, na esteira desses posicionamentos do Supremo Tribunal Federal, considerou aplicável, em diversos julgamentos administrativos, a regra inserta no art. 102 da LOMAN ${ }^{424}$.

${ }^{423}$ Conforme extrato da ata, participaram do julgamento da ADI n 3566 os Ministros Gilmar Mendes, Sepúlveda Pertence, Celso de Mello, Marco Aurélio Mello, Cezar Peluso, Carlos Britto, Joaquim Barbosa, Ricardo Lewandowski e Cármen Lúcia. Ausentes, justificadamente, a os Ministros Ellen Gracie e Eros Grau. Segue a ementa da ADI n ${ }^{\circ}$ 3566, publicada no DJ e no DOU em 5 de março de 2007:

MAGISTRATURA. Tribunal. Membros dos órgãos diretivos. Presidente, Vice-Presidente e CorregedorGeral. Eleição. Universo dos magistrados elegíveis. Previsão regimental de elegibilidade de todos os integrantes do Órgão Especial. Inadmissibilidade. Temática institucional. Matéria de competência legislativa reservada à Lei Orgânica da Magistratura e ao Estatuto da Magistratura. Ofensa ao art. 93, caput, da Constituição Federal. Inteligência do art. 96, inc. I, letra $a$, da Constituição Federal. Recepção e vigência do art. 102 da Lei Complementar federal $\mathrm{n}^{\mathbf{0}}$ 35, de 14 de março de 1979 - LOMAN. Ação direta de inconstitucionalidade julgada, por unanimidade, prejudicada quanto ao $\S 1^{\circ}$, e, improcedente quanto ao caput, ambos do art. $4^{\circ}$ da Lei ${ }^{\circ} 7.727 / 89$. Ação julgada procedente, contra o voto do Relator sorteado, quanto aos arts. $3^{\circ}$, caput, e 11 , inc. I, letra $a$, do Regimento Interno do Tribunal Regional Federal da $3^{\text {a }}$ Região. São inconstitucionais as normas de Regimento Interno de tribunal que disponham sobre o universo dos magistrados elegíveis para seus órgãos de direção (ADI 3566, Relator(a): Min. JOAQUIM BARBOSA, Relator(a) p/ Acórdão: Min. CEZAR PELUSO, Tribunal Pleno, julgado em 15/02/2007, DJe-037 DIVULG 14-06-2007 PUBLIC 15-06-2007 DJ 15-06-2007).

${ }^{424}$ Para ilustrar, seguem as ementas dos Pedidos de Providências n ${ }^{\circ}$ s 0000126-02.2008.2.00.0000, Rel. Cons. Mairan Gonçalves Maia Júnior, e 0001592-65.2007.2.00.0000, Rel. Cons. Paulo Lôbo: 
Em 12 de dezembro de $2012^{425}$, porém, o Supremo Tribunal Federal, no julgamento do Agravo Regimental na Medida Cautelar na Reclamação $n^{\circ} 13115$, da relatoria do Ministro Luiz Fux (vencido), manifestou entendimento diverso quanto à obrigatoriedade de observância, na disciplina regimental concernente à eleição dos cargos diretivos nos tribunais, das disposições previstas no art. 102 da LOMAN.

$\mathrm{Na}$ ocasião, a maioria dos membros do Pretório Excelso ${ }^{426}$, acompanhou o voto divergente do Ministro Marco Aurélio Mello que entendeu ter havido uma mudança normativa constitucional substancial no trato do assunto, uma vez que a Carta de 1969, com a redação que lhe foi dada pela $\mathrm{EC} \mathrm{n}^{\mathrm{o}} 7 / 1977$, dispunha que lei complementar denominada Lei Orgânica da Magistratura Nacional estabeleceria normas relativas à organização, ao funcionamento, à disciplina, às vantagens, aos direitos e aos deveres da magistratura (art. 112, parágrafo único) e que competiria aos tribunais eleger seus presidentes e demais titulares de sua direção, observado o disposto na Lei Orgânica da

PEDIDO DE PROVIDÊNCIAS - COMPETÊNCIA DO CNJ - ATO REGULAMENTAR EDITADO PELO TRT/3 ${ }^{\mathrm{a}}$ REGIÃO - RESOLUÇÃO 180/2006 - ALTERAÇÃO DO REGIMENTO INTERNO QUANTO AOS CRITÉRIOS DE ELEGIBILIDADE - CARGOS DE DIREÇÃO - ORDEM DE ANTIGÜIDADE ADIN N ${ }^{\circ}$ 3976-8 - INELEGIBILIDADE DE MAGISTRADOS OCUPANTES DE CARGOS DIRETIVOS NOS ÚLTIMOS QUATRO ANOS - ART. 102 DA LOMAN - REGRA DE OBSERVÂNCIA OBRIGATÓRIA. I. Competência do CNJ para conhecer o pedido, à vista do disposto no artigo 103-B, $\S 4^{\circ}$, I e II, da Constituição Federal e da repercussão geral, para o Poder Judiciário, da matéria debatida. II. Critérios para aferição da elegibilidade a cargos diretivos de Tribunais: $1^{\circ}$ ) posição de antigüidade do candidato e $2^{\circ}$ ) não-exercício de cargo diretivo, por prazo superior a 04 anos, até que se esgotem todos os nomes na ordem de antigüidade (art. 102 da LOMAN). III. Óbice à aferição da observância do critério da antigüidade, pelo Regimento Interno do TRT da $3^{\mathrm{a}}$ Região, alterado pela Resolução $\mathrm{n}^{\circ}$ 180/2006, à vista da existência da Ação Direta de Inconstitucionalidade $\mathrm{n}^{\circ}$ 3.976-8, em curso no E. STF e cuja decisão tem efeito vinculante e eficácia erga omnes. IV. Desconformidade do artigo 210-A do Regimento Interno do TRT da $3^{\text {a }}$ Região com o art. 102 da LOMAN no tocante à regra da inelegibilidade de magistrados ocupantes de cargos diretivos nos últimos quatro anos. V. Pedido de providências a que se julga procedente para fins de reconhecimento da ilegalidade do artigo 210-A do Regimento Interno do TRT da $3^{\text {a }}$ Região e determinação de adequação de seus termos ao artigo 102 da LOMAN no prazo de 30 dias. (CNJ - PP - Pedido de Providências - Corregedoria 0000126-02.2008.2.00.0000 - Rel. Mairan Gonçalves Maia Júnior - 67 Sessão - j. 12/08/2008).

PEDIDO DE PROVIDÊNCIAS. INTERPRETAÇÃO DO PARÁGRAFO ÚNICO DO ART. 102 DA LOMAN. "MANDATO TAMPÃO”. ELEIÇÃO PARA MESA DIRETORA DE TRIBUNAL. 1. A LOMAN fixou a antiguidade como critério para eleição de magistrados para os cargos de direção nos Tribunais do país. Todavia, a exceção que o parágrafo único do art. 102 da LOMAN estabelece em relação às hipóteses do caput é geral. No caso de eleição para complementar mandato com tempo inferior a 1 (um) ano, não se aplica o requisito de antiguidade. 2. A eleição da mesa diretora do Tribunal deve observar a legislação em vigor, quanto ao número de seus membros. (CNJ - PP - Pedido de Providências - Conselheiro - 000159265.2007.2.00.0000 - Rel. PAULO LÔBO - 53 ${ }^{\mathrm{a}}$ Sessão - j. 04/12/2007).

${ }^{425}$ Após a aposentadoria do Ministro Cezar Peluso (publicada no Diário Oficial da União no dia 31 de agosto de 2012).

${ }^{426}$ Conforme extrato da ata de julgamento, participaram do julgamento os Ministros Joaquim Barbosa, Marco Aurélio Mello, Gilmar Mendes, Ricardo Lewandowski, Cármen Lúcia, Dias Toffoli, Luiz Fux, Rosa Weber e Teori Zavascki, ficando vencidos os Ministros Luiz Fux (Relator), Gilmar Mendes e Joaquim Barbosa (Presidente). Ausentes, justificadamente, o Ministro Celso de Mello e, ocasionalmente, o Ministro Dias Toffoli. 
Magistratura Nacional (art. 115, I). A Constituição de 1988, porém, assegurou a autonomia administrativa e financeira ao Poder Judiciário (art. 99, caput), não estabeleceu, no rol de princípios relativos à magistratura, referência, como princípio a ser adotado pelo Estatuto da Magistratura, a regência dos cargos de direção (art. 93) e dispôs sobre a competência dos tribunais para eleger seus órgãos diretivos, mas, ao contrário da Carta anterior, não remeteu a questão à observância de disposições de Lei Complementar. Assim, enquanto sob a égide da Constituição de 1969, restou estabelecido que a questão referente à eleição dos cargos de chefia nos tribunais deveria ser disciplinada pela Lei Orgânica da Magistratura, a "Constituição Cidadã", em eloquente silêncio ${ }^{427}$, não submeteu mais esse assunto a legislação infraconstitucional ${ }^{428}$.

O Conselho Nacional de Justiça, contudo, não obstante o Supremo Tribunal Federal ter sinalizado uma mudança na orientação referente à obrigatoriedade de observância, pelos tribunais, das regras previstas no art. 102 da LOMAN, em julgamento realizado em 10 de setembro de 2013, por maioria ${ }^{429}$, ratificou a liminar proferida pelo Conselheiro Guilherme Calmon no Pedido de Providências n ${ }^{\circ}$ 0005039-51.2013.2.00.0000 que, mesmo ciente do teor da decisão proferida pelo Supremo Tribunal Federal no Agravo Regimental na Medida Cautelar na Reclamação $\mathrm{n}^{\mathrm{o}} 13115^{430}$, suspendeu a abertura de procedimento eleitoral pelo Tribunal de Justiça de São Paulo com base na sua Resolução no 606, de 7 de agosto de 2013, porque esse ato normativo, ao prever na norma inserta em seu artigo $1^{\circ}$ que poderiam concorrer para os cargos de direção da Corte Bandeirante todos os seus

\footnotetext{
${ }^{427}$ Sobre silêncio eloquente vide nota 214 no item 2.3.5.1.

${ }^{428}$ Segue a ementa do julgado:

“JUDICIÁRIO - AUTONOMIA. Consoante disposto no artigo 99 da Carta de 1988, ao Poder Judiciário é assegurada autonomia administrativa e financeira.

TRIBUNAIS - DIREÇÃO - REGÊNCIA. Ao contrário do versado no artigo 112 do Diploma Maior anterior - Emenda Constitucional no 1, de 1969 -, o atual não remete mais à Lei Orgânica da Magistratura a regência da direção dos tribunais, ficando a disciplina a cargo do regimento interno.

RECLAMAÇÃO - EFEITO TRANSCENDENTE. Reiterados são os pronunciamentos do Supremo no sentido de não se admitir, como base para pedido formulado em reclamação, o efeito transcendente".

${ }^{429}$ Ficaram vencidos os Conselheiros Deborah Ciocci, Emmanoel Campelo e Fabiano Silveira. Estiverem presentes na sessão os Conselheiros Joaquim Barbosa, Francisco Falcão, Maria Cristina Peduzzi, Ana Maria Duarte Amarante Brito, Guilherme Calmon, Flavio Sirangelo, Deborah Ciocci, Saulo Casali Bahia, Rubens Curado Silveira, Gilberto Martins, Paulo Teixeira, Gisela Gondin Ramos, Emmanoel Campelo e Fabiano Silveira (conforme certidão de julgamento da $174^{\text {a }}$ Sessão Ordinária do CNJ).

${ }^{430}$ Segundo consta no relatório do decisão monocrática proferida, o requerente do pedido de providências argumentou que o precedente do STF, nos autos da Reclamação $\mathrm{n}^{\circ} 13115$, não poderia ser considerado porque quatro ministros da Corte Suprema não proferiram voto no referido julgamento, sendo que dois deles teriam entendimento contrário à maioria que se formou na citada Reclamação.
} 
desembargadores ${ }^{431}$, mediante inscrição, no prazo do art. 18 do Regimento Interno, vedada a inscrição simultânea para mais de um cargo, contrariou a disposição da Lei Complementar $n^{\circ} 35 / 1979$.

A decisão do Conselho Nacional de Justiça nos autos do Pedido de Providências $\mathrm{n}^{\mathbf{o}}$ 0005039-51.2013.2.00.0000, no entanto, teve seus efeitos suspensos por força da liminar deferida pelo Ministro Ricardo Lewandowski, em 10 de outubro de 2013, no Mandado de Segurança $\mathrm{n}^{\mathrm{o}}$ 32451, em razão do entendimento trazido pelo Plenário do STF no julgamento do Agravo Regimental na Medida Cautelar na Reclamação n ${ }^{\circ} 13115$, diante da dúvida razoável de natureza constitucional surgida quanto à recepção do art. 102 da LOMAN após as mudanças introduzidas em seu texto pela EC $n^{\circ} 45 / 2004$ e pela ocorrência de conflito do dispositivo da lei complementar com a prerrogativa de autogoverno e autonomia administrativa conferidas aos tribunais pela Carta da República em seus arts. 96, I, “a”, e 99 (o primeiro, como visto, interpretado de forma diversa pelo Ministro Cezar Peluso no julgamento da ADIN nº 3566).

Posteriormente, ante a nova linha de entendimento esboçada no âmbito do Supremo Tribunal Federal sobre o tema, o Ministro Luiz Fux deferiu pedido de liminar em 2 de dezembro de 2014 na Medida Cautelar em Mandado de Segurança $n^{\circ}$ 33288, impetrado pelo Tribunal de Justiça do Estado do Rio de Janeiro contra o Conselho Nacional de Justiça para, preventivamente, evitar qualquer ato praticado pelo Colegiado capaz de esvaziar a autonomia da corte estadual para normatizar a eleição de seu corpo diretivo.

No caso, o Tribunal de Justiça Fluminense alterou seu regimento interno e editou a Resolução TJ/TP/RJ n ${ }^{\circ}$, de 08 de setembro de $2014^{432}$, passando a aceitar a eleição de

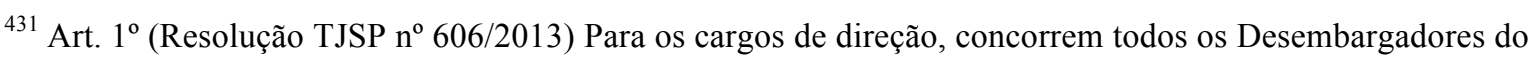
Tribunal, mediante inscrição, no prazo do art. 18 do Regimento Interno, vedada a inscrição simultânea para mais de um cargo.

${ }^{432}$ RESOLUÇÃO TJ/TP/RJ n n 01/2014

Aprova novas regras para o processo eleitoral no âmbito do Poder Judiciário do Estado do Rio de Janeiro. O TRIBUNAL PLENO DO TRIBUNAL DE JUSTIÇA DO ESTADO DO RIO DE JANEIRO, no âmbito de sua competência e no uso de suas atribuições legais e regimentais e tendo em vista o que foi decidido na sessão do dia 21 de agosto de 2014 (Processo n. 0034509-64.2014.8.18.0000), RESOLVE:

Art. $1^{\circ}$ Serão elegíveis para os cargos da Administração Superior do Tribunal de Justiça todos os Desembargadores ativos.

Art. $2^{\circ}$ Não poderá haver reeleição para o mesmo cargo dos membros da Administração Superior do Tribunal de Justiça para o período subsequente.

Art. $3^{\circ}$ Poderá o Desembargador ser novamente eleito para o mesmo cargo, desde que observado o intervalo de dois mandatos.

Art. $4^{\circ} \mathrm{O}$ prazo máximo que o Desembargador poderá ocupar cargos na Administração Superior do Tribunal de Justiça será de 04 anos.

Art. $5^{\circ} \mathrm{O}$ exercício de mandato tampão por membro da Administração Superior do Tribunal de Justiça não será considerado mandato integral para efeito de nova eleição.
} 
todos os seus desembargadores para os cargos de alta administração da corte (art. $1^{\circ}$ ) e admitindo que um anterior membro da administração concorre-se ao mesmo cargo, desde que observado um intervalo de dois mandatos (art. $3^{\circ}$ ).

Houve, junto ao $\mathrm{CNJ}$, questionamentos sobre a validade desses regramentos nos Pedidos de Providências $n^{\circ} \mathrm{s}$ 0006166-87.2014.2.00.0000 e 0006191-03.2014.2.00.0000 e no Procedimento de Controle Administrativo no 0006190-18.2014.2.00.0000, por alegada contrariedade às regras insertas noart. 93 da Constituição da República e no art. 102 da LOMAN, sendo requerida pelo impetrante junto ao STF, liminarmente, a suspensão da tramitação desses procedimentos e a sustação dos efeitos de atos porventura já praticados. Quanto ao mérito, pleiteou-se a extinção e o arquivamento definitivo dos feitos administrativos.

Os autos foram distribuídos originalmente à Ministra Cármen Lúcia, mas, reconhecida a conexão com a Reclamação $n^{0}$ 13115, foram redistribuídos ao Ministro Luiz Fux. Solicitadas informações, o CNJ esclareceu que o relator dos processos administrativos, Conselheiro Paulo Teixeira, deferiu, em 3 de novembro de 2014, o pedido de liminar ${ }^{433}$

Art. $6^{\circ}$ Serão eleitores para os cargos da Administração Superior do Tribunal de Justiça (Presidente/Corregedor/Vices Presidentes), todos os Desembargadores ativos do Tribunal de Justiça.

Art. $7^{\circ} \mathrm{O}$ mandato dos membros eleitos para composição do Órgão Especial não será coincidente com o mandato da Administração Superior do Tribunal de Justiça.

Art. $8^{\circ}$ Cada Desembargador só poderá disputar um dos cargos da Administração Superior do Tribunal de Justiça para o mesmo biênio.

Art. $9^{\circ} \mathrm{O}$ quorum para eleição dos membros da Administração Superior do Tribunal de Justiça será o da maioria absoluta do número de cargos de eleitores existentes.

Art. 10. O quorum para eleição dos membros do Órgão Especial, do Conselho da Magistratura e do Diretor da EMERJ será o da maioria absoluta dos Desembargadores presentes.

Art. 11. O quorum para a escolha dos candidatos ao Quinto Constitucional para integrarem a lista tríplice será o da maioria absoluta dos cargos de Desembargadores existentes.

Art. 12. O quorum para eleição dos Desembargadores e dos Juízes de Direito para integrarem o TRE, assim como dos respectivos suplentes será o da maioria absoluta dos cargos de Desembargadores existentes,

Art. 13. Na eleição para o Conselho de Magistratura estará impedido de concorrer o Desembargador que já o tenha integrado por 04 anos, consecutivos ou não.

Art. 14. As alterações das regras para as eleições para a Administração Superior do Tribunal de Justiça terão vigência e eficácia imediatas.

Art. 15. Esta Resolução entra em vigor na data da sua publicação, revogadas as disposições em contrário.

Rio de Janeiro, 08 de setembro de 2014.

(a) Desembargadora LEILA MARIANO Presidente.

433 Segue a ementa da decisão monocrática (disponível em: $<$ http://www.migalhas.com.br/arquivos/2014/11/art20141105-02.pdf > , acesso em 10.12.2014), pois em consultas realizadas em 10 de dezembro de 2014 no sítio eletrônico do CNJ com os números dos processos administrativos mencionados não foi franqueado acesso à movimentação dos feitos, sempre com indicação de mensagem "número de processo inexistente!":

PROCEDIMENTO DE CONTROLE ADMINISTRATIVO. PEDIDO DE PROVIDÊNCIAS. TRIBUNAL DE JUSTIÇA DO ESTADO DO RIO DE JANEIRO. ELEIÇÃO PARA OS CARGOS DE DIREÇÃO DO TRIBUNAL. ART. $3^{\circ}$ DA RESOLUÇÃO TJ/TP/RJ n. 01/2014. REELEIÇÃO. VEDAÇÃO DO ART. 102 DA LOMAN. LIMINAR DEFERIDA. SUSPENSÃO DO DISPOSITIVO. PRECEDENTE NO PP 615325.2013.2.00.0000. 
para suspender o art. $3^{\circ}$ da Resolução TJ/TP/RJ $n^{\circ}$ 01/2014, decisão posteriormente ratificada pelo Plenário do Colégio Administrativo em 4 de novembro de 2014, com fundamento na proibição de reeleição constante do caput do art. 102 da $\operatorname{LOMAN}^{434}$.

O Ministro Luiz Fux, porém, deferiu o pedido de liminar no writ para tornar sem efeitos a decisão do $\mathrm{CNJ}$, bem como para determinar a suspensão de todo e qualquer procedimento administrativo em tramitação naquele órgão que impugne a resolução do TJRJ, sob o fundamento de que a matéria aguarda apreciação definitiva pelo Pleno do STF.

Sustentou em sua decisão:

Muito embora o Conselho Nacional de Justiça pertença ao Poder Judiciário, trata-se de órgão de natureza administrativa, desprovido de função jurisdicional, razão pela qual não possui, no seu plexo de atribuições administrativas, competência para emitir ordens alicerçadas em interpretações sobre temas judicializados, em especial se a controvérsia [...] estiver pendente de apreciação definitiva do Supremo Tribunal Federal.

E ainda destacou Sua Excelência:

A prevalecer a atribuição do $\mathrm{CNJ}$ [...] em que o tema jurídico central está pendente de apreciação pelo Pleno do STF, ter-se-ia uma indevida inversão do arcabouço estrutural e sistêmico do Poder Judiciário estampado na Carta da República, em que um órgão com atribuições estritamente administrativas poderia estabelecer pré-compreensões sabidamente precárias em relação a matérias que concitam o inexorável desempenho da função jurisdicional, definitiva e imutável, pelo órgão de cúpula da justiça brasileira, qual seja, o Supremo Tribunal Federal

Por fim, afirmou que, apesar do mérito da Reclamação $n^{\circ} 13115$ ainda não ter sido julgado, o Pleno do Supremo Tribunal Federal exteriorizou, em sede de apreciação de

\footnotetext{
${ }^{434}$ Essas informações foram obtidas no relatório da decisão monocrática proferida pelo Ministro Luiz Fux no MS $n^{\circ} 33288$ e em notícia eletrônica disponível em <http://www.cnj.jus.br/noticias/cnj/30012-plenarioratifica-liminar-que-veda-reeleicao-no-tjrj>, acesso em 10 de dezembro de 2014, pois em consultas realizadas em 10 de dezembro de 2014 no sítio eletrônico do CNJ com os números dos processos administrativos mencionados não foi franqueado acesso à movimentação dos feitos, sempre com indicação de mensagem "número de processo inexistente!"
} 
agravo regimental, que a disciplina dos cargos de direção dos tribunais deve ficar a cargo dos seus regimentos internos ${ }^{435}$.

$\mathrm{Na}$ trilha exposta, pois, entendemos que, as decisões do Conselho Nacional de Justiça nos Pedidos de Providências n ${ }^{\mathrm{o}} \mathrm{s}$ 0005039-51.2013.2.00.0000, 0006166-87.2014.2.00.0000 e 0006191-03.2014.2.00.0000 e no Procedimento de Controle Administrativo $\mathrm{n}^{\mathrm{o}}$ 000619018.2014.2.00.0000, apesar de visarem zelar pela observância das regras insertas no Lei Orgânica da Magistratura Nacional, acabaram por implicar em violação dos limites constitucionais de sua atuação, na medida em que o assunto abordado - necessidade de observância das disposições do art. 102 da LOMAN quanto aos critérios de elegibilidade dos cargos eletivos nos tribunais $\mathrm{X}$ autonomia das cortes para normatizar a eleição para seu corpo diretivo - tornou-se controvertido no âmbito do Supremo Tribunal Federal, guardião da Constituição da República.

\subsubsection{Guarda da observância dos princípios e regras da Administração Pública}

A Carta Política (103-B, $\S 4^{\circ}$, II, primeira parte) também prescreve competir ao especificamente ao Conselho Nacional de Justiça zelar pela observância das disposições contidas no art. 37 do texto constitucional.

O referido dispositivo consagra, constitucionalmente, princípios e preceitos básicos da Administração Pública, permitindo um maior ingerência do Poder Judiciário, enquanto no exercício da função jurisdicional, nos seus negócios (MORAES, 2013, pp. 764 e 765).

Por outro lado, no exercício da atípica função administrativa pelos próprios órgãos do Judiciário, os princípios e regras insculpidos nas diversas disposições contidas no art. 37 da Lei Maior também devem ser observados, competindo ao Conselho Nacional de Justiça,

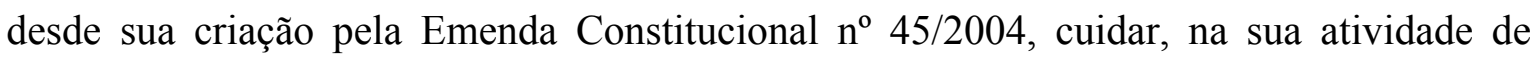
controle, que sejam respeitados.

\footnotetext{
${ }^{435}$ Segue a ementa da decisão monocrática:

DIREITO ADMINISTRATIVO E CONSTITUCIONAL. ALCANCE PODERES E DA ATUAÇÃO DO CNJ. ÓRGÃO DE NATUREZA ADMINISTRATIVA. ELEIÇÃO PARA ÓRGÃOS DE DIREÇÃO DE TRIBUNAL DE JUSTIÇA. CONFLITO ENTRE A LEI ORGÂNICA DA MAGISTRATURA NACIONAL (LC No 35/79) E A NORMA CONTIDA NO REGIMENTO INTERNO DO TJ/RJ. TEMA JURÍDICO DE ELEVADA COMPLEXIDADE QUE SE ENCONTRA SUB JUDICE NO STF NOS AUTOS DA RECLAMAÇÃO 13.115. IMPOSSIBILIDADE DE O CNJ INTERFERIR EM DECISÃO ADMINISTRATIVA ADOTADA POR TRIBUNAL DE JUSTIÇA SOBRE MATÉRIA JUDICIALIZADA NO STF, MORMENTE QUANDO SUA CONCLUSÃO CONTRARIA O QUE DECIDIDO PELO PLENO DO STF EM SEDE DE AGRAVO REGIMENTAL NA ALUDIDA RECLAMAÇÃO. PRESENÇA DO FUMUS BONI JURIS E DO PERICULUM IN MORA. LIMINAR DEFERIDA.
} 
Limites existem, porém, à atuação do Conselho nesse particular.

$\mathrm{Na}$ sua cabeça, o art. 37 da Constituição enuncia os princípios constitucionais que regem a Administração Pública: legalidade, impessoalidade, moralidade, publicidade e eficiência.

Cumpre, ainda que, singelamente, discorrer sobre os conteúdos desses princípios, pois pautam a atuação do Conselho Nacional de Justiça.

a) Princípio da legalidade ${ }^{436}$ :

Segundo referido princípio, a Administração Pública somente pode fazer o que estiver autorizado em lei. O termo "lei" porém, no Estado Democrático de Direito, não se refere apenas à espécie normativa editada após regular processo legislativo. Deve ser entendido, na leitura do princípio, como a submissão do administrador público não somente à lei, mas a outras espécies normativas, valores e princípios, ou seja, como sujeição ao Direito ${ }^{437}$;

b) Princípio da impessoalidade:

A doutrina brasileira em geral faz duas leituras do referido princípio. Alguns o interpretam como corolário do princípio da igualdade previsto no art. $5^{\circ}$ da Carta Política, para impedir que a Administração Pública trate os administrados de forma desigual, aproximando-se do princípio da finalidade administrativa (MEIRELLES, 1999, p. 85; MELLO, 2009, p. 106). Nesse sentido posicionam-se, dentre outros, Alexandre de Moraes (2013b, p. 336), Gilmar Ferreira Mendes e Paulo Gustavo Gonet Branco (2011, p. 861),

\footnotetext{
${ }^{436}$ Apesar do dispositivo constitucional em comento indicar a "legalidade" como um dos princípios que regem a Administração Pública e de considerarmos, neste trabalho, a possibilidade de aplicação, entre eles, das idéias de Dworkin e Alexy, (princípios como mandamentos de otimização), especialmente na hipótese de colisão de princípios, Virgílio Afonso da Silva pontua que somente faz sentido falar-se em princípio da legalidade se for definido "princípio" pela sua fundamentalidade. Na visão do doutrinador, adotados os critérios propostos por Alexy, o "princípio da legalidade" é, na verdade, uma regra (2003, pp. 613 e 614).

${ }^{437}$ Maria Sylvia Zanella Di Pietro (2012, pp. 31 e 32) aponta, em razão do princípio da legalidade significar, no Estado Democrático de Direito, a sujeição ao Direito e ante a ampliação da função normativa da Administração Pública (função reguladora exercida pelas agência e, após a $E C \mathrm{n}^{\circ} 45 / 2004$, também pelo CNJ), a existência de duas tendências opostas entre os administrativistas: a) de um lado, os neoliberais que defendem a ampliação da discricionariedade administrativa, pois o direito administrativo, apoiado no princípio da legalidade, engessa as reformas necessárias, bem como sustentam a impossibilidade de controle judicial da discricionariedade técnica; b) de outro lado, os conservadores que pugnam por maiores limites à discricionariedade administrativa, pois sua atuação deve amparar-se na lei e nos limites trazidos pelos princípios e valores previstos na Constituição, bem como defendem a possibilidade de apreciação judicial da discricionariedade técnica, pois, se trata-se de técnica, somente pode levar a uma solução.
} 
Walter Ceneviva (2003, p. 175), Celso Antônio Bandeira de Mello (2009, p. 114). e Diogenes Gasparini (2011, p. 63). Outros, por seu turno, argumentam que o princípio da impessoalidade tem por escopo impedir que a Administração Pública apresente-se com marca pessoal (TAVARES, 2013, p. 1064), sentido esse que já foi mencionado quando feito o estudo da Resolução CNJ no $140 / 2011^{438}$. Nessa linha, José Afonso da Silva (2013, p. 671) defende que o princípio da impessoalidade "significa que os atos e provimentos administrativos são imputáveis não ao funcionário que os pratica, mas ao órgão ou entidade administrativa em nome do qual age o funcionário". Maria Sylvia Zanella Di Pietro (2012, p. 68), após expor as duas interpretações do princípio da impessoalidade mencionadas, afirma que ele aplica-se também em matéria de exercício de fato, "quando se reconhece validade aos atos praticados por funcionário irregularmente investido no cargo ou função, sob fundamento de que os atos são do órgão e não do agente público".

c) Princípio da moralidade:

Aponta-se Maurice Hauriou (1927, pp. 346 e 347) como o primeiro a tratar da moralidade administrativa, definindo-a como a conduta da Administração Pública, extraida da sua disciplina interna, que distingui, ao mesmo tempo, o bem do mal, o justo do injusto, o lícito do ilícito, o honrado do desonrado, o conveniente do inconveniente. Assim, para Hariou, a moralidade administrativa é, muitas vezes, mais exigente que a legalidade ${ }^{439}$. No desenvolvimento do tema moralidade administrativa, segundo Marcelo Figueiredo (2003, pp. 86 e 87), verifica-se três fases: a) na primeira, de acordo com a doutrina de Maurice Hauriou e Geroge Ripert, a imoralidade é elemento interno da legalidade; b) na segunda, procura-se o controle da Administração Pública, com a verificação dos "motivos de fato discricionariamente considerados pela Administração Pública, bem como as finalidades dos atos administrativos exercidos pelo agente" (desenvolvimento das teorias dos motivos determinantes e do desvio de poder); e, c) na terceira, a moralidade administrativa é enfocada como um "desejo do 'governo honesto"”, sendo "clamada como direito público

\footnotetext{
${ }^{438}$ Vide item 2.3.1.1.

${ }^{439}$ Quant à la moralité administrative, son existence provient de ce que tout être possédant une conduite pratique forcément la distinction du bien et du mal. Comme l'administration a une conduite, elle pratique cette distinction en même temps que celle du juste et de l'injuste, du licite et de l'illicite, de l'honorable et du déshonorant, du convenable et de l'inconvenant. La moralité administrative est souvent plus exigeante que la légalité".
} 
subjetivo" e associada "à lealdade, à boa-fé, aos padrões éticos vigentes em dada época e sociedade.

Ensina Alexandre de Moraes (2013, p. 777):

Pelo princípio da moralidade administrativa, não bastará ao administrador o estrito cumprimento da estrita legalidade, devendo ele, no exercício de sua função pública, respeitar os princípios éticos de razoabilidade e justiça, pois a moralidade constitui, a partir da Constituição de 1988, pressuposto de validade de todo ato da administração pública.

d) Princípio da publicidade:

De acordo com esse princípio, deve haver divulgação oficial de todos os atos realizados pela Administração Pública. Essa publicidade, ressalta Hely Lopes Meirelles, não é elemento formativo do ato, mas requisito de sua eficácia e moralidade, pois visa assegurar seus efeitos externos e propiciar seu conhecimento e controle pelos interessados diretos e pela sociedade (1999, p. 87). A publicidade, pois, somente excepcionalmente pode ser restringida. No âmbito do Poder Judiciário, como será exposto ao se abordar questões controvertidas relacionadas ao controle disciplinar realizado pelo $\mathrm{CNJ}^{440}$, há necessidade de observância desse princípio em todos os julgamentos jurisdicionais e administrativos, inclusive naqueles realizados pelo Conselho Nacional de Justiça, consoante dispõem especificamente as normas previstas no art. 37, IX e X, da Constituição Federal, admitindo-se, somente, que a lei limite a presença, em determinados atos, às próprias partes e a seus advogados, ou somente a estes, para preservação do direito à intimidade do interessado e desde que não haja prejuízo ao interesse público à informação.

e) Princípio da eficiência:

Inserido na Ordem Constitucional pela EC n 19, de 4 de junho de 1998, o princípio da eficiência é tratado pelos italianos, assevera Diogenes Gasparini (2011, p. 76), como o “dever de boa administração" e, assim, "impõe à Administração Pública direta e indireta a obrigação de realizar suas atribuições com rapidez, perfeição e rendimento, além por certo, de observar outras regras, a exemplo do princípio da legalidade”. De sua parte, Marçal

${ }^{440}$ Vide item 3.1.5.1.2. 
Justen Filho (2014, pp. 221 a 223), esclarece que a Administração deve otimizar os recursos públicos, evitando o desperdício e a falha. "É necessário obter o máximo de resultados com a menor quantidade possível de desembolsos". Maria Sylvia Zanella Di Pietro (2012, p. 84) indica dois aspectos do princípio da eficiência: a) quanto ao modo da atuação do agente público, "do qual se espera o melhor desempenho possível de suas atribuições, para lograr os melhores resultados"; e, b) em relação ao modo de organizar, estruturar, disciplinar a Administração Pública, para obter os melhores resultados na prestação do serviço público.

$\mathrm{O}$ art. 37 da Constituição, após indicar, em seu caput, os mencionados princípios que informam a Administração Pública, ainda, em seus diversos incisos e parágrafos, apresenta várias regras basiliares a serem observadas, algumas de aplicabilidade imediata e outras que dependem de integração normativa através de lei.

Ante a forma como estruturado o dispositivo em comento (CF, art. 37), cuja observância no seio do Poder Judiciário compete ao Conselho Nacional de Justiça guardar, para perfeita fixação dos limites de sua atuação, cumpre, fazer uma distinção entre princípios e regras.

Socorre-se, nesse particular, dos pensamentos de Ronald Dworkin (2011) e Robert Alexy (2014) ${ }^{441}$, sintentizados por Virgílio Afonso da Silva (2003, pp. 607 a 630) ${ }^{442}$.

Lembra Virgílio Afonso da Silva (2003, p. 610) que Dworkin, para criticar o positivismo desenvolvido por Herbert Hart - que defende um sistema composto exclusivamente de regras jurídicas ${ }^{443}$ - argumenta que, ao lado das regras, há também

${ }^{441}$ É importante frisar que os termos "norma" e "regra" foram, ao longo desse trabalho, diversas vezes utilizados como sinônimos, a fim, inclusive, de evitar cansativa repetição das mesmas palavras no texto. Alexy, porém, afirma que regras (Regeln) e princípios (Prinzipien) são normas (Normen).

${ }^{442}$ Em outro trabalho, Virgílio Afonso da Silva (2014, pp. 30 e 31) aponta que há três grandes categorias de teorias sobre a distinção entre princípios e regras: a) teorias que propõe uma distinção forte, segundo a qual princípios e regras são normas que têm estruturas lógicas diversas (Ronald Dworkin, Robert Alexy, Jan-R. Sieckmann, Martin Borowski, Marius Raabe e Josef Esser); b) teorias que propõe uma distinção débil, pois entendem que há, entre princípios e regras, somente uma diferença em grau de generalidade, abstração ou fundamentalidade (Joseph Raz); e c) teorias que rejeitam a possibilidade de distinção, pois defendem "que todas as qualidades lógico-deônticas presentes nos princípios estão presentes também nas regras" (Aulis Aarnio e Klaus Günther).

${ }^{443}$ Dworkin (2011, pp. 27 e 28) aponta três proposições centrais do positivismo: “a) O direito é uma comunidade de regras especiais utilizado direta ou indiretamente pela comunidade com o propósito de determinar qual comportamento será punido ou coagido pelo poder público. Essas regras especiais podem ser identificadas e distinguidas com auxílio de critérios específicos, de testes que não têm a ver com seu conteúdo, mas com o seu pedigree ou maneira pela qual foram adotadas ou formuladas [...]. b) O conjunto dessas regras jurídicas é coextensivo com 'o direito', de modo que se o caso de alguma pessoa não estiver claramente coberto por uma regra dessas (porque não existe nenhuma que pareça apropriada ou porque as 
princípios, que possuem uma dimensão de validade, inerente às regras, mas também uma dimensão de peso. Assim, enquanto, no caso de colisão de regras, elas valem ou não valem, na colisão de princípios, deve-se indagar qual princípio, no caso concreto, é mais importante, tem maior peso, o que não significa que o outro princípio deixará de valer em outros casos concretos.

Afirma Dworkin (2011, pp. 39 a 43):

A diferença entre princípios jurídicos e regras jurídicas é de natureza lógica. Os dois conjuntos de padrões apontam para decisões particulares acerca da obrigação jurídica em circunstâncias específicas, mas distinguem-se quanto à natureza da orientação que oferecem. As regras são aplicáveis à maneira do tudo-ou-nada. Dados os fatos que uma regra estipula, então ou a regra é válida, e neste caso a resposta que ela fornece deve ser aceita, ou não é válida, e neste caso em nada contribui para a decisão.

$[\ldots]$

Os princípios [...], mesmo aqueles que mais se assemelham a regras não apresentam consequências jurídicas que se seguem automaticamente quando as condições são dadas.

$[\ldots]$

Tudo o que pretendemos dizer, ao afirmarmos que um princípio particular é um princípio do nosso direito, é que ele, se for relevante, deve ser levado em conta pelas autoridades públicas, como [se fosse] uma razão que inclina numa ou noutra direção.

$[\ldots]$

que parecem apropriadas são vagas ou por alguma outra razão), então esse caso não pode ser decidido mediante a 'aplicação do direito'. Ele deve ser decidido por alguma autoridade pública, como um juiz, 'exercendo seu discernimento pessoal', o que significa ir além do direito na busca por algum outro tipo de padrão que o oriente na confecção de nova regra jurídica ou na complementação de uma regra já existente. c) Dizer que alguém tem uma 'obrigação jurídica'é dizer que seu caso se enquadra em uma regra jurídica válida que exige que ele faça ou se abstenha de fazer alguma coisa [...]. Na ausência de uma tal regra jurídica válida não existe obrigação jurídica". Ainda destaca Dworkin (2011, pp. 31 e 33) que a versão do positivismo de Hart (1986, 89 a 109) é mais complexa, pois, primeiro, reconhece que as regras podem ser primárias ("aquelas que concedem direitos ou impõem obrigações aos membros da comunidade") ou secundárias ("aquelas que estipulam como e por quem as tais regras podem ser estabelecidas, declaradas legais, modificadas ou abolidas"). Hart também afirma que uma regra pode ser obrigatória porque é aceita como padrão de conduta por um grupo ou porque é válida, pois criada de acordo com um regra secundária qua a fundamenta. Uma sociedade primitiva possui apenas regras primárias, que não formam um sistema (HART, 1986, p. 102). Quando a sociedade desenvolve uma regra secundária fundamental, denominada por Hart (1986, p. 104) de "regra de reconhecimento" (rule of recognition), como remédio para a incerteza do regime de regras primárias, estipulando como elas devem ser identificadas, "nasce a ideia de um conjunto específico de regras jurídicas e, com isso, a ideia de direito" (DWORKIN, 2011, p. 33). 
Essa primeira diferença entre regras e princípios traz consigo outra. Os princípios possuem uma dimensão que as regras não têm - a dimensão do peso ou importância. Quando os princípios se intercruzam [...], aquele que vai resolver o conflito tem de levar em conta a força relativa de cada um. Esta não pode ser, por certo, uma mensuração exata e o julgamento que determina que um princípio ou uma política particular é mais importante que outra frequentemente será objeto de controvérsia . Não obstante, essa dimensão é uma parte integrante do conceito de um princípio, de modo que faz sentido perguntar que peso ele tem ou quão importante ele é.

Também destaca Virgílio Afonso da Silva (2003, pp. 610 e 611) que Alexy, como Dworkin, faz uma distinção qualitativa entre princípios e regras, contribuindo com o desenvolvimento da ideia de princípios como mandamentos de otimização. Alexy ainda realça a diferença entre regras e princípios no caso de colisão destes e conflito daquelas, remetendo à ideia de Dworkin.

Assevera Alexy (2014, pp. 90 e 91):

O ponto decisivo na distinção entre regras e princípios é que princípios são normas que ordenam que algo seja realizado na maior medida possível dentro das possibilidades jurídicas e fáticas existentes. Princípios são, por conseguinte, mandamentos de otimização, que são caracterizados por poderem ser satisfeitos em graus variados e pelo fato de que a medida devida de sua satisfação não depende somente das possibilidades fáticas, mas também das possibilidades jurídicas. O âmbito das possibilidades jurídicas é determinado pelos princípios e regras colidentes.

Já as regras são normas que são sempre ou satisfeitas ou não satisfeitas. Se uma regra valer, então, deve se fazer exatamente aquilo que ela atinge; nem mais, nem menos. Regras contêm, portanto, determinações no âmbito daquilo que é fática e juridicamente possível. Isso significa que a distinção entre regras e princípios é uma distinção qualitativa, e não de grau. Toda norma é ou uma regra ou um princípio.

\section{$[\ldots]$}

Um conflito entre regras somente pode ser solucionado se se introduz, em uma das regras, uma cláusula de exceção que elimine o conflito, ou se pelo menos uma das regras for declarada inválida. 
$[\ldots]$

As colisões entre princípios devem ser solucionadas de forma completamente diversa. Se dois princípios colidem - o que ocorre, por exemplo, quando algo é proibido de acordo com um princípio e, de acordo com o outro, permitido - , um dos princípios terá que ceder. Isso não significa, contudo, nem que o princípio cedente deva ser declarado inválido, nem que nele deverá ser introduzida uma cláusula de exceção. $\mathrm{Na}$ verdade, o que ocorre é que um dos princípios tem precedência em face do outro sob determinadas condições. Sob outras condições a questão da precedência pode ser resolvida de forma oposta. Isso é o que se quer dizer quando se afirma que, nos casos concretos, os princípios têm pesos diferentes e que os princípios com maior peso têm precedência. Conflitos entre regras ocorrem na dimensão da validade, enquanto as colisões entre princípios - visto que só princípios válidos podem colidir ocorrem para além dessa dimensão, na dimensão do peso.

Portanto, ressalta Virgílio Afonso da Silva (2003, pp. 610 e 611), a realização dos princípios, mandamentos de otimização, pode variar "de acordo com o caso concreto, ante a colisão surgida pela necessidade de realização de outro princípio. As regras, ao contrário, são "comandos de definição" (BARCELLOS, 2002, p. 51), pois "expressam deveres e direitos definitivos, ou seja, se uma regra é válida, então deve se realizar exatamente aquilo que ela prescreve". As regras, afirma Ana Paula de Barcellos (2002, p. 50) "têm estrutura biunívoca, aplicando-se com o modelo do 'tudo ou nada', popularizado por Ronald Dworkin. Isto é, dado seu substrato fático, as regras só admitem duas espécies de situação: ou são válidas e se aplicam ou não se aplicam por inválidas".

Por outro lado, na linha do pensamento de Alexy, para Virgílio Afonso da Silva (2003, pp. 612 a 627) não há apenas possibilidade de colisão aparente de princípios, como sugerem Inocêncio Mártires Coelho (2000, pp. 47 a 70) e Humberto Bergmann Ávila (1999, pp. 151 a 179), mas real, pois eles têm consequências abstratamente determinadas $^{444}$. Essa colisão, porém, se houver, resolve-se ao considerar o caso concreto, pois enquanto as regras expressam deveres definitivos, os princípios expressão deveres prima facie. Como doutrina Alexy, a colisão de regras exige ou a definição de uma cláusula de exceção (lex specialis derogat legi generali) ou, na impossibilidade, a

\footnotetext{
${ }^{444}$ Virgílio Afonso da Silva afirma, para exemplificar, que a liberdade de expressão é um princípio cuja otimização pode colidir com a otimização do direito à privacidade, também um princípio.
} 
declaração de invalidade de uma das regras (lex posterior derogat legi priori; lex superior derogat legi inferiori) (2014, pp. 92 e 93). A colisão de princípios, no entanto, exige a definição de relações condicionadas de precedência, pois, como mandamentos de otimização, impõe sua realização na maior medida possível. Assim, não é correto afirmar que um princípio sempre prevalece sobre outro, pois essa prevalência dependende de certas condições observadas no caso concreto ${ }^{445}$ (2014, pp. 94 a 99).

Entendemos - apesar da crítica manifestada por Virgílio Afonso da Silva quanto à adoção, pela doutrina brasileira, da teoria de Alexy em conjunto com a noção de "princípios" como normas fundamentais do sistema, por considerar as teorias incompatíveis $^{446}$ - possível aplicar a lição do professor da Universidade de Kiel para delimitar os limites de atuação do Conselho Nacional de Justiça no exercício de sua específica competência de zelar pela observância, no âmbito do Poder Judiciário, das normas (princípios e regras) insculpidas no art. 37 da Constituição Federal.

Assim, quanto aos princípios insertos na norma prevista no art. 37, caput, da Lei Maior (legalidade, impessoalidade, moralidade, publicidade e eficiência), compete ao Conselho Nacional de Justiça, no controle administrativo do Judiciário, verificar se os demais órgãos do Poder sujeitos à sua fiscalização, na sua atuação administrativa, pautaram-se pela busca da realização máxima possível de todos eles, diante das possibilidades fáticas e jurídicas presentes em cada caso concreto e, em caso de colisão, examinar se as condições apresentadas justificaram a prevalência de um ou mais deles sobre outros.

\footnotetext{
${ }^{445}$ Para ilustrar, Virgílio Afonso da Silva (2003, p. 619) apresenta o seguinte exemplo singelo: "João promete ir a festa de aniversário de seu amigo José. Entrementes fica João sabendo que seu outro amigo, Jorge, está extremamente doente e precisa de sua ajuda. Para João, tanto quanto cumprir as promessas feitas, ajudar um amigo também é um dever. Nesse caso concreto, contudo, não é possível cumprir ambos os deveres. Após ponderação, decide João ajudar seu amigo doente e não ir à festa de José. Isso não significa, porém, que 'cumprir promessas' tenha deixado de ser um dever para João. A constelação aqui é simples e clara: tanto o dever de cumprir promessas, como o dever de ajudar os amigos, são deveres prima facie. Isso significa que, diante das possibilidades do caso concreto, o dever pode não se revelar um dever definitivo, realizável. No caso concreto, o dever definitivo é aquele que é produto de uma ponderação".

446 Virgílio Afonso da Silva afirma que o conceito de "princípios" de Robert Alexy diverge do tradicionalmente utilizado na literatura jurídica brasileira, que os define como mandamentos nucleares ou fundamentais do sistema, concretizados pelas regras, pois, para Alexy, uma norma é um princípio em razão de sua estrutura normativa e não de sua fundamentalidade. Trata-se, assim, de um "conceito axiologicamente neutro e seu uso não expressa nenhuma opção por esta ou aquela disposição fundamental, nem por este ou aquele tipo de constituição" (2003, pp. 612 a 616 e 625 a 627). Em outro trabalho (2010, pp. 133 a 139), o autor critica o fenômeno que denomina de "sincretismo metodológico" consistente no trato, pela doutrina brasileira, dos diversos métodos de interpretação constitucional como se complementares fossem, apesar de ontologicamente inconciliáveis.
} 
Por outro lado, as normas previstas nos mencionados princípios também limitam a atuação do próprio Conselho Nacional de Justiça, que não pode deixar de buscar a máxima realização de todos esses "mandamentos de otimização" e, se determinada situação indicar a existência de colisão entre eles, optar pela prevalência daquele ou daqueles que melhor se justifique(m) no caso concreto.

Exemplo de atuação contrária do CNJ ao afirmado, no nosso sentir, foi apresentado neste trabalho ${ }^{447}$ : a Resolução CNJ no 185/2013, ao impor aos órgãos do Poder Judiciário a implantação integral do sistema eletrônico denominado "Processo Judicial Eletrônico PJe" para processamento das ações judiciais até o ano de 2018, malgrado desejar racionalizar a utilização de recursos orçamentários e uniformizar o sistema eletrônico para processos judiciais, atentou contra a autonomia dos tribunais que o próprio Conselho deveria zelar e ainda estabeleceu uma reserva de mercado, em afronta aos princípios da legalidade e da moralidade.

Quanto às regras concernentes à Administração Pública previstas nos diversos incisos e parágrafos do art. 37 da Constituição, observado o ensinamento de Alexy, deve-se primeiro esclarecer que, como referidas regras encontram-se insertas na Lei Maior vigente, todas expressam deveres definitivos e não se pode cogitar, em princípio, que qualquer uma delas não seja válida em razão de sua revogação (ab-rogação ou derrogação) por outra posterior (lex posterior derogat legi priori) ou superior (lex superior derogat legi inferiori) $^{448}$.

\footnotetext{
${ }^{447}$ Vide item 3.1.1.2.

${ }^{448}$ Não se pode olvidar, contudo, que diversas regras previstas no art. 37 da Constituição Federal tiveram seus textos alterados ou foram introduzidas por meio de emendas constitucionais. Logo, não se pode excluir a hipótese de que sejam "invalidadas" por declaração de inconstitucionalidade do ato do constituinte derivado. O STF já se pronunciou quanto à possibilidade de se reconhecer a inconstitucionalidade de uma emenda constitucional que afronte a Constituição originária. Nesse sentido, podem ser citadas as seguintes ementas:
}

Direito Constitucional e Tributário. Ação Direta de Inconstitucionalidade de Emenda Constitucional e de Lei Complementar. I.P.M.F. Imposto Provisorio sobre a Movimentação ou a Transmissão de Valores e de Créditos e Direitos de Natureza Financeira - I.P.M.F. Artigos 5., par. 2., 60, par. 4., incisos I e IV, 150, incisos III, "b", e VI, "a", "b", "c" e "d", da Constituição Federal. 1. Uma Emenda Constitucional, emanada, portanto, de Constituinte derivada, incidindo em violação a Constituição originaria, pode ser declarada inconstitucional, pelo Supremo Tribunal Federal, cuja função precípua é de guarda da Constituição (art. 102, I, "a", da C.F.). [...] (ADI 939, Relator(a): Min. SYDNEY SANCHES, Tribunal Pleno, julgado em 15/12/1993, DJ 18-03-1994);

EMENTA: MEDIDA CAUTELAR EM AÇÃO DIRETA DE INCONSTITUCIONALIDADE. ART. $2^{\circ}$ DA EMENDA CONSTITUCIONAL N ${ }^{\circ}$ 30, DE 13 DE SETEMBRO DE 2000, QUE ACRESCENTOU O ART. 78 AO ATO DAS DISPOSIÇÕES CONSTITUCIONAIS TRANSITÓRIAS. PARCELAMENTO DA LIQUIDAÇÃO DE PRECATÓRIOS PELA FAZENDA PÚBLICA. [...] 3. A eficácia das regras jurídicas produzidas pelo poder constituinte (redundantemente chamado de "originário") não está sujeita a nenhuma limitação normativa, seja de ordem material, seja formal, porque provém do exercício de um poder de fato ou suprapositivo. Já as normas produzidas pelo poder reformador, essas têm sua validez e eficácia condicionadas à legitimação que recebam da ordem constitucional. Daí a necessária obediência das emendas 
Logo, os órgãos do Judiciário devem atentar para o cumprimento dessas regras e cabe ao Conselho Nacional de Justiça zelar pela observância dos comandos nelas contidos.

Não é possível, dadas as restrições deste trabalho, analisar de forma pormenorizada cada um dos regramentos insertos nos vinte e dois incisos do art. 37 da Constituição, além daqueles constantes nos seus doze parágrafos.

Mas deve-se, ao menos, fixar as diretrizes para a atuação do Conselho Nacional de Justiça no que se refere à sua específica competência de zelar pela observância dessas regras que informam a atuação da Administração Pública, inclusive no âmbito do Poder Judiciário.

Neste ponto, cumpre destacar que não são todas as regras mencionadas no art. 37 da Carta Política cuja observância, no seio da administração do Poder Judiciário, deve ser zelada pelo CNJ. Isso porque o dispositivo constitucional contém regras que simplesmente não se aplicam ao Poder Judiciário, pois dirigidas a outros Poderes ou a entes da Administração Indireta, como aquelas previstas no art. 37, XVIII, XIX, XX e XXII, da Constituição Federal ${ }^{449}$.

Quanto às regras postas no art. 37 da Lei Maior que também devem ser observadas no âmbito da administração do Poder Judiciário, para delimitação da competência específica do Conselho Nacional de Justiça, valê-lo-emos, para trato do tema, do ensinamento de José Afonso da Silva quanto à eficácia das normas constitucionais.

Leciona José Afonso da Silva (2002, pp. 81 e 82) que não há normas constitucionais destituídas de eficácia ${ }^{450}$, pois todas

constitucionais às chamadas cláusulas pétreas. [...] (ADI 2356 MC, Relator(a): Min. NÉRI DA SILVEIRA, Relator(a) p/ Acórdão: Min. AYRES BRITTO, Tribunal Pleno, julgado em 25/11/2010, DJe-094 DIVULG 18-05-2011 PUBLIC 19-05-2011).

${ }^{449}$ Art. 37 (CF) [...]

XVIII - a administração fazendária e seus servidores fiscais terão, dentro de suas áreas de competência e jurisdição, precedência sobre os demais setores administrativos, na forma da lei;

XIX - somente por lei específica poderá ser criada autarquia e autorizada a instituição de empresa pública, de sociedade de economia mista e de fundação, cabendo à lei complementar, neste último caso, definir as áreas de sua atuação;

XX - depende de autorização legislativa, em cada caso, a criação de subsidiárias das entidades mencionadas no inciso anterior, assim como a participação de qualquer delas em empresa privada;

XXII - as administrações tributárias da União, dos Estados, do Distrito Federal e dos Municípios, atividades essenciais ao funcionamento do Estado, exercidas por servidores de carreiras específicas, terão recursos prioritários para a realização de suas atividades e atuarão de forma integrada, inclusive com o compartilhamento de cadastros e de informações fiscais, na forma da lei ou convênio.

${ }^{450}$ José Afonso da Silva (2002, pp. 65 e 66) esclarece que "eficácia” é um palavra com dois sentidos no Direito. Pode se referir a eficácia social, ou seja, à efetiva obediência à norma. Pode também aludir à eficácia jurídica da norma consistente "na capacidade de atingir os objetivos nela traduzidos, que vêm a ser, em última análise, realizar os ditames jurídicos objetivados pelo legislador”. Os sentidos, pois, são diversos. 
irradiam efeitos jurídicos, importando sempre uma inovação da ordem jurídica preexistente à entrada em vigor da constituição a que aderem e a nova ordenação instaurada. O que se pode admitir é que a eficácia de certas normas constitucionais não se manifesta na plenitude dos efeitos jurídicos pretendidos pelo constituinte enquanto não se emitir uma normação jurídica ordinária ou complementar executória, prevista ou requerida.

Na sequência, José Afonso da Silva (2002, pp. 82 a 87) discriminadas as normas constitucionais em três categorias: a) normas constitucionais de eficácia plena; b) normas constitucionais de eficácia contida; e, c) normas constitucionais de eficácia limitada ou reduzida.

As primeiras - normas constitucionais de eficácia plena - têm eficácia imediata, direta, são autoaplicáveis, logo, não necessitam de autorização legislativa ou complementação de seu alcance para produzir todos os seus efeitos jurídicos essenciais.

As normas constitucionais de eficácia contida também são autoaplicáveis, mas, por apresentarem conteúdo amplo, podem ter seu alcance restringido pelo legislador.

As últimas - normas constitucionais de eficácia limitada ou reduzida - são aquelas que "não produzem, com a simples entrada em vigor, todos os seus efeitos essenciais, porque o legislador constituinte, por qualquer motivo, não estabeleceu, sobre a matéria, uma normatividade para isso, deixando essa tarefa ao legislador ordinário ou a outro órgão do Estado". São divididas pelo autor em normas de princípio institutivo ("aquelas através das quais o legislador constituinte traça esquemas gerais de estruturação e atribuições de órgãos, entidades ou institutos, para que o legislador ordinário os estruture em definitivo, mediante lei", podendo sser impositivas ou facultativas, de acordo com a existência ou não de comando de obrigatoriedade do legislador ordinário complementá-las) e normas de princípio programático (que estabelecem orientações a serem cumpridas pelo legislador e pela Administração Pública e, por outro lado, impedem postura que infrinja seus preceitos).

"Uma norma pode ter eficácia jurídica sem ser socialmente eficaz, isto é, pode gerar certos efeitos jurídicos, como, por exemplo, o de revogar normas anteriores, e não ser efetivamente cumprida no plano social". 
No universo das diversas normas-regra ${ }^{451}$ previstas nos incisos e parágrafos do art. 37 da Lei Maior, podem ser encontradas as três categorias mencionadas, como a seguir será exemplificado.

A regra prevista no art. 37, III, da Carta Política ${ }^{452}$, que estabelece o prazo de validade de concurso público de até dois anos, admitindo sua prorrogação, uma vez, por igual período, é uma norma constitucional de eficácia plena. É completamente aplicável e seu alcance não necessitava ser integrado, tanto é que a Lei Federal $n^{\circ} 8112$, de 11 de dezembro de 1990, em seu art. 12, caput $^{453}$, limita-se a reproduzi-la ${ }^{454}$.

O regramento para preenchimento de cargos em comissão, assim declarados em lei de livre nomeação e exoneração (CF, art. 37, II, in fine), inserto no art. 37, V, da Lei Maior, com a redação dada pela Emenda Constitucional no 19, de 4 de junho de 1998, encerra hipótese de norma constitucional de eficácia contida. Segundo disposto no referido preceito, os cargos em comissão destinam-se apenas às atribuições de direção, chefia e assessoramento, devendo lei fixar casos, condições e percentuais mínimos para preenchimento deles por servidores de carreira. Trata-se, pois, de regra autoaplicável, pois permite que os cargos em comissão sejam ocupados por pessoas estranhas aos quadros do funcionalismo, desde que referidos cargos, porém, destinem-se somente às funções de direção, chefia e assesssoramento. Mas a eficácia dessa norma pode ser restringida (contida) pelo legislador infraconstitucional, ao fixar, em lei, requisitos para que um mínimo dos cargos em comissão seja preenchido por servidores de carreira.

E exemplo de norma constitucional de eficácia limitada no âmbito da Administração Pública encontra-se na disposição contida no art. 37, IX, da Constituição da República, que determina o estabelecimento, por lei, dos casos de contratação de pessoal por tempo determinado para atender a necessidade temporária de excepcional interesse público. A regra, para ser aplicada, depende de lei infraconstitucional integrativa, mas ao menos revela um comando negativo a ser observado pelo Administrador: não pode haver, em

${ }^{451}$ O termo "normas-regra" foi utilizado para se referir, observadas as posições de Dworkin e Alexy mencionadas por Virgílio Afonso da Silva, às regras que encerram deveres definitivos, em contraposição aos princípios ("normas-princípio") que expressão, como visto, deveres prima facie, mandamentos de otimização.

452 Art. 37 (CF) [...]

III - o prazo de validade do concurso público será de até dois anos, prorrogável uma vez, por igual período;

${ }^{453}$ Art. 12 (Lei $\mathrm{n}^{\mathrm{o}}$ 8.112/1990) O concurso público terá validade de até 2 (dois ) anos, podendo ser prorrogado uma única vez, por igual período.

${ }^{454}$ Sobre a referida regra, anota Fabrício Macedo Motta (2013, p. 832): “A redação do presente inciso bem demonstra que se está diante de uma regra, ou seja, de uma proposição normativa de baixo grau de abstração, suscetível de aplicação direta, limitadora da discricionariedade conferida à Administração Pública" 
regra, contratação de pessoal sem concurso público, admitindo-se-a apenas em caso de excepcional interesse público, temporariamente, e em hipóteses previamente anunciadas em lei "editada pela entidade contratadora, ou seja, lei federal ${ }^{455}$, estadual, distrital ou municipal, conforme a respectiva competência legislativa constitucional" (MORAES, 2013, p. 836).

O Conselho Nacional de Justiça, enquanto órgão responsável pelo controle da atuação administrativa e financeira do Judiciário, deve observar e deve zelar pela observância, no seio do Poder, de todos os comandos eficazes que podem ser extraídos das regras trazidas no art. 37 da Constituição Federal.

Quanto às normas constitucionais de eficácia plena, dada sua autoaplicabilidade, bastará ao Conselho verificar seus comandos e cotejá-los com os atos da Administração do Poder Judiciário. É evidente, por exemplo, que um edital que estabeleça prazo de validade de concurso público para servidor de órgão do Poder Judiciário superior a dois anos viola a disposição prevista no art. 37, III, da Carta Política, competindo ao CNJ invalidá-lo.

No que se refere às normas de eficácia contida insertas no art. 37 da Constituição Federal, caso não haja lei que venha a restringir seu alcance, cabe ao Conselho Nacional de Justiça observar se eventual ato de administração praticado por órgão do Poder Judiciário contraria a regra constitucional em seu conteúdo amplo. Caso haja lei que restrinja a disposição constitucional, o CNJ deverá verificar se o ato realizado se coaduna com o regramento constitucional e com as restrições trazidas pela lei.

Em relação às regras previstas no art. 37 da Lei Maior classificadas, na visão de José Afonso da Silva, como normas de eficácia limitada, compete ao CNJ, na ausência de lei que densifique seu conteúdo, verificar se o ato da Administração de órgão do Judiciário submetido ao seu controle infringe seus preceitos. Se a regra constitucional tiver sido complementada por lei, o Conselho também deverá analisar se o ato praticado está de acordo com o preceito constitucional e com seu complemento legal.

Entendemos que não cabe ao $\mathrm{CNJ}$, porém, mesmo no exercício do poder normativo primário que lhe foi reconhecido pelo Supremo Tribunal Federal no julgamento da ADC $n^{\circ}$ $12^{456}$, Relator Ministro Ayres, na ausência de lei, estabelecer restrições às regras de eficácia contida relativas à Administração Pública trazidas pela Constituição Federal ou integrar aquelas de eficácia limitada.

\footnotetext{
${ }^{455}$ A Lei n ${ }^{\circ} 8.745$, de 9 de dezembro de 1993, dispõe, no âmbito da União, sobre a contratação de pessoal por tempo determinado de para atender a necessidade temporária de excepcional interesse público.

${ }^{456}$ Vide item 3.1.8.
} 
Com efeito, o Legislador Constituinte determinou, nas disposições previstas nos diversos incisos e parágrafos do art. 37 da Carta da República, que as restrições ou integrações das regras constitucionais concernentes à Administração Pública fossem tratadas em lei.

O termo "lei", no caso, deve ser entendido em seu sentido restrito, ou seja, ato normativo editado pelo Parlamento de acordo com o procedimento constitucionalmente prescrito que implique o exercício de poderes legislativos (Canotilho, 2003, p. 721). Não pode ser interpretado de forma ampla, no sentido de ordenamento jurídico na sua globalidade ou no sentido de norma jurídica, independentemente da fonte normativa ${ }^{457}$, porque a constitucionalização das normas da Administração Pública visou delimitar o campo de atuação do Administrador Público e permitir um alargamento do controle jurisdicional dos seus atos (MORAES, 2013, pp. 764 e 765). Somente a lei, no sentido restrito mencionado, como expressão da vontade geral, pode, pois, restringir ou integrar as regras constitucionais relativas a Administração Pública ${ }^{458}$.

Afinal, a interpretação em sentido contrário, ou seja, admitir-se que outros atos normativos estabelecem as restrições ou integrassem as regras constitucionais previstas no art. 37 da Lei Maior, esvaziaria o conteúdo desses preceitos constitucionais de eficácia contida ou limitada, pois permitiria que o próprio Administrador regulasse seu campo de atuação. Se o própria Administração Pública pudesse, por exemplo, através de ato normativo próprio, estabelecer os casos de contratação de pessoal por tempo determinado para atender a necessidade temporária de excepcional interesse público, o comando constitucional (evitar contratação de pessoal sem concurso público) poderia ser

\footnotetext{
${ }^{457}$ Sobre os diversos sentidos do termo "lei" na Constituição Portuguesa de 1976, em lição que pode ser aplicada à Ordem Constitucional Brasileira, observadas suas peculiaridades, cumpre destacar a lição de J. J. Gomes Canotilho (2003, pp. 720 e 721).

${ }^{458}$ Essa leitura aparenta ser tranquila para Eros Roberto Grau (2005, pp. 240 a 247), pois entende que o princípio da legalidade insculpido no art. $5^{\circ}$, II, da Constituição deve ser tomado em termos relativos, porque contempla tanto a reserva de lei quanto a reserva da norma. Na reserva da lei, há vinculação da Administração às definições da lei, expressão da função legislativa. Na reserva da norma, há vinculação da Administração às definições decorrentes de lei, fixadas em virtude dela. Neste caso - reserva da norma, que pode ser legal, regulamentar ou regimental - nada impede "a atribuição, explícita ou implícita, ao Executivo para, no exercício de função normativa, definir obrigação de fazer e não fazer que se imponha aos particulares - e os vincule". Eros Roberto Grau ainda pontifica que o Legislador Constituinte, quando pretendeu conferir termos absolutos ao princípio da reserva de lei na Constituição, fê-lo de forma explícita, como no art. $5^{\circ}$, XXXIX, no art. 150, I, e no art. 170, parágrafo único, por ser inconcebível que o texto constitucional contenha "disposição despicienda - verba cum effectu sunt accipienda". Adotado esse pensamento, pois, como nas regras constantes de alguns incisos do art. 37 da Carta Política há expressa menção à necessidade de "lei", pela mesma razão deve-se considerar que houve, nas hipóteses, opção pela "reserva de lei", ou seja, as matérias somente podem ser tratadas por lei, "entendida como tipo específico de ato legislativo" (GRAU, 2005, p. 247).
} 
enfraquecido, com a regulamentação de diversas situações para aplicação de regra excepcional.

Assim, cabe ao Poder Legislativo (e não à Administração Pública), através da edição de lei, estabelecer restrições e integrar as regras previstas no art. 37 da Constituição Federal.

Como a função administrativa não se restringe ao Poder Executivo, mas também é exercida, de forma atípica, no seio dos outros Poderes ${ }^{459}$, essa interpretação também deve observada no que tange à Administração Pública no âmbito do Poder Judiciário e pelo seu órgão nacional de controle administrativo.

Assim, reitera-se, não compete ao Conselho Nacional de Justiça, órgão de atuação administrativa, ainda que através do exercício de poder normativo que lhe foi reconhecido pelo Supremo Tribunal Federal na $\operatorname{ADC} n^{0} 12$, na ausência de lei, regular as matérias tratadas nas disposições previstas nos incisos e parágrafos do art. 37 da Consituição Federal aplicáveis no âmbito do Poder Judiciário. Não lhe cabe, por exemplo (considerando os dispositivos constitucionais mencionados - CF, art. 37, V e IX), através de ato normativo próprio, na falta de lei, estabelecer os casos, condições e percentuais mínimos para preenchimento de cargos em comissão por servidores de carreira ${ }^{460}$ ou fixar as hipóteses temporárias e de excepcional interesse público para a contratação de pessoal sem concurso público no âmbito do Poder Judiciário ${ }^{461462}$.

\footnotetext{
${ }^{459}$ Como ressalta Carlos Ayres Britto (2013, pp. 818 e 819), "embora a cabeça do art. 37 da Constituição Federal deixe literalmente posto que a 'administração pública' [...] é algo próprio de cada um dos Poderes orgânicos da União, dos Estados. do Distrito Federal e dos Municípios, o fato é que a matéria está versada no interior do segmento normativo respeitante à organização do Estado Federal como um todo. Não no título alusivo à organização daqueles Poderes estatais (título de n. IV). [...] As coisas se explica. Se a administração pública é algo comum aos três Poderes do Estado, e não uma particularidade desse ou daquele Poder, então que a matéria faça parte (como efetivamente faz) da realidade que abarca todos eles, sem exceção: a realidade do Estado. Que já é uma realidade-continente, enquanto cada qual dos Poderes não passa de uma realidade-conteúdo".

${ }^{460}$ No item 2.3.5.2.1 deste trabalho foi mencionado que a Resolução CNJ n ${ }^{\circ}$ 88/2009 determinou aos Tribunais de Justiça dos Estados que ainda não tivessem regulamentado os incisos IV e V do art. 37 da Constituição Federal, que encaminhassem projetos de lei para regulamentação da matéria, com observância do percentual de pelo menos 50\% (cinquenta por cento) dos cargos em comissão serem destinados a servidores das carreiras judiciárias (art. $2^{\circ}, \S 2^{\circ}$ ). Nota-se que o Conselho Nacional de Justiça absteve de regular diretamente a matéria, pois, como disposto na Constituição Federal, deve ser tratada por lei. Mas, como exposto, também não poderia o CNJ ter imposto aos tribunais o envio de projetos de lei para adequação das legislações locais às disposições da resolução mencionada, pois a iniciativa de lei é ato político e, portanto, não pode sujeitar-se ao controle do Conselho.

${ }^{461}$ A contratação de pessoal por tempo determinado para atender a necessidade temporária de excepcional interesse público é improvável no Judiciário, pois o Supremo Tribunal Federal, no julgamento da ADI $n^{\circ}$ 2987, Relator Ministro Sepúlveda Pertence, decidiu ser inconstitucional essa prática para a admissão de servidores para funções burocráticas ordinárias e permanentes, habitualmente realizadas nos órgãos desse Poder. Segue a ementa do julgado:
} 
Em síntese, a norma prevista na primeira parte do art. 103-B, $\S 4^{\circ}$, II, primeira parte, da Constituição Federal prescreve competir especificamente ao Conselho Nacional de Justiça zelar pela observância, no exercício da atípica função administrativa pelos órgãos do Judiciário, dos princípios e das regras contidas no art. 37 do Texto Constitucional. Quanto aos princípios constitucionais que regem a Administração Pública (legalidade, impessoalidade, moralidade, publicidade e eficiência), mencionados na cabeça do dispostivo constitucional em exame, cabe ao Conselho, no controle administrativo do Judiciário, verificar se os demais órgãos do Poder sujeitos à sua fiscalização pautaram-se, na sua atuação, pela busca da realização máxima possível de todos eles, diante das possibilidades fáticas e jurídicas presentes em cada caso concreto e, na hipótese de colisão de princípios, examinar se as condições apresentadas justificaram a prevalência de um ou mais deles sobre outros. Por outro lado, as normas previstas nos mencionados princípios também limitam a atuação do próprio Conselho Nacional de Justiça, que não pode deixar de buscar a máxima realização de todos esses "mandamentos de otimização" e, se determinada situação indicar a existência de colisão entre eles, optar pela prevalência

Servidor público: contratação temporária excepcional (CF, art. 37, IX): inconstitucionalidade de sua aplicação para a admissão de servidores para funções burocráticas ordinárias e permanentes (ADI 2987, Relator(a): Min. SEPÚLVEDA PERTENCE, Tribunal Pleno, julgado em 19/02/2004, DJ 02-04-2004).

${ }^{462}$ Inconcebível, por outro lado, é a contratação temporária de magistrados, pois a norma inserta no art. 93, I, da Constituição Federal impõe que o ingresso na carreira, no cargo inicial de juiz substituto, ocorrerá mediante concurso público de provas e títulos, exigindo-se do bacharel em direito, no mínimo, três anos de atividade jurídica, admitido-se o ingresso diretamente nos tribunais, por nomeação, nas hipóteses do "quinto constitucional" (CF, art. 94), nas composições do STF (CF, art. 101), do STJ (CF, art. 104), do TST (art. 111-A) e do STM (CF, art. 123), dos membros juristas no TSE (CF, art. 119, II) e nos TREs (CF, art. 120, III) e de parte dos Conselheiros do CNJ (CF, art. 103-B, X, XI, XII e XIII). Ademais, com exceção dos advogados nomeados para os tribunais eleitorais, e dos Conselheiros do CNJ não originários da própria Magistratura ou do Ministério Público, os magistrados gozam da garantia da vitaliciedade prevista no art. 95, I, da Carta (é certo que a vitaliciedade é, no primeiro grau, adquirida após dois anos de exercício, mas, mesmo antes de decorrido esse prazo, a perda do cargo, depende de deliberação do tribunal a que o juiz estiver vinculado, em regular processo administrativo e assegurada a ampla defesa). Apesar de não haver registro da ocorrência desse fato (tentativa de contratação temporária de Magistrados), o STF, no julgamento da ADI n ${ }^{\circ} 2229$, Relator Ministro Carlos Velloso, já decidiu ser inconstitucional lei estadual que autorizou a contratação temporária de defensores públicos, cuja carreira é também constitucionalmente delineada $(\mathrm{CF}$, art. 134). Segue a ementa do acórdão:

CONSTITUCIONAL. ADMINISTRATIVO. SERVIDOR PÚBLICO: DEFENSOR PÚBLICO: CONTRATAÇÃO TEMPORÁRIA. C.F., art. 37, II e IX. Lei 6.094, de 2000, do Estado do Espírito Santo: inconstitucionalidade. I. - A regra é a admissão de servidor público mediante concurso público: C.F., art. 37, II. As duas exceções à regra são para os cargos em comissão referidos no inciso II do art. 37, e a contratação de pessoal por tempo determinado para atender a necessidade temporária de excepcional interesse público. CF, art. 37, IX. Nessa hipótese, deverão ser atendidas as seguintes condições: a) previsão em lei dos cargos; b) tempo determinado; c) necessidade temporária de interesse público; d) interesse público excepcional. II. Lei 6.094/2000, do Estado do Espírito Santo, que autoriza o Poder Executivo a contratar, temporariamente, defensores públicos: inconstitucionalidade. III. - Ação direta de inconstitucionalidade julgada procedente (ADI 2229, Relator(a): Min. CARLOS VELlOSO, Tribunal Pleno, julgado em 09/06/2004, DJ 25-062004). 
daquele(s) que melhor se justifique(m) no caso concreto. Quanto às regras basilares da Administração Pública insertas nos diversos incisos e parágrafos do art. 37 da Carta Política, compete ao CNJ primeiro verificar, em relação a cada uma delas, se são aplicáveis ao Judiciário. Nesse caso, o Colegiado Administrativo, deve observar e deve zelar pela observância, no seio do referido Poder, de todos os comandos eficazes que podem ser extraídos dessas regras. Tratando-se de regra que encerra norma de eficácia plena, dada sua autoaplicabilidade, bastará ao Conselho verificar seus comandos e cotejá-los com os atos da administração do Poder Judiciário. No caso de regra que traduz norma de eficácia contida, caso não haja lei que venha a restringir seu alcance, cabe ao Conselho Nacional de Justiça observar se eventual ato de administração praticado por órgão do Poder Judiciário a contraria em seu conteúdo amplo. Se já existir lei que restrinja a disposição constitucional, o CNJ deverá verificar se o ato realizado se coaduna com o regramento constitucional e com as restrições trazidas pela lei. Quanto à regra que consubstancie norma de eficácia limitada, cabe ao Conselho, na ausência de lei que densifique seu conteúdo, verificar se o ato da administração de órgão do Judiciário submetido ao seu controle infringe seus preceitos. Se a regra constitucional tiver sido complementada por lei, o CNJ deverá analisar se o ato praticado está de acordo com o preceito constitucional e com seu complemento legal. Não compete ao Conselho Nacional de Justiça, porém, na ausência de lei, por ato normativo próprio, em substituição à atuação do Poder Legislativo, estabelecer restrições às regras de eficácia contida ou integrar aquelas de eficácia limitada mencionadas no art. 37 da Constituição Federal.

\subsubsection{Controle da legalidade dos atos administrativos praticados por membros ou órgãos do Poder Judiciário.}

Estabelece a norma prevista na segunda parte do art. 103-B, § 4 , II, da Constituição também competir especificamente ao Conselho Nacional de Justiça "apreciar, de ofício ou mediante provocação, a legalidade dos atos administrativos praticados por membros ou órgãos do Poder Judiciário".

Trata-se de ampla competência de controle administrativo atribuída ao Colegiado que, pode, ao exercê-la, desconstituir, rever ou fixar prazo para adoção das "providências necessárias ao exato cumprimento da lei”, correspondente ao poder de autotutela conferido 
à Administração, como um todo, para controle de seus próprios atos, consagrado nas Súmulas $n^{\text {os }} 346^{463}$ e $473^{464}$ do Supremo Tribunal Federal.

Ressalta ainda a regra constitucional que o exercício desse controle dá-se "sem prejuízo da competência do Tribunal de Contas da União".

Como destacado, esse controle exercido pelo CNJ não se restringe apenas aos atos administrativos propriamente ditos, podendo atingir outros atos de administração, desde que realizados por membros ou órgãos do Judiciário. Por outro lado, apesar de amplo, não é irrestrito, pois não alcança todos os atos operados no Poder ${ }^{465}$.

Ademais, da redação da regra constitucional em exame, extraem-se quatro indagações relacionadas a limites de atuação do Conselho Nacional de Justiça no exercício dessa competência específica:

a) Existe limite temporal para o CNJ apreciar a legalidade dos atos administrativos praticados por membros ou órgãos do Poder Judiciário?

b) Pode o $\mathrm{CNJ}$ exercer controle sobre o ato discricionário praticado no âmbito do Poder Judiciário?

c) Está o CNJ sujeito às deliberações do Tribunal de Contas da União?

d) Pode o CNJ exercer controle de constitucionalidade de lei ou de ato normativo?

Dada a complexidade para respondê-las, cada uma dessas questões será analisada em itens distintos.

\subsubsection{Limite temporal para atuação do CNJ}

A Constituição Federal não estabelece qualquer para prazo para o CNJ rever os atos administrativos praticados por membros ou órgãos do Poder Judiciário.

Mas, como adverte Flávio Pansieri (2013, p. 1438), “os postulados da segurança jurídica, da boa-fé objetiva e da proteção da confiança, enquanto expressão do Estado Democrático de Direito", que também se projetam nas relações jurídicas de direito público, indicam que deve haver limite temporal para a revisão dos atos praticados pela Administração Pública, o que também deve ser aplicado "no contexto das decisões do

\footnotetext{
${ }^{463}$ Súmula no 346 (STF): A Administração Pública pode declarar a nulidade dos seus próprios atos.

${ }^{464}$ Súmula $n^{\circ} 473$ (STF): A Administração pode anular seus próprios atos, quando eivados de vícios que os tornam ilegais, porque deles não se originam direitos; ou revogá-los, por motivo de conveniência ou oportunidade, respeitados os direitos adquiridos, e ressalvada, em todos os casos, a apreciação judicial.

${ }^{465}$ Vide item 2.3.5.2.
} 
CNJ". Assim, "a regra constitucional e legal é a prescritibilidade do poder de revisão de atos no Estado brasileiro, ressalvadas as ações de ressarcimento do erário quando o ato praticado for ilícito, conforme previsão constitucional”.

De fato, como consta na ementa do voto vencedor do Ministro Napoleão Nunes Maia Filho no julgamento do Recurso em Mandado de Segurança n 24430 pela Quinta Turma do Superior Tribunal de Justiça, a invalidação de um ato administrativo ilegal nem sempre é a melhor solução ao interesse público, pois é necessário limitar, temporalmente, em prol da segurança jurídica, a instabilidade surgida do poder de autotutela do Estado ${ }^{466}$.

Assim, na ausência de prazo estabelecido na Lei Maior, a melhor solução é a aplicação do limite temporal de cinco anos estabelecido no art. 54, caput, da Lei no 9.784,

\footnotetext{
${ }^{466}$ Segue a ementa do julgado:

RECURSO ORDINÁRIO EM MANDADO DE SEGURANÇA. ISONOMIA SALARIAL CONCEDIDA PELO PODER PÚBLICO COM BASE EM PARECER DA PROCURADORIA-GERAL DO ESTADO DO ACRE. VERBA DE REPRESENTAÇÃO CONFERIDA AOS PERITOS CRIMINAIS DESDE 1993. SUPRESSÃO POR AUSÊNCIA DE PREVISÃO LEGAL. PREPONDERÂNCIA DO PRINCÍPIO DA SEGURANÇA JURÍDICA E DA RAZOABILIDADE. CONVALIDAÇÃO DOS EFEITOS JURÍDICOS. INTERREGNO DE MAIS DE DEZ ANOS. REDUTIBILIDADE SIGNIFICATIVA DOS PROVENTOS. RECURSO ORDINÁRIO PROVIDO.

1. O poder-dever da Administração de invalidar seus próprios atos encontra limite temporal no princípio da segurança jurídica, pela evidente razão de que os administrados não podem ficar indefinidamente sujeitos à instabilidade originada do poder de autotutela do Estado, e na convalidação dos efeitos produzidos, quando, em razão de suas conseqüências jurídicas, a manutenção do ato atenderá mais ao interesse público do que sua invalidação.

2. A infringência à legalidade por um ato administrativo, sob o ponto de vista abstrato, sempre será prejudicial ao interesse público; por outro lado, quando analisada em face das circunstâncias do caso concreto, nem sempre a sua anulação será a melhor solução. Em face da dinâmica das relações jurídicas sociais, haverá casos em que o próprio interesse da coletividade será melhor atendido com a subsistência do ato nascido de forma irregular.

3. O poder da Administração, dest'arte, não é absoluto, na seara da invalidação de seus atos, de forma que a recomposição da ordem jurídica violada está condicionada primordialmente ao interesse público. O decurso do tempo ou a convalidação dos efeitos jurídicos, em certos casos, é capaz de tornar a anulação de um ato ilegal claramente prejudicial ao interesse público, finalidade precípua da atividade exercida pela Administração.

4. O art. 54 da Lei 9.784/99, aplicável analogicamente ao presente caso, funda-se na importância da segurança jurídica no domínio do Direito Público, estipulando o prazo decadencial de 5 anos para a revisão dos atos administrativos viciosos (sejam eles nulos ou anuláveis) e permitindo, a contrario sensu, a manutenção da eficácia dos mesmos, após o transcurso do interregno mínimo quinquenal, mediante a convalidação ex ope temporis, que tem aplicação excepcional a situações típicas e extremas, assim consideradas aquelas em que avulta grave lesão a direito subjetivo, sendo o seu titular isento de responsabilidade pelo ato eivado de vício.

5. A efetivação do ato que reconheceu a isonomia salarial entre as carreiras de Perito Legal e Delegado de Polícia do Estado do Acre, com base apenas em parecer da Procuradoria-Geral do Estado, e o transcurso de mais de 5 anos, por inusitado que se mostre, consolidou uma situação fática para a qual não se pode fechar os olhos, vez que produziu consequências jurídicas inarredáveis. Precedente do Pretório Excelso.

6. Recurso Ordinário provido, para cassar o ato que suprimiu a verba de representação percebida pelos recorrentes. (RMS 24430/AC, Rel. Ministro NAPOLEÃO NUNES MAIA FILHO, QUINTA TURMA, julgado em 03/03/2009, DJe 30/03/2009)
} 
de 29 de janeiro de $1999^{467}$ para a revisão de atos administrativos pelo Conselho Nacional de Justiça, salvo comprovada má-fé.

Nessa linha decidiu monocraticamente o Ministro Marco Aurélio Mello, ao conceder liminar no Mandado de Segurança $n^{\circ}$ 29970, impetrado perante o Supremo Tribunal Federal contra a decisão proferida pelo Conselho Nacional de Justiça no Procedimento de Controle Administrativo $\mathrm{n}^{\mathrm{o}}$ 002363-72.2009.2.00.000, que invalidou ato administrativo que implicou de nomeação da impetrante como escrivã depois de mais de dez anos.

Em suma, para segurança jurídica ${ }^{468}$, deve ser considerado o prazo de cinco anos estabelecido no art. 54, caput, da Lei no 9.784, de 29 de janeiro de 1999 como limite

${ }^{467}$ Art. 54 (Lei no 9.784/1999). O direito da Administração de anular os atos administrativos de que decorram efeitos favoráveis para os destinatários decai em cinco anos, contados da data em que foram praticados, salvo comprovada má-fé.

${ }^{468}$ A segurança jurídica sempre foi uma das preocupações do homem na formação e desenvolvimento da sociedade e do Estado. Segurança tanto no aspecto individual quanto naquele relativo às relações do homem com o próprio homem na vida social, ou ainda do homem em face do Estado. Segue uma síntese das concepções filosóficas e políticas de três clássicos pensadores sobre o tema.

Para Thomas Hobbes (1979, p. 32) (“o homem é o lobo do homem") o ser homem é mal e tende a viver isolado. No entanto, a possibilidade de uma "guerra de todos contra todos" leva o homem, por medo e para garantir sua própria existência, a aceitar viver em sociedade e ceder seus direitos ao Estado, que se apodera dos poderes sociais e limita a conduta dos indivíduos, concedendo-lhes somente alguns direitos, para garantia da segurança e a paz.

John Locke (1998, p. 37) "todos os homens são passíveis de errar; e a maior parte deles é, em muitos aspectos, por paixão ou interesse tentada a fazê-lo") doutrina que o homem, em seu estado natural, reconhece e respeita a existência de direitos naturais dos demais seres humanos (vida, igualdade, liberdade, propriedade etc), mas concorda em viver em sociedade e sob autoridade para preservar esses direitos (segurança) contra eventuais impulsos malévolos ou egoístas de outros homens.

Segundo Rosseau (2011, p. 21) (“o homem nasceu livre e, não obstante, está acorrentado em toda a parte”), o homem é naturalmente bom. A sociedade que o degenera. No entanto, o homem livre (estado natural), devido a sua limitada capacidade de sobrevivência individual, aceita viver em sociedade (estado civil) para aprimorar sua existência. Assim, abre mão de sua liberdade natural e se submete, espontaneamente, à vontade geral, que limita seus comportamentos, mas garante, através de regras de conduta, a ordem e a igualdade (segurança).

O elemento "segurança", com o surgimento, em oposição ao Estado Absolutista e para limitação do poder estatal, do Estado de Direito (Rechtsstaat - expressão primeiro cunhada pelo jurista alemão Robert von Mohl em sua obra Die deutsche Polizeiwissenschaft nach den Grundsätzen des Rechtsstaates (Tübingen, 1833)) caracterizado, como ensina Manoel Gonçalves Ferreira Filho, pela ausência de um poder governamental arbitrário, a igualdade de todos perante a lei e a inserção, na Constituição, de direitos individuais - ganhou corpo com a consagração do princípio da segurança jurídica.

A conduta humana e as relações em sociedade, no Estado de Direito, devem ser permeadas de estabilidade e segurança, para garantia da convivência pacífica. Pelo princípio da segurança jurídica, o Estado, cujo poder é limitado, deve agir de acordo com as regras vigentes, sem violar direitos individuais. Por outro lado, as relações entre os indivíduos não podem ser alteradas de forma imprevisível pelo Estado, maculando a legalidade e a igualdade.

Afirma J. J. Gomes Canotilho (2003, 257): “o homem necessita de segurança para conduzir, planificar e conformar autônoma e responsavelmente a sua vida. Por isso, desde cedo se consideravam os princípios da segurança jurídica e da proteção à confiança como elementos constitutivos do Estado de direito. Estes dois princípios - segurança jurídica e proteção da confiança - andam estreitamente associados, a ponto de alguns autores considerarem o princípio da proteção de confiança como um subprincípio ou como uma dimensão específica da segurança jurídica. Em geral, considera-se que a segurança jurídica está conexionada com elementos objetivos da ordem jurídica - garantia de estabilidade jurídica, segurança de orientação e realização do direito - enquanto a proteção da confiança se prende mais com as componentes subjectivas da 
temporal para a revisão de atos administrativos praticados por membros ou órgãos do Poder Judiciário pelo Conselho Nacional de Justiça, salvo comprovada má-fé.

\subsubsection{Controle sobre o ato discricionário}

Como destaca Alexandre de Moraes (2013b, pp. 541 a 543), enquanto na "função correicional e disciplinar dos membros, órgãos e serviços do Poder Judiciário, o Conselho atua como órgão administrativamente hierarquicamente superior, podendo analisar tanto a legalidade quanto o mérito de eventuais faltas funcionais", no exercício do controle dos atos administrativos (em sentido amplo) praticados por membros ou órgãos do Poder Judiciário, a atuação do $\mathrm{CNJ}$ pode sofrer restrições.

Pontua o autor que o controle do Conselho é pleno em relação aos atos vinculados, pois, como a lei determina todos os seus elementos, "inexiste vontade subjetiva da administração dos membros ou órgãos dos Tribunais na sua edição".

Quanto aos atos administrativos discricionários, aqueles em que o administrador pode, por conveniência e oportunidade, observando o que melhor atende ao interesse público, optar entre hipóteses legais e moralmente admissíveis, o CNJ, em regra, somente poderá analisar a legalidade e a moralidade dos realizados, pois "é a própria lei que, explícita ou implicitamente, concede maior liberdade aos membros ou órgãos dos Tribunais, permitindo-lhes a escolha da conveniência e oportunidade" (MORAES, 2013b, p. 542) para a sua edição.

segurança, designadamente a calculabilidade e previsibilidade dos indivíduos em relação aos efeitos jurídicos dos actos".

Costuma-se afirmar que, na Constituição, o princípio da segurança jurídica, apesar de não explicitamente mencionado, está disciplinado dentre os direitos e garantias fundamentais, consagrado na norma prevista no art. 5', XXXVI, o qual determina que "a lei não prejudicará o direito adquirido, o ato jurídico perfeito e a coisa julgada". Mas, como pondera André Ramos Tavares (2013, pp. 619 e 620), o princípio em foco tutela uma gama maior de direitos. Assim, assinala o doutrinador: "um direito à segurança jurídica, em sentido amplo, poderá abranger: i) a garantia do direito adquirido, ato jurídico perfeito e coisa julgada; ii) a garantia contra restrições legislativas dos direitos fundamentais (proporcionalidade) e, em particular, contra a retroatividade de leis punitivas; iii) o devido processo legal e o juiz natural; iv) a garantia contra a incidência do poder reformador da Constituição em cláusulas essenciais; v) o direito contra a violação dos direitos; vi) o direito à efetividade dos direitos previstos e declarados solenemente; vii) o direito contra medidas de cunho retrocessivo (redução ou supressão de posições jurídicas já implementadas); viii) a proibição do retrocesso em matéria de implementação de direitos fundamentais; ix) o direito à proteção da segurança pessoal, social e coletiva; $\mathrm{x}$ ) o direito à estabilidade máxima da ordem jurídica e da ordem constitucional" (OBS.: trecho do texto deste item foi originalmente apresentado aos Professores Drs. Manoel Gonçalves Ferreira Filho, Elival da Silva Ramos, Monica Herman Salem Caggiano, Fernando Dias Menezes de Almeida, Fernanda Dias Menezes de Almeida, José Levi Mello do Amaral Júnior e Roger Stiefelmann Leal como parte do trabalho de conclusão denominado "A Segurança Jurídica e as Questões Institucionais Pós 88" referente à disciplina "Princípios Fundamentais de Direito Constitucional", do Curso de pós-graduação da Faculdade de Direito da Universidade de São Paulo em novembro de 2012). 
Assim, ressalta o doutrinador (MORAES, 2013b, pp. 543 e 544):

\begin{abstract}
Nos atos administrativos discricionários expedidos pelo Poder Judiciário, a opção conveniente e oportuna deve ser feita legal e moralmente pelos membros ou órgãos dos Tribunais, ou seja, somente na legalidade e na moralidade que a oportunidade deve ser apreciada pelo Conselho Nacional de Justiça. Consequentemente, não poderá o Conselho Nacional de Justiça invadir a legítima escolha feita pelos órgãos administrativos dos Tribunais, entre as opções legalmente reservadas para a edição do ato discricionário, de maneira a, simplesmente, alterar a opção licitamente realizada, sob pena de atentar contra a independência dos Tribunais.
\end{abstract}

Mas, salienta que "não existe, porém, nenhum ato absolutamente discircionário, pois tal fato converter-se-ia em arbitrariedade". Assim, mesmo um ato administrativo discricionário, ao ser editado, "deve respeito aos seus elementos de competência, forma e finalidade; bem como a veracidade dos pressupostos fáticos para a sua edição (motivo)" (MORAES, 2013b, p. 542).

O Conselho Nacional de Justiça, pois, nas hipóteses de desvio de poder e naquelas em que os motivos determinantes para realização do ato divorciam-se da realidade, poderá exercer controle do ato discricionário (MORAES, 2013b, p. 544)

Segundo Celso Antônio Bandeira de Mello (2008, p. 56), "entende-se por desvio de poder a utilização de uma competência em desacordo com a finalidade que lhe preside a instituição".

Há duas modalidades de desvio de poder. $\mathrm{Na}$ primeira, pratica-se um ato administrativo baseado em uma competência em abstrato mas busca-se uma finalidade estranha ao interesse público. $\mathrm{Na}$ segunda, também com fundamento em competência abstrata, busca-se, na realização do ato, uma finalidade pública diversa da própria da competência manejada (MELLO, 2008, pp. 58 e 59). Presentes essas situações, admissível o controle do ato discricionário realizado no seio de órgão do Poder Judiciário pelo Conselho Nacional de Justiça.

$\mathrm{O}$ ato discricionário praticado no Judiciário por motivo dissociado dos fatos ou do direito que o sustentam também fica sujeito ao controle do Colegiado Administrativo.

Leciona Celso Antônio Bandeira de Mello (2008, pp. 86 e 87) : 
Motivo [...] é a situação de direito ou de fato que autoriza ou exige a prática do ato. [...] Motivo legal é a previsão abstrata de uma situação fática, empírica, contida na regra de direito, ao passo que o motivo de fato é a própria situação fática, reconhecível no mundo empírico, em vista da qual o ato é praticável. Evidentemente, para validade do ato, impende que haja perfeita subsunção do motivo de fato ao motivo de direito; vale dizer, cumpre que a situação do mundo fático, tomada como base do ato, corresponda com exatidão ao motivo legal.

Assim, pela "teoria dos motivos determinantes", a "validade do ato se vincula aos motivos indicados como seu fundamento, de tal modo que, se inexistentes ou falsos, implicam a sua nulidade" (DI PIETRO, 2012, p. 218). Essa validade pode ser verificada, no âmbito do Poder Judiciário, pelo Conselho Nacional de Justiça.

Em síntese, o Conselho Nacional de Justiça não pode exercer controle de ato administrativos discricionário realizado por órgão do Poder Judiciário no que tange à escolha feita entre opções legítimas. Poderá, porém, verificar se o ato discricionário foi praticado dentro da legalidade e da moralidade, invalidando-o se realizado com desvio de poder ou por motivos que não se coadunam com a realidade fática ou legal.

\subsubsection{Não sujeição do CNJ ao TCU}

Segundo dispõe a parte final da norma prevista no art. 103-B, $\S 4^{\circ}$, II, da Constituição de 1988, a competência do Conselho Nacional de Justiça apreciar a legalidade dos atos administrativos praticados por membros ou órgãos do Poder Judiciário dar-se-á sem prejuízo daquela inerente ao Tribunal de Contas da União (TCU)

Dispõem os arts. 70 e 71 da Carta Política que o Congresso Nacional deve exercer o controle externo contábil, financeiro, orçamentário, operacional e patrimonial da União e das entidades da administração direta e indireta, quanto à legalidade, legitimidade, economicidade, aplicação das subvenções e renúncia de receitas.

Para desempenhar esse mister, o Congresso Nacional é auxiliado pelo Tribunal de Contas da União, ao qual compete: a) apreciar as contas prestadas anualmente pelo Presidente da República, mediante parecer prévio que deverá ser elaborado em sessenta dias a contar de seu recebimento; b) julgar as contas dos administradores e demais responsáveis por dinheiros, bens e valores públicos da administração direta e indireta, 
incluídas as fundações e sociedades instituídas e mantidas pelo Poder Público federal, e as contas daqueles que derem causa a perda, extravio ou outra irregularidade de que resulte prejuízo ao erário público; c) apreciar, para fins de registro, a legalidade dos atos de admissão de pessoal, a qualquer título, na administração direta e indireta, incluídas as fundações instituídas e mantidas pelo Poder Público, excetuadas as nomeações para cargo de provimento em comissão, bem como a das concessões de aposentadorias, reformas e pensões, ressalvadas as melhorias posteriores que não alterem o fundamento legal do ato concessório; d) realizar, por iniciativa própria, da Câmara dos Deputados, do Senado Federal, de Comissão técnica ou de inquérito, inspeções e auditorias de natureza contábil, financeira, orçamentária, operacional e patrimonial, nas unidades administrativas dos Poderes Legislativo, Executivo e Judiciário, e demais entidades referidas na letra "b"; e) fiscalizar as contas nacionais das empresas supranacionais de cujo capital social a União participe, de forma direta ou indireta, nos termos do tratado constitutivo; f) fiscalizar a aplicação de quaisquer recursos repassados pela União mediante convênio, acordo, ajuste ou outros instrumentos congêneres, a Estado, ao Distrito Federal ou a Município; g) prestar as informações solicitadas pelo Congresso Nacional, por qualquer de suas Casas, ou por qualquer das respectivas Comissões, sobre a fiscalização contábil, financeira, orçamentária, operacional e patrimonial e sobre resultados de auditorias e inspeções realizadas; h) aplicar aos responsáveis, em caso de ilegalidade de despesa ou irregularidade de contas, as sanções previstas em lei, que estabelecerá, entre outras cominações, multa proporcional ao dano causado ao erário; i) assinar prazo para que o órgão ou entidade adote as providências necessárias ao exato cumprimento da lei, se verificada ilegalidade; j) sustar, se não atendido, a execução do ato impugnado, comunicando a decisão à Câmara dos Deputados e ao Senado Federal; k) representar ao Poder competente sobre irregularidades ou abusos apurados.

Nota-se que o TCU tem natureza de órgão de fiscalização e controle das contas públicas da União. Logo, assim como o CNJ, também é responsável pelo controle da legalidade dos atos administrativos praticados no âmbito dos órgãos do Poder Judiciário Federal (Justiça Federal, Justiça do Trabalho, Justiça Militar Federal e Justiça Eleitoral) ${ }^{469}$.

Há, pois, espaço de concorrência de competências fiscalizatórias por ambos os órgãos.

\footnotetext{
${ }^{469} \mathrm{O}$ controle externo contábil, financeiro, orçamentário, operacional e patrimonial das Justiças Estaduais é exercido pelas respectivas Assembleias Legislativas, com auxílio dos Tribunais de Contas Estaduais. No Estado de São Paulo, a Constituição Estadual disciplina o assunto nas normas insertas nos seus arts. 32 e 33.
} 
Podem, assim, surgir hipóteses de conflito de posturas administrativas, com orientações divergentes em relação ao mesmo caso concreto.

A ressalva estabelecida na parte final do art. 103-B, $\S 4^{\circ}$, II - "sem prejuízo da competência do Tribunal de Contas da União" - não significa, porém, que o Constituinte Derivado optou por atribuir predominância à atuação do Tribunal de Contas da União sobre aquela realizada pelo Conselho Nacional de Justiça. Buscou apenas o dispositivo constitucional ressalvar o espaço institucional de atuação do TCU.

Com efeito, o CNJ é órgão do Poder Judiciário e exerce controle interno (CF, art. 70, caput, in fine e art. 92, I-A). O TCU é órgão de controle externo, vinculado ao Congresso Nacional (CF, art. 71).

Por outro lado, as decisões do Conselho no exercício de suas competências constitucionais não se sujeitam ao controle administrativo do Tribunal de Contas da União.

Não há hierarquia entre o Tribunal de Contas da União e o Conselho Nacional de Justiça. Nenhum dos órgãos pode estabelecer, pois, na hipótese de emanarem orientações divergentes sobre o mesmo caso, qual deva prevalecer.

Mas, como os demais órgãos do Poder Judiciário não podem deixar de cumprir as determinações administrativas emanadas pelo Conselho Nacional de Justiça no exercício do poder de autotutela, na hipótese de divergência, deverão observar as orientações do CNJ, sem que isso importe, porém, em responsabilização por eventual descumprimento de disposição em sentido contrário do TCU.

Nesse sentido foi a decisão proferida pelo Conselho Nacional de Justiça no julgamento do Pedido de Providências $\mathrm{n}^{\circ}$ 445, da Relatoria do Conselheiro Douglas Alencar Rodrigues, realizado em 8 de agosto de 2006, cujo voto contém a seguinte ementa $^{470}$ :

CONSELHO NACIONAL DE JUSTIÇA (CNJ) E TRIBUNAL DE CONTAS DA UNIÃO (TCU). EDIÇÃO DE PRESCRIÇÕES NORMATIVAS DISSONANTES E CONTRADITÓRIAS. FORMA DE SUPERAÇÃO DO CONFLITO. A edição pelo CNJ e pelo TCU de orientações normativas contraditórias acerca de uma mesma questão

\footnotetext{
${ }^{470}$ Estiverem presentes na sessão os Conselheiros Ellen Gracie, Vantuil Abdala, Marcus Faver, Douglas Rodrigues, Cláudio Godoy, Germana Moraes, Paulo Schmidt, Eduardo Lorenzoni, Ruth Carvalho, Oscar Argollo, Paulo Lobo e Alexandre de Moraes. Ausentes, justificadamente, os Conselheiros Antônio de Pádua Ribeiro, Jirair Aram Meguerian e Joaquim Falcão (conforme certidão de julgamento da $4^{\mathrm{a}}$ Sessão Extraordinária do $\mathrm{CNJ})$.
} 
jurídico-administrativa, cada qual desses órgãos no exercício legítimo de suas competências constitucionais, não denota antinomia sistêmica grave, antes evidenciando o resultado do natural e complexo processo de fiscalização da Administração Pública consagrado no Texto constitucional. Não havendo hierarquia entre os órgãos envolvidos, inclusive porque ligados a frações distintas do poder político, não há possibilidade de imposição recíproca de qualquer das orientações proferidas, resguardando-se aos eventuais interessados, em qualquer hipótese, o acesso direto ao Poder Judiciário para a tutela de seus interesses.

$\left(\mathrm{CF}\right.$, art. $\left.5^{\circ}, \mathrm{XXXV}\right)$. Figurando, porém, o CNJ como órgão máximo do controle administrativo do aparato judicial brasileiro, de natureza interna, suas decisões devem ser cumpridas pelos órgãos judiciários, inclusive porque resultantes do exercício da auto-tutela administrativa (S. 473/STF).

Em resumo, no caso de orientações divergentes no exercício do controle dos atos administrativos praticados no âmbito do Judiciário, não fica o Conselho Nacional de Justiça sujeito às deliberações do Tribunal de Contas da União, devendo os órgãos do Poder sujeitos ao controle do CNJ observadas suas orientações, ainda que dissonantes das emanadas do TCU.

\subsubsection{Impossibilidade do CNJ exercer controle de constitucionalidade}

Tema dos mais instigantes sobre as competências do Conselho Nacional de Justiça, cumpre investigar neste item se compete ao órgão exercer o controle de constitucionalidade de leis e atos normativos.

Elival da Silva Ramos (2010, p. 19) esclarece que "registra-se um autêntico consenso doutrinário quanto à afirmação de que o princípio da supremacia das normas constitucionais está na base da fundamentação teórica do controle de constitucionalidade”.

Oswaldo Luiz Palu (2001, p. 64) ensina:

Está a Constituição no mais alto degrau hierárquico das normas, condensando regras e preceitos; onde exista uma Constituição escrita, para que este poderoso instrumento normativo não se torne ineficaz, deve 
haver um sistema para a garantia da superioridade e da preeminência de seus vetores normativos.

Também assevera Luís Roberto Barroso (1998, p. 153):

a supremacia constitucional traduz-se em uma superlegalidade formal e material. A superlegalidade formal identifica a Constituição como a fonte primária de produção normativa, ditando competências e procedimentos para a elaboração dos atos normativos inferiores. E a superlegalidade material subordina o conteúdo de toda a atividade normativa estatal à conformidade com os princípios e regras da Constituição. A inobservância dessas prescrições formais e materiais deflagra um mecanismo de proteção da Constituição, conhecido na sua matriz norteamericana como judicial review ${ }^{471}$, e batizado entre nós de controle de constitucionalidade.

Volta-se à norma em comento.

Determina a primeira parte do art. 103-B, $\S 4^{\circ}$, II, da Constituição competir ao Conselho Nacional de Justiça zelar pela observância dos princípios e regras relativos à Administração Pública insculpidos no art. 37 da Constituição Federal. A segunda parte da mesma disposição constitucional prescreve caber ao CNJ apreciar, de ofício ou mediante provocação, a legalidade dos atos administrativos praticados por membros ou órgãos do Poder Judiciário, podendo desconstituí-los, revê-los ou fixar prazo para que se adotem as providências necessárias ao exato cumprimento da lei.

Aflora a indagação: Pode o CNJ exercer controle de constitucionalidade de lei ou de ato normativo?

Afinal, se cabe ao órgão zelar pela observância dos princípios e regras constitucionais relativos à Administração Pública, teria que afastar atos normativos que os violem, com o escopo de que não sejam observados no seio do Poder Judiciário.

\footnotetext{
${ }^{471}$ O judicial review remonta ao caso Marbury v. Madison julgado pela Suprema Corte Estadunidense em 1803 em que o Chief Justice Marshall questinou qual o propósito de da Constituição limitar os poderes do Legislativo se pudessem ser ultrapassados ("The powers of the legislature are defined and limited; and that those limits may not be mistaken or forgotten, the constitution is written. To what purpose are powers limited, and to what purpose is that limitation commited to writing; if these limits may, at any time, be passed by those intended to be restrained?"), concluindo que uma lei que repugna a Constituição é nula ("A Law repugnant to the Constitution is void"), cabendo ao Poder Judiciário rever os atos do Congresso que violem a Carta Política (It is emphatically the province and duty of the judicial departament to say what the law is). (Marbury v. Madison, 5. U.S. 137 (1803) in BLOOM, 2006, p. 3).
} 
Por outro lado, há disposição constitucional expressa a informar que cabe ao Conselho o controle da "legalidade dos atos administrativos". E controle da legalidade não se confundiria com controle de constitucionalidade.

Como pontua Alexandre de Moraes (2013, p. 720), controle de constitucionalidade "significa verificar a adequação (compatibilidade) de uma lei ou de um ato normativo com a constituição, verificando seus requisitos formais e materiais"

De acordo com o magistério de Elival da Silva Ramos (2010, pp. 53 a 81), o controle de constitucionalidade pode ser: a) político e jurisdicional; b) preventivo e repressivo; c) difuso e concentrado; e, d) incidental e principal (concreto e abstrato).

Segundo o autor, o controle político não pode ser apartado do controle jurisdicional com base em um critério orgânico, porque o Poder Judiciário não exerce apenas função jurisdicional e esta pode ser atribuída a órgãos estranhos ao Poder Judiciário, como o Senado Federal (CF, art. 52, I e II). Assim, doutrina que é "a natureza da função em que se encaixa o controle de constitucionalidade o ponto fulcral da classificação". O controle será jurisdicional se realizado no exercício da jurisdição. Caso contrário, se exercido "no contexto de uma das funções políticas do Estado (atividade legislativa, chefia de Estado, de governo, controle político etc)", será um controle de constitucionalidade político, que poderá ser impróprio, quando realizado no âmbito da função legislativa, durante as etapas do processo legislativo (por exemplo, os pareceres das Comissões de Constituição e Justiça do Poder Legislativo ou o veto presidencial no procedimento legislativo ordinário) ou próprio, pois exercido com autonomia em relação à função legislativa e caracterizado por realizar "a verificação da compatibilidade do ato legislativo com a Constituição [...] por um critério que, predominantemente, leva em conta o mérito do ato controlado e não a sua higidez jurídico-constitucional" ${ }^{\text {474. }}$.

\footnotetext{
${ }^{472}$ Salienta Jorge Miranda (2011, p. 491) que "os grandes pressupostos da fiscalização da constitucionalidade das leis e dos demais atos jurídico-públicos vêm a ser, primeiro, a existência de uma Constituição em sentido formal, e, em segundo lugar, a consciência da necessidade de garantia dos seus princípios e regras com a vontade de instituir meios adequados".

${ }^{473}$ Oswaldo Luiz Palu ( 2001, p. 65) define controle de constitucionalidade de forma mais ampla, "como o ato de submeter-se à verificação de compatibilidade normas de um determinado ordenamento jurídico, inclusive advindas do Poder Constituinte Derivado, com os comandos do parâmetro constitucional em vigor, formal e materialmente (forma, procedimento e conteúdo), retirando do sistema jurídico (nulificando ou anulando) aquelas que com ele forem incompatíveis".

${ }^{474}$ Elival da Silva Ramos (2010, p. 60 a 62) cita como exemplo de controle de constitucionalidade político próprio a norma inserta no parágrafo único do art. 96 da Constituição Brasileira de 1937 que previa, no caso de declaração, pelo Poder Judiciário, de inconstitucionalidade de lei ou de ato do Presidente da República, que este, se julgasse que a lei seria necessária ao bem-estar do povo ou à promoção ou defesa de interesse nacional de alta monta, poderia submetê-la novamente ao exame do Parlamento e, se o Legislativo a confirmasse pelo voto de dois terços em cada uma das Casas, ficaria sem efeito a decisão do Judiciário.
} 
Os controles preventivo e repressivo se distinguem por um critério temporal. Se realizado durante o processo de formação das leis e dos atos normativos, será preventivo. Se após a conclusão e a publicação da espécie normativa, será repressivo.

Prossegue o doutrinador e passa a distinguir os controles de constitucionalidade difuso e concentrado. Afirma que a diferença ocorre em sede de controle jurisdicional: se a competência para efetuar o controle de constitucionalidade estiver dispersa entre os vários órgãos da estrutura jurisdicional, o sistema é difuso. Se, ao contrário, o controle é confiado apenas a um órgão jurisdicional, o sistema é concentrado.

Esclarece o Professor que o controle jurisdicional de constitucionalidade também pode ser classificado em incidental e principal. Explica (2010, pp. 74 a 76):

\footnotetext{
No controle de constitucionalidade incidental o problema da compatibilidade ou não do ato legislativo com a Constituição configura questão prejudicial [...]. O objeto do processo é a relação jurídica de direito material, da qual emergem posições jurídicas ativas e passivas para as partes e sobre as quais se estabelece um litígio entre elas, e não o ato legislativo que serve de supedâneo a tal vínculo jurídico e que tenha a sua higidez constitucional contestada por uma das partes. [...] No controle dito principal, é a própria lei que se converte em objeto único e exclusivo de um processo destinado, especificamente, à averiguação de sua conformidade às normas constitucionais de regência.
}

Elival da Silva Ramos ainda doutrina que o controle de constitucionalidade, "sob um prisma ligeiramente diverso, mas bastante próximo às categorias do controle incidental e principal, ainda pode ser tratado como concreto ou abstrato, dependendo da conformidade da lei à Constituição ser "analisada tendo presentes os direitos ou interesses legítimos agravados por suposta inconstitucionalidade". Em caso positivo, o controle será concreto. Se, porém, o órgão jurisdicional limita-se a verificar, independentemente de existência de situação concreta controvertida, "a compatibilidade ou não do ato legislativo com as normas constitucionais, estaremos diante de controle abstrato".

$\mathrm{Na}$ sequência (2010, pp. 82 a 86), o doutrinador trata dos efeitos subjetivos das decisões de controle de constitucionalidade, que se classificam em inter partes e erga omnes. Afirma que, no controle difuso-incidental, "a decisão da questão prejudicial atinente à conformidade da lei à Constituição não faz coisas julgada" porque integra a fundamentação da sentença. A coisa julgada atinge apenas o dispositivo da decisão e 
refere-se à questão principal discutida. Mas, como a resolução da questão prejudicial de constitucionalidade, "enquanto antecedente lógico do dispositivo da sentença e integrado à sua motivação, produz efeitos restritos às partes", diz-se que os efeitos do controle de constitucionalidade ocorreu inter partes. Os efeitos serão erga omnes, gerais, no controle concentrado, ainda que pela via incidental (sistema europeu de técnica de incidente autônomo de inconstitucionalidade com o monopólio da função de controle deferido a Corte Constitucional), e no controle principal, porque tem como objeto principal a compatibilidade de ato normativo com a Constituição.

Diante essas observações, poder-se-ia, paralelamente, afirmar que o controle da legalidade, no âmbito da Administração Pública, seria a verificação da compatibilidade da atuação administrativa com a lei (entendida como espécie normativa editada após regular processo legislativo), pois somente o que for permitido em lei pode ser feito pelo Administrador Público.

Mas, como visto ${ }^{475}$, a legalidade, erigida a princípio constitucional da Administração Pública, deve ser entendida como sujeição, não apenas à lei, mas ao Direito como um todo. Adverte Marçal Justen Filho (2014, p. 232):

O princípio da legalidade não significa a exigência de disciplina legal literal e expressa. A disciplina jurídica é produzida pelo conjunto das normas jurídicas, o que exige compreenderque, mesmo sem existir dispositivo literal numa lei, o sistema jurídico poderá impor restrição à autonomia privada e obrigatoriedade de atuação administrativa.

Em suma, o princípio da legalidade não conduz a uma interpretação literaldas leis para determinar o que é permitido, proibido ou obrigatório.

Assim, se compete ao Conselho Nacional de Justiça zelar pela observância dos princípios e regras constitucionais concernentes à Administração Pública (inclusive o princípio da legalidade) e apreciar a legalidade dos atos administrativos praticados por membros ou órgãos do Judiciário, caberia ao órgão, ao deparar-se com lei ou ato normativo que infrinja preceito constitucional, afastar sua incidência, para que não seja aplicado no âmbito do Poder?

A doutrina e a jurisprudência divergem sobre o tema.

${ }^{475}$ Vide item 3.1.3. 
Para exposição do nosso ponto de vista, dadas as restrições deste trabalho, serão, primeiro, apresentadas duas posições doutrinárias antagônicas que bem sintetizam os argumentos favoráveis e contrários ao exercício de controle de constitucionalidade pelo Conselho Nacional de Justiça. Em seguida, serão apresentadas decisões proferidas pelo próprio Conselho Nacional de Justiça e pelo Supremo Tribunal Federal sobre o assunto.

A primeira posição doutrinária, contrária ao controle de constitucionalidade exercido pelo CNJ, foi manifestada por Alexandre de Moraes (2014).

Em artigo publicado sob o título "Controle de constitucionalidade é vedado ao Conselho Nacional de Justiça"476, o Professor esclarece que as competências originárias do Conselho Nacional de Justiça estão taxativamente previstas no texto constitucional. São competências somente no âmbito de atuação administrativa, excepcionais, inclusive em relação à autonomia dos tribunais, "não se confundindo com o exercício da função jurisdicional pelos juízes e tribunais, nem tampouco autorizando qualquer tipo de invasão nas competências fixadas aos demais órgãos e Instituições do Estado", para evitar a qualquer "guerrilha institucional".

Assim, defende ser inconcebível que o Conselho Nacional de Justiça passe a exercer controle difuso de constitucionalidade nos julgamentos de seus procedimentos, sob o argumento de que deve zelar pela observância dos princípios e regras constitucionais da Administração Pública.

Sustenta que ao $\mathrm{CNJ}$, assim como ao Ministério Público e outros órgãos administrativos previstos na Lei Maior com atribuições expressas de defesa dos princípios e normas constitucionais, "compete exercer na plenitude todas suas competências administrativas, sem obviamente poder usurpar o exercício da função de outros órgãos, inclusive a função jurisdicional de controle de constitucionalidade", pois esse proceder implicaria em "triplo desrespeito ao texto maior, atentando tanto contra o Poder Legislativo, quanto contra as próprias competências jurisdicionais do Judiciário e as competências privativas de nossa Corte Suprema”.

Afirma que a possibilidade do CNJ declarar a inconstitucionalidade de lei ou ato normativo atentaria contra o Poder Legislativo pois violaria "os mecanismos recíprocos de freios e contrapesos (check and balances) estabelecidos no texto constitucional como pilares à Separação de Poderes", cláusula pétrea (CF, art. 60, $\left.\S 4^{\circ}, \mathrm{III}\right)$, “pois ausente a necessária legitimidade constitucional” ao CNJ para afastar leis emanadas pelo Legislativo.

\footnotetext{
${ }^{476}$ Disponível em <http://www.conjur.com.br/2014-ago-27/alexandre-moraes-controle-constitucionalidadevedado-cnj>. Acesso em 13.12.2014.
} 
Aduz, também, que o controle de constitucionalidade realizado pelo Colegiado Administrativo usurparia a função jurisdicional constitucionalmente atribuída aos juízes e tribunais e ignoraria a competência de guardião da constituição afeta ao Supremo Tribunal Federal, destacando que a declaração de inconstitucionalidade é excepcional e permitida somente no exercício da função jurisdicional.

Ressalta, por fim, que o exercício de controle difuso de constitucionalidade pelo Conselho Nacional de Justiça ainda implica, na maioria das vezes, na transcendência dos efeitos da sua decisão ("que o próprio Supremo Tribunal Federal não permitiu a si mesmo, se autolimitando no julgamento da Reclamação 4.335/AC, julgada em 16 de maio de 2013”), em virtude da sua extensão a todos os tribunais, tornando-a erga omnes e vinculante, pois todo o Poder Judiciário teria que deixar de aplicar a lei declarada inconstitucional pelo Colegiado Administrativo em outros casos idênticos em que incidiria. Assim, além de violação à competência constitucional exclusiva do STF (controle abstrato de constitucionalidade), também haveria usurpação daquela atribuída ao Senado Federal quanto do Senado Federal (mecanismo de ampliação dos efeitos da declaração incidental de inconstitucionalidade - CFD, art. 52, X) ${ }^{477}$.

Em resposta à tese apresentada, Rafael Tomaz de Oliveira e Lenio Luiz Streck publicaram o artigo intitulado "Fiscalização da constitucionalidade não é vedada ao Conselho Nacional de Justiça" ${ }^{478}$.

Sustentam os articulistas que, a tese defendida pelo Professor Alexandre de Moraes “não acompanha os debates e as contribuições desenvolvidas pelo constitucionalismo nos últimos anos. Principalmente no que tange à vinculação dos poderes públicos à Constituição e à abertura dos intérpretes — oficiais — do texto constitucional”.

Argumentam, citando Rui Medeiros, que há, atualmente, um princípio de vinculação de todos os poderes públicos à Constituição. “Assim sendo, a vinculação à constitucionalidade, e sua consequente fiscalização, não pode ficar restrita apenas aos poderes legislativos e judiciário, estando estendida, também, à administração", que, da mesma forma, exerce o papel de intérprete da Constituição e, como consequência, tem o dever de fiscalizar a constitucionalidade.

\footnotetext{
477 Antônio Veloso Peleja Júnior também defende a impossibilidade do CNJ exercer controle de constitucionalidade em artigo intitulado "O CNJ e o controle e constitucionalidade de leis", publicado em 19 de fevereiro de 2009 (Disponível em: <http://www.migalhas.com.br/dePeso/16,MI78651,11049$\mathrm{O}+\mathrm{CNJ}+\mathrm{e}+\mathrm{o}+$ controle $+\mathrm{de}+$ constitucionalidade + de + leis $>$. Acesso em 10.12.2014).

${ }^{478}$ Disponível em: <http://www.conjur.com.br/2014-ago-30/diario-classe-fiscalizacao-constitucionalidadenao-vedada-conselho-nacional-justica $>$. Acesso em 13.12.2014.
} 
Salientam que há certo consenso na doutrina europeia de que a fiscalização da constitucionalidade deve ficar a cargo dos órgãos administrativos de direção superior e destacam que, na Ordem Constitucional brasileira, "a possibilidade da fiscalização no âmbito administrativo é reconhecida pela disposição contida no art. $66, \S 1^{\text {o }}$, da Constituição de 1988, ao estabelecer a possibilidade do "presidente da república interferir no processo legislativo a partir da aposição do veto, que pode ter como motivo técnico a inconstitucionalidade".

Advogam que, no caso do $\mathrm{CNJ}$, embora não seja órgão dotado de jurisdição, pratica atos de resolução de lides e, portanto, deve afastar eventuais inconstitucionalidades em casos concretos e, nas hipóteses de atos dotados de generalidade e abstração, buscar um diálogo institucional, deixando "de aplicar o texto jurídico inquinado de inconstitucional e, na sequência", "chamando à colação um legitimado para propor a devida ação de inconstitucionalidade, como o procurador-geral da República".

Por fim, afirmam que o exercício do controle difuso de constitucionalidade pelo CNJ não representa uma ofensa ao legislativo "em face de uma pretensa - e discutível transcendência de efeitos da decisão", pois, nesse caso, concluir-se-ia que "o poder normativo atribuído ao CNJ [...]seria, igualmente, inconstitucional, uma vez que colocaria o órgão em uma posição de quase-legislador" ${ }^{479}$.

No âmbito do próprio Conselho Nacional de Justiça a questão também é controvertida, fruto, inclusive, das constantes mudanças na composição do Colegiado.

Por exemplo, no julgamento do Procedimento de Controle Administrativo no 199, da relatoria do Conselheiro Marcus Faver, ocorrido em 4 de dezembro de 2006, o Colegiado Administrativo, por votação unânime, não conheceram o pedido formulado por Juízes de Direito do Estado do Acre para declarar a inconstitucionalidade da Lei Complementar daquele Estado $n^{\circ} 161$, de 12 de maio de 2006, por não competir ao órgão, reconhecer a inconstitucionalidade de lei estadual ${ }^{480}$.

\footnotetext{
${ }^{479}$ Alexandre Freire Pimentel e Bruno Freire Pimentel também sustentam a possibilidade do CNJ exercer controle de constitucionalidade em artigo publicado na Revista Bonijuris, $\mathrm{n}^{\mathbf{0}} 579$ (2012, p. 24 a 31), intitulado "Em defesa do controle administrativo de constitucionalidade exercido pelo Conselho Nacional de Justiça". No mesmo sentido, também pode ser conferida a dissertação de mestrado de Fernanda Adriano Fluhr apresentada em 2011 na Universidade Católica de Pernambuco, com o título "A jurisdição constitucional e o Conselho Nacional de Justiça: a possibilidade do exercício do controle de constitucionalidade pelo CNJ" (Disponível em $<$ http://www.unicap.br/tede//tde_busca/arquivo.php?codArquivo=569>. Acesso em 10.12.2014).

${ }^{480}$ Estiverem presentes na sessão os Conselheiros Marcus Faver, Jirair Aram Meguerian, Douglas Rodrigues, Germana Moraes, Paulo Schmidt, Eduardo Lorenzoni, Ruth Carvalho, Oscar Argollo, Paulo Lôbo e Alexandre de Moraes. Ausentes, justificadamente, os Conselheiros Ellen Gracie, Antônio de Pádua Ribeiro,
} 
Nesse mesmo sentido, no julgamento do Pedido de Providências $n^{\circ}$ 000303019.2013.2.00.0000, da relatoria do Conselheiro Rubens Curado Silveira, realizado em 25 de fevereiro de 2014, o Conselho Nacional de Justiça, por maioria, rejeitou pleito formulado por advogado para determinar que o Tribunal de Justiça de São Paulo se abstenha de exigir o recolhimento da "taxa de mandato judicial" prevista na Lei Paulista $\mathrm{n}^{\mathrm{o}}$ 10.394, de 16 de dezembro de 1970, comunicando os juízes de que tal exigência não encontra amparo na Constituição, por falecer-lhe competência para o exame de constitucionalidade de leis, ainda que destinadas ao Poder Judiciário e porque as decisões que determinam o recolhimento da referida "taxa" são proferidas no bojo de processos judiciais, sendo, pois, atacáveis por recurso judicial próprio. O Conselho, no entanto, recomendou $^{481}$ ao Tribunal Bandeirante, nos termos do art. 98 do seu Regimento Interno $^{482}$, por vislumbrar que o cumprimento da previsão legal questionada estaria a gerar impactos diretos na celeridade e na eficiência do judiciário estadual, que adotasse providências e/ou apresentasse ao órgão responsável proposta com vistas à alteração ou extinção da "taxa de procuração" 483 .

Vantuil Abdala, Cláudio Godoy e Joaquim Falcão (conforme certidão de julgamento da $30^{\mathrm{a}}$ Sessão Ordinária do CNJ). Segue a ementa do julgado administrativo:

Procedimento de Controle Administrativo. Desconstituição de ato Administrativo. Estado do Acre. LC 161/06. Autorização dada ao Tribunal de Justiça para, por resolução, fixar a competência de varas e juizados especiais. Alegação de inconstitucionalidade. Não cabe ao Conselho Nacional de justiça, órgão de natureza administrativa, fazer análise da constitucionalidade de leis estaduais. Não conhecimento do pedido (PCA 199, Rel. Cons. Marcus Faver).

${ }^{481}$ Vide item 3.1.8.

${ }^{482}$ Art. 98 (RICNJ). As propostas e sugestões tendentes à melhoria da eficiência e eficácia do Poder Judiciário bem como todo e qualquer expediente que não tenha classificação específica nem seja acessório ou incidente serão incluídos na classe de pedido de providências, cabendo ao Plenário do CNJ ou ao Corregedor Nacional de Justiça, conforme a respectiva competência, o seu conhecimento e julgamento.

${ }^{483}$ Estiverem presentes na sessão os Conselheiros Joaquim Barbosa, Maria Cristina Peduzzi, Ana Maria Duarte Amarante Brito, Guilherme Calmon, Flavio Sirangelo, Deborah Ciocci, Saulo Casali Bahia, Rubens Curado Silveira, Luiza Frischeisen, Gilberto Martins, Paulo Teixeira, Gisela Gondin Ramos, Emmanoel Campelo e Fabiano Silveira. Vencida a Conselheira Deborah Ciocci. Ausente, justificadamente, o Conselheiro Francisco Falcão (conforme certidão de julgamento da $183^{a}$ Sessão Ordinária do CNJ). Segue a ementa do julgado administrativo:

PEDIDO DE PROVIDÊNCIAS. TAXA DE MANDATO JUDICIAL. EXAME DE CONSTITUCIONALIDADE DE LEI ESTADUAL. INCOMPETÊNCIA DO CNJ. NATUREZA JURISDICIONAL DA MATÉRIA. IMPUGNAÇÃO POR MEIO DE RECURSOS PRÓPRIOS. IMPACTO NA CELERIDADE E NA EFICIÊNCIA DO JUDICIÁRIO ESTADUAL. NECESSIDADE DE APERFEIÇOAMENTO DA NORMA.

1. Não compete ao CNJ o exame da constitucionalidade de lei, por se tratar de ato oriundo do Poder Legislativo, estranho, portanto, à sua atribuição precípua de controle da atuação administrativa e financeira do Poder Judiciário.

2. As decisões que determinam o recolhimento da "taxa de mandato judicial" são proferidas no bojo de processos judiciais, pelo que são atacáveis por recurso próprio. Logo, não são alcançadas pelo controle administrativo exercido por este Conselho. 
Em sentido oposto, o Colegiado Administrativo, ao julgar, em 17 de março de 2009, o Pedido de Providências $\mathrm{n}^{\circ}$ 200810000022372, Relator Conselheiro Umberto de Souza Júnior, acolheu, por unanimidade, pedido da Associação dos Magistrados do Estado do Pará que sustentou haver erro no pagamento das substituições por magistrados de entrância ou instância inferior, em razão do Tribunal de Justiça Paraense observar o disposto no art. 221 do Código Judiciário do Pará (Lei n ${ }^{0} 5.008$ de 10 de dezembro de 1981, na redação conferida pela Lei Estadual $n^{\text {o }} 6.811$, de 10 de janeiro de 2006) ${ }^{484}$, em detrimento das disposições dos arts. 93, caput e V, da CF, e 124 da LOMAN ${ }^{485}$.

No seu voto, o Conselheiro Umberto de Souza Júnior, ante a alegação apresentada pelo Tribunal de Justiça do Pará no sentido de que fugiria da competência do CNJ o reconhecimento da inconstitucionalidade do dispositivo legal impugnado, pois essa tarefa é confiada apenas ao Supremo Tribunal Federal, argumentou que essa exclusividade atribuída à Alta Corte Brasileira refere-se apenas à competência para o controle de constitucionalidade dos atos normativos em abstrato. E prosseguiu:

\begin{abstract}
Abraçou o Brasil o sistema híbrido de controle de constitucionalidade, onde convive, ao lado do controle direto e abstrato, o controle difuso, dispersamente atribuído não só aos tribunais em geral, mas, lembrando HÄBERLE e sua Sociedade aberta dos intérpretes da Constituição, a todos os entes humanos e suas ficções jurídicas personificadas. Assim, não usurpa o Conselho Nacional de Justiça nenhuma competência da Suprema Corte quando, para verificar a correção da conduta administrativa dos tribunais, precisa examinar a harmonia ou desafinação de norma local com os parâmetros da Constituição Federal ${ }^{486}$.
\end{abstract}

3. Não obstante, no intuito de buscar o aperfeiçoamento e a eficiência dos serviços judiciários, recomenda-se ao TJSP a adoção de providências e/ou a apresentação ao órgão responsável de proposta com vistas à alteração/extinção da referida "taxa".

4. Pedido de Providências parcialmente procedente. (PP no 0003030-19.2013.2.00.0000, Rel. Cons. Rubens Curado Silveira).

${ }^{484}$ Art. 221 (CJ/PA). O Juiz que for convocado para substituir, magistrado de entrância superior, perceberá o valor correspondente a $3 \%$ (três por cento) de seu subsídio

${ }^{485}$ Art. 124 (LOMAN). O Magistrado que for convocado para substituir, em primeira ou segunda instância, perceberá a diferença de vencimentos correspondentes ao cargo que passa a exercer, inclusive diárias e transporte, se for o caso.

${ }^{486}$ Estiverem presentes na sessão os Conselheiros Gilson Dipp, João Oreste Dalazen, Rui Stoco, Mairan Maia, Altino Pedrozo dos Santos, Andréa Pachá, Jorge Maurique, Antonio Umberto de Souza Júnior, José Adonis Callou de Araújo Sá, Felipe Locke Cavalcanti, Paulo Lobo, Técio Lins e Silva, Marcelo Nobre e Joaquim Falcão (conforme certidão de julgamento da 80 a Sessão Ordinária do CNJ). Segue a ementa do julgado administrativo: 
Na jurisprudência do Supremo Tribunal Federal os dois posicionamentos antagônicos apresentados também são encontrados.

No julgamento do Referendo da Medida Cautelar na Ação Cautelar no 2390, em 19 de agosto de 2010, o Plenário da Corte Suprema, por unanimidade ${ }^{487}$, confirmou a decisão monocrática inicial proferida pela Ministra Cármen Lúcia que suspendeu os efeitos do acórdão proferido pelo Conselho Nacional de Justiça, em 10 de junho de 2009, ao apreciar o Procedimento de Controle Administrativo no 200910000018762, porque esta decisão, ao invalidar ato administrativo do Tribunal de Justiça do Estado da Paraíba de nomeação de servidores para exercer cargos em comissão definidos na Lei Estadual Paraibana $n^{\circ} 8.223$, de 16 de maio de 2007, ante o disposto no art. 37, II e V, da Constituição Federal ${ }^{488}$,

PROCEDIMENTO DE CONTROLE ADMINISTRATIVO. MAGISTRATURA. 1. CONSELHO NACIONAL DE JUSTIÇA. COMPETÊNCIA PARA AFASTAMENTO DA APLICAÇÃO DE NORMA CONFLITANTE COM A CONSTITUIÇÃO NOS CASOS CONCRETOS. EM AMBIENTE DE MÚLTIPLOS LEGITIMADOS AO CONTROLE DIFUSO DA CONFORMAÇÃO CONSTITUCIONAL DOS ATOS NORMATIVOS, HÁ ESPAÇO DE HARMÔNICO CONVÍVIO ENTRE O CONTROLE INCIDENTAL DE CONSTITUCIONALIDADE E O CONTROLE DIRETO, DE COMPETÊNCIA EXCLUSIVA DO SUPREMO TRIBUNAL FEDERAL. 2. SUBSTITUIÇÃO EM ENTRÂNCIA OU INSTÂNCIA. DIREITO À CONTRAPRESTAÇÃO CORRESPONDENTE AO CARGO INTERINO. VALOR REMUNERATÓRIO FIXADO EM LEI ESTADUAL INFERIOR AO PATAMAR ESTIPULADO NA LEI ORGÂNICA DA MAGISTRATURA. RESERVA DE LEI COMPLEMENTAR FEDERAL DE CARÁTER NACIONAL. VERSANDO A LEI ORGÂNICA DA MAGISTRATURA NACIONAL (LEI COMPLEMENTAR $\mathrm{N}^{\circ}$ 35/79) SOBRE O VALOR REMUNERATÓRIO DECORRENTE DAS SUBSTITUIÇÕES POR MAGISTRADOS DE ENTRÂNCIA OU INSTÂNCIA INFERIOR (ART. 124), NÃO HÁ CHANCE CONSTITUCIONAL PARA O EXERCÍCIO INOVADOR DA COMPETÊNCIA LEGISLATIVA DOS ESTADOS (CF, ART. 93, CAPUT), EM DETRIMENTO DA DISCIPLINA CONSTANTE DA LEI NACIONAL. 3. SUBSÍDIOS. SUBSISTÊNCIA DE ADICIONAL DE TEMPO DE SERVIÇO. IMPOSSIBILIDADE. A introdução dos subsídios absorveu todas as verbas de caráter remuneratório, inclusive o adicional por tempo de serviço (Resolução n ${ }^{\circ} 13 / \mathrm{CNJ}$, art. $4^{\circ}$, III). Emergindo em processo aparente situação de afronta à regra constitucional de contenção remuneratória, deve o Conselho Nacional de Justiça, de ofício, no exercício de sua competência fiscalizatória, apurar eventuais desvios administrativos. Pedido acolhido para declarar a exigibilidade da contraprestação integral do cargo interinamente assumido. Ordem de prestação de informações sobre os valores remuneratórios pagos aos magistrados em atividade desde a véspera da implantação dos subsídios até o presente. (Pedido de Providências $n^{\circ} 200810000022372$, Conselheiro Relator Antônio Humberto, publicado no DJ eletrônico $n^{\circ}$ 97/2009, em 16/6/09, p. 16-18).

${ }_{487}$ Presentes à sessão os Ministros Cezar Peluso (presidente), Ellen Gracie, Gilmar Mendes, Ayres Britto, Ricardo Lewandowski, Cármen Lúcia e Dias Toffoli. Ausentes, licenciados, os Ministros Celso de Mello e Joaquim Barbosa e, ocasionalmente, o Ministro Marco Aurélio Mello (conforme extrato da Ata de Julgamento).

${ }^{488}$ Estiverem presentes na sessão os Conselheiros Gilson Dipp, João Oreste Dalazen, Rui Stoco, Mairan Maia, Altino Pedrozo dos Santos, Andréa Pachá, Jorge Maurique, Antonio Umberto de Souza Júnior, José Adonis Callou de Araújo Sá, Felipe Locke Cavalcanti, Paulo Lobo, Marcelo Nobre e Joaquim Falcão. Ausentes, justificadamente, os Conselheiros ilmar Mendes e Técio Lins e Silva (conforme certidão de julgamento da $86^{\mathrm{a}}$ Sessão Ordinária do $\mathrm{CNJ}$ ). Segue a ementa do acórdão administrativo:

PROCEDIMENTO DE CONTROLE ADMINISTRATIVO INSTAURADO DE OFÍCIO. SERVENTUÁRIOS DA JUSTIÇA. 1. NOMEAÇÃO DE ASSISTENTES ADMINISTRATIVOS PARA CARGOS EM COMISSÃO DE LIVRE PROVIMENTO E EXONERAÇÃO. IRREGULARIDADE. No regime constitucional brasileiro a nomeação de servidores públicos somente dispensa a aprovação em 
acabou por afastar a validade e a eficácia da própria norma contida na Lei Estadual (art. $\left.5^{\circ}\right)^{489}$, exercendo, assim, o CNJ, de ofício, controle de sua constitucionalidade, o que lhe é vedado, pois a Carta Política confere essa competência ao Supremo Tribunal Federal ${ }^{490491}$.

Na mesma linha, no julgamento do Agravo Regimental em Mandado de Segurança $\mathrm{n}^{\mathbf{o}}$

concurso público quando se tratar de ocupante de cargo em comissão para o exercício de encargos de chefia, direção ou assessoramento. Inteligência do disposto no art. 37, II e V, da Constituição Federal. 2. LEI ESTADUAL DE CRIAÇÃO DE CARGOS EM COMISSÃO DE LIVRE PROVIMENTO. INSUFICIÊNCIA. NECESSIDADE DE OBSERVÂNCIA DOS LIMITES MATERIAIS DE TOLERÂNCIA DO EXCEPCIONAL INGRESSO NO SERVIÇO PÚBLICO SEM CONCURSO. Não salva da pecha de antijuridicidade a circunstância de serem os cargos comissionados criados por lei porque a reserva de lei (CF, art. 96, II, b) é apenas um dos requisitos constitucionais para a existência regular de cargos em comissão. Declaração de nulidade das nomeações irregulares com determinação para que o tribunal adote as providências para exoneração dos respectivos ocupantes no prazo de sessenta dias.

${ }^{489}$ Art. $5^{\circ}$ (Lei Estadual Paraibana $n^{\text {o }} 8.223 / 2007$ ). Ficam criados, no Quadro de Pessoal do Tribunal de Justiça, 100 (cem) cargos de provimento em comissão, de Assistente de Administração, símbolo PJ-CTJ-155, com vencimento de $\mathrm{R} \$ 112,50$ (cento e doze reais e cinqüenta centavos), cabendo aos seus ocupantes as seguintes atribuições:

I - exercer atividades administrativas de assistência direta aos Gabinetes da Presidência, Vice-Presidência, da Corregedoria Geral, da Secretaria-Geral, dos Juízes Auxiliares da Presidência, das Secretarias Administrativa, Judiciária, de Planejamento e Finanças, de Recursos Humanos e de Tecnologia e Informaçãl, das Consultorias Jurídica e Administrativa e das Coordenadorias;

II - exercer outras atividades administrativas de confiança não incluídas nas atividades privativas dos servidores do quadro efetivo do Poder Judiciário e que lhes forem cometidas pela autoridade competente.

${ }^{490}$ Segue a ementa do acórdão:

AÇÃO CAUTELAR PREPARATÓRIA. LEI N. 8.223/2007 DO ESTADO DA PARAÍBA. CRIAÇÃO LEGAL DE CARGOS EM COMISSÃO NO TRIBUNAL DE JUSTIÇA ESTADUAL. ASSISTENTES ADMINISTRATIVOS. ATO DO CONSELHO NACIONAL DE JUSTIÇA. EXONERAÇÃO DETERMINADA. ALEGAÇÃO DE INCOMPETÊNCIA DO CNJ. LIMINAR DEFERIDA. REFERENDO. 1. Ação Cautelar preparatória de ação destinada à desconstituição da decisão administrativa do Conselho Nacional de Justiça que determinou a exoneração de servidores nomeados para os cargos em comissão criados pela Lei n. 8.223/2007 do Estado da Paraíba. 2. O Tribunal de Justiça da Paraíba deu exato cumprimento à lei ao promover as nomeações, mas, o Conselho Nacional de Justiça concluiu pela exoneração dos servidores em razão de haver "indícios de inconstitucionalidade material" naquele diploma legal. 3. Afastado o vício apontado pelo Conselho Nacional de Justiça sob critérios extraídos da Constituição da República (art. 37, incs. II e V), pois a ilegalidade não residiria nas efetivas nomeações ocorridas no Tribunal de Justiça da Paraíba, mas na própria norma legal que criou os cargos. 4. A Lei n. 8.223/2007, decretada e sancionada pelos Poderes Legislativo e Executivo do Estado da Paraíba, não pode ter o controle de constitucionalidade realizado pelo Conselho Nacional de Justiça, pois a Constituição da República confere essa competência, com exclusividade, ao Supremo Tribunal Federal. 5. Medida liminar referendada (AC 2390 MC-REF, Relator(a): Min. CÁRMEN LÚCIA, Tribunal Pleno, julgado em 19/08/2010, DJe-080 DIVULG 29-04-2011 PUBLIC 02-05-2011).

${ }^{491}$ Cumpre informar que o Procurador-Geral da República ajuizou, perante o Supremo Tribunal Federal, em 17 de outubro de 2012, a ADI $\mathrm{n}^{\circ}$ 4867, distribuída originalmente ao Ministro Joaquim Barbosa e, posteriormente, ao Ministro Roberto Barroso, para questionar a constitucionalidade da norma inserta no artigo $5^{\circ}$ da Lei 8.223/2007, do Estado da Paraíba, porque os cargos que ela criou não se harmonizam com o princípio da livre nomeação e exoneração, pois o exercício de atividades administrativas de assistência aos gabinetes e secretarias do Tribunal são funções típicas da carreira dos servidores públicos do Poder Judiciário, em especial dos cargos de técnico e analista administrativos, não se justificando o caráter comissionado do provimento do cargo. Até a entrega deste trabalho, porém, a referida ADI ainda não havia sido julgada. 
28872, em 24 de fevereiro de 2011, o Supremo Tribunal Federal, por unanimidade ${ }^{492}$, ratificou a decisão proferida pelo Ministro Ricardo Lewandowski, que negou seguimento a writ impetrado contra a decisão proferida no Procedimento de Controle Administrativo $\mathrm{n}^{\mathrm{o}}$ 0001817-17.2009.2.00.0000, não conhecido pelo CNJ, conforme decisão monocrática proferida em 23 de fevereiro de 2010 pelo Conselheiro Paulo de Tarso Tamburini Souza, porque o interessado pretendia que o Colegiado Administrativo se manifestasse sobre diploma legal, no caso, a Lei Estadual Mineira n 12.919, de 29 de junho de 1998. A Alta Corte entendeu, nos termos do voto do relator, que ao Conselho Nacional de Justiça, como órgão do Poder Judiciário somente com atribuições administrativas, não compete manifestar-se sobre a constitucionalidade de diplomas legais ${ }^{493}$.

Há ainda, no mesmo sentido, decisões monocráticas liminares proferida pelo Ministro Celso de Mello em 3 de fevereiro de 2014 e 2 de junho de 2014, respectivamente nos Mandados de Segurança $n^{\circ}$ s $32582^{494}$ e $32865^{495}$, em que Sua Excelência afirma que o

\footnotetext{
${ }^{492}$ Presentes à sessão os Ministros Cezar Peluso (presidente), Celso de Mello, Marco Aurélio Mello, Ellen Gracie, Gilmar Mendes, Ayres Britto, Joaquim Barbosa, Ricardo Lewandowski, Cármen Lúcia e Dias Toffoli. Ausentes, porém, no julgamento, os Ministros Marco Aurélio Mello, Ellen Gracie, Gilmar Mendes e Joaquim Barbosa (conforme extrato da Ata de Julgamento).

${ }^{493}$ Segue a ementa do acórdão:

EMENTA: AGRAVO REGIMENTAL. MANDADO DE SEGURANÇA. CONSELHO NACIONAL DE JUSTIÇA. NÃO CONHECIMENTO DE PROCEDIMENTO DE CONTROLE ADMINISTRATIVO. EXERCÍCIO DE CONTROLE DIFUSO DE CONSTITUCIONALIDADE PELO CNJ. IMPOSSIBILIDADE. MANDADO DE SEGURANÇA A QUE SE NEGOU PROVIMENTO. AGRAVO IMPROVIDO. I - O Conselho Nacional de Justiça, embora seja órgão do Poder Judiciário, nos termos do art. 103-B, § $4^{\circ}$, II, da Constituição Federal, possui, tão somente, atribuições de natureza administrativa e, nesse sentido, não the é permitido apreciar a constitucionalidade dos atos administrativos, mas somente sua legalidade. II - Agravo improvido. (MS 28872 AgR, Relator(a): Min. RICARDO LEWANDOWSKI, Tribunal Pleno, julgado em 24/02/2011, DJe-051 DIVULG 17-03-2011 PUBLIC 18-03-2011).

${ }^{494}$ Segue a ementa da decisão:
}

Conselho Nacional de Justiça. Processo legislativo instaurado por iniciativa de Tribunal de Justiça. Suposta eiva de inconstitucionalidade. Impossibilidade de o Conselho Nacional de Justiça, sob alegação de "aparente vício do projeto original", impor, cautelarmente, ao Presidente do Tribunal de Justiça, que se abstenha de cumprir o diploma legislativo editado. Limitações que incidem sobre a competência do Conselho Nacional de Justiça (CF, art. 103-B, $\S 4^{\circ}$ ). Precedentes. Magistério da doutrina. A instauração do processo legislativo como ato de caráter eminentemente político e de extração essencialmente constitucional. Doutrina. A questão do controle de constitucionalidade pelo Conselho Nacional de Justiça. Reconhecimento, pelo Relator desta causa, de que há, na matéria, controvérsia doutrinária. Inadmissibilidade, contudo, de referida fiscalização segundo precedentes do STF e do próprio CNJ. Medida cautelar deferida.

${ }^{495}$ Segue a ementa da decisão:

CONSELHO NACIONAL DE JUSTIÇA. CONTROLE DE CONSTITUCIONALIDADE. INADMISSIBILIDADE. ATRIBUIÇÃO ESTRANHA À ESFERA DE COMPETÊNCIA DESSE ÓRGÃO DE PERFIL ESTRITAMENTE ADMINISTRATIVO. ATUAÇÃO "ULTRA VIRES". LEGITIMIDADE DO CONTROLE JURISDICIONAL. PRECEDENTES DO SUPREMO TRIBUNAL FEDERAL (PLENO). AUTOGOVERNO DA MAGISTRATURA, PRERROGATIVA INSTITUCIONAL DOS TRIBUNAIS JUDICIÁRIOS E AUTONOMIA DOS ESTADOS-MEMBROS: LIMITAÇÕES CONSTITUCIONAIS QUE NÃO PODEM SER DESCONSIDERADAS PELO CONSELHO NACIONAL DE JUSTIÇA. LIMINAR MANDAMENTAL E A QUESTÃO DA INVESTIDURA APARENTE. PRINCÍPIOS DA 
Conselho Nacional de Justiça, embora integre o Poder Judiciário, tem índole eminentemente administrativa, "não se achando investido de atribuições institucionais que lhe permitam proceder ao controle abstrato de constitucionalidade referente a leis e a atos estatais em geral".

No entanto, no julgamento do Mandado de Segurança $n^{\circ} 28141$ em 10 de fevereiro de 2011, da relatoria do Ministro Ricardo Lewandowski, impetrado pela Associação Matogrossense dos Defensores Públicos - AMDEP contra a decisão do CNJ proferida no Pedido de Providências $n^{\circ}$ 2009.10.00.000103-8, houve manifestações de Ministros do Supremo Tribunal Federal em sentido contrário, admitindo o exercício do controle de constitucionalidade pelo Conselho Nacional de Justiça.

No referido pedido de providências, relatado pelo Conselheiro Jorge Antonio Maurique, o Conselho Nacional de Justiça apreciou caso do Estado do Mato Grosso, onde a Lei Estadual n ${ }^{\text {0 }}$ 8.943, de 29 de julho de 2008, modificou a Tabela "D" da Lei Estadual n 7.603, de 27 de dezembro de 2001, para determinar o repasse de R 0,93 dos valores cobrados de emolumentos judicias, por feito distribuído à Associação Matogrossense dos Defensores Públicos (AMDEP). Referidas leis também estabeleceram idêntico repasse à Ordem dos Advogados do Brasil - Seção Mato Grosso (conforme previsto na Lei Estadual $n^{\circ}$ 5.607/1990), à Associação Mato-grossense do Ministério Público (conforme previsto na Lei Estadual n ${ }^{\circ}$ 4.348/1981), à Associação Mato-grossense dos Magistrados e à Associação dos Notários e Registradores do Estado do Mato Grosso (conforme previsto na Lei Estadual $n^{\circ}$ 3.605/1974) e à Associação dos Procuradores do Estado do Mato Grosso. Ao apreciá-lo, o Conselho Nacional de Justiça, fundado em precedentes do Supremo Tribunal Federal $^{496}$, determinou que os Tribunais do país cessassem o repasse previsto em Leis Estaduais de parte dos valores cobrados à título de emolumentos judiciais, a pessoas jurídicas estranhas ao Poder Judiciário, entidades de classe, ou entidades com finalidade privada. Ainda ordenou que o Tribunal de Justiça do Mato Grosso revisse seus atos normativos sobre regime de custas, no sentido de expurgar qualquer cobrança de emolumento judicial com destinação a qualquer entidade de classe e/ou com finalidade

SEGURANÇA JURÍDICA, DA PROTEÇÃO DA CONFIANÇA E DA BOA-FÉ OBJETIVA. CONSEQUENTE SUBSISTÊNCIA DOS ATOS ADMINISTRATIVOS E/OU JURISDICIONAIS PRATICADOS EM DECORRÊNCIA DO PROVIMENTO CAUTELAR, AINDA QUE EVENTUALMENTE DENEGADO O MANDADO DE SEGURANÇA. DOUTRINA. JURISPRUDÊNCIA. MEDIDA CAUTELAR DEFERIDA.

${ }^{496}{ }^{A D I} n^{\circ} 1145-6-P B$, Rel. Min. Ilmar Galvão, DJ de 11.10.2002; Medida Cautelar em ADI no 1378-5-ES, Rel. Min. Celso de Mello, DJ de 30.05.1997; e, Medida Cautelar em ADI nº 1889, Rel. Min. Nelson Jobim, DJ de 12.11.1999. 
privada.

Para impugnar a determinação, a AMDEP impetrou o Mandado de Segurança $n^{\circ}$ 28141, argumentando que o CNJ usurpou competência jurisdicional do Supremo Tribunal Federal ao retirar a eficácia do art. $1^{\circ}$ da Lei Estadual Matogrossense $n^{\circ} 8.943 / 2008^{497}$.

O Relator, Ministro Ricardo Lewandowski, em seu voto, reconheceu que o Conselho Nacional de Justiça extrapolou os limites de sua competência ao apreciar a constitucionalidade de lei estadual, mas denegou a segurança e declarou a inconstitucionalidade da alteração promovida na Tabela "D" da Lei Estadual n $n^{0}$ 7.603/2001 pela Lei Estadual $n^{\circ} 8.943 / 2008$, ante a pacífica jurisprudência do STF no sentido de ser vedada a destinação de valores recolhidos a título de custas e emolumentos a pessoas jurídicas de direito privado, conforme decidido na ADI n 3660, da relatoria do Ministro Gilmar Mendes ${ }^{498}$.

Apesar de ter constado, no extrato da Ata de Julgamento, que o STF, por unanimidade $^{499}$, nos termos do voto do relator, indeferiu a segurança e declarou a

${ }^{497}$ Art. $1^{\circ}$ (Lei Estadual Matogrossense $n^{\text {o }}$ 8.943/2008) Fica modificada a Tabela "D" - Custas Devidas a Entidades - da Lei $n^{0}$ 7.603, de 27 de dezembro de 2001, com a inclusão da Associação dos Defensores Públicos e dos Procuradores do Estado de Mato Grosso, fixando o valor da participação para cada entidade, com a seguinte redação:

TABELA D

CONTRIBUIÇÕES

\begin{tabular}{|c|c|c|}
\hline 01 & $\begin{array}{l}\text { À ORDEM DOS ADVOGADOS DO BRASIL - SEÇÃO MT } \\
\left.\text { por feito distribuído (Lei } n^{\circ} 5.607 / 90\right)\end{array}$ & $\mathrm{R} \$ 0,93$ \\
\hline 02 & $\begin{array}{l}\text { À ASSOCIAÇÃO MATO-GROSSENSE DO MINISTÉRIO PÚBLICO } \\
\left.\text { por feito distribuído (Lei } n^{\circ} 4.348 / 81\right)\end{array}$ & $\mathrm{R} \$ 0,93$ \\
\hline 03 & $\begin{array}{l}\text { À ASSOCIAÇÃO MATO-GROSSENSE DOS MAGISTRADOS } \\
\left.\text { por feito distribuído (Lei } \mathrm{n}^{\circ} 3.605 / 74\right)\end{array}$ & $\mathrm{R} \$ 0,93$ \\
\hline 04 & $\begin{array}{l}\text { À ASSOCIAÇÃO DOS NOTÁRIOS E REGISTRADORES DO ESTADO DE MATO } \\
\text { GROSSO } \\
\left.\text { por feito distribuído (Lei }{ }^{\circ} 3.605 / 74\right)\end{array}$ & $\mathrm{R} \$ 0,93$ \\
\hline 05 & $\begin{array}{l}\text { À ASSOCIAÇÃO DOS DEFENSORES PÚBLICOS DO } \\
\text { GROSTADO }\end{array}$ & $\mathrm{R} \$ 0,93$ \\
\hline 06 & À ASSOCIAÇÃO DOS PROCURADORES DO ESTADO DE MATO GROSSO & $\mathrm{R} \$ 0,93$ \\
\hline
\end{tabular}

${ }^{498}$ Segue a ementa desse acórdão:

Ação direta de inconstitucionalidade. 2. Efeito repristinatório da declaração de inconstitucionalidade. 3. Custas judiciais. Destinação a entidades privadas. Inconstitucionalidade. O Supremo Tribunal Federal já manifestou, por diversas vezes, o entendimento de que é vedada a destinação dos valores recolhidos a título de custas e emolumentos a pessoas jurídicas de direito privado. Precedentes. 4. Ação julgada procedente. Tendo em vista razões de segurança jurídica e de excepcional interesse social, aplica-se o art. 27 da Lei ${ }^{\circ}$ 9.868/99, para atribuir à declaração de inconstitucionalidade efeitos a partir da Emenda Constitucional $\mathrm{n}^{\circ} 45$, de 31.12.2004 (ADI 3660, Relator(a): Min. GILMAR MENDES, Tribunal Pleno, julgado em 13/03/2008, DJe-083 DIVULG 08-05-2008 PUBLIC 09-05-2008)

${ }^{499}$ Presentes à sessão os Ministros Cezar Peluso (presidente), Celso de Mello, Marco Aurélio Mello, Ellen Gracie, Gilmar Mendes, Ayres Britto, Joaquim Barbosa, Ricardo Lewandowski, Cármen Lúcia e Dias Toffoli. (conforme extrato da Ata de Julgamento). 
inconstitucionalidade da lei local ${ }^{500}$, a leitura dos debates travados em Plenário revela que vozes dissonantes surgiram entre os ministros quanto à tese de que o $\mathrm{CNJ}$ não poderia reconhecer a inconstitucionalidade da norma discutida.

O Ministro Marco Aurélio Mello defendeu que "qualquer órgão da Administração Pública pode deixar de aplicar uma lei que tenha como inconstitucional”.

Lembrou o Ministro Gilmar Mendes que, antes da Constituição de 1988, questinou-se se o Poder Executivo poderia descumprir lei entendendo-a inconstitucional, tendo a antiga Consultoria-Geral da Républica emitido parecer favorável a essa tese. Destacou, também, que a Súmula STF $n^{\circ} 347^{501}$, anterior a atual Ordem Constitucional, autoriza o Tribunal de Contas a apreciar a constitucionalidade de leis e atos do poder público.

Mais enfâtico em seu voto, o Ministro Dias Toffoli considerou que o Conselho Nacional de Justiça atuou no limite de suas prerrogativas, por entender que o juízo sobre a aplicabilidade ou a constitucionalidade de certas normas não é privativo do Poder Judiciário ou do Supremo Tribunal Federal, distinguindo a "condenação, por inconstitucionalidade, de um texto normativo, por um órgão autorizado" da "restrição levada a efeito por qualquer do povo ou por um órgão do Estado, mas sem o resultado de banir a regra do ordenamento jurídico de maneira erga omnes" ${ }^{202}$.

${ }^{500}$ Segue a ementa desse acórdão:

EMENTA: MANDADO DE SEGURANÇA. CONSELHO NACIONAL DE JUSTIÇA. ATO QUE DETERMINOU AO TRIBUNAL DE JUSTIÇA MATOGROSSENSE QUE DEIXASSE DE COBRAR EMOLUMENTO JUDICIAL COM DESTINAÇÃO A QUALQUER ENTIDADE DE CLASSE OU COM FINALIDADE PRIVADA. INADMISSIBILIDADE. NATUREZA ADMINISTRATIVA DO CNJ. DECRETAÇÃO DE INCONSTITUCIONALIDADE DE LEI. IMPOSSIBILIDADE. REESTABELECIMENTO DA COBRANÇA. INVIABILIDADE. SEGURANÇA DENEGADA. I - O Conselho Nacional de Justiça, órgão de natureza administrativa que é, não possui competência para determinar o afastamento de cobrança de emolumento judicial com fundamento na sua inconstitucionalidade, mesmo porque tal ato termina por afastar a aplicação da própria lei tributária. II - A providência a ser adotada, por eventuais interessados em afastá-la, é a propositura de ação direta de inconstitucionalidade com o intuito de por fim a cobrança de tal exação. III - Embora o CNJ não pudesse, no caso, afastar a cobrança da contribuição instituída pela Lei 8.943/2008, para a Associação Matogrossense dos Defensores Públicos AMDEP, não é possível a concessão da segurança, pois restabelecer a citada cobrança seria fazer tabula rasa da jurisprudência desta Corte, que é absolutamente pacífica no sentido de que é vedada a destinação de valores recolhidos a título de custas e emolumentos a pessoas jurídicas de direito privado. IV - Opiniões divergentes de Ministros quanto à decretação de inconstitucionalidade, no caso. V - Segurança denegada (MS 28141, Relator(a): Min. RICARDO LEWANDOWSKI, Tribunal Pleno, julgado em 10/02/2011, DJe-125 DIVULG 30-06-2011 PUBLIC 01-07-2011).

${ }^{501}$ Súmula $\mathrm{n}^{\mathrm{o}} 347$ (STF): O Tribunal de Contas, no exercício de suas atribuições, pode apreciar a constitucionalidade das leis e dos atos do poder público.

${ }^{502}$ No seu voto, o Ministro Dias Toffoli cita a doutrina de Hely Lopes Meirelles (2001, p. 698 e 699), que, pela relevância, é também a seguir transcrita: "O cumprimento de leis inconstitucionais tem suscitado dúvidas e perplexidades na doutrina e na jurisprudência, mas vem-se firmando o entendimento - a nosso ver exato - de que o Executivo não é obrigado a a catar normas legislativas contrárias à Constituição ou a leis hierarquicamente superiores. Os Estados de Direito, como o nosso, são dominados pelo princípio da legalidade. Isso significa que a Administração e os administrados só se subordinam à vontade da lei - mas da 
Nota-se, pois, forte divergência na doutrina, no Conselho Nacional de Justiça e no Supremo Tribunal Federal quanto à possibilidade do Conselho Nacional de Justica exercer o controle de constitucionalidade de leis e atos normativos, com entedimentos extremos em um sentido ou no outro mencionados.

Cremos que, em regra, é vedado ao CNJ verificar a compatibilidade de lei ou ato normativo com a Constituição. Há, no entanto, uma hipótese em que esse proceder é admissível.

Como exposto neste trabalho, o Conselho Nacional de Justiça é órgão de sobreposição administrativa do Judiciário ${ }^{503}$, para controle interno ${ }^{504}$ da atuação administrativa, financeira do demais órgãos do $\operatorname{Poder}^{505}$ e do cumprimento dos deveres funcionais dos juízes $^{506}$.

$\mathrm{O}$ CNJ, porém, não exerce a função típica do Poder Judiciário - a jurisdição - e também não foi contemplado com a função de legislador negativo ${ }^{507}$.

lei corretamente elaborada. Ora, as leis inconstitucionais não são normas jurídicas atendíveis, pela evidente razão de que colidem como mandamento de uma lei superior, que é a Constituição. Entre o mandamento da lei ordinária e o da Constituição deve ser atendido o desta e não o daquela, que lhe é subordinada. Quem descumpre a lei inconstitucional não comete ilegalidade, porque está cumprindo a Constituição. Ocorre, porém, que, como os atos públicos trazem em si a presunção de legitimidade, não cabe ao particular negarlhes validade por entendimento próprio, sem que antes obtenha do Judiciário a declaração de invalidade. Com a Administração, todavia, a situação é diversa, porque a presunção de legitimidade milita a favor dos atos de todos os agentes do Poder Público. Nivelados no plano governamental, o Executivo e o Legislativo praticam atos de igual categoria, e com idêntica presunção de legitimidade. Se assim é, não se há de negar ao Chefe do Executivo a faculdade de recusar a cumprir ato legislativo inconstitucional, desde que por ato administrativo formal e expresso (decreto, portaria, despacho etc.) declare a sua recusa e aponte a inconstitucionalidade de que se reveste".

${ }^{503}$ Vide item 2.3.7.

${ }^{504}$ Vide item 2.3.4.

${ }^{505}$ Vide item 2.3.5.

${ }^{506}$ Vide item 2.3.6.

${ }^{507}$ Leciona Maurício Zockun (2004, p. 168): "quando se aduz que o Poder Judiciário atua como legislador negativo, quer-se com isso dizer que, no exercício de sua típica função estatal, ele pode suprimir as prescrições normativas produzidas pelos Poderes. Não pode, contudo, produzir normas jurídicas que inovem em campo reservado à atuação dos demais Poderes". A expressão foi cunhada por Hans Kelsen (originalmente, em alemão, der negative Gesetzgeber) durante debates, entre o final da década de 20 e o início dos anos 30 do século XX, com Heinrich Triepel e Carl Schmitt sobre quem deveria exercer o papel de "Guarda da Constituição" (Hüter der Verfassung). Como esclarece Gabriel Nogueira Dias (2010), Triepel mostra-se contrário à existência de uma jurisdição em âmbito constitucional, aceitando encampar a sua defesa apenas na qualidade de expert em Direito Constitucional (Staatsrechtler). Assim, entende pertinente, do ponto de vista funcional do Direito, sua adoção, mas afirma que, do ponto de vista do Estado, referido controle não seria oportuno e legítimo, por representar uma intromissão indevida do Direito no âmbito da política. Schmitt, por seu turno, argumenta que conceito de "Guarda da Constituição" é eminentemente Político. Portanto, inaceitável tornar o Poder Judiciário protetor da Constituição, porque isso representaria uma politização da Justiça. Logo, o único guardião possível da Constituição seria o Presidente, como poder neutro em um Estado dominado pelo pluralismo partidário. Kelsen, porém, argumenta que a Constituição é, juridicamente, a corporificação da unidade do Estado. Assim, a sua guarda deve ser exercida por uma Corte Constitucional, "órgão funcionalmente controlador da consonância das normas inferiores com o degrau de 
Assim, não lhe compete o controle jurisdicional da constitucionalidade das leis e dos atos normativos.

Por outro lado, como o Conselho Nacional de Justiça é um órgão de vigilância interno do Poder Judiciário, não lhe cabe, administrativamente, realizar qualquer controle sobre a atividade típica afeta ao Poder Legislativo.

Sob outro prisma, poder-se-ia argumentar que o Conselho Nacional de Justiça, como órgão de chefia administrativa no âmbito do Judiciário, poderia determinar que os demais órgãos do Poder deixassem de aplicar lei que o Colegiado Administrativo considerasse inconstitucional, pois, afinal, admite-se que o Chefe do Poder Executivo ordene que lei com esse vício deixe de ser obedecida ${ }^{508}$.

Com efeito, Elival da Silva Ramos (1994, pp. 236 a 241) discorre sobre a postura que deve adotar o Poder Executivo ao se deparar com uma lei que considere inconstitucional em sistemas, como o brasileiro, em que a sanção para as leis que violem a Constituição é a nulidade. Afirma que, nesse caso, "é irrecusável a competência do Poder Executivo para negar cumprimento à lei inconstitucional", pois ela "é nula de pleno direito e destituída de

criação absoluta do direito", i.e. a Carta Magna", o que não significa politizar a função jurisdicional, mas proteger a Constituição de tentativas de mudança. Por outro lado, a Corte Constitucional age como "legislador negativo" porque não deve de criar novas normas, mas restringir-se a "à função derrogatória ou meramente cassatória de normas em desacordo com a Constituição Federal".

${ }^{508}$ Nesse sentido, há decisões do CNJ ordenando órgãos do Poder Judiciário a afastar a incidência de normas locais consideradas contrárias à Constituição, ainda que reconhecendo a impossibilidade do Conselho exercer controle de constitucionalidade. Nesse sentido, seguem duas ementas de julgados do Colegiado Administrativo:

É sabido que este Conselho jamais poderia realizar controle difuso ou abstrato de constitucionalidade de norma estadual, porque estranho à sua natureza de órgão controlador da administrativa e financeira do Poder Judiciário. Contudo, conforme previsão constante do art. 103-B, § $4^{\circ}$, II da Constituição Federal, compete ao CNJ, dentre outras atribuições, 'zelar pela observância do art. 37 e apreciar, de ofício ou mediante provocação, a legalidade dos atos administrativos praticados por membros ou órgãos do Poder Judiciário, podendo desconstituí-los, revê-los ou fixar prazo para que se adotem as providências necessárias ao exato cumprimento da lei, sem prejuízo da competência do Tribunal de Contas da União'. Assim, considerando o permissivo constitucional, entende-se que o CNJ tem competência para determinar ao Tribunal que afaste a incidência da norma estadual que limita a participação de pessoas em certame público para a carreira da magistratura estadual em razão da idade, obedecendo-se então ao princípio da isonomia, um dos pilares do ordenamento jurídico brasileiro. (PCA n ${ }^{\circ}$ 2008.10.00.000586-6, Rel. Cons. Paulo Lobo, j. 61 $1^{\text {a }}$ Sessão Ordinária, em 29.04.2008, p. DJU de 20.05.2008);

PEDIDO DE PROVIDÊNCIAS. TRIBUNAL DE JUSTIÇA DE GOIÁS. CUMPRIMENTO DA LEI ESTADUAL N. 16.167/2007. CONVOCAÇÃO DE JUIZ AUXILIAR PARA A PRESIDÊNCIA DA CORTE. FACULDADE DO TRIBUNAL. PEDIDO JULGADO IMPROCEDENTE. AFASTAMENTO DE NORMA ESTADUAL QUE FERE A CONSTITUIÇÃO BRASILEIRA DE 1988.

I. A convocação de juízes auxiliares é faculdade atribuída ao Presidente do Tribunal, não sendo matéria afeta às competências do Conselho Nacional de Justiça.

II. Pode o Conselho Nacional de Justiça determinar aos Tribunais que afastem a incidência de norma estadual contrária à Constituição Federal. ( $\mathrm{PP} \mathrm{n}^{\mathrm{o}}$ 2008.10.00.002430-7, Rel. Cons. Andréa Pachá, j. 73ª Sessão Ordinária, em 04.11.2008, p. DJU de 21.11.2008). 
toda e qualquer eficácia desde o seu nascimento" e o Executivo está obrigado a observar a Constituição ${ }^{509}$.

Ressalta, porém, que, "por se tratar de medida extremamente grave e com ampla repercussão nas relações entre os Poderes", a determinação de descumprimento de lei deve emanar somente do Chefe do Poder Executivo e estar devidamente motivada, sob pena de incorrer em crime de responsabilidade ( $\mathrm{CF}$, art. 85, VII), pois, ao tomar posse, presta o compromisso de manter, defender e cumprir a Constituição, bem como observar as leis

${ }^{509}$ O tema não é novo na doutrina. Como citado por Leopoldo César de Miranda Lima Filho em parecer publicado na Revista de Direito Administrativo, vol. 81, 1965, pp. 466 a 475 (disponível em http://bibliotecadigital.fgv.br/ojs/index.php/rda/article/view/27730. Acesso em 10.12.2014), defendem que o Poder Executivo não é obrigado a cumprir as disposições legais violadoras dos preceitos constitucionais: Vicente Rao (Fôlha de São Paulo, 20-3-63, entrevista); José Frederico Marques (O Estado de São Paulo, 17-62, entrevista; Fôlha de São Paulo, 21-3-63, entrevista); Miguel Reale (parecer publicado no Diário Oficial do Estado de São Paulo, número de 19-3-63. págs. 7 e 8); Mário Mazagão (Curso de Direito Administrativo, $3^{a}$ ed., pág. 163); Lúcio Bitencourt (O Contrôle Jurisdicional da Constitucionalidade das Leis, Ed. Rev. Forense, Rio, 1949, pág. 91, nota 3), Carlos Maximiliano (Comentários à Constituição Brasileira. Ed. da Livraria do Globo, Pôrto Alegre, 1929. $3^{\text {a }}$ ed. págs. 312, n· 226, e 505, n 326-B), Felipe Tena Ramírez (Derecho Constitucional Mexicano, Editorial Porrua, S. A., México. 1944, pág. 479), Gaetano Azzariti (Problemi Attuali di Diritto Costituzionale, Dott. A. Giuffrè Editore. Milão, 1951, pág. 197, nº 6) e Seabra Fagundes (O Contrôle dos Atos Administrativos pelo Poder Judiciário. Ed. Rev. Forense, Rio, 1957, $3^{a}$ ed., pág. 298). Em sentido contrário, negando ao Executivo o poder de recusar a aplicação de lei que entende inconstitucional, sustentam: Willoughhy, W. W. (The Constitutional Law of the United States, Baker. Voorhie and Co., Nova Iorque, 1929, $2^{\text {a }}$ ed., vol. I, pág. 16, § 12, vol. III, pág. 1.502, § 983; Principles of the Constitutional Law of the United States, id. ib., págs. 542-544, 1919); Mathews J. M. (The American Constitutional System, McGraw-Hill Book Co., Inc., Nova Iorque e Londres, 1940, 2a ed., pág. 154; Black, H. C., Handbook of American Constitutional Law, West Publishing Co., São Paulo, Minesota, 1927, 4a ed., pág. 54, cap. 4, § 30; Oscar Saraiva, parecer na Revista Forense, vol. 116, pág. 42; Charles Evans Hughes, The Supreme Court of the United States, Garden City Publishing, 1936, pág. 86; Buzaid, Alfredo (Da Ação Direta de Declaração de Inconstitucionalidade no Direito Brasileiro, ed. Saraiva, São Paulo, 1958, págs. 11$12, \mathrm{n}^{\circ} 11,58, \mathrm{n}^{\circ} 19$, e $\mathrm{n}^{\mathrm{o}} 79, \mathrm{n}^{\mathrm{o}} 29$ ). Oscar Saraiva, em voto vencido proferido no MS $\mathrm{n}^{\mathrm{o}} 16003$, relator Ministro Prado Kelly, julgado no STF em 30.09.1966, argumentou que o Executivo não poderia deixar de aplicar a lei, ainda que a considerasse contrária à Carta Política, porque o próprio Chefe do Executivo, anteriormente (ainda que outra pessoa ocupasse o cargo), a sancionou, ou seu veto foi vencido pelo Parlamento (conforme atualmente previsto no art. $66, \S 4^{\circ}$, da Constituição Federal). Assim, "a lei já foi elaborada, já passou através de todos os processos constitucionais de sua elaboração, de sorte que ela, em si, obriga sem necessidade de opção ou interpretação, que é reservada ao Poder Judiciário". Alfredo Buzaid, por seu turno, nessa linha, afirma que "o poder de decretar a inconstitucionalidade das leis, no Brasil, compete privativamente ao Judiciário. Não o pode exercer o legislativo, porque lhe é vedado ser juiz em causa própria; aliás a sua função consiste em elaborar ou revogar leis, não em apreciar a sua validade. Também não o pode exercer o executivo, pois isso o tornaria superior ao Congresso". Porém, Elival da Silva Ramos esclarece que a jurisprudência do Supremo Tribunal Federal consolidou-se no sentido da possibilidade do Chefe do Executivo determinar o descumprimento de lei que repute inconstitucional no julgamento, em $21 \mathrm{de}$ novembro de 1979, da Representação de Inconstitucionalidade $\mathrm{n}^{\circ}$ 980. Na ocasião, o relator, Ministro Moreira Alves, refutou as razões apresentadas por Oscar Saraiva e Alfredo Buzaid. Sustentou que o primeiro confundiu, em seu argumento, a elaboração da lei com a sua execução. Por outro lado, ante o afirmado por Buzaid, como pontifica Frederico Marques (O Estado de São Paulo, 1-7-62, entrevista) "não é só o Judiciário que possui o poder de controlar a constitucionalidade de ato emanado de órgão do Poder Público. Se a última palavra sobre a questão está com os juízes e os tribunais, na da impede, porém, que os outros Poderes também as resolvam, na esfera de suas atribuições. A diferença entre o controle judiciário e a verificação de inconstitucionalidade de outros Poderes reside em que o primeiro é definitivo hic et nunc, enquanto a segunda está sujeita a exame posterior pelas Côrtes de Justiça". Moreira Alves ainda afirmou que, se ao particular, na defesa de seu interesse privado, é dada a opção de cumprir a Constituição ou desrespeitála para dar cumprimento a lei inconstitucional, ao Chefe do Executivo também deve deve ser conferida essa faculdade, pois busca prestigiar, com seu ato, a supremacia da Carta Política. 
$\left(\mathrm{CF}\right.$, art. 78, caput $^{510}$. Funcionários, subalternos, porém, não podem determinar o descumprimento de leis que reputem inconstitucionais, pois esse proceder poderia produzir uma crise institucional, por desautorizar Poder Legislativo.

Acrescenta ainda o doutrinador que, como após o advento da Constituição de 1988, o Presidente da República e os Governadores de Estado passaram a ter legitimidade para a propositura de ação de inconstitucionalidade de lei federal ou estadual, "podendo até mesmo, formular pedido para que o Supremo Tribunal Federal suspenda, liminarmente, a execução do ato impugnado" (CF, art. 102, I, "a" e "p"; CF, art. 103, I e V), a recusa ao cumprimento de lei ordenada pelo Chefe do Poder Executivo pode perdurar "apenas até o julgamento do pedido de medida cautelar, por ele próprio formulado" em sede de ação direta de inconstitucionalidade dirigida à Alta Corte, pois, a partir desse ponto, ou a execução da lei estará suspensa por decisão da Suprema Corte Brasileira de acolhimento o pedido da cautelar, com eficácia erga omnes, ou, no caso de rejeição do pleito, os fundamentos invocados pelo Executivo para seu descumprimento não poderão mais prevalecer em razão da negação do "fumus boni iuris da arguição ou os danos que a execução temporária da lei possa provocar (periculum in mora)" pelo STF.

Essa orientação, no entanto, entendemos, não pode ser aplicada ao Conselho Nacional de Justiça, malgrado desempenhe, no desenho institucional do Poder Judiciário, destacada função administrativa, estando seus membros, inclusive, sujeitos a impechment $(\mathrm{CF}$, art. 52, II).

O CNJ não exerce controle administrativo, financeiro e disciplinar sobre o Supremo Tribunal Federal e seus ministros (e também não pode realizá-lo em relação ao Tribunal Superior Eleitoral) ${ }^{511}$. Portanto, não é um órgão de cúpula do Poder Judiciário (apenas de sobreposição) e não está, assim, em comparação aos demais Poderes da República, no mesmo plano dos seus órgãos superiores (Chefias do Executivo e do Legislativo). Logo, o Conselho não pode ser considerado, apesar de sua posição de predominância na estrutura do Judiciário Brasileiro, como órgão administrativo de direção superior apto a determinar o descumprimento de lei por vício de inconstitucionalidade para todos os demais órgãos do Poder (uma vez, que, como exposto, não controla administrativamente todos os órgãos do Judiciário).

\footnotetext{
${ }^{510}$ Em tom provocativo, questiona Leopoldo César de Miranda Lima Filho (1965, p. 468): "Como pode o Presidente da República responder fielmente ao juramento de 'manter, defender e cumprir a Constituição da República', quando descubra conflito manifesto entre ela e lei votada pelo Legislativo, senão recusando aplicação a esta?".

${ }^{511}$ Vide itens 2.3.7.1 e 2.3.7.2.
} 
Por fim, não cabe ao Conselho Nacional de Justiça verificar a compatibilidade da leis e demais atos normativos com a Constituição porque o próprio Colegiado deve respeito à normatividade estabelecida na $\mathrm{EC} \mathrm{n}^{\mathrm{o}}$ 45/2004, que o concebeu, e ao Estatuto da Magistratura, lei complementar de iniciativa do Supremo Tribunal Federal (CF, art. 93, caput), cujo cumprimento deverá zelar e que também regerá suas atribuições e disciplinará seu funcionamento (CF, art. 103-B, $\S 4^{\circ}$, in fine; $\mathrm{EC} \mathrm{n}{ }^{\mathrm{o}} 45 / 2004$, art. $5^{\circ}, \S 2^{\circ}$ ). Como o amplo controle de constitucionalidade é aceito em nosso ordenamento jurídico pelo STF, podendo ser verificada se qualquer espécie normativa se harmoniza com o Texto Constitucional originário, inclusive as surgidas como manifestação do Poder Constituinte Derivado (emendas constitucionais), se for admitido que o CNJ possa realizá-lo, ou possa determinar a não aplicação de norma que repute inconstitucional, poder-se-á chegar ao extremo do próprio Conselho pretender analisar a constitucionalidade (e, eventualmente, afastar a incidência), das próprias regras que fixaram suas competências e limites, previstas na EC n 45/2004, além daquelas que venham a ser definidas no Estatuto da Magistratura concernentes ao seu funcionamento e atribuições, e cuja observância deverá cuidar, o que não é conferido a qualquer Poder da República.

Portanto, entendemos que a declaração da inconstitucionalidade de lei e/ou a determinação de seu descumprimento por vício de inconstitucionalidade não podem ser realizadas pelo Conselho Nacional de Justiça.

Também, como pontuado pelo Supremo Tribunal Federal no julgamento da Medida Cautelar na Ação Cautelar $n^{\circ}$ 2390, não está o CNJ autorizado a invalidar atos administrativos dos demais órgãos do Judiciário que se limitem a dar cumprimento a lei porque, nesse caso, termina o Colegiado por, indiretamente, reconhecer a sua inconstitucionalidade, ao afastar a aplicação da norma no caso concreto na estrutura judiciária (muitas vezes, ainda, com determinação de observância da decisão a todos os demais órgãos do Poder, tornando-a indireta declaração de inconstitucionalidade erga omnes e vinculante, como salientou Alexandre de Moraes (2014)).

Nesses casos, deverá o Conselho Nacional de Justiça limitar-se a instar um dos atores constitucionalmente legitimados (CF, art. 103, I a IX), normalmente o Procurador-Geral da República, à propositura de ação direta de inconstitucionalidade da lei ou do ato normativo que reputou inconstitucional a fim de que seja estirpado do Ordenamento por decisão do Supremo Tribunal Federal.

Apesar do afirmado, pensamos ser admissível que o Conselho Nacional de Justiça verifique a compatibilidade com a Constituição de ato normativo editado por órgão do 
Poder Judiciário sujeito ao seu controle que não tenha como fundamento de validade uma lei ou outro ato normativo superior infraconstitucional (ou seja, pretende buscar seu alicerce diretamente na Carta Política) porque, nesse caso específico, está a exercer o poder de autotutela que lhe é ínsito e não invade seara alheia à sua área de atuação.

Por exemplo, aceitável que o CNJ afaste a incidência de suposto ato normativo editado por tribunal sujeito ao seu controle que estabeleça etapas prévias para a distribuição de processos judiciais aos relatores (como a remessa dos autos a setores para permanecerem em fila de distribuição em razão de cotas períodicas máximas de distribuição que devam ser observadas), porque a Emenda Constitucional no 45/2004, ao incluir o inciso XV ao art. 93 da Constituição Federal, tornou obrigatória a distribuição imediata dos processos, em todos os graus de jurisdição ${ }^{512}$.

Em síntese, ao CNJ é vedado, em regra, declarar a inconstitucionalidade de lei ou ato normativo ou determinar seu descumprimento por vício de inconstitucionalidade, devendo limitar-se a provocar um dos atores constitucionalmente legitimados a ajuizar ação direta de inconstitucionalidade perante o Supremo Tribunal Federal para que esta Corte, enquanto guarda da Lei Maior, exerça o controle da compatibilidade da norma com os preceitos maiores da Carta Política. Poderá o Conselho, no entanto, em razão do poder de autotutela, verificar a compatibilidade com a Constituição de ato normativo editado por órgão do Poder Judiciário sujeito ao seu controle que não esteja fundado em lei ou outro ato normativo superior infraconstitucional.

\subsubsection{Controle disciplinar}

${ }^{512}$ Em caso semelhante, o Conselho Nacional de Justiça ordenou, por votação unânime, no julgamento, em
31 de março de 2009, do Pedido de Providências n n $^{\circ} 2008.10 .00 .002907-0$, da relatoria do Conselheiro
Marcelo Nobre, que o Tribunal de Justiça do Estado de São Paulo regularizasse a distribuição dos processos
criminais aportados na Corte porque, apesar da regra inserta no art. $1^{\circ}$, caput, da Resolução no 204 , de 20 de
abril de 2005, daquele Sodalício (“art. $1^{\circ}$ - Todos os feitos entrados serão imediatamente distribuídos aos
Desembargadores e Juízes Substitutos em Segundo Grau em exercício"), a Seção Criminal do TJSP
encaminhava os autos para parecer do Ministério Público antes da distribuição necessária. O controle
realizado pelo CNJ, neste caso, porém, não foi da constitucionalidade do ato normativo editado pelo TJSP,
compatível com a regra constitucional, mas do proceder (ato material) da sua Seção Criminal. Estiverem
presentes na sessão os Conselheiros Gilson Dipp, João Oreste Dalazen, Rui Stoco, Mairan Gonçalves Maia
Júnior, Altino Pedrozo dos Santos, Andréa Pachá, Jorge Maurique, Antonio Umberto de Souza Júnior, José
Adonis Callou de Araújo Sá, Felipe Locke Cavalcanti, Paulo Lobo, Técio Lins e Silva e Marcelo. Ausente,
justificadamente, o Conselheiro Joaquim Falcão (conforme certidão de julgamento da $81^{a}$ Sessão Ordinária
do CNJ). Segue a ementa do acórdão administrativo:

PEDIDO DE PROVIDÊNCIAS. DISTRIBUIÇÃO IRREGULAR DOS PROCESSOS CRIMINAIS, DESCUMPRIMENTO RESOLUÇÃO 204/2005 E CONSTITUIÇÃO FEDERAL. "O processo deve ser imediatamente distribuído ao ser protocolizado no Tribunal, não havendo justificativa para postergação da distribuição. Inteligência do art. 93, XV, da Constituição Federal. 
Devido às razões históricas que levaram à criação do Conselho Nacional de Justiça, foi dada muita ênfase ao controle disciplinar que o Conselho Nacional de Justiça passaria a exercer no âmbito do Poder Judiciário.

Ao tratarmos dos elementos constitucionais característicos do $\mathrm{CNJ}$, sustentamos que o órgão, quanto ao controle "do cumprimento dos deveres funcionais dos juízes" (CF, art. 103-B, $\S 4^{\circ}$ ), pode realizá-lo em relação aos deveres jurídicos dos magistrados, positivados, consubstaciem estes ou não também deveres morais. Por outro lado, a atuação do Conselho não pode atingir a independência dos juízes no exercício da jurisdição ${ }^{513}$.

As normas insertas nos incisos III e V do $\S 4^{\circ}$ do art. 103-B, da Constituição da República estabelecem, para efetivação, pelo CNJ, do controle dos deveres funcionais dos magistrados, bem como para a realização de fiscalização sobre seus serviços auxiliares, serventias e tambem sobre os órgãos prestadores de serviços notariais e de registro que atuem por delegação do poder público ${ }^{514}$ ou oficializados, três competências disciplinares específicas: a) recebimento e conhecimento de reclamações (inc. III); b) avocação de processos disciplinares em curso (inc. III); e, c) revisão, de ofício ou mediante provocação, dos processos disciplinares de juízes e membros de tribunais julgados há menos de um ano (inc. V).

Restou explicitado que o Conselho Nacional de Justiça, no âmbito dessas competências disciplinares, pode impor punições administrativas, inclusive determinar a remoção, a disponibilidade ou a aposentadoria com subsídios ou proventos proporcionais ao tempo de serviço, desde que garantido o direito a ampla defesa (CF, art. 103-B, $\S 4^{\circ}$, III). Essas sanções somente poderão ser impostas mediante deliberação da maioria absoluta dos membros do Conselho Nacional de Justiça, consoante dispõem as regras previstas no art. 93, VIII e X, da Lei Maior.

Cumpre observar que, das três competências disciplinares específicas, a primeira recebimento e conhecimento de reclamações contra membros ou órgãos do Poder Judiciário, inclusive contra seus serviços auxiliares, serventias e órgãos prestadores de serviços notariais e de registro que atuem por delegação do poder público ou oficializados - pode ser exercida, ao menos até o julgamento definitivo da ADI $n^{\circ} 4638$, de forma originária e concorrente pelo Conselho Nacional de Justiça.

\footnotetext{
${ }^{513}$ Vide item 2.3.6.

${ }^{514}$ Vide item 2.3.4.
} 
Com efeito, como tratado ${ }^{515}$, quando editada a Resolução CNJ n ${ }^{\text {o }}$ 135/2011, questionou-se, através da ADI $n^{\circ} 4638$, a constitucionalidade da regra prevista em seu art. 12, que reza que "para os processos administrativos disciplinares e para a aplicação de quaisquer penalidades previstas em lei, é competente o Tribunal a que pertença ou esteja subordinado o Magistrado, sem prejuízo da atuação do Conselho Nacional de Justiça", porque reconhece ter o $\mathrm{CNJ}$ competência originária e concorrente a dos tribunais para exercer o controle do cumprimento dos deveres funcionais dos magistrados. Apesar do relator, Ministro Marco Aurélio Mello ter, em decisão liminar, conferido ao dispositivo impugnado interpretação conforme, de modo a assentar a competência subsidiária do Conselho em âmbito disciplinar, no julgamento do referendo da decisão, o Plenário do STF, manteve a norma no Ordenamento em seu inteireza.

Ou seja, até o julgamento definitivo da ADI n 4638 pelo Supremo Tribunal Federal, tem o Conselho Nacional de Justiça competência para conhecer de reclamações contra membros ou órgãos do Poder Judiciário, inclusive contra seus serviços auxiliares, serventias e órgãos prestadores de serviços notariais e de registro que atuem por delegação do poder público ou oficializados, independentemente da prévia existência de reclamação dirigida aos órgãos correicionais dos tribunais que estejam vinculados ou mesmo concomitantemente ao tramitê de processos administrativos contra os reclamados perante os órgãos locais ${ }^{516}$.

A segunda competência disciplinar atribuída ao CNJ - avocação de processos disciplinares em curso - somente pode ser exercida durante o trâmite de processos administrativos perante os órgãos do Poder Judiciário.

Conforme leciona Regis Fernandes de Oliveira (2005, p. 183), com suporte nas ensinanças de Agustín Gordillo, Oswaldo Aranha Bandeira de Mello e Arnaldo de Valles, “avocar é o ato do hierarca que traz para si a competência que é do subalterno" operandose em relação a um ato. Não pode ocorrer avocação "quando a competência do inferior é absoluta e excludente de exercício de competência concorrente" ou quando já há "ato de

\footnotetext{
${ }^{515}$ Vide item 2.3.7.5.1.

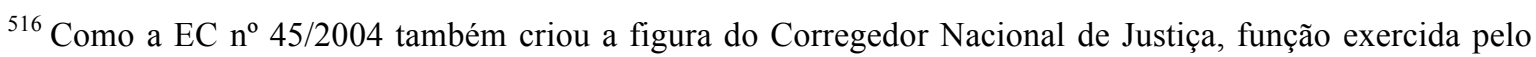
Ministro do Superior Tribunal de Justiça que integra o CNJ, e definiu-lhe, no art. 103-B, $\S 5^{\circ}$, da Carta da República, três atribuições, sem prejuízo de outras a serem conferidas pelo Estatuto da Magistratura, dentre elas a de receber reclamações e denúncias, de qualquer interessado, relativas aos magistrados e aos serviços judiciários (inc. I), o Regimento Interno do CNJ, para disciplinar o assunto, estabelece diversos procedimentos relativos à apreciação de denúncias e reclamações a serem realizados previamente pela Corregedoria Nacional de Justiça antes de submeter suas conclusões à apreciação do Plenário do Colegiado: inspeção, correição, sindicância, reclamação disciplinar e representação por excesso de prazo (vide item 3.2, 3.2 .1 e 3.2 .2 ).
} 
deliberação do inferior no mundo jurídico", pois, "quando o ato já existe e o superior toma a si a responsabilidade de resolver a matéria, fá-lo através não da avocação, mas do poder de reforma de ofício da decisão inferior".

Ao se aplicar a lição supra, mutatis mutandis, na esfera da competência específica do Conselho Nacional de Justiça, pode-se afirmar que somente poderá haver avocação pelo Alto Colegiado de processos disciplinares instaurados nos demais órgãos do Judiciário que ainda não tenham sido definitivamente julgados administrativamente pelos órgãos locais. Se, porém, já houver pronunciamento definitivo na província, ou seja, decisão da qual não caiba mais qualquer recurso administrativo no âmbito local, ainda que os interessados não tenham dela sido cientificados, inadmissível determinar-se a avocação do processo disciplinar.

Cumpre registrar que a avocação de processos disciplinares em curso nos órgãos do Poder Judiciário independe da existência de procedimento correlato em trâmite perante o Conselho Nacional de Justiça ${ }^{517}$.

A terceira competência disciplinar específica do $\mathrm{CNJ}$ - revisão, de ofício ou mediante provocação, dos processos disciplinares de juízes e membros de tribunais julgados há menos de um ano - ao contrário das anteriores, somente pode ser exercida quando já exista ato de deliberação de órgão do Poder Judiciário. Por outro lado, é admitida apenas nos

\footnotetext{
${ }^{517}$ A avocação de processo disciplinar em curso contra membros do Poder Judiciário ou de seus serviços auxiliares, serventias e órgãos prestadores de serviços notariais e de registro é disciplinada pelo Regimento Interno do CNJ. Pode ocorrer mediante representação fundamentada de membro do CNJ, do ProcuradorGeral da República, do Presidente do Conselho Federal da OAB ou de entidade nacional da magistratura. (Art. 79, caput). Se a matéria, de acordo com o Regimento Interno, for da competência da Corregedoria Nacional de Justiça, caberá ao Corregedor Nacional de Justiça sobre ela decidir (art. 79, parágrafo único, primeira parte). Se acolher o pedido, ouvirá o órgão disciplinar local em prazo de 15 dias e adotará as providências pertinentes no âmbito da sua competência da Corregedoria Nacional de Justiça, conhecendo e deliberando definitivamente a respeito, com ciência aos interessados (art. 80). Se a matéria, porém, for da competência do Plenário do CNJ, a representação será autuada e distribuída a um Conselheiro Relator, que determinará seu arquivamento liminar, se manifestamente infundado o pedido (art. 79, parágrafo único, in fine). Se o Relator, porém, considerar relevante o pleito, mandará ouvir, em quinze dias, o magistrado ou o servidor e o órgão disciplinar originariamente competente para a decisão (art. 81, caput). Findo o prazo, com ou sem as informações, o Relator pedirá a inclusão do processo em pauta, para deliberação pelo Plenário (art. $81, \S 1^{\circ}$ ) que, decidindo pela avocação do processo disciplinar, comunicará imediatamente ao tribunal respectivo, para o envio dos autos no prazo máximo de quinze dias (art. $81, \S 2^{\circ}$ ) para serem novamente autuados como processo disciplinar e distribuidos por prevenção ao Relator (ou encaminhados ao Corregedor Nacional nas matérias de sua competência) (art. $81, \S 3^{\circ}$ e 81-A, caput), a quem caberá ordená-lo e dirigi-lo, podendo aproveitar os atos já praticados regularmente na origem (art. $81, \S 4^{\circ}$ e 81 -A, parágrafo único). Caso haja procedimento em curso no $\mathrm{CNJ}$ e verifique-se a necessidade de avocação de procedimento disciplinar correlato, o Corregedor Nacional de Justiça ou o Conselheiro Relator, depois de ouvir o órgão respectivo, proporá, incidentalmente, ao Plenário a medida (art. $81, \S 5^{\circ}$ e art. $81-\mathrm{B}$ ).
} 
processos disciplinares movidos contra magistrados ${ }^{518}$ e deve ser realizada até um ano de seu julgamento final na origem.

Ressalte-se que o Conselho Nacional de Justiça limitou ainda mais a possibilidade de revisão de processos disciplinares, pois estabeleceu, na norma inserta no art. 83 do seu Regimento Interno, que ela somente é admitida: quando a decisão proferida pelo órgão local for contrária a texto expresso da lei, à evidência dos autos ou a ato normativo do CNJ (inc. I), quando fundar-se em depoimentos, exames ou documentos comprovadamente falsos (inc. II) ou quando, após ser prolatada, surgirem fatos novos ou novas provas ou circunstâncias que determinem ou autorizem sua modificação (inc. III) ${ }^{519}$.

\footnotetext{
${ }^{518} \mathrm{O}$ CNJ consolidou entendimento no sentido de que não lhe compete a revisão de processos disciplinadores instaurados contra servidores ou titulares de serventias extrajudiciais, mesmo que o interessado, para tanto, utilize de meio processual administrativo diverso da revisão disciplinar para postular a manifestação do Conselho. Nesse sentido, podem ser citados os seguintes julgados administrativos:
}

RECURSO ADMINISTRATIVO - PROCEDIMENTO DE CONTROLE ADMINISTRATIVO PROCESSO ADMINISTRATIVO DISCIPLINAR DE SERVIDOR - IMPOSSIBILIDADE. 1. Não se insere nas atribuições institucionais do Eg. Conselho Nacional de Justiça o exame de questões meramente individuais, sem repercussão geral ou a revisão de processos disciplinares de servidores do Judiciário. 2. Entendeu-se que o Eg. CNJ não pode ser reduzido a mera instância recursal administrativa, sob pena de inviabilizar-se o cumprimento de suas atribuições constitucionais. Precedentes. 3. Recurso Administrativo a que se nega provimento. (CNJ - RA - Recurso Administrativo em PCA - Procedimento de Controle Administrativo - 0004494-78.2013.2.00.0000 - Rel. MARIA CRISTINA IRIGOYEN PEDUZZI - 176 ${ }^{\mathrm{a}}$ Sessão - j. 08/10/2013);

RECURSO EM PROCEDIMENTO DE CONTROLE ADMINISTRATIVO. TRIBUNAL DE JUSTIÇA E CORREGEDORIA GERAL DE JUSTIÇA DO ESTADO DO ACRE. PROCEDIMENTO DISCIPLINAR. PERDA DE DELEGAÇÃO DE SERVENTIA EXTRAJUDICIAL. AUSÊNCIA DE COMPETÊNCIA DO CNJ. PRECEDENTES. CONSTITUIÇÃO DA REPÚBLICA, ART. 103-B. MATÉRIA PARCIALMENTE JUDICIALIZADA. 1. "Não é cabível a utilização da via do procedimento de controle administrativo para obter revisão de processo disciplinar instaurado contra servidor ou titular de serventia extrajudicial". Precedentes do CNJ. 2. O instrumento processual, no CNJ, para rever penalidade aplicada em processos disciplinares não é o procedimento de controle administrativo, mas a revisão disciplinar, nos termos do art. 82 e seguinte do Regimento Interno deste Conselho. 3. Este Conselho Nacional da Justiça firmou a orientação de não conhecer de matéria anteriormente submetida à via judicial pelo próprio requerente. Recurso a que se nega provimento. (CNJ - RA - Recurso Administrativo em PCA - Procedimento de Controle Administrativo - 0003979-14.2011.2.00.0000 - Rel. WELLINGTON SARAIVA - 135 ${ }^{\mathrm{a}}$ Sessão - j. 27/09/2011).

${ }^{519}$ O Regimento Interno do CNJ estabelece que o processo de revisão disciplinar dos feitos disciplinares de juízes e membros de tribunais julgados, pode ser instaurado, observado o prazo de uma ano da prolação da decisão, de ofício, por deliberação da maioria absoluta do Plenário do CNJ, mediante proposição de qualquer um dos Conselheiros, do Procurador-Geral da República ou do Presidente do Conselho Federal da OAB (art. 86) ou mediante provocação de qualquer interessado (art. 82), através de petição escrita, devidamente fundamentada e com toda a documentação pertinente (art. 84), inclusive a certidão do julgamento do processo disciplinar (art. 85, $\S 1^{\circ}$ ). Esse pleito pode ser indeferido, de plano, pelo Conselheiro Relator, se mostrar-se intempestivo, manifestamente infundado ou improcedente (art. 85, caput). Caso contrário, o Conselheiro Relator poderá determinar que se apensem os autos originais ou cópias autenticadas de todas as peças do processo, requisitando-se ao Tribunal competente as providências necessárias, no prazo de quinze (15) dias (art. 85, $\S 2^{\circ}$ ), devendo a instrução do processo de revisão disciplinar observar os princípios do contraditório e da ampla defesa (art. 87, caput). Encerrada, o Procurador-Geral da República e o magistrado acusado ou seu defensor terão vista dos autos por dez dias, para razões (art. 87, parágrafo único). Julgado procedente o pedido de revisão, o Plenário do $\mathrm{CNJ}$ poderá determinar a instauração de processo 
Em suma, em relação às suas competências disciplinares específicas, pode o Conselho Nacional de Justiça, mediante deliberação da maioria absoluta de seus membros: a) receber e conhecer de reclamações contra membros ou órgãos do Poder Judiciário, inclusive contra seus serviços auxiliares, serventias e órgãos prestadores de serviços notariais e de registro que atuem por delegação do poder público ou oficializados, independentemente da prévia existência de reclamação dirigida aos órgãos correicionais dos tribunais que estejam vinculados ou mesmo concomitantemente ao tramitê de processos disciplinares contra os reclamados perante os órgãos de origem; b) avocar processos disciplinares que ainda não tenham sido definitivamente julgados administrativamente pelos órgãos locais; e, c) rever, de ofício ou mediante provocação, os processos disciplinares de juízes e membros de tribunais julgados há menos de um ano quando a decisão proferida pelo órgão local for contrária a texto expresso da lei, à evidência dos autos ou a ato normativo do $\mathrm{CNJ}$, fundarse em depoimentos, exames ou documentos comprovadamente falsos ou quando, após ser prolatada, surgirem fatos novos ou novas provas ou circunstâncias que determinem ou autorizem sua modificação.

\subsubsection{Questões controvertidas}

A leitura das disposições contidas no art. 103-B, $\S 4^{\circ}$, III e V, da Constituição ainda suscita questionamentos que podem representar limites de atuação do Conselho Nacional de Justiça.

a) Há necessidade de observância do direito à ampla defesa e pode o CNJ impor sanções disciplinares diversas da remoção, disponibilidade ou aposentadoria compulsórias nas revisões de processos disciplinares de magistrados?;

b) Há necessidade de observância dos princípios da motivação das decisões e da publicidade dos atos processuais nos julgamentos administrativos disciplinares realizados pelo $\mathrm{CNJ}$;

c) É exigível quórum qualificado de votação correspondente à maioria absoluta dos membros do CNJ para imposição de qualquer punição disciplinar?;

d) Como resolver o problema da tramitação concomitante de processos administrativos disciplinares relativos aos mesmos fatos perante tribunal local e o CNJ?

administrativo disciplinar, alterar a classificação da infração, absolver ou condenar o juiz ou membro de Tribunal, modificar a pena ou anular o processo (art. 88). 
e) É possível a instauração de processo administrativo disciplinar perante o CNJ após o julgamento definitivo de processo correlato no tribunal local?;

f) $\mathrm{O} \mathrm{CNJ}$ pode rever os próprios processos disciplinares de magistrados julgados há menos de um ano?

g) Qual o termo inicial de contagem do prazo para revisão dos processos disciplinares movidos contra magistrados pelo CNJ?

Nos próximos itens procuraremos responder todas essas indagações.

\subsection{Ampla defesa e sanções aplicáveis nas revisões de processos disciplinares}

A leitura das normas constantes do art. 93, X e do art. 103-B, $\S 4^{\circ}, \mathrm{V}$, ambos da Constituição Federal, em cotejo com aquelas previstas no art. 93, VIII, e do art. 103-B, § $4^{\circ}$, III, também da Carta da República, pode levar à falsa conclusão de que, na revisão de processos disciplinares de magistrados, o direito fundamental à ampla defesa não precise ser assegurado e não pode o Conselho Nacional de Justiça impor sanções disciplinares diversas da remoção, disponibilidade ou aposentadoria compulsórias.

Isso porque, enquanto a regra constante do art. 93, VIII, da Lei Maior estabelece que os atos que impõem as três sanções mencionadas podem ser deliberados pelo tribunal a que esteja vinculado o magistrado ou pelo Conselho Nacional de Justiça, observado o voto da maioria absoluta e assegurada ampla defesa, e a norma prevista no art. 103-B, § $4^{\circ}$, III, da Constituição prevê que o CNJ, ao receber e conhecer das reclamações contra membros ou órgãos do Poder Judiciário, pode também aplicar as referidas sanções administrativas, sem prejuízo de outras, garantido o direito à ampla defesa, a disposição inserta do art. 93, X, da Carta limita-se a rezar que "as decisões administrativas dos tribunais serão motivadas e em sessão pública, sendo as disciplinares tomadas pelo voto da maioria absoluta de seus membros", silenciando, pois, quanto à necessidade de observância do direito à ampla defesa pelo acusado e à possibilidade de decisões administrativas tomadas pelo Conselho Nacional de Justiça imporem outras sanções disciplinares, uma vez que, quanto às punições administrativas de remoção, disponibilidade ou aposentadoria compulsórias, já há previsão expressa (a constante do art. 93, VIII, da CF). Por outro lado, ao tratar da revisão de processos disciplinares de magistrados, a disposição prescrita no art. 103-B, $\S 4^{\circ}$, V, da Constituição limita-se a afirmar que o Conselho pode realizá-la, de ofício ou mediante provocação, em relação aos feitos julgados há menos de um ano, sem estabelecer quais 
penas pode infringir e omitindo-se quanto à necessidade de observância do direito à ampla defesa pelo imputado.

Inadmissível, porém, concluir que as lacunas das disposições constantes do art. 93, X, da Constituição Federal (não menciona, no seu texto, o CNJ e a necessidade de observância do direito à ampla defesa) e do art. 103-B, § 4º V (não informa, no seu texto, quais sanções disciplinares podem ser impostas pelo CNJ se houver revisão do julgado administrativo do tribunal de origem e se deve ser assegurada a ampla defesa) signifiquem que o Conselho Nacional de Justiça possa, ao rever decisões proferidas em processos disciplinares contra magistrados há menos de um ano, deixar de observar o direito à ampla defesa e está limitado a apenas impor, no ato de revisão, sanções disciplinares de remoção, disponibilidade ou aposentadoria compulsórias.

Primeiro porque as disposições que garantem explicitamente o direito à ampla defesa em relação às sanções disciplinares aplicáveis pelo CNJ (CF, arts. 93, VIII, e 103-B, § 4º, III) são redundantes, pois a norma prevista em seu art. $5^{\circ}, \mathrm{LV}$, da Carta da República já assegura aos litigantes, em processo judicial ou administrativo, e aos acusados em geral, o contraditório e a ampla defesa, com os meios e recursos a ela inerentes.

Segundo porque refoge à lógica pretender-se afirmar que o Conselho Nacional de Justiça, nas revisões de processos disciplinares de magistrados, somente possa impor as sanções de remoção, disponibilidade e aposentadoria compulsórias previstas no art. 93, VIII, da Lei Maior, porque a redação do inciso X do mesmo dispositivo constitucional não menciona o Alto Colégio Administrativo e aquela inserta no art. 103-B, $\S 4^{\circ}, \mathrm{V}$, não informa quais sanções disciplinares podem ser determinadas pelo Conselho. Afinal, enquanto órgão de controle e podendo aplicar outras punições administrativas mais brandas quando conhece de reclamações originárias ou avoca processos disciplinares $(\mathrm{CF}$, art. 103-B, $\S 4^{\circ}$, III), não há sentido em estabelecer restrição no universo de medidas que possam ser adotadas pelo CNJ nas revisões de processos disciplinares, o que poderia, inclusive, prejudicar o magistrado, impedindo que sua punição administrativa fosse atenuada no ato revisional.

Bem caminharam, pois, as normas previstas no art. 87, caput, e no art. 88, ambos do Regimento Interno do Conselho Nacional de Justiça ${ }^{520}$, ao disporem que, na instrução do

\footnotetext{
${ }^{520}$ Art. 87 (RICNJ). A instrução do Processo de Revisão Disciplinar observará os princípios do contraditório e da ampla defesa.

Parágrafo único. Finda a instrução, o Procurador-Geral da República e o magistrado acusado ou seu defensor terão vista dos autos por dez dias, para razões.
} 
processo de revisão disciplinar deverão ser observados os princípios do contraditório e da ampla defesa e, julgado procedente, o Plenário do Conselho poderá determinar a instauração de processo administrativo disciplinar, alterar a classificação da infração, absolver ou condenar o juiz ou membro de tribunal, modificar a pena ou anular o processo $^{521}$.

Em resumo, na revisão de processos disciplinares de magistrados, também deve ser assegurado o direito fundamental à ampla e está o Conselho Nacional de Justiça autorizado a aplicar sanções disciplinares diversas da remoção, disponibilidade ou aposentadoria compulsórias.

\subsection{Motivação e publicidade nos julgamentos disciplinares}

O exame isolado das disposições constitucionais mencionadas no item anterior $(\mathrm{CF}$, art. 93, VIII e X, e art. 103-B, $\S 4^{\circ}$, III e V) também pode levar a outra inadequada interpretação consistente na desnecessidade do Conselho Nacional de Justiça ter que fundamentar suas decisões nos julgamentos de processos disciplinares ou de revisões de processos disciplinares e dar-lhes publicidade, sob o argumento de que, da leitura de todas as normas constitucionais mencionadas, verifica-se que somente aquela inserta no art. 93, X, da Carta da República, dirigida exclusivamente aos tribunais, determina a observância dessas imposições constitucionais, ao prescrever que "as decisões administrativas dos tribunais serão motivadas e em sessão pública”.

Essas conclusão, porém, não se sustenta.

A necessidade de fundamentação ${ }^{522}$ e publicidade de todos as decisões, jurisdicionais e administrativas, proferidas por órgãos do Poder Judiciário, inclusive o Conselho Nacional de Justiça (CF, art. 92, II) já é determinada pela disposição constante do art. 93, IX, da Constituição Federal. Admite-se, somente, que a lei limite a presença, em

Art. 88 (RICNJ). Julgado procedente o pedido de revisão, o Plenário do CNJ poderá determinar a instauração de processo administrativo disciplinar, alterar a classificação da infração, absolver ou condenar o juiz ou membro de Tribunal, modificar a pena ou anular o processo.

${ }^{521}$ Como será exposto nos itens 3.1.5.1.4 e 3.1.5.1.5, ante a necessidade de observância dos princípios da segurança jurídica e do ne bis in idem, entendemos apenas que, para o CNJ determinar a instauração de novo processo administrativo disciplinar, deverá, primeiro, anular aquele que tramitou na origem no ato revisional.

${ }^{522}$ Motivar significa apontar os fundamentos fáticos e jurídicos para a tomada da decisão de forma objetiva e clara. Ensina Edmir Netto de Araújo (2010, p. 496): "para o ato administrativo, ao contrário do que ocorre no direito privado, a inexistência de um motivo, atribuível à Administração ao cuidar do interesse público, determina a configuração de vício insanável, pela inexistência, exatamente, de interesse público que determine sua finalidade". 
determinados atos, às próprias partes e a seus advogados, ou somente a estes, para preservação do direito à intimidade do interessado e desde que não haja prejuízo ao interesse público à informação.

Quanto ao princípio da publicidade, a norma inserta no art. 5 LX, da Lei Maior o estabelece como garantia fundamental e, no que tange à Administração Pública, há expressa referência à necessidade de sua obediência, conforme previsto na cabeça do art. 37 da Constituição Federal, competindo ao que Conselho Nacional de Justiça zelar pela sua observância no âmbito do Poder Judiciário (CF, art. 103-B, § $4^{\mathrm{o}}$, II) ${ }^{523}$.

Acertada, portanto, a redação do art. 20 da Resolução CNJ no 135/2011 ${ }^{524}$ ao estabelecer que o julgamento de processo administrativo disciplinar de magistrado será realizado em sessão pública e serão fundamentadas todas as decisões, inclusive as interlocutórias (caput), podendo ser limitada a presença às próprias partes e a advogados, ou somente a estes, desde que a preservação da intimidade não prejudique o interesse público, em determinados atos processuais e de julgamento $\left(\S 1^{\circ}\right)$, que também será público $\left(\S 2^{\circ}\right)$, malgrado a Lei Orgânica da Magistratura Nacional disponha, nas normas constantes de seus artigos 43 a $45^{525}$, aplicação reservada das penas de advertência ou censura a juízes e escrutínio secreto para remoção ou disponibilidade por interesse público de magistrado ${ }^{526}$.

\footnotetext{
${ }^{523}$ Vide item 3.1.3.

${ }^{524}$ Art. 20 (Res. CNJ n ${ }^{\circ}$ 135/2011) O julgamento do processo administrativo disciplinar será realizado em sessão pública e serão fundamentadas todas as decisões, inclusive as interlocutórias.

$\S 1^{\circ}$ Em determinados atos processuais e de julgamento, poderá, no entanto, ser limitada a presença às próprias partes e a seus advogados, ou somente a estes, desde que a preservação da intimidade não prejudique o interesse público.

$\S 2^{\circ}$ Para o julgamento, que será público, serão disponibilizados aos integrantes do órgão julgador acesso à integralidade dos autos do processo administrativo disciplinar.

$\S 3^{\circ} \mathrm{O}$ Presidente e o Corregedor terão direito a voto.

$\S 4^{\circ}$ Os Tribunais comunicarão à Corregedoria Nacional de Justiça, no prazo de 15 dias da respectiva sessão, os resultados dos julgamentos dos processos administrativos disciplinares.

${ }^{525}$ Art. 43 (LOMAN). A pena de advertência aplicar-se-á reservadamente, por escrito, no caso de negligência no cumprimento dos deveres do cargo.

Art. 44 (LOMAN). A pena de censura será aplicada reservadamente, por escrito, no caso de reiterada negligência no cumprimento dos deveres do cargo, ou no de procedimento incorreto, se a infração não justificar punição mais grave.

Parágrafo único - O Juiz punido com a pena de censura não poderá figurar em lista de promoção por merecimento pelo prazo de um ano, contado da imposição da pena.

Art. 45 (LOMAN). O Tribunal ou seu órgão especial poderá determinar, por motivo de interesse público, em escrutínio secreto e pelo voto de dois terços de seus membros efetivos:

I - a remoção de Juiz de instância inferior;

II - a disponibilidade de membro do próprio Tribunal ou de Juiz de instância inferior, com vencimentos proporcionais ao tempo de serviço.

${ }^{526}$ A Sexta Turma do Superior Tribunal de Justiça, em 13 de dezembro de 2007, no julgamento da Recurso
} 


\subsection{Quórum qualificado para imposição de qualquer punição disciplinar}

A leitura conjugada das normas previstas nos art. 93, VIII e X, e no art. 103-B, $\S 4^{\circ}$, III e V, ambos da Lei Maior, ainda pode permitir o entendimento de que, nos julgamentos de processos disciplinares pelo Conselho Nacional de Justiça, a exigência de quórum qualificado de votação correspondente à maioria absoluta dos seus membros, somente se justifica para a imposição de sanções de remoção, disponibilidade e aposentadoria de

Ordinário em Mandado de Segurança $n^{\circ}$ 11.708, da relatoria da Ministra Maria Thereza de Assis Moura, já havia decidido, por votação unânime, que "a previsão da LOMAN de escrutínio secreto para aplicação da pena de disponibilidade de magistrado não foi recepcionada pela Constituição Federal de 1988" porque a decisão administrativa exige motivação, por implicar na aplicação de pena a magistrado consistente em sua disponibilidade, sendo necessário que os votos proferidos sejam abertos e, nos termos do disposto no artigo 93, IX, da Constituição, fundamentados (participaram do julgamento os Ministros Carlos Fernando Mathias (Juiz convocado do TRF $1^{\text {a }}$ Região), Nilson Naves, Hamilton Carvalhido e Paulo Gallotti - DJU 11.02.2008). Não obstante, a AMB, na ADI nº 4638 ajuizada perante o Supremo Tribunal Federal, pleiteou a declaração de inconstitucionalidade da normas insertas no art. $4^{\circ}$ ("o magistrado negligente, no cumprimento dos deveres do cargo, está sujeito à pena de advertência. Na reiteração e nos casos de procedimento incorreto, a pena será de censura, caso a infração não justificar punição mais grave") e na cabeça do art. 20 (“o julgamento do processo administrativo disciplinar será realizado em sessão pública e serão fundamentadas todas as decisões, inclusive as interlocutórias"), ambos da Resolução CNJ n 135/2011, porque a primeira regra teria implicado na supressão da exigência de sigilo na imposição das sanções de advertência e censura, consoante preconizado na Lei Orgânica da Magistratura, o que poderia ser determinado somente por outro Estatuto da Magistratura, e quanto à segunda disposição, argumentou ser do interesse público a decretação de sigilo nos processos disciplinares instaurados contra magistrados, para manter-se a credibilidade do Poder Judiciário e não macular a honra e a integridade do juiz durante o curso do processo, não o sujeitando a situações de constrangimento que possam prejudicar o desempenho da função. Ademais o artigo 93, IX, da Carta da República, com a redação dada pela Emenda Constitucional $\mathrm{n}^{\circ}$ 45/2004, não obstaria a realização de sessão secreta, consoante se depreende da parte final do seu texto. $\mathrm{O}$ Ministro Marco Aurélio Mello, relator da ADI no 4638, porém, em decisão liminar proferida em 19 de dezembro de 2011, não acolheu referidas alegações. Sustentou Sua Excelência que "o respeito ao Poder Judiciário não pode ser obtido por meio de blindagem destinada a proteger do escrutínio público os juízes e o órgão sancionador", por ser tal medida "incompatível com a liberdade de informação e com a ideia de democracia" que pressupõe, como adverte Norberto Bobbio (2000, p. 98), o exercício do poder público em público, de forma a viabilizar a crítica e o controle social. Assim, as decisões em processos disciplinares que envolvam magistrados devem ser "tomadas à luz do dia, à luz da democracia", pois "o sigilo imposto com o objetivo de proteger a honra dos magistrados contribui para um ambiente de suspeição e não para a credibilidade da magistratura, pois nada mais conducente à aquisição de confiança do povo do que a transparência e a força do melhor argumento", tendo a EC n 45/2004, assegurado, no art. 93, IX e X, da Constituição, "a observância do princípio da publicidade no exercício da atividade judiciária, inclusive nos processos disciplinares instaurados contra juízes", o que está "em plena consonância com os ditames democrático e republicano, bem assim com o artigo 37 da Lei Maior, segundo o qual a Administração Pública - gênero - está submetida aos princípios da legalidade, da impessoalidade, da moralidade, da publicidade e da eficiência". Ademais, afirmou, "a Emenda Constitucional n ${ }^{0} 45$, de 2004, não impede a realização de sessões reservadas para garantir o direito à intimidade, consoante prevê o próprio artigo 93, inciso IX, da Carta Federal. O constituinte derivado, no entanto, exige fundamentação específica para a decretação de sigilo no processo disciplinar, porque a transparência é a tônica da atividade pública". Conclui o Ministro Marco Aurélio Mello que, "ante o novo contexto, a Resolução do Conselho Nacional de Justiça, ao prever a publicidade das sanções disciplinares e da sessão de julgamento, não extrapola os limites normativos nem ofende garantia da magistratura, pois, a rigor, tais normas decorrem diretamente do texto constitucional, sobretudo depois da edição da Emenda de reforma do Poder Judiciário". No julgamento do referendo da decisão liminar proferida na $\mathrm{ADI} \mathrm{n}^{\circ}$ 4638, concluído em 9 de fevereiro de 2012, o Plenário do STF, confirmou, nos pontos citados, o indeferimento da liminar conforme decidido pelo Ministro Relator. 
magistrado, por interesse público (CF, art. 93, VIII), ante a limitação estabelecida na regra prevista no art. 93, X, da Constituição Federal (destinada apenas aos tribunais, sem mencionar o CNJ em seu texto), e o silêncio das normas constantes do 103-B, § $4^{\mathrm{o}}$, III e V, da Carta, podendo, consequentemente, ser aceita a cominação de punição diversa apenas por deliberação tomada pelo voto da maioria simples dos Conselheiros.

No nosso sentir, contudo, esse entendimento não prospera.

Antes do advento da Constituição Federal de 1988, a norma prevista no art. 45 da LOMAN estabeleceu, em consonância com a disposição constante do art. $113, \S 3^{\circ}$, da Constituição de 1967/1969, com a redação dada pela EC n $7 / 1977$, que os tribunais ou seus respectivos órgãos especiais poderiam determinar, por motivo de interesse público, pelo voto de dois terços de seus membros efetivos, a remoção de juiz de instância inferior ou a disponibilidade deste ou de membro do próprio tribunal, com vencimentos proporcionais ao tempo de serviço. Porém, quanto às penas de advertência e censura, previstas nos seus arts. 43 e 44, a LOMAN não exigia quórum qualificado para suas imposições.

A redação original do art. 93, VIII, da Constituição de $1988^{527}$ manteve a exigência do voto de dois terços dos membros do tribunal para a imposição das sanções administrativas mais gravosas de remoção e disponibilidade por interesse público, bem como para a aplicação da pena de aposentadoria compulsória a magistrados.

A “Constituição Cidadã”, por outro lado, trouxe outra importante garantia ao acusado em processo administrativo disciplinar julgado no âmbito do Poder Judiciário na regra prevista no seu art. 93, X: a necessidade de observância, para imposição de outras sanções disciplinares, de deliberação tomada pelo voto da maioria absoluta dos membros do tribunal.

Assim, pela sistemática original da ordem constitucional de 1988, a aplicação de sanções mais brandas a magistrados (advertência, censura) passou a exigir o quórum qualificado da maioria absoluta dos membros das cortes. Para a cominação de penas mais graves (remoção, disponibilidade e aposentadoria compulsórias), continuou a ser necessário observar requisito ainda mais rígido: voto de dois terços dos membros dos tribunais.

\footnotetext{
${ }^{527}$ Art. 93 (CF - redação original). [...]

VIII - o ato de remoção, disponibilidade e aposentadoria do magistrado, por interesse público, fundar-se-á em decisão por voto de dois terços do respectivo tribunal, assegurada ampla defesa;
} 
Cumpre lembrar que, quando da promulgação da Constituição de 1988, não foi previsto, na estrutura do Judiciário, um Conselho Administrativo encarregado de exercer o controle dos deveres funcionais dos magistrados, com possibilidade de receber e conhecer de reclamações contra eles, contra os serviços auxiliares do Poder e as serventias extrajudiciais, podendo avocar processos disciplinares em curso e rever aqueles julgados de juízes e membros de tribunais há menos de um ano.

A Emenda Constitucional no 45/2004 - que instituiu esse Conselho Administrativo o CNJ - como órgão de controle do Poder Judiciário - também alterou a redação do art. 93, VIII, da Constituição Federal, reduzindo de dois terços para maioria absoluta o quórum de votação para imposição de penas de remoção, disponibilidade e aposentadoria de magistrado, por interesse público, e explicitamente que essas punições podem também ser impostas pelo Colegiado Administrativo.

Por outro lado, a mesma EC n 45/2004 ainda modificou a redação do art. 93, X, da Constituição Federal, mas preocupou-se apenas em explicitar, no referido dispositivo constitucional, a exigência de que as decisões administrativas dos tribunais também passassem a ser tomadas em sessões públicas, para evitar sigilo nos julgamentos e reforçar a necessidade de torná-los transparentes. Manteve, assim, a exigência de quórum qualificado de votação correspondente à maioria absoluta dos membros dos tribunais para aplicação de sanções disciplinares.

Por fim, a EC n⿳ 45/2004, para ressaltar o viés disciplinar do Conselho Nacional de Justiça definiu, na norma prevista no art. 103-B, $\S 4^{\circ}$, III, poder o órgão aplicar qualquer sanção administrativa, inclusive as mais contundentes (remoção, disponibilidade e aposentadoria compulsórias).

As intenções do Constituinte Derivado, pois, foram claras: a) reduzir a restrição para aplicação de penas administrativas graves aos magistrados (de maioria de votos de dois terços dos membros do órgão julgador para maioria absoluta); b) equiparar os quóruns de votação para imposição de sanções disciplinares pelos tribunais (sempre correspondente ao voto da maioria absoluta dos membros dos tribunais); c) manter a garantia ao acusado administrativamente no âmbito do Poder Judiciário trazida pela Constituição de 1988 (necessidade de deliberação tomada pelo voto da maioria absoluta dos membros do tribunal para imposição de sanções disciplinares); e, d) estender a possibilidade de imposições de quaisquer sanções admistrativas no seio do Judiciário ao novel órgão de controle administrativo criado. 
Evidente, portanto, apesar do Constituinte Derivado ter se olvidado de incluir o Conselho Nacional de Justiça no texto alterado do art. 93, X, da Lei Maior, que a norma nele prevista, em tudo e por tudo, também se aplica ao Colegiado Administrativo, até porque, em relação aos magistrados, a garantia de quórum qualificado para imposição de sanções disciplinares acaba por ser uma extensão daquelas individuais, contidas no art. 95, caput, da Constituição Federal, que tem por escopo prestigiar a independência e a imparcialidade dos juízes. Seria, pois, ilógico que a exigência em comento tivesse que ser observada pelos tribunais - órgãos controlados -, mas não pelo $\mathrm{CNJ}$ - órgão controlador que tem, como primeira competência específica, zelar pela autonomia do Poder Judiciário $\left(\mathrm{CF} \text {, art. 103-B, } \S 4^{\mathrm{o}}, \mathrm{I}\right)^{528}$.

Assim, andou bem o Conselho Nacional de Justiça, portanto, ao estabelecer, na regra prevista no art. 21, caput, da Resolução CNJ no 135/2011, que a punição em processo administrativo disciplinar de magistrado somente pode ser imposta pelo voto da maioria absoluta dos membros do Tribunal ou do respectivo Órgão Especial, ou do próprio Colégio Administrativo (conforme equiparação trazida pelo disposto no art. $2^{\circ}$ do mesmo ato normativo $^{529}$.

Mas, ao mesmo tempo, o Conselho caminhou mal ao definir, no parágrafo único do mesmo dispositivo normativo, que, na hipótese de divergência quanto à pena a ser imposta ao magistrado, não formada maioria absoluta por qualquer uma delas, deve ser aplicada a mais branda, ou, no caso de mais de duas penas alternativas, a mais leve que tiver obtido o maior número de votos ${ }^{530}$.

Referida norma acabou também sendo alvo de pedido de declaração de inconstitucionalidade formulado pela AMB junto ao Supremo Tribunal Federal na ADI $\mathbf{n}^{\mathbf{o}}$ 4638, sob a alegação de não ser admissível punição de magistrado sem o voto da maioria absoluta dos membros do tribunal, sendo que a divergência quanto à aplicação da pena não

\footnotetext{
${ }^{528}$ Vide item 3.1.1.

${ }^{529}$ Art. $2^{\text {o }}$ (Resolução CNJ n ${ }^{\text {13 }}$ 135/2011) Considera-se Tribunal, para os efeitos desta resolução, o Conselho Nacional de Justiça, o Tribunal Pleno ou o Órgão Especial, onde houver, e o Conselho da Justiça Federal, no âmbito da respectiva competência administrativa definida na Constituição e nas leis próprias.
}

Art. 21 (Resolução CNJ n ${ }^{\circ}$ 135/2011). A punição ao magistrado somente será imposta pelo voto da maioria absoluta dos membros do Tribunal ou do Órgão Especial.

${ }^{530}$ Art. 21 (Resolução CNJ no 135/2011). [...]

Parágrafo único. Na hipótese em que haja divergência quanto à pena, sem que se tenha formado maioria absoluta por uma delas, será aplicada a mais leve, ou, no caso de mais de duas penas alternativas, aplicar-se-á a mais leve que tiver obtido o maior número de votos. 
pode servir de pretexto para afastar essa regra maior prevista na norma mencionada no art. 93, X, da Constituição Federal.

Ao apreciar o pedido liminar na ADI $n^{\circ} 4638$, seu relator, o Ministro Marco Aurélio Mello, decidiu suspender a eficácia da regra prevista no art. 21, parágrafo único, da Resolução CNJ n $n^{0}$ 135/2011 por entender que o preceito conflita com a parte final do artigo 93, X, da Carta da República e flexibiliza as garantias processuais do magistrado, enquanto sujeito passivo do processo disciplinar, previstas no Diploma Maior, colocando em em risco a independência que lhe é essencial, pois pode sujeitá-lo a influências externas, ainda que surjam dentro do próprio tribunal que integre.

Quando do julgamento do referendo da mencionada decisão, concluído em 9 de fevereiro de 2012, o Plenário do STF deu interpretação conforme ao art. 21, parágrafo único, da Resolução CNJ no 135/2011 para não conflitar com as disposições contidas no art. 93, VIII e X, da Constituição Federal e decidiu, por maioria de votos (oito votos a três), encampando proposta apresentada pelo Ministro Cezar Peluso, que, na hipótese de divergência do tribunal quanto à sanção a ser imposta ao magistrado, cada sugestão de pena deverá ser votada separadamente para que seja aplicada somente aquela que alcançar quórum de maioria absoluta de votos na deliberação ${ }^{531}$.

Em suma, o Conselho Nacional de Justiça, para imposição de qualquer sanção disciplinar, deve observar a exigência de quórum qualificado de votação correspondente à maioria absoluta dos seus membros tanto para definir se deve ser imposta alguma punição ao administrativamente acusado quanto para estabelecer qual pena lhe deve ser aplicada.

\footnotetext{
${ }^{531}$ É importante registrar, contudo, que os debates no STF no julgamento do referendo da liminar na ADI $n^{\circ}$ 4638 quanto à forma de votação para observância do quórum de maioria absoluta para imposição de sanção disciplinar restringiram-se às penas disciplinares previstas no art. 93, VIII, da Constituição (remoção, disponibilidade e aposentadoria compulsória). No julgamento da ADI $\mathrm{n}^{\mathrm{o}} 2580$, Relator Ministro Carlos Velloso, porém, o Pretório Excelso já havia decidido que, para aplicação das penas de advertência e censura, também faz necessário o referido quórum qualificado. Segue a ementa do julgado:
}

CONSTITUCIONAL. MAGISTRADO: PENAS DISCIPLINARES. COMPETÊNCIA DO TRIBUNAL. C.F., art. 93, X, art. 96, I, a. Lei Complementar 35, de 1979 - LOMAN - arts. 40, 42, parág. único, 46 e 48 . I. - Aos Tribunais compete, privativamente, elaborar seus regimentos internos, dispondo sobre a competência e o funcionamento dos respectivos órgãos jurisdicionais e administrativos. C.F., art. 96, I, a. A competência e o funcionamento do Conselho Superior da Magistratura devem ser estabelecidas pelo Tribunal de Justiça, em regimento interno. II. - As penas de advertência e de censura são aplicáveis aos juízes de $1^{\circ}$ grau, pelo Tribunal, pelo voto da maioria absoluta de seus membros. C.F., art. 93, X. III. - Recepção, pela CF/88, da LOMAN, Lei Orgânica da Magistratura: C.F., art. 93. IV. - Os regimentos internos dos Tribunais estabelecerão o procedimento para a apuração de faltas puníveis com advertência ou censura. LOMAN, art. 48. V. - Regimento Interno, artigos 37 e 40: inconstitucionais em face do art. 96, I, a, da Constituição Federal (maioria). Voto do Relator: empresta-se interpretação conforme a Constituição para estabelecer que citados artigos 37 e 40 dizem respeito apenas às penas de advertência e censura. VI. - ADIn não conhecida em parte e, na parte conhecida, julgada procedente (ADI 2580, Relator(a): Min. CARLOS VELLOSO, Tribunal Pleno, julgado em 26/09/2002, DJ 21-02-2003). 


\subsection{Tramitação concomitante de processos disciplinares}

Como visto, ao menos até o julgamento definitivo da ADI $n^{\circ} 4638$ pelo Supremo Tribunal Federal, a primeira competência disciplinar específica do Conselho Nacional de Justiça - recebimento e conhecimento de reclamações contra membros ou órgãos do Poder Judiciário, inclusive contra seus serviços auxiliares, serventias e órgãos prestadores de serviços notariais e de registro que atuem por delegação do poder público ou oficializados - pode ser exercida de forma concorrente, ou seja, admite-se a tramitação paralela de processos administrativos disciplinares contra reclamados perante os órgãos locais e junto ao $\mathrm{CNJ}^{532}$.

Por outro lado, a avocação de processo disciplinar em curso perante tribunal local (segunda competência disciplinar específica do $\mathrm{CNJ}$ ), até pelo próprio desconhecimento de sua existência, pode não ser determinada pelo Colegiado Administrativo.

Assim, há possibilidade de tramitação simultânea de processos administrativos disciplinares contra o mesmo acusado e relativos aos mesmos fatos perante o tribunal de origem e junto ao Conselho Nacional de Justiça.

Inadmissível, porém, que essa concomitante persecução implique na imposição de sanções administrativas disciplinares em duplicidade ao imputado pelos mesmos fatos apurados - uma imposta na origem e outra, idêntica ou diversa, pelo Conselho Nacional de Justiça - ante a proibição do bis in idem.

Apesar de não haver expressa previsão na Constituição Federal do princípio do ne bis in idem (ou non bis in idem) ${ }^{533}$, também denominado de princípio da vedação da dupla punição pelo mesmo fato (NUCCI, 2007, p. 45), segundo Fábio Medina Osório (2009, pp. 272 a 274), ele decorre das garantias de legalidade, proporcionalidade e do devido processo legal e tem, como idéia básica, a de que "ninguém pode ser condenado ou processado duas ou mais vezes por um mesmo fato" ${ }^{, 534}$.

\footnotetext{
${ }^{532}$ Vide item 3.1.5.

${ }^{533}$ Como pontuado por Keity Mara Ferreira de Souza e Saboya (2006, p. 129 e 130), com apoio em Francisco Javier de León Villalba (1998, p. 35) e Mariano Bertelotti (2001, p. 106), costuma-se utilizar, sem qualquer distinção, as expressões ne bis in idem e non bis in idem. A última denominação, porém, é equivocada, pois as primeiras referências ao princípio utilizam na sua formulação a partícula ne em lugar de non. Ademais, o advérbio non se emprega para negar um fato real (por exemplo, non venit: "não veio") e ne se usa em proibições ou desejos (v. gr., ne eas: "não vá"), "resultando adequado, portanto, seu uso na linguagem prescritiva de textos jurídicos".

${ }^{534}$ Keity Mara Ferreira de Souza e Saboya (2006, p. 131 a 133) menciona que o princípio do ne bis in idem,
} 
No âmbito do Direito Administrativo, o princípio em comento implica, pois, na impossibilidade da imposição de outra punição administrativa se uma conduta já foi sancionada pela Administração Pública ${ }^{535}$.

A respeito, o Supremo Tribunal Federal, há muito tempo, na Sessão Plenária de 13 de dezembro de 1963, editou a Súmula no 19 com o seguinte verbete: "é inadmissível segunda punição de servidor público, baseada no mesmo processo em que se fundou a primeira".

Assim, para conciliar o princípio do ne bis in idem com a competência disciplinar concorrente do CNJ, deve-se observar que, caso haja dois processos administrativos disciplinares sobre os mesmos fatos correndo paralelamente, um perante o tribunal de origem e o outro junto ao Conselho Nacional de Justiça, não poderá o acusado sofrer punições em ambos os feitos.

Por outro lado, como o Conselho Nacional de Justiça é o órgão controlador dos demais tribunais, na hipótese tratada, sua decisão sempre prevalecerá sobre a proferida na origem, independentemente da ordem cronológica em que tenham sido proferidas ${ }^{536}$.

origina-se no Direito Romano, na Lex Repetundarum, vinculado à coisa julgada, tendo se estabelecido na época, na esfera civil, que não seria admitida nova ação pelos mesmo fatos já julgados por sentença. Com o surgimento do processo inquisitório, instituído no século XIII pelo Papa Gregório IX e adotado ao longo dos séculos seguintes em quase toda a Europa, o princípio do ne bis in idem perdeu significado, pois prevalecia a ideia da busca incessante da verdade, com a mitigação dos efeitos da coisa julgada e a possibilidade de reabertura de processos arquivados por falta de provas para condenação. Na Revolução Francesa, o princípio do ne bis in idem, em relação às sentenças penais, foi incluído no art. 9o da Constituição de 1791. Posteriormente, em 1887, a Quinta Emenda incluiu o princípio na Constituição dos Estados Unidos, onde passou a ser conhecido como double jeopardy. Mais recentemente, o princípio do ne bis in idem, segundo Guilherme de Souza Nucci (2007, p. 45), foi incluído no art. 8 4, da Convenção Americana sobre Direitos Humanos (Pacto de San José da Costa Rica), ao estabelecer o dispositivo que "o acusado absolvido por sentença transitada em julgado não poderá ser submetido a novo processo pelos mesmos fatos".

${ }^{535} \mathrm{O}$ princípio do ne bis in idem não impede a responsabilização cumulativa nas esferas civil, penal e administrativa, pois referidas instâncias são autônomas e independentes, consoante já decidiu o Supremo Tribunal Federal, por exemplo, no julgamento, em 23 de abril de 1996, do Habeas Corpus $n^{\circ}$ 73372, Relator Ministro Sydney Sanches, e, no julgamento, em 22 de janeiro de 1988, do Mandado de Segurança $n^{\circ} 22728$, Relator Ministro Moreira Alves. Tanto é que a norma constante do art. 125 da Lei $\mathrm{n}^{\mathrm{o}} 8.112$, de 11 de dezembro de 1990, que dispõe sobre o regime jurídico dos servidores públicos civis da União, das autarquias e das fundações federais, estabelece que "as sanções civis, penais e administrativas poderão cumular-se, sendo independentes entre si”.

${ }^{536}$ Quando dos debates em plenário do STF para referendo da decisão liminar concedida pelo Ministro Marco Aurélio Mello na ADI no 4638, especificamente durante a discussão sobre a disposição constante no art. 12 da Resolução CNJ n ${ }^{\circ}$ 135/2011 e da competência subsidiária ou concorrente do Conselho Nacional de Justiça em âmbito disciplinar, o Ministro Joaquim Barbosa, defensor da tese vencedora, à indagação do Relator, Ministro Marco Aurélio Mello, sobre como resolver o problema da duplicidade de processos na hipótese de se reconhecer, como ocorreu, a competência concorrente do Colégio Administrativo, respondeu que bastaria estabelecer a primazia do Conselho Nacional de Justiça sobre as decisões dos tribunais. E afirmou: "[...] Ao criar o Conselho Nacional de Justiça, a Emenda Constitucional n ${ }^{\circ} 45$ não se limitou a criar mais um órgão para exercer, concomitantemente, atribuições já exercidas com deficiência por outros órgãos existentes, o que a Emenda quis foi requalificar de maneira substantiva uma dada função, atribuindo-a ao novo órgão criado, que dela passou a ser cotitular, numa posição de evidente proeminência ou primazia, e essa palavra a meu ver é chave. Essa proeminência, essa primazia, decorre, em primeiro lugar, do fato de que a própria Constituição conferiu ao Conselho o formidável e extraordinário poder de avocar. Poder de avocar, 
Há primazia da deliberação do Conselho, inclusive, na hipótese de absolvição do acusado por apenas uma das instâncias (CNJ e tribunal local).

Logo, instaurados dois processos disciplinares, no Conselho Nacional de Justiça e no tribunal local, caso o CNJ decida primeiro, sua deliberação já prevalecerá, qualquer que seja o resultado (absolvição ou condenação) e a sanção eventualmente imposta. Portanto, restará prejudicado o seguimento do processo administrativo na província.

Se porém, na aventada hipótese, o processo disciplinar local for julgado primeiro, duas situações podem ocorrer:

a) Se decidido na origem pela absolvição do acusado ${ }^{537}$, como houve instauração de processo disciplinar antes ou durante a tramitação do feito correlato perante o CNJ, poderá o Conselho, ante a sua competência concorrente e devido a primazia das suas decisões, ratificar a absolvição ou impor sanção administrativa ao imputado, sem que isso importe em violação ao princípio do ne bis in idem;

b) Se decidido pela punição do acusado, a existência de processo disciplinar simultâneo no Conselho Nacional de Justiça implicará na necessidade de suspensão da execução do julgado prolatado na província até que seja apreciado o feito em trâmite no órgão de controle, pois a decisão pode ser ratificada, mas também pode haver abrandamento da sanção aplicada ou até absolvição do imputado.

\footnotetext{
no nosso sistema administrativo-constitucional, é uma excrescência, mas, neste caso, a Constituição quis, através da Emenda $n^{\circ} 45$, conferir esse poder extraordinário ao Conselho Nacional de Justiça para avocar processos disciplinares em curso nas Corregedorias dos Tribunais. Ora, não se confere poder marginal, subsidiário a um órgão hierarquicamente superior, ou seja, um órgão de cúpula, que tenha prerrogativa de tomar para si decisões que, em princípio, deveriam ser tomadas por outros órgãos inferiores. Não há qualquer lógica na posição contrária, a meu ver. Em segundo lugar, quando um determinado órgão superior tem o poder de atuar de ofício, e esse é o caso, em campo de atuação, em princípio demarcado para a atuação de um outro órgão inferior, jamais se pode entender que a competência do órgão superior tem natureza subsidiária, a não ser que haja uma norma expressa a estabelecer essa subsidiariedade. [...] Eu vejo que, no caso, isso não ocorre. Em nenhum momento a Emenda $n^{\circ} 45$ aventou a hipótese da subalternidade da ação disciplinar do Conselho Nacional de Justiça em relação às corregedorias. Ao contrário, essa tese é fruto da imaginação criadora de uns poucos que, a exemplo da famosa frase de Lampedusa, querem que as coisas mudem, de uma certa forma, 'para que tudo continue como antes'. O que está em jogo aqui é exatamente isso, não é? Como as decisões do Conselho passaram a expor situações escabrosas no seio do Poder Judiciário Nacional, vem essa insurgência súbita a provocar toda esta reação corporativa contra um órgão que vem, sem dúvida alguma, produzindo resultados importantíssimos no sentido da correição das mazelas do nosso sistema de Justiça" (OBS.: Giuseppe Tomasi di Lampedusa, escritor italiano, autor do romance Il Gattopardo (2009)).

${ }^{537}$ Aqui entendida também a hipótese de arquivamento do processo disciplinar por falta de provas para a persecução administrativa.
} 
Como será destacado no item seguinte, ante a necessidade de observância do princípio da segurança jurídica ${ }^{538}$, o entendimento mencionado (prevalência da decisão do CNJ e não ocorrência de bis in idem) se aplica somente se o processo disciplinar for instaurado no Conselho Nacional de Justiça antes ou durante o curso de processo correlato no tribunal.

Em suma, instaurados dois processos disciplinares, um junto ao tribunal local e outro, antes ou durante a tramitação daquele, no Conselho Nacional de Justiça, se não houver avocação ou suspensão do feito que corre na origem, a decisão do Colegiado Administrativo sempre prevalecerá e não haverá violação ao princípio do ne bis in idem.

\subsection{Impossibilidade de instauração de processo disciplinar ulterior ao julgamento de correlato no tribunal local}

Afirmou-se que, devido à necessidade de respeito aos princípios da segurança jurídica ${ }^{539}$ e do ne bis in idem, a possibilidade de instauração de processo administrativo disciplinar perante o Conselho Nacional de Justiça com prevalência da sua decisão sobre aquela eventualmente prolatada em feito correlato no tribunal de origem relativa ao acusado e referente aos mesmos fatos somente pode ocorrer se o processo administrativo disciplinar local ainda não tiver sido definitivamente julgado.

Ou seja, aplica-se a regra da primazia mencionada alhures apenas se o processo disciplinar for instaurado no Conselho Nacional de Justiça antes ou durante o curso de processo correlato no tribunal. Inaceitável, porém, a instauração de processo disciplinar no Colegiado Administrativo após transitar em julgado decisão administrativa proferida em feito disciplinar na origem porque, nesse caso, não estaria o $\mathrm{CNJ}$ a exercer uma competência originária ou concorrente, mas ulterior. Logo, qualquer decisão que proferir, nessa hipótese, infringirá o princípio do ne bis in idem e não poderá prevalecer sobre aquela exarada na origem.

Essa conclusão fica mais evidente em relação aos processos disciplinares de magistrados, ante o teor da regra inserta no art. 103-B, $\S 4^{\circ}, \mathrm{V}$, da Constituição Federal, pois se a Constituição estabelece prazo de um ano do julgamento para revisão, pelo CNJ, dos processos disciplinares de juízes ou de membros de tribunais, não se pode admitir que o Conselho Nacional de Justiça, para burlar essa norma constitucional, que também visa a

\footnotetext{
${ }^{538}$ Vide nota 468 ao item 3.1.4.1.

${ }^{539}$ Vide nota 468 ao item 3.1.4.1.
} 
segurança jurídica do processado, instaure, como sucedâneo dessa sua terceira competência disciplinar específica, com, porém, limitação temporal, outro processo administrativo disciplinar.

Há, contudo, uma exceção.

O Conselho Nacional de Justiça poderá instaurar processo disciplinar contra magistrado mesmo após transitar em julgado decisão administrativa proferida em feito disciplinar na origem relativo ao mesmo imputado e aos mesmos fatos se, antes, em regular processo de revisão disciplinar $\left(\mathrm{CF}\right.$, art. 103-B, $\left.\S 4^{\circ}, \mathrm{V}\right)$, anular aquele que tramitou no tribunal local no ato revisional (RICNJ, art. 88).

Assim, o exercício da primeira competência disciplinar específica do Conselho Nacional de Justiça - conhecimento de reclamações contra membros ou órgãos do Poder Judiciário, inclusive contra seus serviços auxiliares, serventias e órgãos prestadores de serviços notariais e de registro que atuem por delegação do poder público ou oficializados -, no nosso sentir, não permite a instauração de processo disciplinar no Colegiado Administrativo após a prolação de decisão definitiva em processo disciplinar do tribunal local relativa aos mesmos acusados e fatos, pois não estaria o CNJ mais a exercer uma competência originária ou concorrente, mas ulterior, devendo ser respeitada a decisão administrativa transitada em julgado proferida na origem, sob pena de insegurança jurídica e bis in idem. Admite-se, apenas, a instauração posterior de processo disciplinar no CNJ em face de magistrado se, em prévio processo de revisão disciplinar, for anulado aquele que tramitou na província.

\subsection{Impossibilidade de revisão dos próprios processos disciplinares}

O exercício da terceira competência constitucional disciplinar específica atribuída ao CNJ - revisão, de ofício ou mediante provocação, dos processos disciplinares de juízes e membros de tribunais julgados há menos de um ano - leva à seguinte indagação: pode o Conselho Nacional de Justiça rever os próprios processos disciplinares de magistrados que tramitaram no Colegiado e foram julgados há menos de um ano?

Entendemos que não.

Apesar de não haver qualquer restrição na redação da norma prevista no art. 103-B, $\S$ $4^{\mathrm{o}}$, V, da Constituição Federal, a possibilidade de revisão, pelo $\mathrm{CNJ}$, dos processos disciplinares julgados há menos de um ano, deve ocorrer somente em relação àqueles feitos que tramitaram perante os órgãos locais. Inadmissível, todavia, ainda que não tenha 
decorrido o lapso temporal mencionado, em relação aos processos disciplinares julgados pelo próprio Conselho Nacional de Justiça.

Pensamos que o sentido da norma constitucional em comento é permitir que o Conselho, enquanto órgão controlador, reveja as decisões proferidas pelos tribunais, órgãos controlados. Se o Conselho puder rever suas próprios decisões disciplinares, estará aberta a possibilidade de composições seguintes do Colegiado exercerem controle sobre as deliberações tomadas pelas anteriores. Ademais, se as decisões disciplinares do CNJ pudessem ser revistas pelo próprio órgão, observado o prazo constitucional e as restrições regimentais, haveria possibilidade de criar-se uma sequência interminável de revisões de revisões de processos disciplinares, o que atentaria contra a segurança jurídica ${ }^{540}$.

Assim, consideramos que não pode o Conselho Nacional de Justiça realizar a revisão dos processos disciplinares de magistrados julgados pelo próprio Colegiado há menos de um ano.

\subsection{Termo inicial de contagem do prazo para revisão de processos disciplinares}

A Constituição Federal expressamente estabeleceu que a revisão, de ofício ou mediante provocação, dos processos disciplinares de juízes e membros de tribunais pelo Conselho Nacional de Justiça deve ser realizada no prazo de um ano do julgamento.

Qual é, porém, o termo inicial de contagem desse prazo?

A leitura isolada da regra mencionada no art. 103-B, $\S 4^{\circ}$, V, da Constituição Federal poderia indicar que a data inicial para cálculo do prazo de um ano para revisão do processo disciplinar seria sempre o dia do seu julgamento no tribunal de origem, pois o dispositivo em exame utiliza a singela expressão "julgados há menos de um ano".

Não se pode olvidar, porém, que a Constituição Federal impõe a publicidade das decisões administrativas proferidas pelos tribunais (CF, art. 93, IX e X) e é inviável ao Conselho Nacional de Justiça conhecer da existência e acompanhar todos os julgamentos administrativos disciplinares realizados na quase uma centena de órgãos atomizados ${ }^{541}$ do Poder Judiciário.

\footnotetext{
${ }^{540}$ Vide nota 468 ao item 3.1.4.1.

${ }^{541}$ Quando da criação do CNJ, ante a extinção dos Tribunais de Alçada promovida pela EC no 45/2004 (artigo (art.) $4^{\circ}$ ), havia noventa e um tribunais no país: Supremo Tribunal Federal, Superior Tribunal de Justiça, Tribunal Superior do Trabalho, Tribunal Superior Eleitoral, Superior Tribunal Militar, cinco Tribunais Regionais Federais, vinte e quatro Tribunais Regionais do Trabalho, vinte e sete Tribunais Regionais Eleitorais, vinte e sete Tribunais de Justiça Estaduais e três Tribunais de Justiça Militares
} 
Por outro lado, extrai-se da Resolução CNJ n 135/2011, observado o teor da decisão proferida no referendo da liminar na $\operatorname{ADI} n^{\circ} 4638$, que:

a) A notícia de irregularidade praticada por magistrados poderá ser feita por toda e qualquer pessoa, exigindo-se formulação por escrito, com confirmação da autenticidade, a identificação e o endereço do denunciante (art. $9^{\circ}$ );

b) Pode haver o arquivamento liminar do procedimento pelos tribunais locais quando o fato narrado não configurar infração disciplinar ou ilícito penal (art. $9^{\circ}$, $\left.\S 2^{\circ}\right)$;

c) Nesse caso, deverá ser comunicada a Corregedoria Nacional de Justiça, no prazo de quinze dias da decisão ( $\operatorname{art.} 9^{\circ}, \S 3^{\circ}$, e 28);

d) Cabe recurso do denunciante, no prazo de quinze dias, para o tribunal local, no caso de arquivamento do procedimento de plano (art. 10);

e) Deverá haver decisão do tribunal pleno ou do respectivo órgão especial para a instauração do processo disciplinar, com possibilidade de ser acolhida proposta de arquivamento. Para a sessão de julgamento deverá ser intimado o magistrado ou seu defensor ( $\left.\operatorname{art} .14, \S 1^{\circ}\right)$;

f) Na hipótese de decisão de arquivamento da instauração de processo disciplinar, também deverá ser comunicada a Corregedoria Nacional de Justiça, (art. 28)

g) Acolhida a proposta de abertura de processo administrativo, o Ministério Público será intimado para manifestação (art. 16);

h) Após, o magistrado será citado para apresentar defesa, podendo ser declarada sua revelia em caso de inércia, hipótese em que poderá lhe ser designado defensor dativo (art. 17, "caput”, IV e V);

i) Julgado o processo administrativo, os tribunais deverão comunicar a Corregedoria Nacional de Justiça, no prazo de quinze dias da respectiva sessão, o resultado (art. 20, $\S 4^{\circ}$ e 28 ).

Estaduais. Recentemente, a Emenda Constitucional $\mathrm{n}^{\circ} 73$, de 6 de junho de 2013, criou mais quatro Tribunais Regionais Federais, ainda não instalados (cumpre observar que a EC no 73/2013 teve sua constitucionalidade questionada pela Associação Nacional dos Procuradores Federais (ANPAF) através da Ação Direta de Inconstitucionalidade $\mathrm{n}^{\circ} 5017$ e, por decisão liminar proferida em 17 de julho de 2013, o Ministro Joaquim Barbosa (2013, pp. 1 a 18), na qualidade de Presidente do Supremo Tribunal Federal, apesar do feito ser da relatoria do Ministro Luiz Fux, invocando o disposto na norma inserta no art. 13, VIII, do Regimento Interno da referida Corte (RISTF), que atribui ao seu presidente o poder de decidir questões urgentes nos períodos de recesso ou de férias, deferiu a cautela pleiteada para suspender os efeitos da emenda constitucional em comento, ad referendum do Colegiado). 
Assim, pode-se afirmar que o prazo de um ano previsto no art. 103-B, $\S 4^{\circ}, \mathrm{V}$, para revisão, pelo Conselho Nacional de Justiça, dos processos disciplinares de magistrados julgados pelos tribunais tem por termo inicial:

a) Para o CNJ (revisão de ofício):

I. o dia em que a Corregedoria Nacional de Justiça receber a comunicação da decisão de arquivamento do procedimento prévio de apuração; ou,

II. o dia em que a Corregedoria Nacional de Justiça receber a comunicação da decisão de arquivamento da instauração do procedimento disciplinar; ou,

III. o dia em que a Corregedoria Nacional de Justiça receber a comunicação do resultado do julgamento do processo administrativo disciplinar;

b) Para o denunciante:

I. o dia em que for intimado da decisão que negar provimento ao recurso no caso de arquivamento do procedimento de plano; ou,

II. o dia da publicação oficial do resultado do julgamento que determinar o arquivamento da instauração de processo disciplinar (pois sua intimação para a sessão de julgamento não é exigida pela norma prevista no art. $14, \S 1^{\circ}$, da Resolucão CNJ nº 135/2011); ou,

III. o dia da publicação oficial do resultado do julgamento do processo administrativo disciplinar (pois sua intimação para acompanhar o trâmite do feito administrativo é despicienda);

c) Para o magistrado que apresentou defesa: o dia da sua intimação do resultado do julgamento do processo administrativo disciplinar;

d) Para o magistrado revel:

I. o dia da intimação do seu defensor dativo (se houver) do resultado do julgamento do processo administrativo disciplinar; ou

II. o dia da publicação oficial do resultado do julgamento do processo administrativo disciplinar (se não lhe foi designado defensor dativo);

e) Para o Ministério Público: o dia da sua intimação do resultado do julgamento do processo administrativo disciplinar, caso manifeste interesse em acompanhar o trâmite do feito.

\subsubsection{Dever de representação}


Segundo dispõe o art. 103-B, $\S 4^{\circ}$, IV, da Constituição Federal, também compete ao Conselho Nacional de Justiça "representar ao Ministério Público, no caso de crime contra a administração pública ou de abuso de autoridade".

O verbo "representar", na norma constitucional mencionada significa, comunicar, enviando as provas pertinentes constatadas, a ocorrência de crime ao Ministério Público para que este promova a ação penal pública de que é titular privativo contra o infrator ( $\mathrm{CF}$, art. $129, \mathrm{I})^{542}$.

Não se confunde, pois, com a delatio criminis postulatória "em que a vítima comunica um crime e requer providência do Estado para punir o seu responsável" (NUCCI, 2008, p. 88) e cuja ausência, por se tratar de condição de procedibilidade, no caso de ação penal pública condicionada, impede a instauração de inquérito policial $\left(\mathrm{CPP} \text {, art. } 5^{\circ}, \S 4^{\circ}\right)^{543}$ e a propositura da ação penal (CPP, art. 24, caput $)^{544}$.

A Constituição reza que o Conselho Nacional de Justiça deve, sempre que apurar, na sua atuação, a ocorrência de prática de crime contra a administração pública ${ }^{545}$ ou de abuso de autoridade ${ }^{546}$, informar o Ministério Público para que sejam adotadas as providências cabíveis na esfera criminal.

Trata-se de um dever do qual não pode o CNJ se esquivar, pois, ressalta Flávio Pansieri (2013, p. 1438), "tal atribuição não é facultativa, mas sim vinculante e obrigatória, incorrendo em crime de responsabilidade aquele que se omitir de representar".

$\mathrm{Na}$ verdade, apesar da norma constitucional restringir o dever do Conselho de comunicar o Ministério Público somente nos casos de cometimento de delito contra a administração pública ou de abuso de autoridade, por força do disposto no art. 40 do Código de Processo Penal ${ }^{547}$, aplicável também aos processos administrativos, incumbe ao

\footnotetext{
${ }^{542}$ Art. 129 (CF). São funções institucionais do Ministério Público:

I - promover, privativamente, a ação penal pública, na forma da lei;

${ }^{543}$ Art. $5^{\circ}$ (CPP) [...]

$\S 4^{\circ} \mathrm{O}$ inquérito, nos crimes em que a ação pública depender de representação, não poderá sem ela ser iniciado.

${ }^{544}$ Art. 24 (CPP). Nos crimes de ação pública, esta será promovida por denúncia do Ministério Público, mas dependerá, quando a lei o exigir, de requisição do Ministro da Justiça, ou de representação do ofendido ou de quem tiver qualidade para representá-lo.

${ }^{545}$ Os crimes contra a administraçao pública estão previstos, no Código Penal, nos arts. 312 a 359-H.

${ }^{546}$ Os crimes de abuso de autoridade estão previstos nos arts. $3^{\circ}$ e $4^{\circ}$ da lei $n^{\circ} 4.898$, de 9 de dezembro de 1965.

${ }^{547}$ Art. 40 (CPP). Quando, em autos ou papéis de que conhecerem, os juízes ou tribunais verificarem a existência de crime de ação pública, remeterão ao Ministério Público as cópias e os documentos necessários ao oferecimento da denúncia.
} 
CNJ também informar o Parquet sempre que verificar a existência de crime de ação penal pública $^{548}$.

Se o Conselho Nacional de Justiça, porém, constatar a prática de crime de ação penal autenticamente privada, regida pelo princípio da oportunidade ${ }^{549}$, não deverá representar ao Ministério Público, pois, nesse caso, a instauração do inquérito policial (CPP, art. $5^{\circ}, \S$ $\left.5^{\circ}\right)^{550}$ e o ajuizamento da ação penal dependem de iniciativa do ofendido (CPP, art. 30 $)^{551}$.

\subsubsection{Estudo de norma: RICNJ, art. $4^{0}$, VII - Não discriminação de hipóteses de de representação}

Dispõe a norma inserta no art. $4^{\circ}$, VII, do Regimento Interno do Conselho Nacional de Justiça (Resolução CNJ n 67/2009) competir ao seu Plenário "encaminhar peças ao Ministério Público, a qualquer momento ou fase do processo administrativo quando verificada a ocorrência de qualquer crime, ou representar perante ele nos casos de crime contra a administração pública, de crime de abuso de autoridade ou nos casos de improbidade administrativa".

Referida disposição, inspirada no preceito constitucional previsto no art. 103-B, $\S 4^{\circ}$, IV, da Carta da República, e salutar no que tange à previsão de representação também na hipótese de constatação de improbidade administrativa ${ }^{552}$, padece, porém, de dois equívocos.

\footnotetext{
${ }^{548}$ Sob a ótica da legitimidade ativa, há duas espécies de ação penal: a) pública, quando ajuizada pelo Ministério Público, através do oferecimento da denúncia; e, b) privada, quando intentada pelo ofendido ou seu representante legal, mediante queixa. A ação penal pública subdivide-se em: a) pública incondicionada $\left(\mathrm{CP}\right.$, art. $100, \S 1^{\circ}$, primeira parte; $\mathrm{CPP}$, art. 24 , caput, primeira parte, e $\left.\S 2^{\circ}\right)$, quando o Ministério Público age independentemente de qualquer condição de procedibilidade; e, b) pública condicionada $(\mathrm{CP}$, art. $100, \S$ $1^{\circ}$, in fine; CPP, art. 24, caput, in fine, e $\S 1^{\circ}$ ), quando o Ministério Público depende de representação da vítima ou de requisição do Ministro da Justiça para ajuizá-la. A ação penal privada também se subdivide em duas: a) autenticamente privada $\left(\mathrm{CP}\right.$, art. $100, \S 2^{\circ}$; CPP, art. 30), quando somente pode ser intentada pelo ofendido, seu representante legal, ou por pessoas autorizadas pela lei, no caso de morte ou ausência (CP, art. $100, \S 4^{\circ}$; CPP, art. 31); e, b) privada susidiária da pública (CF, art. $5^{\circ}$, LIX; CP, art. 100, $3^{\circ}$; CPP, art. 29), quando, nos crimes de ação pública, o Ministério Público não oferece denúncia no prazo legal.

${ }^{549}$ Enquanto a ação penal pública é regida pelo princípio da obrigatoriedade, ou seja, deve o Estado ajuizá-la, a ação penal privada regula-se pelo princípio da oportunidade, ou seja, o ofendido tem a faculdade de intentála contra o agressor (a respeito confira-se NUCCI, 2008, p. 142).

${ }^{550}$ Art. $5^{\circ}$ (CPP) [...]

$\S 5^{\circ}$ Nos crimes de ação privada, a autoridade policial somente poderá proceder a inquérito a requerimento de quem tenha qualidade para intentá-la.

${ }^{551}$ Art.30 (CPP). Ao ofendido ou a quem tenha qualidade para representá-lo caberá intentar a ação privada.

${ }^{552}$ A Lei ${ }^{0} 8.429$, de 2 de junho de 1992, dispõe sobre as sanções aplicáveis aos agentes públicos no exercício de mandato, cargo, emprego ou função na administração pública direta, indireta ou fundacional nos casos de prática de atos de improbidade administrativa que importem enriquecimento ilícito (art. $9^{\circ}$ ), causem
} 
Primeiro peca pela redundância, pois não há qualquer diferença ontológica entre “encaminhar peças ao Ministério Público [...] quando verificada a ocorrência de qualquer crime" e "representar perante ele nos casos de crime contra a administração pública"e "de crime de abuso de autoridade", exceto que a primeira atribuição é mais abrangente e engloba a segunda.

Segundo porque a leitura literal da norma indica que o Plenário do CNJ deve comunicar o Ministério Público e encaminhar-lhe peças sempre que verificar a ocorrência de "qualquer crime", ou seja, mesmo que observe a prática de crime de ação penal autenticamente privada, o que, como exposto anteriormente, não é correto, pois nessa espécie de ação penal vige o princípio da oportunidade e seu titular é o ofendido.

Ao que parece, procurou-se mesclar, no mesmo dispositivo regimental, as regras previstas no art. 40 do Código de Processo Penal e no art. 103-B, $\S 4^{\mathrm{o}}$, IV, da Carta da República, além de se incluir no dispositivo previsão de comunicação ao Ministério Público em caso de constatação de prática de improbidade administrativa. Porém, olvidouse que, além de tornar a norma repetitiva em relação aos crimes contra a administração pública e de abuso de autoridade, uma vez que, na hipótese de representação ao Ministério Público ante a constatação de ocorrência dos referidos delitos, também ser-lhe-ão encaminhadas as peças processuais pertinentes, inadvertidamente, ao se fazer constar no preceito a expressão "qualquer crime", inclui-se também os de ação penal autenticamente privada, intentada, facultativamente, pelo ofendido, e da qual o Ministério Público não é titular.

Melhor seria que o Regimento Interno do Conselho Nacional de Justiça tivesse tratado da representação nos casos de verificação de prática de improbidade administrativa em inciso distinto e utilizado, na redação do dispositivo em comento, os termos singelos do preceito constante no art. 59 da LOMAN, que, ao tratar de semelhante atribuição em relação ao Conselho Nacional da Magistratura, restou assim redigido:

Art. 59 (LOMAN) O Conselho Nacional da Magistratura, se considerar existente crime de ação pública, pelo que constar de reclamação ou representação, remeterá ao Ministério Público cópia das peças que entender necessárias ao oferecimento da denúncia ou à instauração de inquérito policial.

prejuízo ao erário (art. 10) e atentem contra os princípios da Administração Pública (art. 11), impondo cominações independentemente de outras sanções penais, civis e administrativas (art. 12). 
Em suma, não se mostra adequada a redação do inciso VII do artigo $4^{\circ}$ do Regimento Interno do Conselho Nacional de Justiça, pois deve haver representação ao Ministério Público, com encaminhamento de cópias relacionadas aos fatos, em todos os crimes de ação penal pública e tal não deve ocorrer se verificada a prática de crime de ação penal privada.

\subsubsection{Dever de elaboração de relatórios com proposta de providências ao parlamento}

Prescrevem as nomas insertas no art. 103-B, $\S 4^{\circ}$, VI e VII, da Constituição Federal, também competir ao Conselho Nacional de Justiça elaborar: a) semestralmente, relatório estatístico sobre processos e sentenças prolatadas, por unidade da Federação, nos diferentes órgãos do Poder Judiciário; e, b) anualmente, relatório propondo as providências que julgar necessárias, sobre a situação do Poder Judiciário no País e as atividades do Conselho.

O relatório anual deverá integrar mensagem do Presidente do Supremo Tribunal Federal a ser remetida ao Congresso Nacional, por ocasião da abertura da sessão legislativa.

José Adércio Leite Sampaio (2007, pp. 303 e 304) denomina essa competência espécífica do CNJ de atribuição informativa e propositiva. Ressalta que "o destinatário da providência pode ser a autoridade ou o órgão competente para exercê-la" e salienta que "o caráter propositivo não se restringe ao instante dos relatórios" pois, pela sua própria natureza, pode o Conselho "a qualquer tempo, elaborar notas técnicas, seja por iniciativa própria, seja mediante requerimento de agentes de outros Poderes, sobre anteprojetos de leis ou projetos de lei que tramitam no Congresso Nacional ou nas Assembleias Legislativas, quando caracterizado o interesse do Poder Judiciário".

Nessa linha, o art. 103 do Regimento Interno do CNJ reza que seu plenário poderá, de ofício, ou mediante provocação, elaborar notas técnicas sobre: a) políticas públicas que afetem o desempenho do Poder Judiciário, anteprojetos de lei, projetos de lei, e quaisquer outros atos com força normativa que tramitem no Congresso Nacional, nas Assembléias Legislativas ou em quaisquer outros entes da Administração Pública Direta ou Indireta, quando caracterizado o interesse do Poder Judiciário (de ofício ou mediante requerimento de agentes de outros Poderes) (inc. I); b) normas ou situações específicas da Administração Pública quando caracterizado o interesse do Poder Judiciário (inc. II); e, c) projetos de lei de iniciativa do Poder Judiciário, a serem endereçadas ao Supremo Tribunal Federal (inc. 
III).

Essa competência executiva do Conselho Nacional de Justiça é importante para o desempenho de seu papel de planejador e gestor estratégico do Poder Judiciário, pois permite que colete dados e influêncie as ações políticas destinadas ao Judiciário afetas aos demais órgãos de Poder.

Justificável, pois, as disposições previstas nos arts. 36 a 40-B do Regimento Interno do Conselho (Resolução CNJ no 67/2009) que tratam de dois departamentos na sua estrutura: o Departamento de Pesquisas Judiciárias (DPJ), órgão de assessoramento técnico do CNJ, e o Departamento de Monitoramento e Fiscalização do Sistema Carcerário e do Sistema de Execução de Medidas Socioeducativas (DMF), criado pela Lei no 12.106 , de 2 de dezembro de 2009, como órgão do CNJ de acompanhamento e fiscalização do sistema carcerário e de execução de medidas socioeducativas no âmbito do Poder Judiciário - art. $1^{\mathrm{o})}$.

O Departamento de Pesquisas Judiciárias (DPJ), é responsável por, segundo dispõe o art. 37 do RICNJ: a) subsidiar a Presidência do Conselho na elaboração do relatório anual (inc. I); b) desenvolver pesquisas destinadas ao conhecimento da função jurisdicional brasileira (inc. II); c) realizar análise e diagnóstico dos problemas estruturais e conjunturais dos diversos segmentos do Poder Judiciário (inc. III); d) elaborar relatórios conclusivos e opinar sobre matéria que lhe seja submetida pelo Plenário, pelo Presidente, pelo Corregedor Nacional de Justiça, por Conselheiro ou pelas Comissões (inc. IV); e) fornecer subsídios técnicos para a formulação de políticas judiciárias (inc. V); e, f) disseminar informações e conhecimentos por meio de publicações, seminários e outros veículos (inc. VI). ${ }^{553}$.

O Departamento de Monitoramento e Fiscalização do Sistema Carcerário e do Sistema de Execução de Medidas Socioeducativas (DMF), tem, consoante prevêm as normas constantes do art. $1^{\mathrm{o}}, \S 1^{\mathrm{o}}$, da Lei $\mathrm{n}^{\mathrm{o}}$ 12.106, de 2 de dezembro de 2009 e do art. 37 do RICNJ, os seguintes objetivos, dentre outros correlatos que possam ser administrativamente estabelecidos: a) monitorar e fiscalizar o cumprimento das

\footnotetext{
${ }^{553}$ O relatório "Justiça em Números", elaborado pelo Conselho Nacional de Justiça com o auxílio do seu Departamento de Pesquisas Judiciárias é considerado, pelo próprio Conselho, como sua principal fonte estatística e utilizado para sua atuação nacional, pois suas informações sistematizadas e analisadas "possibilitam um conhecimento amplo do Judiciário, capaz de fomentar medidas de integração, redução das disparidades regionais, bem como considerações sobre as especificidades dos desafios a serem enfrentados por cada ramo judicial no aprimoramento da prestação jurisdicional" (Justiça em números 2014: ano-base 2013/Conselho Nacional de Justiça - Brasília: CNJ, 2014, p. 5, disponível em ftp://ftp.cnj.jus.br/Justica_em_Numeros/relatorio_jn2014.pdf. Acesso em 12.12.2014).
} 
recomendações e resoluções do Conselho Nacional de Justiça em relação à prisão provisória e definitiva, medida de segurança e de internação de adolescentes (inc. I); b) planejar, organizar e coordenar, no âmbito de cada Tribunal, mutirões para reavaliação da prisão provisória e definitiva, da medida de segurança e da internação de adolescentes e para o aperfeiçoamento de rotinas cartorárias (inc. II); c) acompanhar e propor soluções em face de irregularidades verificadas no sistema carcerário e no sistema de execução de medidas socioeducativas (inc. III); d) fomentar a implementação de medidas protetivas e de projetos de capacitação profissional e reinserção social do interno e do egresso do sistema carcerário (inc. IV); e) propor ao Conselho Nacional de Justiça, em relação ao sistema carcerário e ao sistema de execução de medidas socioeducativas, a uniformização de procedimentos, bem como de estudos para aperfeiçoamento da legislação sobre a matéria (inc. V); f) acompanhar e monitorar projetos relativos à abertura de novas vagas e ao cumprimento da legislação pertinente em relação ao sistema carcerário e ao sistema de execução de medidas socioeducativas (inc. VI); g) acompanhar a implantação e o funcionamento de sistema de gestão eletrônica da execução penal e de mecanismo de acompanhamento eletrônico das prisões provisórias (inc. VII); e h) coordenar a instalação de unidades de assistência jurídica voluntária no âmbito do sistema carcerário e do sistema de execução de medidas socioeducativas (inc. VIII).

A competência específica em comento também revela limites constitucionais à atuação do Conselho Nacional de Justiça.

Com efeito, na normatização das suas atividades de pesquisa e monitoramento, para elaboração dos seus relatórios, deve o Conselho Nacional de Justiça limitar-se a buscar dados objetivos junto às diversas unidades judiciais, sem, no entanto, imiscuir-se na atividade jurisdicional ou legislativa.

Também não deve o Conselho, ao exigir a prestação de informações para monitoramento das atividades judiciais, olvidar-se que a atividade-fim dos órgãos do Poder Judiciário é a prestação jurisdicional. Ou seja, a apresentação de dados pelas unidades judiciais não pode tornar-se um fardo e comprometer o desenvolvimento da função típica do Poder Judiciário.

Por outro lado, enquanto órgão de controle administrativo interno do Judiciário, a proposta de providências constante do relatório anual do Conselho Nacional de Justiça e as notas técnicas aprovadas por seu plenário devem cingir-se a questões políticas de interesse desse Poder.

A seguir será apresentado exemplo de violação a esses limites constitucionais de 
atuação.

\subsubsection{Estudo de norma: Resolução CNJ nº 66/2009 - Requisitos extravagantes na apreciação do auto de prisão em flagrante}

O Conselho Nacional de Justiça, através da Resolução no 66, de 27 de janeiro de 2009, com a redação que lhe foi dada pela Resolução CNJ n 87, de 15 de setembro de 2009, objetivou criar mecanismos de controle estatístico e disciplinar o acompanhamento, pelos juízes e tribunais, dos procedimentos relacionados à decretação e ao controle dos casos de prisão preventiva.

Determinou ao juiz (art. $1^{\circ}$ ) que, ao receber o auto de prisão em flagrante, imediatamente, ouvido o Ministério Público nas hipóteses legais, profira decisão fundamentada sobre: a) a concessão de liberdade provisória, com ou sem fiança, quando a lei admitir (inc. I); ou, b) a manutenção da prisão, quando presentes os pressupostos da prisão preventiva, observada a legislação pertinente; ou, c) o relaxamento da prisão ilegal.

Estabeleceu, também, o dever do juiz de, em até quarenta e oito horas da comunicação da prisão, não sendo juntados documentos e certidões que entender imprescindíveis à decisão e, não havendo advogado constituído, nomeie um defensoe dativo ou comunique a Defensoria Pública para regularização, em prazo não superior a 5 dias $\left(\S 1^{\circ}\right)$, dispensada a providência quando a certidão e o esclarecimento de eventuais antecedentes estiverem ao alcance do próprio juízo, por meio do sistema informatizado $\left(\S 2^{\circ}\right)$.

Ordenou, ainda, que as varas de inquéritos policiais, com competência criminal e de infância e juventude encaminhassem relatório às Corregedorias Gerais de Justiça locais, com periodicidade mínima trimestral, com demonstração do número das prisões em flagrante, temporárias e preventivas, e de internações, indicando o nome do preso ou internado, o número do processo, a data e a natureza da prisão ou da internação, unidade prisional ou de internação, a data e o conteúdo do último movimento processual (art. $2^{\circ}$, caput).

Posteriormente, em 6 de abril de 2010, por força do julgamento do processo Ato Normativo $\mathrm{n}^{\mathrm{o}}$ 0002272-45.2010.2.00.0000-Emenda $\mathrm{n}^{\mathrm{o}}$ 1, foi incluído o art. $2^{\circ}$-A na Resolução CNJ no 66/2009 para instituir o Cadastro Nacional de Prisões Cautelares e Internações Provisórias (caput) e determinar às mesmas unidades judiciais acima mencionadas, o cadastramento das prisões em flagrante, temporárias e preventivas e das internações temporárias existentes nos processos de sua competência, no prazo de vinte e 
quatro horas após a comunicação, bem assim de sua prorrogação, encerramento e outras intercorrências $\left(\S \S 1^{\mathrm{o}}\right.$ e $\left.2^{\mathrm{o}}\right)$.

Ocorre que, o Código de Processo Penal não determinava, na época da edição da mencionada resolução, que, em caso de prisão em flagrante, o juiz devesse, na hipótese de não serem apresentados documentos indispensáveis para a prolação de sua decisão, e ante a impossibilidade de sua obtenção por meio de sistema informatizado, a nomeação, se o agente não tivesse constituído advogado, de defensor dativo ou público para regularização, no prazo máximo de cinco dias.

A nova redação do Estatuto de Ritos Processuais Penais, dada pela pela Lei no 12.403 , de 4 de maio de 2011, também não trouxe qualquer inovação nesse sentido. De acordo com a regra inserta no art. 310 do Código de Processo Penal (com a redação que lhe foi dada pela Lei $n^{o}$ 12.403/2011), o juiz, ao receber o auto de prisão em flagrante, deve, fundamentadamente: a) relaxar a prisão ilegal (inc. I); ou, b) converter a prisão em flagrante em preventiva, quando presentes os requisitos legais (para garantia da ordem pública, da ordem econômica, por conveniência da instrução criminal, ou para assegurar a aplicação da lei penal, quando houver prova da existência do crime e indício suficiente de autoria, e se revelarem inadequadas ou insuficientes as medidas cautelares diversas da prisão - CPP, art. 312) (inc. II); ou, c) conceder liberdade provisória, com ou sem fiança (inclusive se verificar que o agente praticou o fato em estado de necessidade, legítima defesa, estrito cumprimento de dever legal ou no exercício regular de direito (CP, art. 23, I a III)).

Nota-se que a Resolução CNJ n 66/2009, apesar de objetiva criar mecanismos de controle estatístico e disciplinar o acompanhamento efetivo das prisões provisórias decretadas, inovou no ordenamento jurídico, pois as regras previstas em seu art. $1^{\text {o }}$ invadiram seara reservada à atividade legislativa da União (legislar sobre processo penal $\mathrm{CF}$, art. 22, I). Ademais, as determinações constantes do dispositivo regimental em comento afetam a atividade jurisdicional e ainda criam obrigação para pessoas que não integram o Poder Judiciário (advogado dativo ou defensor público) ${ }^{554}$. Houve, no nosso sentir, flagrante violação dos limites constitucionais de atuação do Conselho Nacional de Justiça nesse particular ${ }^{555}$.

\footnotetext{
${ }^{554}$ Nos consideranda da Resolução CNJ n $n^{\circ}$ 66/2009 consta referência, para justificar as determinações mencionadas, às garantias constantes no art. $5^{\circ}$, LXII, LXIII, LXIV, LXV, LXVI e LXXVIII, da Constituição Federal.

${ }^{555}$ A Associação Nacional dos Magistrados Estaduais (Anamages) ajuizou, em 16 de novembro de 2009, no Supremo Tribunal Federal (STF), a ADI n $n^{\circ} 4344$, para impugnar as disposições constantes no o art. $1^{\circ}$ da
} 
Por outro lado, a instituição do Cadastro Nacional de Prisões Cautelares e Internações Provisórias (caput) e a determinação, às varas de inquéritos policiais, com competência criminal e de infância e juventude, de alimentação de cadastros de prisões em flagrante, temporárias e preventivas e de internações temporárias, bem assim de sua prorrogação, encerramento e outras intercorrências (Art. 2º -A da Resolução CNJ nº 66/2009) gerou inconvenientes, ante a existência de mais de de mais de duzentos mil presos provisórios no Brasil, a sobrecarga de trabalho das unidades judiciais mencionadas, a necessidade de preenchimento, por parte dos Magistrados de Primeiro Grau, de um bom número de cadastros implantados no âmbito e por determinação do CNJ e a necessidade diária de alimentação do cadastro, a demandar constante alocação de recursos humanos para a realização deste mister. Constatou-se, também, a prescindibilidade de dados estatísticos de natureza individual para fins de formulação de macropolíticas públicas para as áreas criminais e de infância e juventude e que, no próprio âmbito do Conselho haveria necessidade de criação de uma considerável estrutura para monitorar o Cadastro Nacional instituído em termos individuais ${ }^{556}$.

As determinações constantes da art. 2º-A da Resolução CNJ nº 66/2009 acabaram, ante o motivos mencionados, sendo suspensas pela Resolução CNJ n ${ }^{\circ} 117$, de 3 de agosto de 2010, até a implantação do processo judicial eletrônico (PJe) ${ }^{557}$.

\subsubsection{Regulamentar.}

Estudadas sete competências específicas estabelecidas pelo texto constitucional para o Conselho Nacional de Justiça (guarda da autonomia do Poder Judiciário; guarda do

Resolução CNJ n ${ }^{\circ}$ 66/2009, com a redação que lhe foi dada pela Resolução CNJ no 87/2009. Alegou que o ato normativo ofendeu as seguintes normas constitucionais: a) art. 22, I, (competência privativa da União para legislar sobre direito processual, pela via do Congresso Nacional); b) art. 103-B, § $4^{\circ}$ (atribuições do CNJ); c) art. $5^{\circ}$, II, e 37 (princípio da legalidade); e d) artis. $2^{\circ}$ e 48 (princípio federativo). A ação foi distribuída à relatoria da Ministra Cármen Lúcia. O mérito do pleito, porém, não foi apreciado pelo STF, pois a ministra relatora, por decisão monocrática proferida em 16 de junho de 2011, negou seguimento à ação, por entender que ser a associação autora parte ilegitimidade ativa para a causa, uma vez que os dispositivos que impugnados têm repercussão para todos os magistrados nacionais e não apenas aos substituídos pela Anamages. Interposto agravo regimental contra referida decisão, o Supremo Tribiunal Federal, em Sessão Plenária realizada em 19 de novembro de 2014, negou provimento ao recurso, nos termos do voto da ministra relatora.

${ }^{556}$ Conforme consta nos consideranda da Resolução CNJ no 117, de 3 de agosto de 2010.

${ }^{557}$ No item 3.1.1.2, foi questionada a constitucionalidade das regras constantes da Resolução CNJ $n^{\circ}$ 185/2013, que determinaram a implantação necessária do sistema eletrônico denominado "Processo Judicial Eletrônico - PJe" em todos os órgãos do Poder Judiciário até o ano de 2018, com a criação, ainda, no âmbito dos tribunais, de "Comitês Gestores". 
cumprimento do Estatuto da Magistratura; guarda da observância dos princípios que regem a Administração Pública; controle da legalidade dos atos administrativos praticados por membros ou órgãos do Poder Judiciário; controle disciplinar; dever de representação; e dever de elaboração de relatórios com proposta de providências ao parlamento), deixou-se o exame da denominada neste trabalho "competência regulamentar" 558 para o final porque, apesar de prevista no art. 103-B, § 4 , I, in fine, da Constituição, os limites que o CNJ sofre no seu exercício são ditados por todas as demais, uma vez que a competência ora analisada visa justamente a normatização daqueloutras.

Reza a norma contida no art. 103-B, $\S 4^{\circ}$, I, in fine, da "Carta de Outubro", que o Conselho Nacional de Justiça também pode expedir atos regulamentares, no âmbito de sua competência, ou recomendar providências.

Cumpre investigar, pois, quais são os limites constitucionais de atuação do Conselho Nacional de Justiça em relação a essa específica competência que lhe foi atribuída pela Emenda Constitucional no ${ }^{\text {45/2004. }}$

$\mathrm{Na}$ verdade, o comando constitucional estabelece duas competências ao Conselho: a) expedir atos regulamentares, no âmbito de sua competência; e, b) recomendar providências.

A segunda diretriz de atuação mencionada - recomendação providências - não demanda aprofundado estudo, porque não implica na consecução de conduta obrigatória para os órgãos a que se dirige. Não é impertativa. Traz em seu bojo apenas um conselho, uma orientação (CUNHA, 2013, p. 59).

E justamente por não ser vinculante, a recomendação de providências pode dirigir-se tanto aos órgãos controlados pelo Conselho Nacional de Justiça, quanto a outros, inclusive dos demais Poderes da República, ou até a instituições públicas e privadas. Por ser desprovida de força coercitiva, a sanção pela não observância de recomendação é apenas política e social (constrangimento junto a sociedade pelo não cumprimento da recomendação) (SAMPAIO, 2007, pp. 286 e 287) $)^{559}$.

\footnotetext{
558 José Adércio Leite Sampaio (2007, p. 277) denomina de "atribuição regulamentar" e "poder regulamentar" a competência do CNJ em comento. Alexandre de Moraes de "poder normativo" (2013b, p. 540). Flávio Pansieri de "Poder Regulamentar (2013, p. 1439). Pedro Rafael Malveira Deocleciano de "atividade regulamentadora" (2010, p. 75). Essas expressões serão utilizadas como sinônimas no texto. Preferiu-se, contudo, denominar inicialmente o objeto do estudo deste item de "competência regulamentar", dado o critério classificatório adotado neste trabalho e a redação da norma constitucional inserta no art. 103$\mathrm{B}, \S 4^{\mathrm{o}}$, da Carta Política.

${ }^{559}$ José Adércio Leite Sampaio (2007, pp. 286 e 287) denomina de "atribuição mandamental" a possibilidade do CNJ recomendar providências e entende que haverá apenas sanção política e social nas hipóteses de descumprimento de orientações feitas pelo Colegiado a autoridades públicas externas. Ensina, porém, que a
} 
A competência de expedição de atos regulamentares, no entanto, pede investigação mais aprofundada.

Para tanto, parte-se da análise da decisão proferida em 16 de fevereiro de 2006 pelo Supremo Tribunal Federal na Medida Cautelar na Ação Declaratória (ADC) $\mathrm{n}^{\mathrm{o}} 12$, da relatoria do Ministro Ayres Britto, que trouxe importantes parâmetros para o estudo do poder regulamentar do Conselho Nacional de Justiça.

O CNJ, em 18 de outubro de 2005, editou a Resolução $n^{\circ} 7$ para disciplinar o exercício de cargos, empregos e funções por parentes, cônjuges e companheiros de magistrados e de servidores investidos em cargos de direção e assessoramento, no âmbito dos órgãos do Poder Judiciário.

A Resolução CNJ no 7/2005 visou proibir a prática do nepotismo ${ }^{560}$ no âmbito de todos os órgãos do Poder Judiciário (art. $\left.1^{\circ}\right)^{561}$, explicitando as suas hipóteses $\left(\operatorname{art.~} 2^{\circ}\right)^{562}$

recomendação de providências interna "tem o sentido de ordem para os integrantes e servidores do Judiciário, acompanhada de sanções cabíveis a todo descumprimento de mandado de autoridade competente".

${ }^{560}$ Como afirmado pelo Ministro Cezar Peluso em seu voto na Medida Cautelar na ADC $\mathrm{n}^{\circ} 12$, "historicamente todo mundo sabe que o nepotismo nasceu do hábito de alguns Papas que nomeavam os sobrinhos (e também outros parentes). De fato, segundo o Dicionário Houaiss (disponível em: $<$ http://houaiss.uol.com.br/busca?palavra=nepotismo>. Acesso em 26.12.2014), a primeira definição de nepotismo (do latim nepos = neto ou descendente) é autoridade exercida pelos sobrinhos ou demais parentes do papa na administração eclesiástica. No julgamento da $\mathrm{ADC}^{\circ} 12$, a MInistra Cármen Lúcia lembrou que já se afirmou que, ao final da carta endereçada por Pedro VAz de Caminha ao Rei de Portugal, dando notícia do descobrimento do Brasil, havia pleito nepotista: "E pois que Senhor He certo que asy neeste careguo que leuo como em outra qualquer coussa que de vosso serucio for uosa alteza há de seer de my mujto seruída, aela peci que por me fazer singular mercee made viyr dajha de Sam thomme Jorge dosoiro meu jenro, o que dela receberey em mujta mercee. Beijo as maãos de vossa alteza. Deste porto seguro da vossa jilha de vera cruz oje sesta feita primeiro dia de mayo de 1500".

${ }^{561}$ Art. $1^{\circ}$ (Resolução $\mathrm{CNJ} \mathrm{n}^{\circ} 7 / 2005$ ) É vedada a prática de nepotismo no âmbito de todos os órgãos do Poder Judiciário, sendo nulos os atos assim caracterizados.

${ }^{562}$ Art. $2^{\circ}$ (Resolução $\mathrm{CNJ} n^{\circ} 7 / 2005$ ) Constituem práticas de nepotismo, dentre outras:

I - o exercício de cargo de provimento em comissão ou de função gratificada, no âmbito da jurisdição de cada Tribunal ou Juízo, por cônjuge, companheiro ou parente em linha reta, colateral ou por afinidade, até o terceiro grau, inclusive, dos respectivos membros ou juízes vinculados;

II - o exercício, em Tribunais ou Juízos diversos, de cargos de provimento em comissão, ou de funções gratificadas, por cônjuges, companheiros ou parentes em linha reta, colateral ou por afinidade, até o terceiro grau, inclusive, de dois ou mais magistrados, ou de servidores investidos em cargos de direção ou de assessoramento, em circunstâncias que caracterizem ajuste para burlar a regra do inciso anterior mediante reciprocidade nas nomeações ou designações;

III - o exercício de cargo de provimento em comissão ou de função gratificada, no âmbito da jurisdição de cada Tribunal ou Juízo, por cônjuge, companheiro ou parente em linha reta, colateral ou por afinidade, até o terceiro grau, inclusive, de qualquer servidor investido em cargo de direção ou de assessoramento;

IV - a contratação por tempo determinado para atender a necessidade temporária de excepcional interesse público, de cônjuge, companheiro ou parente em linha reta, colateral ou por afinidade, até o terceiro grau, inclusive, dos respectivos membros ou juízes vinculados, bem como de qualquer servidor investido em cargo de direção ou de assessoramento;

V - a contratação, em casos excepcionais de dispensa ou inexigibilidade de licitação, de pessoa jurídica da qual sejam sócios cônjuge, companheiro ou parente em linha reta ou colateral até o terceiro grau, inclusive, dos respectivos membros ou juízes vinculados, ou servidor investido em cargo de direção e de 
com a determinação de exoneração dos ocupantes de cargos em provimento em comissão e de funções gratificadas que nelas se ajustassem $\left(\operatorname{art.} 5^{\circ}\right)^{563}$.

A aplicação da Resolução $\mathrm{CNJ} \mathrm{n}^{\mathrm{o}} 7 / 2005$, porém, passou a ser judicialmente questionada através da impetração de mandados de segurança. Órgãos do Poder Judiciário também se omitiram em dar cumprimento às suas regras.

Por esses motivos, a Associação dos Magistrados Brasileiros (AMB) ajuizou, em 2 de fevereiro de 2006, a $A D C n^{0} 12$, requerendo a declaração de constitucionalidade da Resolução CNJ nº 7/2005. Pleiteou, ainda, em sede de medida cautelar, com eficácia erga omnes e efeitos vinculantes, que se determinasse aos juízes e tribunais a suspensão do julgamento de processos que envolvessem a aplicação da referida resolução até o julgamento definitivo da ação declaratória de constitucionalidade, bem como a suspensão, com eficácia ex tunc, dos efeitos de quaisquer decisões, proferidas a qualquer título, que tivessem afastado a aplicação da Resolução CNJ n ${ }^{0} 7 / 05$.

A $\mathrm{ADC} \mathrm{n}^{\mathrm{o}} 12$ foi distribuída à relatoria do Ministro Ayres Britto que, diante da relevância do tema, pautou o julgamento da medida cautelar postulada para a Sessão Plenária do STF de 16 de fevereiro de 2006.

Em seu voto, o Ministro Ayres Britto afirmou que a Resolução CNJ no 7/2005 retirou diretamente da Constituição o seu fundamento de validade, sendo um ato normativo primário inovador do ordenamento jurídico. Argumentou que, apesar da Constituição ter estabelecido, em regra, que a lei editada pelo parlamento que tem o condão de inovar no ordenamento jurídico, admitem-se exceções, quando presentes outros interesses relevantes ${ }^{564}$, como nas hipóteses de competências legislativas exclusivas do Senado

assessoramento.

$\S 1^{\circ}$ Ficam excepcionadas, nas hipóteses dos incisos I, II e III deste artigo, as nomeações ou designações de servidores ocupantes de cargo de provimento efetivo das carreiras judiciárias, admitidos por concurso público, observada a compatibilidade do grau de escolaridade do cargo de origem, a qualificação profissional do servidor e a complexidade inerente ao cargo em comissão a ser exercido, e que o outro servidor também seja titular de cargo de provimento efetivo das carreiras jurídicas, vedada, em qualquer caso a nomeação ou designação para servir subordinado ao magistrado ou servidor determinante da incpmpatibilidade. (Redação dada pela Resolução $\mathrm{CNJ}^{\circ}{ }^{\circ} 181$, de 17.10.2013)

$\S 2^{\circ}$ A vedação constante do inciso IV deste artigo não se aplica quando a contratação por tempo determinado para atender a necessidade temporária de excepcional interesse público houver sido precedida de regular processo seletivo, em cumprimento de preceito legal.

${ }^{563}$ Art. $5^{\circ}$ (Resolução CNJ n ${ }^{\circ}$ 7/2005) Os Presidentes dos Tribunais, dentro do prazo de noventa dias, contado da publicação deste ato, promoverão a exoneração dos atuais ocupantes de cargos de provimento em comissão e de funções gratificadas, nas situações previstas no art. $2^{\circ}$, comunicando a este Conselho. Parágrafo único Os atos de exoneração produzirão efeitos a contar de suas respectivas publicações.

${ }^{564}$ Consta do seu voto (pp. 17, 19, 20 e 21): “[...] tenho que a Resolução em foco intenta retirar diretamente da Constituição o seu fundamento de validade, arrogando-se, portanto, a força de diploma normativo primário. [...] O Estado-legislador é detentor de duas caracterizadas vontades normativas: uma primária, 
Federal (CF, art. 52, VII, VIII e IX; art. 155, § 2, V, “a" e "b”), a adoção de medidas provisórias pelo Presidente da República em casos de relevância e urgência (CF, art. 62, caput), a elaboração dos regimentos internos dos tribunais (CF, art. 96, I, "a") e a autorização para o Chefe do Executivo dispor, por decreto (regulamento autônomo) sobre organização e funcionamento da administração federal, quando não implicar aumento de despesa nem criação ou extinção de órgãos públicos" (CF, art. 84, VI, “a”).

Sustentou, nessa linha, que o Conselho Nacional de Justiça, como órgão central de controle de atuação administrativa e financeira do Poder Judiciário e com os poderes expressos no texto constitucional de (a) zelar pela observância das normas constantes do art. 37 da Constituições Federal, (b) apreciar, de ofício ou mediante provocação, a legalidade dos atos administrativos praticados por membros ou órgãos do Poder Judiciário, (c) podendo desconstituí-los, revê-los ou fixar prazos para que se adotem as providências necessárias ao cumprimento da lei”, (d) sem prejuízo da competência do Tribunal de Contas da União" (CF, art. 103-B, § 4 , II), tem o poder, ainda que inexpresso na Carta Política, de dispor, primariamente, com normatividade em abstrato, sobre aqueles núcleos expressos, minimizando "a possibilidade das transgressões em concreto".

Ressaltou Sua Excelência, também, que a Emenda Constitucional n 45/2004, ao fixar o regime jurídico de três conselhos judiciários, o Conselho da Justiça Federal (CF, art. 105, II), o Conselho Superior da Justiça do Trabalho (CF, art. 111-A, $\S 2^{\circ}$, II) e o Conselho Nacional de Justiça (CF, art. 103-B), determinou expressamente que as competências dos dois primeiros seriam exercidas na forma da lei, silenciando em relação ao CNJ.

Salientou que deve ser feita uma "interpretação panorâmica ou sistemática ou imbricada" das disposições constantes do art. 103 da Lei Maior, pois logicamente concatenadas "para fazer do Conselho um órgão de planejamento estratégico do Poder Judiciário, assim no campo orçamentário, como no da celeridade, transparência, segurança,

outra derivada. A vontade primária é assim designada por se seguir imediatamente à vontade da própria Constituição, sem outra base de validade que não seja a Constituição mesma. Por isso que imediatamente inovadora do Ordenamento Jurídico, sabido que a Constituição não é diploma normativo destinado a tal inovação, mas a própria fundação desse Ordenamento. Já a segunda tipologia de vontade estatal-normativa, vontade tão-somente secundária, ela é assim chamada pelo fato de buscar o seu fundamento de validade em norma intercalar; ou seja, vontade que adota como esteio de validade um diploma jurídico já editado, este sim, com base na Constituição. Logo, vontade que não tem aquela força de inovar o Ordenamento com imediatidade. [...] É de elementar conhecimento que o Magno Texto de 1988 fez da lei a expressão emblemática do ato normativo primário. Lei em sentido formal, na acepção de que editada por órgão ou órgãos do Poder Legislativo [...] Acontece que as normas ditadas por essa lógica da mais abrangente irradiação sistêmica admitem contemporização. Comportam atenuação, exatamente para ceder espaço a valores e interesses outros que, embora de menor compleição material, são relevantes o bastante para merecer um tratamento heterodoxo. Um tratamento peculiar, despadronizado, por se traduzir numa nota de relativização àquela mais abrangente racionalidade sistêmica". 
democratização e aparelhamento tecnológico da função jurisdicional do Estado", permitindo-se, assim, que o CNJ densifique os princípios constitucionais da Administração Pública, aplicando-os imediatamente, tanto em concreto quanto em abstrato.

Afirmou ainda o Ministro Ayres Britto, quanto ao próprio teor da Resolução $\mathrm{CNJ} \mathrm{n}^{\circ}$ 7/2005, que o ato normativo densificou apropriadamente os princípios previstos no art. 37 da Constituição Federal, não tendo atentado contra os regramentos que estabelecem a liberdade de nomeação e exoneração dos cargos em comissão e funções de confiança (CF, art. 37, II e V) porque as restrições constantes da resolução do CNJ já estavam impostas pela Carta de 1988, pois "dedutíveis dos republicanos princípios da impessoalidade, da eficência e da igualdade [...]. O que já era constitucionalmente proibido permanece com essa tipificação, porém, agora mais expletivamente positivado".

Por fim, concedeu a liminar pleiteada, mas indicou dois ajustes no ato normativo: a) entendeu necessário emprestar interpretação conforme aos incisos do art. $2^{\circ}$ da Resolução $\mathrm{CNJ} \mathrm{n}^{\mathrm{o}} 7 / 2005$, para restringir o parentesco por afinidade da linha colateral "aos irmãos do cônjuge ou companheiro", porque o ato normativo, ao distender as fronteiras do parentesco para incluir, nas hipóteses de nepotismo, os "parentes de terceiro grau por afinidade", ultrapassando o instituto do cunhadio, invadiu matéria de caráter civil reservada à competência do Poder Legislativo Federal; e, b) julgou necessário também conferir interpretação conforme à Resolução CNJ no 7/2005 porque o ato normativo deixou de mencionar nos incisos do seu art. $2^{\circ}$ o vocábulo "chefia", constante do art. 37, V, da Constituição Federal.

O voto do Ministro Ayres Britto foi acompanhado pelos votos Ministros Eros Grau, Joaquim Barbosa, Cezar Peluso, Gilmar Mendes, Ellen Gracie, Celso de Mello, Sepúlveda Pertence e Nelson Jobim.

O Ministro Eros Grau destacou, para conceder a liminar, que a Constituição Federal consagra a legalidade como reserva de lei (vinculação às definições da lei) e como reserva da norma (vinculação às definiç̧ões decorrentes de previsão implícita ou explícita de lei) que pode ser legal, regulamentar ou regimental. Assim, como o princípio da legalidade expressa reserva de lei em termos relativos, "não impede a atribuição, explícita ou implícita, ao Executivo e ao Judiciário, para, no exercício de função normativa, definir obrigação de fazer e não fazer que se imponha aos particulares e os vincule ${ }^{565}$.

Em seu voto, o Ministro Joaquim Barbosa salientou que os dogmas da inexistência de

${ }^{565}$ Vide nota 458 do item 3.1.3. 
regulamento autônomo no Direito Brasileiro e da vedação da inovação normativa por via infralegal já haviam sido quebrados pela Emenda Constitucional no 32 , de 11 de setembro de 2001, ao prever a possibilidade do Presidente da República extinguir funções e cargos públicos vagos criados por lei mediante decreto (CF, art. 84, VI, “b”), tendo o art. 103-B, $\S$ $4^{\text {o }}$, II, novamente os excepcionado, ao atribuir ao Conselho Nacional de Justiça a competência para zelar pela observância do art. 37 da Lei Maior. No caso, o constituinte derivado implicitamente outorgou ao $\mathrm{CNJ}$ os meios práticos para exercer a referida competência, por meio de atos administrativos, sendo "curial que se entenda lícita a possibilidade de imposição, pelo Conselho, mediante ato normativo próprio, de obrigações nesse específico sentido".

Quanto ao poder regulamentar do Conselho Nacional de Justiça, o Ministro Cezar Peluso também asseverou que, como a Constituição da República atribuiu ao CNJ o dever de velar pela observância dos princípios insculpidos no seu art. 37 e de controlar a validez dos atos administrativos, "lhe deu, implicitamente [...] o poder de regulamentar a aplicação desses princípios, sobretudo o da impessoalidade”. E prosseguiu: “o Conselho tem, assim, poder jurídico de explicitar o alcance do princípio na matéria [...] o que pode ser feito apenas mediante a edição de ato com caráter normativo e de sentido geral", havendo previsão expressa no art. 103-B, $\S 4^{\circ}$, I, da Lei Maior, não restrito às hipóteses somente comtempladas no referido inciso.

Após o voto do Ministro Cezar Peluso, o Ministro Nelson Jobim, ante a primeira ressalva mencionada pelo relator, argumentou que a questão do parentesco por afinidade definida no Código Civil não deveria ser aplicada ao caso, pois pretendeu a Resolução CNJ $n^{\circ} 7 / 2005$ prestigiar o princípio da impessoalidade. Secundado pelo Ministro Cezar Peluso, o relator concordou em retirar seu apontamento de necessidade de ajuste do ato normativo, entendendo que a resolução "nada mais fez do que transformar o terceiro grau de parentesco num simples critério de inibição".

O Ministro Gilmar Mendes pontuou que as normas constantes do art. 103-B, $\S 4^{\mathrm{o}}$, da Constituição Federal autorizam expressamente a expedição de atos regulamentares pelo Conselho Nacional de Justiça, no âmbito de sua atuação, inclusive para zelar pela observância das disposições previstas no art. 37 da Lei Maior. Destacou também que a Resolução CNJ no 7/2005 encontra seu fundamento de validade diretamente na Constituição e, citando García de Enterría (2004, p. 441), salientou que a ideia de submissão da Administração à lei não implica concluir que "lei" é apenas aquela em sentido formal, pois “o conceito de legalidade não faz referência a um tipo de norma 
específica, mas ao ordenamento jurídico, como um todo, o que HAURIOU chamava de 'bloco de legalidade", ${ }^{\prime 56}$. A Constituição, portanto, também emite comandos normativos direcionados à atividade administrativa, com estruturas de regras ou de princípios. Neste último caso, "a estrutura normativa aberta deixa certas margens de 'livre apreciação (freie Ermessen) ao Poder Administrativo". Salientou, ainda, que dos poderes discricionários concedidos ao CNJ delimitados pelas regras de competência do art. 103-B e pelos princípios do art. 37, ambos da Constituição Federal, decorrem poderes administrativos inerentes ou implícitos ${ }^{567}$. Argumentou que sequer haveria necessidade de instituição de lei formal para proibir o nepotismo, pois ela decorre do conjunto de princípios. Assim, a Resolução CNJ no 7/2005 "limitou-se a explicitar, de modo declarativo, o que já resultava da normatividade da Constituição" e em "em estrita observância com as decisões legislativas fundamentais já externadas pelo Poder Legislativo", não tendo o CNJ inovado ou avançado em esfera reservada a lei, mas apenas modulado, "face a uma definição pressuposta pelo Poder Legislativo [...] às situações concretamente existentes e identificadas na prática do Poder Judiciário de todo o país", através de um ato administrativo de efeitos "interorgânicos" ou "interadministrativos". Por fim, afirmou que, ante o caráter nacional atribuído ao Poder Judiciário e reconhecido na ADI $n^{\circ} 3367$, no âmbito de suas competências, o "CNJ atua sobrepondo-se inclusive à legislação nãonacional (ou seja, federal - em sentido estrito -, estadual ou, se for o caso, municipal)" estando vinculado às normas constitucionais, às suas próprias regras de funcionamento e aos conceitos jurídicos previamente estabelecidos na legislação de âmbito nacional

\footnotetext{
${ }^{566}$ Nas palavras de Maurice Hauriou (1900, p. 28 a 31): Je prends légalité dans le sens de règne souverain de la loi. La loi dans sa définition complete est la règle écrite, oeuvre délibérée de réflexion sociale, contenat une determination du régime d'État, cést-à-dire une réforme dans le sens de la liberté. Le régime de la légalite est établi: $1^{\circ}$ Lorsque tontes les sources du droit autres que la loi sont soumises à la loi; $2^{\circ}$ Lorsque toutes les existences sociales, y compris l'État consideré comme individualité politique, gouvernementale et administrative, sont soumises au bloc du droit légal [...] De la soumission au "bloc légal" de toutes les existences sociales y compris l'Etat lui-même - Il ne suffit pas que le droit légal établisse son empire sur les autres formes du Droit, il faut encore que toute vie sociale lui soit soumise. Il convient de distinguer ici les administrés et l'administration. Il va de soi que les administrés sont aux lois et aux règlements légalement pris; ils supportent donc les obligations établies par le bloc de la législation avec les seules différences de sanction qui peuvent exister entre les lois et les règlements [...] En revanche, il a fallu longtemps pour faire admettre que l'État consideré comme gouvernement et comme administration, était lui aussi obligé par le bloc légal, c'est-à-dire par l'ensemble des lois et des règlements légalement pris. La principale difficulté a été d'admettre que l'administration s'obligeât elle-même par les règlements qu'elle prend pour s'organiser. Mais le droit administratif est entré résolument dans cette voie que est simplement celle de la limitation de la souveraineté par elle-même.

${ }^{567}$ A teoria dos poderes implícitos foi concebida pela Suprema Corte Americana, no ano de 1819, no caso McCulloch vs. Maryland. Em síntese, segundo a teoria, a Constituição, ao conceder uma competência expressa a determinado órgão ou instituição estatal, também lhe proporciona, implicitamente, os meios necessários para a realização da atribuição que lhe foi outorgada.
} 
(admitindo, no entanto, o uso de conceito distinto pelo ato normativo, com na questão do parentesco civil).

Em seu voto, a Ministra Ellen Gracie asseverou que o Conselho, ao editar a Resolução $\mathrm{CNJ} \mathrm{n}^{\mathrm{o}} 7 / 2005$, exerceu, ante a gama de atribuições que lhe conferida, a "atividade de verificação ou guarda da própria constitucionalidade dos atos administrativos expedidos pelos tribunais".

O Ministro Celso de Mello também afirmou que a Resolução CNJ n 7/2005 “traduz emanação direta do que prescreve a própria Constituição da República”, pois a atividade estatal "está necessariamente subordinada à observância de parâmetros ético-jurídicos que se refletem na consagração constitucional do princípio da moralidade administrativa", pressuposto de validade dos atos administrativos após a Constituição de 1988. Discorreu ainda sobre o conceito de bloco de constitucionalidade ${ }^{568}$ e argumentou que a "Resolução $\mathrm{CNJ}^{\mathrm{o}} 7$, de 2005, prestou efetiva reverência ao texto da Constituição Federal, revelandose fiel aos grandes princípios fundados na ética republicana e consagrados na Carta Política do Brasil".

Quanto à competência normativa do Conselho Nacional de Justiça, o Ministro Sepúlveda Pertence sustentou que "da competência para rever a ação administrativa dos órgãos judiciários, a ele submetidos decorre o poder de o Conselho regulamentar as soluções que dê às questões de legalidade que lhe sejam submetidas", impondo "uniformidade na interpretação do ordenamento jurídico aos que estejam submetidos à sua autoridade administrativa".

O Ministro Nelson Jobim limitou-se a afirmar que "o texto da Resolução n $n^{\circ}$ 07/05 importou, pura e simplesmente, na declaração normativa do que está vedado na

\footnotetext{
${ }^{568}$ Segundo Canotilho (2003, pp. 919 e 920) é necessário verificar qual o parâmetro para realização do controle de constitucionalidade pois, "todos os actos normativos devem estar em conformidade com a Constituição [...]. Significa isto que os actos legislativos e restantes actos normativos devem estar subordinados, formal, procedimental e substancialmente, ao parâmetro constitucional. Mas qual é o estalão normativo de acordo com o qual se deve controlar a conformidade dos actos normativos? As respostas a este problema oscilam fundamentalmente entre duas posições: (1) o parâmetro constitucional equivale à constituição escrita ou leis com valor constitucional formal, e daí que a conformidade dos actos normativos só possa ser aferida, sob o ponto de vista da sua constitucionalidade ou inconstitucionalidade, segundo as normas e princípios escritos da constituição (ou de outras leis formalmente constitucionais); (2) o parâmetro constitucional é a ordem constitucional global, e, por isso, o juízo de legitimidade constitucional dos actos normativos deve fazer-se não apenas segundo as normas e princípios escritos das leis constitucionais, mas também tendo em conta princípios não escritos integrantes da ordem constitucional global. Na perspectiva (1), o parâmetro da constitucionalidade (=normas de referência, bloco de constitucionalidade) reduz-se às normas e princípios da constituição e das leis com valor constitucional; para a posição (2), o parâmetro constitucional é mais vasto do que as normas e princípios constantes das leis constitucionais escritas, devendo alargar-se, pelo menos, aos princípios reclamados pelo 'espírito' ou pelos 'valores' que informam a ordem constitucional global".
} 
Constituição".

Único a discordar da maioria, o Ministro Marco Aurélio Mello, apesar de não concordar com a prática do nepotismo, por não se coadunar com a Constituição de 1988, defendeu não haver base constitucional para o Conselho Nacional de Justiça realizar normatização abstrata, substituindo-se ao Congresso Nacional.

Diante dos mencionados votos, o Supremo Tribunal Federal, por maioria, concedeu a liminar pleiteada pela $\mathrm{AMB}$, para, com efeito vinculante e erga omnes; a) suspender, até exame do mérito da $\mathrm{ADC} \mathrm{n}^{\mathrm{o}} 12$, o julgamento dos processos que tinham por objeto questionar a constitucionalidade da Resolução CNJ no 7/2005; e, b) impedir que juízes e tribunais proferissem decisões que impedissem ou afastassem a aplicabilidade da referida resolução; e c) suspender, com eficácia ex tunc, ou seja, desde a sua prolação, os efeitos de decisões proferidas, no sentido de afastar ou impedir a mencionada aplicação ${ }^{569}$.

${ }^{569}$ Segue a ementa do acórdão:

AÇÃO DECLARATÓRIA DE CONSTITUCIONALIDADE, AJUIZADA EM PROL DA RESOLUÇÃO N ${ }^{\circ}$ 07, de 18/10/2005, DO CONSELHO NACIONAL DE JUSTIÇA. MEDIDA CAUTELAR. Patente a legitimidade da Associação dos Magistrados do Brasil - AMB para propor ação declaratória de constitucionalidade. Primeiro, por se tratar de entidade de classe de âmbito nacional. Segundo, porque evidenciado o estreito vínculo objetivo entre as finalidades institucionais da proponente e o conteúdo do ato normativo por ela defendido (inciso IX do art. 103 da CF, com redação dada pela EC 45/04). Ação declaratória que não merece conhecimento quanto ao art. $3^{\circ}$ da resolução, porquanto, em 06/12/05, o Conselho Nacional de Justiça editou a Resolução ${ }^{\circ} 09 / 05$, alterando substancialmente a de $n^{\circ} 07 / 2005$. A Resolução $\mathrm{n}^{\circ}$ 07/05 do CNJ reveste-se dos atributos da generalidade (os dispositivos dela constantes veiculam normas proibitivas de ações administrativas de logo padronizadas), impessoalidade (ausência de indicação nominal ou patronímica de quem quer que seja) e abstratividade (trata-se de um modelo normativo com âmbito temporal de vigência em aberto, pois claramente vocacionado para renovar de forma contínua o liame que prende suas hipóteses de incidência aos respectivos mandamentos). A Resolução no $07 / 05$ se dota, ainda, de caráter normativo primário, dado que arranca diretamente do $\S 4^{\circ}$ do art. 103-B da Carta-cidadã e tem como finalidade debulhar os próprios conteúdos lógicos dos princípios constitucionais de centrada regência de toda a atividade administrativa do Estado, especialmente o da impessoalidade, o da eficiência, o da igualdade e o da moralidade. O ato normativo que se faz de objeto desta ação declaratória densifica apropriadamente os quatro citados princípios do art. 37 da Constituição Federal, razão por que não há antinomia de conteúdos na comparação dos comandos que se veiculam pelos dois modelos normativos: o constitucional e o infraconstitucional. Logo, o Conselho Nacional de Justiça fez adequado uso da competência que lhe conferiu a Carta de Outubro, após a Emenda 45/04. Noutro giro, os condicionamentos impostos pela Resolução em foco não atentam contra a liberdade de nomeação e exoneração dos cargos em comissão e funções de confiança (incisos II e V do art. 37). Isto porque a interpretação dos mencionados incisos não pode se desapegar dos princípios que se veiculam pelo caput do mesmo art. 37. Donde o juízo de que as restrições constantes do ato normativo do $\mathrm{CNJ}$ são, no rigor dos termos, as mesmas restrições já impostas pela Constituição de 1988, dedutíveis dos republicanos princípios da impessoalidade, da eficiência, da igualdade e da moralidade. É dizer: o que já era constitucionalmente proibido permanece com essa tipificação, porém, agora, mais expletivamente positivado. Não se trata, então, de discriminar o Poder Judiciário perante os outros dois Poderes Orgânicos do Estado, sob a equivocada proposição de que o Poder Executivo e o Poder Legislativo estariam inteiramente libertos de peias jurídicas para prover seus cargos em comissão e funções de confiança, naquelas situações em que os respectivos ocupantes não hajam ingressado na atividade estatal por meio de concurso público. O modelo normativo em exame não é suscetível de ofender a pureza do princípio da separação dos Poderes e até mesmo do princípio federativo. Primeiro, pela consideração de que o CNJ não é órgão estranho ao Poder Judiciário (art. 92, CF) e não está a submeter esse Poder à autoridade de nenhum dos outros dois; segundo, porque ele, Poder Judiciário, tem uma singular compostura de âmbito nacional, perfeitamente compatibilizada com o caráter estadualizado de uma parte 
A Ação Declaratória de Constitucionalidade $n^{\circ} 12$ foi definitivamente julgada pelo Pretório Excelso somente em 20 de agosto de $2008^{570}$. Quanto à possibilidade do exercício de poder normativo pelo Conselho Nacional de Justiça, Os Ministros Ayres Britto (relator), Marco Aurélio Mello (vencido), Eros Grau, Cezar Peluso, Celso de Mello e Gilmar Mendes mantiveram seus votos anteriores. Os Ministros Menezes Direito ${ }^{571}$, Cármen Lúcia $^{572}$ e Ricardo Lewandowski ${ }^{573}$, que não participaram do julgamento da Medida Cautelar, apresentaram seus votos e concordaram com o relator ${ }^{574}$.

Sobre o tema em estudo, o Ministro Menezes Direito orientou-se no sentido de que os princípios constantes do art. 37, caput, da Constituição Federal têm eficácia própria e podem ser imediatamente aplicados, "com a força efetiva de uma norma constitucional [...] independentemente da existência de uma lei formal, competindo ao CNJ, pois, disciplinálos ante "ao poder administrativo que detém no âmbito do Poder Judiciário".

A Ministra Cármen Lúcia limitou-se a afirmar que o CNJ atuou em sede que lhe é própria, fiscalizando a efetividade dos princípios constitucionais da Administração Pública.

Por fim, o Ministro Ricardo Lewandowski afirmou comungar do entendimento de que

dele. Ademais, o art. 125 da Lei Magna defere aos Estados a competência de organizar a sua própria Justiça, mas não é menos certo que esse mesmo art. 125, caput, junge essa organização aos princípios “estabelecidos" por ela, Carta Maior, neles incluídos os constantes do art. 37, cabeça. Medida liminar deferida para, com efeito vinculante: a) emprestar interpretação conforme para incluir o termo "chefia" nos inciso II, III, IV, V do artigo $2^{\circ}$ do ato normativo em foco b) suspender, até o exame de mérito desta ADC, o julgamento dos processos que tenham por objeto questionar a constitucionalidade da Resolução $n^{\circ}$ 07/2005, do Conselho Nacional de Justiça; c) obstar que juízes e Tribunais venham a proferir decisões que impeçam ou afastem a aplicabilidade da mesma Resolução $\mathrm{n}^{\circ}$ 07/2005, do CNJ e d) suspender, com eficácia ex tunc, os efeitos daquelas decisões que, já proferidas, determinaram o afastamento da sobredita aplicação (ADC 12 MC, Relator(a): Min. CARLOS BRITTO, Tribunal Pleno, julgado em 16/02/2006, DJ 01-09-2006).

${ }^{570}$ Como o resultado da $\mathrm{ADC} \mathrm{n}^{\mathrm{o}} 12$ em relação à vedação ao nepotismo gerou efeitos vinculantes somente no Poder Judiciário, apenas nove dias depois do seu julgamento, o Supremo Tribunal Federal publicou a Súmula Vinculante $\mathrm{n}^{\mathrm{o}} 13$ (DJe $\mathrm{n}^{\mathrm{o}} 162$ de 29.08.2008, p. 1.; DOU de 29.08.2008, p. 1.) com o seguinte teor: "A nomeação de cônjuge, companheiro ou parente em linha reta, colateral ou por afinidade, até o terceiro grau, inclusive, da autoridade nomeante ou de servidor da mesma pessoa jurídica investido em cargo de direção, chefia ou assessoramento, para o exercício de cargo em comissão ou de confiança ou, ainda, de função gratificada na administração pública direta e indireta em qualquer dos Poderes da União, dos Estados, do Distrito Federal e dos Municípios, compreendido o ajuste mediante designações recíprocas, viola a Constituição Federal”.

${ }^{571}$ A posse, no STF, do Ministro Menezes Direito ocorreu em 5 de setembro de 2007 (Disponível em $<$ http://www.stf.jus.br/portal/cms/verTexto.asp?servico=bibliotecaConsultaProdutoBibliotecaPastaMinistro\& pagina $=$ MenezesDireitoPrincipal $>$. Acesso em 10.12.2014.

${ }^{572}$ A posse, no STF, da Ministro Cármen Lúcia ocorreu em 21 de junho de 2006 (Disponível em $<$ http://www.stf.jus.br/portal/cms/verTexto.asp?servico=bibliotecaConsultaProdutoBibliotecaPastaMinistro\& pagina $=$ CarmenLuciaPrincipal $>$. Acesso em 10.12.2014.

${ }^{573}$ A posse, no STF, do Ministro Ricardo Lewandowski ocorreu em 16 de março de 2006 (Disponível em $<$ http://www.stf.jus.br/portal/cms/verTexto.asp?servico=bibliotecaConsultaProdutoBibliotecaPastaMinistro\& pagina=RicardoLewandowskiPrincipal $>$. Acesso em 10.12.2014.

${ }^{574}$ Os Ministros Ellen Gracie e Joaquim Barbosa estavam, justificadamente, ausentes na Sessão Plenária. 
os princípios constitucionais previstos no art. 37 da Lei Maior "são auto-aplicáveis no que diz respeito à vedação do nepotismo", tendo a Resolução CNJ no 7/2005 apenas disciplinado seu conteúdo através de seu poder regulamentar.

Extrai-se de todos os votos mencionados duas importantes conclusões ${ }^{575}$.

Primeira: apesar de forte posicionamento da doutrina brasileira tradicional no sentido de que o regulamento, no Brasil, não inova no Ordenamento Jurídico, pois vincula-se à lei e tem o papel de especificá-la e permitir sua execução ${ }^{576}$, o Supremo Tribunal Federal

${ }^{575} \mathrm{O}$ acórdão que apreciou o mérito da $\mathrm{ADC} \mathrm{n}^{\mathrm{o}} 12$ recebeu a seguinte ementa:

AÇÃO DECLARATÓRIA DE CONSTITUCIONALIDADE, AJUIZADA EM PROL DA RESOLUÇÃO No 07, de 18.10.05, DO CONSELHO NACIONAL DE JUSTIÇA. ATO NORMATIVO QUE "DISCIPLINA O EXERCÍCIO DE CARGOS, EMPREGOS E FUNÇÕES POR PARENTES, CÔNJUGES E COMPANHEIROS DE MAGISTRADOS E DE SERVIDORES INVESTIDOS EM CARGOS DE DIREÇÃO E ASSESSORAMENTO, NO ÂMBITO DOS ÓRGÃOS DO PODER JUDICIÁRIO E DÁ OUTRAS PROVIDÊNCIAS". PROCEDÊNCIA DO PEDIDO. 1. Os condicionamentos impostos pela Resolução $n^{\circ} 07 / 05$, do CNJ, não atentam contra a liberdade de prover e desprover cargos em comissão e funções de confiança. As restrições constantes do ato resolutivo são, no rigor dos termos, as mesmas já impostas pela Constituição de 1988, dedutíveis dos republicanos princípios da impessoalidade, da eficiência, da igualdade e da moralidade. 2. Improcedência das alegações de desrespeito ao princípio da separação dos Poderes e ao princípio federativo. O CNJ não é órgão estranho ao Poder Judiciário (art. 92, CF) e não está a submeter esse Poder à autoridade de nenhum dos outros dois. O Poder Judiciário tem uma singular compostura de âmbito nacional, perfeitamente compatibilizada com o caráter estadualizado de uma parte dele. Ademais, o art. 125 da Lei Magna defere aos Estados a competência de organizar a sua própria Justiça, mas não é menos certo que esse mesmo art. 125, caput, junge essa organização aos princípios "estabelecidos" por ela, Carta Maior, neles incluídos os constantes do art. 37, cabeça. 3. Ação julgada procedente para: a) emprestar interpretação conforme à Constituição para deduzir a função de chefia do substantivo "direção" nos incisos II, III, IV, V do artigo $2^{\circ}$ do ato normativo em foco; b) declarar a constitucionalidade da Resolução $n^{\circ}$ 07/2005, do Conselho Nacional de Justiça (ADC 12, Relator(a): Min. CARLOS BRITTO, Tribunal Pleno, julgado em 20/08/2008, DJe-237 DIVULG 17-12-2009 PUBLIC 18-12-2009).

${ }^{576}$ Nesse sentido, podem ser citados: a) Luciano Ferreira Leite (1986, pp. 22 e 25): “Os atos regulamentares constituem-se, tanto quanto as demais categorias (atos individuais quanto aos destinatários ou concretos quanto a estrutura) em comandos complementares da lei, possibilitando, ao contrário dos atos concretos, repetidas aplicações, na medida em que reiterarem as hipóteses neles previstas. [...] "A única forma possível de se estabelecer nítida distinção, entre ato legislativo e ato regulamentar decorre de que o primeiro se constitui em criação do direito. Em outras palavras, através da função legislativa o Estado inova primariamente a ordem jurídica"; b) Celso Antônio Bandeira de Mello (2009, p. 259): "Os regulamentos não podem aportar à ordem jurídica direito ou obrigação que já não estejam, na lei, previamente caracterizados e de modo suficiente, isto é, nela delineados, ao menos pela indicação dos critérios e balizamentos indispensáveis para o reconhecimento de suas composturas básicas; c) Pontes de Miranda (1970, p. 316): "Se o regulamento cria direitos ou obrigações novas, estranhas à lei, ou faz reviverem direitos, deveres, pretensões, obrigações, ações ou execuções que a lei apagou, é inconstitucional. Tampouco pode ele limitar, modificar, ampliar direitos, deveres, pretensões, obrigações ou exceções"; d) Geraldo Ataliba (1969, p. 23): "Não há regulamento autônomo no Brasil, porque só a lei pode obrigar [...] e porque nossos decretos só existem para assegurar a fiel observância das leis. [...] Sua função é facilitar a execução da lei, é específicá-la de modo praticável e, sobretudo, acomodar o aparelho administrativo para bem observá-la"; e) Seabra Fagundes $(1979$, p. 24): O regulamento "prende-se em essência ao texto legal. O seu objetivo é tão-somente facilitar, pela especificação do processo executório e pelo desdobramento minucioso do conteúdo sintético da lei, a execução da vontade do Estado expressa em ato legislativo". [...] Não lhe cabe alterar situação jurídica anterior, mas apenas pormenorizar as condições de modificação originária de outro ato (a lei). Se o fizer, exorbitará, significando uma invasão pelo Poder Executivo da competência legislativa do Congresso"; f) Oswaldo Aranha Bandeira de Melo (2010, pp. 359 e 370): "Os regulamentos são regras jurídicas gerais, abstratas, impessoais, em desenvolvimento da lei, referentes à organização e ação do Estado, enquanto Poder Público. São emanados pelo Poder Executivo, mediante decreto". [...] "Os regulamentos hão de ter por 
admitiu a densificação das regras concernentes à vedação ao nepotismo no âmbito do Poder Judiciário através de ato normativo (resolução) do Conselho Nacional de Justiça, primário, com fundamento de validade diretamente na Constituição Federal ${ }^{577}$.

Segunda: o Conselho Nacional de Justiça pode expedir atos regulamentares somente para normatizar, em abstrato, de forma inovadora, os núcleos expressos relativos às suas competências previstas no art. 103-B da Constituição Federal, inclusive os princípios constitucionais relativos à Administração Pública (CF, art. 37, caput).

Cumpre salientar que, apesar dos votos de alguns ministros não permitirem cristalina compreensão de que consideraram a Resolução CNJ n 7/2005 um ato normativo primário, pois afirmou-se também que referida resolução apenas declarou o que já estava consagrado na normatividade constante dos príncípios previstos no art. 37, caput, da Carta Política e de outras diplomas legais, o Ministro Relator Ayres Britto (secundado amplamente pelos Ministros Eros Grau e Joaquim Barbosa), defendeu explicitamente que a Resolução CNJ n ${ }^{\circ}$ 7/2005 inovou no ordenamento jurídico.

De fato, a leitura das disposições contidas na Resolução $\mathrm{CNJ} \mathrm{n}^{\circ} 7 / 2005$, no nosso sentir, revelam conteúdo de criação no ordenamento, ainda que limitado aos órgãos do Poder Judiciário sujeitos ao controle do Conselho Nacional de Justiça.

Com efeito, admissível a desnecessidade da regra inserta no art. $1^{\mathrm{o}}$ da resolução em comento - "é vedada a prática de nepotismo no âmbito de todos os órgãos do Poder Judiciário, sendo nulos os atos assim caracterizados" - pois seu conteúdo pode ser extraído dos princípios basilares da Administração Pública presentes na Carta de 1988.

Mas as normas previstas nos arts. $2^{\circ}$ e $5^{\circ}$ da Resolução CNJ n ${ }^{\circ} 7 / 2005$ - indicação das hipóteses específicas que constituem prática de nepotismo e fixação de prazo de noventa dias para exoneração daqueles insertos nas situações mencionadas - revelam regras que concretizam os princípios mencionados. Houve, em relação à vedação ao nepotismo, densificação, pelas regras estabelecidas no referido ato normativo, dos princípios prescritos

conteúdo regras orgânicas e processuais destinadas a pôr em execução os princípios institucionais estabelecidos por lei, ou para desenvolver os preceitos constantes de lei, expressos ou implícitos, dentro da órbita por ela circunscrita, isto é, as diretrizes, em pormenor, por ela determinadas"; g) Hely Lopes Meirelles (1999, p. 163): “Os regulamentos são atos administrativos, postos em vigência por decreto, para especificar os mandamentos da lei ou prover situações ainda não disciplinadas por lei. Desta conceituação ressaltam os caracteres marcantes do regulamento: ato administrativo (e não legislativo); ato explicativo ou supletivo da lei; ato hierarquicamente inferior à lei; ato de eficácia externa".

${ }^{577}$ A aceitação, além da lei, de outra origem primária de positivação jurídica (no caso, as resoluções do CNJ) pelo Supremo Tribunal Federal não deixa de retratar hipótese de fenômeno observado Zagrebelsky (1999, pp. 38 e 39) nas atuais sociedades pluralistas, que criam ordenamentos jurídicos plurais de difícil compreensão, pois contêm diversas fontes de produção normativa. 
no art. 37, caput, da Constituição. As regras positivadas pela Resolução CNJ nº 7/2005 forneceram critérios para as ações a serem tomadas no seio dos órgãos do Poder Judiciário, a fim de evitar a ocorrência de situações de fato (nepotismo) não aceitas pelos princípios da Ordem Constitucional brasileira ${ }^{578}$.

Essas regras, por outro lado, ainda que inspiradas em outros diplomas normativos ${ }^{579}$,

${ }^{578}$ Sobre as distinções entre princípios e regras, pertinente, neste ponto, a respeito, a lição de Zagrebelsky (1999, pp. 110 e 111): En primer lugar, sólo los principios desempeñan un papel propriamente constitucional, es decir, "constitutivo" del orden jurídico. Las reglas, aunque estén escritas en la Constitucion, no son más que leyes reforzadas por su forma especial. Las reglas, en efecto, se agotan en sí mismas, es decir, no tienen ninguna fuerza constitutiva fuera de lo que ellas mismas significan. Aparte de esto, sin embargo, quizás la diferencia más importante pueda venir sugerida por el distinto "tratamiento" que la ciencia del derecho otorga a reglas y principios. Sólo a las reglas se aplican los variados y virtuosistas métodos de la interpretación juridica que tiene por objeto el lenguaje del legislador. En las formulaciones de los principios hay poco que interpretar de este modo. Por lo general, su significado lingüistico es autoevidente y no hay nada que deba ser sacado a la luz razonando sobre las palabras. Las fórmulas "de principio" son a menudo expresiones un tanto banales, "producto de una recepción jurídica de tercera o cuarta mano", pero no por ello menos venerables, que remiten a tradiciones históricas, contextos de significado, etc., y que, más que "interpretadas" a través del análisis del lenguaje, deben ser entendidas en su ethos. En pocas palabras, a las reglas "se obedece", y, por ello, es importante determinar con precisión los preceptos que el legislador establece por medio de las formulaciones que contienen las reglas; a los principios, en cambio, "se presta adhesión" $y$, por ello, es importante comprender el mundo de valores, las grandes opciones de cultura jurídica de las que forman parte y a las que las palabras no hacen sino una simple alusión. Así pues - por lo que aquí interesa -, la distinción esencial parece ser la siguiente: las reglas nos proporcionan el criterio de nuestras acciones, nos dicen cómo debemos, no debemos, podemos actuar en determinadas situaciones específicas previstas por las reglas mismas; los principios, directamente, no nos dicen nada a este respecto, pero nos proporcionan criterios para tomar posición ante situaciones concretas pero que a priori aparecen indeterminadas. Los principios generan actitudes favorables o contrarias, de adhesión y apoyo o de disenso y repulsa hacia todo lo que puede estar implicado en su salvaguarda en cada caso concreto. Puesto que carecen de "supuesto de hecho", a los principios, a diferencia de lo que sucede con las reglas, sólo se les puede dar algún significado operativo haciéndoles "reaccionar”ante algún caso concreto. Su significado no puede determinarse en abstracto, sino sólo en los casos concretos, y sólo en los casos concretos se puede entender su alcance. Se podría indicar la diferencia señalando simplemente que son las reglas, y sólo las reglas, las que pueden ser observadas y aplicadas mecánica y pasivamente. Si el derecho sólo estuviese compuesto de reglas no sería insensato pensar el la "maquinización” de su aplicación por medio de autómatas pensantes, a los que se les proporcionaría el hecho y nos darían la respuesta. Estos autómatas tal vez podrían hacer uso de los dos principales esquemas lógicos para la aplicación de reglas normativas: el silogismo judicial y la subsunción del supuesto de hecho concreto en el supuesto abstracto de la norma. Ahora bien, tal idea, típicamente positivista, carece totalmente de sentido en la medida en que el derecho contenga principios. La "aplicación”de los principios es completamente distinta y requiere que, cuando la realidad exija de nosotros una "reacción", se "tome posición" ante ésta de conformidad con ellos. Una máquina capaz de "tomar posición”en el sentido indicado es una hipótesis que ni siquiera puede tomarse en consideración mientras la máquina siga siendo máquina.

${ }^{579}$ A Lei Imperial de $1^{\circ}$ de outubro de 1828 , que dava nova forma às Câmaras Municipais, já continha regra proibitiva do nepotismo em seu bojo (“Art. 38. Nenhum Vereador poderá votar em negocio de seu particular interesse, nem dos seus ascendentes, ou descendentes, irmãos, ou cunhados, emquanto durar o cunhadio. Igualmente não votarão aquelles, que jurarem ter suspeição"). Também constam normas semelhantes na Lei $\mathrm{n}^{\mathrm{o}}$ 8.112, de 11 de dezembro de 1990 (Regime Jurídico dos Servidores Civis da União - “Art. 117. Ao servidor é proibido: [...] VIII - manter sob sua chefia imediata, em cargo ou função de confiança, cônjuge, companheiro ou parente até o segundo grau civil"), na Lei n ${ }^{\circ} 11.416$, de 15 de dezembro de 2006 (Carreiras dos Servidores do Poder Judiciário da União - "Art. $6^{\circ}$ No âmbito da jurisdição de cada tribunal ou juízo é vedada a nomeação ou designação, para os cargos em comissão e funções comissionadas, de cônjuge, companheiro, parente ou afim, em linha reta ou colateral, até o terceiro grau, inclusive, dos respectivos membros e juízes vinculados, salvo a de ocupante de cargo de provimento efetivo das Carreiras dos Quadros de Pessoal do Poder Judiciário, caso em que a vedação é restrita à nomeação ou designação para servir perante o magistrado determinante da incompatibilidade") e no Regimento Interno do STF (“Art. 357. 
foram estabelecidas através de opções políticas feitas pelos conselheiros, atividade tipicamente parlamentar e criadora na ordem jurídica. A vedação do exercício de cargo de provimento em comissão do "parente" por afinidade na linha colateral até terceiro grau do juiz ou servidor investido em cargo de direção ou de assessoramento, malgrado o disposto no art. 1.595 do Código Civil ${ }^{580}$, e a definição do prazo de noventa dias para que os Presidentes de Tribunais exonerassem os ocupantes de cargos em infringência aos termos da Resolução CNJ nº 7/2005 revelam claras escolhas públicas primárias.

Assim, defende José Carlos Francisco (2009, p. 119):

$\mathrm{O}$ art. 103-B, $\S 4^{\circ}$, I, da Constituição (inserido pela Emenda Constitucional $n^{o} 45 / 04$ ) criou o Conselho Nacional de Justiça, quem foi atribuída competência para zelar pela autonomia do Poder Judiciário e pelo cumprimento do Estatuto da Magistratura, podendo expedir atos regulamentares, no âmbito de sua competência, ou recomendar providências. Esses regulamentos são atos normativos primários, de maneira que esse órgão do Judiciário pode impor direitos e obrigações ${ }^{581}$

Comporão os Gabinetes dos Ministros: [...] § $2^{\circ}$ Não pode ser nomeado para cargo em comissão, na forma deste artigo, cônjuge ou parente, em linha reta ou colateral, até o terceiro grau, inclusive, de qualquer dos Ministros em atividade").

${ }^{580}$ Art. 1.595 (CC). Cada cônjuge ou companheiro é aliado aos parentes do outro pelo vínculo da afinidade. $\S 1^{\circ} \mathrm{O}$ parentesco por afinidade limita-se aos ascendentes, aos descendentes e aos irmãos do cônjuge ou companheiro.

$\S 2^{\circ} \mathrm{Na}$ linha reta, a afinidade não se extingue com a dissolução do casamento ou da união estável.

${ }^{581}$ Exemplo de ato regulamentar expedido pelo Conselho Nacional de Justiça que estabeleceu direitos aos Magistrados é a Resolução CNJ n 133, de 21 de junho de 2011, que "dispõe sobre a simetria constitucional entre Magistratura e Ministério Público e equiparação de vantagens" e concede auxílio-alimentação aos Magistrados (art. 1 ${ }^{\circ}$, “a”). Esse ato regulamentar é objeto da Ação Direta de Inconstitucionalidade n 4822 , ajuizada pelo Conselho Federal da Ordem dos Advogados do Brasil perante o Supremo Tribunal Federal em 26 de junho de 2012, ainda não definitivamente julgada. Seu relator, Ministro Marco Aurélio Mello, considerou, em seu voto, inconstitucional o benefício concedido aos Magistrados, por entender que o CNJ extrapolou de suas funções, pois a questão deve ser tratada pelo Poder Legislativo, não sendo possível afastar a reserva legal sob o argumento de simetria constitucional entre as carreiras mencionadas, porque o dispositivo da Constituição Federal que sustenta essa alegação, art. 129, § $4^{\circ}$, determina apenas a extensão, ao Ministério Público, das regras relativas à Magistratura previstas no art. 93 da Lei Maior, no que couber, e não o contrário (a regra não estabelece uma via de mão dupla), e envolve apenas as "garantias funcionais indispensáveis ao exercício independente das competências constitucionais" (disponível em $<$ http://s.conjur.com.br/dl/voto-ministro-marco-aurelio-adi-4822.pdf $>$. Acesso em 10.12.2014). O Ministro Teori Zavascki, porém, abriu divergência no julgamento da ADI $n^{\circ} 4822$, entendendo que a decisão do Conselho Nacional de Justiça foi eminentemente administrativa, não tendo o órgão extrapolado de suas atribuições, pois o STF já se manifestou no sentido de que o Conselho pode extrair diretamente da Constituição Federal os critérios para fundamentação de suas decisões administrativas. Ademais, o art. 65 da LOMAN, que estabelece as vantagens devidas aos magistrados, tornou-se incompatível com a Constituição desde a promulgação da Emenda Constitucional n ${ }^{\circ}$ 19, de 4 de junho de 1998, que estabeleceu a remuneração dos magistrados pelo subsídio, e não pelo vencimento, o que autoriza o CNJ "a estabelecer regras remuneratórias da magistratura, frente ao déficit normativo e ao descompasso entre o legislador constitucional 
aos integrantes da Magistratura Nacional com fundamento direto na Constituição, em decorrência da independência necessária à gestão interna de cada um dos Poderes da República (a exemplo do que faz o Conselho Nacional do Ministério Público, o Legislativo em seu Regimento Interno e o Executivo em seu regulamento autônomo ${ }^{582}$.

Portanto, o Supremo Tribunal Federal reconheceu que a Emenda Constitucional $\mathrm{n}^{\mathrm{o}}$ 45/2004 atribuiu ao Conselho Nacional de Justiça poder normativo primário. Esse poder, porém, deve ser exercido somente no âmbito das competências constitucionais conferidas ao CNJ.

Logo, conclui-se que todas as limitações constitucionais de atuação apresentadas neste trabalho devem ser observadas pelo Conselho Nacional de Justiça quando do exercício de

$<$ http://www.stf.jus.br/portal/cms/verNoticiaDetalhe.asp?idConteudo=249916\& caixaBusca=N $>$. Acesso em 10.12.2014). O Ministro Luiz Fux acompanhou a divergência, entendendo também estar o CNJ habilitado a editar atos normativos primários para dar concretude ao texto constitucional. Salientou, ainda, que a simetria constitucional entre as carreira da Magistratura e do Mnistério Público impõe a aplicação tanto das mesmas vedações quanto das mesmas prerrogativas remuneratórias. Após seu voto, , o julgamento foi suspenso por pedido de vista do Ministro Dias Toffoli (disponível em $<$ http://www.stf.jus.br/portal/cms/verNoticiaDetalhe.asp?idConteudo=253935>. Acesso em 10.12.2014).

${ }^{582}$ Em sentido oposto, em artigo intitulado "Os limites constitucionais das resoluções do Conselho Nacional de Justiça (CNJ) e Conselho Nacional do Ministério Público (CNMP)" (disponível em $<$ http://jus.com.br/imprimir/7694/os-limites-constitucionais-das-resolucoes-do-conselho-nacional-de-justicacnj-e-conselho-nacional-do-ministerio-publico-cnmp $>$. Acesso em 10.12.14), elaborado em novembro de 2005 e publicado em dezembro de 2005 (após, portanto, a edição da Resolução CNJ n n $^{\circ} / 2005$, mas antes da decisão proferida na Medida Cautelar na ADC n 12 pelo STF), Clèmerson Merlin Clève, Lenio Luiz Streck e Ingo Wolfgang Sarlet sustentam ser equivocado aceitar que o CNJ e o CNMP possam, através de atos regulamentares, criar direitos e obrigações, inovar no ordenamento, porque o constituinte derivado não delegou a esses órgãos "o poder de romper com o princípio da reserva de lei”, substituindo-se à vontade geral. Asseveraram que as resoluções dos Conselhos, destinadas a concreções e individualizações (matérias com menor amplitude normativa), não podem estar na mesma hierarquia das leis, produzidas pelo Poder Legislativo, "essência da democracia representativa", que têm caráter geral e regulam situações abstratas. Ademais, "a atuação dos membros do Poder Judiciário e do Ministério Público está regulada em leis específicas (LOMAN, LOMIN's estadual e federal, postas no sistema em estrita obediência à Constituição)". Assim, pontuam, a menção, no art. 103-B, § 4º I, no art. 130-A, § 2º I, ambos da Constituição da República, ao poder de expedir "atos regulamentares" tem "o objetivo específico de controle externo, a partir de situações concretas que surjam no exercício das atividades de judicatura e de Ministério Público", pois "no Estado Democrático de Direito, é inconcebível permitir-se a um órgão administrativo expedir atos (resoluções, decretos, portarias, etc) com força de lei, cujos reflexos possam avançar sobre direitos fundamentais, circunstância que faz com que tais atos sejam ao mesmo tempo legislativos e executivos". Por fim, afirmam haver uma "nítida distinção entre a matéria reservada à lei (geral e abstrata) e aos atos regulamentares", pois a lei refere-se à previsão de comportamentos futuros e os atos regulamentares "dizem respeito as diversas situações que surjam da atividade concreta dos juízes e membros do Ministério Público". Também contrário ao poder normativo primário conferido ao CNJ, posicionou-se, após a decisão liminar proferida na $\operatorname{ADC~n}^{\circ} 12$, José Adércio Leite Sampaio (2007, p. 277): "Embora o regulamento não se limite a repetir o texto da lei, tem por função precípua minudenciar a disciplina normativa que torne a lei mais exeqüível e operativa, integrando-a como um residual poder de colmatação de suas lacunas de natureza técnica, ainda que a dúvida séria deixada pelo legislador não possa vir a ser por ele resolvida". 
sua competência regulamentar ${ }^{583}$.

Por outro lado, entendemos que, na hipótese de lei superveniente vier a dedicar-se sobre a mesma matéria cuidada por ato regulamentar do $\mathrm{CNJ}$, prevalecerão as disposições legais, fruto da expressão da vontade geral, pois a Emenda Constitucional no 45/2004 não conferiu ao Conselho uma reserva legislativa no seu espaço de atuação, devendo prevalecer as competências conferidas pela Constituição Federal ao Poder Legislativo.

Por fim, não pode o Conselho Nacional de Justiça pretender afastar a incidência de disposições legais através do exercício de sua competência normativa, pois, nesse caso, estaria, indiretamente, exercendo um controle de compatibilidade da lei com a Constituição o que, como defendido ${ }^{584}$, lhe é vedado.

Em suma, o exercício da competência regulamentar pelo Conselho Nacional de Justiça, com poder de normatização primária, deve ocorrer somente no âmbito das competências do órgão, que deverá observar seus limites de atuação, e não poderá se sobrepor à $1 \mathrm{ei}^{585}$.

\subsection{Competências constitucionais específicas do Corregedor Nacional de Justiça}

Após o estudo das competências do Conselho Nacional de Justiça, enquanto órgão colegiado, cumpre examinar aquelas previstas no art. 103-B, $\S 5^{\circ}$ e incisos, da Carta Política, específicas e singulares do Corregedor Nacional de Justiça.

Estabelece a disposição em comento que o Ministro do Superior Tribunal de Justiça exercerá a função de Ministro-Corregedor ${ }^{586}$ do Conselho Nacional de Justiça. Em seguida, aponta-lhe três competências e permite que outras lhe sejam conferidas pelo Estatuto da Magistratura.

As competências fixadas na Constituição Federal para o Corregedor Nacional da Justiça desempenhar singularmente ${ }^{587}$ são:

\footnotetext{
${ }^{583}$ Interessante observar, pois, que o poder normativo primário do CNJ reconhecido pelo Supremo Tribunal Federal será exercido no âmbito do Poder Judiciário, mas não atingirá o próprio STF.

${ }^{584}$ Vide item 3.1.4.4.

${ }^{585} \mathrm{O}$ Regimento Interno do Conselho Nacional de Justiça, nas normas previstas em seu art. 102, estabelece que o Plenário do órgão poderá, por maioria absoluta, editar atos normativos mediante resoluções, instruções ou enunciados administrativos e, ainda, recomendações. As resoluções e os enunciados administrativos têm força vinculante e seus efeitos podem ser definidos pelo Colegiado.

${ }^{586}$ Apesar da Lei Maior denominar o cargo em comento de "Ministro-Corregedor", o Regimento Interno do $\mathrm{CNJ}\left(\right.$ art. $7^{\circ}$ ) o intitula de "Corregedor Nacional de Justiça".

${ }^{587}$ Sobre a diferença de órgão singular e órgão colegiado, vide item 2.3.2.2.
} 
a) Receber as reclamações e denúncias, de qualquer interessado, relativas aos magistrados e aos serviços judiciários;

b) Exercer funções executivas do Conselho, de inspeção e de correição geral;

c) Requisitar e designar magistrados, delegando-lhes atribuições, e requisitar servidores de juízos ou tribunais, inclusive nos Estados, Distrito Federal e Territórios.

Cumpre lembrar que, apesar de ainda não ter sido editado o Estatuto da Magistratura, a Emenda Constitucional $n^{\circ} 45 / 2004$, na norma prevista em seu art. $5^{\circ}, \S 2^{\circ}$, outorgou poder ao Conselho Nacional de Justiça para definir as atribuições adicionais de seu Ministro-Corregedor até o advento daquele diploma legal. $\mathrm{O}$ art. $8^{\circ}$ do Regimento Interno do $\mathrm{CNJ}^{588}$ o fez em vinte e um incisos.

Ressalte-se que, dada a miríade e a complexidade das atividades do MinistroCorregedor, bem caminhou o constituinte derivado ao excluí-lo da distribuição de processos no Superior Tribunal de Justiça.

Passaremos ao estudo de cada uma das competências prescritas no art. 103-B, $\S 5^{\circ}$, da Constituição em itens distintos. Por fim, dadas as restrições deste trabalho, será feita, em item único, mas com uma ramificação tópica, uma análise global daquelas previstas no art. $8^{\circ}$ do RICNJ.

\subsubsection{Recebimento de reclamações e denúncias.}

O inconformismo da sociedade com a lentidão da máquina judiciária e o espanto com denúncias de práticas ilícitas no âmbito do Poder Judiciário supostamente não investigadas ou cujos responsáveis não sofreram punições foram, dentre outros fatores, motivos para para a criação do Conselho Nacional de Justiça.

Compreensível, pois, a postura do constituinte derivado, na reforma promovida pela Emenda Constitucional no 45/2004, de dotar o novel órgão de fiscalização de mecanismos jurídicos para exercer controle disciplinar no âmbito do Poder Judiciário ${ }^{589}$ e atribuir ao seu Ministro-Corregedor competência para receber reclamações e denúncias, de qualquer interessado, relativas aos magistrados e aos serviços judiciários.

\footnotetext{
${ }^{588}$ Quanto à inconstitucionalidade na redação da cabeça do art. $8^{\circ}$ do RICNJ, vide item 3.1.1.1.

${ }^{589}$ Vide item 3.1.5.
} 
Nota-se que a Constituição Federal foi, inclusive, redundante quanto a essa competência para o recebimento de reclamações, pois atribuiu-a tanto ao Colegiado (CF, art. 103-B, $\S 4^{\circ}$, III, primeira parte), quanto ao seu Ministro-Corregedor (CF, art. 103-B, $\S$ $\left.5^{\circ}, \mathrm{I}\right)$.

Para disciplinar o assunto, o Regimento Interno do Conselho Nacional de Justiça, em sintonia com as normas constitucionais mencionadas, estabelece diversos procedimentos relativos à apreciação de denúncias e reclamações a serem realizados previamente pela Corregedoria Nacional de Justiça antes de submeter suas conclusões à apreciação do Plenário do Colegiado: inspeção, correição, sindicância, reclamação disciplinar e representação por excesso de prazo. Os dois primeiros serão analisados no item seguinte, pois vinculados à competência específica prevista no art. 103-B, $\S 5^{\circ}$, II, da Carta Política. Passaremos ao estudo dos demais.

A sindicância é um procedimento investigativo sumário levado a efeito pela Corregedoria Nacional de Justiça, com prazo de conclusão de sessenta dias, admitida prorrogação por decisão fundamentada, destinado a apurar irregularidades atribuídas a magistrados ou servidores nos serviços judiciais e auxiliares, ou a quaisquer serventuários, nas serventias e nos órgãos prestadores de serviços notariais e de registro, cuja apreciação não se deva dar por inspeção ou correição (RICNJ, art. 60). O sindicado ou seu procurador deve ser intimado para acompanhar a inquirição de testemunhas, podendo formular perguntas (RICNJ, art. 62). O sindicado será ouvido, poderá apresentar defesa e requerer a produção de prova no prazo de 10 (dez) dias a contar da ciência da instauração da sindicância (RICNJ, art. 63, caput). Encerrada a investigação, elaborar-se-á relatório, cabendo ao Corregedor Nacional de Justiça, se convencido da existência de infração, propor ao Plenário do CNJ a instauração de processo disciplinar, o que será precedido da intimação para apresentar defesa prévia em 15 (quinze) dias, devendo constar da intimação a descrição do fato e a sua tipificação legal, bem como cópia do teor da acusação (RICNJ, artr. 63, parágrafo único). Não sendo apurado ato ou fato que justifique a aplicação de penalidade, a sindicância será arquivada por ato singular do Corregedor Nacional ou, a seu juízo, levada à apreciação do Plenário, em qualquer caso comunicando-se os interessados (RICNJ, art. 64). No caso de instrução das sindicâncias para a apuração de infrações cometidas "por servidores do CNJ ou servidores do Poder Judiciário" 590 , aplicam-se, no que couberem, as disposições relativas a processos disciplinares previstas na legislação

\footnotetext{
${ }^{590}$ A expressão da norma regimental é equivocada, porque o servidor do CNJ também é servidor do Judiciário, pois o CNJ é o órgão desse Poder.
} 
federal ou estadual pertinente à hipótese (RICNJ, art. 66, caput). No caso de sindicância para apuração de infração disciplinar imputada a titular de serviços notariais e de registro, será observado o procedimento previsto na respectiva legislação (RICNJ, art. 66, parágrafo único).

A reclamação disciplinar pode ser proposta contra membros do Poder Judiciário e contra titulares de seus serviços auxiliares, serventias e órgãos prestadores de serviços notariais e de registro e deve ser dirigida ao Corregedor Nacional de Justiça em requerimento assinado contendo a descrição do fato, a identificação do reclamado e as provas da infração (RICNJ, art. 67, caput e $\S 1^{\circ}$ ). O Corregedor Nacional de Justiça pode arquivar sumariamente a reclamação quando não atendidos os requisitos legais ou o fato narrado não configurar infração disciplinar (RICNJ, art. 67, § 2 $2^{\circ}$. Caso contrário, o reclamado é notificado a prestar informações em quinze dias, podendo requisitar informações à corregedoria local e ao tribunal respectivo ou determinada diligência para apuração preliminar da verossimilhança da imputação (RICNJ, art. 67, § $3^{\circ}$ ). Poderá o Corregedor Nacional de Justiça, ainda, nas reclamações oferecidas contra magistrados de primeiro grau, enviar cópia da petição e dos documentos à Corregedoria de Justiça respectiva, fixando prazo para apuração dos fatos e comunicação das providências e conclusão adotadas (RICNJ, art. 67, $\S 4^{\circ}$ ). Prestadas as informações pelo reclamado, o Corregedor Nacional de Justiça arquivará a reclamação se confirmado que o fato não constitui infração disciplinar (RICNJ, art. 68). Configurada, porém, a evidência de possível infração disciplinar atribuída a magistrado, proporá ao Plenário do CNJ a instauração incontinenti de processo administrativo disciplinar, se as provas já forem suficientes para tanto (RICNJ, art. 69, caput, primeira parte), permitindo ao magistrado, antes de submeter o feito à apreciação do Colegiado, o oferecimento de defesa prévia também no prazo de quinze dias, devendo constar da intimação a descrição do fato, a sua tipificação legal e cópia do teor da acusação (RICNJ, art. 70). Caso contrário, instaurará sindicância para investigação dos fatos (RICNJ, art. 69, caput, in fine). No caso de restar evidenciada possível falta ou infração atribuída a servidor, serventuário ou delegatário de serventia extrajudicial, poderá o Corregedor Nacional de Justiça propor ao Plenário, se já houver elementos suficientes, a imediata instauração de processo administrativo disciplinar. Caso contrário, poderá determinar, a instauração de sindicância. Em qualquer dessas hipóteses, ainda, poderá o Corregedor Nacional de Justiça encaminhar os dados à corregedoria local para as providências cabíveis (RICNJ, art. 71, caput e parágrafo único). 
Se o Plenário do CNJ determinar a instauração de processo administrativo disciplinar, instrumento destinado a apurar responsabilidades de magistrados e de titulares de serviços notariais e de registro por infração disciplinar praticada no exercício de suas atribuições (art. 73), o feito será distribuído a um conselheiro relator a quem competirá ordenar e dirigir a instrução respectiva (art. 74, caput), obedecido ao procedimento ditado no Estatuto da Magistratura, inclusive no que concerne à aplicação pelo CNJ das penas disciplinares respectivas, sujeitando-se subsidiariamente, no que não for incompatível à Resolução CNJ nº 135/2011, à Lei no 8.112/1990, e à Lei no 9.784/1999 (art. 75, caput) ou, tratando-se de processo administrativo disciplinar instaurado contra titular de serviços notariais e de registro, ao procedimento estabelecido na legislação funcional (art. 76). Poderá ainda ser determinado, por deliberação motivada da maioria absoluta do Colegiado, em qualquer fase do procedimento, o afastamento do magistrado ou servidor das suas funções (art. 75, parágrafo único). Finda a instrução, o Ministério Publico e o magistrado ou seu procurador, terão, sucessivamente, vista dos autos por 10 (dez) dias para razões (art. 77, caput), podendo ainda se manifestar, no mesmo prazo, o Procurador Geral da República ou o órgão do Ministério Público por este designado. (art. 77, parágrafo único).

Também inclui-se entre os procedimentos de competência do Corregedor Nacional de Justiça realizados previamente à apreciação das conclusões pelo Plenário do CNJ, a representação contra magistrado, por excesso injustificado de prazo, para a prática de ato de sua competência jurisdicional ${ }^{591}$ ou administrativa, que pode ser formulada por qualquer pessoa com interesse legítimo, pelo Ministério Público, pelos presidentes de tribunais ou, de ofício, pelos conselheiros (RICNJ, art. 78, caput), e deverá ser instruída com os documentos necessários à sua demonstração (RICNJ, art. 78, § $\left.1^{\circ}\right)$. O Corregedor Nacional de Justiça poderá indeferir sumariamente da representação ou permitir que o magistrado oferte defesa e indique provas a produzir em quinze dias (RICNJ, art. 78, $\S 2^{\circ}$ ). Neste caso, o Corregedor Nacional de Justiça proporá ao Plenário, conforme o caso, o arquivamento da representação ou a instauração de processo disciplinar (RICNJ, art. 78, $\S 3^{\circ}$ ) e também, se verificada a existência de grave atraso ou de grande acúmulo de processos, a adoção de providência (RICNJ, art. $78, \S 5^{\circ}$ ). Possível também a instauração de procedimento especial para apuração concertada se verificada a generalizada ocorrência de atraso ou

\footnotetext{
${ }^{591} \mathrm{O}$ art. 133, II, e parágrafo único, do Código de Processo Civil reza que o juiz responderá por perdas e danos quando recusar, omitir ou retardar, sem justo motivo, providência que deva ordenar de ofício, ou a requerimento da parte, reputando-se verificadas essas hipóteses somente depois que a parte, por intermédio do escrivão, requerer ao magistrado que determine a providência e este não Ihe atender o pedido dentro de 10 dias.
} 
acúmulo de processos envolvendo dois ou mais magistrados, de primeiro ou segundo grau, do mesmo órgão judiciário.

Entendemos que em todos esses procedimentos deverá o Corregedor Nacional de Justiça atentar-se para todas as mesmas limitações de atuação impostas ao colegiado que integra apresentadas ao longo deste trabalho.

\subsubsection{Exercício de funções executivas de inspeção e correição.}

A Constituição Federal também estabelece (art. 103-B, § 5 , II) competir ao Corregedor Nacional de Justiça “exercer funções executivas do Conselho, de inspeção e de correição geral".

O Regimento Interno do Conselho Nacional de Justiça estabeleceu procedimentos semelhantes para a inspeção e a para a correição.

A primeira é realizada pela Corregedoria Nacional de Justiça para apuração de fatos relacionados ao conhecimento e à verificação do funcionamento dos serviços judiciais e auxiliares, das serventias e dos órgãos prestadores de serviços notariais e de registro, havendo ou não evidências de irregularidades (RICNJ, art. 48, caput), rotineiramente ou a qualquer tempo, por iniciativa da própria Corregedoria Nacional, por proposição de qualquer Conselheiro ou a requerimento de autoridade pública, sem prejuízo da atuação disciplinar e correicional dos respectivos tribunais (RICNJ, art. 48, parágrafo único). É empreendida independentemente de convocação ou comunicação prévia, com ou sem a presença das autoridades responsáveis pelos órgãos inspecionados (RICNJ, art. 50, caput).

A correição é efetuada pela Corregedoria Nacional de Justiça para apuração de fatos determinados relacionados com deficiências graves dos serviços judiciais e auxiliares, das serventias e dos órgãos prestadores de serviços notariais e de registro, sem prejuízo da atuação disciplinar e correicional dos tribunais, e também para promoção de diligências necessárias solicitadas por conselheiro para a instrução de processo sob sua relatoria (RICNJ, art 54). Deverá, em regra, ser precedida de ato convocatório com indicação dos fatos a apurar e realizada na presença das autoridades responsáveis pelos órgãos correicionados, que terão direito a prestar esclarecimentos e fazer observações que reputem de interesse para a elucidação do objeto de apuração (RICNJ, art. 56, caput). Contudo, em caso de extrema urgência ou "em virtude de relevante motivação devidamente 
fundamentada" 592 , a correição poderá ser realizada sem a comunicação prévia e independente da ciência da autoridade judiciária responsável (RICNJ, art. 48, parágrafo único).

Concluída a inspeção ou a correição, é lavrar um auto circunstanciado (RICNJ, arts. 51 e 57) e o Corregedor Nacional de Justiça poderá adotar as medidas cabíveis de sua competência e propor ao Plenário do $\mathrm{CNJ}$ as demais que tenha por necessárias e adequadas aos objetivos do procedimento realizado (RICNJ, arts. 52, caput, e 58, caput). O Colegiado ou o Corregedor Nacional de Justiça poderão encaminhar traslado do expediente de inspeção/correição à corregedoria do tribunal ao qual esteja o órgão inspecionado/correicionado vinculado para a adoção das providências a seu cargo com ou sem prazo (RICNJ, arts. 52, $\S 1^{\circ}$, e $58, \S 2^{\circ}$ ) e deverão comunicar o Ministério Público irregularidades constatadas que constituam ilícito penal ${ }^{593}$ (RICNJ, arts. 52, $\S 2^{\circ}$ e $58, \S$ $1^{\circ}$ ). O Plenário do $\mathrm{CNJ}$, ainda, poderá, ante o teor das atas de inspeção/correição, regulamentar práticas administrativas, uniformizando procedimentos com vista à melhoria da organização, do funcionamento e do controle dos serviços de administração da Justiça (RICNJ, arts. 53 e 59), observado, no entanto, os limites de sua atuação, em especial as disposições contidas no art. 96, I, "a" e "b", da Constituição.

Assim como ressaltado no item anterior, na nossa opinião, deverá o Corregedor Nacional de Justiça, nos procedimentos de inspeção e correição, observar as fronteiras de atuação impostas ao CNJ para consecução de suas tarefas.

\subsubsection{Requisição e designação de magistrados e servidores.}

A última específica competência do Corregedor Nacional de Justiça prevista na Carta Política permite-lhe "requisitar e designar magistrados, delegando-lhes atribuições, e requisitar servidores de juízos ou tribunais, inclusive nos Estados, Distrito Federal e Territórios (CF, art. 103-B, $\S 5^{\circ}$, III).

a) Requisições:

\footnotetext{
592 A expressão constante do texto da norma regimental confunde "motivo" e "motivação". Maria Sylvia Zanella Di Pietro (2012, p. 217) doutrina que motivo e motivação tem significados distintos. "Motivo é o pressuposto de fato e de direito que serve de fundamento ao ato administrativo" e "motivação é a exposição dos motivos, ou seja, é a demonstração, por escrito, de que os pressupostos de fato realmente existiram”.

${ }^{593}$ Vide item 3.1.6.
} 
Requisitar, no contexto, é ordenar a retirada de magistrados e servidores dos quadros de determinados órgãos do Poder Judiciário para auxiliar e assessorar o Corregedor Nacional de Justiça e robustecer a equipe de trabalho ordinária da Corregedoria Nacional de Justiça.

Entendemos que, em relação aos servidores requisitados, não pode haver recusa do órgão cedente e do próprio servidor ao atendimento da requisição.

Primeiro em razão do comando constitucional mencionado, autoaplicável.

Segundo porque a norma inserta no art. 93, II, da Lei $\mathrm{n}^{\mathrm{o}} 8.112 / 1990^{594}$ contempla a cessão de servidores "em casos previstos em leis específicas" $" 595$ e o Decreto $n^{\circ} 4.050$, de 12 de dezembro de 2001, que regulamenta referido dispositivo legal, estabelece que a requisição é ato irrecusável.

Porém, ante o teor da regra prevista no art. 37, II, da Constituição, as requisições de servidores de órgãos do Poder Judiciário não podem se eternizar e deve haver o preechimento dos quadros do Conselho Nacional de Justiça (e da Corregedoria Nacional de Justiça, em particular) através de aprovação em concurso público ${ }^{596}$.

Quanto à requisição de magistrados, pensamos que, diante dos termos da norma constitucional em comento, também não pode haver negativa de atendimento da requisição emanada do Corregedor Nacional de Justiça pelo órgão judiciário a que estejam vinculados.

Mas, devido a garantia constitucional da inamovibilidade (CF, art. 95, II), o magistrado pode recusar a requisição para auxiliar ou assessorar o Corregedor Nacional de Justiça sem incorrer em falta funcional.

Cumpre ainda registrar que, de acordo com as disposições contidas nos parágrafos $1^{\mathrm{o}} \mathrm{e}$ $2^{\circ}$ do art. $8^{\circ}$ do RICNJ, os magistrados e servidores requisitados pelo Corregedor Nacional

\footnotetext{
${ }^{594}$ Art. 93. (Lei no 8.112/1990) O servidor poderá ser cedido para ter exercício em outro órgão ou entidade dos Poderes da União, dos Estados, ou do Distrito Federal e dos Municípios, nas seguintes hipóteses:

$[\ldots]$

II - em casos previstos em leis específicas.

${ }^{595}$ A requisão de servidores é regulada, por exemplo: a) Para a Justiça Eleitoral pela Lei no $6.999 / 1982$ e pela Resolução TSE no 23.255/2010 (vide item 2.3.7.3.1); b) Para a Advocacia Geral da União pela Lei ${ }^{\circ}$ 8.682/1993; c) Para o Instituto Nacional do Seguro Social pela Lei no $8.889 / 1994$; d) Para a Presidência da República pela Lei no 9.007/1995; e, e) Para a Defensoria Pública da União pela Lei no 9.020/1995.

${ }^{596}$ Nesse sentido já decidiu o Tribunal de Contas da União:

Os institutos da cessão e requisição, por terem caráter nitidamente temporário e de exceção, devem ser utilizados tão somente pelo tempo necessário ao atendimento do interesse público específico e pontual que motivou a requisição, não podendo servirem como forma de preenchimento permanente dos quadros funcionais dos órgãos cessionários/requisitantes, cujos cargos devem ser providos por meio de concurso público (AC 1571/2008, Relator Ministro Marcos Vilaça, j. 06.08.2008).
} 
de Justiça conservam os direitos e as vantagens inerentes ao exercício de seus cargos ou empregos de origem, como se em atividade normal estivessem, sendo que a requisição de magistrados não pode exceder a dois anos, podendo ser prorrogada uma única vez ${ }^{597}$.

Em suma, o Corregedor Nacional de Justiça pode requisitar magistrados e servidores. A requsição de servidores é irrecusável tanto pelo órgão cedente quanto pelo servidor, mas não deve se eternizar. A requisição de magistrados não não pode ser negada pelo órgão do Poder Judiciário cedente, mas pode ser recusada pelo próprio magistrado pois garantido pela inamovibilidade.

b) Designação:

O Corregedor Nacional de Justiça também pode designar magistrados para atribuições específicas.

O Regimento Interno do Conselho Nacional de Justiça admite designação para realização de inspeção (RICNJ, art. 49), correição (RICNJ, art. 55), sindicância (RICNJ, art. 61, caput) e reclamação disciplinar (RICNJ, art. 72, caput).

No caso de magistrado previamente requisitado, não pode haver recusa da designação, porque concordou anteriormente em auxiliar e assessorar o Corregedor Nacional de Justiça. A atribuição específica que lhe é deferida visa a satisfação do interesse público (OLIVEIRA, 2005, pp. 137 a 139).

Admissível, no entanto, a recusa da designação de magistrado que ainda não auxilia ou assessora o Corregedor Nacional de Justiça, pois, nesse caso, a designação importa em implícita requisição e deve ser observada a garantia constitucional da inamovibilidade.

d) Delegação

De nada adiantaria a designação de magistrados para atribuições específicas pelo Corregedor Nacional de Justiça se não lhe fosse possível transferir o exercício de parcela de competência aos designados.

A delegação, como define Regis Fernandes de Oliveira (2005, p. 56 a 57) é a “transferência do exercício de competência, constitucional ou legal, de um órgão ou agente a outro, no interior ou fora de uma pessoa jurídica, em caráter precário".

\footnotetext{
${ }^{597}$ Normas semelhantes em relação às requisições de magistrados e servidores pela Presidência do CNJ constam no art. $6^{\circ}, \S \S 1^{\circ}$ e $2^{\circ}$, do RICNJ.
} 
A delegação já foi analisada neste trabalho ${ }^{598}$. Cumpre neste item apenas ressaltar que o Regimento Interno do Conselho Nacional de Justiça admite-a não só para os magistrados que auxiliam e assessoram o Corergedor Nacional de Justiça, mas também para outros conselheiros e servidores (RICNJ, art. 8, VI, VII e XVIII; art. 18, IV; art. 61, caput; e art. 72).

\subsubsection{Outras competências previstas no RICNJ.}

As competências do Corregedor Nacional de Justiça previstas nos incisos do art. $8^{\circ}$ do Regimento Interno do CNJ decorrem diretamente das normas previstas no art. 103-B, § $5^{\circ}$, da Constituição Federal e no art. $5^{\circ}, \S 2^{\circ}$, da Emenda Constitucional n ${ }^{o}$ 45/2004. São, portanto, competências originárias, não delegadas do Plenário do Conselho.

Deve-se rememorar que essas competências, com exceção daquelas que reproduzem as disposições constitucionais $\left(\mathrm{CF}\right.$, art. $\left.103-\mathrm{B}, \S 5^{\circ}\right)$, poderão, apesar da redação do art. $8^{\circ}$, caput, do RICNJ, ser alteradas pelo Estatuto da Magistratura ${ }^{599}$.

As competências previstas nos incisos I, II, III, IV, VI, VII, XII, XVIII e XX do mencionado dispositivo regimental foram analisadas nos itens anteriores, pois decorrem das regras constitucionais estudadas ${ }^{600}$.

\footnotetext{
${ }^{598}$ Vide item 2.3.2.2.

${ }^{599}$ Vide itens 3.1.1.1 e 3.1.2.

${ }^{600}$ Art. $8^{\circ}$ (RICNJ) Compete ao Corregedor Nacional de Justiça, além de outras atribuições que lhe forem conferidas pelo Estatuto da Magistratura:

I - receber as reclamações e denúncias de qualquer interessado relativas aos magistrados e Tribunais e aos serviços judiciários auxiliares, serventias, órgãos prestadores de serviços notariais e de registro, determinando o arquivamento sumário das anônimas, das prescritas e daquelas que se apresentem manifestamente improcedentes ou despidas de elementos mínimos para a sua compreensão, de tudo dando ciência ao reclamante;

II - determinar o processamento das reclamações que atendam aos requisitos de admissibilidade, arquivandoas quando o fato não constituir infração disciplinar;

III - instaurar sindicância ou propor, desde logo, ao Plenário a instauração de processo administrativo disciplinar, quando houver indício suficiente de infração;

IV - promover ou determinar a realização de sindicâncias, inspeções e correições, quando houver fatos graves ou relevantes que as justifiquem, desde logo determinando as medidas que se mostrem necessárias, urgentes ou adequadas, ou propondo ao Plenário a adoção das medidas que lhe pareçam suficientes a suprir as necessidades ou deficiências constatadas;

$[\ldots]$

VI - requisitar magistrados para auxílio à Corregedoria Nacional de Justiça, delegando-lhes atribuições, observados os limites legais;

VII - requisitar servidores do Poder Judiciário e convocar o auxílio de servidores do CNJ, para tarefa especial e prazo certo, para exercício na Corregedoria Nacional de Justiça, podendo delegar-lhes atribuições nos limites legais;

$[\ldots]$

XII - executar, de ofício ou por determinação, e fazer executar as ordens e deliberações do CNJ relativas à matéria de sua competência;
} 
Os preceitos dos incisos VIII e IX determinam ao Corregedor Nacional de Justiça a elaboração e apresentação ao Plenário do $\mathrm{CNJ}$ de relatório anual referente às suas atividades desenvolvidas, bem como, relatório das inspeções e correições realizadas ou diligências e providências adotadas sobre qualquer assunto, em quinze dias de sua finalização. Esses relatórios têm conteúdo informativo. Permitem que os demais conselheiros tenham ciência do trabalho desenvolvido pela Corregedoria Nacional de Justiça e determinem, no Colegiado, as providências pontuais necessárias.

As normas constantes dos incisos XIII, XIV, XV, XVI, XVII e XXI tratam de providências burocráticas para consecução das atividades afetas ao Corregedor Nacional de Justiça e de relacionamento com as demais corregedorias do Poder Judiciário ${ }^{601}$.

$\mathrm{O}$ inciso X contém regra que permite atividade normativa pelo Corregedor Nacional de Justiça ${ }^{602}$. No nosso sentir, ao contrário do decidido na ADC $\mathrm{n}^{\circ} 12$ em relação aos atos regulamentares expedidos pelo Plenário do $\mathrm{CNJ}^{603}$, não tem o Ministro-Corregedor competência normativa originária, tanto é que, quando vislumbrar a necessidade de inovação do ordenamento no âmbito do Poder Judiciário, deverá formular proposta ao Colegiado, consoante dispõe a regra prevista no inciso XI do art. $8^{\circ} \mathrm{em}$ análise ${ }^{604}$.

XVIII - delegar, nos limites legais, aos demais Conselheiros, aos Juízes Auxiliares ou aos servidores expressamente indicados, atribuições sobre questões específicas;

XX - promover de ofício, quando for o caso de urgência e relevância, ou propor ao Plenário, quaisquer medidas com vistas à eficácia e ao bom desempenho da atividade judiciária e dos serviços afetos às serventias e aos órgãos prestadores de serviços notariais e de registro;

${ }^{601}$ Art. $8^{\circ}$ (RICNJ) [...]

XIII - dirigir-se, no que diz respeito às matérias de sua competência, às autoridades judiciárias e administrativas e aos órgãos ou às entidades, assinando a respectiva correspondência;

XIV - indicar ao Presidente, para fins de designação ou nomeação, o nome dos ocupantes de função gratificada ou cargo em comissão no âmbito da Corregedoria Nacional de Justiça, cabendo àquele dar-lhes posse;

XV - promover a criação de mecanismos e meios para a coleta de dados necessários ao bom desempenho das atividades da Corregedoria Nacional de Justiça;

XVI - manter contato direto com as demais Corregedorias do Poder Judiciário;

XVII - promover reuniões periódicas para estudo, acompanhamento e sugestões com os magistrados envolvidos na atividade correicional;

XXI - promover, constituir e manter bancos de dados, integrados a banco de dados central do CNJ, atualizados sobre os serviços judiciais e extrajudiciais, inclusive com o acompanhamento da respectiva produtividade e geração de relatórios visando ao diagnóstico e à adoção de providências para a efetividade fiscalizatória e correicional, disponibilizando seus resultados aos órgãos judiciais ou administrativos a quem couber o seu conhecimento.

${ }^{602}$ Art. $8^{\circ}$ (RICNJ) [...]

$\mathrm{X}$ - expedir Recomendações, Provimentos, Instruções, Orientações e outros atos normativos destinados ao aperfeiçoamento das atividades dos órgãos do Poder Judiciário e de seus serviços auxiliares e dos serviços notariais e de registro, bem como dos demais órgãos correicionais, sobre matéria relacionada com a competência da Corregedoria Nacional de Justiça;

${ }^{603}$ Vide item 3.1.8.

${ }^{604}$ Art. $8^{\circ}$ (RICNJ) [...] 
A diretriz prevista no inciso XIX permite que o Corregedor Nacional de Justiça solicite aos órgãos dos Poderes Executivo e Legislativo, ou a entidade pública, a cessão temporária por prazo certo, sem ônus para o $\mathrm{CNJ}$, de servidor detentor de conhecimento técnico especializado, para colaborar na instrução de procedimento em curso na Corregedoria Nacional de Justiça, uma vez que a Constituição Federal permite-lhe apenas a requisição de servidores de juízos e tribunais $\left(\mathrm{CF} \text {, art. 103-B, } \S 5^{\circ}, \mathrm{III}\right)^{605}$.

Por fim, a regra contemplada no inciso $\mathrm{V}$ do art. $8^{\circ}$ do Regimento Interno do Conselho Nacional de Justiça, demanda estudo mais aprofundado, o que será feito em subitem a seguir, pois eivada de parcial inconstitucionalidade.

\subsubsection{Estudo de norma: RICNJ, arts. $4^{\circ}, \mathrm{XV}$, e $8^{\circ}, \mathrm{V}$ - Impossibilidade de quebra de sigilo bancário e fiscal pelo $\mathrm{CNJ}$}

O Regimento Interno do Conselho Nacional de Justiça confere, nas normas insertas no art. $4^{\mathrm{o}}, \mathrm{XV}^{606}$, e no art. $8^{\circ}, \mathrm{V}^{607}$, ao Plenário do órgão e ao seu Ministro-Corregedor, competência para requisitar das autoridades fiscais, monetárias e de outras autoridades competentes informações, exames, perícias ou documentos, sigilosos ou não, imprescindíveis ao esclarecimento de processos ou procedimentos.

Ocorre que o Conselho Nacional de Justiça é um órgão do Poder Judiciário, mas não exerce a atividade jurisdicional ${ }^{608}$. Assim, tanto seu Plenário quanto seu MinistroCorregedor, apesar das disposições regimentais citadas, não podem requisitar das autoridades fiscais e monetárias dados sigilosos para esclarecimento de processos ou procedimentos administrativos submetidos à sua apreciação.

XI - propor ao Plenário do CNJ a expedição de recomendações e a edição de atos regulamentares que assegurem a autonomia, a transparência e a eficiência do Poder Judiciário e o cumprimento do Estatuto da Magistratura;

${ }^{605}$ Vide item 3.2.3.

${ }^{606}$ Art. $4^{\text {o }}$ (RICNJ) Ao Plenário do CNJ compete o controle da atuação administrativa e financeira do Poder Judiciário e do cumprimento dos deveres funcionais dos magistrados, cabendo-lhe, além de outras atribuições que lhe forem conferidas pelo Estatuto da Magistratura, o seguinte:

$[\ldots]$

$\mathrm{XV}$ - requisitar das autoridades fiscais, monetárias e de outras autoridades competentes informações, exames, perícias ou documentos, sigilosos ou não, imprescindíveis ao esclarecimento de processos ou procedimentos de sua competência submetidos à sua apreciação;

${ }^{607}$ Art. $8^{\circ}$ (RICNJ) [...]

$\mathrm{V}$ - requisitar das autoridades fiscais, monetárias e de outras autoridades competentes informações, exames, perícias ou documentos, sigilosos ou não, imprescindíveis ao esclarecimento de processos ou procedimentos submetidos à sua apreciação, dando conhecimento ao Plenário;

${ }^{608}$ Vide item 2.3.5.1. 
As normas insertas no art. $5^{\circ}$, X e XII, da Constituição estabelecem, como liberdades individuais, a inviolabilidade da intimidade, da vida privada, da honra e da imagem das pessoas, bem como, especificamente, do sigilo "da correspondência e das comunicações telegráficas, de dados e das comunicações telefônicas, salvo, no último caso, por ordem judicial, nas hipóteses e na forma que a lei estabelecer para fins de investigação criminal ou instrução processual penal".

Como doutrina Alexandre de Moraes (2013a, pp. 179),

\begin{abstract}
Apesar de a exceção constitucional expressa referir-se somente à interceptação telefônica, entende-se que nenhuma liberdade individual é absoluta [...], sendo possível, respeitados certos parâmetros, a interceptação das correspondências e comunicações sempre que as liberdades públicas estiverem sendo utilizadas como instrumento de salvaguarda de práticas ilícitas.

A interpretação do [inciso XII] deve ser feita de modo a entender que a lei ou a decisão judicial poderão, excepcionalmente, estabelecer hipóteses de quebra das inviolabilidades da correspondência, das comunicações telegráficas e de dados, sempre visando salvaguardar o interesse público e impedir que a consagração de certas liberdades públicas possa servir de incentivo à prática de atividades ilícitas ${ }^{609}$. No tocante, porém, à inviolabilidade das comunicações telefônicas, a própria Constituição Federal antecipou-se e previu os requisitos que deverão, de forma obrigatória, ser cumpridos para o afastamento dessa garantia.
\end{abstract}

\footnotetext{
${ }^{609}$ Nesse sentido:

HABEAS CORPUS - ESTRUTURA FORMAL DA SENTENÇA E DO ACÓRDÃO - OBSERVANCIA ALEGAÇÃO DE INTERCEPTAÇÃO CRIMINOSA DE CARTA MISSIVA REMETIDA POR SENTENCIADO - UTILIZAÇÃO DE COPIAS XEROGRAFICAS NÃO AUTENTICADAS PRETENDIDA ANALISE DA PROVA - PEDIDO INDEFERIDO. - A estrutura formal da sentença deriva da fiel observância das regras inscritas no art. 381 do Código de Processo Penal. O ato sentencial que contém a exposição sucinta da acusação e da defesa e que indica os motivos em que se funda a decisão satisfaz, plenamente, as exigências impostas pela lei. - A eficácia probante das cópias xerográficas resulta, em princípio, de sua formal autenticação por agente público competente (CPP, art. 232, paragrafo único). Peças reprográficas não autenticadas, desde que possivel a aferição de sua legitimidade por outro meio idôneo, podem ser validamente utilizadas em juízo penal. - A administração penitenciária, com fundamento em razões de segurança pública, de disciplina prisional ou de preservação da ordem jurídica, pode, sempre excepcionalmente, e desde que respeitada a norma inscrita no art. 41, paragrafo único, da Lei n. 7.210/84, proceder a interceptação da correspondência remetida pelos sentenciados, eis que a cláusula tutelar da inviolabilidade do sigilo epistolar não pode constituir instrumento de salvaguarda de práticas ilícitas. - $\mathrm{O}$ reexame da prova produzida no processo penal condenatório não tem lugar na ação sumarissima de habeas corpus (STF, HC 70814, Relator(a): Min. CELSO DE MELLO, Primeira Turma, julgado em 01/03/1994, DJ 24-06-1994).
} 
A Lei Complementar $n^{\circ} 105$, de 10 de janeiro de 2001, que dispõe sobre o sigilo de instituições financeiras, reza que a quebra do sigilo bancário pode ser determinada pelo Poder Judiciário, no exercício da atividade jurisdicional (art. $1^{\circ}, \S 4^{\mathrm{o}}$, e art. $3^{\mathrm{o}}$ ) ${ }^{610}$, pelo Poder Legislativo Federal (art. $4^{\mathrm{o}}$, caput), pelas Comissões Parlamentares de Inquérito da Câmara dos Deputados e do Senado Federal, após prévia aprovação do pedido pelos plenários das referidas Casas ou pelos plenário de suas respectivas comissões parlamentares de inquérito (art. $4^{\circ},\left(\S \S 1^{\circ}\right.$ e $\left.2^{\circ}\right)$ e pelas autoridades e os agentes fiscais tributários da União, dos Estados, do Distrito Federal e dos Municípios, quando houver processo administrativo instaurado ou procedimento fiscal em curso e tais exames sejam considerados indispensáveis $\left(\operatorname{art.} 6^{\circ}\right)^{611612}$.

A quebra do sigilo em procedimentos administrativos (inclusive naqueles que tramitam nos próprios órgãos do Poder Judiciário) destinados a apurar a responsabilidade

\footnotetext{
${ }^{610}$ Art. $1^{\circ}$ As instituições financeiras conservarão sigilo em suas operações ativas e passivas e serviços prestados.

$[\ldots]$

$\S 4^{\circ} \mathrm{A}$ quebra de sigilo poderá ser decretada, quando necessária para apuração de ocorrência de qualquer ilícito, em qualquer fase do inquérito ou do processo judicial, e especialmente nos seguintes crimes:

I - de terrorismo;

II - de tráfico ilícito de substâncias entorpecentes ou drogas afins;

III - de contrabando ou tráfico de armas, munições ou material destinado a sua produção;

IV - de extorsão mediante seqüestro;

$\mathrm{V}$ - contra o sistema financeiro nacional;

VI - contra a Administração Pública;

VII - contra a ordem tributária e a previdência social;

VIII - lavagem de dinheiro ou ocultação de bens, direitos e valores;

IX - praticado por organização criminosa.

[...]

Art. $3^{\circ}$ Serão prestadas pelo Banco Central do Brasil, pela Comissão de Valores Mobiliários e pelas instituições financeiras as informações ordenadas pelo Poder Judiciário, preservado o seu caráter sigiloso mediante acesso restrito às partes, que delas não poderão servir-se para fins estranhos à lide.

$\S 1^{\circ}$ Dependem de prévia autorização do Poder Judiciário a prestação de informações e o fornecimento de documentos sigilosos solicitados por comissão de inquérito administrativo destinada a apurar responsabilidade de servidor público por infração praticada no exercício de suas atribuições, ou que tenha relação com as atribuições do cargo em que se encontre investido.

$\S 2^{\circ}$ Nas hipóteses do $\S 1^{\circ}$, o requerimento de quebra de sigilo independe da existência de processo judicial em curso.

${ }^{611}$ Tramita no Supremo Tribunal Federal a ADI n 2390 que questiona a constitucionalidade do art. $1^{\circ}, \S 4^{\circ}$, art. $5^{\circ}$ e art. $6^{\circ}$ e seu parágrafo único, todos da Lei Complementar $n^{\circ} 105 / 2001$ da totalidade do Decreto $\mathrm{n}^{\circ}$ 3724 , de 10 de janeiro de 2001, que regulamenta o último dispositivo legal mencionado.

${ }^{612}$ Há julgado no STF em sede de controle difuso de constitucionalidade reconhecendo que a Receita Federal não tem poderes para afastar o sigilo de dados de contribuinte. Segue a ementa do acórdão:
}

SIGILO DE DADOS - AFASTAMENTO. Conforme disposto no inciso XII do artigo $5^{\circ}$ da Constituição Federal, a regra é a privacidade quanto à correspondência, às comunicações telegráficas, aos dados e às comunicações, ficando a exceção - a quebra do sigilo - submetida ao crivo de órgão equidistante - o Judiciário - e, mesmo assim, para efeito de investigação criminal ou instrução processual penal. SIGILO DE DADOS BANCÁRIOS - RECEITA FEDERAL. Conflita com a Carta da República norma legal atribuindo à Receita Federal - parte na relação jurídico-tributária - o afastamento do sigilo de dados relativos ao contribuinte (RE 389808, Relator(a): Min. MARCO AURÉLIO, Tribunal Pleno, julgado em 15/12/2010, DJe-086 DIVULG 09-05-2011 PUBLIC 10-05-2011). 
de servidor público por infração praticada no exercício de suas atribuições, ou que tenha relação com as atribuições do cargo em que se encontre investido depende de prévia autorização do Poder Judiciário, no exercício da atividade jurisdicional (Lei Complementar $\mathrm{n}^{\mathrm{o}} 105 / 2001$, art. $3^{\mathrm{o}}, \S \S 1^{\mathrm{o}}$ e $2^{\mathrm{o}}$ ).

O Supremo Tribunal Federal decidiu que o Tribunal de Contas da União não tem poderes para determinar a quebra do sigilo bancário, não cabendo interpretação extensiva da Lei Complementar $n^{\circ}$ 105/2001, ante o princípio constitucional da proteção a intimidade e a vida privada $\left(\mathrm{CF}, \text { art. } 5^{\circ}, \mathrm{X}\right)^{613}$.

Por outro lado, no julgamento da $\operatorname{ADC} \mathrm{n}^{\circ}$ 12, restou decidido pelo Pretório Excelso que o Conselho Nacional de Justiça pode editar atos regulamentares primários, ou seja, que inovem no ordenamento jurídico, porém somente no âmbito de suas competências ${ }^{614}$.

Inadmissível, portanto, que ato normativo do CNJ excepcione direito individual previsto na Constituição para conferir ao próprio órgão e ao seu Ministro-Corregedor competência para quebra de sigilo bancário ou fiscal.

Em síntese, há parcial inconstitucionalidade nas normas constantes do art. $4^{\circ}, \mathrm{XV}$, e do art. $8^{\circ}, \mathrm{V}$, ambas do Regimento Interno do Conselho Nacional de Justiça, porque o Conselho Nacional de Justiça não pode, através de ato regulamentar, atribuir-se competência para quebra de sigilos bancários e fiscais, em violação a preceitos fundamentais insculpidos na Constituição da República relativos à proteção da intimidade, da vida privada e ao sigilo de dados.

\footnotetext{
${ }^{613}$ Mandado de Segurança. Tribunal de Contas da União. Banco Central do Brasil. Operações financeiras. Sigilo. 1. A Lei Complementar ${ }^{\circ}$ 105, de 10/1/01, não conferiu ao Tribunal de Contas da União poderes para determinar a quebra do sigilo bancário de dados constantes do Banco Central do Brasil. O legislador conferiu esses poderes ao Poder Judiciário (art. $3^{\circ}$ ), ao Poder Legislativo Federal (art. $4^{\circ}$ ), bem como às Comissões Parlamentares de Inquérito, após prévia aprovação do pedido pelo Plenário da Câmara dos Deputados, do Senado Federal ou do plenário de suas respectivas comissões parlamentares de inquérito ( $\S 1^{\circ} \mathrm{e} 2^{\circ}$ do art. $\left.4^{\circ}\right)$. 2. Embora as atividades do TCU, por sua natureza, verificação de contas e até mesmo o julgamento das contas das pessoas enumeradas no artigo 71, II, da Constituição Federal, justifiquem a eventual quebra de sigilo, não houve essa determinação na lei específica que tratou do tema, não cabendo a interpretação extensiva, mormente porque há princípio constitucional que protege a intimidade e a vida privada, art. $5^{\circ}, \mathrm{X}$, da Constituição Federal, no qual está inserida a garantia ao sigilo bancário. 3. Ordem concedida para afastar as determinações do acórdão ${ }^{\circ}$ 72/96 - TCU - $2^{\text {a }}$ Câmara (fl. 31), bem como as penalidades impostas ao impetrante no Acórdão n ${ }^{\circ}$ 54/97 - TCU - Plenário (STF, MS 22801, Relator(a): Min. MENEZES DIREITO, Tribunal Pleno, julgado em 17/12/2007, DJe-047 DIVULG 13-03-2008 PUBLIC 14-03-2008).

${ }^{614}$ Vide item 3.1.8.
} 


\section{CAPÍTULO 4 - O CONTROLE JURISDICIONAL DA ATUAÇÃO DO CONSELHO NACIONAL DE JUSTIÇA PELO SUPREMO TRIBUNAL FEDERAL}

Perceptível, pela leitura dos capítulos anteriores, o amplo leque de competências atribuídas pelo constituinte derivado ao Conselho Nacional de Justiça, estabelecidas em dispositivos constitucionais cujos textos permitem abertura interpretativa de suas normas.

O desenho institucional do Conselho, pois, tem sido traçado, em larga medida, pelas decisões proferidas pelo Supremo Tribunal Federal, quando judicialmente questionada a atuação do órgão

Este capítulo, pois, tratará da forma como é realizado o controle jurisdicional da atuação do CNJ pelo Pretório Excelso.

Verifica-se que o Supremo exerce o controle jurisdicional da atuação do Conselho Nacional de Justiça de três formas: a) enquanto guarda da Constituição, através do controle principal, de feição abstrata, da constitucionalidade dos atos normativos editados pelo CNJ (CF, art. 102, I, “a”); b) em razão de competência originária expressa (CF, art. 102, I, "r"); e, c) devido à sua competência recursal (CF, art. 102, III).

a) Controle jurisdicional direto da constitucionalidade:

Quanto ao controle jurisdicional de constitucionalidade realizado pelo Supremo Tribunal Federal em relação à atuação do Conselho Nacional de Justiça, cumpre lembrar que o Pretório Excelso reconheceu que o $\mathrm{CNJ}$ pode editar atos normativos no âmbito de sua competência ${ }^{615}$.

Como destacou o Ministro Ayres Britto no julgamento da Ação Declaratória de Constitucionalidade $\mathrm{n}^{\mathrm{o}} 12$, esses atos normativos revestem-se dos atributos da generalidade, impessoalidade e abstratividade, podendo ter caráter normativo primário, como no caso da Resolução CNJ nº 7/2005.

Como o Conselho Nacional de Justiça é um órgão do Poder Judiciário da União, expede atos normativos federais com efeitos nacionais ${ }^{616}$, o que permite que a

\footnotetext{
${ }^{615}$ Segundo dispõe a norma prevista no art. 102, caput, do Regimento Interno do Conselho Nacional de Justiça (Resolução $\mathrm{CNJ} \mathrm{n}^{\circ}$ 67/2009), o Plenário do órgão pode, por maioria absoluta, editar atos normativos mediante Resoluções, Instruções ou Enunciados Administrativos e, ainda, Recomendações.

${ }^{616}$ Vide item 2.3.1.1.
} 
constitucionalidade das normas neles insertas seja questionada ou afirmada pelo manejo de ações diretas de inconstitucionalidade ou ações declaratórias de constitucionalidade (CF, art. 102, I, "a") $)^{617}$.

Deve-se ressaltar que as decisões definitivas de mérito nas ações diretas de inconstitucionalidade e nas ações declaratórias de constitucionalidade tem eficácia contra todos (erga omnes) e efeito vinculante, "relativamente aos demais órgãos do Poder Judiciário e à administração pública direta e indireta, nas esferas federal, estadual e municipal" (CF, art. 102, $\left.\S 2^{\circ}\right)$.

b) Competência originária:

Em relação ao controle jurisdicional realizado pelo Supremo Tribunal Federal sobre a atuação do Conselho, segundo a norma inserta no art. 102, I, "r", da Constituição da República, incluída pela Emenda Constitucional no 45/2004, cabe à Alta Corte Brasileira processar e julgar, originalmente, as ações contra ${ }^{618}$ o Conselho Nacional de Justiça e contra o Conselho Nacional do Ministério Público.

Como pontuado pelo Ministro Sepúlveda Pertence no julgamento da Petição no 3.674, em 4 de outubro de 2006, duas leituras se ofereceram à demarcação do alcance da referida cláusula da competência originária do Supremo Tribunal Federal:

a) a primeira, restritiva, nela compreendida apenas as ações nas quais segundo o entendimento dominante, submisso à doutrina dos writs do direito anglo-americano - o órgão e não a pessoa jurídica seria a parte legitima a figurar no pólo passivo da relação processual: assim, o mandado de segurança, o de injunção, o habeas corpus e o habeas data; b) a outra, mais ampla, atrairia para o Supremo qualquer processo no qual esteja em causa a revisão jurisdicional de atos dos referidos colegiados do chamado "controle externo" do Poder Judiciário ou do Ministério Público.

\footnotetext{
${ }^{617}$ Não há registro de manejo de arguição de descumprimento de preceito fundamental em face de ato do CNJ.

${ }^{618}$ O Ministro Sepúlveda Pertence, no julgamento da Pet. 3674, afirmou: “esta expressão 'contra é rombuda. Na verdade, não há ações contra órgão colegiado da União".
} 
Em direção à interpretação restritiva inclinou-se a Suprema Corte Brasileira por dois motivos.

Primeiro porque sempre se compreendeu que a competência originária do STF restringe-se às hipóteses taxativamente previstas na Constituição, "pois qualifica-se como um conjunto de atribuições jurisdicionais de natureza constitucional (MORAES, 2013a, p. 1422). Inadmissível, pois, a sua extensão a outras situações que não se amoldem àquelas previstas nas diversas alíneas do art. 102, I, da Carta Política.

Segundo porque o Conselho Nacional de Justiça e o Conselho Nacional do MInistério Público não constituem pessoas jurídicas. São apenas órgãos do Poder Judiciário (CF, arts. 92, I-A e 103-B) e do Ministério Público da União (CF, art. 130-A) e não têm, pois, personalidade jurídica própria.

Desse modo, o Supremo Tribunal Federal passou a decidir somente ter competência originária para processar e julgar os mandados de segurança, mandados de injunção, habeas corpus e habeas data impetrados contra deliberações do Conselho Nacional de Justiça (e também do Conselho Nacional do Ministério Público) porque, nesses remédios constitucionais, a autoridade impetrada é o próprio Colegiado ou seu presidente, "isso diante da chamada personalidade judiciária que é conferida aos órgãos das pessoas político-administrativas para defesa de seus atos e prerrogativas nessas ações constitucionais mandamentais" "619. Quanto às demais ações, como o CNJ (e também o CNMP) é um órgão da União, esta é a legitimada a figurar no pólo passivo, por ser pessoa jurídica de direito público e, portanto, ante o disposto no art. 109, I, da Constituição Federal, o STF firmou posicionamento no sentido de que devem ser processadas perante o Juízo Federal.

Essa orientação foi ressaltada pelo Ministro Celso de Mello, relator da Ação Originária $\mathrm{n}^{\mathrm{o}} 1.706$, julgada em 18 de dezembro de 2013:

A competência originária do STF, cuidando-se de impugnação a deliberações emanadas do Conselho Nacional de Justiça (CNJ), tem sido reconhecida apenas na hipótese de impetração, contra referido órgão do Poder Judiciário (CNJ), de mandado de segurança, de habeas data, de habeas corpus (quando for o caso) ou de mandado de injunção, pois, em tal situação, o CNJ qualificar-se-á como órgão coator impregnado de

\footnotetext{
${ }^{619}$ Decisão monocrática proferida pelo Ministro Ayres Britto em 10 de fevereiro de 2011 (publicada no DJ de 14 de fevereiro de 2011), na Ação Cível Originária nº 1.680.
} 
legitimação passiva ad causam para figurar na relação processual instaurada com a impetração originária, perante a Suprema Corte, daqueles writs constitucionais. Em referido contexto, o CNJ, por ser órgão não personificado, define-se como simples 'parte formal' (Pontes de Miranda. Comentários ao Código de Processo Civil. tomo I/222-223, item n. 5, 4 ed., 1995, Forense; CARVALHO FILHO José dos Santos. Manual de direito administrativo. p. 15/17, item n. 5, 25 ed., 2012, Atlas, v.g.), revestido de mera 'personalidade judiciária' (LEAL Victor Nunes. Problemas de direito público. p. 424/439, 1960, Forense), achando-se investido, por efeito de tal condição, da capacidade de ser parte (MARINONI Luiz Guilherme; MITIDIERO Daniel. Código de Processo Civil. p. 101, 5 ed., 2013, RT; THEODORO JÚNIOR Humberto. Curso de direito processual civil. vol. I/101, item n. 70, 54 ed., 2013, Forense; NERY JÚNIOR Nelson; e NERY Rosa Maria de Andrade. Código de Processo Civil comentado. p. 233, item n. 5, 13 ed., 2013, RT, v.g.), circunstância essa que plenamente legitima a sua participação em mencionadas causas mandamentais. Tratando-se, porém, de demanda diversa (uma ação ordinária, p. ex.), não se configura a competência originária da Suprema Corte, considerado o entendimento prevalecente na jurisprudência do STF, manifestado, inclusive, em julgamentos colegiados, eis que, nas hipóteses não compreendidas no art. 102, I, $d$ e $q$, da Constituição, a legitimação passiva ad causam referir-se-á, exclusivamente, à União Federal, pelo fato de as deliberações do CNJ serem juridicamente imputáveis à própria União Federal, que é o ente de direito público em cuja estrutura institucional se acha integrado o $\mathrm{CNJ}$

Assim, diversas ações populares ${ }^{620}$, ações civis públicas ${ }^{621}$ e ações originárias ${ }^{622}$

${ }^{620}$ Nesse sentido:

Competência originária do Supremo Tribunal para as ações contra o Conselho Nacional de Justiça e contra o Conselho Nacional do Ministério Público (CF, art. 102, I, r, com a redação da EC 45/04): inteligência: não inclusão da ação popular, ainda quando nela se vise à declaração de nulidade do ato de qualquer um dos conselhos nela referidos. 1. Tratando-se de ação popular, o Supremo Tribunal Federal - com as únicas ressalvas da incidência da alínea $n$ do art. 102, I, da Constituição ou de a lide substantivar conflito entre a União e Estado-membro -, jamais admitiu a própria competência originária: ao contrário, a incompetência do Tribunal para processar e julgar a ação popular tem sido invariavelmente reafirmada, ainda quando se irrogue a responsabilidade pelo ato questionado a dignitário individual - a exemplo do Presidente da República - ou a membro ou membros de órgão colegiado de qualquer dos poderes do Estado cujos atos, na esfera cível como sucede no mandado de segurança - ou na esfera penal - como ocorre na ação penal originária ou no habeas corpus - estejam sujeitos diretamente à sua jurisdição. 2. Essa não é a hipótese dos integrantes do Conselho Nacional de Justiça ou do Conselho Nacional do Ministério Público: o que a Constituição, com a EC 45/04, inseriu na competência originária do Supremo Tribunal foram as ações contra os respectivos 
ajuizadas diretamente no Supremo Tribunal Federal, tendo como cenário a atuação do Conselho Nacional de Justiça (e também do CNMP), não foram conhecidas pelo Pretório Excelso.

E, mesmo nas hipóteses de impetração de mandado de segurança, o Supremo ainda firmou outra restrição para conhecimento dessas ações constitucionais mandamentais: sob o argumento de que a Corte não pode se tornar uma instância ordinária de revisão de todas as decisões do CNJ, passou a admitir os writs somente nos casos de impugnações a deliberações positivas do Conselho, ou seja, naquelas que impliquem ingerência na competência dos juízos e tribunais que fiscaliza, porque nas demais, em que o Conselho se recusa a intervir, o órgão "não substitui por ato seu o ato ou a omissão dos tribunais, objeto da reclamação, que, por conseguinte, remanescem na esfera de competência ordinária destes” MS 26710 QO/DF, rel. Min. Sepúlveda Pertence, 2.8.2007. (MS-26710). (Informativo $474,1^{\circ}$ a 3 de agosto de 2007) ${ }^{623}$.

colegiado, e não, aquelas em que se questione a responsabilidade pessoal de um ou mais dos conselheiros, como seria de dar-se na ação popular (STF, Pet 3674 QO, Relator(a): Min. SEPÚLVEDA PERTENCE, Tribunal Pleno, julgado em 04/10/2006, DJ 19-12-2006).

${ }^{621}$ Nesse sentido:

PETIÇÃO. AÇÃO CIVIL PÚBLICA CONTRA DECISÃO DO CONSELHO NACIONAL DE JUSTIÇA. INCOMPETÊNCIA, EM SEDE ORIGINÁRIA, DO SUPREMO TRIBUNAL FEDERAL. I- Nos termos do art. 102 e incisos da Magna Carta, esta Suprema Corte não detém competência originária para processar e julgar ações civis públicas. II - Precedentes. III - Agravo desprovido (STF, Pet 3986 AgR, Relator(a): Min. RICARDO LEWANDOWSKI, Tribunal Pleno, julgado em 25/06/2008, DJe-167 DIVULG 04-09-2008 PUBLIC 05-09-2008 EMENT VOL-02331-01 PP-00032).

${ }^{622}$ Nesse sentido, já mencionado no texto, STF, AO 1706 AgR, Relator(a): Min. CELSO DE MELLO, Tribunal Pleno, julgado em 18/12/2013, PROCESSO ELETRÔNICO DJe-033 DIVULG 17-02-2014 PUBLIC 18-02-2014.

${ }^{623}$ Nesse sentido:

AGRAVO REGIMENTAL EM MANDADO DE SEGURANÇA. PROCEDIMENTO DE CONTROLE ADMINISTRATIVO NO CONSELHO NACIONAL DE JUSTIÇA CONTRA DECISÃO DO SEGUNDO VICE-PRESIDENTE DO TRIBUNAL DE JUSTIÇA DE MINAS GERAIS. COMPOSIÇÃO DA BANCA EXAMINADORA DO CONCURSO PÚBLICO PARA DELEGAÇÃO DOS SERVIÇOS DE TABELIONATO DE REGISTRO. DELIBERAÇÃO NEGATIVA DO CONSELHO NACIONAL DE JUSTIÇA. REDUÇÃO TELEOLÓGICA DA PROTEÇÃO PREVISTA NO ART. 102, INC. I, ALÍNEA R, DA CONSTITUIÇÃO DA REPÚBLICA. ATO COATOR PROFERIDO POR AUTORIDADE NÃO PREVISTA NO ROL DO ART. 102, INC. I, ALÍNEA D, DA CONSTITUIÇÃO DA REPÚBLICA. SÚMULA N. 624 DO SUPREMO TRIBUNAL FEDERAL. PRECEDENTES. 1. A competência originária do Supremo Tribunal para processar e julgar ações contra o Conselho Nacional de Justiça não o transforma em instância revisora de toda e qualquer decisão desse órgão administrativo. 2. As decisões do Conselho Nacional de Justiça que não interferem nas esferas de competência dos tribunais ou dos juízes não substituem aquelas decisões por eles proferidas, pelo que não atraem a competência do Supremo Tribunal. 3. A Constituição da República prevê, no art. 102, inc. I, alínea 'd', as hipóteses de competência originária do Supremo Tribunal para conhecer de mandado de segurança, entre as quais não consta a possibilidade de impetração contra ato de outro tribunal (Súmula n. 624). 4. Agravo regimental ao qual se nega provimento (MS 29118 AgR, Relator(a): Min. CÁRMEN LÚCIA, Tribunal Pleno, julgado em 02/03/2011, PROCESSO ELETRÔNICO DJe-071 DIVULG 13-04-2011 PUBLIC 14-04-2011). 
Esse posicionamento restritivo adotado pelo Supremo Tribunal Federal quanto ao conhecimento de ações originárias na hipótese prevista no art. 102, I, "r", da Constituição Federal, em especial quanto ao não conhecimento daquelas manejadas contra a União, mas relativas a atos praticados pelo Conselho Nacional de Justiça, porém, pode gerar duas inconsistências.

A primeira é a possibilidade de confusão de partes no mesmo processo.

Com efeito, como a União postula em favor de seus órgãos e o Conselho Nacional de Justiça é um dos órgãos da União, a determinação do Supremo Tribunal Federal implicaria no ajuizamento, no Juízo Federal, de uma ação em que a mesma pessoa jurídica de direito público - a União - figuraria em ambos os polos da demanda, o que poderia levar à interpretação de incidência da regra prevista no art. 267, X, do Código de Processo Civil $^{624}$, com a consequente extinção do processo sem resolução do mérito ${ }^{625}$.

Tome-se, como exemplo, a decisão proferida pelo Supremo Tribunal Federal em 18 de dezembro de 2013 no Agravo Regimental na Ação Originária nº 1706, da relatoria do Ministro Celso de Mello, cuja ementa foi anteriormente mencionada.

No caso, a União Federal postulou, em face do Conselho Nacional de Justiça, a declaração da nulidade da decisão proferida pelo órgão no PCA no $0007312-$ 42.2009.2.00.0000, na parte em que CNJ considerou legais os pagamentos efetivados pelo Superior Tribunal de Justiça e pela Justiça Federal a seus servidores em desacordo com decisão do Tribunal de Contas da União ${ }^{626}$, para que processos individuais de cobrança retomassem os seus trâmites. O Pretório Excelso, ao estabelecer que, na hipótese, a legitimação passiva para a demanda seria da União Federal, sendo competente para conhecer da causa o Juízo Federal, impôs a presença, nessa eventual ação, da União

\footnotetext{
${ }^{624}$ Art. 267 (CPC). Extingue-se o processo, sem resolução de mérito:

$[\ldots]$

$\mathrm{X}$ - quando ocorrer confusão entre autor e réu;

${ }^{625}$ Theotonio Negrão (2011, p. 377) informa que a "confusão" a que se refere o art. 267, X, do CPC é a relativa ao instituto de direito material (CC, arts. 381 a 384) e "deve ser de todo o direito demandado, e não de parte dele". Portanto, reporta-se à extinção de obrigação patrimonial por se confundirem, na mesma pessoa, as qualidades de credor e devedor. É a hipótese, por exemplo, de incidência da Súmula $\mathrm{n}^{\mathrm{o}} 421$ do Superior Tribunal de Justiça: "Os honorários advocatícios não são devidos à Defensoria Pública quando ela atua contra a pessoa jurídica de direito público à qual pertença". Sob esse enfoque, poder-se-ia aceitar uma ação movida pela União Federal (na defesa de posicionamento de um de seus órgãos) contra a própria União Federal (na defesa de posicionamento do CNJ), sendo representada, em cada polo, por diferentes advogados da União (CF, art. 131), pois não haveria discussão de direito patrimonial no seu bojo. Cintra, Grinover e Dinamarco (2007, p. 314), no entanto, ensinam que um dos princípios básicos relativos às posições do demandante e do demandado no processo é o "princípio da dualidade das partes, segundo o qual é inadmissível um processo sem que haja pelo menos dois sujeitos em posições processuais contrárias, pois ninguém pode litigar consigo mesmo".

${ }^{626}$ Sobre a não sujeição do $\mathrm{CNJ}$ ao TCU, vide item 3.1.4.3.
} 
Federal em ambos os polos da lide.

A segunda inconsistência que se verifica na orientação restritiva do Supremo Tribunal Federal em análise refere-se à possibilidade de órgãos do Poder Judiciário que são administrativamente fiscalizados pelo CNJ poderem, em sede jurisdicional, controlar os atos do Conselho.

Esse último problema foi detectado pelo Ministro Dias Toffoli no julgamento, em 24 de setembro de 2014, do Agravo Regimental na Ação Originária n 1680 e da Questão de Ordem na Ação Originária $n^{0} 1814$, respectivamente relatadas pelos Ministros Teori Zavascki e Marco Aurélio Mello.

Apesar dos relatores das mencionadas ações terem reconhecido, com fulcro na orientação reinante na Excelsa Corte, não competir ao Supremo Tribunal Federal processálas e julgá-las, e ter sido determinada, por votação unânime, a remessa de ambas à Justiça Federal, o Ministro Dias Toffoli, em seu voto, apresentou outros fundamentos para estabelecer a incidência da norma prevista no art. 102, I, "r" da Constituição Federal.

Sua Excelência argumentou que a competência do Supremo Tribunal Federal para julgar casos decididos no Conselho Nacional de Justiça não pode ser restringida, por equiparação, às hipóteses de cabimento de ações mandamentais ou às causas em que há interesse de todos os membros da Magistratura ou de mais da metade dos membros do tribunal de origem (CF, art. 102, “d", "n" e "q") porque esse critério de definição de competência é estritamente processual e permite, em algumas situações, a subversão da posição constitucional atribuída ao órgão "e a imperatividade de suas decisões, em face dos órgãos e dos membros submetidos a sua autoridade".

Assim, o Ministro Dias Toffoli sustentou que a competência originária do Pretório Excelso deve ser definida pela substância do ato realizado pelo Conselho Nacional de Justiça (e não pela "pessoalidade" na integração do polo passivo), observada uma perspectiva dúplice: “de um lado, restritiva, a ponto de preservar a feição excepcional da competência da Corte Suprema; de outro, amplificada, de modo a não delimitar a apreciação originária do Supremo Tribunal com foco apenas na natureza processual da demanda".

Afirmou que a Carta da República, quando pretendeu delimitar ações de natureza constitucional, o fez taxativa e especificamente (CF, art. 102, I, “d”, “i” e “q”). Porém, não estabeleceu restrições nas hipóteses das ações de interesse direto ou indireto de todos os membros da Magistratura (CF, art. 102, I, "n") e daquelas dirigidas em razão da atuação do CNJ ou do CNMP (CF, art. 102, I, "r"). Por outro lado, ainda que referidos Conselhos não 
tenham personalidade jurídica, a própria Constituição, por conveniência, atribuiu-lhes essa condição, à semelhança do que a lei processual o faz com a massa falida e o espólio ${ }^{627}$, para que sejam partes em outras demandas ${ }^{628}$.

Defendeu, assim, em relação às ações movidas em face do Conselho Nacional de Justiça, para prestigiar o regime de direito estrito da competência originária do STF (evitando que se torne uma instância revisora ordinária do $\mathrm{CNJ}$ ), mas evitar sua definição com base somente em critério formal-processual que pode fragilizar a autoridade das decisões do órgão, que a delimitação das atribuições originárias do Supremo com base na norma inserta no art. 102, I, "r", inserido da Lei Maior pela Emenda Constitucional n 45/2004, seja feita com base na "ratio subjante à edição da reforma constitucional", superando-se a interpretação literal do dispositivo.

Nessa linha, Sua Excelência sustentou que:

[...] devem ser preservadas à apreciação primária desta Suprema Corte as demandas que digam respeito às atividades disciplinadora e fiscalizadora do CNJ que repercutam frontalmente nos tribunais ou em seus membros, ainda que não veiculadas por ação mandamental ou, em expressão mais sucinta: todas as ações que digam respeito à autonomia dos tribunais ou ao regime disciplinar da magistratura.

$[\ldots]$

Nessa senda, seriam, fatalmente, de competência primária desta Corte: (i) demandas relacionadas ao exercício do poder disciplinar do CNJ sobre os membros da magistratura; (ii) ações em face de decisões do Conselho que desconstituam ato normativo ou deliberação de tribunal local relacionados a matérias a esse diretamente afetas [...]; e (iii) outras em que a atuação do $\mathrm{CNJ}$ se dê, precipuamente, na consecução de sua atividade fim, quando direta e especialmente incidente sobre membros e órgãos a ele diretamente subordinados.

\footnotetext{
${ }^{627}$ O Ministro cita a lição de Celso Agrícola Barbi (1991, p. 85): “a capacidade de ser parte liga-se à existência de personalidade jurídica. Mas, por questão de conveniência, a lei processual pode atribuir aquela capacidade a figuras que não têm essa personalidade", tal como se dá com a massa falida, a herança jacente, o espólio, a sociedade de fato e a massa do devedor civil insolvente, a teor dos arts. 12, III, IV, V e VII; e 766, II, do Código de Processo Civil.

${ }^{628}$ O Ministro Dias Toffoli menciona, em seu voto, o magistério de Cândido Rangel Dinamarco (2009, p. 291): "Do disposto no art. 102, inc. I, letra $r$, da Constituição Federal (competência do Supremo Tribunal Federal para as ações contra o Conselho Nacional de Justiça e contra o Conselho Nacional do Ministério Público) infere-se que também essas entidades, conquanto não tenham capacidade jurídica plena, gozam da capacidade de ser parte - ou seja, têm uma capacidade de ser parte que autoriza a propositura de demandas em face delas".
} 
Assim, concluiu, os atos proferidos pelo Conselho Nacional de Justiça no exercício de sua atividade finalística, como os relacionados à autonomia do Poder Judiciário ou ao cumprimento do Estatuto da Magistratura, bem como as referentes a deliberações positivas de caráter disciplinar de magistrados, ficarão sempre sujeito à jurisdição do Supremo Tribunal Federal. Os demais atos do Conselho, que não atinjam as cortes locais diretamente, mas apenas incidentalmente, como aqueles relativos aos servidores ou às serventias extrajudiciais, atos administrativos gerais dos tribunais não sujeitos a regulamentação distinta do Judiciário (concursos públicos ou licitações, por exemplo), ou decisões que não digam respeito a interesse exclusivo de toda magistratura, ficarão sujeitos à jurisdição de primeira instância.

c) Competência recursal:

O Supremo Tribunal Federal, devido à sua competência recursal e por ter sido adotado, no Brasil, o modelo da unidade de jurisdição (AMARAL JÚNIOR, 2009, p. $1174)^{629}$, ainda pode exerce o controle jurisdicional das atividades do Conselho Nacional de Justiça de forma difusa, ao apreciar eventuais recursos extraordinários intentados nas causas decididas em única ou última instância (CF, art. 102, III), movidas inicialmente na primeira instância da Justiça Federal em face da União Federal, mas que têm como pano de fundo a atuação do Conselho.

Por fim, cumpre mencionar que, em 28 de maio de 2014, Supremo Tribunal Federal aprovou, por unanimidade, proposta de emenda ao Regimento Interno da Corte para transferir da competência do plenário para as turmas o julgamento de ações ajuizadas contra atos do Conselho Nacional de Justiça (CNJ) e do Conselho Nacional do Ministério Público (CNMP), permanendo na competência do plenário, porém, o julgamento de mandados de segurança impetrados contra atos do presidente do STF e do ProcuradorGeral da República, na condição de presidentes do CNJ e do CNMP, respectivamente ${ }^{630}$.

\footnotetext{
${ }^{629}$ Vide item 2.3.5.1.

${ }^{630}$ Conforme notícia "STF aprova emenda regimental que acrescenta competências às Turmas", disponível em $<$ http://www.stf.jus.br/portal/cms/verNoticiaDetalhe.asp?idConteudo=267821\&caixaBusca $=\mathrm{N}>$. Acesso em 24.12.2014).
} 


\section{CONCLUSÃO}

Um desafio foi lançado no início deste trabalho: investigar os limites constitucionais de atuação do Conselho Nacional de Justiça.

Acompanharam-no diversas indagações.

Pode o CNJ controlar a constitucionalidade das leis? Pode exercer poder normativo primário? Suas deliberações podem suspender ou modificar decisões judiciais? Os atos do Conselho podem atingir pessoas e entidades estranhas à Justiça? Os membros do Colegiado podem agir e decidir monocraticamente?

Ao longo da caminhada, buscou-se, com reflexão, as respostas a essas e diversas outras questões lançadas.

Primeiro fez-se uma jornada histórica em busca das origens dos Conselhos Superiores da Magistratura e do Conselho Nacional de Justiça. A compreensão da gênese do órgão foi vital para direcionar os rumos da pesquisa.

Em seguida, pelo método proposto, com apoio em distinta doutrina e farta jurisprudência, foram perquiridos os limites de atuação do Conselho Nacional de Justiça decorrentes de seus elementos constitucionais característicos.

Compreendeu-se que o Conselho integra o Poder Judiciário e forma um colegiado. Seus membros, pois, também pertencem aos quadros da magistratura e ostentam os predicados da carreira. Por outro lado, o atuar do órgão é informado pelo princípio da colegialidade.

Verificou-se que o Colegiado Administrativo é um órgão de controle e, assim, não deve adiantar-se na execução das missões institucionais acometidas aos demais órgãos do Poder Judiciário.

Constatou-se que a novel instituição é responsável pelo controle interno da atuação administrativa e financeira do Poder e do cumprimento dos deveres funcionais dos magistrados, e ainda fiscaliza as atividades dos prestadores de serviços notariais e de registro que atuem por delegação do poder público. Portanto, não pode controlar outros órgãos externos, não exerce jurisdição e, mesmo na verificação de ato de administração, deve atentar-se à sua natureza, pois também sofre restrições de controle, como na hipótese do ato político.

Ante a outra característica elementar do Conselho Nacional de Justiça - responsável pelo controle do cumprimento dos deveres funcionais dos juízes - buscou-se a exata 
compreensão do seu alcance, o que envolveu longa investigação quanto à relevância da independência da Magistratura.

Diante desses elementos característicos do Conselho, conclui-se que se trata de um órgão de sobreposição, pois, apesar de sua posição de destaque na estrutura do Poder Judiciário, não vincula o Supremo Tribunal Federal e seus ministros. Defendeu-se, também, a não sujeição do Tribunal Superior Eleitoral e das questões específicas da Justiça Eleitoral ao mando do CNJ.

Na sequência, ante o estudo das competências constitucionais específicas do Conselho Nacional de Justiça, verificou-se que o órgão é guarda da autonomia do Poder Judiciário e do cumprimento do Estatuto da Magistratura.

Ao se abordar a competência do Conselho de guarda da observância dos princípios e regras da administração pública, de controle da legalidade dos atos administrativos praticados por membros e órgãos do Poder Judiciário, e de controle disciplinar, o trabalho voltou-se para uma análise criteriosa dos caminhos a serem seguidos pelo órgão. Procurouse, de forma refletida, amparada na melhor doutrina e observada a posição da jurisprudência, indicar o melhor percurso, apresentando respostas a diversas questões controvertidas. Defendeu-se a impossibilidade do CNJ exercer controle de constitucionalidade e procurou-se fixar critérios para a solução de diversos problemas no âmbito dos processos disciplinares.

Discorreu-se, ainda, sobre as demais competências específicas do Conselho, com especial destaque para a regulamentar, ante a decisão proferida pelo Supremo Tribunal Federal na Ação Declaratória de Constitucionalidade $n^{0} 12$, que reconheceu o poder normativo primário ao órgão.

Por fim, foram apontados limites às competências singulares do Corregedor Nacional de Justiça e analisada a forma como o Supremo Tribunal Federal enfrenta os questionamentos judiciais das ações do Colegiado Administrativo.

Acreditamos que o desafio foi vencido. A pesquisa conseguiu identificar os limites constitucionais de atuação do Conselho Nacional de Justiça a partir das suas próprias características e competências. Estudos de casos e de normas ilustraram as conclusões apresentadas.

Esperamos, pois, que este trabalho possa contribuir para a solução de diversas questões jurídicas que ainda envolvem as fronteiras institucionais de atuação do Conselho Nacional de Justiça. 


\section{REFERÊNCIAS.}

ALEXY, Robert. Teoria dos direitos fundamentais. Tradução Virgílio Afonso da Silva. $2^{\mathrm{a}}$ ed., $3^{\text {a }}$ tiragem. São Paulo: Malheiros, 2014.

ALMEIDA, Fernanda Dias Menezes de. Competências na constituição de 1988. $5^{\mathrm{a}}$ ed. São Paulo: Atlas, 2010.

ALVES, José Carlos Moreira. Poder Judiciário. In: MARTINS, Ives Gandra da Silva (Coord.). A Constituição brasileira 1988: interpretações. Rio de Janeiro: Forense Universitária, 1988, p. 195.

AMARAL JÚNIOR, José Levi do. Comentário aos artigos 92 e 93, inc. VIIIA. In: BONAVIDES, Paulo; MIRANDA, Jorge; AGRA, Walber de Moura (Coords. Editoriais). Comentários à Constituição Federal de 1988. Rio de Janeiro: Forense, 2009, pp. 1169 a 1185 .

AMARAL JÚNIOR, José Levi do. Comentário aos artigos 93, inc. X ao 99. In: BONAVIDES, Paulo; MIRANDA, Jorge; AGRA, Walber de Moura (Coords. Editoriais). Comentários à Constituição Federal de 1988. Rio de Janeiro: Forense, 2009, pp. 1195 a 1226.

ARAÚJO, Edmir Netto de. Curso de Direito Administrativo. 5a ed. São Paulo: Saraiva, 2010, p. 496

ARAÚJO, Luiz Alberto David; NUNES JÚNIOR, Vidal Serrano. Curso de direito constitucional. 13 ${ }^{\text {a }}$ ed. São Paulo: Saraiva, 2009.

ARENDT, Hannah. Da violência. São Paulo: Ática, 1988.

ARISTÓTELES. A política. Tradução Nestor Silveira Chaves. Bauru: Edipro, 2009.

ATIENZA, C.A. Documentação jurídica: introdução à análise e indexação de atos legais. Rio de Janeiro: Achiamé, 1979.

ATIENZA, C.A. Técnicas de indexação de pronunciamentos judiciais. São Paulo: [s.n.], 1981. (Mimeogr.).

ÁVILA, Humberto Bergmann. A distinção entre princípios e regras e a redefinição do dever de proporcionalidade. Revista de Direito Administrativo 215 (1999): 151-179.

BALEEIRO, Aliomar. Uma introdução à ciência das finanças. $6^{\mathrm{a}}$ ed. Rio de Janeiro: Forense, 1969.

BARBI, Celso Agrícola. Comentários ao código de processo civil. $6^{\mathrm{a}}$ ed. Rio de Janeiro: 
Forense, 1991. v.1.

BARBOSA, Ruy. O direito do Amazonas ao Acre setentrional. Rio de Janeiro, Fundação Casa de Ruy Barbosa, 1983, Obras Completas de Ruy Barbosa, v. 37, t. 5.

BARCELlOS, Ana Paula de. A eficácia jurídica dos princípios constitucionais: o princípio da dignidade da pessoa humana. Rio de Janeiro: Renovar, 2002.

BASTOS, Celso Ribeiro. Hermenêutica e interpretação constitucional. 2. ed. São Paulo: Instituto Brasileiro de Direito Constitucional, 1999.

BELLOCH, Juan Alberto; IBARRA, Juan Luis. Control democrático de los órganos judiciales y de los órganos gubernativos del poder judicial. In: Jueces para la Democracia, Información y Debates, n. 4, Madrid, set./1988, p. 21.

BENETI, Sidnei Agostinho. Da conduta do Juiz. $3^{\text {a }}$ ed. São Paulo: Saraiva, 2003.

BERGERON, Gérard. Fonctionnement de l'État. $2^{a}$ ed. Paris: Armand Colin, 1965.

BERMUDES, Sérgio. A reforma do Judiciário pela Emenda Constitucional $n^{\circ} 45$. Rio de Janeiro: Forense, 2005.

BERTELOTTI, Mariano. In: HENDLER, Edmund S. (comp.). Las garantías penales y procesales. Enfoque histórico-comparado. Buenos Aires: Departamento de Publicaciones de la Facultad de Derecho - Universidad de Buenos Aires, 2001, p. 106.

BLOOM, Lackland H., Jr. Methods of interpretation: how the Supreme Court reads the constitution. New York: Oxford University Press, 2009

BRASIL. Assembleia Legislativa do Estado de São Paulo. Disponível em: $<$ http://www.al.sp.gov.br>. Acesso em 10.12.2014.

BRASIL. Câmara dos Deputados. <http://www.camara.gov.br>. Acesso em 10.12.2014.

BRASIL. Câmara dos Deputados. Proposta de Emenda Constituição n no 96/1992. Disponível em: $<$ http://www.camara.gov.br/proposicoesWeb/fichadetramitacao?idProposicao=14373>. Acesso em 01.11.2014.

BRASIL. Conselho Federal da Ordem dos Advogados Do Brasil. Provimento $n^{\circ} 113$, de 10 de setembro de 2006.2 Disponível em: $<$ http://www.oab.org.br/leisnormas/legislacao/provimentos/113-2006 $>$. Acesso em 10.12.2014.

BRASIL. Conselho Nacional de Justiça. Atos normativos. Disponível em: $<$ http://www.cnj.jus.br/atos-normativos $>$. Acesso em 10.12.2014. 
BRASIL. Governo do Estado de Santa Catarina. Glossário do Portal da Saúde e Cidadania. Disponível em: $<$ http://portalses.saude.sc.gov.br/arquivos/sala_de_leitura/saude_e_cidadania/ed_07/10.ht $\mathrm{ml}>$. Acesso em 23.06.2013.

BRASIL. Governo do Estado de São Paulo. Disponível em: $<$ http://www.legislacao.sp.gov.br $>$. Acesso em 10.12.2014.

BRASIL. Ministério da Justiça. Reforma do Judiciário. Disponível em: $<$ http://portal.mj.gov.br/main.asp?View $=\{$ BB93AF25-26C9-4EB2-A4CC0E5F80657034\}>. Acesso em 30.06.2013.

BRASIL. Prefeitura do Município de São Paulo. Disponível em: $<$ http://www.prefeitura.sp.gov.br>. Acesso em 10.12.2014.

BRASIL. Presidência da República. Disponível em: <http://www.planalto.gov.br/>. Acesso em 10.12.2014.

BRASIL. Senado Federal. Disponível em: <http://www.senado.gov.br>. Acesso em 10.12.2014).

BRASIL. Supremo Tribunal Federal. Disponível em: $<$ http://www.stf.jus.br/portal/principal/principal.asp $>$. Acesso em 10.12.2014.

BRASIL. Tribunal Regional Federal da $1^{\text {a }}$ Região. Notícias. Juiz de direito que se aposentou na comarca de Salvador pode exercer a advocacia no estado da Bahia. Disponível em: $\quad<$ http://portal.trf1.jus.br/portaltrf1/comunicacaosocial/imprensa/noticias/juiz-de-direito-que-se-aposentou-na-comarca-de-salvador-podeexercer-a-advocacia-no-estado-da-bahia.htm\#>. Acesso em 05.07.2014

BRITTO, Carlos Ayres. Comentário ao artigo 37, caput. In: CANOTILHO, J. J. Gomes; MENDES, Gilmar F.; SARLET, Ingo W.; STRECK, Lenio L. (Coords.). Comentários à Constituição do Brasil. São Paulo: Saraiva/Almedina, 2013, pp. 818 a 823.

BUENO, Cassio Scarpinella. Curso sistematizado de direito processual civil: teoria geral do direito processual civil. Vol. I. 7. ed. rev. e atual. São Paulo: Saraiva, 2013.

BULOS, Uadi Lammêgo. Curso de direito constitucional. 5ª ed. São Paulo: Saraiva, 2010.

CALAMANDREI, Piero. Eles, os juízes, vistos por nós, os advogados. Tradução Ivo de Paula. São Paulo: Editora Pillares, 2013.

CANOTILHO, J. J. Gomes. Direito constitucional e teoria da constituição. $7^{\mathrm{a}}$ ed. Coimbra: Almedina, 2003. 
CAPPELETTI, Mauro. Juizes irresponsáveis?. Trad. Carlos Alberto Álvaro de Oliveira. Porto Alegre: Sergio Antônio Fabris, 1989.

CASSEB, Paulo Adib. Processo legislativo: atuação das comissões permanentes e temporárias. São Paulo: Revista dos Tribunais, 2008.

CENEVIVA, Walter. Direito constitucional brasileiro. $3^{\mathrm{a}}$ ed. São Paulo: Saraiva, 2003.

CENSIO, Jorge Silva. El control de la Administración. Revista de Direito Público, n. 39/40, jul.-dez., 1976.

CHAPUS, René. Droit Administratif Général, tome 1. 15ème ed. Paris: Montchrestien, 2001

CHINEM, Rivaldo. Juiz repudia “canga no Judiciário". O Estado de São Paulo, São Paulo, 06.11.1987. Caderno de política, p. 5.

CINTRA, Antonio Carlos de Araújo; GRINOVER, Ada Pellegrini; DINAMARCO, Cândido Rângel. Teoria geral do processo. $23^{\mathrm{a}}$ ed. São Paulo: Malheiros, 2007.

COELHO, Inocêncio Mártires. Constitucionalidade/inconstitucionalidade: uma questão política?. Revista de Direito Administrativo, 221 (2000): 47-70.

CONAN, Sébastien. Independência dos juízes e direitos humanos internacionais. In: Independência dos juízes: aspectos relevantes, casos e recomendações (LIMA JR., Jayme Benvenuto (org.) (CONAN, Sébastien (co-org). Recife: Gajop; Bagaço, 2005.

CONEGLIAN, Olivar. A Justiça Eleitoral: o Poder Executivo das eleições, uma justiça diferente. In: Direito eleitoral contemporâneo: doutrina e jurisprudência. Belo Horizonte: Del Rey, 2003.

CONEGLIAN, Olivar. Radiografia da Lei das Eleições. Curitiba: Juruá, 1998.

CRETELLA JÚNIOR, José. Anulação do ato administrativo por desvio de poder. Rio de Janeiro: Forense, 1978.

CRETELla JÚNIOR, José. Teoria do Ato Político. Revista dos Tribunais, janeiro 1988, vol. 627, p. 8 .

CUNHA, Sérgio Servulo da. Princípios constitucionais. 2a ed. São Paulo: Saraiva, 2013.

DALLARI, Dalmo de Abreu. O poder dos juízes. São Paulo: Saraiva, 1996.

DALLARI, Dalmo de Abreu. O poder dos juizes. São Paulo: Saraiva, 1996. 
DEOCLECIANO, Pedro Rafael Malveira (2010). O Conselho Nacional de Justiça e o controle democrático do Poder Judiciário: uma realidade possível?. Dissertação de mestrado apresentada à Universidade de Fortaleza. Fortaleza. 2010. 134 folhas.

DI PIETRO, Maria Sylvia Zanella. Direito administrativo. 25ª ed. São Paulo: Atlas, 2012.

DIAS, Gabriel Nogueira. "Legislador Negativo" na obra de Hans Kelsen: origem, fundamento e limitações à luz da própria Reine Rechtslehre. Revista Brasileira de Estudos Constitucionais RBEC, Belo Horizonte, ano 4, n. 15, jul./set. 2010.

DINAMARCO, Cândido Rangel. Instituições de direito processual civil. $6^{\mathrm{a}}$ ed., rev. e atual. São Paulo: Malheiros, 2009. v. II.

DIPP, Gilson. Prefácio da edição brasileira. In: Nações Unidas (ONU). Escritório Contra Drogas e Crime (Unodc). Comentários aos Princípios de Bangalore de Conduta Judicial. Tra-dução de Marlon da Silva Malha e Ariane Emílio Kloth. Brasília : Conselho da Justiça Federal, 2008. 179 p.

DROMI, José Roberto. Instituciones de Derecho Administrativo. Buenos Aires: Astrea de Rodolfo Depalma y Hnos, 1973.

DUARTE, Alessandra; OTAVIO, Chico. Brasil faz 18 leis por dia, e a maioria vai para o lixo. $O$ Globo, Rio de Janeiro, 18.06.2011. Disponível em: $<$ http://oglobo.globo.com/politica/brasil-faz-18-leis-por-dia-a-maioria-vai-para-lixo2873389>. Acesso em 23.06.2013.

DUVERGER, Maurice. Le système politique français. $18^{\mathrm{a}}$ ed. Paris: Presses Universitaires de France, 1985.

DWORKIN, Ronald. Levando os direitos a sério. Tradução Nelson Boeira. São Paulo: Martins Fontes, 2011.

FAGUNDES, Seabra. O controle dos atos administrativos pelo Poder Judiciário. $5^{\mathrm{a}}$ ed. Rio de Janeiro: Forense, 1979.

FALCÃO, Joaquim. O múltiplo Judiciário. In: SADEK, Maria Tereza. Magistrados: uma imagem em movimento. Rio de Janeiro: Editora FGV, 2006.

FALCÃO, Márcio. CNJ pune juiz por 'paquerar'candidata em banca de concurso. Folha de São Paulo (eletrônica). Disponível em: $<$ http://www1.folha.uol.com.br/poder/2014/06/1464552-cnj-pune-juiz-por-paquerarcandidata-em-banca-de-concurso.shtml $>$. Acesso em 02.08.2014

FERREIRA FILHO, Manoel Gonçalves. Curso de direito constitucional. $38^{\mathrm{a}}$ Ed. São Paulo: Saraiva, 2012. 
FERREIRA FILHO, Manoel Gonçalves. Do Processo legislativo. $7^{\mathrm{a}}$ ed. São Paulo: Saraiva, 2012.

FIGUEIREDO, Marcelo. O controle da moralidade na Constituição. $1^{\mathrm{a}}$ ed. $2^{\mathrm{a}}$ tiragem. São Paulo: Malheiros, 2003.

FLUHR, Fernanda Adriano. A jurisdição constitucional e o Conselho Nacional de Justiça: a possibilidade do exercício do controle de constitucionalidade pelo CNJ. Dissertação de Mestrado apresentada na Universidade Católica de Pernambuco. 2011.

FORSTHOFF, Ernst. Die Umbildung des Verfassungsgesetzes (1959). in Rechtsstaat im Wandel - Verfassungsrechtliche Abhandlungen 1950-1964, Stuttgart: Kohlhammer, 1964.

FORTI, Ugo. I controlli dell'amministrazione communale. Primo trattado completo di diritto amministrativo italiano, a cyra di Orlando Vittorio Emanuele. Milão: Società Editrice Libraria, 1915. vol. 2, $2^{\text {a }}$ Parte.

FRANÇA. Conseil Constitutionnel. Charte constitutionnelle du 4 juin 1814. Disponível em: $\quad<$ http://www.conseil-constitutionnel.fr/conseil-constitutionnel/francais/laconstitution/les-constitutions-de-la-france/charte-constitutionnelle-du-4-juin1814.5102.html>. Acesso em 10.12.2014.

FRANÇA. Conseil Constitutionnel. Constitution de 1848, IIe République. Disponível em: $<$ http://www.conseil-constitutionnel.fr/conseil-constitutionnel/francais/la-constitution/lesconstitutions-de-la-france/constitution-de-1848-iie-republique.5106.html $>$. Acesso em 10.12.2014.

FRANÇA. Conseil Constitutionnel. Constitution de 1946, IVe République. Disponível em: $<$ http://www.conseil-constitutionnel.fr/conseil-constitutionnel/francais/la-constitution/lesconstitutions-de-la-france/constitution-de-1946-ive-republique.5109.html $>$. Acesso em 10.12.2014.

FRANÇA. Conseil Constitutionnel. Constitution du 4 octobre 1958. Disponível em: $<$ http://www.conseil-constitutionnel.fr/conseil-constitutionnel/francais/la-constitution/laconstitution-du-4-octobre-1958/texte-integral-de-la-constitution-du-4-octobre-1958-envigueur.5074.html>. Acesso em 10.12.2014.

FRANÇA. Conseil Constitutionnel. Constitution $d u$ termidor An X. Disponível em: $<$ http://www.conseil-constitutionnel.fr/conseil-constitutionnel/francais/la-constitution/lesconstitutions-de-la-france/constitution-du-16-termidor-an-x.5088.html $>$. Acesso em 10.12.2014.

FRANÇA. Legifrance. Loi constitutionnelle $n^{\circ} 2008-724$ du 23 juillet 2008 de modernisation des institutions de la Ve République. Disponível em: $<$ http://www.legifrance.gouv.fr/affichTexte.do?cidTexte=JORFTEXT00001923725>. Acesso em 10.12.2014. 
FRANÇA. Legifrance. Loi constitutionnelle $n^{\circ} 93-952$ du 27 juillet 1993 portant révision de la Constitution du 4 octobre 1958 et modifiant ses titres VIII, IX, X et XV. Disponível em: $\quad<$ http://legifrance.gouv.fr/affichTexte.do?cidTexte=JORFTEXT000000529277>. Acesso em 10.12.2014.

FRANCISCO, José Carlos. Função regulamentar e regulamentos. Rio de Janeiro: Forense, 2009.

GARCÍA DE ENTERRÍA, Eduardo; FERNÁNDEZ, Tomás-Ramón. Curso de Derecho Administrativo. 12a ed. Madrid: Civitas; 2004.

GARGIULO, Ugo. I collegi amministrativi. Napoli: Casa Editrice Dott. Eugenio Jovene, 1962.

GASPARINI, Diogenes. Direito administrativo. 16a ed. São Paulo: Saraiva, 2011.

GIANNINI, Massimo Severo. Controllo: nozioni e problemi. Rivista Trimestrale di Diritto Pubblico, n. 4, 1974.

GOMES, Luiz Flávio. A dimensão da magistratura no estado constitucional e democrático de direito. São Paulo: Revista dos Tribunais, 1997.

GONZALES, Douglas Camarinha. Competencia legislativa dos entes federados: conflitos e interpretação constitucional. 2011. 176 f. Dissertação (Mestrado em Direito) - Faculdade de Direito da Universidade de São Paulo, São Paulo, 2011.

GRAU, Eros Roberto. $O$ direito posto e o direito pressuposto, $6^{\mathrm{a}}$ edição. São Paulo: Malheiros, 2005.

GRINOVER, Ada Pellegrini. As garantias constitucionais do direito de ação. São Paulo: Revista dos Tribunais, 1973.

GUILLIEN, Raymond; VINCENT, Jean. Lexique de termes juridiques. $8^{\mathrm{a}}$ ed. Paris: Dalloz, 1990.

GUIMARÃES, José Augusto Chaves. Elaboração de ementas jurisprudenciais: elementos teórico-metodológicos. Brasília: Subsecretaria de Divulgação e Editoração da Secretaria de Pesquisa e Informação Jurídicas do Centro de Estudos Judiciários, 2004.

HÄBERLE, Peter. Hermenêutica constitucional: a sociedade aberta dos intérpretes da Constituição: contribuição para a interpretação pluralista e "procedimental" da Constituição. Trad. Gilmar Ferreira Mendes. Porto Alegre: Sergio A. Fabris, Editor, 1997.

HABERMAS, Jüergen "Hannah Arendt's Communications Concept of Power". In S. Lukes (ed.), Power: Readings in Social and Political Theory. New York: New York University Press, 1986. 
HAMILTON, Alexander; MADISON, James; JAY, John. O federalista. Tradução de Hiltomar Martins Oliveira. Belo Horizonte: Líder, 2003.

HARADA, Kiyoshi. CPI do Judiciário. Jus Navigandi, Teresina, ano 4, n. 33, 1 jul. 1999. Disponível em: <http://jus.com.br/artigos/1964>. Acesso em: 13.11.2014.

HARADA, Kiyoshi. Direito financeiro e tributário. 22a ed. São Paulo: Atlas, 2013.

HART, Herbert L. A. O conceito de direito. Tradução A. Ribeiro Mendes. Lisboa: Fundação Calouste Gulbenkian, 1986.

HAURIOU, Maurice. Précis de droit administratif et de droit public. Paris: Librarie de la Société du Recueil Sirey, 1900.

HAURIOU, Maurice. Précis de Droit Administratif et de Droit Public. 11. ed. Paris: Recueil Sirey, 1927.

HOBBES, Thomas. Leviatã. São Paulo: Abril Cultural, 1979.

HOUAISS. Disponível em: <http://houaiss.uol.com.br>. Acesso em 26.12.2014.

INFOX. Infox Tecnologia da Informação Ltda. Disponível em $<$ http://www.infox.com.br/ler_noticia.wsp?tmp.tipo_noticia $=$ no\&tmp.noticia_cod $=8>$. Acesso em 29 de setembro de 2014.

ITÁLIA. Automazione Gazzeta Ufficiale Storica. Gazzeta Ufficiale Del Regno D'Italia, Roma, 23.07.1907. Disponível em: $<$ http://augusto.digitpa.gov.it/gazzette/index/download/id/1907174_PM>. Acesso em 10.12.2014.

ITÁLIA. Governo italiano. La Costituzione della Repubblica Italiana. Disponível em: $<$ http://www.governo.it/Governo/Costituzione/2_titolo4.html $>$. Acesso em 10.12.2014.

JARDIM, Torquato. Direito Eleitoral Positivo. 2. ${ }^{a}$ Ed. Brasília: Brasília Jurídica, 1998.

JUSTEN FILHO, Marçal. Curso de Direito Administrativo. 10a ed. São Paulo: Revista dos Tribunais, 2014.

KELSEN, Hans. Jurisdição constitucional. Trad. Alexandre Krug, Eduardo Brandão, Maria Ermantina de Almeida Prado Galvão. São Paulo: Martins Fontes, 2007.

KELSEN, Hans. Teoria Geral do Direito e do Estado. $2^{\mathrm{a}}$ ed. Tradução de Luís Recaséns Siches e Justino de Azcárate. Barcelona: Bosch, 1934.

LADEGAILLERIE, Valérie. Lexique de termes juridiques. Paris: Anaxagora, 2005. 
LAMPEDUSA, Giuseppe Tomasi di. Il Gattopardo. Milão: Feltrinelli, 2009.

LARENZ, Karl. Metodologia da ciência do direito. Tradução José Lamego. Lisboa: Fundação Calouste Gulbenkian, 1997.

LEITE, Luciano Ferreira. O regulamento no direito brasileiro. São Paulo: Revista dos Tribunais, 1986).

LENZ, Carlos Eduardo Thompson Flores. O Conselho Nacional de Justiça e a administração do Poder Judiciário. Revista Forense, Rio de Janeiro, v. 389, 2007.

LEÓN VILLALBA, Francisco Javier de. Acumulación de sanciones penales y administrativas. Sentido y alcance del principio ne bis in idem. Barcelona: Bosch, 1998.

LIMA FILHO, Leopoldo César de Miranda. Parecer. Revista de Direito Administrativo, vol. 81, 1965, pp. 466 a 475. Disponível em: http://bibliotecadigital.fgv.br/ojs/index.php/rda/article/view/27730. Acesso em 10.12.2014)

LIMA LOPES, José Reinaldo de. Crise da norma jurídica e reforma do judiciário. In: FARIA, José Eduardo (org.). Direitos humanos, direitos sociais e justiça. São Paulo: Malheiros, 2002.

LITTRÉ. Dictionnaire Littré. Disponível em: <http://www.littre.org/definition/comité>. Acesso em 28 de setembro de 2014.

LOCKE, John. Dois tratados sobre o governo. São Paulo: Martins Fontes, 1998.

LOCKE, John. Segundo tratado sobre o governo civil, XII, XIII e XIV. In: Segundo tratado sobre o governo civil e outros escritos. Petrópolis: Vozes, 1994.

LOEWENSTEIN. Karl. Political power and the Governmental process. Chicago: The University of Chicago Press, 1957.

LOEWENSTEIN. Karl. Verfassungslehre. Tradução Rüdiger Boerner. Tübingen: Mohr Siebeck, 2000.

MALUF, Paulo José Leonesi (2013). Conselho Nacional de Justiça: análise de sua competência disciplinar. Dissertação de mestrado apresentada à Universidade de São Paulo. São Paulo. 2013. 193 folhas.

MARBURY V. MADISON, 5. U.S. 137 (1803).

MARIENHOFF, Miguel. Tratado de Derecho Administrativo, tomo II. Buenos Aires: 1966. 
MARINONI, Luiz Guilherme; MITIDIERO, Daniel. Código de processo civil comentado artigo por artigo. São Paulo: Revista dos Tribunais, 2008.

MARTINEZ, Luciano. Curso de direito do trabalho: relações individuais, sindicais e coletivas do trabalho. $3^{\text {a }}$ ed. São Paulo: Saraiva, 2012.

MATOS, André Salgado de. A fiscalização administrativa da constitucionalidade. Coimbra: Almedina, 2004.

MAYER, David N. The Constitutional Thought of Thomas Jefferson. Charlottesville: University Press of Virginia, 1994.

MEDAUAR, Odete. Ato de Governo. Revista de Direito Administrativo, vol. 191, janeiro/março, 1993, editora Renovar Rio de Janeiro, p. 69/70.

MEDAUAR, Odete. Controle da Administração Pública. 2a ed. São Paulo: Revista dos Tribunais, 2012.

MEDEIROS, Rui. A Decisão de Inconstitucionalidade. Lisboa: Universidade Católica, 1999.

MEIRELLES, Hely Lopes. Direito administrativo brasileiro. $24^{\mathrm{a}}$ ed. São Paulo: Malheiros, 1999.

MEIRELLES, Hely Lopes. Direito municipal brasileiro. 12a ed. São Paulo: Malheiros, 2001.

MELlO, Celso Antônio Bandeira de. Curso de Direito Administrativo. $26^{\mathrm{a}}$ ed. São Paulo: Malheiros, 2009.

MELLO, Celso Antonio Bandeira de. Discricionáriedade e controle jurisdicional. $2^{\mathrm{a}}$ ed. $9^{\mathrm{a}}$ tiragem. São Paulo: Malheiros, 2008.

MELlO, Oswaldo Aranha Bandeira de. Princípios gerais de direito administrativo. $3^{\text {a }}$ ed., $2^{\mathrm{a}}$ tiragem. São Paulo: Malheiros Editores, 2010, v. 1.

MENDES, Gilmar Ferreira; BRANCO, Paulo Gustavo Gonet. Curso de direito constitucional. $6^{\text {a }}$ ed. São Paulo: Saraiva, 2011.

MICHAELIS. Dicionário de Português Online Michaelis. Disponível em $<\mathrm{http}$ ://michaelis.uol.com.br>. Acesso em 10.12.2014.

MIRANDA, Jorge. Manual de Direito Constitucional. $3^{\text {a }}$ ed. Coimbra: Coimbra Ed., 1996. t. 2. 
MOLINARO, Carlos Alberto. Comentário ao artigo 236. In: CANOTILHO, J. J. Gomes; MENDES, Gilmar F.; SARLET, Ingo W.; STRECK, Lenio L. (Coords.). Comentários à Constituição do Brasil. São Paulo: Saraiva/Almedina, 2013, pp. 2159 e 2160.

MONTESQUIEU. O espírito das leis. Tradução Pedro Vieira Mota. $9^{\mathrm{a}}$ ed. $2^{\mathrm{a}}$ tiragem. São Paulo: Saraiva, 2010.

MORAES, Alexandre de. Constituição do Brasil interpretada e legislação constitucional. $9^{a}$ ed. São Paulo: Atlas, 2013.

MORAES, Alexandre de. Controle de constitucionalidade é vedado ao Conselho Nacional de Justiça. Consultor Jurídico. Disponível em <http://www.conjur.com.br/2014-ago27/alexandre-moraes-controle-constitucionalidade-vedado-cnj>. Acesso em 13.12.2014.

MORAES, Alexandre de. Direito constitucional. 29a ed. São Paulo: Atlas, 2013.

MORAIS, Carlos Blanco de. Justiça Constitucional. Tomo I, garantia da constituição e controlo da constitucionalidade. $2^{\text {a }}$. ed. Coimbra: Coimbra Editora, 2006.

MORTATI, Costantino. Istituzioni di diritto pubblico. $4^{\mathrm{a}}$ ed. Padova: Casa Editrice Dott. Antonio Milani, 1958.

MOTTA, Fabrício Macedo. Comentário ao artigo 37, III. In: CANOTILHO, J. J. Gomes; MENDES, Gilmar F.; SARLET, Ingo W.; STRECK, Lenio L. (Coords.). Comentários à Constituição do Brasil. São Paulo: Saraiva/Almedina, 2013, pp. 831 a 833.

NAÇÕES UNIDAS (ONU). Escritório Contra Drogas e Crime (Unodc). Comentários aos Princípios de Bangalore de Conduta Judicial. Tra-dução de Marlon da Silva Malha e Ariane Emílio Kloth. Brasília : Conselho da Justiça Federal, 2008. 179 p.

NASCIMENTO, Amauri Mascaro. Curso de direito do trabalho: história e teoria geral do direito do trabalho: relações individuais e coletivas do trabalho. $26^{\text {a }}$ ed. São Paulo: Saraiva, 2011.

NASCIMENTO, Amauri Mascaro. Curso de direito processual do trabalho. $14^{\mathrm{a}}$ ed. São Paulo: Saraiva, 1993.

NASCIMENTO, Amauri Mascaro. Curso de direito processual do trabalho. $28^{\mathrm{a}}$ ed. São Paulo: Saraiva, 2013.

NEGRÃO, Theotonio; GOUVÊA, José Roberto; BONDIOLI, Luis Guilherme Aidar; FONSECA, João Francisco Naves da. Código de processo civil e legislação processual em vigor. 43ª ed. São Paulo: Saraiva, 2011.

NERY JUNIOR, Nelson; NERY, Rosa Maria de Andrade. Constituição Federal comentada e legislação constitucional. $4^{\mathrm{a}}$ ed. São Paulo: Revista dos Tribunais, 2013. 
NUCCI, Guilherme de Souza. Código de processo penal comentado. $8^{\mathrm{a}}$ ed. $2^{\mathrm{a}}$ tiragem. São Paulo: Revista dos Tribunais, 2008.

NUCCI, Guilherme de Souza. Código penal comentado. $7^{\mathrm{a}}$ ed. $2^{\mathrm{a}}$ tiragem. São Paulo: Revista dos Tribunais, 2007.

NUCCI, Guilherme de Souza. O princípio da colegialidade. Carta Forense, São Paulo, 10.03.2008. Disponível em: <http://www.cartaforense.com.br/conteudo/colunas/oprincipio-da-colegialidade/1148>. Acesso em 29.06.2013.

OLIVEIRA, Rafael Tomaz de; STRECK, Lenio Luiz. Fiscalização da constitucionalidade não é vedada ao Conselho Nacional de Justiça. Consultor Jurídico. Disponível em: $<$ http://www.conjur.com.br/2014-ago-30/diario-classe-fiscalizacao-constitucionalidadenao-vedada-conselho-nacional-justica $>$. Acesso em 13.12.2014.

OLIVEIRA, Regis Fernandes de. Delegação e avocação administrativas. $2^{\mathrm{a}}$ ed. São Paulo: Revista dos Tribunais, 2005.

ONLINE. Dicionário online de português. Disponível em: <http://www.dicio.com.br>. Acesso em 10.12.2014.

OSÓRIO, Fábio Medina. Direito administrativo sancionador. $3^{\mathrm{a}}$ ed. São Paulo: Revista dos Tribunais, 2009.

PACIOLI, Luca Bartolomeo de. La Summa de Arithmetica, Geometria, Proportioni et Proportionalitá. Veneza, 1494.

PALU, Oswaldo Luiz. Controle de constitucionalidade: conceitos, sistemas e efeitos. $2^{\mathrm{a}}$ ed. São Paulo: Revista dos Tribunais, 2001.

PANSIERI, Flávio. Comentário ao artigo 103-B. In: CANOTILHO, J. J. Gomes; MENDES, Gilmar F.; SARLET, Ingo W.; STRECK, Lenio L. (Coords.). Comentários à Constituição do Brasil. São Paulo: Saraiva/Almedina, 2013, pp. 1433 a 1440.

PELEJA JÚNIOR, Antônio Veloso. Conselho Nacional de Justiça e a magistratura brasileira. $2^{\text {a }}$ ed. Curitiba: Juruá, 2011.

PELEJA JÚNIOR, Antônio Veloso. O CNJ e o controle e constitucionalidade de leis. Migalhas. Disponível em: <http://www.migalhas.com.br/dePeso/16,MI78651,11049$\mathrm{O}+\mathrm{CNJ}+\mathrm{e}+\mathrm{o}+$ controle + de + constitucionalidade $+\mathrm{de}+\mathrm{leis}>$. Acesso em 10.12.2014.

PIERI, Sueli Aparecida de. Súmula impeditiva de recurso de apelação. Piracicaba: Cadernos de Direito, 2008. 
PIMENTEL, Alexandre Freire; PIMENTEL, Bruno Freire. Em defesa do controle administrativo de constitucionalidade exercido pelo Conselho Nacional de Justiça. Revista Bonijuris, nº 579 (2012, pp. 24 a 31.

PONDÉ, Lafayette. Peculiaridades do órgão colegial. Revista de Direito Público, v. 20. 1972.

PONTES DE MIRANDA. Comentários ao Código de Processo Civil. Rio de Janeiro: Forense, 1975, t. 7.

PORTAL DA CONTABILIDADE. Disponível em: $<$ http://www.cosif.com.br/mostra.asp?arquivo=contabil07partidas $>$. Acesso em 01.05.2014).

PRIBERAM. Dicionário Priberam da Língua Portuguesa. Disponível em: $<$ http://www.priberam.pt $>$. Acesso em 10.12.2014.

PRUDENTE, Antônio Souza. CPI sobre o Judiciário: tribunal de exceção. Jus Navigandi, Teresina, ano 4, n. 31, 1 maio 1999. Disponível em: <http://jus.com.br/artigos/230>. Acesso em: 13.11.2014.

RAMOS, Elival da Silva. A inconstitucionalidade das leis: vício e sanção. São Paulo: Saraiva, 1994.

RAMOS, Elival da Silva. Controle de constitucionalidade no Brasil: perspectivas de evolução. São Paulo: Saraiva, 2010.

REZENDE, Joffre Marcondes de. Laudar, laudado. Revista de Patologia Tropical. Goiânia: Instituto de Patologia Tropical e Saúde Pública da Universidade Federal de Goiás, v. 39, pp. 228-230, jul./set. 2010.

ROUSSEAU, Jean-Jacques. Do contrato social. Tradução Antonio de P. Machado. Rio de Janeiro: Nova Fronteira, 2011.

RULli NETO, Antonio. Controle externo do Poder Judiciário no Brasil. 2007. 312 f. Tese (Doutorado em Direito) - Faculdade de Direito da Universidade de São Paulo, São Paulo, 2007.

SABOYA, Keity Mara Ferreira de Souza e. Ne bis in idem: limites jurídico-constitucionais à persecução penal. Dissertação apresentada ao Programa de Pós-Graduação em Direito, Curso de Mestrado em Direito da Universidade Federal do Rio Grande do Norte. Natal, 2006.

SAMPAIO, José Adércio Leite. O Conselho Nacional de Justiça e a independência do Judiciário. Belo Horizonte: Del Rey, 2007. 
SANTOS, Francisco Cláudio de Aleida. Delegação de competência: exame de delegação invocada pela corregedoria do CNJ. Revista dos Tribunais, São Paulo, v. 906, 2011.

SEQUEIRA, Claudio Dantas. Cantadas indecorosas nos tribunais. Isto É (eletrônica). $2170 . \quad$ Disponível em : $<$ http://www.istoe.com.br/reportagens/141509_CANTADAS+INDECOROSAS+NOS+TR IBUNAIS $>$. Acesso em 02.08.2014.

SILVA, De Plácido e. Vocabulário jurídico. $27^{\mathrm{a}}$ ed. Rio de Janeiro: Forense, 2007.

SILVA, José Afonso da. Aplicabilidade das normas constitucionais. $6^{a}$ ed. São Paulo: Malheiros, 2002.

SILVA, José Afonso da. Curso de direito constitucional positivo. $36^{\mathrm{a}}$ ed. São Paulo: Malheiros, 2013.

SILVA, José Afonso da. O constitucionalismo brasileiro: evolução institucional. São Paulo: Malheiros Editores, 2011.

SILVA, Virgílio Afonso da (Org.). Interpretação constitucional. $1^{\mathrm{a}}$ ed. $3^{\mathrm{a}}$ tiragem. São Paulo: Malheiros Editores, 2010.

SILVA, Virgílio Afonso da. A constitucionalização do direito: os direitos fundamentais nas relações entre particulares. $1^{\mathrm{a}}$ ed. $4^{\mathrm{a}}$ tiragem. São Paulo: Malheiros, 2014.

SILVA, Virgílio Afonso da. Princípios e regras: mitos e equívocos acerca de uma distinção. Revista Latino-Americana de Estudos Políticos 1 (2003), pp. 607-630.

TÁCITO, Caio. Repertório de direito brasileiro. Verbete “delegação de competência”. Rio de Janeiro: Borsoi.

TAVARES, André Ramos. Curso de direito constitucional. $11^{\mathrm{a}}$ ed. São Paulo: Saraiva, 2013.

TAVARES, André Ramos. Manual do poder judiciário brasileiro. São Paulo: Saraiva, 2012.

TEMER, Michel. Elementos de direito constitucional. 10a ed. São Paulo: Malheiros, 1993.

TEMER, Michel. Elementos de direito constitucional. 12a ed. São Paulo: Malheiros, 1996.

UNITED NATIONS. Composition of macro geographical (continental) regions, geographical sub-regions, and selected economic and other groupings. Disponível em: $<$ http://unstats.un.org/unsd/methods/m49/m49regin.htm\#europe>. Acesso em 30.06.2013. 
VELloso, Carlos Mário da Silva; AGRA, Walber de Moura. Elementos de direito eleitoral. $3^{\text {a }}$ ed. São Paulo: Saraiva, 2012.

WEBER, Max. Três tipos de poder e outros escritos. Tradução Artur Morão. Lisboa: Tribuna da História, 2005.

ZAGREBELSKY, Gustavo. El derecho dúctil. Ley, derechos, justicia. Trad. Marina Gascón. $7^{\mathrm{a}}$ ed. Madrid: Editorial Trotta, 2007.

ZOCKUN, Maurício. A separação dos poderes e o Judiciário como legislador positivo e negativo. Revista Trimestral de Direito Público (RTDP) 47, pp. 162 a 173. São Paulo: Malheiros, 2004. 